UNIVERSIDADE DE SÃO PAULO

FACULDADE DE FILOSOFIA, LETRAS E CIÊNCIAS HUMANAS PROGRAMA DE PÓS-GRADUAÇÃO EM HISTÓRIA SOCIAL

LEANDRO PENNA RANIERI

CONCEPÇÕES DE CORPO NA ASSÍRIA DO PRIMEIRO

MILÊNIO AEC: ENTRE MATERIALIDADE E

TEXTUALIDADE

Versão Corrigida

SÃO PAULO

2018 


\title{
CONCEPÇÕES DE CORPO NA ASSÍRIA DO PRIMEIRO MILÊNIO AEC: entre materialidade e textualidade
}

\author{
Versão Corrigida
}

Tese apresentada ao Programa de Pósgraduação em História Social da Faculdade de Filosofia, Letras e Ciências Humanas da Universidade de São Paulo para obtenção do título de Doutor em Ciências, Programa: História Social.

Orientador: Prof. Dr. Marcelo Rede 
Autorizo a reprodução e divulgação total ou parcial deste trabalho, por qualquer meio convencional ou eletrônico, para fins de estudo e pesquisa, desde que citada a fonte.

Catalogação na Publicação

Serviço de Biblioteca e Documentação

Faculdade de Filosofia, Letras e Ciências Humanas da Universidade de São Paulo

R173C

Ranieri, Leandro Penna

Concepções de corpo na Assíria do primeiro milênio AEC: entre materialidade e textualidade / Leandro Penna Ranieri ; orientador Marcelo Rede. - São Paulo, 2018.

$261 \mathrm{f}$.

Tese (Doutorado) - Faculdade de Filosofia, Letras e Ciências Humanas da Universidade de são Paulo. Departamento de História. Área de concentração: História Social.

1. Assíria. 2. Mesopotamia. 3. Ninive. 4. Palácios. 5. Baixo Relevo. I. Rede, Marcelo, orient. II. Título. 


\title{
CONCEPÇÕES DE CORPO NA ASSÍRIA DO PRIMEIRO MILÊNIO AEC: entre materialidade e textualidade
}

\author{
Tese apresentada ao Programa de Pós- \\ graduação em História Social da Faculdade de \\ Filosofia, Letras e Ciências Humanas da \\ Universidade de São Paulo para obtenção do \\ título de Doutor em Ciências, Programa: \\ História Social.
}

Data da Defesa:

Resultado:

Banca Examinadora

Prof. Dr. Marcelo Rede

Universidade de São Paulo

Prof. Dr.

Instituição:

Prof. Dr.

Instituição:

Prof. Dr.

Instituição

Prof. Dr.

Instituição 
À minha família:

Domingos, Lucile, Gisele e Larissa 


\section{AGRADECIMENTOS}

Aos meus pais, Domingos Ranieri e Lucile Penna Ranieri, e à minha irmã, Gisele Penna Ranieri, pelo apoio e suporte nas minhas escolhas e pela minha formação pessoal.

Às minhas avós, Dilce Tamiglio Ranieri (in memoriam) e Olenka Cardoso Penna, pelo amor e suporte incondicionais dados durante toda a minha vida, especialmente durante minha formação acadêmica.

À minha esposa, Larissa Corat Fernandes, pelos anos de companherismo, amizade e amor. Sou muito grato por termos crescido juntos e por ter sempre você comigo. E nunca poderei agradecer o suficiente pela paciência, compreensão e carinho dedicados a mim nesse período de doutorado.

À minha tia, Cecília Cardoso Penna, pelo carinho e incentivo durante meu período de doutorado.

Às famílias Corat e Fernandes, pelo suporte e estímulos constantes.

Ao Prof. Dr. Cristiano R. A. Barreira, pela formação profissional e pessoal de quem sou hoje.

Ao Prof. Dr. Thomás Augusto S. Haddad, pelas inspirações iniciais, pelo apoio e estímulos a mim dirigidos para seguir na pesquisa em História.

Aos colegas do Departamento de Educação Física e Motricidade Humana (DEFMH) da Universidade Federal de São Carlos (UFSCar), que me receberam bem e construíram um ambiente favorável à minha atuação como professor substituto nos anos anteriores ao meu ingresso no doutorado. Em especial, agradeço à Prof. ${ }^{a}$ Dr. ${ }^{a}$ Ana Cláudia Duarte pelos conselhos profissionais e, enquanto Chefe de Departamento, por ter facilitado meus afastamentos para poder prestar o processo seletivo do doutorado. E ao colega e amigo Prof. Dr. Cleiton Augusto Libardi, pela companhia em terras são-carlenses e, sobretudo, pelo exemplo inestimável e pela inspiração profissional. 
Ao meu orientador, Prof. Dr. Marcelo Rede, muitos agradecimentos. Agradeço por ter me recebido como aluno, mesmo eu sendo "estrangeiro", pelas orientações sempre precisas, pelo empréstimo de volumes de sua biblioteca pessoal, por toda a disponibilidade em sempre me atender e em resolver as burocracias do mundo acadêmico e por todo apoio e confiança dados a mim. Mesmo após quase cinco anos de minha formação sob sua orientação, ainda gostaria de ter mais momentos de contato e colaboração.

Aos professores Dr. ${ }^{a}$ Vânia Carneiro de Carvalho e Dr. Carlos Gonçalves, por terem aceito participar em meu exame de qualificação, pela gentileza e cuidado na leitura de meu material e pelas contribuições valiosas para a continuidade da pesquisa.

Novamente ao Prof. Dr. Carlos Gonçalves, pela colaboração agradável e estimulante e pelo auxílio em todos os momentos desta pesquisa. Em especial, pela oportunidade de formação de um grupo de trabalho, inicialmente para o estudo de língua acadiana, sem o qual eu não teria condições de avançar em muitos aspectos que desenvolvi nesta tese.

Aos colegas do Laboratório do Antigo Oriente Próximo (LAOP), Anita Fattori, Carolina Velloza, Érika Maynart, Matheus Treuk, Rafael Pires e Renato Ferreira, pela companhia durante a caminhada acadêmica, pela confiança muitas vezes dada a mim e por terem compartilhado comigo um pouco de suas aflições, alegrias e dos momentos da vida de vocês. Em especial, agradeço à Anita pela ajuda rápida e eficaz em ler trechos da tese e na resolução de problemas que eu não encontrava resposta.

Aos funcionários da Faculdade de Filosofia, Letras e Ciências Humanas (FFLCH) que muito facilitaram minha vida e passagem pelo Departamento de História. Aos professores com quem tive contato nesse Departamento, por terem me recebido bem e me ajudado sempre com bastante compreensão e presteza.

Aos amigos da vida com quem compartilhei momentos nesses últimos anos. Em especial, agradeço à Marina Serra dos Santos, minha amiga de longa data e historiadora, pelo incentivo e auxílio durante a minha caminhada. Ao Pedro Paulo Melara pela amizade mesmo nos momentos em que estive ausente. Ao Steffen Lehmann pelos anos de amizade, por fazer acontecer nossos momentos juntos e por sempre me apoiar e incentivar. E aos amigos do 
Clube 8, por reforçarem em mim que a felicidade é sempre compartilhada. Dentre eles, sempre agradecerei ao Everton Aquino por ter insistido na busca em nos recolocar em contato após anos afastados.

Ao Prof. Davide Nadali, da Sapienza Università di Roma, por me acolher tão bem durante meu período na Itália, pela amabilidade, disponibilidade constante em me ajudar com minha pesquisa e pelo exemplo profissional.

Ao Prof. Lorenzo Verderame, da Sapienza Università di Roma, meu inesperado e bem-vindo segundo supervisor durante meu estágio de pesquisa em Roma, pelas gentilezas do dia a dia, precisão nas orientações e pela disponibilidade imensa em sempre me atender. Também agradeço à Dr. ${ }^{a}$ Maria Érica Couto Ferreira, que tive o prazer de conhecer, pela recepção, gentileza e ajuda.

Aos colegas de Roma que também me receberam muito bem, me ajudaram a enfrentar as barreiras do cotidiano e pelos momentos que tivemos juntos. À Silvia Boccolini, Flavia Pacelli, Edoardo Zanetti, Andrea Rebecca Savoi, Ludovica Bertolini, Marinella Ceravolo, Bernardo Pasqua, George Contreras, Mohammad Odeh e Gianni Conte.

À Fundação de Amparo à Pesquisa do Estado de São Paulo (FAPESP), pelos suportes financeiros por meio dos processos n..$^{\circ}$ 2014/22125-2 e BEPE n. ${ }^{\circ}$ 2016/02241-2, sem os quais esta pesquisa não poderia ser realizada. 
A Teologia não é diferente de muitas outras coisas. Existe uma teologia que é arte e uma outra que é ciência ou que, pelo menos, se esforça para sê-lo. Isto não constitui novidade alguma e sempre assim foi, ontem como hoje, pois os cientistas são propensos a menosprezar os vinhos velhos, pensando nas futuras safras, ao passo que os artistas se contentam com aquêles e pouco estão interessados em saber se haverá novas safras ou não, ou o gôsto que terá o vinho de uvas que ainda não brotaram nos vinhedos. $\mathrm{E}$ a gente comum prefere às explicações dos homens de Ciência as ilusões e equívocos dos artistas, portadores de alegrias e consolações imediatas. É a antiga luta desigual entre a criação e a crítica, entre a arte e a ciência, em que esta tem sempre a razão sem que se tire algum proveito disso e aquela faz eternamente brotar nos corações humanos a semente da crença, do amor, da beleza e dos pressentimentos de eternidade, e encontra sempre terra boa onde frutificar. Pois a vida é mais forte e apaixonada do que a morte, e a crença é mais poderosa do que a dúvida (HESSE, 1971, p. 38-39). 


\section{RESUMO}

RANIERI, Leandro Penna. Concepções de corpo na Assíria do primeiro milênio AEC: entre materialidade e textualidade. 2018. $260 \mathrm{f}$. Tese (Doutorado em Ciências, programa História Social) - Faculdade de Filosofia, Letras e Ciências Humanas, Universidade de São Paulo, São Paulo, 2018.

O objetivo desta pesquisa é examinar e compreender as concepções de corpo na Assíria do fim do século VIII e do século VII AEC, a partir da análise de fontes palacianas imagéticas e textuais. As primeiras são compostas pelos relevos dos palácios dos reis Senaqueribe (704681) e Assurbanipal II (669-627) em Nínive (no atual nordeste do Iraque). As segundas são Inscrições Reais, Tratados e Juramentos, Cartas e textos literários, sendo que todos esses gêneros têm como eixo de produção os palácios assírios. Os relevos são placas de pedra com esculturas em baixo relevo, que foram utilizadas nas paredes dos palácios assírios a partir do final do segundo milênio AEC. Esse uso foi continuado por todo o período denominado Neoassírio ou Tardo Assírio (934-610 AEC), expondo imagens de pessoas, animais, plantas, paisagens e arquiteturas. A configuração desses elementos figurativos expressa cenas de narrativas espaciais por meio de imagens. A disposição orquestrada dos relevos nas paredes dos palácios evidencia potenciais modos de percepção das imagens pela movimentação nos ambientes palacianos. A recorrência da expressão do corpo nos relevos suscita uma perspectiva atenta à materialidade, à relação entre as imagens do corpo e aos modos de percepção e contato com esses objetos no período. A presença constante de expressões corporais em textos neoassírios também constitui um tratamento ao corpo através da linguagem. Considerando a complementaridade entre fontes imagéticas e escritas no período e o fato de as concepções de corpo poderem estar expressas em textos e imagens, qual é o lugar e o uso do corpo neste período? Como o corpo aparece nos relevos e textos palacianos? Quais aspectos materiais dos relevos constituem os indícios da concepção de corpo? Como as imagens do corpo e as expressões corporais escritas indicam suas concepções?

Palavras-chave: Assíria. Primeiro milênio AEC. Dinastia Sargônida. Relevos e textos palacianos. Concepções de corpo. 


\begin{abstract}
RANIERI, Leandro Penna. Conceptions of body in the first millennium Assyria: between materiality and textuality. 2018. 260 f. Tese (Doutorado em Ciências, programa História Social) - Faculdade de Filosofia, Letras e Ciências Humanas, Universidade de São Paulo, São Paulo, 2018.

The aim of this research is to examine and comprehend the conceptions of the body in Assyria at the end of the 8th and 7th centuries BCE, from the analysis of palatial images and texts. The visual sources are composed by the reliefs of the kings of Sennacherib (704-681) and Assurbanipal II (669-627) in Nineveh (present-day northern of Iraq). The written sources are Royal Inscriptions, Treaties and Oaths, Letters and literary texts. All these texts had the Assyrian royal palaces as production axis. The reliefs are stone plaques with bas-relief sculptures, which were used on the walls of the Assyrian palaces from the end of the second millennium BCE. This use was continued throughout the period called Neo-Assyrian or Late Assyrian (934-610 BCE), exposing images of people, animals, plants, landscapes and architectures. The configuration of these figurative elements expresses scenes of spatial narratives through images. The orchestrated arrangement of the reliefs on the walls of the palaces shows potential ways of perception of the images by the movement in the palatial environments. The recurrence of the body expression in the reliefs evokes an attentive threefold perspective: on the materiality, the images of the body and the modes of perception and contact with these objects in that period. The constant presence of body expressions in Neo-Assyrian texts also constitutes a way to treat body through language. Considering the complementarity between visual and written sources in the Neo-Assyrian period and the fact that body conceptions can be expressed in texts and images, what is the status and use of the body in this period? How does the body appear in the reliefs and palatial texts? What are the material aspects of the reliefs? How do body images and written body expressions indicate their conceptions?
\end{abstract}

Keywords: Assyria. First millennium BCE. Sargonid dinasty. Palace reliefs and texts. Conceptions of the body. 


\section{LISTA DE FIGURAS}

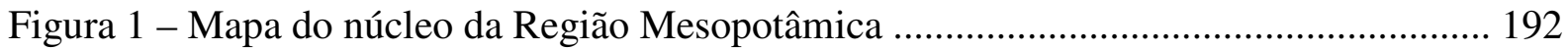

Figura 2 - Mapa do núcleo assírio na Alta Mesopotâmia ..................................................... 193

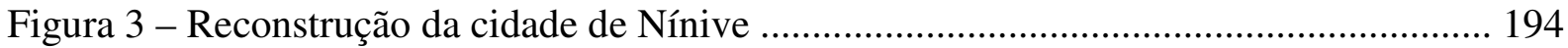

Figura 4 - Reconstrução do monte Kuyunjik, cidadela de Nínive ....................................... 194

Figura 5 - Plano reconstrutivo do monte Kuyunjik, a partir do plano de Thompson (1934)

Figura 6 - Plano baixo do Palácio Sudoeste de Nínive, de Senaqueribe (PATERSON, 1915)

Figura 7 - Plano baixo do Palácio Sudoeste de Nínive, de Senaqueribe (KERTAI, 2015a)

Figura 8 - Plano baixo do Palácio Norte de Nínive, de Assurbanipal II (BARNETT, 1976)

Figura 9 - Plano baixo do Palácio Norte de Nínive, de Assurbanipal II (KERTAI, 2015a)

199

Figura 10 - Relevos da sala VI do Palácio Sudoeste de Nínive (placa 13) ......................... 200

Figura 11 - Relevos da sala VI do Palácio Sudoeste de Nínive (placa 53) ......................... 200

Figura 12 - Relevos da sala VI do Palácio Sudoeste de Nínive (placa 59 ou 60) ................ 201

Figura 13 - Relevos da sala VI do Palácio Sudoeste de Nínive (placa 61) ......................... 201

Figura 14 - Relevos da sala VI do Palácio Sudoeste de Nínive (placa 63) ......................... 202

Figura 15 - Relevos da sala VI do Palácio Sudoeste de Nínive (placa 64) ......................... 202

Figura 16 - Relevos da sala VI do Palácio Sudoeste de Nínive (placa 66) .......................... 203

Figura 17 - Relevos da sala XIV do Palácio Sudoeste de Nínive (placa 4) ......................... 204

Figura 18 - Relevos da sala XIV do Palácio Sudoeste de Nínive (placa 5) ......................... 204

Figura 19 - Relevos da sala XIV do Palácio Sudoeste de Nínive (placa 6) ......................... 205

Figura 20 - Relevos da sala XIV do Palácio Sudoeste de Nínive (placas 8-9) ..................... 205

Figura 21 - Relevos da sala XIV do Palácio Sudoeste de Nínive (placa 10) ........................ 206

Figura 22 - Relevos da sala XIV do Palácio Sudoeste de Nínive (placa 11) ....................... 206

Figura 23 - Relevos da sala XIV do Palácio Sudoeste de Nínive (placas 13-14) ............... 207

Figura 24 - Relevos da sala XIV do Palácio Sudoeste de Nínive (placa 15) ....................... 207

Figura 25 - Relevos da sala XIX do Palácio Sudoeste de Nínive (placa 19) ....................... 208

Figura 26 - Relevos da sala XIX do Palácio Sudoeste de Nínive (placa 18) ....................... 208

Figura 27 - Relevos da sala XIX do Palácio Sudoeste de Nínive (placa 17) ....................... 209

Figura 28 - Relevos da sala XIX do Palácio Sudoeste de Nínive (placas 12-11) ............... 210

Figura 29 - Relevos da sala XIX do Palácio Sudoeste de Nínive (placas 11-10) ............... 210

Figura 30 - Relevos da sala XXVIII do Palácio Sudoeste de Nínive (placas 2-3) ............... 211

Figura 31 - Relevos da sala XXVIII do Palácio Sudoeste de Nínive (placa 3) .................... 211

Figura 32 - Relevos da sala XXVIII do Palácio Sudoeste de Nínive (placa 4) .................... 212

Figura 33 - Relevos da sala XXVIII do Palácio Sudoeste de Nínive (placa 5) ..................... 212

Figura 34 - Relevos da sala XXVIII do Palácio Sudoeste de Nínive (placa 6) .................... 213

Figura 35 - Relevos da sala XXVIII do Palácio Sudoeste de Nínive (placa 7) ................... 213

Figura 36 - Relevos da sala XXVIII do Palácio Sudoeste de Nínive (placa 8) .................... 214

Figura 37 - Relevos da sala XXVIII do Palácio Sudoeste de Nínive (placa 9) ................... 214

Figura 38 - Relevos da sala XXVIII do Palácio Sudoeste de Nínive (placa 10) .................. 215

Figura 39 - Relevos da sala XXVIII do Palácio Sudoeste de Nínive (placa 11) .................. 215

Figura 40 - Relevos da sala XXVIII do Palácio Sudoeste de Nínive (placa 12) ................. 216

Figura 41 - Relevos da sala XXVIII do Palácio Sudoeste de Nínive (placa 13) .................. 216 
Figura 42 - Relevos da sala XXVIII do Palácio Sudoeste de Nínive (placa 14) ................. 217

Figura 43 - Relevos da sala XXXIII do Palácio Sudoeste de Nínive (placa 1) .................... 218

Figura 44 - Relevos da sala XXXIII do Palácio Sudoeste de Nínive (placa 2) .................... 218

Figura 45 - Relevos da sala XXXIII do Palácio Sudoeste de Nínive (placa 3) .................... 219

Figura 46 - Relevos da sala XXXIII do Palácio Sudoeste de Nínive (placa 4) .................... 219

Figura 47 - Relevos da sala XXXIII do Palácio Sudoeste de Nínive (placa 5) ................... 220

Figura 48 - Relevos da sala XXXIII do Palácio Sudoeste de Nínive (placa 6) .................... 220

Figura 49 - Relevos da sala XXXVI do Palácio Sudoeste de Nínive (placa 5) ................... 221

Figura 50 - Relevos da sala XXXVI do Palácio Sudoeste de Nínive (placa 6) ................... 221

Figura 51 - Relevos da sala XXXVI do Palácio Sudoeste de Nínive (placa 7) .................. 222

Figura 52 - Relevos da sala XXXVI do Palácio Sudoeste de Nínive (placa 8) .................. 222

Figura 53 - Relevos da sala XXXVI do Palácio Sudoeste de Nínive (placas 8-9) ............... 223

Figura 54 - Relevos da sala XXXVI do Palácio Sudoeste de Nínive (placa 9) .................. 223

Figura 55 - Relevos da sala XXXVI do Palácio Sudoeste de Nínive (placas 9-11) ............ 224

Figura 56 - Relevos da sala XXXVI do Palácio Sudoeste de Nínive (placa 11) ................ 224

Figura 57 - Relevos da sala XXXVI do Palácio Sudoeste de Nínive (placa 11-12) ........... 225

Figura 58 - Relevos da sala XXXVI do Palácio Sudoeste de Nínive (placa 12) ................. 225

Figura 59 - Relevos da sala XXXVI do Palácio Sudoeste de Nínive (placa 13) ................ 226

Figura 60 - Relevos da sala XXXVI do Palácio Sudoeste de Nínive (placas 13-15) .......... 226

Figura 61 - Relevos da sala LI do Palácio Sudoeste de Nínive (placas 30-32) ................... 227

Figura 62 - Relevos da sala LI do Palácio Sudoeste de Nínive (placas de posição imprecisa)

Figura 63 - Relevos da sala LI do Palácio Sudoeste de Nínive (placas 10-11) ................... 228

Figura 64 - Relevos da sala LI do Palácio Sudoeste de Nínive (placa 13) .......................... 228

Figura 65 - Relevos da passagem ao Templo de Ištar do Palácio Sudoeste de Nínive (placa 2)

Figura 66 - Relevos da passagem ao Templo de Ištar do Palácio Sudoeste de Nínive (placa 3)

Figura 67 - Relevos da passagem ao Templo de Ištar do Palácio Sudoeste de Nínive (placa 4)

Figura 68 - Relevos da passagem ao Templo de Ištar do Palácio Sudoeste de Nínive (placa 8) 230

Figura 69 - Relevos da passagem ao Templo de Ištar do Palácio Sudoeste de Nínive (placa A)

Figura 70 - Relevos da passagem ao Templo de Ištar do Palácio Sudoeste de Nínive (placa B)

Figura 71 - Relevos da passagem ao Templo de Ištar do Palácio Sudoeste de Nínive (placa D)

Figura 72 - Relevos da passagem ao Templo de Ištar do Palácio Sudoeste de Nínive (placa E)

Figura 73 - Relevos da passagem ao Templo de Ištar do Palácio Sudoeste de Nínive (placa F)

Figura 74 - Relevos do corredor R do Palácio Norte de Nínive (placas 6-5) ...................... 234

Figura 75 - Relevos do corredor R do Palácio Norte de Nínive (placas 4-3) ....................... 234

Figura 76 - Relevos do corredor R do Palácio Norte de Nínive (placas 2-1) ...................... 235

Figura 77 - Relevos do corredor R do Palácio Norte de Nínive (placas 28-27) .................. 236

Figura 78 - Relevos do corredor R do Palácio Norte de Nínive (placas 26-25) ................... 236

Figura 79 - Relevos do corredor R do Palácio Norte de Nínive (placa 23) ......................... 237

Figura 80 - Relevos da sala A do Palácio Norte de Nínive (placas 14-16) ......................... 238

Figura 81 - Relevos da sala S do Palácio Norte de Nínive (placas 14-13) ........................... 239 
Figura 82 - Relevos da sala S do Palácio Norte de Nínive (placas 12-11) ......................... 239

Figura 83 - Relevos da sala S do Palácio Norte de Nínive (placas 11-10) ........................... 240

Figura 84 - Relevos da sala S do Palácio Norte de Nínive (placas 10-9) ............................. 240

Figura 85 - Relevos da sala S do Palácio Norte de Nínive (placa 6) ................................... 241

Figura 86 - Relevos da sala C do Palácio Norte de Nínive (placas 5-6) ............................. 242

Figura 87 - Relevos da sala C do Palácio Norte de Nínive (placas 7-8) ............................. 242

Figura 88 - Relevos da sala C do Palácio Norte de Nínive (placas 10-11) ......................... 243

Figura 89 - Relevos da sala C do Palácio Norte de Nínive (placas 11-12) .......................... 243

Figura 90 - Relevos da sala C do Palácio Norte de Nínive (placas 13) ............................... 244

Figura 91 - Relevos da sala C do Palácio Norte de Nínive (placas 13-14) ......................... 244

Figura 92 - Relevos da sala C do Palácio Norte de Nínive (placas 14-15) ......................... 245

Figura 93 - Relevos da sala C do Palácio Norte de Nínive (placas 15-17) ......................... 245

Figura 94 - Relevos da sala C do Palácio Norte de Nínive (placas 16-17) ......................... 246

Figura 95 - Relevos da sala C do Palácio Norte de Nínive (placas 20-21) .......................... 246

Figura 96 - Relevos da sala C do Palácio Norte de Nínive (placas 20-21) .......................... 247

Figura 97 - Relevos da sala C do Palácio Norte de Nínive (placa 22) ................................ 247

Figura 98 - Relevos da sala C do Palácio Norte de Nínive (placas 21-23) .......................... 248

Figura 99 - Relevos da sala C do Palácio Norte de Nínive (placas 22-23) ......................... 248

Figura 100 - Relevos da sala C do Palácio Norte de Nínive (placas 23-24) ....................... 249

Figura 101 - Relevos da sala C do Palácio Norte de Nínive (placas 25-26) ....................... 249

Figura 102 - Relevos da sala C do Palácio Norte de Nínive (placas 26-27) ........................ 250

Figura 103 - Relevos da sala S1 do Palácio Norte de Nínive (placa B, parte inferior) ........ 251

Figura 104 - Relevos da sala S1 do Palácio Norte de Nínive (placa D-E) .......................... 251

Figura 105 - Relevos da sala S1 do Palácio Norte de Nínive (placa A, parte superior) ...... 252

Figura 106 - Relevos da sala S1 do Palácio Norte de Nínive (placas B-C, parte superior) . 252

Figura 107 - Relevos da sala S1 do Palácio Norte de Nínive (placa E) ............................... 253

Figura 108 - Relevos da sala S1 do Palácio Norte de Nínive (placa A) .............................. 254

Figura 109 - Relevos da sala S1 do Palácio Norte de Nínive (placa A, parte inferior) ........ 254

Figura 110 - Relevos da sala F do Palácio Norte de Nínive (placa 1) ................................ 255

Figura 111 - Relevos da sala F do Palácio Norte de Nínive (placas 2-4) ............................ 255

Figura 112 - Relevos da sala F do Palácio Norte de Nínive (placas 5-6) ............................ 256

Figura 113 - Relevos da sala F do Palácio Norte de Nínive (placas 7-9) ............................. 256

Figura 114 - Relevos da sala H do Palácio Norte de Nínive (placa 7, metade inferior) ...... 257

Figura 115 - Relevos da sala H do Palácio Norte de Nínive (placas 8-9) ........................... 257

Figura 116 - Relevos da sala H do Palácio Norte de Nínive (placa 10) ................................ 258

Figura 117 - Relevos da sala L do Palácio Norte de Nínive (placa 9) ................................ 259

Figura 118 - Relevos da sala L do Palácio Norte de Nínive (placa 10) ............................. 259

Figura 119 - Relevos da sala L do Palácio Norte de Nínive (placas 11-12) ........................ 260

Figura 120 - Relevos da sala M do Palácio Norte de Nínive (placas 12-13) ....................... 261

Figura 121 - Relevos da sala M do Palácio Norte de Nínive (placa 17) ............................. 261 


\section{ABREVIATURAS}

AEC - Antes da Era Comum

b. - borda

BM - British Museum

CAD - Chicago Assyrian Dictionary

CDA - Concise Dictionary of Akkadian

EC - Era Comum

lit. - literalmente

r. - reverso

RINAP - Royal Inscriptions of Neo-Assyrian Period

SAA - State Archives of Assyria 


\section{SUMÁRIO}

INTRODUÇÃO ............................................................................................................................. 16

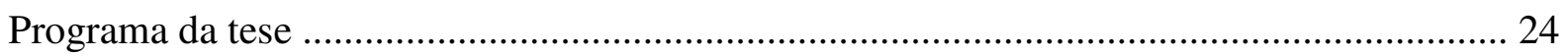

CAPÍTULO 1 - OS RELEVOS PALACIANOS EM CONTEXTO ................................ 28

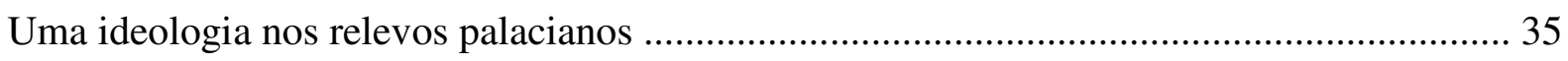

Crítica à noção de ideologia nos relevos palacianos .............................................................. 42

CAPÍTULO 2 - OS RELEVOS E TEXTOS NEOASSÍRIOS COMO FONTES ........... 49

Os relevos e textos como fontes palacianas ...................................................................... 49

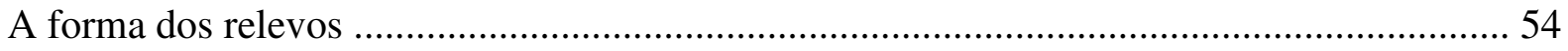

Os relevos dos palácios de Nínive: critérios de seleção ...................................................... 57

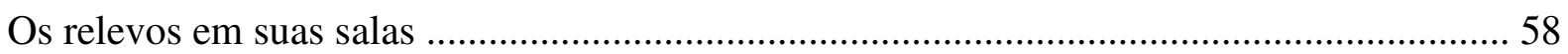

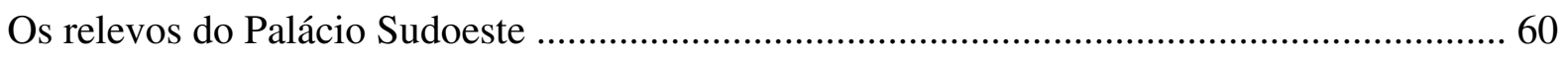

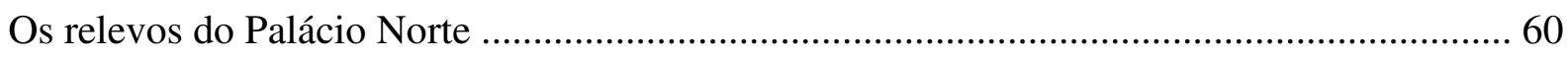

Aspectos narrativos dos relevos selecionados e os programas de suas salas ........................... 61

Textos e seu contexto: locais de achado, gênero e critérios de seleção .................................. 79

Complementaridade das fontes para o estudo das expressões corporais ............................... 82

CAPÍTULO 3 - ASPECTOS CORPORAIS NOS RELEVOS NEOASSÍRIOS .............. 90

Estruturas e princípios expressivos dos relevos palacianos ................................................. 90

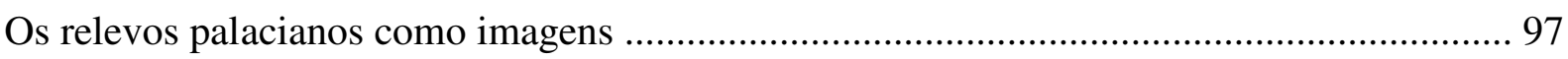

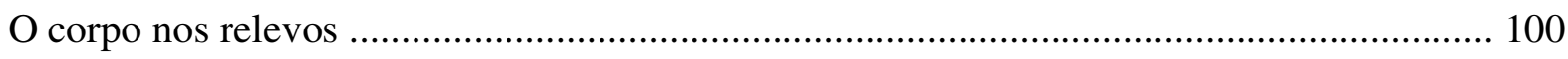

CAPÍTULO 4 - O CORPO EM TEXTOS DO PERÍODO NEOASSÍRIO ................... 124

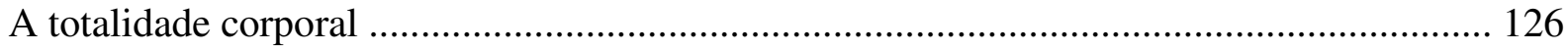

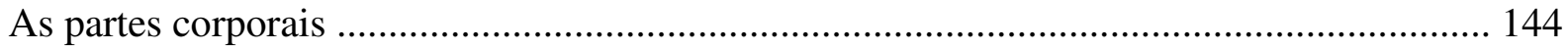

CONCLUSÃO - CONCEPÇÕES DE CORPO: ENTRE MATERIALIDADE, TEXTUALIDADE E CORPOREIDADE ................................................................ 169

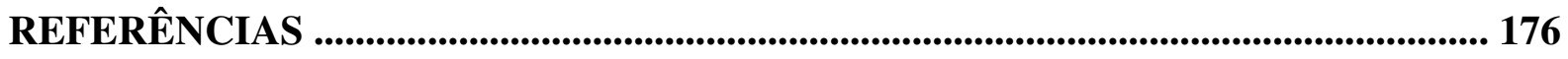

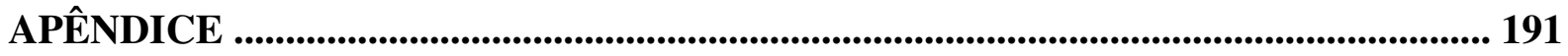




\section{INTRODUÇÃO}

Nesta tese, busco examinar e compreender as concepções de corpo na Assíria do fim do século VIII (704) e do século VII AEC. (até 630). As concepções de corpo nesse recorte temporal e espacial são vistas a partir da análise dos relevos dos palácios da antiga cidade de Nínive, especificamente dos reis Senaqueribe e Assurbanipal II. Além dos relevos, são analisados alguns textos do período Neoassírio, como Inscrições Reais, cartas, tratados e textos literários.

O tema da pesquisa, concepções de corpo, implica uma noção de concepção definida por um fenômeno referente a um tipo de experiência vivida, de pessoas num dado lugar e época. Esse fenômeno pode ser estudado, na pesquisa historiográfica, por meio de indícios e marcas que estão nas fontes do período. Em seu capítulo sobre as concepções de corpo na cosmologia e "ciência" astral mesopotâmica, Ossendrijver (2016, p. 143) tinha como objetivo "caracterizar as representações corporais das entidades celestiais e reconstruir algumas concepções subjacentes". Na visão do autor, uma definição de corpo (ou corporalidade) útil ao estudo dos astros celestes "é uma entidade em um sentido literal como pertencente a corpos de seres animados e objetos inanimados como uma extensão espacial, percebida ou imaginada, no mínimo em duas dimensões”. A partir do exemplo desse estudo, a concepção de corpo pode ser considerada algo subjacente a uma manifestação de aspectos corporais em um dado tipo de fonte. Já com as considerações de Nyord (2012, p. 166), interessado nas concepções de corpo em textos egípcios, há certas "dicas" que relacionam o corpo e suas partes a um "mundo conceitual", relacionado a "experiências mais imediatas do corpo humano em uma dada cultura". Portanto, a partir desses dois exemplos, as concepções de corpo são o resultado da percepção e da compreensão do corpo humano em um dado momento e lugar.

Além de serem o objeto principal examinado na pesquisa, o corpo e suas concepções são considerados como um "laboratório" analítico, no qual, através das manifestações corporais encontradas nas fontes de cultura material (os relevos palacianos) e em textos, é possível também compreender do papel social da imagem e da textualidade no período Neoassírio.

Os baixos relevos dos palácios assírios compõem o universo documental de estudos sobre diferentes temas: arte e estética, ideologia política e propaganda régia, belicosidade etc. Além de poderem ser focalizados em seus aspectos iconográficos e simbólicos, os relevos são 
produtos imagéticos que são investigados sob a ótica da função das imagens naquele contexto social específico. No período Neoassírio (934-610 AEC), os relevos nos palácios foram amplamente utilizados, fato que sustenta explicações sobre suas possíveis funções ideológicas, pois grande parte dos motivos reconhecidos remetem a aspectos centralizados no rei, principalmente num contexto bélico (cf. Capítulo 1). Ao lado das Inscrições Reais encontradas especialmente nos ambientes palacianos, os relevos são a imagem ou a narrativa do Império Assírio.

Contudo, na literatura especializada sobre esse tema no contexto assírio, a função social dos relevos é vinculada somente à ideologia e propaganda régia, ao lado da consideração da materialidade subserviente à textualidade. Isso significa que os modos de compreender a cultura material são vinculados ao tratamento comum destinado à análise textual. Esse perfil interpretativo apresenta uma apreensão parcial do papel social dos relevos e da materialidade e textualidade no contexto tratado ${ }^{1}$. Considerando os relevos como imagens, essa vertente pouco explora e problematiza os modos de se compreender uma imagem. As placas esculpidas das paredes dos palácios assírios são imagens em relevo, destacando-se da platitude e feitas em pedra; contêm pessoas, paisagens, vegetação, animais, objetos, instrumentos, veículos, alimentos; possuem temas ou motivos, vinculados à colheita, construção, cerimônias, caçadas, guerra; constituíam as paredes das salas de palácios, seguindo determinada ordem; algumas possuíam inscrições textuais; possivelmente, eram objeto de "decoração" e de registro histórico; eram "assistidas tacitamente" por determinado grupo autorizado a circular nas dependências palacianas. Esses elementos devem ser entendidos em conjunto para uma compreensão ampliada do papel social (ou agência) desses relevos. Em especial, as pessoas, seus corpos, suas roupas e instrumentos podem ser considerados vetores para examinar as concepções de corpo à época.

A historiografia sobre a Mesopotâmia é um campo de pesquisa marcado por propostas de cerne político ${ }^{2}$ e ancorado em análises somente de fontes escritas e oficiais, também tradicionais do tratamento filológico da Assiriologia. No entanto, novos temas têm sido despertados pelos pesquisadores, como aqueles focalizados em aspectos estéticos (ou artísticos). Essas vertentes de pesquisa têm contribuído para uma compreensão mais ampla do universo mesopotâmico, sobretudo a partir da articulação entre diferentes aspectos culturais

\footnotetext{
${ }^{1}$ Essas críticas são desdobradas por Bachelot (2014), sobre a limitação do estudo das imagens no período antigo.

${ }^{2} \mathrm{O}$ mesmo parece ser válido para outros estudos da Antiguidade (OSBORNE, 2010, p. 35-36).
} 
da época. Nesse percurso, temáticas relacionadas à sensorialidade e ao corpo têm surgido como problemáticas de pesquisa muito recentemente e ainda são pouco exploradas ${ }^{3}$.

A atenção dada à cultura material ao longo do desenvolvimento contemporâneo da historiografia solicitou também a aproximação de novas abordagens metodológicas. Nessa tese, são mobilizados e articulados, mesmo que sem esgotamento, repertórios e interesses da historiografia sobre a Assíria do primeiro milênio AEC, Estudos de Cultura Material, História do Corpo e Arqueologia Cognitiva.

Além disso, essa articulação entre campos é expressa no tratamento das fontes. Para ser objeto de análise historiográfica, as concepções de corpo necessitam ser reconstruídas por fontes que nos aproximam indiretamente de uma experiência específica: a experiência corporal é imediata, sendo sua identificação espaço-temporal imprecisa (VAN DER LEEUW, 1992). Nesse processo de localização e reconstrução de indícios corporais nos relevos palacianos e nos textos, pode-se revelar as concepções de corpo, pois a corporalidade pode ser considerada "o lugar de convergência da cultura e da individualidade" (BAHRANI, 2001, p. 40).

A identificação das concepções de corpo em textos e imagens do período Neoassírio atrela-se ao perfil das fontes. Os registros em materiais escritos atendem a um gênero textual, sendo uma forma de construir o sentido da mensagem de acordo com a intenção de quem escreve, em determinado contexto e seguindo eventuais normas e estilos aceitos pelos seus pares. Por um lado, os gêneros textuais podem apresentar uma reflexão direta sobre uma concepção de corpo. O corpo pode ser o próprio objeto que produz um dado gênero textual: esse é o exemplo de textos de tipo "médico", que focalizam direta ou indiretamente uma realidade corporal. Por outro lado, a concepção de corpo pode estar presente na textualidade, aparecendo especialmente pelas menções ao corpo, com palavras específicas ou com a mobilização de linguagem figurativa. No entanto, mesmo presente nessas situações, ela não é o foco principal do conteúdo do texto. Os textos provenientes da Mesopotâmia, especialmente da região assíria da metade do primeiro milênio AEC, abundam em ocorrências de aspectos corporais, mas tais textos não contêm uma explicitação ou reflexão de qualquer concepção de corpo.

Os elementos ou aspectos corporais são identificáveis em palavras ou em imagens, mas essa identificação pode não ser dada numa primeira abordagem às fontes. A forma dos

\footnotetext{
${ }^{3}$ Boivin (2008) apresentou proficuamente um rol das novas problemáticas de pesquisa relativas à materialidade $\mathrm{e}$ ao corpo, na intersecção entre ciências humanas e ciências naturais. Ver também Boivin et al. (2007), Bachelot (2014) e Nadali (2014).
} 
objetos ou o conteúdo dos textos direcionam o foco de atenção para um sentido pretendido. Os textos têm um conteúdo a transmitir e os relevos palacianos uma cena ou evento a apresentar imageticamente. Nessa linha, as referências corporais ficam em camadas do próprio documento que, em conjunto, o formam e contribuem à realização de sua função final. Então, pode-se ter um reconhecimento imediato da presença do corpo nos textos e nas imagens, ou uma identificação posterior da mesma presença, que não foi percebida no primeiro contato. Isso pode ter relação com as propriedades dos tipos documentais. Nos textos, podem ser usadas palavras referentes ao corpo de maneira metafórica, que fazem perder a referência direta da palavra à dimensão corporal (cf. Capítulo 4). Na cultura material, o primeiro impacto perceptivo é a totalidade do objeto com a qual se tem o primeiro contato, o que toma toda a atenção de quem o vê. No todo ou em partes, essa totalidade da forma é dada pelos aspectos corporais. Então, se no primeiro contato o que chama a atenção é a forma, o corpo presente nela fica "obscurecido".

Além disso, no contato com a documentação, o sentido de uma concepção de corpo é construído na aproximação entre o corpo que a percebe e o corpo que é percebido na fonte. De acordo com R. Porter (2011), “os corpos estão presentes para nós apenas por meio da percepção que temos deles” (p. 301). Assim, o tema concepções de corpo em imagens e textos envolve os indícios corporais nesses tipos de fontes, assim como, através desses mesmos indícios, o corpo que interage (ou interagia no contexto histórico assírio) com esses documentos.

Do ponto de vista historiográfico, tal relevância dada ao corpo como tema de pesquisa fez parte de uma disposição teórico-metodológica, possibilitada a partir do interesse dedicado pelos historiadores do movimento dos Annales, e pela atenção à cultura material. O processo de abertura da historiografia passou do trato com fontes escritas e do tradicional privilégio aos acontecimentos políticos a uma história enquanto projeto investigativo também atento aos seres humanos, à sua sensibilidade, à materialidade e ao corpo (LE GOFF; TRUONG, 2003, p. 23-24) ${ }^{4}$. Com relação ao corpo como tema de pesquisa, R. Porter $(2011$, p. 301) defende que "devemos enxergar o corpo como ele tem sido vivenciado e expresso no interior de sistemas culturais particulares, tanto privados quanto públicos, por eles mesmos alterados através dos tempos". A "Nova História” estimulou a promoção de investigações para tratar os "significados simbólicos do corpo [...] como contextualizado no interior de sistemas de

\footnotetext{
${ }^{4}$ Consequência desse interesse ao corpo foi a produção dos volumes História do Corpo (2012), organizados por Alain Corbin, Georges Vigarello e Jean-Jacques Courtine e, mais recentemente, História da Virilidade, também sob cuidado dos mesmos autores.
} 
mudança social" (PORTER, R., 2011, p. 300). Nesse meio, a cultura material tornou-se fonte numa ampliação de tipos documentais utilizados, que levou em consideração aspectos mais próximos da materialidade e relativos à corporalidade: hábitos de vestir-se, de alimentar-se, de gostar, de sentimentos, de preparação técnica ou tecnológica etc. (PESEZ, 1993).

No entanto, ampliação dada pelos Annales com relação ao uso e entendimento da cultura material acabou por "abstralizar" os mesmos. Isso significa que eles foram recrutados e mobilizados nas pesquisas, em meio ao alargamento de possibilidades temáticas, mas tenderam à abstração pelo seu tratamento como materiais a serem lidos e analisados como textos (BOIVIN, 2008, p. 43). Além disso, os materiais não foram considerados como algo de primeira ordem da operação analítica, o que manteve os aspectos corporais nas fontes distantes do campo de observação. Mesmo que a materialidade fosse convocada, havia ainda uma dicotomia: a vestimenta em si estava distante do hábito de vestir-se, o alimento (e sua preparação gestual, podendo ser pensada à maneira de Marcel Mauss ${ }^{5}$ ) estava distante do gosto, o objeto distante da técnica de produção e uso etc. Então, houve uma atenção à cultura material, mas não num nível de sua mobilização enquanto documento, enquanto instrumento que poderia relevar indícios de uma experiência humana. Os modos de concepção de corpo, por exemplo, relacionados às práticas corporais e esportivas, aos ideais de beleza e métodos ortopédicos, às condutas morais relacionadas às posturas e condicionamentos corporais, às exigências sociais ditas femininas e masculinas, foram bem localizados nas pesquisas ${ }^{6}$. No entanto, novamente, foi realçada a presença dessas concepções no ideário de determinados recortes históricos, especialmente a partir de documentação textual, mas aquilo que de fato é físico do corpo, pouco apareceu (REDE, 2012, p. 143). Como argumenta R. Porter, esse é “o problema de inserir a história do corpo a uma história das ideias ou das mentalidades (representações de corpo diferentes de outras representações), explicando essa história a partir das representações no discurso, um caminho de base textual" (2011, p. 302). O autor ainda defende e apresenta que faz parte das tradições interpretativas a prioridade dos significados mentais e ideais em detrimento aos aspectos materiais, corporais e sensuais (p. 298). Isso é tanto uma marca da contribuição cartesiana do esquema hierárquico corpo e mente (MESKELL, 2000, p. 15), como de influências clássicas e judaico-cristãs (PORTER, R., 2011, p. 298), especialmente da tradição filológica e exegética dos textos clássicos e bíblicos, herança carregada pela disciplina História Antiga (VLASSOPOULOS, 2007).

\footnotetext{
${ }^{5}$ Cf. Mauss (2003).

${ }^{6}$ Cf. Corbin, Courtine, Vigarello (2012).
} 
Nessa linha, a atenção aos elementos materiais da produção humana ainda não contemplava todo o potencial da materialidade, ou essa ainda estava rebaixada ao modo interpretativo textual e linear, isto é, os objetos deveriam ser "lidos" e interpretados, como textos em coisas ${ }^{7}$. Paralelamente, o corpo era considerado um conceito visto a partir dos resquícios de determinada cultura, “[...] convocado como um objeto, uma coisa, uma metáfora para a sociedade [...]" (MESKELL, 2000, p. 13), e não como um meio de expressão de significados, nem como um traço relativo a uma experiência corporal, nem como indicativo da relação entre o corpo expresso em textos e imagens e a corporeidade que interagia com essas fontes. Dessa maneira, como afirma Meskell (2000, p. 20), os corpos tendem a ser considerados "inabitados e sem materialidade".

Uma historiografia atenta ao corpo tem seu caráter empírico ao envolver uma complexidade contextual (a dimensão social), e ao buscar ver, nas fontes, "os materiais disponíveis mais cotidianos e tangíveis" (PORTER, R., 2011, p. 304). Isso significa que a comunhão entre corpo e cultura material pode ser analisada ao se considerar os traços dos indivíduos nas coisas e nas práticas (MESKELL, 2000, p. 20).

Ao pretender analisar os aspectos corporais em fontes históricas, especialmente naquelas fontes visuais e imagéticas, implicam-se na pesquisa as concepções sobre as imagens. Uma tendência no tratamento (limitador) da imagem, por exemplo, a trata como "documento visual" e a coloca somente como objeto a ser classificado iconograficamente. Tal modo de proceder com esse tipo de fonte perde de vista não somente seu potencial de ser "vetor" de relações sociais, como também compreender o papel do corpo na forma de agente perceptivo, que concebe a imagem, ao mesmo tempo que é tal percepção e concepção que dão lugar e realizam a imagem no ambiente circundante ${ }^{8}$. Sobre a importância do corpo e dos sentidos como constituintes e constituidores do mundo cultural e social ${ }^{9}$, não somente o corpo, mas a materialidade é que pode permitir o exame da experiência passada, por ser "uma característica compartilhada entre os vivos e os mortos" (BOIVIN et al., 2007, p. 289). Como afirma Boivin (2008, p. 6), a materialidade "afeta o mundo social de modo real, não somente por causa de sua habilidade para agir como veículo de ideias e conceitos, mas também porque sua própria materialidade exerce força que, nas mãos humanas, torna-se uma força social". O mundo material está para além do verbal, "seu poder pode residir no fato de serem parte da dimensão sensível, da experiência e da emoção, em vez do mundo de conceitos, códigos e

\footnotetext{
${ }^{7}$ Cf. Boivin (2008, p. 10), Tilley (2008, p. 48), Meneses (2012, p. 247) e Rede (2012, p. 138-140). Sobre a sobreposição da lógica linguística ao estudo das imagens, ver, por exemplo, Courtine (2013, p. 11-46).

${ }^{8}$ Cf. Meneses (2012, p. 248-249), trazendo as contribuições de Hans Belting.

${ }^{9}$ Ver, por exemplo, Boivin et al. (2007).
} 
significações" (BOIVIN, 2008, p. 9). A imagética e a materialidade constituem a apropriação e a memória dos sujeitos, não descoladas de uma experiência vivida. Como aponta Courtine (2013, p. 43), "toda imagem se inscreve em uma cultura visual, e esta cultura supõe a existência junto ao indivíduo de uma memória visual, de uma memória das imagens onde toda imagem tem um eco". Entre o sujeito e a imagem, há um intermediário, um meio e suporte, tanto aquele da materialidade, como o corpo que interage com o ambiente e os objetos ${ }^{10}$.

O lugar do corpo em imagens e textos pode servir de guia: por um lado, "antes como meras 'ilustrações' do que como coisas a serem explicadas", a visualidade das imagens do corpo é uma evidência histórica em si, e não um reflexo de um significado prévio; por outro, na linguagem, refere-se ao corpo "como veículo para mensagens ocultas" sobre ele mesmo. Ambos os aspectos solicitam uma melhor integração de fontes escritas e textuais (PORTER, R., 2011, p. 328). "O corpo é o sistema de comunicações primário" com "seus códigos e chaves" (PORTER, R., 2011, p. 329), sendo necessário o cuidado para que a corporalidade, assim como a linguagem e a materialidade, não seja reconsiderada um receptáculo de significado, uma forma vazia ou um molde conceitual que recebe sentidos, mas sim considerar a corporeidade e a materialidade participantes na constituição do sentido.

Nesse sentido, é válido destacar que a forma de estudo do tema concepções de corpo é enriquecida não somente pelas compreensões advindas da área de cultura material, mas também pela noção de agência. Esse termo, uma tradução da palavra inglesa agency, tem sido utilizado para se referir aos objetos e coisas, portando o significado de um conceito operativo que compreende a "capacidade humana para uma ação motivada" (ROSS; STEADMAN, 2010, p. 1). Para além da consideração unívoca da agência como um atributo de pessoas e/ou dos objetos, a agência está distribuída e diluída nas relações sociais. A agência está na relação entre as pessoas e entre as pessoas e as coisas, pois é possível tratar de uma "interação agentiva" (FELDMAN, 2010, p. 150-151). A cultura material é um produto da experiência humana e, por essa razão, possui uma materialidade ancorada e correspondente a uma existência de sujeitos históricos, a qual, por assumir uma função social enquanto objeto, seja política, propagandista etc., pode ser vivida e compartilhada culturalmente por membros de uma sociedade em determinado período histórico. A experiência humana materializada perpassa o corpo. Nesse sentido, não é sem importância que o corpo e o movimento corporal são temas caros à abordagem da cultura material.

${ }^{10}$ Cf. Courtine (2003, p. 43-44), destacando também as contribuições de H. Belting. 
Uma parte considerável da cultura material é formada por objetos manipuláveis. Sua função social se estabelece, então, em uma relação imediata e direta com o corpo. Mesmo para os demais, cuja manipulação é casual e indireta, a relação com o corpo continua a ser fundamental, pois não se trata apenas de um contato físico imediato, mas também de articulações menos evidentes e que, no cotidiano, podem passar despercebidas, como, por exemplo, a disposição espacial dos elementos no ambiente frequentado pelo corpo. Certas situações diluem consideravelmente a percepção do vínculo físico, é o caso da articulação corpo-paisagem ou das relações em que os contatos são predominantemente visuais. No entanto, em todos os casos, o corpo se impõe como um balizador maior da experiência material do homem (do indivíduo, como da sociedade) e, por consequência, como variante importante do estudo antropológico (REDE, 2000/2001, p. 283).

Portanto, não considerar o espaço (com seus objetos) e os corpos como elemento significativo no dinamismo da realidade social ou marginalizá-los de alguma forma no fazer investigativo, a ponto de tornar passiva a materialidade, reforça um dualismo constante na perspectiva científica sobre o próprio ser humano. Nesse sentido,

a precedência e a ascendência do mental sobre o natural só pode ser, portanto, superada se aceitarmos que a própria formulação conceitual (de valores, significados etc.) se dá na interação com a materialidade e que, em um quadro de relações complexas, as capacidades de atuação não se limitam exclusivamente aos atores humanos. Também as coisas são dotadas de animação, também elas exercem força motriz, também elas atuam socialmente, conformando um quadro de referências, possibilidades e limites ao agente humano, independente de este ter consciência disso ou não (REDE, 2012, p. 145).

Em certas abordagens da dimensão corporal no contexto das sociedades antigas, há esforços investigativos relevantes, tanto sobre o contexto desta pesquisa ${ }^{11}$, como sobre outros da Antiguidade ${ }^{12}$. Recentemente, o corpo e os modos de expressá-lo também foram tema de Reuniões Científicas e Seminários de pesquisas $^{13}$. Contudo, as concepções de corpo em fontes

\footnotetext{
11 Ver Asher-Greve (1997), Bahrani (2001; 2008; 2014), Assante (2009), Couto Ferreira (2009), Steadman e Ross (2010), Bachelot (2014) e Nadali (2014).

${ }^{12}$ Ver Coakley (1997), Reale (2002), Baines (2007), Osborne (2011), Squire (2011) e Meskell (2014). Meister (2014) aponta um agrupamento dos estudos temáticos sobre o corpo na História Antiga, especialmente aquela desenvolvida na Alemanha, com uma breve interconexão com a História Cultural. Entre os autores e obras mencionados, vale destacar: Bodiou, Frère e Mehl (2006), Cleland, Harlow e Llewellyn-Jones (2005), Corbeill (2004), Dasen e Wilgaux (2008), Garrison (2010), Moreau (2002), J. Porter (1999) e Post e Wilgaux (2006), Montserrat (2011).

13 Ver, por exemplo, o simpósio internacional "Figure del corpo nel mondo antico", realizado no Palazzo Massimo (Roma, Itália), em novembro de 2016; o seminário interdisciplinar de pesquisa "The individual and his body in the Ancient Mediterranean Basin”, organizado por Alice Mouton (UMR 8167 - CNRS, Paris, França), de 2016 a 2018; e também o ciclo internacional de conferências "Bodies in Stone and Clay: Perception and
} 
provenientes da Assíria, sejam imagens ou textos, ainda não foram objeto de um estudo especializado.

\section{Programa da tese}

A pesquisa desta tese nasceu pelo interesse nos aspectos corporais das imagens dos relevos palacianos neoassírios. Algumas considerações sobre o estatuto ou a ontologia das imagens neste recorte espaço-temporal indicaram a relação entre materialidade (e sua agência) e a textualidade em alguns tipos de suporte. Por mais que a interação entre texto e imagem no caso dos relevos apareça ao mesmo tempo mais restrita e mais realçada quando compartilham o mesmo suporte (relevos com inscrições), como o tema de estudo é as concepções de corpo, fontes textuais do mesmo período serviram como paralelo e subsídio à análise das imagens dos relevos, mesmo que não necessariamente se cruzem no mesmo suporte material. Há relações de conteúdo e de contexto histórico entre cenas nos relevos e outros documentos textuais, como é o caso das inscrições reais. Nesse sentido, há uma ênfase nos relevos palacianos, mas os textos seguiram uma forma de análise específica com vistas a compreender as concepções de corpo no período.

A estrutura da tese foi construída em quatro capítulos mais uma conclusão. Nesta Introdução, a tentativa de um panorama amplo sobre o tema e o objeto da pesquisa serve ao que é mobilizado ao longo da tese, focalizando no período Neoassírio e nas fontes imagéticas e textuais. No Capítulo 1, uma contextualização desse recorte histórico é feita, levando em consideração os aspectos do desenvolvimento da Assíria e retomando brevemente elementos do período anterior, a época Médioassíria. Essa etapa possibilita a discussão com a literatura e a localização de algumas tendências quase explicativas e de definição conceitual sobre o tema. São retomados sinteticamente os elementos conhecidos da política de expansão imperial assíria, os fundamentos da chamada ideologia real, de cunho bélico e imperialista, e seus usos historiográficos nesse recorte de pesquisa. Contudo, os aspectos contextuais levantados têm como eixo os relevos dos palácios assírios, principal motor do tema desta tese. Assim, uma ponderação sobre o que se atribui como função social dos relevos palacianos é objeto de revisão no primeiro capítulo. São realçados elementos pouco considerados no tratamento dos relevos palacianos, os quais podem ser agrupados na noção de materialidade. Então, com essa

Images of Living Beings in Mesopotamia”, organizado por Laura Battini e Anne-Isabelle Langlois (UMR 7192) e realizado em novembro de 2017 no Collège de France, em Paris, França. 
análise crítica - breve, conceitual e historiográfica - atende-se ao princípio de "desdocumentalização" (MENESES, 2012) inicial para a pesquisa, que está mais bem explicitado no segundo capítulo.

O Capítulo 2 é configurado pela dimensão teórico-metodológica no que se relaciona às fontes materiais e textuais. Também são apresentados os critérios de seleção dos relevos e dos textos. Houve a oportunidade de se observar e fotografar alguns relevos nos museus British Museum (em Londres) e Pergamonmuseum (em Berlim). Preferencialmente, foram utilizadas as imagens fotografadas, seguidas das imagens oferecidas pelos bancos de dados dos museus e, por fim, pelas imagens disponíveis nos catálogos impressos. Todas as imagens utilizadas compõem o Apêndice desta tese.

Os textos foram lidos a partir de edições recentes, como o State Archives of Assyria (SAA) e o Royal Inscriptions of the Neo-Assyrian Period (RINAP). A partir dessas edições atualizadas da documentação escrita, foi possível selecionar os textos pelo seu conteúdo, buscando referências a aspectos corporais.

Por fim, ainda no Capítulo 2, os lugares dos relevos nos ambientes palacianos e seus aspectos narrativos foram apresentados, com base nas imagens selecionadas para a análise. As considerações sobre a complementaridade entre as fontes imagéticas e textuais encerram esse capítulo teórico-metodológico.

Os próximos dois capítulos são constituídos pelas análises focadas no objeto de pesquisa (concepções de corpo), articulando os relevos (Capítulo 3) e os textos (Capítulo 4). No terceiro capítulo, é feita uma consideração a respeito da noção de imagem no contexto mesopotâmico. Em seguida, são elencados os aspectos corporais nos relevos, partindo dos elementos básicos da escultura e depois aos usos do corpo em imagens.

Já no Capítulo 4, a análise dos textos parte das ocorrências ao corpo como uma totalidade e, em seguida, às menções às partes corporais. Os textos do período Neoassírio foram escritos utilizando o sistema de escrita cuneiforme e a língua acadiana. Nesse Capítulo 4, foram mobilizados alguns recursos de formatação de texto convencionados na Assiriologia para indicar palavras do idioma acadiano ${ }^{14}$. As palavras nessa língua aparecem em itálico. Em alguns trechos dos textos, na sua forma original escrita em tabletes de argila, há o uso de sinais que correspondem a sílabas, enquanto outros correspondem a palavras de uma outra língua tradicional na região: o sumério. A utilização da língua suméria é através de sinais cuneiformes logogrâmicos. Nesse caso, cada sinal do sistema de escrita, em vez de expressar

\footnotetext{
${ }^{14}$ Essas convenções foram mantidas dentro do sistema brasileiro de formatação de trabalhos acadêmicos (da Associação Brasileira de Normas Técnicas - ABNT).
} 
uma sílaba, expressa uma palavra integral do sumério. Essas palavras aparecem escritas em letras maiúsculas. No caso citações inteiras dos textos do período, foi mantida a sua forma de escrita transliterada e silábica, correspondente a cada sinal utilizado no original. Por exemplo, a palavra acadiana $q \bar{a} t u$, que significa mão, era escrita com sinais cuneiformes silábicos, $q \bar{a}-$ $t u$, ou com o sinal logogrâmico sumério ŠU.

Há também algumas poucas ocorrências de palavras próprias do idioma sumério; nesses casos, elas aparecem em letras minúsculas, mas com um espaçamento entre caracteres expandido (por exemplo, igi, olho). Em alguns casos, aparecem números subscritos junto às sílabas. Eles significam que o sinal correspondente àquela sílaba está numa frequência de sinais diferentes para a mesma, estando então na posição indicada pelo número. Por exemplo, o sinal cuneiforme $s u_{2}$ corresponde ao segundo sinal mais frequente para a sílaba ou fonema $s u$. Sílabas sem essa indicação numérica subscrita referem-se a um sinal único ou ao mais frequente para aquele caso.

Nas menções aos textos, aparecem nomes de pessoas, especialmente dos escribas que produziam os textos, de príncipes e reis. Esses nomes são escritos em sua forma acadiana normalizada, isto é, não são divididos em sílabas - e não aparecem em itálico. Muitos desses nomes são compostos por mais de uma palavra (por exemplo, o nome do escriba Mar-issar). Para nomes mais recorrentes, são utilizadas preferencialmente as formas convencionadas para a língua portuguesa, muitas vezes baseada nas traduções dos textos do Antigo Testamento bíblico, onde os mesmos nomes aparecem (por exemplo, Senaqueribe, Assurbanipal, Sargão). Alguns nomes de cidades também seguem esse padrão utilizado para nomes de pessoas, mas locais menos conhecidos aparecem aqui em itálico, assim como nomes de deuses. Um caso particular é formado pelas palavras Assur e Ǎ̌šur. Apesar de serem a mesma palavra, a primeira refere-se a capital assíria mais tradicional, enquanto a segunda indica o nome do deus patrono assírio. Somente nesse caso foi feita uma distinção gráfica entre uma mesma palavra. Além disso, a cidade Assur também aparece no texto bíblico do Antigo Testamento.

Com relação à pronúncia das palavras, há vocábulos do acadiano que apresentam fonemas diferentes, indicados por caracteres especiais. A letra $\check{s}$ é pronunciada como $c h \mathrm{em}$ chapéu $^{15}$. A letra h é falada como o duplo erre (r) em carro. A letra $s^{16}$ não possui correspondente na língua portuguesa, apesar de se assemelhar a pronúncia do duplo zê (z) na palavra italiana pizza. Já as letras $t$ e $q$, apesar de consideradas consoantes enfáticas no conjunto das línguas semíticas, podem ser pronunciadas normalmente, pois há uma

\footnotetext{
${ }^{15}$ Representação fonética [J].

${ }^{16}$ Representação fonética [ts].
} 
imprecisão maior com relação à sua pronúncia original ${ }^{17}$. Por fim, as vogais com um traço sobrescrito (chamado mácron), indicam uma pronúncia vocálica mais alongada, em dois tempos.

Ainda no capítulo 4, as referências aos dicionários de língua acadiana e às edições principais dos textos obedeceram a um sistema para indicar suas citações no capítulo. Começando pelos dicionários, o Chicago Assyrian Dictionary (CAD), composto de volumes para cada letra, aparece nas chamadas pela sua abreviatura, seguida da letra do volume correspondente e, separado por vírgula, da página onde se encontra o que foi mencionado no capítulo (por exemplo, CAD A, p. 1). No caso do Concise Dictionary of Akkadian (CDA), por constituir um único volume, aparece somente sua abreviatura e número de página (por exemplo, CDA, p. 1). Já com relação às edições dos textos, dos State Archives of Assyria (SAA), sua abreviatura aparece, seguida do volume (em algarismos romanos maiúsculos), número do texto e linhas (por exemplo, SAA X 1 1-2). Como os tabletes cuneiformes foram escritos em seus dois lados (anverso e reverso) e em suas bordas, todas e quaisquer linhas que não sejam do anverso são indicadas por uma abreviação para reverso (r.) e para borda (b.). Por fim, com relação às Inscrições Reais editadas pelos Royal Inscriptions of Neo-Assyrian Period (RINAP), as chamadas aos trechos aparecem pela abreviatura da edição, seguida de seu volume (3/1 ou 3/2), número do texto, coluna (se houver, em algarismos romanos minúsculos) e linhas (por exemplo, RINAP 3/1 1 i 1-2). Como muitos dos suportes dos textos apresentam danificações, nem sempre a reconstrução de sua configuração pode ser exata. Nesse sentido, em textos em que não se sabe precisamente qual seria a linha em sua versão original, são apresentadas nas edições a numeração das linhas a partir daquela que pode ser identificada como tal. Assim, para indicar isso, é colocado um apóstrofo após o número indicativo da linha (por exemplo, SAA X 13 ' $\left.-4{ }^{\prime}\right)^{18}$.

Por fim, a Conclusão da tese foi pensada com a finalidade de discutir a intersecção dos aspectos corporais em ambas as fontes (imagens e textos), sintetizando todos pontos resultantes das análises.

\footnotetext{
${ }^{17}$ No entanto, tendo vista as suas correspondências em outras línguas semíticas (como o hebraico), tende-se a adotar uma pronúncia mais uvular para $q$, e mais oclusiva retroflexa para $t$.

${ }^{18}$ Em alguns poucos casos, especialmente de inscrições reais, há mais de um apóstrofo. A adição desse sinal, após o primeiro, indica que há uma (nova) lacuna no objeto inscrito, e as linhas foram numeradas novamente após cada lacuna. Então, por exemplo, 1',' indica a primeira linha que pôde ser contada após a terceira lacuna no texto. Também nos trechos citados dos textos, há acréscimos e supressões marcados por colchetes e parênteses. O que está entre colchetes aparece nas edições publicadas dos textos; em parênteses estão acréscimos de interesse para a presente análise e compreensão. Supressões nos trechos que também ocorrem nos próprios tabletes inscritos são indicadas por três pontos entre parênteses; supressões adaptadas para a presente pesquisa figuram em três pontos entre colchetes.
} 


\section{CAPÍTULO 1 \\ OS RELEVOS PALACIANOS NEOASSÍRIOS EM CONTEXTO}

No fim do segundo milênio AEC, placas de pedra passaram a compor as paredes dos palácios assírios, contendo um trabalho de escultura em baixo relevo. O uso desses relevos foi continuado e recorrente por todo o período denominado Neoassírio (934-610). Esses painéis são um tipo de escultura que se destaca da platitude, contendo elementos ornamentais realçados em um plano de fundo, com mais ou menos saliência, o que favorece a presença de elementos de ambiente. Seu uso é comum em decorações arquiteturais e para narração figurativa (RELIEF..., 2008, p. 569).

Nos relevos, é possível localizar elementos individuais como também cenas em suas configurações. Os relevos possuem imagens de pessoas, paisagens, vegetação, animais, objetos diversos, instrumentos, veículos, alimentos; os motivos são vinculados à colheita, construção, cerimônias, caças, guerra e simbolismos apotropaicos. Há também ocorrências de inscrições monumentais nos relevos, visando, em alguns casos, um relato da cena como um todo e, em outros, especificar uma parte sua. Os componentes da imagem, individual ou conjuntamente, possibilitam o reconhecimento de topografia da paisagem, contextos da cena, dinâmicas de movimento (tempo e espaço) dos corpos, certas identidades étnicas e sociais. Os relevos constituíam as paredes das salas de palácios, seguindo determinada ordem, e eram setorizados, dentro e entre salas. Sua particularidade é de uma dupla possibilidade expressiva: a primeira é a escultura de uma cena narrada espacialmente, ou seja, a narração é exposta em uma ou mais placas de pedra; a segunda reside no posicionamento programado dos relevos nas paredes dos palácios. Essa característica expressiva torna claro que a percepção das placas depende da visualidade e do tipo de movimentação e circulação nas salas palacianas.

A escultura em baixo relevo também foi encontrada em estelas comemorativas obeliscos e portões entalhados (em suas partes metálicas). As figurações em relevo também apareciam quando da impressão em argila fresca dos selos cilíndricos. Contudo, no período Neoassírio, os relevos palacianos foram o tipo sistemático da escultura em pedra, dando-se nas principais capitais assírias.

Os baixos relevos parietais apareceram primeiramente nos reinados de Tukulti-Ninurta I (Tukulti-Ninurta, 1243-1207 AEC) e Assurnasirpal II (Aššūr-nāṣir-apli, 883-859) ${ }^{19}$, sendo que com esse último os relevos passaram a ser utilizados recorrentemente nas paredes dos

\footnotetext{
${ }^{19}$ As versões em acadiano dos nomes dos reis estão baseadas em Radner (1998).
} 
palácios $^{20}$. A opção pela escultura (em pedra) pode ser justificada pela maior durabilidade do material, além do que a Assíria, região localizada no nordeste da Mesopotâmia, estava próxima a montanhas, fonte rochosa ${ }^{21}$. Esta opção de suporte também não é estranha nem uma novidade: tendo a região pouca disponibilidade de recursos materiais básicos, era comum a importação de matérias primas ao longo dos milênios de sua história ${ }^{22}$. Então, o contexto político exterior - como em situações de exploração, de alargamento de fronteiras e de relações comerciais e diplomáticas - estimulou uma condição favorável ao desenvolvimento da utilização dos relevos (BACHELOT, 1991, p. 113).

Do que sabemos a partir das escavações arqueológicas conduzidas nos palácios, a maioria dos ambientes e salas contém relevos em suas paredes. Aliás, os relevos foram em grande medida os motivadores e definidores das escolhas e das rotas internas de escavação nos sítios das ruínas palacianas (READE, 2016, p. 12). Mais do que o palácio, a coleta das placas esculpidas e dos tabletes de argila escritos era o objetivo primário das delegações arqueológicas, pois esses objetos poderiam ser transportados às nações que patrocinavam as primeiras escavações na região. O foco estava mais nas placas esculpidas do que nos tabletes de argila, indicando a motivação no recolhimento de cultura material para preenchimento dos museus europeus.

Ao longo de sua história, especialmente em seus momentos imperiais finais, a organização geopolítica da Assíria foi encaminhada para a valorização, organização e centralização de certas cidades, incluindo seus palácios e templos, concentrando o poder na capital ou núcleo do império, polo de referência na relação às outras cidades (aliadas ou não) da região (PARPOLA, 2003, p. 100; RADNER, 2014, p. 103-104). De maneira geral, no início do desenvolvimento urbano em toda região mesopotâmica, especificamente na Baixa Mesopotâmia no terceiro milênio AEC, os templos foram as primeiras instituições centralizadoras de um poder social, religioso, político e administrativo (SALLABERGER, 2007, p. 265-269). A unidade palaciana surge e passa a ser utilizada estritamente para funções administrativas, tornando-se paulatinamente um núcleo monumental e institucional dos

\footnotetext{
${ }^{20}$ Cf. Winter (1993, p. 32; 2010a, p. 14); Cifarelli (1998, p. 210); Dolce (2004); Kertai (2014a, p. 708), é possível que esse uso tenha sido semelhante a um costume de empregado em monumentos sírios.

${ }^{21} \mathrm{O}$ nordeste mesopotâmico fica relativamente próximo às bases de duas cadeias montanhosas: a do Taurus, a norte e noroeste, e a do Zagros, a nordeste e leste. Russell (1987, p. 520; 522; 1991, p. 97-100; 265; 267; 277), Mooney (1999, p. 32) e Mitchell e Middleton (2002, p. 94) mencionam a extração de pedras em Balatai (moderna Eski Mosul), região aproximadamente a vinte quilômetros de Nínive, a região do monte Nipur (norte da Assíria) e Tastiate, próxima ao rio Tigres, para a a elaboração dos colossos e relevos palacianos. Sobre a constituição físico-química das pedras, ver Middleton (1998).

${ }^{22}$ Cf. Liverani (2016), mas a ausência pontual de certas matérias primas em cada local é contrabalanceada por movimentos humanos de organização, deslocamento e interação interregional (p. 45-70).
} 
reinados locais ou conglomerados. No primeiro milênio, mesmo os palácios na Mesopotâmia não sendo geograficamente centrais nas cidades, eles representavam uma centralização da atenção e do poder, ao lado dos templos (STONE, 2000, p. 244-248).

Os palácios eram os centros administrativos e a casa da corte e da realeza. Em quase cada ambiente do palácio, havia um conjunto de relevos com tipos de motivos diferentes. Paralelamente, conforme apontam Kertai (2014a; 2015a), Winter (2010b) e Nadali (2006; 2008; 2012; 2014), é possível diferenciar funções e modos de circulação de cada uma das salas ou de áreas a partir das quais o palácio era organizado. Os motivos dos relevos e os usos e ocupações das salas quase sempre se correspondiam (NADALI, 2006, p. 17). Por exemplo, todos os palácios continham uma sala retangular grande e alongada, onde se encontrava um patamar (uma espécie de degrau), sobre o qual devesse ficar trono do soberano. Nesse ambiente, era comum haver a "decoração" parietal com relevos com imagens bélicas, representando as conquistas (militares) assírias e a posição do rei. O desenrolar dessas imagens na cenografia era típico, conforme destacam Bachelot (1991, p. 111) e Nadali (2006, p. 17): havia uma preparação e marcha do exército à batalha, depois um ataque a uma cidade ou um momento de combate em ambiente aberto, e, por fim, a procissão do exército com prisioneiros e espólios em direção ao rei. Por ser uma sala do trono, o lugar destinado ao exercício do poder pelo soberano, a presença de motivos bélicos vincula-se ao destaque da guerra no âmbito real assírio. Então, a guerra como componente da atuação política assíria era registrada recorrentemente em imagens nos relevos palacianos - e em textos, como é o caso das Inscrições Reais. A guerra e a violência na documentação escrita do período também acompanham um discurso, com grande carga simbólica, de um "exercício do poder absoluto e sem igual" pelo rei (BACHELOT, 1991, p. 109). Em certa medida, as salas do trono com relevos fazendo referência a campanhas militares informam a realidade do império (p. 113).

Nesse tipo de relevo, também presente em outras salas dos palácios, há cenas de brutalidade. As batalhas guerreiras são reconhecíveis através de elementos mais ou menos evidentes ou de rápida localização visual: a presença de armas, de combate físico entre guerreiros, de corpos espalhados pela cena (em pé ou estirados ao chão), de caoticidade da dinâmica da cena etc. A brutalidade é vista pelas partes que vão além de cenas de combate convencionadas pelos elementos supracitados: paralelamente, nos relevos, há decapitações, empilhamento e contagem de cabeças, empalações, atropelamentos equinos, corpos caindo de alturas etc. Dessa forma, a presença de relevos nas salas de trono e nos outros ambientes palacianos, com cenas de conquistas assírias e ações bélicas, estava conectada ao ambiente político da Assíria, pela presença constante das guerras. 
A atividade militar compunha as estratégias utilizadas para a continuidade do desenvolvimento do núcleo assírio, desde o início de uma formação imperial (KUHRT, 2003, p. 479; RADNER, 2014, p. 106). A constante brutalidade do exército, e das ações reais relacionadas à guerra, é característica presente em fontes da região, sejam escritas ou imagéticas, desde o final do terceiro milênio AEC. O elemento bélico, brutal e guerreiro é eixo comum e conhecido da política do período Neoassírio, registrado também nas inscrições reais e nos motivos dos relevos palacianos.

Tal recorrência da guerra não foi somente uma expressão do período Neoassírio. Uma constante vigília bélica (GARELLI; NIKIPROWETSKY, 1982, p. 49; CHARPIN, 2000, p 822) marca a história da Assíria: desde o fim do segundo milênio, a região foi governada pelos arameus ${ }^{23}$. Em termos contextuais, há argumentos que defendem que o elemento disparador e influenciador da Assíria guerreira foi justamente a experiência de dominação aramaica (GARELLI; NIKIPROWETSKY, 1982, p. 49). Mesmo com essa imposição dos arameus sobre a Assíria, Charpin (2000, p. 822) realça que a região passou a se tornar mais destacada a partir dos governos de Assur-Uballit I (Aššur-uballiț, 1366-1330), Salmaneser I (Salmānu-ašarēd, 1274-1245), Tukulti-Ninurta I (1244-1208) e Tiglath-Pileser I (Tukultī-apilEšarra, 1115-1077). As características políticas principais que marcaram essa emergência da Assíria foram a concentração de terras férteis e próximas ao seu núcleo regional na cidade de Assur (Figuras 1-2) e a definição de rotas favoráveis ao comércio.

O que possivelmente favoreceu a manutenção de uma estrutura da Assíria durante os períodos de maior fragilidade política foram: uma força tradicional, com uma linha única de reis, provavelmente da mesma família; a centralidade política e religiosa, originariamente em Assur, incluindo a preservação de rituais e cultos da realeza; uso contínuo das inscrições e registros históricos (como aqueles de campanhas militares); e a formação de um conjunto de grandes cidades que constituem um núcleo geográfico assírio (Kalhu, Nínive e Arbela, Figuras 1-2) a partir do século IX AEC (KUHRT, 2003, p. 478). A Assíria mantinha modos próprios de elaboração de sua tradição escrita e em cultura material, mesmo sob influência mais ou menos forte dos arameus. O registro em inscrições reais e posteriormente nos relevos e a continuidade da prática escribal, seja de cunho administrativo, votivo, decorativo e divinatório, favoreciam a preservação da tradição e do conhecimento. Essa preservação estava ancorada na continuidade do uso escrita cuneiforme e da língua acadiana. Comparativamente, a prática documental aramaica era centrada no registro em tinta no papiro ou couro, ou até o

\footnotetext{
${ }^{23}$ Ver, por exemplo, a síntese panorâmica de Charpin (2000, p. 821-822).
} 
uso de cera em pranchas de madeira, todos materiais frágeis e dificilmente conserváveis perante às condições climáticas e de preservação da região (CHARPIN, 2000, p. 121).

Desde uma resistência bélica em momentos de submissão a uma atuação para a retomada de sua hegemonia, chegando ao ápice de dominação territorial, a sombra militar nunca deixava de estar presente durante a imposição da Assíria (BEDFORD, 2009, p. 36). Sua retomada de poder iniciou-se no começo do primeiro milênio AEC, primeiramente com Adad-Nerari II (911-891) e Tukulti-Ninurta II (890-884). No entanto, o governo de Assurnasirpal II, seguido por Salmaneser III (858-823), marcou o perfil de atuação da política assíria que durou até fins do século VII AEC. A ênfase nas ações estava na retomada de territórios perdidos - ou a reorganização de territórios recém ou anteriormente conquistados -, na criação de um sistema de controle de rotas comerciais e de comunicação (ambas mais ao norte da primeira capital Assur), visando o aumento do potencial econômico da Assíria, e no pagamento de tributos a partir do estabelecimento de províncias do império. Para Kuhrt (2003, p. 479), essas ações configuram o início de uma formação imperial. Ao retomar os territórios, pretendia-se não somente o crescimento econômico (para abastecer, por exemplo, a construção e manutenção das capitais e do exército profissional), mas também o retorno a uma ordem política que havia sido desestabilizada no período Médioassírio (BEDFORD, 2009, p. 41). Nesse sentido, as estratégias utilizadas pelo governo assírio envolviam investidas militares e caracterizaram-se singularmente pela brutalidade do exército, além de envolver a pilhagem e a deportação em massa de pessoas para outras cidades, estratégias que ganharam amplitude no decorrer do primeiro milênio. A intervenção militar e a organização do império pelo controle difundido passaram a ser multifacetadas de acordo com a necessidade. Foi no momento de aumento de destaque interregional dado pela reconquista e pela consolidação que houve um crescimento (e criação) de capitais, local de concentração de recursos humanos e materiais, muitos resultantes de deportações, pilhagens e espólios.

Então, o recorte cronológico da Assíria do início do primeiro milênio AEC pode ser esquematicamente caracterizado por: um período de recuperação (RADNER, 2014, p. 103) que vinha na passagem do segundo ao primeiro milênio, dada a presença de controle aramaico; a continuidade no desenvolvimento com a retomada do poder e de territórios e a consolidação dos mesmos (LIVERANI, 2016, p. 635), o que envolveu um expansionismo territorial inicial (JOANNÈS, 2002, p. 21; RADNER, 2014, p. 104), implicando a incorporação de novas cidades ao projeto assírio (RADNER, 2014, p. 104); um período de crise, aproximadamente entre 823 e 745 AEC, seguida de uma refundação ou novo movimento expansivo (JOANNÈS, 2002, p. 26; LIVERANI, 2016, p. 641; 647); e, por fim, 
um apogeu imperial (JOANNÈS, 2002, p. 29; LIVERANI, 2016, p. 655), especificamente no período da Dinastia Sargônida, marcado pela coesão e consolidação do projeto imperial (RADNER, 2014, p. 105). O fim do período Neoassírio é caracterizado pela supressão paulatina da Assíria pela Babilônia no final do século VII, encerrando a hegemonia assíria no primeiro milênio. Todas essas fases são permeadas por uma noção de império. Na fase de ápice da política assíria, a belicosidade e a monumentalização caracterizaram o momento.

O governo de Tiglath-Pileser III (Tukultī-apil-Ešarra, 744-727) foi um período que marca a relevância de um Império $\mathrm{Neoassírio}^{24}$, cujo ápice chegou a estender o território dominado e atingindo de Susa (antiga capital do Elam, atual Irã) ao Egito (CHARPIN, 2000, p. 823). A política militar continuou sob os mesmos princípios mais sofisticados, o que permitiu o desenvolvimento antes incipiente da deportação em massa e do domínio de outros grandes núcleos, como é o caso da Babilônia. Após seu período e daquele de seu filho sucessor Salmaneser V (725-721), deu-se início uma série de reinados chamados hoje de Dinastia Sargônida. Os quatro sucessores reais definidos dentro da dinastia foram Sargão II (Šarru-ukīn, 721-705), Senaqueribe (Sīn-ahḩe-erība, 704-681), Esarhaddon (Aššūr-ahuiddina, 680-669) e Assurbanipal II (Aššūr-bāni-apli, 669-627). Sargão II começou a construir uma nova capital, Dur-Šarrukin (atual Khorsabad, no nordeste iraquiano), deixando Kalhu, a cidade assíria principal desde Assurnasirpal II - sendo que este já havia deixado o núcleo tradicional e religioso de Assur dois séculos antes. Senaqueribe, que deu continuidade à obra de Sargão II, deixou Dur-Šarrukin e constituiu capital em Nínive (Nīnua), construindo um palácio entre 703 e 694, o conhecido "Palácio Sem Rival" (ekal šānina lā iš̂u), na parte

\footnotetext{
${ }^{24}$ Elementos definidores que marcam uma formação imperial assíria são debatidos na literatura. Charpin (2000, p. 823) menciona os aspectos sobre o início do império: reconquista territorial prévia, com consequente expansão, política militar, provincialização e estratégia de deportações em massa. Radner (2014) aponta a passagem de um império hegemônico que extrapola um poder regional em direção a uma extensão, implicando um tipo de relacionamento e organização de outros núcleos não centrais, a um império territorial, que envolve maiores investimentos em expansão, incorporação, transformação e sistematização. Para a autora, o aspecto temporal do desenvolvimento de um império é variável importante. Recentemente, Liverani (2017) pauta-se nos seguintes elementos para a compreensão de um império: uma missão ideológica clara, profundamente assumida e posta em prática, conquista e expansão territorial, submissão por conquista ou controle indireto, regime operativo de administração e uso de recursos materiais. Também em contribuição recente, Frahm (2017) destaca elementos de um mindset assírio que favoreceram sua configuração imperialista: um "senso de ordem" (p. 162, grifo meu), que vai desde a forma de escrita à organização administrativa provincial, envolvendo uma hierarquia de comando; e uma prática de apropriação, que comporta o comércio tradicional, o veio militar, com uso de violência, a concentração de materiais (frutos do mercado ou do espólio), a captação cultural, especialmente de origem babilônica. Além disso, a forma de dominação do Império Assírio pode ser caracterizada por um "modo de produção tributário" (diferentemente de um império comercial ou colonial, conforme Bang e Bayly, 2011, p. 6). Em termos gerais, período Neoassírio e Império Neoassírio não coincidem em termos de cronologia histórica. O primeiro termo pode abranger o desenvolvimento histórico-político prévio à ascensão e clímax imperial, além de ser utilizado para se referir a um estágio de desenvolvimento da língua acadiana. Já o segundo é configurado pelos debates que definem as características acima expostas e pode ser circunscrito, a depender do critério de evidência assumido, por um período mais restrito. Aqui, o termo Império é utilizado por melhor se aplicar ao projeto ou caso assírio, e permite qualificar a realidade contextual das fontes analisadas nesta pesquisa.
} 
sudoeste do monte Kuyunjik (na atual Mossul). Esarhaddon, filho de Senaqueribe, primeiramente foi colocado no trono da Babilônia, tendo dominado também o trono assírio em seguida. Seu reinado foi curto por conta de sua saúde frágil, sendo sucedido por Assurbanipal II, continuador do projeto imperial assírio e que estabeleceu um novo palácio em Nínive, na parte norte do monte principal.

Em síntese, no desenrolar inicial de uma formação imperial (KUHRT, 2003, p. 479), ações de cunho militar compunham as estratégias utilizadas para a continuidade do desenvolvimento do império ${ }^{25}$, militarismo marcado pela constante brutalidade do exército. Com o ambiente assírio funcionando em meio aos conflitos bélicos recorrentes, é possível notar que os palácios não se desvinculavam da guerra. Tal fato pode ser observado primeiramente pelas intenções do rei e, particularmente, pela "decoração" pelos relevos, que continham elementos bélicos. Então, isso leva a crer que a guerra é um elemento fundamental para a compreensão do contexto assírio. Como identificado por Rede (2018, p. 596), a historiografia sobre a Mesopotâmia também tendeu a apontar o elemento bélico, brutal e guerreiro como "[...] definidor do conjunto social assírio, patamar qualificador da política, da economia, das artes, da literatura, da religião e do próprio deus Assur".

Outros elementos também devem ser ponderados para uma compreensão do perfil imperial assírio. É fato a presença abusiva no uso da força militar no processo de expansão, mas não como seu sustentáculo principal. A sofisticação política da Assíria é emblemática, cujas inovações das tecnologias administrativas, estratégias de comunicação, uso da diplomacia através de tratados e o processo de "assirianização" compõem o grande quadro da estrutura imperial assíria, na qual o exército é um aspecto $^{26}$. A partir do início do primeiro milênio, a organização, o controle, as consolidações e coesões de territórios davam-se especialmente por meio de acordos ou tratados diplomáticos, que estabeleciam uma relação de troca, mesmo que desbalanceada, em favor da Assíria. Dessa maneira, o Império Assírio

\footnotetext{
${ }^{25}$ A saber, segundo Radner (2014), estratégia para expansão territorial e sua consolidação. Para a autora, há certa discussão na literatura a respeito da natureza do Império Assírio, em especial sobre se houve de fato ou não uma consolidação imperial. Nesse aspecto, há destaque para o envolvimento de uma concepção temporal (longevidade, estabilidade e manutenção) no âmbito investigativo sobre a estrutura dos impérios na história.

${ }^{26}$ Cf. Radner (2014). A assirianização pode fazer parte desse conjunto que caracteriza a política assíria, mas não pode ser considerada uma atuação unidirecional e acurada, nem uma iniciativa com resultados diretos e uniformes. Ao contrário, ela seria um processo obviamente intencional por parte do núcleo assírio, mas que deve ser visto como um mecanismo de contato intercultural. Nesse sentido, há em jogo a influência assíria - que também recebia influências babilônicas e sírio-hititas - e uma contrapartida aramaica, seja na língua certamente presente desde os períodos de supressão aramaica - como também pelo fruto do contato das deportações. Charpin (2000, p. 821) afirma que estas últimas "aceleraram uma 'aramaicização' da Assíria". Sobre o processo aramaicização da Assíria, ver Tadmor (1981). Argumentos e contextos específicos desses tipos de contatos estão, por exemplo, no volume 86 da revista Syria, de 2009, incluindo bibliografia geral ao final do volume (p. 159-178). Ver, em especial, Kepinski e Tenu (2009), Bunnens (2009), Rouault (2009) e MasettiRouault (2009).
} 
assumiu uma configuração ampla de um domínio relativo de territórios e com dois níveis principais de submissão: o acordo para o estabelecimento de uma província, que envolvia o pagamento de tributos por parte de um governante local; e via a organização sob gestão assíria, o que implicava a substituição do governo da cidade por um regente assírio.

\section{Uma ideologia nos relevos palacianos}

Com o ambiente assírio funcionando em meio aos conflitos bélicos recorrentes, é possível notar e entender a vinculação dos palácios à guerra: pela "decoração" pelos relevos, muitos com motivos bélicos, e por ser o centro da atuação do rei. A evolução no uso dos relevos ao longo do período Neoassírio pode ser vista atrelada ao exercício do poder e à carga simbólica do discurso a ele correspondente. Nas palavras de Bachelot (1991, p. 110), “o poder absoluto, a violência e a produção simbólica a partir dos baixos relevos aparecem como o produto, a consequência da ordem política bem como a representação, o reflexo das violências engendradas pelo exercício do poder". A “decoração" luxuosa e completa dos palácios, incluindo-se os relevos, pode ser considerada um programa, uma organização planejada e intencional, que formaria as características da cultura da realeza. Tal "luxo programado" podia contribuir, conforme Thomason $(2004$, p. 151-152; 157; 161), para a formação da identidade palaciana e imperial.

Essa formação da identidade a partir dos elementos bélicos, brutais e ostentatórios tem sido depreendida na literatura sobre o Império Assírio a partir de justificativas sobre sua função ideológica e propagandista ${ }^{27}$, que visava mostrar a brutalidade como forma de propaganda "psicológica" de terror (MILLER, 2009, p. 135), impondo a ideologia da Assíria guerreira (BAHRANI, 2008, p. 24; JOANNÈS, 2002, p. 42). As cenas e as inscrições em que é relatado o processo de construção dos palácios também são julgadas como ideológicas, ao realçarem o empenho colossal de recursos materiais e humanos nessas empreitadas. O registro do processo de construção, materializado pelo próprio palácio pronto, é visto por sua retórica

\footnotetext{
${ }^{27}$ A ideologia nos relevos e de todo exercício imperial Neoassírio compõe um argumento trazido de forma mais ou menos declarada e criticada por diversos autores, por exemplo: Reade (1979), Winter (2010a), Bahrani (1995), Cifarelli (1998), Lanfranchi (2000), Parpola (2003), Fales (2006), Nadali (2006), Takla (2008), Miller (2009), Parker (2011) e Liverani (2016). Algumas publicações nacionais se dedicaram à discussão sobre a ideologia no caso dos relevos palacianos assírios, especialmente em imagens envolvendo a guerra e a violência. Ver, por exemplo, Pozzer (2011; 2013), Marinho, Siqueira e Pozzer (2012), Pozzer e Santos (2012), Santos (2013a; 2013b) e Silva (2013). Uma discussão sobre os aspectos de uma ideologia e propaganda da realeza assíria presente nos textos do período está, por exemplo, no aparato introdutório e crítico das edições das cartas dos escribas feitas por Parpola (2014, SAA X) e de textos literários (LIVINGSTONE, 1989, SAA III).
} 
ideológica e impactante da superioridade do Império Assírio do primeiro milênio AEC (PARKER, 2011, p. 374) ${ }^{28}$.

A ideologia pode ser considerada um componente próprio de uma dinâmica imperial, ao lado da legitimação do poder e da autoridade de um soberano supremo (relacionado com a divindade) e da implementação de um sistema político-ideológico (PARKER, 2011, p. 358) ${ }^{29}$. A partir da disponibilidade de fontes e das análises sobre o desenvolvimento governamental no período Neoassírio, é possível observar, segundo Winter (1993, p. 31), uma retórica real, constituída por um conjunto de "atitudes em prol ao governo" e que permitem o acesso a "experiências de autoridade". Enquanto Winter (1993) focaliza tais experiências na construção e decoração dos palácios, a retórica real assíria é a portadora de uma ideologia. Nesse sentido, a força motriz seria a elite real, constituída pelos escribas especialistas e pela corte (eunucos, guardiões do palácio, cozinheiros, músicos, a família do rei e suas outras esposas), podendo ser considerada tanto interna à capital ou ao palácio, como provincial. Essa elite pode ser considerada a mantenedora do sistema ideológico, através da criação, sustentação e disseminação desse sistema (PARKER, 2011, p. 364; 368-372). Centrado na figura do soberano e implementado por uma corte real, o império consolidara-se, de um lado, por vias simbólicas e, de outro, pela presença bélica recorrente.

A trajetória da historiografia sobre os aspectos políticos da Assíria ${ }^{30}$ é marcada pela utilização de fontes escritas, incorporando gradualmente a cultura material. Nesse aumento de repertório documental, por vezes os relevos palacianos eram mobilizados para confirmar o conteúdo de textos. Contudo, ampliando a análise para além do nível textual, as imagens apresentavam particularidades que exigiam mais recursos compreensivos. Grosso modo, a ideologia pode ser considerada um fenômeno próprio das relações sociais, mas ela serviu como um recurso conceitual utilizado nas pesquisas sobre a história assíria. Nesse sentido, uma ideologia da organização política assíria não estaria arraigada somente em textos, mas também nas imagens do período. Essa tendência na historiografia foi acompanhada por desdobramentos de teorias na pesquisa arqueológica, apontados por Kristiansen (2009, p. 72-

\footnotetext{
${ }^{28}$ Os projetos construtivos materializados pelo exercício do rei foram analisados por Albenda (1986), Russell (1987) e Winter (1993) a partir da articulação entre texto e cultura material, fontes nas quais é declarada a importância de tais projetos no período.

${ }^{29}$ Parpola (2003, p. 101), Parker (2011, p. 364; 368-372), Radner (2014, p. 105; 109) e Pongratz-Leisten (2015) também argumentam sobre o papel da elite como influenciadora da expansão assíria.

${ }^{30}$ Destaca-se, por um lado, um grupo de publicações em torno das décadas de 1980 e 1990, concentradas na temática do Império Assírio (por exemplo, Reade (1979; 1981), Fales (1981), Tadmor (1981), Parpola e Whiting (1997) e a primeira edição italiana, de 1988, de Liverani (2016)). Por outro lado, são relevantes as publicações recentes e que possuem acesso a um maior conjunto de fontes editadas (principalmente escritas). Ver, por exemplo: Fales $(2001,2010)$, o volume organizado por E. Frahm, incluindo seu capítulo específico sobre período Neoassírio (FRAHM, 2017), Liverani (2017) e Radner (2014; 2015b).
} 
74). Assim, a ideologia não é só um fenômeno localizado no plano de ações abstratas, simbólicas, em discursos, mas é também atribuído a suportes, como a materialidade. Os objetos poderiam ser considerados meios singulares de veiculação ideológica, portando mensagens não-verbais, que não podiam ser transmitidas pelos textos, e favorecendo a realização da comunicação. Como descreve Marcus (2000, p. 2487),

\begin{abstract}
Materiais visuais têm um papel único na expressão da ideologia. A cultura material pode tomar a responsabilidade de carregar certas mensagens que a cultura não pode confiar à linguagem. A habilidade da arte e outros bens materiais de carregar mensagens de modo não verbal as torna meios especialmente sutis e furtivos para comunicar certas mensagens políticas potencialmente controversas, sem o risco de protesto, recusa ou controversa. Nesse sentido, eles podem tornar-se ferramentas poderosas de persuasão pelas quais um grupo de pessoas ganha a obediência de outros.
\end{abstract}

Conforme afirma Kristiansen (2009, p. 76), a ideologia é atrelada às intenções e escolhas deliberadas. Essas intenções permeiam as relações sociais de dominação (produção e reprodução dos meios de dominação). Tendo isso em vista, exige-se que as imagens e os artefatos documentais sejam considerados manifestações culturais e intencionais (ou seja, expressões de uma ideologia), por terem sido, assim como os textos, manipulados com uma intenção. A análise desses produtos é fixada no plano das estruturas de relações sociais de dominação, com o objetivo de identificar "as condições que governam as manifestações culturais [...]” (KRISTIANSEN, 2009, p. 77). Então, conectar as práticas culturais (como os artefatos e imagens) ao conjunto amplo de produção e reprodução material ajuda a explicitar como formas culturais/ideológicas "correspondem a suas funções materiais de reprodução" (p. 77). Portanto, como afirma Kristiansen (2009, p. 77), a ideologia

não é considerada como um reflexo passivo da sociedade, mas, ao contrário, um fato ativo que pode ser usado por indivíduos e grupos sociais em competição para estabelecer e legitimar sua dominância através de uma ideologia baseada na sociedade como um todo e expressada em símbolos, normas sociais, regras e rituais.

No início do período Neoassírio, a ideologia é reconhecida no modo de atuação imperialista da política da realeza. Uma marca dessa "missão ideológica" é encontrada nas fontes, como é o caso dos relevos palacianos. O registro histórico presente nesse tipo de escultura em pedra conteria uma ideologia através do realce de seus componentes figurativos, visando dar realismo à expressão visual. Dois exemplos, apontados por Battini (2016, p. 41) e Nadali (2016, p. 83), são a carga simbólica na imagem do rei, especialmente em sua posição 
espacial nas placas dos relevos, e a guerra como um tema banal nos mesmos. A aproximação entre as experiências vividas e o que está no relevo é o que permite um enraizamento ideológico mais efetivo. Gradualmente, o realismo era enfatizado e legitimado pela recorrência de imagens padronizadas, construindo uma unidade com o passado, uma tradição (MARCUS, 2000, p. 2488). A padronização de elementos da realidade não depende somente de aspectos relativos às técnicas escultóricas, mas também do uso de marcadores visuais repetidos, que favorecem a identificação de elementos tradicionais. Como no caso das cenas de batalhas, a posição e a dinâmica cenográfica do exército assírio, assim como os lugares do rei nas cenas de "acolhimento" dos resultados da batalha ou nas caçadas, são indícios que realçam a figura do rei e o reatualizam constantemente no cenário assírio real e figurativo.

O aumento do realismo (pela padronização de imagens da realidade vivida) e o uso da narratividade $^{31}$ ao longo da implementação dos relevos são os fatores que facilitam a compreensão, colaborando para reforçar a ideologia da realeza, em comunhão com os registros textuais (BACHELOT, 1991, p. 114). Outro fator implicado ao realismo e à ideologia assíria é a diminuição das referências mitológicas ${ }^{32}$ nas imagens. Tal indício pode ter relação com a "evolução do império", processo que exige um aumento da transmissão do conteúdo ideológico de acordo com a situação geopolítica (BACHELOT, 1991, p. 114). Nesse sentido, a maior extensão do império causa o aumento da heterogeneidade de um núcleo mental ${ }^{33}$, o que impõe a necessidade de "encontrar um meio para elaborar uma mensagem compreensível para um número maior de pessoas, de onde a evolução de uma arte que será além do simbólico, teoricamente difícil de interpretar, a uma anedota mais acessível a um público amplo" (BACHELOT, 1991, p. 115). No período Neoassírio, a dependência de figuras vinculadas a uma divindade poderia não funcionar como elemento de uma imagem a ser exposta num "mundo" ampliado pela expansão do império. O uso de um estilo narrativo para expressar visualmente imagens de uma experiência real poderia ser mais efetivo dada a concretude daquilo que é exposto.

\footnotetext{
${ }^{31}$ Esse é um termo recorrente na literatura ao se tratar da dinâmica visual do que é representado pelos relevos. O uso deste tipo narrativo nos palácios assírios relaciona-se com a presença de uma "narrativa histórica", envolvendo a representação de um único evento e com personagens participantes da cena. Esse estilo de representação também foi se desenvolvendo paulatinamente durante o período Neoassírio. As opções utilizadas para o registro escultórico das cenas são a sobreposição das pessoas representadas, possivelmente indicando distância em termos de perspectiva e profundidade; uso de bandas e faixas para diferenciar acontecimentos concorrentes; a dispersão de elementos pela placa, também como tentativa de expressar perspectiva.

32 Sobre os indícios mitológicos e religiosos, Kristianssen $(2009$, p. 76) menciona que a religião, atrelada a uma concepção mitológica de mundo, está relacionada a uma dinâmica ideológica. Marcus (2000, p. 2487) afirma que a dimensão religiosa é mais difícil de ser acessada, por atuar por meio de símbolos.

${ }^{33}$ Cf. Liverani (2016), que utiliza recorrentemente o conceito "mapas mentais".
} 
Então, é possível conceber que aquilo que era expresso nos relevos é ideológico pela seleção (intencional) do que é posto. Conforme afirma Marcus (2000, p. 2490-2491), o conteúdo estaria atrelado ao processo do próprio desenvolvimento imperial: seu estabelecimento e legitimação via a ação militar e os ganhos econômicos (os "frutos" da guerra). Ambos os elementos desse processo têm como eixo a figura do rei: é a partir dele que emana a aspiração imperialista e para ele (no centro do império) que os resultados chegam (BATTINI, 2016, p. 44).

A expressão imagética do rei e dos assírios é padronizada e alcançada também pela escultura de suas posturas corporais nas placas. A possibilidade de reconhecimento dos assírios implica a diferenciação destes com os outros, os não assírios. Pela representação assíria e de sua alteridade, é possível perceber marcadores corporais, indumentários e grupais de uma identidade assíria e não-assíria ${ }^{34}$. A presença de elementos tradicionais na figuração do rei faz parte de agrupamento de disposições visuais que caracterizaram a identidade assíria. Já a alteridade contrastante, os não assírios, são expressados na condição de prisioneiros, rendidos, depositantes de tributos, sujeitados à violência corporal ou ao controle numa procissão de deslocamento territorial. Eles não eram esculpidos de forma arbitrária, o que, por um lado, marca as diferenças para com o ideal assírio e, por outro, justamente realça a realidade da situação (MARCUS, 2000, p. 2492) ${ }^{35}$. Mesmo que seja possível localizar precisamente a cena no tempo e no espaço, a tentativa de esculpir a realidade atende a um realismo balanceado: não há benefícios distintivos particulares, como em representações corporais diferentes para distinguir - e privilegiar - de modo exacerbado uma visão de um grupo $^{36}$. Adicionalmente, mesmo sendo possível distinguir entre tipos diferentes de pessoas,

\footnotetext{
${ }^{34}$ Ver Cifarelli (1998).

35 Reade (1979, p. 333-334) apresenta uma categorização de outros (estrangeiros) que aparecem em fontes assírias, especialmente nos relevos. Sobre a representação de "outros" nos relevos assírios, ver, por exemplo, Reade (1998a), sobre árabes, e Albenda (1982), sobre egípcios. Sobre a relação entre formas e estilos de expressão que apresentam um tipo de influência interregional, ver Breasted (1932), Ataç (2006) e Feldman (2014). Sobre a noção de etnicidade no contexto mesopotâmico, ver Bahrani (2001; 2006), e para o caso assírio, ver Emberling (2014) e Feldman (2014). Para Rede (2018, p. 596), "a guerra e seus aspectos conexos - em particular, a crueldade sem limites - são apresentados como um forte componente étnico e 'nacional', inerente a uma Assíria marcial. A conquista sem fronteiras, o domínio severo sobre as regiões vizinhas e a repressão sangrenta de toda resistência ou rebelião formam o quadro que confere sentido a essa caracterização". Para o mesmo autor (p. 618-619), uma concepção binária constitui os lados de uma relação de oposição entre o interno (assírio) e externo (outro), seja no confronto bélico em si, ou na caracterização dos polos do bem e do mal, do espaço ordenado e do "selvagem", e do comportamento tido como não pertencente aos deuses reconhecidos. O modo de representar cidades e paisagens também permite não só uma precisão ou delimitação de um topos, mas também ao circunscrever o espaço e a paisagem assírios, já se delimita de um espaço diferente, habitado por outras pessoas, de fora, não assírios. Sobre a representação de paisagens e de outras cidades nos relevos palacianos, ver, por exemplo, Albenda (1972), Nadali (2006), Nadali e Rivaroli (2007) e Micale (2011). Sobre a expressão de uma cidade assíria nos relevos, ver Reade (1998b) e Nadali (2015) para o caso de Nínive.

36 Bachelot (1991, p. 111) destaca que, nos relevos, o rei "não se beneficia de algum tratamento particular, estatura, atitude ou lugar na cena mais vantajoso que as outras figuras".
} 
não se reconhece um rosto, como um retrato (READE, 1979, p. 331; BAHRANI, 2008, p. 97-

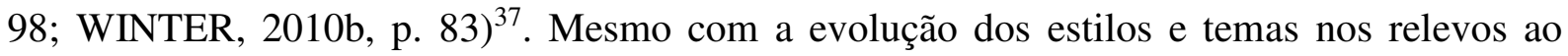
longo do período Neoassírio, do ponto de vista ideológico, a variação de figuras não indica uma alteração na configuração da ideologia evocada (READE, 1979, p. 331). Então, seria uma única ideologia, aquela atrelada à missão imperial assíria, que seria veiculada por meio dos relevos palacianos. Os diferentes motivos e estilos escultóricos estariam de acordo com a mensagem ideológica a ser divulgada.

Até aqui, a definição de uma ideologia dos relevos contém um corpus de sentidos (intencionais) veiculados por um suporte, especialmente material. A meta é a legitimação dessas intenções promovidas por um grupo de pessoas, principalmente em posição de poder político. Este é um lado da consideração ideológica a respeito dos relevos palacianos. O outro lado é a comunicação com aqueles que de algum modo receberiam a informação ideológica. Nesse sentido, é possível especular sobre a audiência dos relevos palacianos.

Havia uma audiência pretendida e uma audiência potencial dos relevos (FALES, 2006, p. 88-95; BAGG, 2016, p. 60). A primeira era composta pelos reis futuros, que viessem a ocupar os palácios, e os deuses, a quem a construção era dedicada e que eram convidados como visitantes quando da inauguração do monumento. Aos deuses também era destinada a atuação real, através do exercício e da concretização material do poder, respectivamente ao alargar as fronteiras do império e ao erigir novas construções. Nos relevos palacianos, eles são evocados na imagem em paralelo à figura do rei - através de seus símbolos. Além desse tipo de iconografia, uma relação entre o rei e o divino aparece nas figuras apotropaicas e nos colossos (os lamassû, em língua acadiana). As primeiras aparecem em relevos na forma de seres alados e antropomórficos; já os colossos são esculpidos em grandes pedras, tipicamente com corpo de touro, alado e com cabeça humana, e ficavam nas laterais de grandes entradas do interior palacianos. Os motivos apotropaicos dos relevos não teriam então somente uma função protetora, mas serviam para colocar o rei coligado à esfera divina - além de indicar a presença dos deuses no ambiente palaciano.

Ainda sobre a audiência divina, os deuses garantiam a realeza do rei, e este era, numa concepção mesopotâmica mais ampla, o guia e pastor da nação. Assim, por exemplo, o deus patrono Aššur não só designa a realeza, mas também acompanha os reis assírios em seu

\footnotetext{
${ }^{37}$ Por outro lado, os relevos foram objetos de danificação posterior após a invasão das capitais assírias. Um principal alvo foram os rostos das figuras dos reis. Sobre esse tema, ver Bahrani (1995). Sobre o aspecto referencial e performativo do corpo esculpido nos relevos palacianos, ver Bahrani (2008).
} 
exercício de governo (READE, 1979, p. 332). O exercício do poder e a religião têm como eixo a figura do soberano no ambiente palaciano (REDE, 2018, p. 620).

Dessa forma, a presença dos deuses seria múltipla: na materialização do palácio e do governo, na ação real, nos relevos e até como possíveis visitantes do palácio. Como afirma Rede (2018, p. 618), “[...] a ação mundana do rei prolonga a vontade dos deuses na Terra, reitera o embate mítico entre ordem e caos, fazendo da guerra a perfeita tradução, em seu cenário humano, dos planos divinos, mais universais, mais ancestrais e mais abstratos". Assim, nos termos de Liverani (2017, p. 41), dentre os canais de comunicação possíveis e estabelecidos entre os deuses e o rei, os relevos atuariam num nível de ritualização do exercício da realeza e da presença divina por meio da materialidade do espaço arquitetônico em que é realizado e das pessoas que viviam no lugar palaciano.

Com relação a uma audiência humana, o interior dos palácios é lugar obviamente restrito por sua dinâmica habitacional e administrativa. Poucos teriam acesso às salas e pátios internos. Logo, a efetividade ideológica do império poderia ser alcançada por aqueles poucos, mas em posições de destaque, que visitavam o palácio, ou pela exposição pública de outros monumentos, como estelas e pedras de fronteira, ou pela visualização do próprio palácio nas cidadelas assírias. Especificamente quanto aos relevos, por grande parte estar no interior da unidade palaciana, é possível depreender sua função interna e ritualística, visando a construção de uma imagem e de uma identidade unitária e leal do projeto assírio (MARCUS, 2000, p. 2491-2492). Seria uma resposta a um problema apontado por Reade (1979, p. 329): "como os assírios viam si mesmos e sua relação com o mundo exterior, e como eles desejam que o mundo exterior os visse". A ideologia pretendida atuaria mais no interior da comunidade palaciana, como uma "auto-simbolização", do que exteriormente.

Os palácios em si poderiam expor uma ideologia do poder monumental: "era o corpo massivo de propaganda pessoal" (READE, 1979, p. 331). A monumentalidade palaciana representava a centralização do poder e o lugar da realeza. Dentro do palácio, o que era mostrado nos relevos encontrava a realidade, como é o caso do rei expresso e presente nas salas do trono (MARCUS, 2000, p. 2492-2493; WINTER, 2010a, p. 15-16; 22-23; 2010b, p. 94). Bens luxuosos, "decorações" em pedra simulando tapeçarias ${ }^{38}$ e adornos corporais são outros exemplos de distinção de uma identidade interna da realeza e são sinais, conforme Marcus (2000), do fenômeno ideológico. Todos esses elementos confluem numa noção de centralidade: o palácio assírio estava no centro da Assíria, e essa era o centro do mundo.

\footnotetext{
${ }^{38}$ Ver, por exemplo, Albenda (1978; 1991).
} 


\section{Crítica à noção de ideologia nos relevos palacianos}

A consideração e a interpretação unívocas sobre uma ideologia e propaganda assírias são bastante revisadas pela literatura recente, que aponta também uma limitação desse tipo de interpretação do papel social dos relevos. Nesse sentido, a noção de ideologia dos relevos palacianos pode ser criticada pela sua consideração que, de um lado, reduz os relevos a veículos não textuais de mensagens e, de outro, desconsidera seu contexto. Primeiramente, é contestada na literatura a redução da ascensão imperial somente pela via militar (PARPOLA; WATANABE, 1988, p. XIV; XXV; RADNER, 2014). A sofisticação das estratégias políticas da Assíria é polissêmica, e o exército assume uma parte desse conjunto de ações (RADNER, 2014). Mesmo a belicosidade sendo uma marca dos registros históricos assírios, especialmente através dos traços bastante evidentes da violência e da brutalidade nas fontes imagéticas e textuais (REDE, 2018, p. 596), as estratégias militares seguiam uma linha de atuação delimitada no conjunto de atividades do projeto imperial. O emprego excessivo e desproporcional de força, visando mais do que a anulação eficaz do inimigo em batalha, era uma postura, apesar de aparente nas fontes, bastante circunscrita a determinadas situações, como descreve Bagg (2016, p. 60). O cuidado está em não considerar a guerra como o motor principal da atividade imperial da Assíria. Ao ponderar inadequadamente o lugar da guerra no ambiente assírio, o risco é entrar numa "dupla ficção", seja das fontes provenientes da realeza palaciana, seja da produção historiográfica (REDE, 2018, p. 599). As condições geopolíticas e históricas da região favoreceram uma atividade militar sem precedentes, mas sem aparatos bem implementados para a organização do poder (como uma rede eficiente de comunicação e uma sistemática administrativa), um império assírio não teria existido (REDE, 2018).

A limitação também pode ser justificada pela caracterização do público que tinha contato, no presente da época ${ }^{39}$, aos relevos. A dinâmica do interior palaciano envolvia um público bastante restrito: realeza, funcionários do palácio, mensageiros e membros da elite assíria eram aqueles que circulavam nas salas dos palácios e teriam uma proximidade com o rei (READE, 1979, p. 336; 338-340). Um maior número de pessoas podia entrar nas dependências palacianas somente nas inaugurações do local. A partir dessa dinâmica interna do palácio, as noções de ideologia e propaganda não confluem para interpretar o caso dos

\footnotetext{
${ }^{39}$ Os relevos e as inscrições palacianas tinham o objetivo de servir de referência aos futuros príncipes e reis, além de estarem voltados também aos deuses (FALES, 2006, p. 91-94; BAGG, 2016, p. 60).
} 
relevos assírios, pois ambos os conceitos não se enquadram à caracterização da audiência: a influência pela propaganda e a aderência a uma ideologia do poder assírio não são proporcionais ao grupo pequeno que circulava no ambiente do palácio (BACHELOT, 1991, p. 116). Como afirma Bachelot (1991, p. 117), são ambiguidades dessa "lógica de comunicação particular, diferenciada" própria dos relevos: "a comunicação estabelecida por meio dos baixos-relevos não era destinada [...] a uma população inteira, mas àqueles indivíduos somente, que podiam eventualmente transmitir a um público mais largo aquilo que viram e aquilo que experimentaram [...]". Mesmo apresentando um nível elevado de realismo na elaboração e exatidão em suas figuras, o público que teve contato com relevos nas paredes era pequeno. Por mais que houvesse um investimento na capacidade narrativa, visando facilitar a compreensão da realidade esculpida, há uma abertura à diversidade interpretativa, um caráter que solicita do observador um investimento pessoal mais ou menos participativo (BACHELOT, 1991, p. 118), ou seja, a subjetividade do sujeito que vê o relevo não é constrita, o que, grosso modo, daria margem a "leituras" diferentes das imagens.

Outro fator de limitação no uso das noções de propaganda e ideologia é o fato de que poucas pessoas possuíam repertórios de conhecimentos para compreender o que estava exposto nos relevos, em especial a leitura de inscrições neles contidas em várias placas (RUSSELL, 1999, p. 2). As intenções das figuras dos relevos poderiam estar relacionadas à concretização e exposição do sentido daquilo que era escrito, sendo o texto destinado a um público com conhecimento para decodificar plenamente as informações (PARKER, 2011, p. 368; FALES, 2006, p. 92-93). Tal público seria o grupo que constituiu a cultura escribal da época, que possuía um poder diferenciado de promulgar uma ideologia assíria ${ }^{40}$, não deixando, por essas razões, de ser restrito. Se houvesse influência "tácita" dos relevos, através da movimentação e percepção das pessoas com a mensagem narrada nas salas, talvez tal influência tivesse funcionado mais para aquela comunidade interna - e para aqueles que sabiam da configuração palaciana - do que por poucas "visitas" diretas pelo palácio. Se a visitação de pessoas externas à unidade do palácio era programada, atendendo a determinado fim (uma visita diplomática, por exemplo), é difícil esperar que houvesse um tempo de apreciação das paredes, além de exigir, como já mencionado, um repertório mínimo de conhecimento para entender o que estava exposto.

Ainda sobre a audiência pretendida ou efetiva, há a proposta de dinâmicas, problemas e abordagens sobre os palácios assírios como um todo (RUSSELL, 1987; 1991; KERTAI,

\footnotetext{
${ }^{40}$ Parker (2011, p. 370) argumenta sobre a cópia e distribuição para as províncias de certos registros escribais, por exemplo, sobre eventos militares.
} 
2014a; 2015a). No plano de desenvolvimento arquitetural palaciano, havia disposições para circulação pelo palácio, na forma de rotas únicas, que poderiam conduzir a uma experiência direcionada (intencionalmente ou não) de movimentação. Certas pessoas tinham acesso a certos setores, outras a mais lugares, possivelmente dependendo da realização de suas funções e do grau de envolvimento com a realeza. A organização arquitetural dos palácios neoassírios favorecia uma funcionalidade em áreas ou setores com relativa autonomia, não sendo necessários grandes deslocamentos pelo palácio para a realização de tarefas que poderiam ser logisticamente coordenadas em uma parte localizada (KERTAI, 2014a, p. 696-697; 2015a, p. 11).

Uma audiência potencial depende da acessibilidade dos sujeitos ao ambiente palaciano. Por um lado, como afirma Bachelot (1991, p. 114), o aumento do realismo na escultura dos relevos, através do emprego de detalhes da realidade e da narrativa nas cenas, podia favorecer a compreensão dos sujeitos, aproximando o observador de algo por ele já experienciado. Por outro lado, isso não exime a necessidade de um "conhecimento prévio" e de "competências cognitivas do receptor", ambas relativas à materialidade e à textualidade esculpidas (BACHELOT, 1991, p. 115). Também a percepção dos detalhes dos relevos é determinada por: funções das salas, dimensão e iluminação; escala de escultura (tamanho das figuras e das placas, posição e altura); e a posição da cena em cada placa. Então, conforme defende Bagg (2016, p. 66-71), para entender o aspecto do contexto arquitetônico dos relevos, é necessário pensar nesses elementos como "condições de visibilidade", mesmo com a consideração indubitável de que havia um nível mínimo de exposição dos relevos ${ }^{41}$. A ampla largura das salas ${ }^{42}$ também não favoreceria uma influência ou percepção tácita do conteúdo

\footnotetext{
$41 \mathrm{O}$ argumento e a importância da visibilidade para compreender a função social de monumentos especialmente considerados propagandísticos e ideológicos - já tinham sido apontados consistentemente, em outro contexto histórico, por Veyne (2010, p. 328-364). Outro elemento discutido por Kertai (2015a, p. 187-190) é relativo à incidência de luz nos ambientes palacianos, envolvendo, consequentemente, uma apreciação sobre entradas parietais para ventilação e iluminação.

${ }^{42}$ A largura dos ambientes dos palácios é, a partir das estimativas, bastante variável, de extremos mais amplos, como dos pátios, a menores, em corredores e pequenas salas. Kertai (2014a, p. 693; 2015a, p. 8) aponta que, de maneira geral, nos palácios do período Neo ou Tardo Assírio, salas menores, como banheiros, podiam ter entre 25 e cinquenta $\mathrm{m}^{2}$; já salas do trono, os maiores ambientes (fechados) palacianos, podiam chegar a quinhentos $\mathrm{m}^{2}$. Winter (1993, p. 36) indica uma medida aproximada de dez metros de largura por 45 metros de comprimento para as salas do trono de Assurnasirpal II e Sargão II, o que resulta numa média estimada próxima a de Kertai. De uma média das estimativas, tomando o exemplo de um corredor ou sala retangular, que podia exigir percorrêlo por completo, tem-se uma largura de cinco a sete metros; uma pessoa em trânsito, se ficasse no meio da sala, estaria equidistante de cada uma das paredes a, no mínimo, de dois a quatro metros aproximadamente. Essa distância certamente não favoreceria nem a observação direta (dificultada pela distância relativa da posição acima proposta ou eventualmente pelo deslocamento em execução) ou indireta (relativa à visão periférica, praticamente impossibilitada). As alturas estimadas das paredes também poderiam entrar nesse cômpito como um outro fator influenciador do plano arquitetônico na percepção espacial num ambiente fechado dentro do palácio. Sobre a altura das salas, ver Kertai (2015a, p. 8-10) e, incluindo um debate e a constatação da
} 
dos relevos, já que esses são baixos-relevos e, por isso, dificultariam ainda mais uma visão à distância, ou até uma percepção visual periférica no transitar pelos ambientes. Se a visitação de pessoas externas à unidade do palácio era programada, atendia a determinado fim, é difícil esperar que houvesse um tempo de apreciação das paredes, além de exigir, como já mencionado, um repertório mínimo de conhecimento para entender o que estava exposto. Por exemplo, se uma pessoa estivesse em trânsito numa sala do trono, indo em direção ao rei, talvez ela não voltasse os olhos a uma direção diferente daquela focada na pessoa do soberano. Então, uma influência tácita na experiência de circulação pelo palácio, se não inexistente, seria mínima.

A circulação no palácio poderia ser influenciadora da experiência através da exigência corporal imposta por tipos de movimentação ou alternância de direção no deslocamento pelos ambientes. Bachelot (1991), Nadali (2006; 2008; 2012; 2014) e Winter (2010a) apontam que essa experiência de movimentação obedece também a uma programação, na qual os relevos teriam um papel de, por um lado, conduzir o deslocamento e, por outro, servir para apresentar uma dada imagem ao transeunte. Mesmo que tenha havido um programa ou uma orquestração espacial dos relevos em favor da circulação no ambiente palaciano, tal conjunto programado não necessariamente teria sido entendido. Contudo, mais do que as imagens dos relevos, um programa de movimentação e circulação corporalmente estimulado pode ter sido mais influenciador da experiência visual de quem tinha acesso aos palácios. A influência pela movimentação poderia ser, por exemplo, através do deslocamento acompanhado visualmente pela narrativa dos relevos; a disposição das placas com imagens relevantes de frente às entradas de cada ambiente, somada ao lugar de outros objetos no espaço, como os colossos nos acessos aos recintos ou a posição do trono do rei em suas grandes salas, também poderiam implicar uma influência durante à experiência de movimentação.

Complementarmente, os locais da presença dos relevos no palácio podem ser pensados não como pontos determinados a uma exposição e consequente observação. Por exemplo, as cenas de batalhas e seus locais poderiam levar ao entendimento da natureza de onde são expostas, como ambientes mais públicos. Contudo, as imagens são bastante espalhadas pelos palácios, em locais que certamente não estariam acessíveis. Então, como indica Nadali (2016, p. 85-85), as imagens dos relevos não são sempre visíveis, no sentido de uma exposição total, não sendo, portanto, uma fonte para influenciar um público. Ao mesmo tempo, as placas esculpidas, pelo seu realismo narrativo, não encerram tudo aquilo que deve ser visto ou 
entendido a qualquer um, pois exigem uma postura do sujeito observador ao criarem uma lacuna ou uma "indeterminação interpretativa" (BACHELOT, 1991, p. 122).

Tendo em vista os argumentos sobre uma auto-simbolização ou auto-ritualização, as paredes dos palácios tendem a ser locais de uma memória compartilhada entre os reis (BACHELOT, 1991, p. 122), seja através da ocupação sucessiva de um mesmo palácio por vários soberanos, seja pelo aproveitamento de palácios diferentes para funções diversas ${ }^{43}$. Se os feitos da realeza são registrados nos relevos, o registro não finaliza sua ação, no sentido de a experiência passada não ter mais relação com o presente. $\mathrm{O}$ objeto trazia o passado à tona na contemporaneidade, assim como lançava as bases de um futuro desejado, através da preservação da memória (DI PAOLO, 2016, p. 35). Os relevos vêm antes do que virá: dão legitimidade, força, criam um clímax para o reinado. Então, segundo Nadali (2016, p. 85-86), a visibilidade e os observadores não são importantes: mesmo os relevos sendo um "aqui e agora" visível, como aponta Fales (2006, p. 86), não há exposição para ser vista, mas sim um ambiente participativo de uma experiência do palácio, especialmente para quem nele habita.

Ao se considerar a ideia de palácio assírio, os seus espaços arquiteturais e os relevos parietais estavam contidos na sua configuração. Isso fortalece a noção de que a concepção do palácio assírio era voltada à sua comunidade interna. O que definimos por período Neoassírio durou pouco mais de trezentos anos e os palácios construídos nesse período tiveram pouca variação em sua concepção monumental e arquitetônica (WINTER, 1993, p. 31-32; KERTAI, 2014a, p. 708-709). É preciso considerar que essa comunidade palaciana foi produtora do maior volume de materiais culturais. Se essa corte real recriava palácios seguindo um modelo, essas recriações e os próprios relevos podem ser vistos como objeto de ritualização cotidiana, implementos de um habitus que configura não só sua identidade, mas também sua personalidade. Se vemos uma função dos relevos mais atrelada à interioridade de quem habitava no palácio, havia então uma preservação sem necessariamente externalização; se, por um lado, a recorrência de motivos, como os bélicos, e o uso dos relevos contribuem para categorizá-los em termos de uma banalização de uma prática, a sua função social voltada ao interior os desbanaliza naquela contemporaneidade (BACHELOT, 1991, p. 119).

\footnotetext{
${ }^{43}$ Como exemplos, após a primeira transferência de capital de Assur a Kalhu por Assurnasirpal no século IX AEC, os reis passam a ser "enterrados" em Assur. Dois séculos depois, com os reis Senaqueribe e Assurbanipal II, haviam diferentes unidades palacianas: o palácio principal, na face sudoeste do monte Kuyunjik, o palácio auxiliar, no monte Nebi Yunus, ambos em Nínive (Figura 3), e com Assurbanipal II o palácio da face norte, que, pelo seu tamanho, não se sabe exatamente se era a residência permanente do rei. Além disso, há relevos nas paredes de algumas salas do Palácio Sudoeste (de Senaqueribe) que são relativos ao período de Assurbanipal II.
} 
[...] o erigir de estruturas que marcam as capacidades destrutivas da humanidade tem provido escopo à empresa escultural.

O desejo de lembrar, seja a partir de uma preocupação pessoal ou expediente político, manifesta em si mesmo a necessidade de estruturas criadas a partir de materiais duradouros para evocar uma diversidade de sentimentos, da honra, glória e sacrifício ao sofrimento e ódio. Memoriais podem ter uma função memorial arquitetural, mas é a necessidade de lembrar que tem frequentemente dirigido o grupo de escultores a evocar em forma plástica a memória da guerra e suas vítimas (MORIARTY, 2004, p. 1046).

Considerados desse modo, os relevos são relativos à prática da memória das experiências de um grupo pequeno, o que permite perceber: uma solidariedade entre os próximos do soberano; uma comunhão daqueles que estão na mesma missão imperial; um compartilhamento das vivências experimentadas numa condição semelhante. Tal memória, segundo Bachelot (1991, p. 119), confia na imagem "o papel de manter em permanência, de fixar para sempre os fatos e gestos do soberano". No contato direto com os relevos, haveria a possibilidade de "consumo" compartilhado, através da visão, daquilo que faz referência à situação experimentada por aquela comunidade (BACHELOT, 1991, p. 116-117). Vistos de outro ângulo, o ato de planejamento, projeção e implementação do programa escultórico do palácio é carregado dessas experiências, destinadas a serem cuidadas pela memória. $\mathrm{O}$ conteúdo dos relevos como uma forma de manter a memória atualiza, por meio de novos componentes esculpidos, tanto as novas experiências dos contemporâneos, como aquilo que vem de uma tradição e que passa a ser reatualizado ritualisticamente, para se tornar sempre compreensível e compartilhável.

Partindo da crítica sobre a noção de ideologia, mobilizando recursos contextuais, chegando a aspectos próprios dos relevos, o que é expresso nas cenas não é estático e monofotográfica. O caráter narrativo do objeto esculpido é dado pela construção visual de eventos (BAHRANI, 2008, p. 59). Os relevos contêm essas narrativas visuais ${ }^{44}$ que exigem um processo de acompanhamento visual diferente da leitura de um material textual. Essas narrativas funcionam como registro histórico por meio de cenas e assumem um caráter de narrativa espacial, ou um "espaço narrativo" (WINTER, 2010a, p. 3). Tal espaço envolve uma

\footnotetext{
${ }^{44}$ A título ilustrativo, Watanabe (2004, p. 103) analisa o estilo de narrativa presente nos relevos de Assurbanipal II. A autora define a narrativa do período como estilo contínuo, que é, pela definição de L. Andrews trazida pela autora, "um número de ações que ocorrem em momentos diferentes, mas envolvendo os mesmos personagens apresentados juntos em um espaço único e unificado". Desse modo, outra opção escultórica é a repetição de certas pessoas nas cenas, indicando, através da variação de sua localização espacial na placa, a passagem de um fluxo temporal. Contudo, Winter (2010a, p. 3-6) destaca que a palavra narração porta uma ideia de leitura, na qual a textualidade está implicada. Nesse sentido, essa autora argumenta que a imagem dos relevos cria um "espaço narrativo" (p. 3). A noção de espaço narrativo e de narrativa visual favorecem, de um lado, a compreensão da especificidade expressiva dos relevos e, de outro, o cuidado para não se empregar um modo de leitura textual à narratividade desse tipo escultórico.
} 
tensão estrutural entre o que está representado (o evento), como está sendo representado (por exemplo, lugar do rei nas cenas de guerra, a disposição vitoriosa assíria) e as razões dessa representação (os motivos pelos quais os relevos encontram-se no palácio real) (WINTER, 2010a, p. 6). Portanto, aquilo que é mostrado nos relevos e a própria superfície longa das paredes (como destaca Winter, 2010a, p. 14), exigiriam não somente o deslocamento corporal e ocular, mas também um movimento de repertório cognitivo.

A consideração ideológica em termos do conteúdo dos relevos pode, pela sua limitação de abordagem, perder de vista os aspectos materiais próprios dessa expressão de cultura material.

Portanto, a via de abordagem dos relevos palacianos neoassírios pautada numa noção de ideologia obscurece uma abordagem que favoreça o entendimento de seu papel social, ou de sua agência. Além do destaque que pode ser dado ao se realçar os relevos enquanto cultura material, enquanto materialidade peculiar de um contexto histórico circunscrito, o esforço de comungar elementos contextuais dá mais sentido à pesquisa e sua especificidade temática; por exemplo, é preciso entender os relevos como um elemento integrante da realeza enquanto manifestação social, com suas intenções particulares (GINZBURG, 2014), estruturado num ambiente físico, arquitetônico, geográfico próprio. Então, é preciso colocar a consideração ideológica momentaneamente em suspenso para compreender o potencial da dinâmica social dos relevos. Partindo disso, a análise de seus componentes é favorecida, como é especificamente o caso das concepções de corpo expressadas nos relevos.

Os relevos constituem uma prática de registro imagético intencional, contendo elementos de uma visão de mundo, sem ser um meio de imposição direta de ideias. Mais que isso, suas imagens reafirmam algo certamente já difundido e presente naquele período, mas não sendo por isso secundário. Os relevos apresentam uma dinâmica ritualística, de operatividade interna, àqueles que criaram e viviam nos palácios. A presença e a dinâmica dos relevos renovam naquela contemporaneidade a visão de mundo registrada. 


\section{CAPÍTULO 2 \\ OS RELEVOS E TEXTOS NEOASSÍRIOS COMO FONTES}

\section{Os relevos e textos como fontes palacianas}

Em imagens e textos assírios, é possível identificar modos de expressar aspectos corporais, o que favorece um estudo das concepções de corpo do período Neoassírio. O caso das imagens dos relevos palacianos tem a particularidade do uso bastante circunscrito no interior dos palácios. Já uma parte da documentação escrita da época era produzida tendo como eixo o núcleo palaciano. Por exemplo, textos epistolares eram escritos para ou a partir dos palácios; textos literários, religiosos, administrativos e comentários serviam para a realização de funções no interior daqueles locais. Dessa forma, imagens e textos do período são fontes de origem palaciana, seja por sua proveniência (isto é, por terem sido encontrados nos sítios arqueológicos dos palácios), ou pelo monumento palaciano ser o ponto inicial e/ou final de sua produção.

$\mathrm{Na}$ Assíria, essa época foi marcada pelo clímax da sistematização imperial sob o governo da Dinastia Sargônida. A definição de um centro de poder governamental é fundamentada no investimento numa capital e, dentro dela, no palácio. Nele, habitava a realeza e sua corte, sendo então o lugar da casa real e do governo da região. O rei era designado e legitimado pelo deus patrono para o exercício do governo. As atividades governamentais envolviam tarefas administrativas e diplomáticas, sendo ambas centralizadas no ambiente palaciano. Além dos palácios tornarem-se um local de concentração de poder, a conexão do soberano com o divino incorpora os aspectos religiosos à casa da realeza. Ao lado dos palácios, a dinâmica de rituais religiosos e de cultivo dos saberes tradicionais relacionados às divindades eram conduzidos nos ambientes dos templos, espacialmente próximos às unidades palacianas. Outras construções ganharam destaque nas cidadelas assírias, ao lado dos palácios e dos templos. Uma das diretrizes da política imperial envolvia o investimento num exército. A administração militar passou a ser realizada numa construção própria dentro das cidadelas. Além de terem uma função de defesa interna, seu papel principal era organizar o poder militar, suas contingências administrativas e suas demandas materiais (STONE, 2000, p. 246-247; LIVERANI, 2016) ${ }^{45}$.

\footnotetext{
${ }^{45}$ No caso de Nínive, havia um palacete menor (chamado em acadiano ekal māšarti, palácio militar ou arsenal), numa parte denominada monte Nebi Yunus (Figura 3). O nome, em árabe, refere-se ao profeta bíblico Jonas e o monte seria o suposto local de enterro do profeta. Posteriormente, já na EC, houve a construção de um
} 
A presença do palácio, do templo e da edificação militar caracterizava as maiores organizações urbanas das cidadelas assírias do primeiro milênio. As cidades-capitais passaram a ser dispostas claramente dessa forma a partir das iniciativas expansionistas do século IX AEC. É característica dessa fase imperial a transferência de cidades para se tornarem capitais do império em construção. A partir de Assurnasirpal II, transpor uma capital a outra localidade exigia a apropriação de construções e a elaboração de novas edificações, como é o caso de novos palácios. Assim, a instituição de novas capitais era acompanhada pelo desenvolvimento monumental nas cidades, especialmente das unidades palacianas.

Assur era a cidade tradicional da Assíria; ela tinha o mesmo nome do deus patrono e era a principal capital da região. Em 879 AEC, Assurnasirpal transferiu a sede do império em formação para a cidade $K a l h u$, que ficava mais ao norte ${ }^{46}$. Além da construção de novos monumentos régios, foi nesse período que houve um crescimento do uso dos relevos nos palácios. Desse modo, um perfil imperial assírio era caracterizado pela monumentalidade dos projetos construtivos urbanos.

A transferência de cidades ocorreu em outros momentos desde o século IX e durante os séculos VIII e VII, com a Dinastia Sargônida. Os esforços de construção arquitetônica e organização urbana figuravam entre os projetos (e problemas) políticos centrais no período, que envolviam também, conforme Kuhrt (2003, p. 499), as relações entre territórios e novas conquistas expansionistas. Como argumenta Reade (1979), o prestígio da Assíria era abrilhantado pelos seus palácios ${ }^{47}$ nas grandes cidades e pelas suas funções sociais.

Após Kalhu, outras cidades tornaram-se capitais da Assíria. Primeiro, Sargão II começou a construir uma nova sede do império em Dur-Šarrukin, na atual Khorsabad, entre 717 e 706 AEC, deixando $K a l h u^{48}$. A monumentalidade do projeto construtivo tem a ver não somente com as dimensões arquiteturais da unidade palaciana, mas também pelo esforço de organização de um enorme projeto construtivo e pelo emprego de recursos humanos elevados

monastério cristão e, depois, de uma mesquita (dirigida ao profeta também). De acordo com Stone (2000, p. 247), durante os reinados dos sargônidos, esse palacete ficava destinado somente à organização militar. Ver também Turner (1970).

${ }^{46}$ Ver Nimrud, na Figura 2.

${ }^{47}$ Reade também menciona, em linha gerais, a importância dos palácios e de suas configurações no período Neoassírio, pois havia um costume de cada rei construir (ou reformar) o seu próprio (e às vezes novo) palácio em determinada capital eleita. Conforme aponta Winter (1993), o significado do palácio na Mesopotâmia não se restringe ao local de exercício administrativo do rei ou sua moradia, mas como o lugar do reinado, como a incorporação do Estado, sendo composto por uma gama de atividades, conforme mencionado acima. Especificamente sobre os aspectos arquitetônicos da construção dos palácios, ver Roaf (2000). As fontes escritas e imagéticas do período Neoassírio contêm descrições variadas sobre os projetos construtivos dos palácios assírios.

${ }^{48}$ O palácio da nova cidade de Dur-Šarrukin foi escavado por Paul Émile Botta a partir de 1843 (ALBENDA, 2003) 
para a criação de uma nova cidadela (PARPOLA, 1995, p. 50). Essa sofisticação urbanística é relatada pelo rei Sargão II em fontes escritas e imagéticas do período, visando o registro histórico da perspectiva do império assírio a respeito de seus próprios feitos. Conforme Kertai (2015a), a organização interna do novo palácio de Sargão II também destoa em tamanho e disposição de suas partes em comparação às construções das capitais anteriores (Assur e $K a l h u)^{49}$. Acrescido a isso, os relevos parietais faziam parte do palácio da nova cidade, contendo cenas de campanhas militares encabeçadas pelo rei a leste e a oeste do núcleo $\operatorname{assírio~}^{50}$.

A construção de Dur-Šarrukin foi acompanhada e continuada pelo filho de Sargão II, Senaqueribe. Após a morte do pai, ele transferiu a constituição de uma nova capital para Nínive, construindo um palácio entre 703 e 694 AEC $^{51}$. Nínive não era uma cidade desconhecida: a cidade foi centro religioso desde o fim do terceiro milênio, tornando-se local prestigioso de culto a partir do final do segundo milênio, devido à presença do templo dedicado à deusa Ištar (READE, 1998c, p. 396). Antes de Senaqueribe, Salmaneser I e Tiglath-Pilaser I construíram palácios na cidade no final do segundo milênio, cujos restos arqueológicos são extremamente escassos (KERTAI, 2014a, p. 690). Nesse sentido, Nínive foi passando a ser integrada no sistema administrativo e político assírio, além de se tornar a

\footnotetext{
${ }^{49}$ Como destaca Kertai (2015a), "o complexo palaciano pode ser descrito como um urban emsemble assim como uma construção singular” (p. 94). Nesse sentido, diferente dos outros palácios assírios, o novo projeto construtivo do monumento estava englobado num projeto de elaboração urbana como um todo. Outros exemplos precisos sobre o diferencial do palácio, para além de seu grande tamanho conhecido por ter sido bem escavado, são a organização de suas áreas internas em quadrantes (p. 94) e a presença de rampas de acesso a terraços (p. 87) - último aspecto que aparecerá no Palácio Sudoeste de Nínive, de Senaqueribe.

${ }^{50}$ Grande parte dos relevos provenientes desse palácio é conhecida através dos desenhos realizados pelos artistas que acompanhavam as delegações nas escavações do século XIX EC. Já as placas de relevos remanescentes de Dur-Šarrukin foram pouco conservadas ao longo do tempo. Muitas foram mantidas no próprio sítio arqueológico, enquanto outra parte (composta também por fragmentos e placas desgastadas) foi levada principalmente a Paris, no Museu do Louvre. Pelo catálogo de Albenda (1986), observa-se que muitos dos relevos remanescentes desse local apresentavam figuras de grande porte e de tipo apotropaico, possivelmente das áreas externas do palácio (muros e paredes). Já nas salas internas, havia placas esculpidas tematizando diversos eventos contemporâneos à época, como as campanhas militares. Por meio dos desenhos dos relevos, se conhece outras cenas esculpidas, como aquelas de banquetes comemorativos e imagens com paisagens fluviais e marítimas (ALBENDA, 2003). Apesar de não ser uma novidade sem precedentes, o cenário aquático foi usado de uma maneira original nos relevos do palácio de Sargão II. Enquanto de Kalhu, do período Assurnasirpal II, há relevos representando um ambiente aquático (inclusive com nadadores, por exemplo, nos relevos do British Museum de n. $\left.{ }^{\circ} 124538 ; 124543 ; 124551\right)$, o uso desse cenário torna-se mais paisagístico e cenográfico nos eventos esculpidos no período de Sargão II. A alteração no uso da paisagem, o cenário aquático diferenciado e a quase ausência de cenas de banquete são marcas dos relevos analisados nesta pesquisa, dos períodos de Senaqueribe e Assurbanipal II, respectivamente filho e bisneto de Sargão II.

51 Seguindo uma cronologia sugerida pelas inscrições reais de Senaqueribe, esse período abrange os oito primeiros anos de seu reinado. Em suas inscrições, ele relata etapas da "construção" de Nínive, em especial de seu palácio. Então, não significa que essa faixa temporal tenha sido o período de construção do palácio e depois, quando concluída a obra, o rei passou a habitar nele. Houve um momento elaboração inicial da construção, seguido de reformas (para renovação ou manutenção) e a implementação de sofisticações.
} 
residência real no final do segundo milênio (TENU, 2004; 2015), atingido um estatuto excepcional no fim do século VIII e durante o século VII AEC.

No entanto, a mudança de uma capital nova para Nínive por Senaqueribe não foi arbitrária. Existem duas possíveis razões para isso. A primeira foi a localização privilegiada de Nínive para um sistema de rotas setentrionais (ainda melhor em comparação à "subida" de Assur a Kalhu e desta a Dur-Šarrukin. Tal posicionamento proporcionou um acesso mais eficiente às bordas ocidentais (na região síria e na Anatólia) e às fronteiras mais orientais (próximas às cadeias montanhosas do Zagros). A confluência de outros rios com o grande Tigre também parecia favorecer o desenvolvimento mais facilitado de um sistema de canais e aquedutos, para o abastecimento de água na cidade e para o transporte fluvial de produtos. A segunda razão foi subjetiva, de acordo com Frahm (2008, p. 15): especula-se sobre o receio de Senaqueribe em continuar em Dur-Šarrukin após a derrota e morte do pai em batalha. A mudança desvincularia o antecedente negativo da figura de Sargão II, favorecendo a criação de uma imagem renovada do centro do império. Tendo optado por Nínive e tendo tido uma participação ativa no projeto construtivo de Dur-Šarrukin durante seu período de príncipe herdeiro, Senaqueribe construiu seu palácio denominado ekal šānina lā išŝu $\hat{u}^{52}$, o Palácio Sem Rival. Ele ficava localizado na face sudoeste do monte Kuyunjik, na região de Mossul, no atual Iraque (Figura 5). Por sua localização no monte iraquiano, o palácio é denominado Palácio Sudoeste de Nínive ${ }^{53}$.

A dinastia prosseguiu com o reinado do filho mais novo de Senaqueribe, Esarhaddon. Ele primeiramente foi colocado no trono da Babilônia em 689, após o pai ter destruído aquela cidade; sua designação ao trono babilônico provavelmente se deu por um receio de Senaqueribe (e especialmente de sua mãe, Zakutu) de que o filho fosse morto pelos irmãos. Quase uma década depois, Esarhaddon assumiu o trono assírio, que estava nas mãos de seus irmãos, aparentemente conspiradores de longa data (LEICHTY, 2000, p. 951-952). Seu reinado foi curto por causa de sua saúde frágil, passando a sucessão (e o ideal político-militar) a seu filho Assurbanipal II, transferência também marcada por um ambiente de garantia contra eventuais conspiradores ao trono ${ }^{54}$. Esarhaddon também apresentou projetos construtivos, como: uma reconstrução da Babilônia logo após a morte de seu pai (LEICHTY,

\footnotetext{
52 Conforme consta nas inscrições reais de Senaqueribe, escritas na variação dialetal neobabilônica do acadiano, o nome normalizado seria Egalzadinutukua.

53 A primeira escavação moderna em Nínive foi conduzida pelo inglês Austen Henry Layard (1817-1894) em 1847.

${ }^{54}$ Um exemplo emblemático de documento que sobreviveu do período é o tratado de juramento para a sucessão de Assurbanipal II, de 689 AEC, permeado em diferentes partes por garantias contra um eventual ataque ao herdeiro ao trono. Essa carta (SAA 2 6) é analisada nesta pesquisa.
} 
2000, p. 952), renovações nos palácios militares de Nínive e Kalhu e a construção de novo palácio nessa última cidade (KERTAI, 2015a, p. 155) ${ }^{55}$.

Nínive recebeu a construção de um outro palácio por Assurbanipal II ${ }^{56}$. Assim como o Palácio Sudoeste, o Palácio da face norte do monte Kuyunjik continha relevos em grande parte de suas salas. Pelo menos metade dos espaços do palácio - entre salas, salas do trono e pátios - apresentavam em suas paredes as atividades do rei: as caçadas (por exemplo, aos leões); as cenas bélicas (com narrativas militares), envolvendo momentos de batalhas propriamente ditas e a recepção de prisioneiros e pilhagens; e uma sala com ambos os temas (GERARDI, 1988, p. 3). No entanto, comparativamente, o palácio de Assurbanipal II era muito menor do que o de seu avô. Os relevos de ambos os palácios, muitos bem conservados, estão espalhados por museus, com maior concentração no British Museum (BM) de Londres (BARNETT, BLEIBTREU, TURNER, 1998).

A construção de uma nova capital com Sargão II, em Dur-Šarrukin, e a reformulação ${ }^{57}$ de Nínive com Senaqueribe e Assurbanipal II foram os emblemas monumentais da exposição do ápice imperial da Assíria no primeiro milênio AEC. Os palácios eram o símbolo do poder construtivo, expansionista e bélico dos assírios. Destaca-se a recorrência dos relevos acompanhando essa experiência de poder. Além disso, a presença constante de textos no ambiente palaciano estava tanto nas inscrições espalhadas em suas paredes, como também na organização de locais de armazenamento internos, incluindo nesse tipo o projeto compilatório dos considerados principais saberes conhecidos à época, encabeçado por Assurbanipal II em sua atualmente chamada "biblioteca de Nínive". Assim sendo, os monumentos palacianos de Nínive foram fruto de um projeto imperial construtivo e que contava com o investimento substancial em uma produção visual e textual, que formam as fontes principais para o estudo da Assíria.

\footnotetext{
${ }^{55}$ A partir de meados de 2017, investigações arqueológicas foram iniciadas em Mossul na área de Nebi Yunus. A mesquita que ficava nesse local foi destruída pelos ataques do grupo Estado Islâmico do Iraque e da Síria. Embaixo dos escombros, foram reveladas as ruínas de um monumento, provavelmente o palacete ou, como hipótese aventada, um palácio do rei Esarhaddon, incluindo a presença de relevos parietais.

${ }^{56}$ O palácio de Assurbanipal foi finalizado por volta de 646 AEC. Suas ruínas foram descobertas por Hormuzd Rassam (1826-1910), dirigente da expedição inglesa e sucessor de Layard, em 1853 (READE, 2016).

${ }^{57}$ Por Nínive já ter sido uma cidade com momentos ocupacionais ao longo de sua história, em vez dela ter se tornado uma nova cidade, ela foi reformulada para ser a capital e abrigar uma fase do governo imperial (NADALI, 2008).
} 


\section{A forma dos relevos}

O desenvolvimento das capitais assírias prosseguiu ao norte pelo território das planícies da alta Mesopotâmia. Além da aproximação com regiões mais eficientes para rotas (comerciais e de comunicação) e com o cruzamento de rios para construção de canais, outro fator envolvido era a proximidade com regiões montanhosas. Tal fato tinha seus prós e contras: por um lado, havia a desvantagem em lidar com grupos nômades que habitavam em regiões mais altas; por outro, a vantagem era o acesso a fontes rochosas. $\mathrm{O}$ crescimento do império exigia a concentração de recursos econômicos em seu núcleo e a disponibilidade de recursos materiais importantes, como as pedras, especificamente para o abastecimento eficiente dos projetos construtivos dos reis assírios.

Essa proximidade da Assíria com regiões de cadeias montanhosas pode ter favorecido o uso da pedra como matéria prima para a produção dos relevos palacianos. Essas pedras são definidas pela sua constituição físico-química de origem calcária ${ }^{58}$. Especificamente com relação aos relevos palacianos, duas variações desse tipo formam o suporte de sua escultura: a gipsita e o alabastro ${ }^{59}$. Genericamente, é um tipo rochoso com relativa maleabilidade ${ }^{60}$.

Essas considerações a respeito das propriedades físico-químicas das pedras que serviam de suporte à escultura em baixo relevo permitem especular sobre a sua manipulação. Como sua constituição mineral é de relativa maleabilidade, as placas de pedra podem ser consideradas suportes modificáveis com a imposição de um esforço físico reduzido, assim como essa propriedade material pode ter favorecido seu transporte menos dificultado (MITCHELL; MIDDLETON, 2002) ${ }^{61}$.

É possível pensar sobre o uso ou a função dos relevos nesse ambiente, nas etapas de sua produção. Os relevos foram confeccionados dentro dos palácios ou fora destes, sendo

\footnotetext{
${ }^{58}$ A constituição desse tipo calcário contém mais de trinta por cento de carbonato de cálcio (de fórmula físicoquímica é $\mathrm{CaCO}_{3}$ ). Essa rocha também pode conter outros minerais, como a calcita (mais dura) ou aragonita. A rocha calcária é um tipo sedimentar, que pode conter traços fósseis (MIDDLETON, 1998, p. 41-42).

59 A variação calcária gipsita é composta (por percentual de peso molecular) pelos elementos físico-químicos: cálcio $(23,28)$, hidrogênio $(2,34)$, enxofre $(18,62)$, oxigênio $(55,76)$. É formada pela precipitação de sulfito de cálcio da água do mar em regiões vulcânicas, com ação do ácido sulfúrico nos minerais que contêm cálcio (calcários) e encontrada na maioria das argilas (GRABAR, 2004, p. 728). A atribuição do alabastro como base dos relevos inclusive foi feita por Layard (LAYARD, 1849, p. 254; MITCHELL; MIDDLETON, 2002, p. 93). O alabastro pode conter um componente a mais, o sulfato de cálcio hidratado $\left(\mathrm{CaSO}_{4} \mathrm{H}_{2} \mathrm{O}\right)$.

${ }^{60}$ Com relação à maleabilidade da rocha calcária, em termos de uma escala de dureza (chamada de escala de Mohs), ela atinge um nível dito 3, o que significa que ela não pode ser facilmente arranhada, somente quando se usa um objeto metálico. Já o alabastro é menos duro (mais maleável, de nível 2 nessa escala de Mohs), podendo ser arranhado pela unha.

${ }^{61}$ O próprio Layard, em seus relatos da escavação na região assíria (1849, p. 313-314), aventa a facilidade de transposição das pedras para a elaboração dos relevos.
} 
trazidos posteriormente ${ }^{62}$ A diferença entre os materiais da estrutura física das paredes e a maleabilidade das rochas utilizadas para a escultura em relevo é um indício do uso ornamental ou decorativo das placas? A partir do período Neoassírio, os relevos são incorporados sob uma inspiração e um uso sírios, passando a fazer parte de uma concepção de palácio como um todo. Provavelmente, a presença dos relevos constituía o projeto total dos palácios. Seu uso é recorrente nas paredes palacianas e eles expressavam dimensões da experiência de reinado consideradas importantes pelo rei e sua corte. Então, independentemente de sua produção dentro ou fora do palácio, os relevos são marcas congênitas da concepção palaciana. No limite, eles podem ser diferenciados da estrutura arquitetônica que dá base às paredes do palácio, mas eram inerentes e constituidores dos ambientes palacianos.

Esquematicamente, a partir dos planos baixos dos palácios de Senaqueribe e Assurbanipal II (Figuras 6-7 e 8-9, respectivamente), os recintos palacianos tinham dimensões e formas variadas. Essa variação implicava um comprimento diferente das paredes, o que por sua vez se relaciona com o tamanho das placas usadas para a confecção dos relevos. Nas salas de dimensão quadrada, as placas com relevos esculpidos possuem em média de 1,5 a 2,5 metros de altura por dois metros de largura. Em corredores, que tinham uma forma mais retangular, e em pátios, também de forma quadrada e maiores que uma sala, as placas podem chegar além de dois metros de altura e mais de quatro metros de comprimento. Em muitas dessas placas maiores, havia a expressão de figuras apotropaicas, que podiam aparecer também nas fachadas dos palácios.

Daquilo que se caracteriza como típico da escultura em baixo relevo, na tipologia moderna, o relevo é considerado um dos três ramos da arte escultórica ${ }^{63}$ (MIRABELLA, 2008, p. 1399). Um relevo envolve o processo de escultura que retira porções do suporte, gerando um nível de saliência. Nesse sentido, no suporte material, sua parte frontal original torna-se o pano de fundo daquilo que é esculpido em relevo, criando uma "existência física implicitamente continuada" (RELIEF..., 2004, p. 570) entre figura e fundo. A configuração de uma placa com relevo posta em uma parede "enfatiza sua função arquitetural" (RELIEF..., 2004, p. 570): sua presença coloca em relacionamento o meio (ou seja, a parede) e o que é

\footnotetext{
${ }^{62}$ Há argumentos na literatura sobre os relevos serem encaixados nas paredes dos palácios (por exemplo, em Leick, 2003, p. 241). Contudo, tal fato não implica que os relevos tivessem sido projetados de maneira desconectada dos ambientes palacianos. Nesse sentido, eles não seriam complementares, mas sim foram uma parte constituinte da arquitetura palácios desde sua concepção.

${ }^{63}$ Ao lado da escultura por perfuração e da escultura em bloco (também chamada de escultura livre), cf. Mirabella (2008, p. 1399). Ele também é uma das vertentes mais abundantes com relação aos tipos de materiais usados e aos tamanhos atestados.
} 
destacado pelo relevo. Sendo assim, no ambiente arquitetônico, a parede torna-se o suporte do relevo.

Nos baixos relevos, não há subcortes que destacam completa ou parcialmente a figura esculpida do plano de fundo. Isso exige mais do artífice para criar uma ilusão em duas dimensões. Segundo as noções modernas da arte em pedra (MIRABELLA, 2008, p. 1400), efeitos de luz e sombra são criados pela escultura em relevo, que também pode receber a pintura para aumentar esses efeitos. $\mathrm{O}$ enquadramento visual das cenas pode apresentar como características: a presença de uma linha de base que define o chão cenográfico (MIRABELLA, 2008, p. 1400); e a sobreposição de elementos esculpidos para a criação de uma profundidade, ou seja, camadas ou parcelas de espaço em direção ao plano de fundo podem dar noção de uma profundidade proporcional. Então, nesse tipo de escultura, poucas camadas de pouco milímetros poderiam dar noção de profundidade grande (RELIEF..., 2004, p. 570; MIRABELLA, 2008, p. 1400). Nesse sentido, o primeiro plano (o dos elementos esculpidos) seria mais relevante que o plano de fundo; a ação de uma cena acontece visualmente no espaço entre o plano frontal e o fundo. Contudo, o próprio material (sua dimensão física) e a escultura em baixo relevo impõem dificuldades à expressão de profundidade (RELIEF..., 2004, p. 570).

A narratividade como uma marca da expressão nos relevos, especialmente nas particularidades daqueles do período Neoassírio, é favorecida pela repetição de elementos. A recorrência de componentes esculpidos em diferentes partes de uma placa cria o efeito de apresentação de momentos de uma história que compartilha o mesmo espaço (RELIEF..., 2004, p. 570; NADALI, 2006). Contudo, no caso dos relevos Neoassírios, uma estratégia ou recurso auxiliar para o desenvolvimento de narrativas é a divisão do espaço cenográfico em bandas, de duas a três, que permitem tanto separar momentos, como também integrar sincronicamente elementos que estão dispostos numa "diacronia" espacial (NADALI, 2006).

Por fim, uma das particularidades dos relevos palacianos Neoassírios é a ocorrência de textos esculpidos em algumas placas. São dois tipos principais de textos lapidares. No início da implementação dos relevos nos palácios, especialmente com Assurnasirpal II, havia uma faixa de pedra com um texto inscrito "separando" duas placas (superior e inferior) esculpidas. Posteriormente, as inscrições passam a aparecer no meio das cenas, como se fossem "legendas". Muitos relevos apresentam essa relação com um tipo de texto na forma de inscrições no mesmo suporte. Dessa forma, os aspectos relativos ao suporte físico são importantes para entender as imagens e a interação entre elas e os textos num mesmo espaço. 


\section{Os relevos dos palácios de Nínive: critérios de seleção}

Os relevos analisados nesta pesquisa são provenientes dos palácios de Senaqueribe e Assurbanipal II. Grande parte deles foi escavada durante as primeiras missões arqueológicas inglesas na região da antiga Nínive em meados do século XIX EC. Hoje, a maioria das placas que foi escavada e retirada do sítio arqueológico compõe as salas de exposição do BM de Londres. Esses relevos também foram fotografados e compilados por Barnett (1976), em livro sobre o palácio de Assurbanipal II, e por Barnett, Bleibtreu e Turner (1998), em livro sobre o palácio de Senaqueribe. Então, as formas de se ter acesso aos relevos são pela visitação ao museu em Londres ou pela consulta aos catálogos. Nesses últimos, há grande parte dos desenhos feitos pelos artistas que compunham as missões arqueológicas. Eles desenharam os relevos que não puderam ser retirados de seus locais originais. Esses desenhos contribuem bastante para a ampliação do conhecimento sobre o conteúdo da expressão escultórica nos relevos palacianos. Além disso, o BM disponibiliza em seu banco de dados virtual fotos em alta resolução dos relevos.

Tendo em vista a disponibilidade de acesso aos relevos, optou-se por alguns critérios de seleção para análise, de acordo com o tema da pesquisa. Um primeiro critério é a escolha de imagens que possuem figuras de corpos humanos. Contudo, quase a totalidade dos relevos envolve a presença de corpos. Então, um critério seguinte é a seleção dos relevos remanescentes que ainda existem em museus, e não são conhecidos somente através dos desenhos feitos pelos artistas oficiais das primeiras delegações arqueológicas. Tal critério justifica-se pelo interesse de análise dos aspectos corporais nos relevos e que envolvem tanto seu conteúdo como sua forma saliente nas placas.

Mesmo que o momento da seleção tenha sido amparado pelos catálogos de fotos, a possibilidade de acesso a alguns originais favoreceu as análises. A descrição dos relevos presente na literatura especializada também contribuiu para sua organização nesta pesquisa (BARNETT, 1976; BARNETT; BLEIBTREU; TURNER, 1998; NADALI, 2006; KERTAI, 2015a). Essas informações permitem categorizar as fontes a partir de detalhes de interesse, como: palácio, sala, posição do relevo na parede, relevo anterior e posterior e categorização temática.

Relevos originais muito fragmentários ou deteriorados não foram selecionados. Por mais que elementos corporais (e que fazem parte do cânone escultórico da época) pudessem estar presentes em fragmentos de placas e tal característica pudesse ajudar a virtualmente 
preencher o que está ausente na escultura, isso poderia deixar incertezas ou limitações para uma análise mais precisa. Com esse critério, relevos originais e completos podem ter perdido sua conexão narrativa e poderiam ficar isolados em relação ao conjunto que fazia parte. Nesse sentido, foram selecionados relevos que mantêm a conexão entre si dentro de uma mesma sala do palácio.

O interesse por figuras de corpos humanos é o primeiro critério de seleção dos relevos, sendo tais imagens muito recorrentes. No entanto, a presença de corpos pode aparecer tanto em expressões de pessoas (vivas ou mortas), como também em figuras apotropaicas e antropozoomórficas, ou seja, em seres esculpidos num modelo antropométrico, mas composto por partes corporais humanas e animais. Esse tipo de imagem servia a uma referência a entidades sobrenaturais e teria uma função de proteção. Via de regra, essas figuras costumam aparecer em placas sem um contexto cenográfico ou narrativo. A presença desses corpos realizava sua função protetiva sem remeter a um contexto figurativo direto. Por mais que tais imagens fossem esculpidas tendo por base um modelo humano, esses relevos não foram prioritariamente selecionados para as análises desta pesquisa, mas servem de elemento comparativo e subsidiário. Portanto, nos relevos remanescentes, os modos de expressar o corpo humano são na forma de corpos de pessoas e de seres híbridos, com base antropomórfica. Ambas as imagens podem estar relacionadas às concepções de corpo do período, mas a prioridade de análise está nas imagens de corpos humanos especialmente em cenas narrativas. Nesse tipo de relevo, a expressão de elementos corporais é diversificada, sendo que tal característica favorece a construção das narrativas espaciais.

\section{Os relevos em suas salas}

É possível observar os palácios assírios a partir da organização e disposição de suas salas, assim como na relação com outros ambientes, formando áreas mais amplas dentro do monumento.

A partir de dois critérios de seleção dos relevos, foram delimitados alguns conjuntos de salas em cada palácio. Em cada conjunto, foram privilegiadas salas próximas e que possuem o maior número disponível de placas de relevos, compondo uma ou mais paredes. Cada um desses conjuntos forma uma unidade temática ou cenográfica, seja pela própria conexão entre as placas numa mesma sala, ou pelos motivos dos relevos que se relacionam entre salas diferentes dentro do conjunto delimitado. 
A opção pela delimitação de conjuntos está de acordo com as propostas recentes de Kertai (2014a; 2015a), que defende uma nova morfologia da arquitetura dos palácios assírios. De forma sintética, Kertai aponta que a organização arquitetural palaciana seguia uma "setorização" espacial dos ambientes do palácio em áreas com características em comum. Segundo a categorização de Kertai (2014a, p. 697-700), os tipos de áreas dos palácios neoassírios são: área da sala do trono, área de recepção de lados duplos, área de recepção ou residencial, quadrantes de serviços e área de duplo núcleo (com duas grandes salas retangulares). Nessas áreas, observa-se a disposição paralela ou perpendicular entre as salas, de tamanhos e funções variadas, o que constitui um dispositivo para melhorar a eficiência de circulação pelo palácio (incluindo eventuais controles de acesso a certas áreas), assim como aumentar a monumentalidade da construção. De maneira geral, os ambientes de formato quadrado ou retangular podem ser tipificados em: salas do trono, salas regulares (escritórios, estoques, cozinhas, banheiros), corredores (de trânsito interno ou com acesso ao exterior) e pátios (grandes ambientes quadrangulares abertos).

A tipologia de Kertai é utilizada em situações de caracterização de determinada sala numa dada área precisa do palácio. Adicionalmente, a opção por agrupamentos específicos está relacionada à proximidade das salas (tendo um vínculo com a proposta de Kertai) como também à temática dos relevos.

A visualização da organização arquitetural (e dos possíveis esquemas de movimentação) dos palácios pode ser orientada pelos planos baixos produzidos para cada um. Na literatura especializada, existem os planos "tradicionais" e os mais recentes. Os primeiros são: o plano de A. Paterson (1915, trazido por Barnett, Bleibtreu e Turner, 1998, prancha 15), para o Palácio Sudoeste (Figura 6); e o plano reconstruído de Barnett (1976, p. 28), para o Palácio Norte (Figura 8). Já as reconstruções mais recentes foram feitas por Kertai (2015a) para ambos os palácios (Figuras 7 e 9). Contudo, esses planos baixos estão dispostos e são apresentados diferentemente pelos autores. Por exemplo, tendo como ponto de referência a orientação norte - que inclusive contribui para definir o nome dos palácios com relação à sua posição no monte Kuyunjik -, no plano de Paterson (1915) (Figura 6), a fachada do palácio, voltada a leste, está na parte inferior da imagem. Já no plano de Kertai (2015a, fig. 17) (Figura 7), a disposição do Palácio Sudoeste é invertida, ficando a fachada do palácio na parte superior da imagem.

Já com relação ao Palácio Norte, sua face noroeste é a parte superior da imagem do plano de Barnett (1976, p. 28) (Figura 8). No plano de Kertai (2015a, fig. 19) (Figura 9), a face leste/nordeste é a que encabeça a imagem. 
Atualmente, é necessário ter em vista essas possibilidades, evitando uma "ilusão" do lugar do palácio através de sua representação. Aqui, a menção a esses esquemas da arquitetura é feita quando da descrição de uma sugerida rota de movimentação ou para indicar uma visualização do relato sequencial das salas.

\section{Os relevos do Palácio Sudoeste}

O Palácio Sudoeste era um monumento muito maior em tamanho e número de salas em comparação ao Palácio Norte. Quase mil relevos são registrados e catalogados como provenientes de lá, número total que inclui os originais, os desenhos e aqueles com motivos simulando tapeçarias ou elementos têxteis. Desse total, aproximadamente 164 relevos estão armazenados no BM. Deles, foram selecionados os relevos: de dois grandes pátios (VI e XIX $^{64}$, Figuras 10-16 e 25-29, respectivamente), com salas adjacentes (XIV e XXVIII, respectivamente, Figuras 17-24 e 30-42); de mais um conjunto próximo de salas (XXXIII e XXXVI, Figuras 43-48 e 49-60); e dois corredores (LI e passagem ao templo de Ištar, Figuras 61-64 e 65-73). Essas salas formam conjuntos específicos numa área do palácio, havendo uma coligação entre elas.

Com relação aos motivos, os pátios VI e XIX continham relevos com cenas de construção e de batalhas, respectivamente; as salas XIV, XXVIII, XXXIII, XXXVI, continham cenas de batalhas; por fim, o corredor LI e a passagem ao templo de Ištar apresentam cenas específicas de procissão/caminhada, típicas desse tipo de ambiente arquitetural.

\section{Os relevos do Palácio Norte}

Já com relação aos relevos do Palácio Norte de Nínive, de Assurbanipal II, são dezessete salas que contêm relevos. Dentre elas, foram escolhidas nove salas ${ }^{65}$ : S1, S, C, com

\footnotetext{
${ }^{64}$ Essa numeração das salas segue o catálogo Barnett, Bleibtreu e Turner (1998), de acordo com o plano baixo de Paterson (1915).

${ }^{65}$ Utilizo aqui a numeração seguida pelo catálogo dos relevos de Barnett (1976) a partir da nomeação de salas presente no plano baixo reconstruído pelo autor.
} 
relevos de cenas de caça (Figuras 103-109, 81-85 e 86-102) ${ }^{66}$; F, H, L, com cenas de batalha (Figuras 110-113, 114-116 e 117-119); sala do trono M, também com cena de batalha (Figuras 120-121); e os corredores R e A, cujas placas de relevos expressavam momentos específicos prévios ou posteriores à caçada (Figuras 74-79 e 80). Essas salas contêm o maior número de relevos desse palácio.

Partindo da face noroeste do Palácio Norte, havia um arco de ligação entre uma parte interna e uma externa do palácio através de um caminho que envolvia salas e corredores. Especificamente, esse canal conectava as salas nomeadas S, S1, corredores R e A e a sala C (que era mais central no palácio). Essa última dava acesso a mais duas salas, F e H. A sala C também proporcionava o ingresso a um grande pátio interno (J); por meio dele, era possível acessar a sala L, adjacente à sala do trono (M), que era o principal ambiente do palácio. Estando mais a sudeste do monumento, as salas L e M ficavam próximas a outro conjunto de recintos, mesmo com acesso indireto através da sala $\mathrm{C}$.

Dos relevos selecionados do Palácio Norte, são dois motivos principais: cenas de caça e de batalha. Esses motivos são dispersos pelo palácio, em tipos de salas diferentes, no que se refere à função de cada uma. Os motivos de caça são articulados por dois momentos cenográficos diferentes: o primeiro ocorre em salas onde havia os relevos com cenas de caçada propriamente ditas (salas S1, S, C), e o segundo aparece em corredores (R e A) com cenas de "trânsito", expressando a partida a ou a chegada da caçada. Havia uma interconexão entre esses corredores e salas. Já as cenas de batalhas aparecem em salas menores (F, H, L) e especialmente na sala do trono (M). O conjunto cenográfico é formado pelas seguintes etapas: preparação e marcha à batalha, geralmente em direção a uma cidade; ataque e tomada da cidade, com o registro da batalha em si; por fim, a procissão dos tributos, prisioneiros e deportados em retorno vitorioso à capital.

\section{Aspectos narrativos dos relevos selecionados e os programas de suas salas}

Como os motivos dos relevos apresentam um caráter narrativo, é importante ter em vista a narratividade que integra o programa do interior e, em alguns casos, entre salas. A narrativa desses relevos é um elemento de descrição desse tipo de fonte imagética. Esses aspectos do programa das salas e dos relevos foram examinados por Nadali (2006), que

\footnotetext{
${ }^{66}$ A sala S1 apresenta uma particularidade arquitetural e temática, com um conjunto de relevos de cenas de batalha.
} 
enfocou precisamente na análise da narratividade das cenas esculpidas, destacando a manipulação das relações espaço-temporais expressadas figurativamente. A descrição de Nadali serve para apresentar as salas escolhidas para esta pesquisa, favorecendo a visualização de um panorama desses ambientes e dos motivos dos relevos em cada um deles. Para a reconstrução desses programas narrativos, Nadali considerou os relevos originais e os desenhos daqueles que não existem mais ou que ficaram muito fragmentários. Aqui, são enfocados somente os aspectos dos relevos selecionados para esta pesquisa ${ }^{67}$. São indicadas orientações de direção de movimento dentro do palácio, tendo como base a visualização dos planos baixos dos mesmos. Esses indicativos de orientação contribuem para perceber possíveis caminhos de locomoção pelos ambientes palacianos em paralelo com o direcionamento narrativo das placas em cada sala. Como exemplos, a descrição de uma orientação possível auxilia: no caso de uma sala que apresentava mais de uma entrada; quando é necessário sugerir um ponto de partida à observação das placas; a indicar a posição espacial das paredes; e a sugerir um sentido do movimento pelo ambiente descrito.

Em geral, nas pesquisas (comparativas e/ou descritivas) que tematizam os palácios assírios, os autores adotam a organização da apresentação começando pelos palácios mais antigos e seguindo aos mais recentes. Apesar de a descrição individual de cada um não ser prejudicada se se opta por um relato em uma ordem diferente, por outro lado ganha-se vantagens em começar pelos palácios mais antigos, especialmente na identificação de continuidades e descontinuidades entre eles. Assim, é mantida aqui essa ordem tradicional de apresentação, iniciando pelo Palácio Sudoeste.

Começando pela parte interna desse palácio, de Senaqueribe, na face norte do monumento, há um primeiro grande pátio (VI). Ele é o pátio mais próximo da área que comporta a fachada principal do palácio $(\mathrm{H})$ e a sala do trono (I) adjacente a ela. Entre ele e outro pátio (XIX), há três colunas de salas perpendiculares à sala do trono (I). Segundo Nadali (2006, p. 45; 56), esses grandes ambientes ajudam a criar subdivisões simétricas dentro do grande terreno palaciano. A amplitude desses pátios favorece o aumento da criação de espaços fechados ao entorno. Nesse sentido, com pátios mais amplos e mais salas menores em volta, o volume espacial do palácio como um todo é elevado. Então, sua monumentalidade é

\footnotetext{
${ }^{67} \mathrm{Na}$ literatura sobre os aspectos narrativos dos relevos palacianos, a posição das placas nas paredes é identificada pelas indicações presentes nos catálogos de Barnett (1976) e Barnett, Bleibtreu e Turner (1998). Para ordenar os relevos nas paredes, os autores desses catálogos basearam-se especialmente: nos diários de escavação dos sítios dos palácios; nos desenhos que acompanhavam esses registros; e a partir de planos baixos originais que indicavam as posições dos relevos nas paredes de cada sala.
} 
constituída por um espaço volumoso, além da presença de portais de ingresso a outras salas. Algumas dessas passagens eram flanqueadas por grandes esculturas de touros alados androcéfalos (chamados em acadiano de lamassû).

As placas esculpidas desse pátio apresentam cenas militares (Figura 10) e de construção, relacionadas à obra do próprio Palácio Sudoeste (Figuras 11-16). Vindo da sala do trono I, pelo único acesso dado pela sala $\mathrm{V}$, um fluxo de movimentação pelo pátio seria no sentido esquerda-direita ${ }^{68}$. Nessa rota, a única placa remanescente com cena de batalha está logo no início do percurso, na parede esquerda, enquanto os relevos com cenas de construção estão à direita do pátio. Nesse sentido, o conjunto indicado de cenas de construção seria colocado quase ao final do trajeto completo de deslocamento pelo ambiente, sugerindo uma narrativa que seria de fato da esquerda à direita. No entanto, pelo direcionamento das figuras esculpidas nas placas com as cenas de construção, a narrativa segue da direita à esquerda (NADALI, 2006, p. 47).

As cenas de batalha, à esquerda do pátio, referem-se à segunda campanha militar de Senaqueribe ao oriente, mas grande parte delas só está disponível via desenhos (resta somente uma placa incompleta no BM, a Figura 10). O outro grupo temático é de cenas de construção, expressando principalmente o transporte de pedras, de objetos de madeira já elaborados e de um lamassu (Figuras 11 e 15). A temática das construções também vem realçar o poderio do rei, nesse caso considerado o grande construtor e capaz de mobilizar grandes recursos humanos e materiais para a criação de seu "Palácio Sem Rival" - e que também aparece na cena, "acompanhando" os trabalhos (Figura 13).

Próxima ao pátio VI, a sala XIV continha muitas placas com relevos esculpidos em suas paredes (Figuras 17-24), com mais cenas de batalha de Senaqueribe, ainda referentes à segunda campanha ao oriente ${ }^{69}$. Essas cenas de batalha iniciam-se à esquerda da única entrada (começando na Figura 17 nos relevos remanescentes, no meio da parede), seguindo à direita até seu desfecho no ingresso (terminando na Figura 24 nos relevos remanescentes, no fim da parede à direita da entrada). Não há divisão interna da imagem, ou seja, a cena ocupa a altura

\footnotetext{
${ }^{68}$ Essa movimentação no sentido esquerda-direita é característica sugerida para outras salas do Palácio Sudoeste e do Palácio Norte, como apontado ao longo deste subtópico.

${ }^{69}$ Nadali (2006) menciona suas próprias pesquisas anteriores (2002-5), assim como a de Levine (1973-74), sobre o local da campanha observado através dos relevos: talvez na região da cadeia montanhosa do Zagros, ou na região do rio Diyala (à sudeste de Nínive), ou em Ellipi (região entre a Média e o Elam antigos, no noroeste do atual Irã), ou talvez se refiram à conquista de Alammu, cidade imprecisa, sendo talvez na região da Anatolia ou no Elam.
} 
inteira da placa. No centro desse arco narrativo, de frente para a entrada, há o ápice cenográfico com a tomada de uma cidade (Figura 21$)^{70}$.

O tema desenvolvido nessas placas é esculpido sem bandas divisórias e numa única direção. Contudo, apesar de tal característica favorecer a uniformidade e linearidade da cena, Nadali (2006, p. 55) afirma que é possível perceber três sequências diferentes nesses relevos, onde há pontos de alternância de estado, com elementos estáticos e em movimento (dinâmicos), e mudança de ações, com momentos de marcha, de combate e de uma procissão ao final da narrativa. Logo no início do arco das placas, o movimento de progressão pela cena é indicado pelas figuras dos sujeitos, numa dualidade entre aqueles que andam e aqueles estão numa "caminhada imóvel". Todos os sujeitos aparecem com os membros inferiores numa posição de passo (uma perna na frente da outra). O marcador corporal que sugere à visão um movimento de caminhada é a elevação dos pés, sendo uma das etapas da locomoção. Segundo Nadali (2006, p. 56), um primeiro ponto de mudança de estado é a passagem dos sujeitos parados (numa posição de passo, mas sem elevação dos pés) aos que estão andando (em especial na Figura 19).

Dessa ida à batalha, a progressão da cena ocorre com o aparecimento dos arqueiros, posicionados com seus arcos preparados numa posição de puxada completa - seria o momento final de todo o alongamento da corda da arma, antes do disparo (Figura 20). Eles aparecem primeiro em pé e em seguida agachados. Os relevos ainda preservados vão até esta parte da narrativa; por meio dos desenhos, ela continua com ápice da batalha, num clímax ascendente de movimento e com a duplicidade do ataque (uma ofensiva em ambos os lados de uma muralha citadina: à esquerda nas Figuras 20-21, à direita na Figura 22). Por fim, o desfecho da procissão foi esculpido com a reutilização do particionamento em registros ou bandas (por exemplo, na Figura 23), o que na visão de Nadali (2006, p. 56-57) poderia servir para ordenar o ritmo da marcha. A centralidade do ataque em conjunção com a orientação visual da sala, além da combinação entre relevos sem e com bandas, é uma estratégia que pode estimular o ritmo da narração (NADALI, 2006, p. 57).

Passando a outro pátio, a configuração do pátio XIX é caracterizada por sua reestruturação. A figura do rei, considerado grande construtor, implica também a reforma de conservação de um ambiente anteriormente utilizado pelo seu antecessor. Nas inscrições reais de Senaqueribe, eram descritas suas ações construtivas em Nínive, envolvendo o palácio, os muros da cidadela, a elaboração de canais e aquedutos, o estabelecimento de jardins e

\footnotetext{
${ }^{70}$ Nesses relevos, sua coloração escura provavelmente é um indício do incêndio provocado quando da tomada de Nínive no fim do século VII AEC.
} 
pomares etc. O pátio XIX do Palácio Sudoeste é um exemplo da atividade de reformulação de um ambiente palaciano: nesse local, foram encontrados relevos do período de reinado de Assurbanipal II, neto de Senaqueribe ${ }^{71}$, algo que ocorre também na sala XXXIII ${ }^{72}$. Segundo Nadali (2006, p. 56), tal tarefa de reforma pode ter sido feita nos primeiros anos do reino do neto de Senaqueribe, ou enquanto ele era príncipe herdeiro e habitava no palácio ${ }^{73}$. É possível perceber a diferença de estilos entre os relevos do período do avô e do neto, com uma variação das normas canônicas dos artífices para a escultura (NADALI, 2006, p. 56). Por outro lado, as características narrativas desses relevos mesclam aspectos próprios das esculturas de ambos os períodos. Como os relevos são do período de Assurbanipal II, há a presença de bandas, mesmo havendo um ponto central com a figura do rei ocupando a totalidade de uma delas.

Os relevos remanescentes desse pátio ficavam no canto que dava acesso às salas XXXIV, XXVIII e XXIX. Uma parte fragmentária das placas constitui uma procissão provavelmente após uma batalha (NADALI, 2006, p. 57-58) (Figuras 26-27), culminando num depósito de espólios e cabeças para a contagem de funcionários assírios (Figura 25) Nessas placas, orientação das figuras é da direita à esquerda. Nos outros relevos (Figuras 2829), a centralização do rei sobre seu carro (na parte inferior da Figura 28) marca o ponto de partida da visualização (NADALI, 2006, p. 57). Contudo, há uma divisão feita por um rio. A presença de um rio é um elemento expressivo característico dos relevos de Senaqueribe, visando dar mais realismo às cenas através da paisagem (nesse caso, naturalista) e parecendo ser um estilo herdado por Assurbanipal II. Para Nadali (2006, p. 57-59), a divisão com um elemento da realidade paisagística ajuda a dar uma noção de integração entre as partes: ao invés de separar, o rio serve como divisor e estende o espaço da cena, criando um meio de comunicação entre as partes (Figuras 28-29) ${ }^{74}$.

\footnotetext{
${ }^{71}$ Especula-se sobre a possibilidade de Assurbanipal II ter deixado o Palácio Sudoeste para habitar no Palácio Norte de Nínive, restando o primeiro como um palácio acessório. Sendo o Palácio Sudoeste muito maior e tendo Assurbanipal II provavelmente nascido e crescido nele, a continuidade de ocupação do palácio como casa real no século VII seria bastante esperada.

${ }^{72} \mathrm{Na}$ sala XXXIII, há relevos com cenas de batalha contra os elamitas, próxima ao rio Ulai (ao sudeste mesopotâmico, na região elamita), que se comunica com a cena de banquete da sala S1 do Palácio Norte.

${ }^{73}$ Nadali também apresenta os argumentos de Reade (1979a; 1981) sobre esses relevos dos ambientes XIX e XXVIII do Palácio Sudoeste. Para Reade, eles são na verdade posteriores a Assurbanipal II, especificamente do período de seu filho Sîn-šarru-iškun (627-612 AEC). Sobre esse mesmo problema, Gerardi (1988) também concorda, com Nadali, que o reaproveitamento escultórico do pátio XIX foi feito por Assurbanipal II. Mais evidências sobre essa restruturação pontual são presentes em textos, como a contribuição de Falkner (1952-53), mencionada por Nadali (2006, p. 56).

${ }^{74}$ Tal divisão é mais orgânica, mais natural, menos visualmente abstrata. Comparativamente, quando há uma faixa ou linha de base esculpida, para criar um chão da cenografia, impõe-se uma abstração: é um marcador visual que estabelece a base da observação. Um elemento comum da experiência de mundo, como é o caso de um rio, ajuda a delimitar o espaço escultórico, não impondo um ponto de partida abstrato à visualidade.
} 
Mesmo com duas bandas, há um continuum narrativo, e não duas linhas de narração (NADALI, 2006, p. 57-59). A ligação entre as bandas é feita também pela coincidência de figuras entre elas. Nadali afirma que a programação narrativa é favorecida por uma "fluida continuidade das sequências justapostas" (2006, p. 61). Essa disposição do pátio convida a continuar por outras salas: a partir do pátio XIX, parece haver uma preparação à continuidade temática que se prolonga pelas cenas dos relevos de outros ambientes.

Segundo sua forma e de acordo com Kertai (2015a, p. 142), a sala XXVIII seria um corredor, que conectaria o pátio XIX a um terraço externo ${ }^{75}$. Do pátio ao terraço, a narrativa segue pela parede esquerda em direção à direita. Após ao que parece ter sido uma batalha ou assalto em ambiente aquático (Figuras 30-31), o caminhante é guiado à parte externa com uma cena de procissão provavelmente de espólios (Figuras 32-33). A sequência é interrompida no relevo original no meio do ambiente, com funcionários assírios realizando uma contagem (à direita da Figura 34). Na parede oposta, há dois sentidos: uma procissão da esquerda à direita (na direção do exterior ao pátio, Figuras 35-36), seguida por um centro de encontro, com contagem de cabeças e espólios (Figuras 37-38), e grupos de soldados assírios e cavalos direcionados da direita à esquerda, seguindo a orientação do pátio ao exterior e centralizados também na cena de contagem de produtos (Figuras 39-42).

A narração desse ambiente segue, por um lado, a dinâmica de progressão cenográfica, adaptada à função prática da sala de acompanhamento do caminhante. Contudo, pelos desenhos desses relevos, há uma cena de batalha presente, diferente do que aparece em outros corredores dos palácios de Nínive (NADALI, 2006, p. 64-65). A cena prossegue dessa batalha a uma procissão dividida em faixas. Nadali (2006, p. 64) especula que talvez fossem duas ou três faixas, com duas possibilidades hipotéticas de visualização: poderia haver dois ou três momentos diferentes registrados na placa, cada um em uma banda; ou haveria um único momento, mas envolvendo a apresentação de procissões diferentes. Nesse caso, seriam dois canais narrativos conexos pelo evento que registram.

Além dessa divisão narrativa, Nadali argumenta que há um tipo de divisão temática no interior da cena: entre ambientes de paz e de caos (ou guerra). Esses ambientes são marcados na cena pela presença militar dos soldados assírios e por momentos de batalha, que contêm ações mais caóticas. Já o espaço pacífico apresenta um ritmo mais lento através das características das figuras (e por haver mais ordenação na escultura). Assim, num mesmo

\footnotetext{
75 Nadali (2006, p. 64) também indica que essa comunicação com o terraço tenha favorecido uma visão panorâmica externa da cidade. Ele também concorda com Kertai que essa sala era um corredor, efetivamente pelo seu caráter de passagem.
} 
espaço cenográfico, com as figuras e o pano de fundo, a narrativa dos relevos expressa momentos e lugares de guerra e de paz (NADALI, 2006, p. 65-66).

Acima da área da sala XXVIII e do pátio XIX, os relevos da sala XXXIII recobrem as paredes de cada lado do ambiente. No entanto, são remanescentes somente as placas das paredes próximas à entrada da sala pelo interior do palácio (Figuras 43-48). A cenografia desses relevos contém uma disposição dispersa de elementos, criando um efeito dinâmico de caoticidade de uma batalha em campo aberto (Figuras 43-45). Devido a essa característica, não há uma precisão numa orientação narrativa pela sala, mas uma sugestão possível é da esquerda à direita nessas paredes, vindo do eventual acesso ao exterior do palácio. A partir desse mesmo acesso, três placas estão à esquerda (Figuras 43-45) e as outras três (Figuras 4648) estão à direita da passagem a outro ambiente palaciano (sala XXX). Nesse sentido, a visualização fica à esquerda do observador. Mesmo assim, entre as bandas das placas, há alternância de direção especialmente nos conjuntos de procissão.

As placas também contêm inscrições (nas Figuras 43-45) que auxiliam na compreensão de que são esculturas produzidas no período de Assurbanipal II. São cenas que fazem parte da comemoração da vitória contra o rei elamita, Teumman. A narrativa expressa a morte e o recolhimento dos espólios desse rei $^{76}$. Na escultura desses relevos, mesmo se podendo verificar a existência de faixas ou bandas, parece não haver uma imposição visual de divisão rigorosa, o que aproxima ao estilo dos relevos do período de Senaqueribe ${ }^{77}$. Há somente uma linha sutil, que serve para um "plano de apoio" separado. Um efeito realístico é mais realçado por um intercâmbio entre as faixas através do espalhamento de figuras pelo espaço cenográfico.

Esse grupo de relevos é um dos poucos com cenas de combate em campo aberto ${ }^{78}$, em contraposição aos mais comuns ataques a cidades (NADALI, 2006, p. 68). A dispersão de elementos pelas placas concentra-se em subsequências, criando momentos paralelos. Por exemplo, há momentos de procissão pelas placas (partes superiores das Figuras 45-46 e nas Figuras 47-48), mas em locais e direção diferentes, o que as distingue umas das outras. Essa dispersão e os agrupamentos menores são colocados num esquema rítmico e contêm um rio como delimitador (Figuras 46-48, e na lateral da Figura 45). Enquanto na primeira placa, o rio

\footnotetext{
${ }^{76}$ Conforme afirma Nadali (2006, p. 68-69), esse contexto cenográfico conecta-se com sala S1 do Palácio Norte. A dinâmica narrativa focada nas etapas do episódio de captura do rei elamita Teumman são analisadas especificamente por Watanabe (2004).

77 Nadali (2006, p. 70) aponta a contribuição de Nagel (1967) sobre o fato desses relevos representarem um primeiro estilo escultórico do período de reinado de Assurbanipal II, talvez tendo recebido influência do perfil dos relevos de seu avô.

${ }^{78}$ Esse evento é denominado a batalha de Til Tuba, que ocorreu por volta de 653 AEC.
} 
tende à verticalização (na Figura 45), sua disposição horizontal nos próximos relevos (Figuras 46-48) cria uma borda cenográfica. As figuras de mortos e objetos dispersas pelo rio contribuem para configurá-lo espacialmente no contexto da cena de batalha, pois constitui uma característica topográfica da paisagem, assim como, pelos elementos jogados pelo rio, é conectado ao momento da própria batalha (NADALI, 2006, p. 70).

Na mesma área palaciana, a sala XXXVI contém os relevos com cenas de batalha do período de Senaqueribe. Esses relevos são emblemáticos por expressarem um evento reconhecido como a batalha de Lakiš, cidade localizada na antiga Judá e tomada por Senaqueribe em sua terceira campanha ${ }^{79}$. Esse ambiente era acessível diretamente por um canal único saindo do pátio XIX e passando por duas salas. Segundo Nadali (2006, p. 75), a entrada na sala permitiria uma visão de todas as paredes, assim como uma centralização na parte imediatemente em frente ao acesso. O sentido narrativo pela entrada da sala é duplo, tendo da esquerda à direita a marcha à batalha (Figuras 49-50), com a tomada da cidade ao centro (Figuras 51-52) e a procissão subsequente - envolvendo nesse caso algumas “punições" (Figuras 52-57); já da direita à esquerda, tem-se a perspectiva do cenário e do grupo que acompanhava o rei, presente na cena e observador principal da ação guerreira (Figuras 57-60). As linhas narrativas combinam direcionamentos horizontais e diagonais, com foco central na tomada da cidade (NADALI, 2006, p. 71) (Figura 51).

A narrativa dos relevos desse ambiente é composta por sequências justapostas de um percurso espaço-temporal, marcando a progressão rítmica dos eventos típicos de uma cena de batalha: aproximação, ataque principal e procissão final. De acordo com a descrição de Nadali, o projeto escultórico de Senaqueribe dispõe um só motivo em cada sala. Tal característica na sala XXXVI é dada pelo evento único em Lakiš. Além disso, há convergências de linhas de direção que se destinam ao alto da cena central (na cidade atacada, Figura 51), assim como o centro da parede da sala seria o mesmo clímax cenográfico. Também Senaqueribe esculpido em seu trono (Figuras 57-58) está posicionado numa placa que está quase diante da cena de ataque, como se ele estivesse assistindo duplamente a cena (na configuração das placas e na realidade daquele acontecimento). Pelas placas e pelo ambiente em si, é um único evento expressado numa "única" placa ou parede; a batalha

\footnotetext{
${ }^{79}$ A data atribuída a esse evento é 701 AEC. Em acadiano neoassírio, o nome da cidade era escrito uru $l a-k i$-su. Também conhecida por Lachish, a cidade ficava no atual Tell el-Hesi, em Israel. Esse acontecimento já era conhecido do público pela versão do Antigo Testamento (descrito, por exemplo, nos livros de Reis, Crônicas e mencionado nas profecias de Isaías). Sobre a historiografia desse evento, ver os aspectos levantados no livro organizado por Kalimi e Richardson (2014).
} 
registrada inicia-se e termina no mesmo espaço, seja aquele real, seja aquele imagético (NADALI, 2006, p. 73; 75).

As cenas da tomada de Lakiš contêm as inovações artísticas do construtor do Palácio Sem Rival. Além da disposição e dispersão de elementos por toda a placa e da redução do tamanho das figuras para criar efeitos de perspectiva, profundidade e movimento, outro exemplo é o uso da paisagem para colocar um pano de fundo da batalha. As cenas de Lakǐs colocam a paisagem de montanha para dar realismo ao registro do evento (NADALI, 2006, p. $74)$.

Por fim, os últimos ambientes selecionados com relevos remanescentes são dois corredores: a passagem descendente LI e a passagem ao templo de Ištar. Ambos se localizavam em partes opostas do palácio. Segundo Nadali (2006, p. 92-93), a primeira passagem talvez levasse a uma área externa ou a outro conjunto de ambientes ${ }^{80}$. Já a passagem ao templo de Ištar não é exatamente um ambiente interno do palácio ${ }^{81}$. Contudo, ambos os corredores compartilham não somente a característica e função arquitetônicos, como também o motivo dos relevos de suas paredes.

Conforme afirma Nadali (2006, p. 92-93), o corredor LI é semelhante aos corredores do Palácio Norte, especialmente pelo tamanho aumentado das figuras. Vindo do interior do palácio, seguindo a direção descendente (pela parede esquerda), há a presença de cavalos, sendo como uma saída para a caça (da esquerda à direita, Figuras 61-62). O movimento dessa dinâmica é reforçado pela elevação das patas dos animais, que indicam diferentes velocidades de movimento. Já na parte ascendente (Figuras 63-64), no meio da parede (à esquerda na direção ao interior do palácio), seria como o retorno para dentro (da esquerda à direita) com resultados para um eventual banquete nos relevos remanescentes. Como afirma Nadali (2006, p. 92), são duas paredes com duas narrativas, possivelmente associadas pelo tema da passagem e trânsito de ida e volta entre dentro e fora do palácio. Essa programação narrativa pode ser vista como algo reduzido em comparação a cenas de outras salas, onde as placas das paredes apresentavam mais figuras e com uma organização mais sofisticada. A estreiteza do corredor e sua função de passagem também confluem para uma consideração de que aquilo que está expressado nos relevos seria mais monótono. Contudo, a dinâmica dos corredores e seu serviço para a passagem criam um ambiente funcional que encontra nos relevos a

\footnotetext{
${ }^{80}$ A última hipótese é sugerida pela reconstrução de Kertai (2015a, fig. 17) (Figura 7).

${ }^{81}$ A passagem ao templo de Ištar não foi muito bem escavada pelos arqueólogos. Conforme Kertai (2015a, p. 130), a entrada para esse corredor devia ficar na extremidade oposta do grande pátio $\mathrm{H}$, a mais ou menos $65 \mathrm{~m}$ de distância. Segundo Nadali (2006, p. 96), os relevos desse ambiente foram encontrados a essa distância, durante as escavações conduzidas pela delegação de Rassam.
} 
correspondência em figuras esculpidas de maior porte, mais aproximadas ao tamanho humano. A ausência de pano de fundo e a proposta de movimento também presente nesse tipo de cena - além da temática eventualmente associada à caçada ou ao trânsito em direção à saída ou ao retorno ao interior palaciano - fazem com que os sujeitos que estão nos relevos acompanhem o transeunte. A proposta narrativa dos relevos de corredores tem um efeito expressivo para além de um registro de eventos.

A passagem ao templo de Ištar faria a vinculação do palácio com uma área externa. Nesse corredor, há também um percurso com ascendência e descendência, associado talvez a uma entrada (descida) cerimonial ao templo (Figuras 65-67), e depois um retorno ao palácio (mais elevado) (talvez envolvendo as Figuras 68-73) (NADALI, 2006, p. 96). Nos relevos que recobriam as paredes desse caminho, havia a presença da figura do rei e do príncipe, com duas possibilidades de progressão: ou seria uma única procissão, ou seriam duas: uma em direção ao templo e outra em direção ao palácio $^{82}$. Outro problema é associado a imprecisão da ordem reconstrutiva desses relevos. Nesse debate, as principais diferenças estão na posição do rei e príncipe: ou ambos precedem todo o cortejo cenográfico (Figura 67, com príncipe precedendo um assento carregado por funcionários, em relevos não remanescentes), ou o rei fecha a procissão. Especula-se se é somente uma via (com início e fim) ou um ciclo de movimento expressado nos relevos (NADALI, 2006, p. 101). Para Nadali, mesmo que não seja uma continuidade em caso de mais de uma via, ambos comporiam um mesmo "unicum" narrativo, ajudado pela inclinação do ambiente, que dá sentido e ritmo ao percurso (2006, p. 102). Tal dinâmica de movimento recebe a colaboração da presença dos relevos (independentemente de sua ordenação precisa) para acompanhar o transeunte na passagem pela sala, o que é uma particularidade desses espaços palacianos.

Com relação ao Palácio Norte, os corredores A e R cumprem suas funções de passagem pelo palácio, eventualmente conectando uma área externa com áreas mais internas. O corredor A liga a sala C, mais centralizada no palácio, ao corredor R. Por sua vez, este dava acesso a uma saída a uma área externa. As poucas placas remanescentes desse ambiente ajudam a visualizar um possível movimento de saída, com as figuras esculpidas indo em

\footnotetext{
${ }^{82}$ Nadali (2006) aponta essa discussão para Reade (1967; 2005).
} 
direção à área externa do palácio ${ }^{83}$. De modo particular, o corredor $\mathrm{R}$ apresentaria uma dinâmica de motivo de um pós-caçada, relacionado às salas S e S1. Ele também é considerado uma passagem ascendente ${ }^{84}$ : é um corredor com leve inclinação em direção à saída (NADALI, 2006, p. 135). Então, o caminho formado pelos corredores e as cenas esculpidas teriam relação com a ida e/ou retorno da caça, em comunhão com os outros ambientes (C e S) que tinham a mesma temática (NADALI, 2006 p. 136).

Nos relevos dos corredores A e R, há uma procissão de sujeitos em tamanho maior (em relação à estatura humana comum), de um lado (à esquerda, na direção do interior ao exterior, de inclinação ascendente) partindo à caçada (Figuras 74-76 e 80), de outro (à esquerda, na direção do exterior ao interior, de inclinação descendente) retornando com os resultados (cenas somente no corredor R, Figuras 77-79). A ida à caça é caracterizada pela procissão de ajudantes carregando alguns implementos (arcos, no corredor A, Figura 80); cestos, cordas e redes, no corredor R (Figuras 72-74), acompanhados de animais (jumentos carregadores, cavalo e cães, no corredor $\mathrm{R}$ (Figuras 74-76)). O retorno realçado no corredor $\mathrm{R}$ envolve a imagem de carregamento de três ou quatro leões ${ }^{85}$ (Figuras 77-79), arqueiros e outros funcionários com lanças e escudos (Figura 77). Aparecem também dois funcionários, encabeçando uma segunda linha de procissão (Figura 77). Ambos carregam uma bandeja cada, contendo pequenos animais (talvez aves maduras ou filhotes); em suas outras mãos, carregam uma ave (aparentemente viva, com o funcionário da frente do aparente bloco) e uma lebre (com o segundo funcionário do bloco). Um detalhe apontado por Nadali (2006, p. 136) é com relação ao ritmo de movimento provocado pelos relevos, efeito visto não somente pela escultura de passos de cada sujeito, mas pela aproximação entre eles ao final do lado esquerdo do corredor $\mathrm{R}$ em direção à área externa do palácio. Tal aproximação diminui o ritmo da procissão, podendo indicar a lentidão de chegada ao local da caçada.

Considerando agora as extremidades desse percurso, a sala S apresenta uma entrada com duas colunas. Tal característica é específica de um tipo arquitetural chamado bīt hilāni ${ }^{86}$. As cenas de caça nesta sala também contam com personagens auxiliares e com animais (leões,

\footnotetext{
${ }^{83}$ Conforme o plano baixo de Barnett (1976, p. 28).

${ }^{84}$ Particularidade arquitetônica também presente no Palácio Sudoeste.

${ }^{85}$ De acordo com uma das estratégias da narrativa visual dos relevos, a repetição, pode-se especular se de fato são três ou quatro animais carregados, ou se seria um único ou até dois deles, mas repetidos na mesma posição ou numa outra forma de carregamento, indicando progressão temporal da procissão.

${ }^{86}$ Segundo Kertai (2015a, p. 82), as primeiras ocorrências deste estilo arquitetural (inspirado em elementos arquitetônicos sírios) vêm dos palácios de Adad-nerai III e Tiglath-Pileser III, do fim do século IX a meados do século VIII AEC, em Kalhu. Além de tal ocorrência aparecer nas inscrições reais de Tiglath-Pileser III, Senaqueribe também descreve a criação desses ambientes intra palacianos em suas inscrições, especialmente nos momentos de relato de seus projetos construtivos. Na própria inscrição, ele faz referência à inspiração hitita/síria para sua réplica. Ver, por exemplo, RINAP 3/1 182.
} 
gazelas e equinos), mas especialmente há o rei em atuação como protagonista (NADALI, 2006, p. 136) (Figuras 81-85). É uma caçada a animais diferentes, em dois ambientes: terrestre e aquático (este conhecido somente pelos desenhos). Mesmo sendo possível identificar esses cenários de fundo, o contexto concreto da cena com elementos paisagísticos contrasta com a ausência de paisagem em outras partes - ausência percebida nos relevos que sobreviveram. Isso gera um espaço abstrato onde se passa o evento, o que é uma característica presente também nas cenas de procissão nos corredores (NADALI, 2006, p. 137).

Todos os relevos remanescentes desta sala que apresentam a cena de caça estão na parede esquerda no sentido de dentro para fora partindo do corredor R (Figuras 81-85). A direção principal da narrativa é da esquerda para a direita, mas há alterações de sentido em algumas das três bandas das placas. Especialmente nas últimas placas da parede (como no relevo remanescente da Figura 85), o sentido prossegue principalmente da direita à esquerda, talvez criando um ponto de centralização em pedaços de relevos que não sobreviveram. $\mathrm{Na}$ cena de caçada, o rei é o personagem principal. Ele aparece como figura central em ações repetidas, porém com estados de atuação diferentes: num momento, o rei está atacando (Figura 81); noutro, ele está fora dessa atividade, recebendo ofertas (Figura 82). Então, de um lado há uma dinamicidade na atitude do rei na cena, enquanto de outro há uma passividade (NADALI, 2006, p. 138).

A narrativa dos relevos nessa sala apresenta uma dinâmica horizontal e uma diagonal para a construção da cena (NADALI, 2006, p. 137). Como nessas placas de relevo há bandas, que podem ajudar num enquadramento narrativo, é possível visualizar a ação de maneira sincrônica, acompanhando a dinâmica da cena em cada parte. Também é possível vê-la diacronicamente, se se acompanha a figura do rei interagindo com o leão. Por exemplo, na parte inferior das placas (Figuras 81-84), há a caça em si, que dirige uma narração horizontal dentro da banda. Contudo, sendo o rei uma figura que se repete entre as bandas (na Figura 81, da banda superior a inferior), pode haver uma passagem diagonal de visualização ${ }^{87}$ (NADALI, 2006, p. 143). Esta forma diagonal de rastreamento visual exige mais da abstração, pois se descola de um contexto enquadrado na imagem por uma banda única e com uma paisagem definida. Focalizando na interação entre o rei e o leão, há uma ênfase no modo como o soberano mata o animal. Então, além das cenas de caça serem um dos motivos

\footnotetext{
${ }^{87}$ Possibilidade de visualização que também acontece nos relevos da sala L.
} 
principais dos relevos de Assurbanipal II, dentro desta temática se enfatiza a interação do rei com a sua presa ${ }^{88}$.

Já no interior do palácio, a sala $\mathrm{C}$ também apresentava em suas paredes um conjunto de cenas de caçada. Preliminarmente, Nadali (2006, p. 106) afirma que este ambiente é proporcionalmente equiparável à arquitetura da sala $\mathrm{M}$, onde ficava o trono. Vindo do corredor $\mathrm{A}$, a narrativa dos relevos da sala $\mathrm{C}$ pode ser vista do sentido da esquerda à direita na parede esquerda (Figuras 86-93, continuando pelas paredes de fundo e direita nas Figuras 93102). Contudo, nesse conjunto de placas, grande parte delas sem bandas de divisão, há muitas inversões de sentido partir da disposição dos personagens no relevo. Nas esculturas, o rei também tem destaque: ele ocupa uma posição central, tem como antagonista um animal e sua figura chega a ocupar do equivalente a duas bandas (Figura 84) à totalidade da placa (Figuras 91-92, 95-96 e 100). Com relação à narratividade, segundo Nadali (2006), há na cena uma “contemporaneidade de ações diacrônicas" (p. 107), isto é, dois grandes momentos de um evento de caçada são colocados num mesmo espaço cenográfico, servindo à narrativa como um efeito de continuidade da narração (p. 109). São dois momentos diferentes dentro do acontecimento da caçada, mas eles foram postos num mesmo arco temporal espacialmente delimitado no relevo. Tal disposição expressiva talvez promovesse a intenção de uma sucessividade dos acontecimentos, ou até de uma circularidade - incluindo nesse caso o ambiente como um todo. A conjunção desses grandes momentos num mesmo espaço narrativo pode ser também considerada uma sobreposição ${ }^{89}$ dos mesmos, visando uma síntese do evento da caça (NADALI, 2006, p. 112). Essa sucessividade é marcada também pela dispersão dos elementos figurativos na cena, o que favorece uma fluidez no espaço visual, ao mesmo tempo que dá dinamismo à ação narrativa (NADALI, 2006, p. 116) ${ }^{90}$. Então, há a

\footnotetext{
${ }^{88}$ No conjunto de relevos da sala $S$, um elemento que corrobora a essa compreensão é a utilização, por parte do rei, de todas as armas à disposição no conjunto das cenas: adaga ou pequena espada na banda superior, lança na banda intermédia e arco na banda inferior (Figura 81), este último se repetindo na banda superior de outra placa (Figura 84). Conforme Nadali (2006, p. 145) afirma, isso tem relação com as inscrições presentes na sala S1, mencionando a maestria do rei habilidoso.

${ }^{89}$ A sobreposição é um princípio expressivo dos relevos que ocorre de maneira similar no caso do registro de corpos numa procissão, buscando dar uma dimensão de perspectiva ou profundidade.

${ }^{90}$ Essa dispersão de elementos também aparece no conjunto de cenas de batalhas, contribuindo à fluidez da narrativa e a uma dose de caoticidade na cena, algo esperado na representação de uma guerra. Os relevos da sala XXXIII do Palácio Sudoeste são um exemplo emblemático desse efeito. Outra confluência particular entre as cenas de caça e de batalha é o compartilhamento da mesma dinâmica ou ritmo. Nas cenas de batalha, ficam bastante evidentes as etapas do evento, que incluem um processo de marcha, confronto e procissão final. Para o caso das cenas de caça, há um processo semelhante, com momentos preparatórios, de realização da caçada e uma conclusão. A proporcionalidade de ritmo e velocidade de partes do evento esculpido em ambos os motivos também é uma semelhança entre os temas. As diferenças estariam em efeitos e gestuais simbolizados em cada um, com uma particularidade especial, sobretudo, na construção desse processo narrativo através de um programa entre salas: a caçada é expressada em determinadas placas, enquanto sua preparação, encaminhamento e retorno aconteceriam em outros conjuntos de relevos e com o efeito suscitado em corredores. Apesar desses
} 
preparação para a caça, num ambiente de colina (Figuras 86-87), com personagens, espectadores e implementos, e um momento da caçada em si, envolvendo uma dinâmica de defesa e ataque do rei (Figuras 91-92, 95-96 e 100) (NADALI, 2006, p. 108; 110) ${ }^{91}$.

A sala $\mathrm{C}$ pode ser considerada o fim de um percurso do exterior ao interior do palácio, passando pelas salas S e S1 e pelos corredores R e A. Retornando ao início desse caminho, a sala S1 é tratada à parte por causa de suas particularidades. Primeiramente, especulava-se sobre seu lugar verdadeiro: se era no plano térreo, ou se era um eventual piso superior ${ }^{92}$. Uma multiplicidade de temas de seus relevos também é característica desse ambiente: há cenas de caça (Figuras 103-104), de banquete (Figuras 105-107) e cenas bélicas (Figura 108), sendo as duas últimas relativas ao contexto histórico de conflitos com o antigo Elam. Portanto, além de ela se relacionar com outras salas específicas, como a $\mathrm{S}$ e a $\mathrm{C}$, ela sintetiza temas de todos os palácios assírios (NADALI, 2006, p. 146). Devido à imprecisão da localização dessa sala no palácio, uma sugestão de orientação por ela fica comprometida, mas é possível visualizar as alternâncias de direção dos personagens nas cenas esculpidas. Nessa sala, esses temas foram postos em placas com três registros, cada um com sua narrativa horizontal - mesmo existindo um complemento entre as bandas, que as conecta (NADALI, 2006, p. 147). Em comparação com a sala C, Nadali (2006, p. 148) afirma que a disposição em três bandas causou uma diminuição do tamanho das figuras ${ }^{93}$. Então, num mesmo tipo de placa de pedra, a opção por esculpir cenas divididas em bandas demanda principalmente a redução tanto no tamanho das figuras, como na abordagem espacial entre elas (mais ou menos próximas). Assim, a estratégia escultórica muda os efeitos de luminosidade, transparência (clara distinção entre as figuras pela placa) e profundidade. Por outro lado, Nadali apresenta que essas alternativas também habilitam novos tipos de visualização das cenas (2006, p. 148), ampliando as possibilidades de expressão da narrativa visual nos relevos.

\footnotetext{
temas serem dispersos pelo palácio, a narrativa de batalhas específicas tende a ser concentrada num mesmo ambiente, enquanto a temática da caçada coliga-se entre salas e corredores.

${ }^{91}$ Segundo Nadali $(2006$, p. 108; 110; 139; 146; 152; 279), a interação entre rei e animal (geralmente um leão) numa ação de ataque-defesa é uma cena emblemática que aparece, por exemplo, na iconografia de selos cilíndricos. Sobre os selos cilíndricos neoassírios como marca iconográfica de um poder (inclusive difundido), ver Nadali (2009/2010).

92 Atualmente, o debate está encerrado pelas impossibilidades arquiteturais do palácio assírio suportar um segundo piso (dadas as alturas bem elevadas de suas paredes, o que exigiria uma espessura maior das mesmas e, consequentemente, maior espaço para a construção do monumento) e pela ausência de razões plausíveis para se ter um segundo andar num palácio cuja complexidade arquitetural devia resolver todas as suas necessidades funcionais (KERTAI, 2014a, p. 694-695).

${ }^{93}$ Essa evidência contribui ao argumento de que os relevos do pátio XIX do Palácio Sudoeste tenham sido do período de Assurbanipal II, tendo em vista que neles as figuras também sofreram reduções de tamanhos (possivelmente por limitações impostas pelo suporte).
} 
Enquanto as cenas bélicas desta sala são conhecidas somente através de desenhos, e as cenas de caça são bem conhecidas dentro do universo do Palácio Norte, os artífices de Assurbanipal II retomaram as cenas de banquete ${ }^{94}$. As cenas de caça e as cenas bélicas da sala S1 complementam todos os aspectos da realeza assíria (NADALI, 2006, p. 156): na caça, o rei aparece com as armas utilizadas por ele; como na sala $\mathrm{C}$, a presença de um motivo de caçadas com o rei protagonizando e manipulando diferentes implementos são elementos da síntese do rei caçador (NADALI, 2006, p. 151); na guerra, não somente é destacado (pelos desenhos) o que vem depois da batalha (a procissão dos tributos e deportados), mas é enfatizada a celebração da vitória no momento de gozo no banquete (Figura 106). A conjunção num mesmo espaço dessas cenas exemplares favorece a imagem de um rei potente ${ }^{95}$.

Os relevos da sala $\mathrm{S} 1$ possuem maior recorrência da figura do rei em cada cena e a retomada das inscrições nas placas. Novamente, os artífices não somente copiam, mas readaptam temas e esquemas em condições narrativas diversas (NADALI, 2006, p. 156). Afora um eventual cumprimento de um cânone, a presença constante do rei nas cenas pode indicar o uso frequente da sala pelo soberano, ao poder se ver nas paredes de seu palácio. Já com relação à retomada das inscrições, os artífices atuaram diferentemente: em vez de inserirem inscrições em bandas centrais entre placas com relevos esculpidos superior e inferiormente, algo que ocorria no século IX AEC (no palácio de Assurnasirpal em Kalhu), as inscrições no esquema dos relevos da sala S1 estão em meio às imagens. Nesse sentido, como argumenta Nadali (2006), o papel dos elementos esculpidos desse tipo de placa é primário com relação ao texto presente; este é menor e serve à imagem (p. 152). A retomada de inscrições no meio dos relevos talvez tenha relação com interesse na cultura escrita por parte de Assurbanipal II. Sendo aliás uma sala bastante restrita do palácio - mesmo disposta numa direção mais externa -, a presença do texto nos relevos é mais um argumento de a sala ser frequentada pelo rei (p. 156).

Seguindo para o interior do palácio, há as salas F e H com cenas de batalhas. Segundo Kertai (2015a, p. 137; 175), a sala F apresentava uma forma semelhante à disposição de um banheiro (uma sala pequena e quadrada, de cerca de $25 \mathrm{~m}^{2}$ ), enquanto a outra seria de tamanho intermediário entre a sala do trono e um corredor.

\footnotetext{
94 Esse foi um motivo iniciado com Sargão II em Dur- ̌̌arrukin, mas, pelos relevos remanescentes e desenhos referentes ao Palácio Sudoeste, parece não ter sido utilizado por Senaqueribe (NADALI, 2006, p. 156).

95 Segundo Nadali (2006, p. 152), tais cenas também são modelos ou modeladores dos selos reais, considerado um meio iconográfico de realçar (e difundir) essas características da realeza.
} 
A sala menor (F) apresentava em suas paredes cenas de batalhas que puderam ser reconhecidas (Figuras 110-113) ${ }^{96}$. Essas cenas estão em relevos com duas bandas horizontais, uma característica relacionada ao perfil expressivo do Palácio Sudoeste de Senaqueribe (cada uma dividida em duas linhas na maior parte). Uma direção sugerida de acompanhamento dos relevos pela sala é a partir da única entrada pela sala G: os relevos seguem da esquerda para a direita, à esquerda de quem os visualiza (a partir da Figura 110). Contudo, há a criação de um duplo percurso narrativo nas bandas (entre as faixas superiores e inferiores, nas Figuras 111113), com ritmos próprios de cada uma das duas direções, o que pode indicar um modo de transitar pela sala (NADALI, 2006, p. 117). Em cada banda, há dois episódios distintos no espaço e no tempo, mas ambos têm um começo e um fim iguais. Há correspondências entre os registros das bandas superior e inferior. Então, isso permite considerar a existência de uma relação horizontal, na sequência da cena em cada banda, e de uma relação vertical, nesse caso através da conexão entre a figura do rei (banda inferior, Figura 111) e a expressão da batalha (banda superior, Figura 109). A comunhão entre o início e o fim acontecem justamente no rei, ultrapassando também nesses relevos os limites delimitados de uma única linha numa banda (NADALI, 2006, p. 118).

Já na sala $\mathrm{H}$, os relevos que restaram ${ }^{97}$ apresentam uma primeira etapa das cenas de batalha, a saber a marcha à guerra (Figuras 114-116). Contudo, o registro narrativo é orientado vindo da sala $\mathrm{G}$, nas paredes esquerda e direita do acesso ao pátio J. Os relevos que sobreviveram são aqueles do lado esquerdo (e talvez uma placa do lado direito) ${ }^{98}$.

A marcha a uma batalha pontual tem nesses relevos, numa primeira observação, a direção única da cena (segue à direita, a partir da Figura 114). Contudo, há interrupções na continuidade da narrativa visual que impõem um ritmo diferente a algo aparentemente monodirecional. Seriam "sequências sugestivas", a partir de diferentes meios de ir em direção à guerra e o papel dos sujeitos que voltam o olhar ao caminho percorrido (NADALI, 2006, p. 122), o que ocorre em todas as placas. As expressões gestuais desses sujeitos são marcadores

\footnotetext{
96 Teria sido uma batalha em Susa, capital do antigo Elam, especificamente na cidade de Hamanu.

${ }^{97}$ Não foi possível remontar adequadamente as placas de relevos dessa sala, o que gerou um debate sobre a composição entre elas. Ver Nadali (2006, p. 121), que retoma esse debate principalmente a partir de Gadd (1936), Reade (1969; 1998a) e Barnett (1976).

98 Também se especula sobre o contexto histórico específico dessa cena. Talvez tenha sido a marcha para uma batalha na Babilônia, contra o irmão de Assurbanipal II (Šamaš-šum-ukin), seguindo depois ao Elam - pois há a presença de soldados elamitas com Assurbanipal II. Nadali (2006, p. 122) afirma que a cidade que aparece nas bandas superiores talvez seja a própria Nínive, ao invés da Babilônia, além do realce do jardim, uma obra do avô, Senaqueribe, com seu projeto cuidadoso de construção de canais de irrigação (p. 123). Os relevos então realçam visualmente as obras de Senaqueribe (celebradas em suas inscrições reais), aproveitadas por Assurbanipal II como herdeiro dinástico, alinhando não somente um pertencimento familiar, mas também um caráter da realeza assíria.
} 
que lançam para trás, mesmo que transitoriamente, a sequência narrativa (ou o olhar de um observador). A alternância na repetição de certas figuras na cena também colabora para essas interrupções numa sequência considerada monodirecional e linear.

Mais cenas de batalhas estão na sala L, próxima ao centro do palácio. Ela seria um ambiente que possibilitaria o acesso à sala do trono a partir do interior palaciano. Nela, havia os relevos com episódios justapostos de uma batalha contra tribos árabes (NADALI, 2006, p. 127). Vindo do pátio $\mathrm{J}$, os relevos seguem a parede imediatamente à esquerda. As placas remanescentes dessa sala ficavam expostas na parede oposta a esse acesso pelo pátio, à direita da entrada à sala do trono (Figuras 117-119). Contudo, mesmo com a sequência sugerida da esquerda à direita, o sentido principal das bandas (com alternâncias de movimento pontuais) é da direita à esquerda.

As cenas dessa sala estão em placas divididas em três registros, com dinâmicas de visualização horizontal e vertical, tendo uma metade no sentido direita-esquerda, e outra esquerda-direita, com sequências principais repetidas (NADALI, 2006, p. 128). A progressão e a repetição na cena são concentradas por um grupo de figuras que aparecem em bandas diferentes. Sendo assim, há uma dispersão de elementos por faixas diferentes e com uma progressão em orientações na horizontal ou na diagonal. Há uma outra manipulação das bandas: algumas imagens as ultrapassam (por exemplo, o topo das tendas na Figura 117 e os arcos na Figura 119); em certas partes, as bandas aparecem de modo inteiro; em outras, elas são desarticuladas (o que é visto somente por desenhos). Então, há um sincronismo e um diacronismo na narrativa, com a superação do espaço físico da escultura. A dispersão de elementos e a multidirecionalidade favorece o modo de expressar os assírios e os outros (nesse caso, os árabes). Por meio desses recursos nas cenas, expõe-se a ordem dos assírios em comparação ao caos de um outro (NADALI, 2006, p. 130).

A correspondência entre cenas de batalhas em relevos e as salas do trono seria bastante esperada. A sala $\mathrm{M}$ do Palácio Norte seria o ambiente mais majestoso do monumento e continha uma exaltação sintética de campanhas militares pelos relevos, algo presente também no Palácio Sudoeste. No caso da sala do trono de Assurbanipal II, são campanhas presentes que expõem o alcance do império nas regiões do mundo, do sul da Babilônia ao Egito (NADALI, 2006, p. 131). A narrativa total da sala é muito fragmentária, com poucos relevos remanescentes, mas se acredita que a figura do rei é recorrentemente central em todas as paredes, sempre em cima de um grande carro ${ }^{99}$ e superando as bandas de divisão das placas

\footnotetext{
${ }^{99}$ Assim como nos relevos de Senaqueribe e Assurnasirpal II (dois séculos antes).
} 
(Figura 120). A realidade da sala do trono contribui para uma duplicação do rei: em pessoa sentado ao trono e expresso nos relevos.

Dentre as paredes, somente uma contém poucas placas mais bem conservadas e que permitem tecer considerações sobre os aspectos narrativos do ambiente completo (Figuras 120-121). Essa é a parede imediatamente à esquerda da entrada pela sala L. A cena envolve uma batalha registrada na banda superior (provavelmente com o sentido da direita à esquerda, Figura 120), enquanto na parte inferior há a apresentação de tributos e a contagem de cabeças e objetos diante do rei (da esquerda à direita, na Figura 120). Em ambas as bandas, há a presença de um rio, funcionando como um delimitador do espaço narrativo. Nesse sentido, ele ajuda a dar uma "unidade espacial" a um motivo bastante comum dos relevos. A procissão de tributos é reforçada como algo natural ao evento, na realidade e no registro visual (NADALI, 2006, p. 133).

$\mathrm{Na}$ parede oposta (quase no canto do acesso a um provável pátio), há uma placa remanescente com uma cena de batalha e recolhimento de espólios (Figura 121). Nesse evento esculpido, um ataque assírio a uma cidade encontra-se na parte superior da placa (sendo os muros da cidade o centro cenográfico), enquanto na parte inferior, há uma procissão possivelmente de deportados (da direita à esquerda). Ambas as porções são separadas por um tênue chão cenográfico, mas na parte inferior da placa há um rio esculpido delimitando a paisagem do contexto da cena ${ }^{100}$.

Pode-se considerar que a sala do trono servia para abrigar esses relevos com cenas de batalhas em lugares e momentos diferentes. Tais cenas circundam o ambiente dando mais louvor à atuação do rei. A duplicação seria estendida para além da pessoa do soberano: paralelamente, um eventual visitante da sala $M$ seguiria o percurso em direção ao rei. $\mathrm{O}$ direcionamento das placas segue os mesmos princípios analisados por Winter (2010a) sobre a sala do trono do palácio de Kalhu, de Assurnasirpal II, e da sala I do Palácio Sudoeste de Senaqueribe: a transição da entrada ao trono é acompanhada pela direção e pela posição do rei nas cenas esculpidas (NADALI, 2006, p. 134).

Por fim, nesses eventos, Assurbanipal II não aparece envolvido com a batalha em si, mas é sempre o ponto final da atuação bélica. Essa terminação da narrativa seguia direções diversas, em relação às bandas inferior e superior, e alternadas, de acordo com os lados da

\footnotetext{
${ }^{100}$ Acredita-se que essa cena se refira à tomada da cidade elamita de Hamanu (ou talvez Susa), com a entrega do soberano Ummanaldas. Na mesma cena, apareceria a entrega do irmão de Assurbanipal II (Šamaš-šumu-ukin). Então, a cena comporta talvez a oitava campanha militar do rei assírio num de seus domínios de alcance ecumênicos (NADALI, 2006, p. 132). Em outra parte, o contexto de fundo seria uma primeira ou segunda campanha ao Egito, envolvendo cenas com a mesma dinâmica: ataque, deportação e tributos. A direção desse último momento à figura do rei em seu grande carro seria algo esperado (NADALI, 2006, p. 133).
} 
sala. O patamar do trono e a entrada em si também faziam parte dessa orquestração (NADALI, 2006, p. 133-134). A estratégia escultórica envolveu a reutilização dos registros em bandas para criar uma narrativa. Tal forma permite a coligação no espaço e no tempo, assim como alternância de leituras e temas. Complementarmente, a posição do rei muda em relação às posições superior e inferior. Essa evidência serve de indicativo de como se poderia prosseguir no rastreamento visual durante a observação da narrativa (NADALI, 2006, p. 135).

Esses conjuntos de salas foram delimitados com o objetivo de se ter uma visualização panorâmica de onde os relevos originais eram dispostos nos palácios de Nínive. Esses conjuntos compartilham características, sejam temáticas, funcionais e/ou de aproximação. Eles eram organizados de maneira sofisticada tanto para servirem funcionalmente, como para um programa visual dos relevos - o que se costuma chamar de decoração. Dentre as funções específicas desses recintos (passagem, sala do trono, armazenamento, banheiros), o armazenamento favorece o encontro de outros objetos nas mesmas salas. É o caso de salas palacianas onde eram guardados textos escritos em cuneiforme sob o suporte de argila.

\section{Textos e seu contexto: locais de achado, gênero e critérios de seleção}

A definição das fontes da pesquisa como fontes palacianas tem nuances com relação aos documentos textuais. Os textos foram selecionados a partir das edições de tabletes cuneiformes especialmente das coleções do $\mathrm{BM}^{101}$. A princípio, eles são provenientes de Kuyunjik, o monte principal da antiga cidade de Nínive, sendo de quaisquer de seus monumentos, sejam palácios ou templos. Então, nem todos os textos são de fato de proveniência arqueológica palaciana ${ }^{102}$.

\footnotetext{
${ }^{101}$ A principal coleção é a Kuyunjik Collection (conhecida por coleção K), catalogada primeiramente por Bezold (1889).

102 Reade (1986, p. 213) aponta que muitos tabletes do conjunto K não foram encontrados no monte Kuyunjik. As razões sobre a existência de tabletes de proveniências diferentes nessa coleção são: primeiramente, houve uma mistura de tabletes antes deles chegarem em Londres; segundo, alguns objetos (não somente tabletes) receberam a identificação $\mathrm{K}$, mas não se sabia exatamente de onde vieram; o último motivo está relacionado a momentos distintos das missões arqueológicas inglesas em Nínive: peças inscritas escavadas antes de 1860 foram misturadas às peças dos tabletes assírios, escavados na década de 1850, e permaneceram sem numeração até 1870 ou até depois disso; então, receberam a numeração K não importando a sua origem precisa. Apesar das imprecisões, Reade (1986, p. 213) afirma que os tabletes de numeração baixa, entre K 1 e K 278 , com poucas exceções, foram bem registrados durante escavações feitas por Layard na década de 1850 e são provenientes do Palácio Sudoeste (especialmente das salas XL e XLI). Em geral, segundo Parpola (1986), a coleção K é composta por um lado por documentos da biblioteca de Nínive e, por outro lado, por documentos arquivados, de diferentes categorias ou gêneros: cartas, relatórios astronômicos, consultas oraculares, documentos legais,
} 
Do que se pode indicar dos aspectos dos palácios e seus locais internos onde os textos foram encontrados, Reade (1986, p. 218) defende que no Palácio Sudoeste eles foram exumados de ambientes de escritórios. No período de Assurbanipal II, quando havia dois palácios na cidade, esse rei reformou parte desses ambientes do Palácio Sudoeste. Como ele era o "proprietário" de ambos os palácios, o fato de que todos os tabletes recebiam a identificação de seu colofão pode significar que os textos tenham sido provenientes de qualquer um dos palácios ${ }^{103}$.

Com relação ao Palácio Norte, três tipos principais de textos foram encontrados: documentos (estampados com selos) de arquivos de funcionários oficiais, foram recuperados na sala $\mathrm{C}^{104}$; tabletes foram escavados na área sul do palácio, próxima à localização do templo de $N a b \hat{u}^{105}$, o que favoreceu a identificação da biblioteca de Nínive; por fim, na área nordeste do palácio, encontraram um conjunto de textos que se assemelhava à forma de tabletes de origem babilônica, o que pode estar relacionado às motivações de Assurbanipal II em concentrar, num mesmo ambiente, textos considerados de valor cultural prestigioso.

Os textos de interesse para esta pesquisa foram editados por dois grandes projetos, os quais envolvem as transliterações ${ }^{106}$ e a tradução (para língua inglesa). O primeiro projeto de edição de interesse é o State Archives of Assyria (SAA), uma coleção focada principalmente nos documentos escritos dos (ou para os) palácios de Nínive ${ }^{107}$. Por ser um projeto de edição de textos especialmente focado no período neoassírio, todos os textos selecionados para esta pesquisa foram produzidos durante a faixa temporal entre os reinados de Senaqueribe e Assurbanipal II (de 704 a aproximadamente 630 AEC). Esses textos envolvem a pessoa do rei, ou, como afirma Verderame $(2014 \text {, p. } 714)^{108}$, o rei é eixo central da produção textual do

registro de censo, listas de tributos etc. Além da coleção K, há outros conjuntos importantes do período. Eles são subcoleções fruto de escavações posteriores no sítio de Mossul e estão armazenadas no BM. Por exemplo, há coleções com a numeração de chamada indicada pela data de escavação, escrita de maneira contrária (ano-mêsdia). Também há a coleção DT, com os tabletes coletados quando da expedição patrocinada pelo jornal Daily Telegraph. Alguns poucos tabletes são registrados com a siglas de Rassam (Rm ou Sm). E, por fim, há aqueles provenientes de outros sítios, como Assur (coleção Ph.Ass.), Nimrud (ND, de Kalhu), Sultantepe (SU), e os tabletes armazenados no atual Pergamommuseum, em Berlin (Vorderasiatische Abteilung Tontafeln, coleção VAT).

${ }^{103}$ Contudo, ainda de acordo com Reade (1986), mesmo com essa possibilidade de ambiguidade de origem a partir da mistura de tabletes provenientes de diferentes locais na mesma coleção K, não é necessariamente seguro afirmar que os tabletes fossem armazenados dessa maneira pelos assírios.

${ }^{104}$ Durante as escavações conduzidas por Rassam em 1853.

105 Durante as expedições de Smith entre 1873-74 e de Rassam 1878-82.

106 Transliteração (ou transcrição) é a passagem do texto escrito em cuneiforme, diretamente dos suportes originais, de fotografias ou de cópias, para caracteres romanos.

${ }^{107}$ Foram editados vinte volumes desse projeto entre os anos de 1987 e 2017.

108 “O papel desempenhado pelo rei é deduzível a partir das referências a suas ordens ou pelas citações diretas nas cartas dos especialistas. [...] o rei é de fato o pivot de todo o sistema de informação, assim como o principal 
período, especialmente no que se refere à documentação epistolar. Com relação aos tipos dos textos mobilizados nesta pesquisa, primeiramente são trazidos tratados e juramentos de lealdade do período (PARPOLA; WATANABE, 1988, SAA II). Eles formam é um tipo de texto comum no desenvolvimento da diplomacia política assíria. São peças fundamentais nos processos de expansão e consolidação imperial. Aqui, foram selecionados dois tratados: o primeiro é do rei Esarhaddon garantindo a passagem dos tronos assírio e babilônico aos príncipes herdeiros, Assurbanipal II e Šamaš-šumu-ukin, respectivamente (SAA II 6); e o segundo é tratado entre Esarhaddon e um rei fenício, Baal (SAA II 5).

Também foram mobilizados textos de cunho literário, que podem ser definidos como composições que não atendem a modelos de escrita formulares, mas sim expressam a criatividade através da linguagem (LIVINGSTONE, 1989, p. XVI, SAA 3). A maior parte desses textos é correspondente ao período de Assurbanipal II. Com relação aos estilos, há hinos (a deuses, reis, cidades), poesia épica, cartas poéticas e literatura mitológica.

Por fim, a correspondência epistolar dos períodos de reinado de Assurbanipal II e de seu pai, Esarhaddon, foram produzidas pelos altos escribas da época, principalmente dirigidas ao rei. Esses escribas, chamados de ummānû em acadiano, faziam parte da corte do palácio e atuavam nas diferentes formas de saberes ("científicos"), como: medicina (ramificada em exorcismo e cura), astronomia, lamentações e adivinhação (PARPOLA, 2014, SAA X). Havia os escribas que atuavam de maneira mais próxima ao rei e outros que se vinculavam aos primeiros, o que formava uma rede de contato de altos funcionários eruditos com o rei. Alguns deles ficavam na capital, enquanto outros permaneciam em diferentes locais para cumprir suas atividades específicas.

As cartas expressam as facetas da interação entre o governante e esses altos funcionários ${ }^{109}$. Nelas, é possível encontrar a implementação de recursos expressivos que envolvem aspectos corporais. Então, apesar da intertextualidade e dos aspectos contextuais próprios dessa documentação, a seleção desse tipo de texto foi a partir da mobilização de expressões relativas aos aspectos corporais, de maneira direta ou, especialmente, de modo figurado.

Além dos tratados, textos literários e cartas, há as Inscrições Reais especificamente do período de Senaqueribe. As traduções dessas inscrições foram feitas por Grayson e Novotny (2012, RINAP 3/1; 2014, RINAP 3/2), nos volumes The Royal Inscriptions of the Neo-

referente e endereçado das atividades e estratégias dos ummân $\bar{u}$ " (VERDERAME, 2014, p. 714). Ver adiante sobre o perfil dos escribas da realeza, os ummânū.

${ }^{109}$ Ver em Verderame (2014) a discussão sobre parte dessas interações. 
Assyrian Period (RINAP) ${ }^{110}$. As inscrições reais assírias possuem uma estrutura específica: com exceção de um "preâmbulo", são escritas em primeira pessoa, contendo o relato descritivo dos feitos do rei, seu reconhecimento por parte da divindade e uma mensagem à posteridade, isto é, aos reis futuros. Nas inscrições, são registrados relatos de campanhas militares, expedições de caça, construção ou renovação de monumentos e diferentes menções a aspectos religiosos. A maior parte dos objetos inscritos com esse tipo de texto foi encontrada nas principais cidades da Assíria, especialmente Assur, Kalhu e Nínive.

Além da uniformidade entre os textos dada pelo recorte (contextual, cronológico, geográfico etc.), um elemento que os coliga é a língua: todos os textos tratados aqui foram produzidos em língua acadiana e escritos em cuneiforme. O acadiano (ou acádio) era difundido por todo o Médio Oriente como uma língua "oficial”, mas sua concentração de uso estava no núcleo mesopotâmico. Na região Assíria, mesmo o acadiano sendo a língua nativa, havia a influência do aramaico, devido ao período de dominação no fim do segundo milênio. Essa presença do aramaico na região faz-nos questionar qual era de fato a língua falada no período, conforme sugerem Kaufman (1974) e Luukko (2004). Destaca-se também o uso recorrente na escrita dos logogramas sumérios para o referimento lexical mais rápido (LUUKKO, 2004). Por fim, a língua da Assíria era uma variação dialetal do acadiano, um subgrupo linguístico da família de línguas semíticas; essas variações em dialetos ocorreram em períodos diferentes e entre as grandes regiões assíria (Alta Mesopotâmia) e babilônica (Baixa Mesopotâmia). Então, parte da documentação está escrita em sua variação dialetal neoassíria, e outra parte na versão padronizada do babilônico.

\section{Complementaridade das fontes para o estudo das expressões corporais}

As fontes textuais e imagéticas selecionadas para análise nesta pesquisa possuem particularidades com relação ao suporte material, ao repertório temático, à sua organização etc. Mesmo com essas particularidades, essas fontes são provenientes de um mesmo período e região, um universo cujo eixo era o palácio e a figura do rei. Suas capacidades expressivas

\footnotetext{
${ }^{110}$ Assim como os SAA, os volumes de RINAP fazem parte de um projeto bastante amplo de compilação de fontes escritas do período Neoassírio, com organização e contextualização de apoio, transliteração, tradução e orientação bibliográfica. Nesse projeto, o foco está nas inscrições oficiais reais, que recobrem um período de 744 a 609 AEC e formam um corpus de entre 850 a 900 inscrições. Essas inscrições oficiais foram escritas em diferentes suportes (cilindros, prismas, tabletes, tijolos, inscrições em estelas, epígrafes em monumentos e paredes, entre outras) e são fundamentais para uma história política da Assíria. Com relação à língua, elas foram escritas principalmente em babilônico padrão.
} 
dão-se pela materialidade (do suporte ou da escultura imagética) e pela textualidade (do texto escrito). Tais capacidades são coligadas através de um funcionamento num mesmo ambiente ou até uma co-presença de imagens e textos num mesmo suporte.

Mesmo que parte dos relevos e textos analisados nesta pesquisa não constitua um grupo de fontes que compartilham simultaneamente traços imagéticos e textuais, ambos configuravam um ambiente que continha essa característica, o que estimula a análise de fontes materiais e escritas sob um mesmo propósito (ASHER-GREVE, 1997; ASSANTE, 2009; ATAÇ, 2010; BACHELOT, 2014). A proposta de analisar as concepções de corpo através de aspectos expressivos em textos e imagens também recebe contribuições dessa complementaridade de fontes. Tendo em vista o papel dos relevos como constituidores do contexto palaciano do período e os textos com sua função social atrelada à figura do soberano, o suporte material, o conteúdo temático e o lugar de existência de cada um desses objetos escritos e imagéticos concretizam aquilo que é expresso por esses suportes. Então, os aspectos corporais encontrados em relevos e textos do período não seriam abstrações de imagens ou de linguagens, no sentido de conceitos representados que ganhariam materialidade através do suporte. Ao contrário, aquilo que era expresso em imagens e textos interagia com a própria realidade que expressava.

A expressão concreta dada por um ambiente de confluência entre materialidade e textualidade cria um sentido de realismo que também envolvia os aspectos corporais. Por exemplo, a base (canônica) antropomórfica da escultura servia tanto a expressão de corpos humanos, como de corpos híbridos, aqueles de relevos de motivos apotropaicos. Outro caso é composto pelos corpos de seres humanos e de animais nos relevos palacianos, que poderiam apresentar certa analogia através de uma proximidade não exatamente formal, mas entre posturas e gestos, podendo indicar modos da relação ou da concepção (de corpo) entre os homens e animais (ATAÇ, 2010, p. 12-13). A dimensão de realismo através da imagem pode ser atingida através de recursos expressivos no que tange à cenografia ou narrativa. Outro exemplo ilustrativo e de interesse em termos do tema desta pesquisa é o realismo atingido através do detalhamento de traços corporais: impressões osteomusculares ${ }^{111}$ tanto nos corpos de animais, como nos de seres humanos são frequentes ${ }^{112}$.

A expressividade concreta nos textos é alcançada por uma retórica que se vale da linguagem figurada constantemente. Nesses recursos linguísticos, o discurso é dirigido seja ao

111 O termo osteomuscular refere-se a traços corporais nas pessoas e animais representados nos relevos, especialmente aqueles aspectos de articulações corporais. Em um ou outro caso, é possível observar com mais certeza se o traço é ósseo ou muscular.

112 Aspectos analisados precisamente por Czichon (1992). 
detalhamento ou ao apelo a um sentimento, experiência, evento ou parte corporal para chamar a atenção do destinatário e afetá-lo ao máximo possível pelo sentido pretendido.

Essa concretude dada na confluência de expressões imagéticas e textuais tem nos exemplos supracitados casos internos, isto é, próprios da intenção do que se quer expressar através daquela forma e meio. A concretude das fontes e seu realismo pretendido alongam-se para os ambientes e pessoas que interagiam com esses documentos no período. A consideração dos relevos palacianos como uma prática dinamiza a figura rei que compartilhava o espaço com os relevos em determinados ambientes do palácio. Nesse sentido, na disposição dos relevos nas salas do trono, a localização do rei está no plano figurativo e real: quando se entrava na sala, os relevos apresentam uma ação ou um comando do rei e, ao percorrê-la, passando pelo desenrolar da cena, chegava-se ao rei em pessoa. Na narrativa e na realidade, as ações iniciavam-se e finalizavam-se no rei. Sua figura era duplicada (NADALI, 2008, p. 476; 479-480), como num "sistema de equivalência absoluta" (BACHELOT, 2014, p. 26) entre a imagem e a realidade. Conforme afirma Bachelot (1991, p. 111-112), "na realidade ou simplesmente em seu reflexo, é sempre a figura do rei que dá orientação, o sentido da ação, e o efeito alegórico, de toda a ação possível”. Na mesma linha, duplicava-se uma procissão esculpida nas duas paredes de uma sala. Dessa forma, ao se deslocar pelo ambiente, uma pessoa poderia "adentrar" no fluxo da caminhada sugerida pelos relevos (ALBENDA, 1997, p. 225).

As cenas expressas pelos relevos apresentam imagens com um propósito temático que se manifestam num ambiente palaciano específico. O palácio também era o âmbito de produção ou direção de inúmeros textos, centralizados na pessoa do rei. Esses escritos contêm recursos expressivos que extrapolam seus objetivos estritos relativos ao gênero a que pertencem. Desse modo, textos e relevos fazem parte de um ambiente de produção material e textual onde ambas as naturezas expressivas (materialidade e textualidade) podem confluir-se. Nesse sentido, Muth et al. (2012) afirmam que imagens e textos em realidades da antiguidade são considerados modos de expressão concomitantes (que se realizam juntos), sem relações estritas de hierarquia comunicativa, mas sim de justaposições e interações, cada um com o potencial das especificidades de seus suportes. São "dois suportes distintos de uma comunicação coerente" (p. 221). Essas considerações são resultado de um processo centrado na contextualização, nos modos de mobilização desses objetos no período histórico estudado.

A confluência concreta entre imagens e textos pode apresentar um aspecto relativo às concepções de corpo na tradição cultural da região mesopotâmica. Como afirma Bachelot (2014, p. 23-24), na narração de textos poéticos e literários relacionados à cosmogênese e 
antropogênese, há a presença do corpo (divino e humano) como um fator de disputa para a criação do mundo e dos seres humanos. Nesses textos, é possível também observar uma continuidade entre uma dimensão cósmica (o mundo onde se passa a história) e as dimensões corporais de pessoas e deuses ${ }^{113}$.

Essa interação entre mundo e corpo também estava presente numa concepção de natureza e temporalidade na Mesopotâmia: o corpo, humano ou animal, assim como outros fenômenos naturais, serviam como modo de leitura do que aconteceria em determinadas situações. Eles eram meios de registro que continham a base para a condução das práticas de adivinhação (BAHRANI, 2008, p. 63) ${ }^{114}$. A leitura de presságios em eventos naturais do ambiente e de organismos vivos dava-se através de métodos sistemáticos, realizados com propósitos e em ambientes rituais e cúlticos. Nesse sentido, a adivinhação tinha como o suporte a divindade $\check{S} a m a \check{s}$ (deus associado ao sol), aquela que havia escrito os sinais no mundo, que deveriam ser lidos pelos escribas especialistas em adivinhação. Pelos rituais executados por eles (chamados barû em acadiano) ${ }^{115}$, era possível prever acontecimentos de um futuro próximo, constituindo um saber preditivo constante em textos.

Então, é possível perceber uma valorização do corpo como agente no mundo, que inclusive contém sinais expressivos do que pode vir a ser e vir a ocorrer num dado momento. Mais que uma mera representação, mero reflexo ou mimese (BAHRANI, 2014) do real, havia uma integralização de coisas: textos, imagens e corpos são objetos que faziam parte de uma realidade "ritualizada". Portanto, havia uma integralização entre o corpo e mundo expressa pelas fontes escritas e imagéticas do período.

No entanto, essas particularidades acabaram não sendo consideradas prioritariamente nas pesquisas, devido à concepção de imagem como um meio (ideológico) de transpor determinada mensagem e à sua subserviência a uma dimensão textual. Ao contrário do tratamento do relevo como ilustração de uma narrativa escrita, texto e imagem compartilham o mesmo patamar de fonte significativa e expressiva de aspectos corporais. Conforme Bahrani (2008, p. 41), ao destacar especialmente o registro escultórico de cenas de batalhas, "a imagem do relevo não é uma cópia, na forma visual, da narrativa escrita da batalha, mas as duas versões estão não obstante, conectadas". Portanto, o argumento sobre a necessidade do

\footnotetext{
113 Ver em Bachelot (2014) exemplos oferecidos da epopeia de Gilgameš e da composição poética de Atra-hasīs. ${ }^{114}$ A palavra utilizada à época para designar as práticas divinatórias era $b$ ārûtu. A acepção desse termo engloba o ato em si, os equipamentos envolvidos, o corpo de conhecimento e os textos relacionados (CAD B, p. 131-133). 115 Segundo Bahrani (2008, p. 63-64), o substantivo barû deriva do verbo ver. Conforme as ocorrências e sentidos citados no CAD (B, p. 115), tem-se o adjetivo barû (para pessoa com problemas visuais) e o ato (verbo) de ver, observar, vigiar. Ver é uma ação executada por deuses e por homens, está relacionada com a consulta a oráculos e é relativa à tarefa de conferência cuidadosa de tabletes. Da palavra original chega-se à grafia $b \bar{a} r \hat{u}$, cujo sentido refere-se à pessoa que realiza as práticas de adivinhação de presságios.
} 
estudo conjunto das imagens e dos textos é justificado pelo paralelismo elevado entre ambas as fontes (WINTER, 2010a, p. 19). Especialmente nas situações em que imagens e textos compartilham o mesmo suporte, um fazia parte da "lógica interna" do outro (BAHRANI, 1995, p. 372), havendo "convergências entre as duas ordens de evidência" (MUTH et al., 2012, p. 229). Nesse sentido, "o privilégio da reflexividade não é apenas do texto, mas também as imagens em si, por meio do 'pensamento figurativo', têm a capacidade de colocar em cena uma interpretação consciente de si mesma e de suas potencialidades múltiplas" (SCHMITT, 2010, p. 2). O relevo e seu conteúdo imagético, no limite, podiam amplificar, no espaço, aquilo que foi escrito, e podia encontrar, na época, as próprias pessoas representadas, especialmente o rei (NADALI, 2006, p. 312).

Todas essas considerações sobre a relação entre imagem e texto podem ser conduzidas por um entendimento da agência das imagens (e da materialidade) e de sua interrelação com a textualidade. A agência muitas vezes é entendida como uma característica dos objetos que opera no plano simbólico e dos significados, e não algo ancorado na materialidade. Contudo, considerando os aspectos materiais dos objetos, além de seus lugares (físicos) nos ambientes, os sujeitos que os produziriam e com quem interagiam, a agência possui um dinamismo concreto, físico, corporal. A propriedade imagética dos relevos palacianos e seu contexto palaciano os configuram como uma prática.

Além das imagens, os textos estão implicados com a atividade escribal, que por sua vez estava totalmente vinculada ao suporte (os tabletes de argila), ao tipo de conhecimento, às relações sociais e entre os papéis exercidos por cada pessoa que escrevia (RADNER, 1995; CARR, 2005; ROSS, 2010). Um exemplo emblemático são certos registros em tabletes que ficavam situados num ambiente cerimonial, desempenhando um papel atuante na dinâmica ritual (RADNER, 1995, p. 74). Nesse sentido, a complementaridade entre texto e imagem não ocorre como um preenchimento de lacunas, isto é, de um preenchimento mútuo em que um objeto contém um aspecto que outro não apresenta (e vice-versa). Ao contrário, ao se considerar o espaço, as pessoas e as intenções como elementos de uma rede de interação na qual textos e imagens estão incluídos, a complementaridade das fontes é de tipo funcional: texto e imagem manifestam-se juntos, têm suas funções particulares e que muitas vezes interagem.

Tendo em vista a complementaridade entre fontes escritas e de cultura material para se analisar as concepções de corpo no período Neoassírio, percebe-se que os aspectos corporais e suas relações com sentidos, com o movimento e com a experiência corporal podem ser reveladores dos modos antigos da relação entre pessoas e seus objetos (TILLEY, 2008). 
Como afirmam Muth et al. (2012, p. 230), ao se tratar de imagens antigas, trata-se também de uma experiência do observador antigo. Os autores alertam para não separar a ontologia das imagens (ou seja, tudo aquilo que configura sua presença expressiva e material num determinado meio) e as experiências da visualidade dos sujeitos que interagem com as imagens. No caso do corpo que é expresso na imagem ou no texto, ele pode conter significados apropriados de uma tradição, assim como pode estar relacionado a uma experiência corporal das pessoas em interação com seus objetos naquela contemporaneidade. Então, o potencial da análise proposta está na dimensão expressiva relativa ao modo que o corpo humano aparece. A imagem do corpo e as referências textuais a ele são tanto correlatas a uma experiência vivida (de tipo corporal), como também participam na elaboração da concepção de corpo, através da materialização (imagética ou textual) de seu sentido. Nessa linha, a expressão (a forma de expressar o corpo) e a concepção do corpo (aquilo que é concebido como corpo no período) possuem uma correspondência que é manifestada através das imagens e textos, cada qual com sua natureza expressiva. Portanto, aproxima-se da concepção de corpo através de fontes (textuais, materiais, ambientais) de determinado período, constituídas pela experiência corporal na relação com o mundo material e o meio ambiente (TILLEY, 2008, p. 41).

Os aspectos corporais nas fontes palacianas do período Neoassírio constituem um foco de análise que ganha substância ao se considerar a complementaridade entre materialidade e a textualidade. Esses argumentos configuram alguns princípios metodológicos que favorecem a análise atual. Quando da seleção das fontes, elas são tomadas como documento da pesquisa visando suprir as necessidades da execução do exame historiográfico. Nesse sentido, um princípio metodológico importante é a desdocumentalização (MENESES, 2012, p. 254-255). Ele é uma operação que visa devolver o documento para seu contexto de relações sociais, buscando observar seu sentido dentro do recorte escolhido (NADALI, 2014, p. 36). Isso permite olhar para a fonte desempenhando seu papel no seu lugar histórico (BELTING, 1997). As fontes deixam de ser tratadas como documentos, para que sejam vistas a partir de seu lugar, observando sua dinâmica e funcionamento no contexto.

Nesse sentido, vale retomar um aspecto dos relevos palacianos relacionado à sua percepção. Colocados em seu contexto (dentro de determinadas salas dos palácios, em determinadas posições nas paredes), destaca-se sua potencialidade de serem percebidos 
corporalmente, o que inclui a visualidade (FELDMAN, 2010) ${ }^{116}$. É possível entender os relevos enquanto produtos ou objetos visuais como

um meio expressivo da visão de mundo e também um meio de comunicação que não passa imediatamente pela via do intelecto, ainda que o implique, juntamente com as demais dimensões do dinamismo psíquico humano como o ver, tocar, imaginar, a vida afetiva e também a vida intelectual (ALES BELLO, 2004, p. 314).

Pensando o relevo como uma prática e um "produto e vetor de relações sociais" (MENESES, 1983, p. 113), eles faziam parte do ambiente circundante vivenciado pelas pessoas que habitavam e circulavam pelo palácio. Foram produzidos por sujeitos que conheciam o propósito dessas esculturas e sabiam fazê-las com determinados recursos habilidosos. Nesse sentido, destaca-se uma noção de apropriação dos relevos pelos sujeitos como forma de interação mútua entre a comunidade e a materialidade (REDE, 2012, p. 145). Tal apropriação não se desenvolve somente em um processo de cunho abstrato e intelectual, seja por parte daqueles que produziam materialmente as placas, seja por parte daqueles que de alguma maneira interagiam com os relevos dentro do palácio. A apropriação envolve também a dimensão corporal, no que tange à percepção (visual e tátil) do material e da imagem. $\mathrm{O}$ posicionamento das placas com relevos nos ambientes palacianos e a existência de uma orquestração da apresentação dependente de condições de visibilidade e dirigida a determinadas condições implicam condições de visualidade e de movimentação. Assim, tema, contexto, local e função dos relevos, adaptações escultóricas (perspectiva, assimetria e proporcionalidade entre os elementos esculpidos), relação de elementos imagéticos com a realidade paisagística e arquitetural e motricidade são aspectos que permitem considerar o corpo que interage com esses objetos ${ }^{117}$. Essas noções de percepção e movimento permitem uma análise dos aspectos vividos em relação aos relevos palacianos (NADALI, 2014, p. 45). Então, dentro de uma proposta de análise das concepções de corpo nos relevos, estão incluídas as figuras esculpidas do corpo e seus potenciais indícios relativos à percepção corporal.

\footnotetext{
${ }^{116}$ Pautada no conceito de agência, Feldman argumenta sobre a possibilidade de análise dessa visualidade como capacidade de percepção a partir de fontes de cultura material. Mais especificamente, ela define a visualidade como a "percepção visual dos relacionamentos espaciais" (2010, p. 151), destacando a importância desse núcleo sensorial para determinadas práticas na Mesopotâmia.

${ }^{117}$ Esses elementos foram depreendidos a partir dos resultados de uma análise preliminar de Nadali (2014) sobre a relação espaço e lugar a partir dos relevos palacianos e inspirada pela identificação de aspectos fenomenológicos da percepção dessas esculturas.
} 
A complementaridade entre imagem e texto é singular especialmente quando há uma co-presença entre ambos num mesmo suporte físico. No entanto, as fontes textuais e imagéticas escolhidas para essa pesquisa apresentam parcialmente esta co-presença. A complementaridade documental é uma particularidade das fontes que favorece a compreensão dos aspectos corporais presentes nas imagens e nos textos. A expressividade em ambos os tipos de fontes é diferente, mas há comunicações e aproximações entre as maneiras de indicar os aspectos corporais, especialmente com relação àquilo que se quer expressar por meio do corpo. 


\section{CAPÍTULO 3 \\ ASPECTOS CORPORAIS NOS RELEVOS NEOASSÍRIOS}

\section{Estruturas e princípios expressivos dos relevos palacianos}

Os relevos dos palácios assírios são esculturas em baixa saliência contendo narrativas visuais de cenas agrupadas em grandes temas, como caçadas a animais, batalhas, transporte de materiais para construção e procissões de pessoas. Esses relevos fizeram parte das paredes dos palácios especialmente na primeira metade do primeiro milênio AEC, acompanhando o desenvolvimento grandioso do império assírio. Nesse sentido, eles compunham o ambiente palaciano, considerado a sede do poder imperial, e faziam parte de uma experiência visual daqueles que habitavam dentro dos palácios e os frequentavam esporadicamente. Em cada ambiente do monumento, havia salas com relevos de um ou mais temas, dispostos intencionalmente em placas e posicionados de determinado modo. Esta disposição poderia sugerir um caminho de acompanhamento visual das cenas, enquanto tal configuração era favorecida pela narrativa proposta pelas imagens. Por sua vez, a narratividade possivelmente é indicadora - assim como indutora - de percursos de movimentação pela sala. Então, os relevos faziam parte de um contexto político que favoreceu o desenvolvimento de cidades nucleares e monumentais, enquanto eram uma prática de exposição controlada de uma memória compartilhada por aqueles que viviam na comunidade palaciana.

A consideração dos relevos como uma prática social situada num contexto histórico amplo e, em seguida, num contexto arquitetônico particular implica a interação entre a materialidade desses objetos e a percepção corporal por pessoas que entravam em contato com eles dentro de um palácio. Novamente, a disposição das placas esculpidas pelos ambientes palacianos sugere uma relação com os transeuntes. Como são baixos relevos, sua visualidade é dependente da alteração de luminosidade de sua superfície saliente, a qual era limitada e relativa às condições de visibilidade em cada ambiente palaciano. Uma movimentação pelas salas é necessária para uma tentativa de visão ampla da apresentação das placas, tendo em vista as suas dimensões e as dos recintos palacianos. Essa percepção do todo também exige a aproximação e o distanciamento corporais entre o observador e as paredes, alterando o modo de interação com esses objetos. A relação de aproximação e distanciamento é relativa não somente à dimensão das salas, mas às suas funções dentro da área do palácio. Por sua vez, a percepção corporal está vinculada à passagem do transeunte por um local 
específico do palácio e que contém relevos em suas paredes. Portanto, considerando a movimentação corporal, o foco da visão durante o deslocamento e o tamanho das salas (que implica a distância das paredes com relação a um sujeito), o que é melhor percebido num primeiro contato são as formas das figuras esculpidas que se destacam nas placas. Esses fatores formariam uma primeira impressão na experiência de proximidade com os relevos, pois, mesmo que as formas salientes formem as cenas narrativas, a completude cenográfica e a progressão da narração dependeria de uma observação detida dos detalhes.

Numa síntese possível de uma primeira abordagem dos relevos palacianos, grande parte das formas esculpidas das placas é composta por figuras humanas. O corpo de pessoas está visualmente presente na escultura, interagindo com diferentes objetos e em ambientes artificiais ou naturais. Essa objetivação por meio da imagem está atrelada aos usos do corpo relacionados ao contexto sociocultural. Nos relevos assírios, há sempre corpos humanos. Em alguns poucos "relances", partes dos relevos são deixadas sem pessoas. Também é possível reconhecer o corpo do soberano, de soldados, de funcionários do palácio, de prisioneiros e de (inimigos) estrangeiros (vivos ou mortos), de mulheres e crianças. Toda expressão do corpo humano envolve posturas e ações corporais: corpos em pé, agachados ou sentados; em posturas de ação e movimento; corpos caídos e inativos; corpos decapitados; corpos em simbiose com outros seres não humanos. Nessas possibilidades de expressão dos aspectos corporais, vê-se sempre todo o corpo com mais ou menos aparatos indumentários. Em alguns casos, há a interação da figura de sujeitos com objetos transportáveis. Quando as cenas possuem um contexto, expresso por meio de um cenário paisagístico (água, montanha, árvores), está implicado um corpo interagindo em um ambiente. Nesses contextos cenográficos, muitas vezes há a relação entre o corpo e a arquitetura quando há a apresentação de cidades e construções. Em outros casos, o corpo não é visível em sua totalidade, pois está oculto por um anteparo. Há também o detalhamento de partes corporais, com aspectos osteomusculares realçados. Não há somente seres humanos, mas também seres divinos, na forma de símbolos, em relevos com figuras apotropaicas e antropozoomórficas.

Todos esses aspectos do corpo nos relevos palacianos estão relacionados a princípios e estruturas expressivos. A imagem do corpo é modelada e serve à capacidade expressiva dos baixos relevos, marcada pela narratividade, ou seja, pela organização dos elementos na composição (GILLMANN, 2015, p. 267). A disposição das figuras favorecendo a narrativa atrela-se a um tema ancorado num registro histórico, a partir da visão daqueles autores, ao invés de ser uma síntese ou aglomerado visual de elementos simbólicos. Os temas são apresentados com mais ou menos repetições (num mesmo ambiente, num mesmo palácio, ou 
entre palácios diferentes) e são utilizados nos palácios de acordo com uma finalidade pretendida. Para Gillmann (2015, p. 268), essa configuração narrativa é a principal diferença entre a prática dos relevos neoassíria e a cultura visual precedente na Mesopotâmia. Segundo o autor, a narratividade de cunho histórico requisita a presença de elementos realísticos, para favorecer o reconhecimento de uma experiência passada. Portanto, um objetivo da imagem assíria seria transmitir um conhecimento de cunho histórico e narrativo (GILLMANN, 2014a, p. 733).

Com relação a aspectos iconográficos mais precisos, mesmo com variações entre os relevos dos palácios de diferentes reis assírios, há padrões para a expressão narrativa nos relevos. A definição de uma expressão imagética como narrativa implica uma dimensão espacial (os lugares pontuais das figuras na cena e a própria materialidade dos relevos) e uma dimensão temporal (passagem de uma cena no tempo) (WATANABE, 2004). De acordo com Gillmann (2015, p. 269), essas duas dimensões constituem ontologicamente a imagem dos relevos palacianos. A escultura em baixo relevo impõe dificuldades para a expressão de efeitos imagéticos, como é o caso da perspectiva. Nesse sentido, a narratividade exige uma solução satisfatória ao problema da espacialidade, condição da própria existência da imagem e de seu sentido. Segundo Gillmann (2015, p. 269), os artífices assírios possuíam estratégias para realizar tal efeito visual, como: a colocação da cena ou de ações em contexto especialmente paisagístico (por exemplo, nas cenas das Figuras 30-32 e 49-60); e a criação de camadas entre seres, objetos e a paisagem (primeiramente arquitetônica, em seguida naturalística), que favorece tanto uma ilusão de perspectiva, como sobretudo distingue e realça o que parece estar em um primeiro plano (por exemplo, nas Figuras 17-24 e 43-45). As intenções de realismo histórico ou imagético na narrativa dos relevos atrelam-se à tendência à expressão de uma objetividade visual, pela qual o espaço imagético é bastante delimitado e ordenado (GILLMANN, 2014a, p. 734-735). Então, os elementos de realismo na imagem são ajustados à realidade material da escultura em relevo. Esquematicamente, há a manipulação de dois espaços: o do suporte, que delimita a cena (inclusive com faixas, bandas e linhas de base), e o da cenografia, que é o espaço onde ocorre o evento e que é construído pelas aproximações e distanciamentos entre os componentes, pela sobreposição e disposição deles e pela direção da cena.

Essa abordagem entre os elementos esculpidos e agrupados de acordo com uma finalidade é uma característica da estrutura dos relevos que sugere uma ideia de espaço infinito. No caso assírio, há "um espaço representado negativamente, isto é, um espaço que o espectador deduz sobre a base da justaposição de diferentes elementos que compõem a cena" 
(GILLMANN, 2014a, p. 735). Nesse sentido, tendo em vista as estratégias relacionadas à construção da narrativa envolvendo os efeitos adaptados de perspectiva, cada elemento esculpido individualmente tem prioridade em relação ao modo como cena acontece, isto é, mesmo que cada elemento esteja inserido num espaço cenográfico total, cada figura ocupa e cria um espaço próprio, como um novo espaço, independente até certo ponto da espacialidade geral da cena (GILLMANN, 2015, p. 269). Sendo assim, "o espaço passa a ser individual para cada grupo de protagonistas, como se este espaço não fosse dado comumente a todos [...]" (GILLMANN, 2014a, p. 736), ou seja, o espaço é objetivamente manipulado durante a escultura, havendo uma "pluralidade de espaços" (p. 737) numa mesma placa de relevos. Essa pluralidade espacial habilita a alteração de tamanhos e posições das figuras esculpidas em prol da narrativa, mas simultaneamente mantendo uma unidade de sentido em si mesma. Exemplos disso são a diminuição no tamanho das figuras e sua dispersão pela placa, estratégias escultóricas que ajudam a mostrar as relações espaciais na cena (como no canto superior esquerdo da Figura 32, relativa à cenografia das placas anteriores (Figuras 30-31), e nas Figuras 43-45, 50-52, 86-87).

Tais aspectos da espacialidade residem em possibilidades de expressão através de recursos técnicos escultóricos destinados a favorecer a apresentação de um registro histórico. Apesar dessas características, há formas na escultura que podem ser vistas como específicas de um período e que atendem a intenções expressivas dos artífices de determinado rei. Por exemplo, em relevos do Palácio Sudoeste, de Senaqueribe, a diminuição de figuras e a dispersão ampla da cena nas placas de relevos colocam mais ênfase visual no desenvolvimento do evento, do que na focalização em pontos precisos - ou numa progressão linear e horizontal, quando há a presença de bandas ${ }^{118}$. Na visão de Gillmann (2014a, p. 737), ainda nos relevos do Palácio Sudoeste (por exemplo, nas Figuras 51-52), o espaço pode ser linearizado ou enquadrado, quando há a presença de rampas em placas sem divisórias, instrumentos utilizados pelos soldados assírios para superar as muralhas das cidades atacadas. A representação de tais rampas nos relevos ajuda a conduzir a dinâmica visual: somada aos soldados que por elas transitam, a direção da continuidade da cena é dada (Figuras 51-52). Adicionalmente, as rampas servem de elemento figurativo na formatação de uma parte específica da cena, por exemplo, focalizando ou centralizando um recorte cenográfico

\footnotetext{
${ }^{118}$ Tal variação nos tamanhos das figuras pode estar relacionada também a um efeito de profundidade, de acordo com Nadali (2006, p. 114). Nessa linha, componentes menores e em posições diferentes nas placas sugeririam não uma sobreposição (vertical) entre eles, mas sim um distanciamento horizontal. Por exemplo, o elemento mais acima na placa corresponderia a sua posição mais afastada (e não elevada) com relação ao componente de baixo.
} 
(geralmente, a cidade atacada). A própria utilização de bandas divisórias ou das linhas de chão nuançadas, sustentadoras dos elementos esculpidos numa cena, são recursos variáveis nos relevos de cada palácio, mas que contribuem para realizar esses efeitos visuais. Por outro lado, sabendo da existência dessa estratégia escultórica, em muitas situações há a ausência dessas linhas, o que sugere então um sentido diferente do espaço (ocupado ou livre) dentro da cena.

A presença de uma paisagem de fundo principalmente em cenas narrativas também caracteriza particularmente a espacialidade dos relevos. Um exemplo emblemático é composto pelos relevos da sala XXXVI do Palácio Sudoeste (Figuras 49-60), com uma paisagem montanhosa preenchendo toda a cena. Contudo, um fundo cenográfico do suporte pode estar ausente, como nos relevos de corredores e passagens. Há ainda aqueles com paisagens multiformes, com variação de terreno e vegetação, como na sala XXVIII do Palácio Sudoeste (Figuras 30-32) e na sala H do Palácio Norte (Figuras 115-116); a presença de fauna também sugere uma outra espacialidade (por exemplo, a presença de camelos nos relevos da sala L do Palácio Norte, nas Figuras 118-119). Em ambos os palácios, os rios são indicadores de um lugar, assim como delimitadores de um espaço. Por fim, pode haver a combinação de presença e ausência de fundo paisagístico, o que pode sugerir uma dosagem mais ou menos precisa do lugar, enquanto abstrai e generaliza os temas utilizados numa sala (por exemplo, na variedade temática dos relevos da sala S1, Figuras 103-107). O preenchimento do ambiente cenográfico constitui a ritmicidade a ponto de mostrar não somente ações individuais, mas também um efeito de passagem ou deslocamento pelo lugar da cena. Portanto, em conjunto, cada parte do relevo suscita "a noção de espaço sem o imitar" (GILLMANN, 2014a, p. 737). O mesmo vale para uma "profundidade não imitada, mas simplesmente sugerida, evocada" (p. $738)^{119}$.

A disposição dos elementos esculpidos no espaço do suporte visa também atender a necessidades temporais de progressão na cena. Conforme os argumentos de Nadali (2006), as ações nos relevos são concentradas num mesmo espaço, logo é sugerida uma mesma temporalidade encapsulada no espaço cenográfico. Contudo, não necessariamente se trata de uma sincronia ou linearidade. Muitas vezes são diacronias que compartilham o mesmo espaço imagético. Essas diacronias podem corresponder aos níveis de temporalidade indicados por Gillmann (2015): há um tempo de uma ação principal e o tempo de ações secundárias (p. 270). Segundo o autor, essa distinção entre níveis pode atender a requisitos de um tipo de

\footnotetext{
${ }^{119}$ Tal efeito poderia ter sido realçado pela presença de pinturas e a depender da iluminação sobre os relevos.
} 
cena, como, por exemplo, expressar uma hierarquia entre quem e o que merece mais destaque num determinado momento cenográfico. Essa diferenciação é complementada pela centralização, engrandecimento ou rebaixamento das cenas ou de suas partes. Tal manipulação do tempo através do espaço imagético pode estar implicada também com o programa de apresentação dos relevos pelas salas e ambientes dos palácios. Gillmann (2015, p. 271) aponta para outros dois níveis da temporalidade dos relevos: o agora e o depois; num mesmo espaço, eles se entrelaçam na narrativa da cena. Esses tempos são altamente dependentes do momento de visualização por parte do observador: o agora da cena é o agora da visualização. Então, os níveis de temporalidade e os motivos das cenas implicam-se, porque a temática narrativa envolve a progressão (temporal e espacial) de uma ação e as consequências dela (por exemplo, a ida à batalha, a batalha propriamente dita e suas consequências). Ao mesmo tempo, há noções específicas de temporalidade caracterizadoras de uma dada narrativa: há diacronias dentro da sincronia de uma narrativa espacial de uma cena. Por exemplo, numa cena geral de batalha, eventos distintos e menores são encapsulados dentro dela, com uma temporalidade interna. Esse é o caso dos contatos específicos entre combatentes numa batalha. As temporalidades menores constituem a temporalidade maior da narrativa.

Os aspectos espaciais e temporais da imagem narrativa são manipulados nos relevos a partir dos recursos e estratégias escultóricas dos artífices diante do suporte e para expressar significados com relação ao realismo e ao registro histórico. Nesse sentido, espaço e tempo interagem e formam uma dimensão espaço-temporal própria da narratividade dos relevos assírios (NADALI, 2006, p. 241).

A dimensão espaço-temporal nos relevos palacianos faz parte de uma estruturação da imagem que pode ser vista a partir de suas partes menores e mais precisas. Gillmann (2007, p. 41) indica que, nos relevos, os componentes e as partes apresentam graus de semelhança e oposição. Por exemplo, a mesma disposição corporal e espacial de pessoas cria um efeito de ritmo pela semelhança (a situação exemplar é uma fila de procissão). Outro exemplo destacado por Gillmann (2007, p. 41) é o das figuras humanas dispostas umas frente às outras. Segundo o autor, essas duplas parecem ser conjugadas em blocos, quando há, por exemplo, grupos de pessoas - e nesses grupos, há uma aproximação frontal de duas pessoas, muitas vezes encabeçando duas filas. Esses blocos formam um componente maior da cena, ocupando um certo espaço e se contrapondo a espaços livres, não preenchidos. Em toda cena de um relevo narrativo, a dinâmica estrutural dá-se na existência de um centro de equilíbrio entre zonas (ocupadas e livres) e pelas linhas de dinamismo dos grupos de pessoas. Gillmann 
(2007, p. 55) exemplifica tal estruturação com uma cidade fortificada, ao centro de uma narrativa, que é uma figura estática e fixa ao observador, fazendo oposição ao dinamismo do exército, que se movimenta em direção a ela. Nadali e Rivaroli (2007, p. 11) acrescentam que o uso dos espaços (livres ou preenchidos com contexto paisagístico) podem ser vistos, em contraposição aos blocos esculpidos de pessoas e objetos, como um uso seletivo do espaço, indicando então significados ao se expressar ou não tais aspectos nas placas. Isso quer dizer que não somente o preenchimento do espaço com blocos de figuras pode significar algo, mas o espaço livre, não preenchido, também pode ser apresentado de tal maneira visando cumprir um efeito visual e expressar um sentido intencionado. Além do exemplo das cenas com a presença de cidades, em cenas de caçada, o leão também parece ser um ponto fixo, existindo então o confronto cênico pela ação do rei que o caça. Grosso modo, se o leão é o ponto estático, a contraposição é dada pelo dinamismo da ação do rei. Então, não só o espaço ocupado ou preenchido por grupos de figuras forma uma unidade de significado, mas também o uso de espaços ditos vazios possui uma intenção e funciona como intermediário, pois possibilita a abordagem entre figuras individuais.

O uso e a expressão do espaço - e consequentemente do tempo - nos relevos constituem a dinâmica narrativa, que por sua vez é auxiliada pela noção de movimento expressa nas cenas, principalmente através dos corpos humanos. Para Gillmann (2007, p. 4243), esse dinamismo pode ser realizado por meio de quatro tipos de movimentos corporais, expressos pelos artífices com maior ou menor presença nos diferentes palácios: movimentos horizontal, oblíquo, rotativo e de gesto sugestivo. Em conjunto, os movimentos horizontal e oblíquo atuam para imprimir uma linearidade na movimentação e o deslocamento no espaço cenográfico, com um ponto final de chegada. O movimento oblíquo é aplicado para complementar a linearidade quando há a superação de uma estrutura estática (a invasão de uma cidade é o melhor exemplo dado pelo autor). Já o movimento rotativo é visto numa inclinação das figuras corporais no decorrer de uma ação principal da cena. A rotatividade dá o efeito de curvatura do movimento, mesmo na escultura em duas dimensões dos relevos. Por fim, o gesto sugestivo ajuda a dar ritmo às partes das cenas. Por exemplo, a disposição dos personagens em faixas e sua repetição ajudam a dar ritmicidade pela redundância das figuras. Assim, os gestos esculpidos servem para indicar um ritmo na narrativa. Essa dinâmica ocorre principalmente em procissões ou filas de personagens, onde há uma noção de deslocamento (progressão horizontal) e de cadência dada pelos membros inferiores dos corpos esculpidos. Gillmann (2007, p. 43) argumenta que o dinamismo da movimentação não aparece marcado iconograficamente como algo em si, mas ele se faz presente na capacidade de "evocação" do 
sentido pretendido a partir desses gestos e movimentos esculpidos. Quando há a repetição de uma mesma figura na cena (como em diversas ocorrências nos relevos do Palácio Norte de Assurbanipal II, e emblematicamente em seus relevos apresentados no Palácio Sudoeste, na sala XXXIII), há a decomposição das imagens em episódios numa mesma placa, o que dá a sensação de fases sucessivas e contribui ao dinamismo pela "persistência da retenção" (GILLMANN, 2007, p. 43).

Em resumo, a dinâmica é expressa na escultura assíria pelas formas das massas que dão "movimento estrutural ao conjunto" (GILLMANN, 2007, p. 55). Então, os artífices assírios valiam-se de critérios de estruturação e composição das imagens a serviço da narração (GILLMANN, 2007, p. 44). Eles criaram uma expressão por meio de um cenário, com naturalismo e particularismo de uma visão de mundo "nacional", e com uma dinâmica temporal e espacial que atende às intenções de sua elaboração. Devido a essas características (sejam as estratégias escultóricas gerais ou as singularidades de cada período), os relevos podem solicitar do espectador a colocação de sua própria posição para a compreensão da cena, o que implica também seu posicionamento corporal no ambiente das salas (NADALI, 2006; WINTER, 2010a) e uma disposição subjetiva (BACHELOT, 1991). Simultaneamente, realidade e abstração são evocadas nos relevos palacianos: de um lado, as cenas possibilitam a expressão de uma realidade, através do registro histórico de um evento e com a presença de elementos iconográficos que dão contexto a ele. Por outro, a narrativa é estruturada imageticamente tendendo à abstração, especialmente ao serem manipulados o tempo e o espaço figurativo. Portanto, emerge um espaço visto e pensado por alguém, o que envolve tanto os mantenedores e consumidores daquela experiência vivida (habitantes do palácio), como aqueles que produziam tecnicamente aqueles objetos.

\section{Os relevos palacianos como imagens}

Além das estratégias técnicas que estruturam as imagens dos relevos, sua colocação nos palácios de maneira orquestrada favorece tanto a percepção visual pretendida, como um ingresso corporal naquele ambiente arquitetônico envelopado por relevos narrativos. Do contexto social dos relevos à sua estruturação imagética, os princípios escultóricos e ontológicos de sua realidade visual são reconectados à concepção de imagem assíria.

Uma noção particular de imagem é expressada pela palavra acadiana șalmu. Seu significado não implica a semelhança física entre uma entidade real e a sua "representação" 
imagética, como um retrato, mas seu sentido comporta a concepção de uma imagem como cópia de um ser, numa relação de identidade entre representante e representado (GILLMANN, 2014b, p. 397; 399). Grosso modo, șalmu significa a comunhão entre a imagem (abstrata) e a sua materialização (NADALI, 2012, p. 584). Uma ocorrência apontada por Gillmann (2014b) é a expressão șalam šarrutiya, em referência a uma imagem ou representação do rei, sem implicar um suporte material (p. 396). Na visão do autor, considerando essa noção de șalmu, é possível refletir sobre o quanto uma imagem real pode conter traços fisionômicos de uma realeza histórica (dos reis assírios). Nesse sentido, o autor defende que nesse caso há uma "ausência de individualização", no sentido de uma imagem própria de um rei. Então, șalam šarrutiya é entendida como "a imagem de minha realeza" (p. 398), ou seja, por mais que seja relativa a um rei, a expressão refere-se à imagem de sua função como soberano.

Outra expressão seria șalam bunnannîya ou tamšil bunnannîya, com um sentido de "imagem de meus traços/de minha aparência” (p. 400). Novamente, tal expressão suscita o questionamento sobre se essas imagens reenviam a traços idiossincráticos, ou se são "produtos de uma convenção ou de uma fórmula" (p. 399) que pode variar com tempo. Ancoradas na acepção da palavra șalmu, ambas as figuras são relativas a "atributos fisionômicos do poder" e a "sinais visíveis da realeza" (p. 401), sendo então uma concepção de imagem que exprime os traços que traduzem a natureza e a função de um sujeito (p. 402). Portanto, a análise de Gillmann (2014b) reforça essa concepção imagética pela sua "presença autêntica" e sua "dimensão autenticamente mágica" (p. 405), concluindo que a imagem no horizonte semântico acadiano é a presença de uma existência, ambas se relacionando (p. 408). Com o afirma Bahrani (2008; 2014), o papel social da imagem é uma forma de existência, mais uma maneira de ser no mundo, e não somente um objeto passivo e imitativo. Sendo assim, há uma "equivalência ontológica" (BAHRANI, 2008; 2014) entre o real e o expresso imageticamente.

No caso dos relevos palacianos, o saldo entre as condições materiais do suporte e as estratégias visuais da estrutura da imagem cria as possibilidades de evocação que dão sentido ao que é visto. Somado a isso está o uso desse tipo de imagem relacionado à sua intenção de produção, de disposição num ambiente circundante e de sua expressividade. A correspondência entre o real e o imagético no caso dos relevos está na possibilidade de comunhão entre a ação vivenciada (o evento real) e uma ação representada (na narrativa visual), constituindo uma performance (NADALI, 2012, p. 592). Essa noção apresenta a imagem como possuidora de um poder e de uma performatividade, especialmente dentro de 
seu contexto de prática, não significando somente um registro histórico e ideológico (BAHRANI, 2008, 2014; FALES, 2009; NADALI, 2012). Além da vinculação entre o evento real e a narrativa visual do relevo, sua expressividade no ambiente palaciano coliga o observador e o objeto observado, propriedade também implicada na noção de șalmu.

A estrutura organizacional dos relevos reside nessas características expressivas da imagem acadiana. Contra a consideração da imagem como uma cópia ilusória de um modelo,

a própria iconografia contém a primeira parte da solução: através das convenções que a regem, tudo é feito para distanciar a representação daquilo que ela representa. [...] O escultor desarticula sistematicamente os volumes que compõem seu modelo e recompõe uma nova realidade (GILLMANN, 2014b, p. 403).

Esse processo de decomposição e recomposição pode ser exemplarmente visto nos relevos palacianos. Os casos dessa desarticulação sistemática estão na escultura dos corpos e cidades, dentro das partes ou blocos das cenas esculpidas. Gillmann (2007, 2014a, 2014b, 2016) indica a decomposição corporal como meio de expressar uma (melhor) visão do que se pretendia apresentar por aquele elemento. No caso do corpo humano, são esculpidas numa visão frontal partes corporais que na realidade são laterais: a cabeça e as pernas são apresentadas de perfil, estando as pernas sempre separadas na distância sugestiva de um passo; já o tronco é apresentado em seu plano frontal. Na visão de Gillmann, é um novo corpo, uma nova realidade constituída com sua própria autonomia no espaço imagético (2014b, p. 403). Tal desconstrução serve tanto para a figura de sujeitos, como para a imagem de arquiteturas, apresentando, por exemplo, uma construção arquitetônica em faces frontais. $\mathrm{O}$ caso das arquiteturas é emblemático, especialmente a escultura das muralhas das cidades (NADALI, 2006; MICALE, 2011; GILLMANN, 2014a; 2016). O que parece ser uma grande muralha nos relevos, possivelmente expressa as camadas de cinturões de muros de uma cidade. O que se vê verticalmente de baixo para cima seriam na realidade as camadas de muros, do mais externo (inferior), ao mais interno (superior), com a parte mais alta na imagem correspondendo à fachada de um palácio (por exemplo, nas Figuras 28, 108, 111, $116,120)$.

Esse é um princípio chamado de simultaneidade: várias faces compõem uma mesma e nova visão de uma realidade corporal (ou arquitetural). Tal princípio implica "desconstruir a forma percebida para reconstruir uma nova forma, não imitativa, fiel à forma conhecida e apta a apresentar todas as características do objeto da representação" (GILLMANN, 2014a, p. 731). A simultaneidade está relacionada à multiplicidade dos pontos de vista que é favorecida 
pela expressão dos relevos (GILLMANN, 2014a, p. 732). Isso demanda uma abstração do elemento visualizado de sua realidade espacial e sua proposição em uma nova visão. Então, marca-se e coloca-se um ponto de vista para a observação (GILLMANN, 2015, p. 273).

Nos relevos, pode ser encontrada uma manipulação de seus componentes figurativos para atender a uma intenção. Nesse sentido, a expressão do corpo é um processo que envolve sua disposição recomposta atendendo a um princípio de simultaneidade. A forma de esculpir o corpo e seus aspectos possui particularidades coligadas à configuração dos relevos. Sendo assim, dos aspectos da elaboração das narrativas visuais à escultura de figuras de corpos humanos, há níveis da produção material que implicam e são implicados num modo de conceber o corpo humano. Tendo em vista essas características da expressão de elementos nas placas, há mais particularidades dos aspectos corporais nos relevos palacianos que podem indicar facetas da concepção de corpo no período.

\section{O corpo nos relevos}

A presença do corpo esculpido nos relevos palacianos é configurada pela sua decomposição e pela apresentação frontal de planos corporais diferentes. Essa simultaneidade das partes do corpo que constituem o todo é uma primeira característica dos aspectos corporais nos relevos. A decomposição forma uma base cujo ponto de partida é um modelo de posicionamento corporal: um indivíduo em pé, com a postura ereta. Ambos os membros inferiores e superiores são contemplados e exibidos: os posicionamentos dos membros são variados, mas aqueles inferiores aparecem principalmente numa posição de passo (uma perna em frente à outra). É a partir dessa base manipulada que se constroem gestos e ações corporais nos relevos.

Em geral, as posturas são sempre na posição básica, mas há também sujeitos agachados ou sentados; há situações em que a figura da pessoa está em pé, mas com o tronco inclinado em direção ao chão; também ocorrem sujeitos ajoelhados, prostrados ao chão e deitados. Cada uma dessas posturas corporais mais recorrentes e básicas é passível de repetição em diferentes relevos. Dentre os muitos exemplos, nas placas da sala $\mathrm{H}$ do Palácio Norte (Figuras 115-116), diferentes tipos de repetições de posturas são evidentes. Figuras em posição sentada também servem de comparativo entre diferentes palácios (por exemplo, na sala XXVIII do Palácio Sudoeste, no centro da Figura 31 e nas salas S1 e F do Palácio Norte, 
respectivamente nas Figuras 109 e 112). Em uma placa da sala XXXIII do Palácio Sudoeste (Figura 47), há vários sujeitos ajoelhados, parecendo um modelo repetido de postura corporal.

Com relação à postura mais básica e recorrente, os sujeitos em pé e eretos encontramse em posição de passo, tanto em conjuntos cenográficos que sugerem uma dinâmica de locomoção e deslocamento espacial, como em momentos em que o ritmo parece mais lento ou até se sugere um momento estacionário. Então, uma mesma postura corporal é utilizada para estados de movimentação diferentes, incluindo uma ausência de movimento. A percepção de que há uma sucessividade na caminhada é dada por elementos do conjunto cenográfico que conduzem a visualização progressivamente. Em alguns casos, há uma amplitude maior do passo, ou seja, os membros inferiores estão mais espaçados entre si (como exemplos sugestivos nas Figuras 61, 115-116, 119, incluindo o uso do mesmo espaçamento nos membros dos cavalos). Isso é percebido no conjunto de uma cena como uma velocidade maior de seu ritmo.

A alteração dessa postura básica pode ocorrer em situações em que há uma manipulação de um objeto ou um gesto focalizado nos membros superiores. Gestos como indicar com as mãos (por exemplo, nas Figuras 12, 15, 44), atacar com uma lança (por exemplo, Figuras 43 e 117), usar um arco (por exemplo, Figuras 43, 45 e 81), podem fazer com que o tronco seja levemente inclinado à frente, em direção ao alvo ou objetivo da ação gestual. Também nas ocorrências em que se interage com um grande objeto ou animal, por exemplo nas cenas de manipulação de objetos de construção (por exemplo, nas Figuras 11 e 109), há uma leve inclinação do sujeito, indicando sua proximidade e atuação no alvo. Por outro lado, tal inclinação corporal não ocorre significativamente quando a direção do movimento indicada pelos membros inferiores não é a mesma que a do tronco: isso acontece quando há uma rotação do tronco para trás, visando um alvo direcional que, em termos de orientação espacial, está atrás do sujeito (ver por exemplo, na Figura 43). Por exemplo, quando um arqueiro visa atacar um alvo que está atrás de si, não há uma inclinação do corpo; numa procissão, quando um sujeito se volta para a fila para conduzir ou interagir (provavelmente falando) com outro, não há tal inclinação (por exemplo, nas Figuras 113-114). Esse ajustamento postural, relacionado com um dos tipos de movimento propostos por Gillmann, quando existe, é uma leve nuance da posição corporal da figura esculpida. Então, os artífices assírios mantêm os objetivos de realismo de sua escultura inclusive através de uma precisão maior ou menor de posturas e gestos a partir de uma posição básica corporal, atendendo também ao princípio da simultaneidade. 
Esses ajustamentos de posturas e gestos ocorrem quando indivíduos se encontram sentados. Isso é expresso especialmente quando sujeitos estão montados em seus cavalos: nesse caso, o ajustamento ocorre nos membros inferiores, como se o quadril estivesse parcialmente flexionado (o que indica uma posição de estar sentado), mas com os membros se ajustando ao corpo do cavalo (como exemplos nas Figuras 44, 82 e 102). O tronco pode ou não estar levemente inclinado à frente, quando há uma ação (especialmente ofensiva) com os membros superiores, mas a base postural é a mesma.

Tendo como referência o modelo básico de postura, outra possibilidade de movimento é a amplitude de ação com os membros superiores. Assim como existe um aumento de amplitude do passo para sugerir uma velocidade maior de movimento, uma maior amplitude de membros superiores pode ser utilizada para indicar um momento de uma ação em processo: por exemplo, quando sujeitos visam levantar e atacar com uma maça (Figuras 19 e 49) ou outra arma (Figuras 30 e 31), ou visam decapitar um inimigo (Figuras 23, 30, 43 e 56), uma das mãos que segura a arma se encontra acima da cabeça, enquanto a outra é posicionada para dar equilíbrio à sua lateral oposta, ou ela segura o alvo do golpe. Assim, há uma visão aberta do tronco e membros superiores, em termos de uma "envergadura". Tal amplitude também é evidente quando um indivíduo é atingido numa batalha (por exemplo, nas Figuras 43-44 e 117), ou quando há uma perda de equilíbrio (pela mesma razão anterior, ou porque seu carro ou animal foi atingido, Figuras 10, 44 e 118), ou até quando ele está caindo de uma altura (em muitos desses casos, a visão dessa amplitude é da parte posterior do sujeito, de suas costas, Figuras 111 e 121). Nesse sentido, a exposição da amplitude é similar, mas se evidencia uma falta de equilíbrio e de compensação entre os membros, assim como uma ausência de verticalidade (que é marca da postura ereta).

O uso da amplitude de membros superiores pode também estar presente em sua forma reduzida, com movimentos mais discretos, por exemplo quando os membros superiores parecem estar junto ao tronco e num movimento mais aproximado das mãos. Contudo, o extremo máximo dessa amplitude ocorre quando há corpos considerados mortos. Além de sua posição não ser vertical, sendo especialmente horizontal, seus membros parecem ultrapassar as próprias convenções do que é comum dentro do princípio de simultaneidade. Assim, a amplitude de membros superiores é totalmente inorgânica, o que pode favorecer uma visualização de algo frouxo, flácido e, portanto, sem vida. Isso aparece especialmente nos relevos do período de Assurbanipal II, tanto no Palácio Norte (Figuras 111 e 117-119), como no Palácio Sudoeste (Figuras 43-48). 
As ações com os membros superiores são bastante destacadas nos relevos, enquanto, a princípio, os membros inferiores servem para indicar especialmente a locomoção, assim como acompanham a postura corporal em posições diferentes daquelas do sujeito em pé. Mesmo com pouca frequência, é possível observar gestos com os membros inferiores. Além do agachamento, do sentar-se e da genuflexão (indicando uma prostração), há situações em que os membros inferiores indicam a subida por uma inclinação (artificial, como uma rampa, ou natural, como uma montanha, ambas as condições que caracterizam o movimento oblíquo proposto por Gillmann). Contudo, há casos em que a diferença de inclinação do ambiente não é evidente, apesar disso há sujeitos numa ação de subida (exemplos com e sem uma linha de base estão nas Figuras 52-54 e 57). Isso pode ser tanto para atender a uma elevação natural do terreno (contextualizando um monte), ou um movimento de subida para se atingir ao patamar superior do rei, que assume uma posição privilegiada de observador da batalha (Figuras 5758). Um outro gesto, raro, é uma pisada ou chute dado por um soldado assírio em um inimigo (na banda medial da Figura 117). Se não for o único caso em relevos remanescentes, é um dos raríssimos gestos feitos com os membros inferiores para além da locomoção ou ajustamento postural. $\mathrm{O}$ corpo do soldado assírio é inclinado à frente, com um membro inferior sobre o corpo em queda do inimigo e, simultaneamente, com uma mão segura o escudo de proteção e com a outra desfere um ataque com uma lança.

Esses aspectos corporais podem ser vistos em detalhe quando se focaliza a ação das partes e membros do corpo. Eles sempre fazem parte de um conjunto que é recebedor e atribuidor de sentido em cada elemento de sua totalidade, isto é, as partes corporais constituem a cena como um todo. Cada movimento e gesto pode ser repetido visando um efeito num bloco cenográfico maior. Por exemplo, quando há filas, alinhamentos de pessoas e procissões, a repetição dos padrões corporais pode oferecer volume àquele grupo e servir para mais efeitos visuais. Conforme afirma Nadali (2006, p. 114), a largura e o comprimento de filas de pessoas contribui a uma delimitação do espaço cenográfico, como um cordão. Um caso apontado pelo autor está na sala $\mathrm{C}$ do Palácio Norte (Figuras 86-88), onde um grupo de soldados dispostos em bandas diferentes circunda o rei que ultrapassa as divisórias internas da placa do relevo, assim como funcionários são colocados com cães, uns sobre os outros, indicando um "perfilamento" e formando um cordão separador da arena de caça. Desse modo, vários corpos formam uma massa uniforme em sua forma e função. Esse uso de corpos em conjunto constitui um novo objeto, um novo volume corporal no espaço. Isso pode estar relacionado ao efeito de acompanhamento que é causado em corredores dos palácios, onde os relevos com figuras maiores e progredindo numa certa direção transforma o corpo esculpido 
num estimulador de movimento. Ao mesmo tempo, a escultura em corredores é inspirada pelo tipo de ação que configura sua função arquitetural. Nesse sentido, o corpo presente em filas e procissões de corredores forma uma nova unidade com uma função para além de sua figura individualizada. Os corpos individuais postos em conjunto são elementos que se transformam, por meio de uma "cadeia de associação" (LATOUR, 1991, p. 11-12), em um novo objeto ou em um novo sentido dentro do espaço imagético.

As posturas corporais podem formar em conjunto uma unidade com uma função visual e expressiva diferente de seu significado. Nesse sentido, além de sugerir um tipo de postura e movimentação, a postura básica em pé e ereta traça uma relação de verticalidade com o ambiente cenográfico - a princípio, é apenas uma decorrência do bipedismo biológico humano. Alguns corpos aparecem mais ou menos inclinados, agachados e sentados, sendo que tais posições também conservam uma verticalidade. Contudo, há os casos de corpos na horizontal, o que sugere seu estado não vivo. Desse modo, a verticalidade dos corpos pode ser um elemento visual para entender o que é e está ativo.

Nessa mesma linha, a verticalidade parece ser uma marca manipulada especialmente em cenas de batalhas. Corpos que atacam (geralmente relacionados aos corpos assírios) sempre se encontram numa verticalidade, enquanto os outros (inimigos) aparecem com suas "verticalidades" fragilizadas. O caso exemplar é o da batalha em campo aberto esculpida na sala XXXIII do Palácio Sudoeste (Figuras 43-45). Os não assírios são os únicos que aparecem na horizontal.

Essa relação entre o eixo de posicionamento corporal e um sentido relacionado à identificação dos corpos, ou se o corpo está vivo ou morto, tem uma nuance nos casos de cenas de procissão. Nelas, todos os corpos aparecem dentro desse eixo vertical. No entanto, os elementos figurativos parecem indicar uma relação entre dominadores e dominados. Nas procissões, a direção de toda a cena tem como alvo o rei. Uma fila de corpos é direcionada ao fim do caminho, onde se encontra uma contagem, ou seja, há um momento de controle criado por um controlador. Essa fila de corpos de pessoas é contabilizada, tornando-se o número de presos ou deportados.

Aquilo que o corpo porta serve de critério diferenciador de características corporais. Com relação à indumentária, as vestimentas utilizadas são totalmente diferentes e evidentemente relacionadas a quem pertencia ou não ao ambiente assírio. Alguns sujeitos são apresentados presos em seus punhos, que podem estar para trás ou para frente (Figuras 23, 25, 26, 28, 29, 31, 32, 121; na banda inferior das Figuras 33-34, os sujeitos parecem estar amarrados uns aos outros pelos seus punhos). Nesse caso, as figuras apresentam os punhos 
amarrados na altura no peito, servindo de gesto escultórico de realce da condição de prisioneiro. Então, marcas corporais contribuem, ao lado do eixo postural, para construir uma relação desproporcional entre quem pode controlar corpos e quem tem seu próprio corpo controlado.

Ainda a partir da noção de verticalidade dos corpos, há situações de encontro onde sujeitos diferentes são mantidos num eixo vertical, mas sua direcionalidade na cena os distingue. Por exemplo, soldados assírios e não assírios em cenas de batalhas ou em cenas de confronto entre o rei e o leão estão numa postura vertical, mas um dos lados pode estar fragilizado, assim como um pode seguir a mesma direção do outro. Então, os dois prosseguem numa mesma direção, como se um estivesse indo atrás do outro (exemplos estão nas Figuras 43-45 e 119). Tal dinâmica de direcionamento entre esses corpos sugere uma posição de dominância, como se o primeiro caçasse e o segundo fugisse. Nesse sentido, o corpo do atacante é aquele que se dirige ao atacado, enquanto este último pode tentar distanciar-se do primeiro seguindo a mesma linha direcional. Portanto, além da verticalidade constante, os assírios são aqueles que se dirigem a seus alvos; eles são o motor e o ponto de partida de suas próprias ações.

Nos momentos de confronto entre o rei e o leão, eles praticamente se espelham: ambos atacam, ambos estão na vertical e um se dirige ao outro. No entanto, os elementos da cena expõem um sentido diferente: o rei aparece sempre caçando, enquanto o leão aparece morrendo, morto, atingido, sofrido (Figuras 88-90, 92-93 e 97-102). Ambas as figuras (a do rei e a do leão) aparecem em etapas: o leão muda de condição ao longo da cena, sempre como presa inescapável, enquanto a imagem do rei se mantém única e uniforme - ou, quando é diversa, serve para realçar sua ação de caçador. Adicionalmente, a posição do leão pode ser vista como estática na visualização da cena, similar ao caso das cidades atacadas: mesmo que ele seja esculpido em ação, é o rei que se movimenta no plano cenográfico, enquanto o animal é a caça fixa.

Outro caso é um corpo que aparece numa "outra verticalidade": corpos de inimigos assírios, atacados em suas cidades, caem de alturas, restando na vertical (Figuras 28, 111 e 121). Essa posição pode ter uma correspondência precedente com figuras de soldados jogando ou forçando a queda de inimigos em rios. Por exemplo, na Figura 30, dois sujeitos caem ou são jogados de uma embarcação, enquanto um terceiro já aparece na água. Na Figura 45, há vários sujeitos também sendo jogados num rio. Já na Figura 55, há dois soldados segurando os tornozelos de dois sujeitos, que estão na horizontal, sugerindo também que eles estão sendo lançados ao rio. Contudo, essa é uma "verticalidade invertida": o corpo que cai é 
verticalmente dirigido ao chão. Esses corpos também aparecem "fragilizados" em seus movimentos corporais, não apresentando um equilíbrio ou controle. Expressar essa condição de queda de uma altura (comumente conhecida por aquela comunidade acostumada a ver muralhas e palácios), suscita uma sensação corporal de dor ou uma noção de morte inescapável.

Por fim, um último aspecto que está relacionado às posturas corporais e seus sentidos é relativo à organização da cena, precisamente a ordenação dos sujeitos que podem ser identificados como pertencentes a cada lado (assírios e não assírios). Conforme Nadali afirma (2006, p. 56), os ataques assírios são sempre organizados, seja do ponto de vista estratégico e tático, seja do ponto de vista expressivo. Como os assírios estão sempre na vertical, em posturas eretas e sempre atacando, isso dá a percepção de uma ordem, enquanto os outros, com suas posturas variáveis, com corpos vivos e mortos, são um emblema de sua defesa bélica caótica. Segundo o autor, o jogo de horizontalidade e verticalidade também funciona para expressar, no conjunto, a organização assíria e a confusão do outro. Os posicionamentos corporais e seus lugares no espaço da cena favorecem a visualização de duas constantes: a que assume o eixo ordenado e vertical e a que está "fora dos eixos", dispersa. Tal disposição das figuras na imagem associadas à sua identidade assíria ou à sua alteridade não é arbitrária. Esse modo de apresentar os assírios, em especial o posicionamento do rei, tem relação com a concepção de realeza do período, tradicionalizada na figura do soberano como ordenador do mundo, através da missão designada pela divindade, e que deve enfrentar a desorganização e o caos. A função do rei como ordenador é incorporada na imagem através de seu próprio corpo e dos aspectos corporais de todos aqueles que estão ao seu lado. Tal concepção de realeza ordenadora aparece dessa maneira nos relevos se valendo de todos os princípios expressivos da escultura nas placas de pedra, especialmente das unidades e gestos corporais e do agrupamento em blocos da cena.

A ordenação dos corpos de pessoas no espaço cenográfico pode relacionar-se com a possibilidade de reconhecimento ou identificação de alguns corpos. Pelas posturas e diferenciação de vestimentas, é possível visualizar ao menos quem eventualmente é assírio e quem não é. Por mais que sejam todos os corpos de pessoas, as imagens nos relevos não prezam pela retratação precisa dos indivíduos. Contudo, as configurações nas figuras humanas permitem categorizar e distinguir os corpos. A diferenciação de identidades é possível por aspectos figurativos nos corpos e por detalhes de vestimenta. Com relação aos primeiros, a altura das figuras não serve tanto para diferenciar hierarquia e gênero, mas se presta a discriminar adultos e crianças (Figuras 23, 36, 45, 48, 53, 112-113, 121). É evidente que tal 
característica é correspondente ao realismo proposto pelos relevos narrativos. Outra distinção pode ser feita entre homens e mulheres, pela presença de barba ${ }^{120}$. Já com relação às roupas, geralmente as mulheres usam vestimentas mais longas do que as dos homens. Isso permite ver, por exemplo, traços osteomusculares nas pernas dos corpos masculinos - o que não parece ser o caso em corpos de mulheres. Diferenciados pela barba, pelo tipo de cabelo, pelos objetos portados e pelo contexto da cena, certos homens também poderiam vestir roupas mais longas, ainda que diferentes daquelas femininas (Figuras 65-67, 72-73 e 105), o que ajuda a identificá-los como funcionários da realeza e de um patamar mais elevado. E homens também são os únicos que utilizam uma vestimenta relacionada à sua atuação militar. No contexto de cenas de batalhas, há diferenças de indumentária: alguns indivíduos possuem roupas com mais detalhes possivelmente têxteis, usam uma espécie de capacete e de cota de malha, incluindo um calçado, enquanto outros aparecem descalços, com vestes menos detalhadas e sem capacete, ou somente com um tipo de faixa na cabeça. Essa diferença de indumentária militar - ou uma diferença entre quem tinha uma vestimenta "profissional" de batalha e quem batalhava como podia - marca a distinção entre assírios e não assírios, sendo que esses últimos podem ser os inimigos, ou os aliados, mas identificados como "estrangeiros", características dadas pelos contextos da cena (a paisagem) e pelas inscrições reais (por exemplo, a distinção indumentária entre soldados assírios e não assírios aliados pode ser vista nas Figuras 43-45 e 119). Então, os soldados assírios são aqueles que mantêm sempre uma postura vertical imponente, sempre estão na ofensiva e são aqueles que possuem melhor equipamento bélico - sem mencionar sua participação num agrupamento mais organizado, em termos de posicionamento espacial na cena e de estratégia ofensiva.

Em síntese, o corpo esculpido atende a um princípio de simultaneidade para a expressão visual das narrativas dos relevos. Essa base é manipulada para constituir a cena, através do movimento e dos gestos corporais. A posição e a forma em que os corpos são dispostos servem não somente à configuração da imagem, mas indicam sentidos por meio do corpo. Tais significados são relativos à identificação dos assírios e não assírios, homens e mulheres, ordem e caos, dominante e dominado, caçador e caçado. O corpo é usado nas diferentes camadas de concepção da imagem por meio dos relevos, assim como a própria imagética contém os indícios do modo de conceber o corpo: quem tem o corpo mais forte, associado à nação, que pode dominar um corpo caótico, não ordenado, caçado, morto.

\footnotetext{
${ }^{120}$ Em alguns casos, há sujeitos com traços masculinizados, mas sem barba. Eles acompanham o rei em seu carro ou durante as caçadas, ou até nas placas de corredores. Em realidade, eles são eunucos, que desempenham funções específicas nos palácios ou na administração do exército. Sua condição genital causa alterações hormonais que, por sua vez, implicam no não crescimento de barba.
} 
Essa primeira identificação dos aspectos da configuração expressiva dos corpos nos relevos corresponde ainda a outras características e sentidos gerais. Mesmo atendendo ao princípio de simultaneidade, a decomposição dos corpos, de seus gestos e posições é imediatamente acompanhada pela recomposição dos mesmos. Nesse sentido, o corpo é sempre expresso integralmente e sua inteireza é apresentada na totalidade da base postural ereta. Os corpos que não aparecem visualmente inteiros ou são aqueles encobertos por um anteparo - ou seja, é uma pessoa atrás de um muro, atrás de um carro etc. - ou são corpos não vivos. Em geral, corpos vivos e mortos são expressos em sua integralidade. Diferenças são encontradas na expressão de violência radical, como em casos de decapitação (quando se mostra o momento prévio à decapitação, com um guerreiro empunhando uma lâmina no pescoço ou cabeça de uma pessoa, como nas Figuras 23, 43, 45, 55, 56, 120; na Figura 117, um sujeito parece ser atacado na cabeça) ou quando há corpos decapitados e cabeças sem corpos - condição acompanhada principalmente pelo posicionamento corporal inorgânico, sugerindo a ausência de vida. Corpos decapitados residem ao chão ou flutuam em águas fluviais (Figuras 43-45 e 48, respectivamente); cabeças são empilhadas (Figuras 25, 29, 37 , 43, 120) ou carregadas (Figuras 23, 29, 37, 121) - com exceção da cabeça pendurada em uma árvore (Figura 106). Há mais realces da condição de morte. Um exemplo dos relevos é a presença pássaros (talvez corvos) sobre corpos caídos ao chão, sugerindo que eles estão se alimentando dos cadáveres (Figura 45). Corpos (inteiros ou decapitados) boiando em rios também indicam sua condição cadavérica (Figuras 45-48). Uma punição corporal vista pelos relevos é a empalação (Figura 51), que não necessariamente indica uma situação de estar morto, podendo expressar o sofrimento prévio à morte (BAGG, 2016, p. 64) ${ }^{121}$. Portanto, são duas formas de expressar a unidade corporal, relacionadas à presença ou ausência de vida. Há um contraste entre as unidades corporais inteiras e os corpos decapitados. O significado e a relação com a vida aparecem por esse contraste, ou seja, corpos inteiros e decapitados possuem um "valor intrínseco" pela existência de sua contrapartida (DI PAOLO, 2016, p. 31). Assim como gestos e posições corporais, as decapitações formam uma "unidade visual" relativa a quem executa e a quem sofre as ações, formando os elementos que compõem o ritual da cena (DI PAOLO, 2016, p. 31-32).

Há cenas em que se apresentam somente cabeças empilhadas (por exemplo, nas Figuras 25, 29, 37, 43 e 120), ou não há correspondência nem orgânica, nem quantitativa

${ }^{121}$ Ver também Radner (2015a) sobre a punição por empalação. 
entre cabeça-corpo decapitado, com relação ao número de cabeças e número de corpos presentes na cena (por exemplo, nas Figuras 43-48). Pelos relevos remanescentes, parece não haver partição de membros corporais além da cabeça ${ }^{122}$. A presença da cabeça isolada e sem correspondência a um corpo (através de uma proximidade entre figuras, ou através de um canal diretivo que relacionasse a cabeça ao resto de um corpo), constitui uma nova unidade corporal em si e, consequentemente, é um novo (uso) do corpo: a cabeça e o corpo decapitado servem para dar sentido ao resultado da ação assíria: a condição de morte associa-se à eliminação do componente do caos do mundo. Esse resultado é passível de reprocessamento: a violência fatal não é só efetivada, mas é controlada quantitativamente pelas cabeças dos mortos (LIVERANI, 2017). Nos relevos, a morte do inimigo resultante da ação guerreira precisa ser duplicada, de um lado, pelos corpos atingidos, caídos, despencados, jogados, decapitados e, de outro, pela manipulação da parte mais significativa desses corpos (a cabeça) para fins de objetivação através de um controle quantitativo (a contagem). Acrescentam-se a isso os corpos que também são efetivamente presos ou balizados numa longa fila de deportados, que também serão contabilizados (por exemplo, nas Figuras 34 e 111). Esses resultados da ação assíria devem ser vistos como parte de um cenário ou contexto de memória da comunidade palaciana. As cabeças decepadas, carregadas e empilhadas deixam de ser cabeças de um corpo ou a referência a um corpo ausente, e tornam-se uma unidade corporal com significado em si mesma e expressando simultaneamente a negatividade da morte do outro e a positividade de ser um resultado controlável por parte de quem as decepou. Tais eventos estão expostos nas paredes dos palácios pelas suas conotações positivas dentro da experiência visual e imperial da realeza assíria ${ }^{123}$.

Os casos das cabeças decepadas e dos corpos decapitados mostram que a totalidade corporal é manipulada nos relevos para mostrar o resultado da atuação assíria e a condição de morte. Nos relevos remanescentes do período de Senaqueribe não aparecem corpos mortos, apesar de serem expressos corpos sofrendo punições (empalações, decapitações e um "arremesso" de sujeitos, na Figura 55) e cabeças empilhadas. Já nos relevos do período de Assurbanipal II, aparecem corpos mortos dispostos na horizontal, com ou sem cabeças. Essa diferença está relacionada a aspectos do estilo de escultura de cada período. Durante o reinado

\footnotetext{
${ }^{122}$ Destaca-se que, na cultura mesopotâmica (suméria e acadiana), a cabeça possui um significado cultural elevado como síntese do indivíduo, lugar de manifestação e percepção de sentimentos e como alvo principal de ataques corporais em situações bélicas (COUTO FERREIRA, 2009, p. 88-89). Contudo, o desmembramento corporal é reconhecido como uma prática punitiva no período. Ver, por exemplo, Bagg (2016) sobre as menções a desmembramentos corporais em textos assírios.

${ }^{123} \mathrm{O}$ caso mais emblemático de celebração desse tipo de resultado positivo é a cena de banquete da sala $\mathrm{S} 1$ do Palácio Norte (Figura 106), analisada por Rede (2018) dentro do contexto "ritualístico" palaciano, que compunha o projeto imperial assírio.
} 
de Senaqueribe, implementou-se o uso de algumas placas de relevos sem bandas divisórias, o que favorece uma narratividade mais ampla num ambiente cenográfico mais realista. O evento como um todo passa a interessar mais que os elementos da imagem. Nesse sentido, o caso dos relevos do período de Senaqueribe reforça a ideia da tentativa de expressão realista não da morte, mas do modo que se mata, não sendo necessário então mostrar um corpo morto. No caso dos nos relevos de Assurbanipal II, o realismo é dirigido à concretização da morte, aos seus resultados apresentados através dos corpos ao chão. Isso pode estar relacionado a uma outra forma de apresentar (e legitimar) a ação bélica do rei: não como um processo de guerrear, mas como desfecho de sua atuação.

A alteração do corpo integral serve para criar sentidos visuais correspondentes a uma ação. Nessa ótica, a integralidade dos corpos é, portanto, uma marca da vida, da atividade. Por outro lado, a presença da morte está relacionada à inatividade do corpo, este particionado ou não. Nessa linha, encontra-se a capacidade expressiva do corpo vivo e em ação, assim como do corpo morto e inativo, sendo o segundo o resultado da ação do primeiro.

Essa dualidade entre atividade e inatividade se desenrola no uso de objetos, especialmente as armas. Aqueles que atacam possuem sua arma ativa, em ação, em movimento. Por exemplo, os arcos dos soldados em batalha ficam preparados para o disparo (em fase de puxada completa, pronto para a largada), com as flechas posicionadas (como, por exemplo, na Figura 49); as lanças e as flechas lançadas dos assírios sempre tocam outros corpos (Figuras 43-45) ${ }^{124}$; escudos são sempre empunhados junto ao corpo dos soldados. Da outra parte, os objetos inativos encontram-se descolados de sujeitos ou, quando em posse de alguém, estão desativados, não são vetores de uma ação primária (por exemplo, em situações de repouso, onde há uma fila de soldados). Como exemplos, aljavas, arcos e lanças parecem "planar" num ambiente de batalha em campo aberto (Figuras 43-45), possivelmente indicando sua dispersão pelo solo. Inclusive armas aparecem na mão de não assírios que se encontram caídos ou em gesto de rendição (Figuras 29 e 43-45). Então, um princípio similar para expressar a atividade e inatividade dos corpos é utilizado para mostrar a ativação dos objetos no espaço cenográfico. Nesse sentido, corpos e objetos são apresentados pelo seu potencial de atividade e controle, além de expressarem entre si relações de distinção: quem é ativo porta objetos ativos e diferentes daqueles inativos.

\footnotetext{
124 Raras exceções são as flechas que "planam” nas salas S e C do Palácio Norte (Figuras 82, 83 e 90). Certamente disparadas pelos caçadores durante as caçadas, elas estão sem contato com um corpo. No entanto, pela dinâmica narrativa desses relevos, entende-se que o artífice possivelmente buscou captar o momento de trajetória das flechas, pois elas apresentam um direcionamento bastante indicativo com relação aos alvos próximos.
} 
A dualidade entre ação e inação relaciona-se principalmente à disposição postural dos corpos. Há corpos sempre em pé, verticais, enquanto outros estão abaixados, caídos. Os primeiros tendem a uma maior atividade, enquanto os últimos estão inativos. Parece haver um certo fluxo ou uma dinâmica de contraste: algumas pessoas estão em ação, em pé, verticalizadas, atacando outras, que são afetadas, deixando a posição vertical e passando a um abaixamento progressivo, até a horizontalidade total, a não ação, a morte. A ação e a inação poderiam ser vistas como atividade e passividade, ou movimento e ausência de movimento. Em qualquer um dos casos, o contraste entre os lados expressa evidentemente uma relação de maior atuação de um, enquanto há passividade de outro.

Essas ocorrências nos modos de expressar corpo vinculam-se às concepções de corpo no período, com relação, por um lado, ao posicionamento e lugar dos corpos nos relevos e, por outro, ao que é possível expressar por meio da figuração corporal (vida e morte, ação e inação). Gestos precisos também são marcadores da expressividade corporal nos relevos. Numa acepção ampla, todas as ações corporais esculpidas nos relevos podem ser consideradas gestos: são movimentos corporais em direção a um alvo ou à realização de uma ação. Foram mencionados anteriormente vários gestos vinculados a ações guerreiras, especialmente na utilização de armas. Contudo, há ações corporais esculpidas que podem ter relação com um significado, destacando-se pela sua singularidade, e não pela sua recorrência.

Uma posição gestual do membro superior, especialmente das mãos, é sempre mobilizada, mesmo em situações em que um dos lados poderia estar "em repouso". Isso quer dizer que, do mesmo modo que os membros inferiores aparecem principalmente em posição de passo inclusive num momento estacionária, os membros superiores também precisam figurar "ativados", seja segurando um objeto, seja realizando uma ação gestual. Nos casos em que o membro superior e/ou a mão estão "desocupados", como nas cenas de procissão da passagem ao templo de Ištar no Palácio Sudoeste (Figuras 66, 67, 69, 70), a mão aparece totalmente aberta. Por um lado, isso pode ser uma padronização da escultura das mãos, em imagens de tamanho maior em comparação às placas com cenas narrativas. Por outro lado, a mão aberta pode ser justamente um gesto figurativo ou ritual, que apresenta a parte do corpo ativa, em ação. O paralelo com objetos que aparecem de modos diferentes nos relevos, como os arcos, é um contraponto para mostrar que na expressão escultórica dos relevos é possível expressar a atividade e inatividade de mais de uma parte corporal por meio de um gesto e/ou do contato com objetos. Nesse caso, os membros superiores são apresentados sempre ativos, ativados, em ação. 
Enquanto as posições das mãos são realçadas em diferentes ações corporais, elas também aparecem esculpidas em situações em que, por dedução, poderiam ficar encobertas e invisíveis. Dois casos particulares são do corredor R do Palácio Norte. Num dos lados da parede (à esquerda de um observador que segue ao interior do palácio), figuras de funcionários portam os resultados de uma provável caçada para um eventual banquete (Figuras 77-79). Alguns levam bandejas em suas mãos esquerdas, outros carregam, em conjunto e na altura de seus troncos, os corpos de leões. Tendo em vista o princípio de simultaneidade, é possível entender o modo "estranho" de carregar as bandejas (Figura 77). Numa visão bastante "literal", os recipientes são portados pelas pontas dos dedos. No entanto, sabendo dos princípios sugestivos da escultura assíria, percebe-se que se pretende mostrar, em uma face frontal, a parte do corpo que carrega a bandeja, especificamente a palma da mão que tocaria a base do recipiente.

Já no caso dos carregadores de leões, a visão de suas figuras é de seu lado direito. Então, vê-se o membro superior direito segurando por um lado o corpo do animal (que está na horizontal) e, por outro, seria esperado que o braço esquerdo passasse por trás do leão, ficando invisível no relevo. Isso acontece com os funcionários do meio (que carregam o primeiro e o segundo leão), enquanto com os funcionários das pontas, é mostrado como eles seguram com a mão esquerda (o mesmo acontece com os funcionários do meio da fila que carregam o terceiro leão, Figuras 77-79). Numa primeira visão, parece haver um gesto de flexão do punho para segurar a parte carregada do leão, deixando a mão à mostra. Inclusive com as mãos direitas, alguns funcionários aparecem com as mãos fechadas, sugerindo que eles estariam segurando os leões pela sua pele ou pelos. Essa estratégia escultórica realça o modo de carregar o leão. Não se destacava na imagem um modo geral de segurar e carregar o animal, como uma sugestão visual de que os sujeitos representados estariam levando o leão. $\mathrm{O}$ realce está no detalhamento o mais preciso possível do gesto realizado com a parte corporal para que o carregamento fosse realizado. Por mais banal que seja atividade expressada nos relevos, a parte corporal que executa a ação em andamento era esculpida em detalhe para que o gesto expressivo realizasse seu sentido visual.

O uso dos membros superiores pode contribuir ao direcionamento da imagem e da narrativa, também cumprindo uma função em sua unidade figurativa, ao expressar um gesto ou ação, que por sua vez aparece com sentidos múltiplos. Um desses gestos é o apontar ou levantar as mãos (com estas semiabertas e as palmas voltadas para cima), acompanhado ou não de um voltar-se para trás com a cabeça, possivelmente indicando uma situação de fala (Figuras 29, 32, com ambos os movimentos, e nas 33, 112-113 com somente gesto com a 
cabeça). A respeito desses gestos especialmente com as mãos, apontando para uma pessoa, juntamente com o movimento de cabeça, como se a figura se voltasse para trás, Nadali (2006, p. 64) argumenta que tal gestualidade pode ser associada a um momento de fala captado na expressão imagética. $O$ potencial da gestualidade figurativa em expressar momentos de fala é complementado por Thomason (2016), ao destacar os gestos como parte de um conjunto cenográfico que pode suscitar as sensações corporais (como os cheiros em uma paisagem vegetativa ou numa temática relativa a um banquete). A existência de movimento gestual de apontar e voltar-se para trás pode estar associado com o momento da fala, seja o precedendo, o sucedendo, ou o acompanhando contemporaneamente. A capacidade de expressão de tal gesto em um momento preciso de um evento, como em uma procissão, reforça a proposta realista das narrativas dos relevos, ao captar e intencionalmente expressar uma ação bastante automática das relações interpessoais.

Os exemplos dos gestos com os membros superiores fazem parte do conjunto da disposição corporal para expressar uma ação do sujeito. As situações em que um gesto com as mãos e um movimento de "voltar-se para trás" poderiam ser acompanhadas por uma conversa compõem principalmente as filas, onde uns poderiam dirigir-se a outros. Gestos semelhantes aparecem quando sujeitos sentados parecem conversar (Figuras 30, 109 e 111-112). Um caso singular é uma criança que parece se dirigir à mulher próxima (Figura 45). Soldados também parecem controlar verbalmente a procissão (por exemplo, nas Figuras 29, 36, 111, 113, 120, fazendo uso de uma vara ou bastão que talvez ajudasse a balizar a fila), ou comandar uma ação durante o transporte de produtos à construção (como nas Figuras 11-12 e 14-15), durante as caçadas (Figuras 82, 84 e 102, inclusive parecendo conversar na Figura 85), no encaminhamento dos rituais para o banquete (Figura 105) ou até o que parece ser uma coordenação de uma fila ou posicionamento de funcionários realizando um gesto mais incisivo com ambos os membros superiores enquanto se desloca (Figura 86). Um direcionamento de uma marcha à batalha, eventualmente acompanhado de palavras de ordem ou de comando, pode ser encontrado com repetições intercalares de sujeitos que, cavalgando, dirigem-se para trás de suas filas (Figuras 114-116). Durante as procissões, os soldados podem figurar punindo pessoas (por exemplo, nas Figuras 33, 111, 121), ou com um dos membros superiores levantados e segurando uma arma (Figuras 34, 121) - talvez como ameaça, como "motivador" à continuidade da procissão ou até como um momento prévio ao golpe propriamente dito. Inimigos aparecem com um dos membros superiores levantados, na tentativa de proteger-se de um ataque durante uma batalha (Figuras 30 e 43-45). Presos ou deportados poderiam questionar sua condição, além de reclamar e lamentar (banda inferior da 
Figura 29, 32, 112; pessoas parecem dirigir-se aos soldados, como na Figura 109). Em um breve momento numa cena ampla de batalha, dois sujeitos encontram-se em meio a uma vegetação, sendo um indicando talvez um caminho de fuga, enquanto outro está num posicionamento de rendição (com as mãos levantadas acima da cabeça, na Figura 111). Em outros casos, algumas pessoas fazem um gesto com ambas as mãos levadas à cabeça (Figuras 43 e 112, inclusive nesta última com uma criança fazendo o gesto com uma das mãos).

Nesse sentido, para além da presença de um gesto figurativo evocando uma expressão verbal, eles podem também sugerir uma carga de sentimento. Os gestos com as mãos semiabertas, com as palmas voltadas para cima, podendo ou não ser acompanhados de um momento de fala, podem sugerir um questionamento ou dúvida diante da situação. Os artífices dos relevos, ao terem de inserir tais cenas, suscitam o realismo e o conhecimento de um gestual diante da condição de estar sendo caçado ou dominado.

Os gestos de rendição (casos singulares no Palácio Sudoeste, nas Figuras 28-29, na Figura 30, com sujeitos ajoelhados dentro do barco, e na banda medial da Figura 43) e de prostração (Figuras 47, 57, 82 e 105, destacando na segunda e na terceira uma progressão no gesto de prostrar-se), são englobados num contexto de submissão, pela proximidade com a figura do rei. Há um caso singular de um "pedido de morte" (Figura 44), acompanhado de uma inscrição real. Os gestos nessas ocorrências (com exceção da última, que claramente posiciona a mão do sujeito como uma lâmina a cortar seu pescoço), assemelham-se pela elevação de um ou ambos os membros superiores e com o mesmo posicionamento das mãos (semiabertas). Tal gestual pode variar de um movimento atrelado à súplica ou louvor (Figuras 111-112, 117, 119-120), especialmente quando uma procissão está diante do rei, ou até o desespero ou incerteza diante daquela experiência. Também há um outro gesto, com os membros superiores um pouco mais elevados que anteriormente: as mãos chegam acima da cabeça, o que talvez expresse um total desespero diante da situação (Figuras 43, 112) ${ }^{125}$. O contexto narrativo no qual esses gestos estão inseridos atrelam-se à manifestação de sentimentos associados ao domínio (brutal) assírio.

Um exemplo específico do contexto de submissão é o da sala S1 do Palácio Norte. Os relevos parietais dessa sala expressam muitos dos motivos da escultura assíria, da guerra à caça e ao banquete. Na banda inferior (Figura 104), o rei encontra-se num momento ritualístico possivelmente posterior à caçada aos leões (que aparece expressada nas bandas

${ }^{125}$ Cifarelli (1998, p. 220-221) menciona que tal gesto não possui paralelos em fontes mesopotâmicas, mas pode estar associado, por comparações com fontes mediterrânicas, egípcias e bíblica, ao gesto de lamentação e choro diante de um sofrimento. 
superiores), vertendo um líquido sobre o corpo dos animais e segurando um arco. Conforme aponta Nadali (2006, p. 150), tal cena é correspondente a uma inscrição ${ }^{126}$ sobre a imposição do arco de Ištar sobre o inimigo, indicando submissão e humilhação, havendo no relevo o paralelo entre o animal morto e o inimigo. Tal imposição gestual dos inimigos perante o rei é algo repetido pelos soberanos assírios, especialmente em fontes textuais - nesse caso aparecendo em imagem ${ }^{127}$. O autor destaca a similaridade iconográfica na equalização entre inimigos e animais através do posicionamento corporal, colocando, na concepção imagética assíria, seres humanos inimigos e animais caçados numa mesma condição. Isso se relaciona com a recorrência da horizontalidade da posição do outro, especialmente em situações associadas à fragilidade corporal (atingida) e à morte. Novamente, a figura do corpo é utilizada para expressar um significado através de sua disposição no espaço cenográfico.

Os gestos de rendição, súplica, lamentação, questionamento e desespero fazem parte de uma disposição corporal que funciona como uma fórmula utilizada pelo artífice para se referir ao outro. Ele cria uma imagem da alteridade através do corpo e dos gestos corporais: um sujeito que corporalmente louva e se desnorteia, condições marcadas gestualmente. Além das possibilidades de fala quando há uma gesticulação entre indivíduos, essas ocorrências podem expor ambientes sonorizados: como sugere Thomason (2016), os relevos expressam também outros sentidos; as súplicas poderiam ser acompanhadas de falas repetidas e de música (como pode ser sugerido, por exemplo, na Figura 47, com a presença de músicos). Nessa linha, os relevos como parte de uma ritualização cotidiana dentro dos ambientes palacianos também são recipientes de rituais em suas narrativas visuais. Os recintos do palácio nos quais os relevos se encontravam poderiam configurar um "ambiente sensorial": em especial os momentos de preparação e de realização dos banquetes certamente envolviam odores relativos aos alimentos preparados, além da presença de incensos, música, canto e dança. A ritualização é composta desde seus amplos motivos cenográficos (a batalha, a caçada, a construção, o banquete) até os componentes individuais da cena. Nessa configuração, as esculturas do corpo são utilizadas para formalizar esses ambientes cenográficos, favorecendo o direcionamento, o ritmo e a dinâmica imagética, assim como a

\footnotetext{
${ }^{126}$ As inscrições reais do período de Assurbanipal II farão parte do quinto volume das RINAP. Por enquanto, as inscrições foram editadas e estão disponíveis online na página do projeto, englobado no Open Richly Annotated Cuneiform Corpus (ORACC). As inscrições onde aparecem menções à Ištar e seu arco são, por exemplo, Rinap 5 Asb. 3 v 51-53; 7 v 130 b.

127 A presença de um arco próximo à figura do rei aparece em outras situações, como próximo ao trono de Senaqueribe na sala XXXVI do Palácio Sudoeste (Figura 58), ou atrás da cadeira de Assurbanipal II durante o banquete, na sala S1 do Palácio Norte (Figura 106). O arco é carregado por funcionários (e o cetro, símbolo de poder), como quando o rei está em seu carro imponente recebendo os tributos (Figura 111, 120), ou por soldados, durante uma procissão num corredor (Figuras 69-70).
} 
expressão de momentos individuais, seja de si mesmos (assírios), seja de uma alteridade (os não assírios). Se os relevos podem suscitar sentimentos, mesmo que de uma maneira formular e em meio a um ambiente preenchido de marcadores de sentidos, tal potencialidade imagética também demonstra os modos que os artífices assírios imprimiam gestos associados a situações distintas e singulares, especialmente demonstrando a fragilidade dos outros.

Nesse sentido, a possibilidade de suscitar sentimentos por meio das imagens esculpidas pode partir do repertório de suas experiências vividas ou é uma expressão daquilo que eles veem ou querem que seja imposto como uma atitude dos outros. Em ambos os casos, as diferenciações entre assírios e não assírios são complementadas por diferenças gestuais. Assim como os assírios sempre atacam, são verticalizados e sempre dirigem as ações (ou são o seu objetivo final), eles não são expressos com variações gestuais que suscitariam, pelos relevos, um repertório de sentimentos da alteridade. Portanto, os gestos corporais podem evocar sentimentos distintos, formando polaridades entre os assírios e não assírios.

Contudo, há gestos compartilhados que mostram, de um lado, usos mais banais do corpo, enquanto, por outro, indicam mais elementos que dão força à imagem dos assírios, especialmente à figura do rei. Por exemplo, no conjunto de relevos da sala $\mathrm{C}$ no Palácio Norte de Nínive, de Assurbanipal II, com o motivo de caça controlada a leões, o rei recebe o arco, um dos instrumentos de sua atuação, estendendo o braço e pegando-o com a mão direita, enquanto a mão esquerda pousa sobre sua lâmina embainhada (Figura 86). Similarmente, em outro conjunto de cenas de caça, na sala $\mathrm{S}$ do Palácio Norte, o rei acolhe os produtos da caça com o mesmo gesto (banda central da Figura 82). Enquanto no primeiro caso, a figura do rei é apresentada pelo seu lado esquerdo, nessa última vê-se seu lado direito. Então, ele aponta e recebe o produto principal da caçada (dois leões mortos) pelos seus servos, estendendo o braço direito, enquanto a mão esquerda pousa em sua lâmina embainhada. Da outra parte, nas mesmas placas da sala $\mathrm{S}$, um grupo de funcionários apresenta os leões mortos, com o mesmo gesto: braço direito estendido, enquanto a mão esquerda segura uma arma. O mesmo gestual espelhado entre rei e funcionários cria um canal visual em direção ao leão, morto e centralizado nesse trecho. Então, um gesto relativo a uma ação totalmente prática, como indicar e acolher objetos com as mãos, parece exigir obrigatoriedades na expressão dos relevos: os membros superiores naturalmente indicam a direção da ação ou do movimento, mas também podem indicar um significado referente à posse ou ao poder daquele que recebe e pode controlar um dado objeto.

Quando o rei se encontra em seu carro acompanhando e recebendo as procissões de pessoas e produtos, suas mãos apresentam uma disposição com uma mão levantada 
(geralmente a direita), e a outra mais abaixo (ou talvez apoiada também sobre sua lâmina embainhada) (por exemplo, nas Figuras 13, 28 e 111). Tal gesto repetido compõe um repertório de posturas do rei, que nesse caso saúda os resultados da ação emanada pela sua atuação.

O uso variado dos membros superiores pelo soberano mostra as potencialidades de suas ações, que vão desde o controle de armas, a posse de produtos até seu gesto ritual como marca da sua pessoa e de sua função. O gesto, combinado à indumentária, com seu aparato de objetos e pessoas dentro do contexto, concentra as potencialidades de ser rei por meio, especialmente, de suas posturas e ações corporais. As disposições do corpo e os gestos que diferenciam assírios de não assírios, ação e não ação, dominante e dominado, força e fragilidade, diferenciam as singularidades da imagem do rei. Por mais que não haja uma marcação que destoasse exageradamente a figura do soberano (como uma estatura mais elevada, uma borda que o separasse dos outros personagens, ou uma separação muito grande entre ele e os outros no espaço cenográfico), o rei possui tanto atributos e posições únicos (em seu carro, ou em seu trono), assim como é focalizado em partes da imagem - mesmo que não centralizado no espaço cenográfico. No entanto, as mesmas partes do corpo humano são manipuladas para significar ações e sentimentos no âmbito dos diferentes temas dos relevos. De um lado, o corpo do rei compartilha o mesmo gestual próprio da escultura dos baixos relevos; por outro, ele consegue ser nuançado e destacado, sendo reconhecida a sua figura.

Um exemplo de realce das partes corporais como formadoras de um gesto é em uma cena de batalha do Palácio Sudoeste de Nínive, de Senaqueribe. Arqueiros e soldados aparecem com as suas mãos e cabeças elevadas, indicando a direção da ação na cena (na Figura 50, o alvo é cidade em posição mais alta na imagem). Em conjunto, a posição da cabeça e dos membros superiores dos soldados contribui para a narrativa, mostrando a direção da sequência visual. No nível individual, essas posições corporais obedecem ao mesmo princípio de simultaneidade, para dar o sentido de direção de movimento da cena, do conjunto menor de elementos a cena como um todo. Cada soldado posicionado, seja em pé ou agachado, com suas cabeças dirigidas ao alto e acompanhadas pela direção de suas armas, formam um grupo que direciona para onde a cena de ataque deve acontecer. Contudo, destaca-se que, dentro do princípio de simultaneidade, não é a totalidade do corpo dos soldados que aponta a direção cena, mas são somente duas partes corporais (a cabeça e os membros superiores) especialmente mobilizadas para servir de gatilho direcionador e para mostrar o gesto corporal utilizado. 
Percebe-se através desse exemplo que, nos relevos, há a presença da totalidade corporal, mas parece haver uma ênfase na manipulação das partes corporais no desempenho de ações e gestos no espaço cenográfico. O princípio de simultaneidade não serve somente para favorecer a visão do todo corporal, mas atua para mostrar o gesto ou a ação corporal através da mobilização de partes do corpo. Portanto, nesse nível expressivo, o corpo inteiro atua por meio de suas partes.

Os modos de esculpir o corpo nos relevos palacianos e o entendimento de significados através dos aspectos corporais estão embutidos nos próprios temas das narrativas visuais. Nesse sentido, os usos expressivos do corpo aparecem modelados a seus lugares na cena, que podem ser expressados por um corpo posto em meio a batalhas, atacando e sendo atacado. Nos relevos, o corpo pode ser agrupado, formando uma unidade que o identifica com corpos iguais e o diferencia de outros, pelo que realiza, carrega e pelo o que é. Os corpos formam o exército assírio ou o grupo de trabalho que carrega objetos para a construção da cidade, enquanto há outros corpos que perfilam em direção a um lugar, numa condição de prisão e deportação. Tomados em conjunto, os corpos deixam de ser corpos individuais, formando, por exemplo, cordões de pessoas ou soldados, ou também sugerindo o movimento de um corredor onde se encontram esculpidos. O corpo pode ser de um assírio, sempre verticalizado, funcionando como componente do grupo militar ou palaciano. Em contrapartida, enquanto há um corpo reconhecido como assírio, há um corpo outro, controlável e controlado. O não assírio é passível de carregar marcas de sua condição frágil, de ser desmembrado, de ser morto. O corpo do rei, mesmo sendo mais um entre vários, é sempre realçado e destacado, seja pelo seu lugar no espaço visual, seja pela singularidade do que faz e porta. O corpo do soberano é tanto o centro de ações e atenções, assim como é principal observador e mandante dos eventos realizados. O seu corpo é o ponto de partida que promove a ação e o ponto de chegada após sua realização. Em todas essas situações corporais, o corpo inteiro apresenta gestos por meio de suas partes, as quais são realçadas e servem para fins narrativos e de expressão de significados. Esses lugares e formas dos corpos nos relevos encontram-se num outro espaço: o ambiente palaciano, a casa do rei e núcleo do império. A duplicação do rei na imagem e na realidade é reforçada: o soberano e os relevos se retroalimentam. Os relevos registram a ideia do que o rei idealmente faz por meio de seu corpo em meio a outros corpos que constituem as cenas.

A relação entre o que está nos relevos e onde eles se encontravam indica novamente a intenção de programação de sua disposição no palácio e a exigência da movimentação para serem vistos, que estão em locais que interagem com as próprias pessoas expressadas (como o 
rei) e que possuem motivos posicionados nas salas (WINTER, 2010b; NADALI, 2006; 2008; 2012; 2014). Os aspectos corporais realçados nos relevos servem para expressar tanto opções e estratégias escultóricas e visuais para dar um significado, como também são elementos que estão ancorados na materialidade corporal. No entanto, a noção de corpo é extrapolada tanto no nível figurativo (seguindo o princípio de simultaneidade), como no nível evocativo, ou seja, o corpo, seu lugar nas cenas, suas posturas e gestos sugerem um significado. Então, a programação dos relevos palacianos sintetiza a expressão do corpo humano e uma ideia de corpo. O corpo faz parte de um programa, mas pode ser em grande medida a visibilidade (ou seja, um corpo objetivado na escultura de determinado modo) daquilo que é ordinário, comum e, portanto, invisível ${ }^{128}$.

Os aspectos corporais são formadores das imagens dos relevos palacianos, servindo para compor as estruturas das narrativas visuais e para expressar significados, da gestualidade à identidade. A lógica própria da expressão assíria não corresponde a uma "leitura linear e textual" de seu conteúdo imagético. A análise contextual e a crítica aos modos de tratamento dos relevos contribuem para perceber que as relações entre eles, seus motivos, seus lugares no ambiente palaciano e quem poderia interagir com eles são fundamentais para o entendimento de seu papel social.

Nesse processo de tratamento dos relevos palacianos partindo do contexto histórico geral até a sua expressividade singular, percebe-se a implicação de sujeitos produtores e experimentadores no interior dos palácios. A materialidade dos relevos sintetiza, de um lado, narrativas visuais construídas por meio de corpos esculpidos e, por outro, a percepção corporal de quem tinha contato com essas imagens.

Essas considerações relacionam-se com a perspectiva analítica das imagens, no que se refere a um "postulado metodológico": uma imagem pode implicar um "espectador implícito" (MUTH et al., 2012, p. 229). Por um lado, retomando a afirmação de Nadali (2016), algumas imagens, mesmo presentes, não são feitas para serem vistas. Por outro lado, "estruturas imanentes à imagem", como seus princípios expressivos, podem "orientar e provocar certas formas de percepção e de recepção" (MUTH et al., 2012, p. 229). Mesmo que um espectador ou uma audiência não estejam implicados, "oferece-se a nós uma percepção da imagem correspondente à recepção ideal esperada pelo seu produtor" (MUTH et al., 2012, p. 229).

${ }^{128}$ Noção inspirada em Tilley (2008, p. 25). 
Dessa maneira, ao analisar uma imagem antiga, trata-se também da experiência do observador antigo. Nesse sentido, conforme afirmam Muth et al. (2012, p. 230), a imagem e sua ontologia não estão separadas da experiência de visualidade vivida por sujeitos num dado espaço e tempo, mesmo que sejam imagens restritas ou de relativa invisibilidade. Essas considerações sobre a imagem servem aos relevos palacianos ao convidarem a equacionar a audiência e a movimentação pelos ambientes onde as placas esculpidas estavam dispostas. À luz dessas considerações, os componentes dos motivos podem ser revisitados, especialmente os aspectos corporais.

A imagem dos relevos comporta modos múltiplos de buscar a expressão de coisas reais. Os artífices fizeram um produto estruturado com elementos visuais e espaciais, podendo ser vistos individual ou conjuntamente. A interação entre eles é balanceada como linhas de direção que criam visualmente partes estáticas e dinâmicas. Com essas relações, criam-se narrativas com diferentes tipos de movimento (WATANABE, 2004; 2014; NADALI, 2006; 2008; 2012; 2014; 2018; GILLMANN, 2007; WINTER, 2010a). Essa narratividade implica o cumprimento de requisitos de tempo e de espaço cenográficos. Uma certa perspectiva expressiva, relações de horizontalidade e verticalidade e as estratégias de impressão de dinâmica, ritmo e profundidade são realizadas utilizando camadas, sobreposições e manipulações dos corpos e dos objetos. Simultaneamente, esses recursos expressivos ajudam a mostrar a temporalidade: diferentes sobreposições criam várias temporalidades (diacronia), assim como elementos repetidos expressam um tempo simultâneo (WATANABE, 2014; GILLMANN, 2015; NADALI, 2018).

Nos relevos palacianos, os aspectos corporais atuam para compor as intenções de elaboração dessas imagens. As posições e posturas corporais podem indicar um modo de construção das cenas, em relação à espacialidade representada e à visualidade dos relevos. $\mathrm{O}$ corpo pode servir para indicar um movimento da cena, assim como ele é utilizado a visualização de significados especialmente através de gestos.

Os modos de esculpir o corpo também têm efeitos visuais, a partir da simultaneidade, princípio proposto por Gillmann (2014a; 2016). As partes corporais diferentes manipuladas e dispostas em uma face frontal, mesmo que de uma maneira decomposta e "inorgânica", funcionam como um tipo de abstração que torna possível (e, então, real), no espaço visual, algo irreal (MICALE, 2011; GILLMANN, 2014a). Essa decomposição corporal não é somente um recurso técnico, mas também um modo de expressar o espaço, o movimento, a atividade, a inatividade através dos aspectos corporais. 
Retomadas essas considerações, os elementos nos relevos podem ser individualizados, focalizando-se em cada sujeito, objeto ou paisagem. $\mathrm{Na}$ individualização dos corpos humanos, podem ser vistas suas decomposições para mostrar de um bom modo um significado pretendido - então, é observado o princípio de simultaneidade. Em seguida, a observação pode passar a conjuntos ou grupos de elementos individuais, formando os blocos ou partes que constituem uma cena narrativa. Por exemplo, observa-se a interação entre sujeitos, ou entre sujeitos-objetos-sujeitos. Nesse momento, a decomposição corporal é funcional para colocar em relação componentes dos relevos, e ainda expressar um gesto ou uma dinâmica de ação-inação no espaço figurativo. Por fim, na focalização de uma cena inteira (em uma ou mais placas), quando se vê a cena completa e acompanha-se sua narrativa, o todo faz sentido pela sequência narrativa por meio de imagens.

Nesse percurso, pode-se encontrar um efeito: a cena é composta pela narrativa, a qual é ancorada em manipulações e decomposições figurativas e do espaço cenográfico. Com relação ao corpo, as partes corporais, posicionadas em faces diferentes para compor o todo da figura, não interrompem a percepção visual da narrativa como um todo. As figuras corporais com suas faces decompostas não causam um estranhamento a ponto de não permitir a sequência e o direcionamento visuais da cena. Ao contrário, esse modo de esculpir o corpo é a forma que torna possível os significados visuais, a dinâmica da narração e a possibilidade expressiva de gestos e posturas corporais. O corpo formado pela simultaneidade de partes decompostas e recompostas é uma totalidade figurativa reconhecida pela sua forma e atuação dentro da narrativa dos relevos. A decomposição das faces do corpo, que serve às estratégias de significação e expressão da narrativa, "desaparece" durante o engajamento visual com os relevos. De um lado, as figuras corporais como elementos escultóricos são importantes para dar sentido à cenografia, tanto no que se refere aos gestos e ações dos indivíduos, como no direcionamento da narrativa. Por outro lado, na totalidade de uma cena nos relevos, a visualização não é presa na forma decomposta de escultura do corpo, sendo, então, que este se torna meio ou passagem do decorrer da narração. Nas placas esculpidas, a abstração sugerida para a compreensão de suas partes passa ao acompanhamento visual da narrativa, e o que foi abstraído (o corpo de faces decompostas) torna-se parte de um todo (o corpo na cena), independentemente de sua forma.

Nesse sentido, o contexto no qual os relevos foram realizados e seus lugares nas paredes dos palácios relacionam-se ao estilo de escultura. Através das marcas e traços presentes na própria imagem, é possível perceber como a figura do corpo era mobilizada para expressar sua concepção. A decomposição das faces corporais exprime tanto os recursos 
estilísticos para a elaboração da narrativa espacial, como também uma concepção de corpo, que envolve sua inteireza, capacidade de ação e capacidade de expressar sentidos relacionados à vitalidade (e a ausência dela), identidade e sentimentos. Decompor é um recurso técnico e se relaciona ao modo de visualizar o corpo, numa inteireza corporal. Assim, a decomposição corporal atua em significados da gestualidade (o todo corporal atuando por meio de suas partes) e no nível da visualidade, seja na construção imagética da cena, seja na percepção visual.

Então, tendo em vista esse processo de escultura do corpo com suas faces decompostas, é possível considerá-lo como parte integrante da natureza material dos relevos palacianos. Como eles estão atrelados a um processo de visualização que favorece a narrativa, é possível pensar que, na materialidade dos relevos, haja traços e marcas implicados com a percepção humana. Isso indica uma inseparabilidade entre a ação de elaboração, produção, interação e os objetos propriamente ditos (MALAFOURIS, 2013). Ao invés de compreender os relevos como um produto estático originado de um empenho do pensamento e das habilidades (manuais) humanas, é possível conceber que a sua materialidade está atrelada e é dependente de sujeitos, que por sua vez dependiam dos contatos físicos com eles para atuar no ambiente. Nesse sentido, os objetos e seus componentes expressivos são (e não somente contêm) marcas e marcadores de gestos e linhas de pensamento, assim como são parte integral do funcionamento da ação humana e de suas concepções culturais. Essas considerações sobre o significado dos materiais os definem através de um outro processo lógico: em vez de somente sinais comunicativos, representativos ou linguísticos, os materiais são coisas processuais (MALAFOURIS, 2013). Nos relevos, a expressão dos aspectos corporais pode estar vinculada a muitos sentidos, mas a sua própria forma material tem um significado em si mesma e está vinculada a uma possibilidade de conceber o corpo e as imagens. Desse modo, o significado não é anterior à imagem ou à materialidade; ambos se confundem, confluem em si na própria manifestação material (MALAFOURIS, 2013).

Das cenas completas esculpidas em várias placas de pedra ao contexto situado onde os relevos estavam dispostos, pode-se perceber uma organicidade entre o lugar do império, o palácio, os relevos como componentes arquiteturais e as ações registradas por meio das imagens. Essa conjunção é encontrada singularmente através de estratégias visuais nas paredes palacianas, certamente entendidas e experimentadas por aquela comunidade interna. Os aspectos corporais dos relevos assírios constituem as imagens ao mesmo tempo que serviam para expressar determinados sentidos por meio do corpo. Os relevos como objetos configuram as práticas e os processos de atuação ou agência humana, não como componentes 
passivos, mas como elementos engajados e que se constituem na ação. As expressões corporais nesses relevos podem servir como um ponto de compreensão de como os objetos são práticas e estão interlaçados com os sujeitos que com eles interagiam. Essa possibilidade de abordagem dos relevos elucida os significados figurativos da expressão corporal, assim como os aspectos da experiência corporal (visual) da percepção dos relevos. 


\section{CAPÍTULO 4 O CORPO EM TEXTOS DO PERÍODO NEOASSÍRIO}

Os textos escolhidos para a análise tinham como eixo de sua produção o palácio e a pessoa do soberano. Dos períodos de Senaqueribe e Assurbanipal II, foram selecionados textos epistolares, literários, tratados ou juramentos de lealdade e inscrições reais. Todos esses tipos assumiam uma função específica no âmbito imperial: as cartas funcionavam em favor da manutenção de um império altamente conectado e informado, especialmente dos acontecimentos em regiões mais distantes do núcleo, assim como das condutas que deveriam ser assumidas por parte do governo, a partir do acompanhamento de sinais divinatórios (PARPOLA, 2014, SAA X). Já os tratados escolhidos são um tipo de documento comum no desenvolvimento da diplomacia política assíria, sendo peça fundamental nos processos de expansão e consolidação imperial (PARPOLA; WATANABE, 1988, SAA II). Por sua vez, os textos literários, componentes do contexto de fomento ao recolhimento da produção escribal mesopotâmica, encabeçado por Assurbanipal II, são produções escribais poéticas (poesia, cartas literárias, lamentações, hinos, textos mitológicos e cúlticos) (LIVINGSTONE, 1989, SAA III). Por fim, as inscrições reais do reinado de Senaqueribe (GRAYSON; NOVOTNY, 2012, RINAP 3/1; 2014, RINAP 3/2) funcionavam como registro histórico produzido pelo ambiente palaciano com o objetivo de preservar a memória do império, e expô-la.

A seleção dos textos para análise, através da localização de menções ao corpo e suas partes, possui uma uniformidade inicialmente dada pelo recorte (contextual, cronológico, geográfico etc.). Além disso, a língua utilizada nos textos é outro elemento que os coliga. A versão dialetal do acadiano, denominada neoassíria, é idioma de grande parte da documentação. Outras variações do acadiano que estão presentes são a partir de versões da vertente babilônica, seja neobabilônica, seja babilônica padronizada. A primeira aparece nos textos literários (mesmo com seu cerne neoassírio), enquanto a segunda é protocolar na realização das inscrições reais. A presença dessas variações dialetais configura o quadro linguístico do ambiente assírio do primeiro milênio ${ }^{129}$.

\footnotetext{
${ }^{129}$ Além dessas variações do acadiano, na Assíria havia ainda a presença corrente da língua aramaica, mas que aparece muito pouco na documentação escolhida aqui (por exemplo, em alguns textos literários). Também havia a influência tradicional da língua suméria na região, mobilizada através dos sinais cuneiformes logogrâmicos, visando aumentar a rapidez da expressão escrita. A título ilustrativo, em vez escrever uma palavra que envolvesse dois ou três sinais cuneiformes para cada sílaba, utilizava-se um único sinal, correspondente à palavra suméria, para expressar o termo pretendido.
} 
Essas características dos textos do período neoassírio têm a ver com seu uso para determinados fins. Os gêneros e as variações dialetais envolvidos eram produto de uma especialização escribal, favorecida pela expansão do projeto imperial da realeza assíria. A função dos escribas não era mobilizar somente um conhecimento da escrita adequada para a formulação dos textos oficiais. Sua atuação escribal, letrada, envolvia um longo processo de formação arraigada em elementos tradicionais milenares, tanto relacionados à escrita e às línguas (principalmente o acadiano e o sumério), como dos textos canônicos, das mais diversas "áreas do saber". Tais escribas, conhecidos pela palavra acadiana ummânû, muitas vezes faziam parte de uma "dinastia" da prática escribal e eram designados para atuar com "saberes" pertencentes a determinadas áreas (o que era denominado por ummâni lè ûti). Conduzidas de maneira concomitante ou exclusiva por cada especialista, suas áreas de especialização são: o escriba de modo geral ou o astrônomo/astrólogo é designado pela palavra țup̌arru; em resumo, a prática da astronomia envolvia, de um lado, a observação e acompanhamento do movimento celeste e, por outro, o registro e interpretação dessa movimentação para fins divinatórios; bārû é o harúspice ou adivinho, responsável pela condução de práticas divinatórias, como o exame de entranhas de animais (extispicia), ou especificamente do fígado (hepatoscopia), e sua posterior interpretação; āšipu e asû eram responsáveis pelas práticas "médicas", sendo que o primeiro era um exorcista que lidava com as causações sobrenaturais de acometimentos físicos, e o segundo lidava com tratamentos físicos diretos no corpo; por fim, kalû é o encantador de lamentações, incumbido na condução de pregações específicas de rituais (PARPOLA, 1983, p. 6-10; PARPOLA, 2014, p. XIII$\mathrm{XIV)}$.

Os escribas especialistas são identificados nas cartas pelos seus nomes, que constam, em sua grande maioria, nos cabeçalhos de abertura das mesmas. O teor da correspondência e o relato dos próprios escribas permitem reconhecer qual é sua atuação principal - quando esta não é abertamente declarada na comunicação epistolar. Em alguns textos literários, também é possível identificar seus autores. Contudo, como no caso dos tratados e das inscrições reais escolhidas para análise, quem de fato escreveu ou gravou os textos não é evidente. Os autores "ideais" que muitas vezes aparecem são o rei ou divindades. Em conjunto, os textos escribais do período Neoassírio foram feitos por grandes sabedores e com mãos habilidosas ${ }^{130}$, que

\footnotetext{
${ }^{130}$ Em ambas as qualidades, a noção de texto implicada é dupla e interconectada: os escribas como altamente especializados produziam os textos enquanto conjunto de ideias ou conteúdos estilizados num gênero textual, assim como tinham competência manual para produzir materialmente uma versão do texto.
} 
tinham uma proximidade variável com o rei e que compunham a elite vinculada ao eixo palaciano.

\section{A totalidade corporal}

A presença do corpo no repertório linguístico do período Neoassírio possui um espectro de usos: desde os mais diretos, em que se utiliza a palavra da parte corporal para se referir ao próprio corpo ou ao corpo de alguém, até em expressões metafóricas, em que termos de partes físicas servem para suscitar uma ideia não diretamente indicativa do corpo. Em certa medida, as referências corporais na linguagem são ao mesmo tempo o meio expressivo e a concretização de uma concepção corporal. Conforme Reale (2002), "a linguagem é muito mais que um instrumento com o qual o pensamento exprime a coisa, à medida que é a própria linguagem que traz à luz a coisa e permite ao pensamento pensá-la” (p. 44). Pensar a linguagem como mediadora entre o sujeito e o mundo possibilita o reconhecimento do papel da língua no contato e na formação de concepções ${ }^{131}$.

Uma primeira abordagem aos aspectos corporais a partir dos textos é a verificação da presença de menções diretas ao corpo como uma unidade integral. Nos textos selecionados, há ocorrências desse tipo, envolvendo as palavras acadianas zumru, pagru, šīru e lānu. Do ponto de vista lexical, elas fazem parte do vocabulário acadiano para o referimento à estrutura corporal total (COUTO FERREIRA, 2009, p. 343). Essas palavras podem ser encontradas no singular, especificando um único corpo, ou no plural, forma que constitui um agrupamento de mais de uma unidade corporal (vários corpos). Com relação à semântica, essas palavras não são idênticas, apesar de se referirem ao corpo como um todo.

Partindo de ocorrências da palavra zumru nos textos literários, há um registro onírico do então príncipe Assurbanipal II, no qual é descrita sua experiência de contato com entidades divinas. Num dado momento, ele caracteriza a figura de um homem que lhe apareceu durante o sonho: “[Havia] um jovem/homem, seu corpo (zu-mur-šu $\left.u_{2}\right)$ preto como breu...” (SAA III 32 r. 10). Mais adiante no mesmo relato, há um trecho fragmentário onde é mencionada uma

131 Contudo, essa consideração, baseada numa perspectiva linguística do pensamento, não leva em conta as potencialidades da percepção e da interação humanas com outros objetos materiais no ambiente circundante, desconsiderando, então, outros modos pelos quais as concepções sobre as coisas são elaboradas. Um exemplo desse limite está na própria sequência do texto de Reale (2002, p. 45), em que aparece: "a falta de uma palavra apta para exprimir a coisa não significa que não exista o ser da coisa, mas que o ser daquela coisa não está presente à consciência do homem". Portanto, é reconhecida a importância da linguagem como mediadora parcial entre o sujeito e o mundo percebido, sendo inclusive o meio a partir do qual se pode observar os modos de interação (linguísticos e sensoriais) do ser humano no mundo. 
proteção de divindades dirigida especificamente ao corpo do rei: "Yabru, Humban e Naprušu seu corpo (zu-mur-šu $)$ protegem [...]" (SAA III 32 r. 25) ${ }^{132}$.

Nos tratados e juramentos, a palavra zumru aparece em seções formulares do texto onde são detalhadas as maldições a quem descumprir o acordo. Esse é um trecho comum nesse tipo de gênero ${ }^{133}$, envolvendo uma listagem de maldições, com ou sem a invocação de uma divindade, e uma punição que pode ser causada a quem vier a romper o contrato.

Em um tratado entre Esarhaddon e Baal, rei de Tiro, cidade fenícia da região levantina (SAA II 5), são estabelecidos os pontos de cumprimento do tratado por parte de Baal e, em seguida, a listagem das maldições. Numa delas, é invocada a divindade Gula, associada à prática da medicina ${ }^{134}$. No caso desse tratado, aparece: "Possa Gula, [a grande] chefe médica, [doença e fraqueza em vossos corações] e ferimento persistente em vossos corpos (zu-um-ru$k u-n u$ ) [colocar]" (parte IV linhas 3'-4'). Em outro tratado, o emblemático juramento de sucessão de Esarhaddon (SAA II 6) aos seus filhos Assurbanipal II e Šamaš-šumu-ukin garantindo-os aos tronos da Assíria e da Babilônia, respectivamente, também há uma longa listagem de maldições. A palavra zumru aparece no mesmo tipo de maldição invocando a divindade Gula. "Possa Gula, a grande chefe médica, doença e fraqueza [em vosso coração] e ferimento persistente em vosso corpo (zu-um-ru-ku-nu) colocar" (linhas 461-462).

Em inscrições reais, a palavra zumru aparece tanto em sua forma de escrita silábica, como logogrâmica. Num trecho de uma inscrição, quando o rei relata de onde tirou as pedras para a construção de seus colossos (lamassû) $)^{135}$ palacianos, ele menciona: "esfinges de alabastro, cuja aparência bem-feita (lit. escolhida, selecionada) como o dia brilha e seus corpos (zu-mur-šin) muito brilhantes..." (RINAP 3/1 17 vi 69-71) ${ }^{136}$.

\footnotetext{
${ }^{132}$ Humba(n), Naprušu(a) e Yabru são divindades elamitas, sendo a última considerada uma das mais elevadas do panteão. Os nomes dessas divindades estão em acadiano.

133 As maldições também aparecem escritas em inscrições de fundação de monumentos (palácios e templos). Essas inscrições estão em objetos que são colocados nas fundações, nas paredes ou soleiras das portas (nesse último caso, especificamente em grandes pedras que ficavam nas soleiras e contribuíam para a rotação das portas). Tais objetos inscritos eram uma prática comum na implementação de projetos construtivos e continham, em geral, a declaração de quem promoveu a construção, uma diretriz para que a arquitetura fosse conservada e uma ou mais maldições para caso haja descuido para com o monumento.

${ }^{134}$ Sobre a imagem da deusa Gula no âmbito da medicina babilônica, ver o estudo compreensivo de Böck (2014). Cf. Black e Green (2004, p. 101), Gula era associada à cura (pois ela "entendia a doença") e era matrona dos "médicos".

${ }^{135}$ Nas inscrições reais de Senaqueribe, as menções aos colossos com corpo de touro, alados e androcéfalos (os lamassû) são feitas pela sua escrita logogrâmica d ALAD.LAM, que em acadiano neobabilônico pode ser escrito como aladlammu. O uso do sinal determinativo ${ }^{\mathrm{d}}$ (referente ao logograma DINGIR e à palavra acadiana îlu, deus), tipicamente usado na escrita para preceder um nome de uma divindade, é utilizado nesse caso pois provavelmente indicasse a dimensão sobrenatural dos colossos, como entidades apotropaicas.

${ }^{136}$ Como as inscrições são padronizadas e formulares, e tendo o(s) escriba(s) somente a liberdade de ajustar o conteúdo dos relatos à largura das linhas (ou seja, eles não têm abertura a variações de estilo), os trechos desse gênero são repetidos em inscrições de suportes diferentes e com uma configuração de conteúdos variada em seus temas. Por exemplo, o trecho citado aparece também em RINAP 3/2 42 11' (um texto reconstruído de uma
} 
Em outras duas inscrições, onde é encontrado o relato das oito campanhas militares de Senaqueribe ${ }^{137}$, é mencionada uma aliança entre os reis do Elam (Umman-menanu), da Babilônia e os sheiks caldeus ${ }^{138}$, que, assustados com a força do exército assírio em batalha, tiveram seus corpos encobertos, "envelopados", oprimidos pelo terror. "(Com) ele, Ummanmenanu, rei do Elam, o rei da Babilônia e os xeiques da Caldeia ao seu lado foram, o terror da minha batalha, como demônios alü ${ }^{139}$, seus corpos (zu-mur-šu $\left.u_{2}-n u\right)$ foram oprimidos" (RINAP $3 / 122$ vi $24-27)^{140}$.

Pelas menções nesses excertos textuais, as ocorrências da palavra zumru confluem ao sentido do corpo e da pessoa como uma unidade física total. Esse vocábulo tem as acepções dirigidas ao corpo humano, corpo animal e corpo de um objeto. Com relação ao corpo humano, o sentido pode ser tanto a concretude física inteira do corpo, assim como o contraste entre uma unidade central corporal em contraposição aos membros (como quando se refere ao corpo e suas partes). Também pode fazer referência à unidade da pessoa (CAD Z, p. 157160). Outra acepção possível é a indicação ao "corpo" de um exército e ao "corpo" de uma cidade, templo e construção (CDA, p. 449), sendo então o vocábulo corpo destinado à menção de uma unidade configurada pelo interior de um lugar espacial. A partir dessas possibilidades semânticas (das ocorrências e da forma de dicionário), zumru refere-se a uma unidade grupal ou espacial de uma totalidade ou generalidade.

Especificamente a partir dos trechos mencionados dos textos, zumru é uma totalidade material que pode ser considerada de dois modos. O primeiro é o corpo em sua superficialidade total, que pode ser vista e que é formadora de um todo. Esse é o caso da

inscrição em colosso da entrada da sala do trono I do Palácio Sudoeste de Senaqueribe, em Nínive), e em RINAP 3/2 43 59; 44 54; 46137 e 47 6' (todas essas ocorrências são de outros colossos). Neste capítulo, nas ocorrências mencionadas em inscrições, sempre que possível são apontados alguns exemplos em outras inscrições e seu tipo de suporte. Sobre um detalhamento do conteúdo completo de cada inscrição, ver o aparato introdutório das edições RINAP 3/1 (GRAYSON; NOVOTNY, 2012a) e 3/2 (GRAYSON; NOVOTNY, 2012b).

137 As campanhas militares de Senaqueribe são registradas em suas inscrições reais, juntamente com suas obras de construção em Nínive. Nem todos os objetos inscritos recebem o relato de todas as campanhas, tendo em vista que cada inscrição era elaborada no ano seguinte ao dos eventos nela narrados. Para uma cronologia das inscrições, ver o aparato introdutório das edições RINAP 3/1 (GRAYSON; NOVOTNY, 2012a) e 3/2 (GRAYSON; NOVOTNY, 2012b). Dentre todas as inscrições reais do período de reinado de Senaqueribe, são registradas oito campanhas (numeradas assim nas próprias inscrições), mais duas não referenciadas por números. Elas ocorreram durante seus primeiros catorze anos de reinado (704-689).

138 Especificamente, a coligação entre os reis é descrita pela menção ao soberano elamita, com os outros marchando ao seu lado (A $2.2-\check{s} u_{2}$, idušu, seu lado) (RINAP 3/1 22 vi 26).

${ }^{139}$ A palavra alû faz referência a uma entidade ou poder demoníaco (CAD A1, p. 375; CDA, p. 13).

${ }^{140} \mathrm{Na}$ tradução ao inglês, aparece "(As for) him, Umman-menanu (Humban-menanu), the king of the land Elam, along with the king of Babylon (and) the sheikhs of Chaldea who marched at his side, terror of doing battle with me overwhelmed them like alû-demons". Na versão inglesa, a palavra corpo não aparece. A tradução concebe o sentido dos reis que foram suprimidos pelo terror, mas, literalmente, a referência é a seus corpos. O mesmo trecho também aparece nas inscrições em um prisma (RINAP 3/1 23 vi 22) e em um tablete com inscrições reais (RINAP 3/2 230 96), encontrado em Samarra, cidade que ficava na borda oriental do rio Tigre, a aproximadamente duzentos quilômetros ao norte de Bagdá. 
descrição no sonho de Assurbanipal II (SAA III 32) e do trecho da inscrição real onde se menciona o caráter brilhante do corpo das esfinges (RINAP 3/1 17). Na descrição onírica, há a associação metafórica da qualidade de um corpo (visto num sonho) com um produto (o breu), ligados pela cor natural compartilhada (preta). Já na inscrição, a qualidade do objeto é descrita pela sua visualidade, associada a uma condição natural (o dia), experiência visual através do estado de percepção da luz irradiada (o brilho).

O segundo modo é o corpo (e a pessoa) como um recebedor unitário. No caso das menções a zumru nos textos, o corpo é um ponto físico de chegada ou de recebimento sobre o qual acontece uma ação. No segundo excerto da descrição onírica, não aparece uma alusão de proteção ao rei, mas sim a um aspecto seu, de sua pessoa, isto é, uma proteção ao seu corpo. Nesse sentido, parece que a destinação da proteção precisa ser materializada, não bastando uma referência ao rei, mas sim ao seu corpo.

A contrapartida do corpo que recebe a ação protetora é aquela dos casos de maldição. Quando a divindade Gula é invocada, há algum detalhamento corporal mais específico - e especializado, envolvendo um vocabulário de tipo médico ${ }^{141}$. Em ambos os exemplos (SAA II 5 e 6), há uma continuidade da maldição: “(em) sangue e pus, como (em) água, banhe-se!". No trecho onde aparece zumru, a maldição é destinada ao coração (ou seja, ao interior da pessoa) e simultaneamente ao corpo ou à superfície corporal, através de um ferimento ${ }^{142}$. Já o trecho final e reconstruído evoca fluidos corporais internos - inclusive um associado a condições infecciosas, o pus - para ser usado metaforicamente como a água de banho. A evocação então impõe algo do (interior do) corpo para servir anormalmente sobre si mesmo, na exterioridade corporal ${ }^{143}$.

O corpo como recipiente de destino de ações também é mencionado, a princípio, pelo "terror" autoproclamado por Senaqueribe em sua inscrição. Os corpos dos sujeitos foram tomados de terror. Contudo, a aparente abstração ou efeito psicológico que uma noção de terror implica tem uma base material provavelmente bastante vívida, quando o que precisamente causa terror é a "minha batalha", a ação bélica do exército de Senaqueribe - que poderia ser vista e sentida.

\footnotetext{
${ }^{141}$ De maneira geral, a divindade Gula é também mencionada em meio às adulações e bons desejos ao rei, em cartas escritas por especialistas "médicos".

142 Talvez isso implique uma noção de ação que parte do exterior à superfície corpo e, na sequência, a seu interior.

143 Sendo o sangue e o pus fluidos internos ao corpo, e sendo seu extravasamento associado a condições anormais (e possivelmente dolorosas, visto que especialmente o pus é relacionado a uma infecção), a sugestão de uma imagem de banhar-se com tais líquidos certamente sugere uma aflição física (e psicológica).
} 
Nessas menções ao termo zumru, vê-se seus modos de referência ao corpo em sua totalidade, configurada seja como uma superfície e/ou por ser um recipiente (físico) de determinadas ações. Destaca-se também que essas alusões ao corpo são sempre relativas a um sujeito (a seu corpo físico), não parecendo descoladas de uma pessoalidade - como, por exemplo, se existissem referências a um corpo genérico e conceitual, sem correspondência a um ser vivo ou a um objeto.

Em outros textos, é atribuída à palavra zumru uma escrita logogrâmica específica. Num fragmento de uma carta de adulação a Assurbanipal II (então rei, não mais príncipe) ${ }^{144}$, o remetente desconhecido escreveu seus desejos e preces aos deuses, destinando-os ao rei: "pela tua vida, (...) tua saúde (física) (...) e por teu corpo (SU) [...]” (SAA III 28 15’). Já em um texto literário denominado os ritos de Egašankalamma (SAA III 38) ${ }^{145}$, há menções a partes do corpo relacionadas a gestos, estes associados a divindades. Inclusive num dos trechos, elementos da natureza são associados às porções corporais de uma divindade específica. Antes dele, separado por um traço divisório, há o excerto: "[A imagem?] $]^{146}$ de teu irmão, que na cerveja foi imersa, o corpo (SU) do irmão eleva, como foi dito" (linha r. 8) ${ }^{147}$. Em ambos os casos, é utilizado o logograma SU, sendo traduzido nas edições por corpo. Porém, tal logograma também pode significar pagru, uma outra palavra para se referir ao corpo. No início do mesmo texto dos ritos de Egašankalamma, aparece: "seu corpo/couro (SU-š $u_{2}$ ), como foi arrancado, e como Orion com seu sangue foi vestido, Anu, no topo de sua cabeça cortada, separou" (linha 21) ${ }^{148}$. Nesse caso, a palavra SU é traduzida por pele, carcaça, couro, tendo paralelo com sua forma original suméria, possibilitando a leitura como pele (COUTO FERREIRA, 2009, p. 351), estando então mais associada a pagru do que a zumru (CDA, p. 260). Essa possibilidade de leitura dá-se pelo verbo que constitui a sentença: kâṣu, que significa (des)pelar, esfolar, descascar (CDA, p. 152), ação realizada tanto em animais

\footnotetext{
144 Apesar de ser denominada como uma carta (uma comunicação epistolar), tal texto é considerado uma produção literária, de acordo com os critérios apontados por Livingstone (1989, SAA III). De acordo com o autor, esse texto apresenta um avanço criativo e estilístico no uso da língua, além de extrapolar a prática usual das correspondências por cartas.

145 Egašankalamma é o nome do templo dedicado à deusa Ištar em Arbela. Na Mesopotâmia, monumentos e construções, como palácios, templos, muros, e suas partes, como portas e portões, recebiam nomes.

${ }^{146}$ A possibilidade de um sinal cuneiforme referente à imagem é pelo logograma NU, mas, na edição do texto, o sinal é associado à partícula de negação $l a$, não.

${ }^{147}$ A menção à imersão em cerveja pode estar relacionada a um ritual de libação (BLACK; GREEN, 2004, p. 117).

${ }^{148}$ Nesse trecho, a menção a $A n u$ é uma referência à divindade celeste e uma das mais superiores do panteão mesopotâmico (sumério e acadiano). Já Orion seria o correspondente zodiacal grego a uma divindade mesopotâmica auxiliar a Anu, chamada Ninšubur (assimilada posteriormente ao deus Papsukkal), e considerada um "Grande Pastor de Anu” (BLACK; GREEN, 2004, p. 141; 190).
} 
como em pessoas. Em um comentário literário ${ }^{149}$ a um calendário cúltico assírio, aparece uma ocorrência semelhante do logograma SU acompanhado do verbo kâșu: "o senhor, como o derrotou, sua pele (SU-šsu $)$ arrancou na casa...” (SAA III 40 22).

Nesse sentido, a noção de corpo pagru refere-se a corpos mortos ou cadáveres. Suas acepções comportam a noção de corpo, tronco, cadáver, carcaça (CAD P, p. 12-17). Com relação às ocorrências encontradas nos textos, todas foram associadas à noção de corpo morto ou cadáver. Dessa forma, em comparação às menções que indicam a pele ou couro, talvez as duas referências ao corpo escritas com o logograma SU se referissem à dimensão corporal total, porém numa condição diferente, tendendo ao sofrimento e à morte.

Diferentemente de zumru, pagru é um termo que aparece em todos os gêneros textuais escolhidos nesta pesquisa. Essa palavra aparece escrita, por exemplo, na expressão logogrâmica (LU2.UŠ 2 ). A grafia $\mathrm{LU}_{2} . \mathrm{US} \check{S}_{2}$ equivale ao acadiano amēlu pagru (então, $\mathrm{LU}_{2}$ significa homem e UŠ $\check{S}_{2}$ significa estar morto, morrer).

Novamente no registro onírico de Assurbanipal II (SAA III 32 r. 22), numa alusão fragmentária a uma fala do deus $\operatorname{Nergal}^{150}$, indica-se um cadáver $\left(\mathrm{LU}_{2} . \mathrm{US}_{2}\right)$ sepultado no "mundo inferior". Em um outro texto literário do período de reinado de Assurbanipal II, a respeito da derrota de Teumman e da anexação do Elam ao império ${ }^{151}$ (SAA III 31), aparece um trecho fragmentário onde são relatados os "cadáveres $\left(\mathrm{LU}_{2} . \mathrm{US} \breve{S}_{2}\right.$.MEŠ) no meio deles (ina ŠA 3 -šu $\left.u_{2}-n u\right)$ " (linha r. 7) após uma investida das forças assírias.

Nos ritos de Egašankalamma (SAA III 38), também aparece a palavra cadáver, em relação a um deus: "Ištar, quando ela chorou e lamentou por Ištaran, seu irmão, sua(s) mão(s) ela levantou e no templo de Ištar ela foi. O cadáver (LU2.UŠ 2$)$ de Ištaran ela viu e sangue para o mundo inferior fluiu (lit. foi cobrir)" (linhas 4-7). No mesmo texto, aparece: "A taça que foi preparada para si é a taça de $A \check{s} \check{s} u r . B e l^{152}$ foi e Anum ele derrotou. Sua pele (SU-šš, de Anum) ele arrancou e seu corpo/cadáver ( $\left.\mathrm{LU}_{2} \cdot \mathrm{US}_{2}-\check{S}_{2}\right)$ aos Anunnaki ${ }^{153}$ ele confiou" (linhas 17-19). Em outro caso, numa compilação de excertos mitológicos (SAA III 39),

\footnotetext{
149 A definição do texto como comentário o englobaria em um gênero textual específico, composto por produções de interpretação de textos escribais canônicos. No entanto, mesmo tendo como base um material padronizado (um calendário ritualístico), esse texto não se dirigia estritamente à leitura e atualização do textobase, mas possui um trabalho de explicação e interpretação de cunho mitológico, categorizado então como um texto de tipo literário (LIVINGSTONE, 1989, p. XXX).

${ }^{150}$ Divindade associada à morte e às guerras.

${ }^{151}$ Tal tema aparece também nos relevos assírios nas salas XXXIII do Palácio Sudoeste (Figuras 43-48) e - a comemoração após a vitória numa cena de banquete - na sala S1 do Palácio Norte de Nínive (Figuras 105-107).

${ }^{152} \mathrm{Bel}$ é uma forma de se referir a divindade babilônica Marduk, incorporada no panteão assírio.

${ }^{153}$ Anunnaki faz referência ao conjunto de divindades superiores e primordiais. Pode também significar o mesmo agrupamento considerado como pertencente ao "mundo superior", em detrimento das divindades tidas como do "mundo inferior" (Igigi).
} 
aparece: "o carro dos elamitas, onde não há assento (lit. que assento não existe), o corpo/cadáver $\left(\mathrm{LU}_{2} . \mathrm{US}_{2}\right)$ de Enmešara em seu interior (ina $\check{\mathrm{S}}_{3}$ ) foi transportado" (linha $24)^{154}$.

Em sua forma logogrâmica, pagru aparece no tratado de sucessão de Esarhaddon (SAA II 6), também em meio à declaração de maldições comuns a quem romper com o tratado. "Possam, na vossa presença (IGI- $k u-n u$ ), os seios das vossas jovens e o pênis dos vossos jovens, cão e porcos, na praça de Assur, arrastar. Possa vossos cadáveres $\left(\mathrm{LU}_{2}\right.$.UŠ́ 2 .MEŠ- $\left.k u-n u\right)$ a terra não receber e possa na barriga do cão e de porcos ser vosso lugar de enterro" (linhas 481-484) ${ }^{155}$.

Nas inscrições reais de Senaqueribe, há menções repetidas a cadáveres, mas especialmente escritas de modo silábico ou envolvendo um outro logograma (ADDA). No relato de sua primeira campanha (contra a Babilônia e seus aliados elamitas, caldeus e arameus, assim como contra a cidade de Hirimmu) ${ }^{156}$, Senaqueribe menciona sua atuação brutal: "o povo/tropa de Hirimmu, inimigos, eu esfolei. Com a espada fiz com que caíssem e não deixei algum. Seus corpos/cadáveres (pag-ri-šsu2-un) em postes eu suspendi e no entorno da cidade (os) dispus" (RINAP $3 / 14$ 16) ${ }^{157}$. Na continuidade do texto, uma situação semelhante é relatada sobre sua terceira campanha: "Eltekeh (e) Tamnâ eu circundei, conquistei e alaguei. De Ekron eu me aproximei e os governadores e nobres, que delinquiram (lit. crime realizaram), eu matei, e em torres do entorno da cidade eu suspendi seus corpos/cadáveres (pag-ri-šsu2-un)" (linha 46) $)^{158}$.

A forma logogrâmica ADDA para pagru aparece em outras inscrições. Numa delas Senaqueribe menciona: “As tropas do inimigo com arcos ușs e mulmullu eu perfurei (verbo $\check{s} a q \bar{a} r u$ ) e todos os seus corpos/cadáveres (ADDA.MEŠ-šu2-nu) eu perfurei (verbo palāšu)" (RINAP 3/1 22 v 81) ${ }^{159}$. Outra alusão a corpos/cadáveres está em um texto de uma inscrição monumental, esculpida em um penhasco. Há uma descrição sobre a segunda campanha militar

\footnotetext{
${ }^{154}$ Enmešara seria uma das divindades associadas ao mundo "inferior" (BLACK; GREEN, 2004, p. 76).

${ }^{155}$ A menção à palavra barriga é a partir da escrita kar-ši , da palavra acadiana kařš, que significa estômago, entranhas, interior corporal (CDA, p. 149).

${ }^{156}$ A antiga cidade de Hirimmu foi um "distrito" da Babilônia.

${ }^{157}$ Esse trecho também aparece idêntico em RINAP 3/1 15 ii 3, 16 i 83; 17 i 72; 17 iii 26; 18 i 7'; 22 i 59; 23 i 54 - e está também em um tablete de cópia da inscrição para arquivo, RINAP 3/2 138 i 17'). A empalação é uma punição comum relatada em inscrições reais, mas possui um amparo legal à época (inclusive dentro da acepção da palavra poste ou estaca ( gišišu ), como um objeto utilizado para uma empalação legal ou militar, CDA, p. 91). Sobre o tema, ver Radner (2015a).

${ }^{158}$ Este trecho também aparece em RINAP 3/1 15 iii 30'; 16 iii 64; 18 iii 5; 22 iii 10; 23 iii 9. A terceira campanha de Senaqueribe (possivelmente realizada entre 701 e 700 AEC) envolveu uma investida contra uma aliança egípcia e etiópica. Eltekeh é a atual Beit Lyqia, na Palestina e Tamnâ era uma cidade da região dos atuais Iêmen e Omã. Ekron foi uma das maiores cidades da Filisteia (na região sudoeste do antigo Levante, no atual Tell Miqne, a 35 quilômetros de Jerusalém).

${ }^{159} \mathrm{O}$ trecho também aparece em RINAP 3/1 23 v 70.
} 
de Senaqueribe à Babilônia, mencionando metaforicamente como foi sua investida. Na sequência, ele relata: "Seu povo, jovem (lit. pequeno) e velho (lit. grande), eu não deixei, e

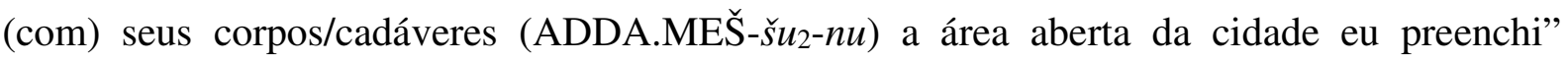
(RINAP 3/2 223 45).

Em outros trechos de inscrições, refere-se a pagru com um sentido semelhante. Senaqueribe descreve a finalização de uma batalha contra Humban-undaša (arauto ou alto oficial elamita), relatando seus últimos procedimentos violentos:

\begin{abstract}
Seus pescoços eu cortei como ovelhas, suas vidas preciosas eu arranquei como fios. Como inundação numa temporada de chuva, seu sangue fiz fluir na ampla terra. Os rápidos cavalos de guerra atrelados a meu carro no vosso sangue elevado submergiram como num rio. Meus carros de guerra, que arrasam maus e vilões, em sangue e excremento foram banhados em suas rodas. Os cadáveres (pag-ri) de seus guerreiros como grama eu preenchi a planície. Seus lábios eu cortei e sua dignidade eu destruí. Como pepinos frescos na temporada, eu arranquei suas mãos (RINAP 3/1 22 vi 2-12) ${ }^{160}$.
\end{abstract}

Por fim, em cartas, são poucas as ocorrências da palavra pagru, seja em sua escrita silábica ou logogrâmica. Logo na abertura de uma carta de um rei babilônico, Marduk-šapikzeri, há uma certa adulação: “Ao rei das terras, rei forte, rei do mundo, seu senhor: teu servo Marduk-šapik-zeri, o homem/corpo morto $\left(\mathrm{LU}_{2}-\right.$ pa-gru), a caveira leprosa, a respiração comprimida, aquele que entre os cadáveres $\left(\mathrm{LU}_{2} . \mathrm{US}_{2} . \mathrm{MES}\right)$, o rei, meu senhor, ressuscitou e nomeou entre outros" (SAA X 160 2-3). Nesse excerto, a palavra pagru é escrita de modo diverso: homem/corpo morto foi escrito combinando o logograma $\mathrm{LU}_{2}$ e pagru; já cadáveres foi escrito com a forma logogrâmica $\mathrm{LU}_{2} . \mathrm{US}_{2} . \mathrm{MES} \check{S}^{161}$. Em outro caso, numa carta babilônica de um exorcista, Zākir, também há citação fragmentária de corpos mortos (LU2.UŠ 2 .MEŠ) que foram "revividos" pela ação divina ou do rei (SAA X 169 4-5) ${ }^{162}$.

\footnotetext{
${ }^{160} \mathrm{O}$ trecho também aparece em RINAP 3/1 23 v 77-78, vi 1-9.

${ }^{161} \mathrm{O}$ detalhe da palavra caveira vem de gulgullu, mais precisamente entendida como crânio (humano ou animal). No trecho, caveira aproxima-se mais do sentido de um ser morto.

162 Essa noção de que o rei "reviveu" pessoas parece bastante complexa. Pode ser relativa à concepção da figura do rei como provedor da vida (no sentido de ordenador do mundo e potencializador da fertilidade da terra), concepção canalizada no exercício do poder. No contexto neoassírio, imagina-se a complexidade da sofisticação do urbanismo e da elevação da população citadina no núcleo do império, o que implicava um desejo das pessoas em estar na cidade e principalmente vinculadas ao palácio. A possibilidade de exercer uma função junto à unidade palaciana deveria ser bastante aspirada por aqueles que poderiam cogitar tal possibilidade, como é o caso das famílias de escribas. Nesse sentido, a noção de reviver pode ser relativa a uma "chance" dada pelo rei ao sujeito, permitindo-o atuar no palácio, ou retomando relações, ou até pode se caracterizar num contexto de vinculação econômica com o rei. Assim, as "dádivas" e "perdões" de dívidas praticados no período (ver em Kataja e Whiting, 1995, SAA XII), poderiam complementar esse sentido da função do rei. Em outra carta (SAA X 226), o exorcista Adad-šumu-ușur profere adulações ao rei dizendo que ele revive e liberta. Em SAA X 224, o escriba também menciona, na última frase, que o rei tem "revivido" muitas pessoas. "Sobre o rei, meu senhor, reviveu muitas pessoas" (linhas r. 6-8). Isso se conecta com a carta adulatória (SAA X 160), indicando
} 
As noções de corpo em zumru e pagru o expõem como algo que é da pessoa e simultaneamente é a pessoa. Segundo Couto Ferreira (2009, p. 352), inclusive metonimicamente pagru serve para designar o indivíduo. A autora também indica que a palavra suméria adda é estritamente relativa à noção de corpo morto e "geralmente aparece mencionada em contextos bélicos, agonísticos e catastróficos, nos quais os indivíduos se veem privados de vida e reduzidos a simples matéria orgânica” (p. 351). Mesmo que pagru possa aludir a corpos vivos ou mortos, conforme Couto Ferreira também afirma (p. 352), nas ocorrências acima, todos os casos de pagru apontam para a condição de ausência de vida das pessoas mencionadas.

Nesse sentido, a noção de corpo morto ou cadáver implicada na palavra pagru conjuga o sentido de um corpo, antes vivo, agora sem vida pelo resultado de uma ação que ocorreu previamente. Isto é diferente de um conceito ou categoria genérico para corpo morto ou cadáver, pois a acepção e as ocorrências a pagru remetem a uma ideia do processo, de uma referência, apesar de óbvia, à passagem do estado vivente prévio à condição de estar morto. Contudo, sendo ainda uma referência à pessoa, o corpo morto é uma condição estendida da existência pessoal. Num primeiro momento, as menções aos cadáveres aparecem no desfecho de batalhas (SAA III 31; RINAP 3/1 4, 22; 3/2 223), em alguns casos envolvendo uma ação prévia de uma violência corporal - que inclusive caracteriza uma situação de violência entre divindades (SAA III 38). A morte resultante da ação violenta e como um estado característico do cadáver - que inclusive pode ser uma condição visualmente percebida, em SAA III 38 não encerra o que se faz com o corpo: cadáveres são carregados (pelos seus iguais, SAA III 39), ou são "reutilizados", na continuidade do flagelo da violência corporal (RINAP 3/1 4, 22; $3 / 2$ 223). Também a referência metonímica à condição de morte e seu retorno a um estado de vivacidade (SAA X 160, 169) aponta para a negatividade da condição. O corpo morto continua a ser submetido a ações violentas, para evocar uma imagem da dor ao leitor. Enquanto é o corpo que continua a ser afetado na descrição textual, quer-se afetar (física e psicologicamente) a pessoa que a lê.

Há uma outra menção do que se faz com o corpo morto: o sepultamento do cadáver (SAA III 32). No entanto, aparece também a restrição dessa condição como punição à pessoa em seu ambiente social. Mencionar que o corpo de uma pessoa morta não receberá um

metaforicamente o rei que revive pessoas, ou seja, ele traz para perto de si ou ativa seus funcionários. Tal "poder" pode estar conectado também com a figura do rei como receber de "mão boa" por parte de Bel e Marduk (na carta SAA X 235). 
tratamento comum (SAA II 6), inclusive sendo rebaixado ao corpo de animais ${ }^{163}$, estende a pessoalidade do sujeito para além do corpo vivo. Nesse sentido, o que se faz com o corpo morto possui um sentido importante ao vivo, advertido pela maldição. Assim como a apresentação de corpos mortos e decapitados nos relevos palacianos pode servir tanto para mostrar o resultado da ação, passível de quantificação, o discurso da maldição direcionado aos leitores vivos também mostra o que acontece com a pessoa em caso de oposição à condição imposta pelos assírios. Nos tratados, especialmente aquele destinado a garantir a sucessão adequada aos filhos de Esarhaddon, o recado da maldição, como um componente de todo o contexto desse tipo textual, tem sua eficácia ao ser um gênero que coloca em relação partes diversas num acordo, mesmo que desbalanceado. A interpessoalidade inerente ao tratado é ainda mais realçada pela difusão que este documento teve no período ${ }^{164}$.

No excerto da maldição, o corpo foi consumido em suas partes vinculadas à vida, a saber: os seios como a extremidade corporal da mulher que secreta o leite e o pênis como extremo do corpo do homem de onde o sêmen é expelido. Acrescenta-se a tal situação a sugestiva exposição e visualização do momento pelos seus próximos. Então, a realização imaginada da maldição contém a expressão de "várias mortes": a primeira é uma desvitalização do corpo, ao ser consumido fisicamente; a segunda é uma morte da condição da pessoa, em perder o seu potencial de prover a vida e de sua condição de integridade; por fim, uma terceira morte seria a realização dos sentidos anteriores ao apelar a um espectador, especialmente um próximo com relação ao amaldiçoado. Nesse caso, a menção aos cadáveres encontra-se próxima à denominação de suas partes corporais, o que sugere então uma condição de fragmentação do corpo. Também a desvitalização é amplificada pelo dano corporal em si, pelo dano causado por um animal (o que rebaixa a pessoa) e pelo dano a extremidades do corpo associadas à promoção e manutenção da vida.

Não obstante, estes corpos não poderão sequer prosseguir um caminho comum da condição de corpo morto. Couto Ferreira afirma que, "em relação às honras funerárias que se devem aos mortos, o corpo devia ser adequadamente sepultado: somente assim se assegurava

\footnotetext{
${ }^{163}$ Segundo a afirmação de Couto Ferreira, a partir de um contexto mais antigo (do período de UR III, no fim do terceiro milênio AEC), particularmente a palavra suméria adda servia também para designar partes de animais que não poderiam ser aproveitadas à alimentação. Nesse sentido, "a adda dos animais mortos se utilizava como alimento de cães e leões” (2009, p. 351). Paralelos na representação de corpos humanos e animais são apontados por Ataç (2010). Enquanto, por um lado, a figura dos cachorros é associada à proteção (inclusive com uma próxima associação à deusa Gula e sua capacidade curativa (cf. Black e Green, 2004, p. 70)), por outro os cães podem incorporar um significado ameaçador e destrutivo (cf. Steinkeller, manuscrito).

${ }^{164} \mathrm{O}$ tratado é datado de 672 AEC, três anos antes da sucessão de Assurbanipal ao trono assírio. As versões do texto foram encontradas em locais distantes, sendo que em um caso o tablete inscrito foi escavado num ambiente templário - o que sugere possivelmente uma "adoração" ao texto. No mínimo, houve uma dispersão do texto no período (PARPOLA; WATANABE, 1988, SAA II).
} 
o bem-estar do defunto e o repouso de seu fantasma" (2009, p. 351). Na maldição presente no tratado, a humilhação da pessoa por meio de seu corpo é continuada e reamplificada pela recusa da terra e o destino em se misturar com a entranha animal ${ }^{165}$.

A noção de corpo expressa por zumru e pagru alude à totalidade material do corpo. No excerto apresentado da carta adulatória a Assurbanipal II (SAA III 28), aparece outra indicação a uma condição corporal, traduzida por saúde (física). Tal expressão foi escrita usando o logograma UZU, correspondente ao acadiano šīru e podendo ser traduzido por carne. Tal termo também pode ser considerado uma alusão ao corpo humano e à sua matéria. Do ponto de vista lexical, o logograma indica a palavra em sumério uzu, utilizada para se referir à carne animal desmembrada para o preparo ao consumo humano. No entanto, por extensão de sentido, pode se referir à "carne" de uma pessoa. Na língua suméria, um dos poucos exemplos de uzu para carne é relativo a um animal morto (COUTO FERREIRA, 2009, p. 353-354). A versão acadiana šîru serve tanto para carne, tanto para corpo, como também pode ser específica para as entranhas de um animal (CDA, p. 377). Assim, a precisão do sentido de carne pode ser para designar o que está abaixo da pele (e então, uma parte do corpo humano) e o corpo como totalidade física, enfatizando o que constitui a pessoa (COUTO FERREIRA, 2009, p. 354-355) $)^{166}$.

O logograma UZU aparece em cartas destinadas ao rei com cabeçalhos formulares alongados, estendendo os desejos adulatórios de bênçãos ao soberano. As cartas dos escribas contêm comumente cabeçalhos curtos e formulares, do tipo: "Para o rei, meu(nosso) senhor, teu(s) servo(s) [nome do(s) escriba(s) remetente(s)]. Boa saúde/bem-estar ao rei, meu senhor. Possam Nabû e Marduk o rei meu(nosso) senhor, abençoar”. Nos casos de cabeçalhos mais alongados, inclui-se, por exemplo: "A plenitude do rei, meu senhor, e seu bem-estar/saúde [UZU.MEŠ] na resposta de minha carta eu possa ouvir" (SAA X 94 6-9). Numa carta sobre uma consulta e interpretação astronômica ao então rei Esarhaddon, o escriba Akkullanu

\footnotetext{
165 Nota-se que há uma dualidade aqui. Por um lado, a comparação do ser humano aos animais é um rebaixamento de sua condição existencial. Por outro, alguns animais são privilegiados, seja como presas ou oferendas, seja pelo potencial de serem veículos da manifestação de divindades, como é o caso das ovelhas. Nesse sentido, as entranhas desses animais, especialmente o fígado, são o local onde as divindades

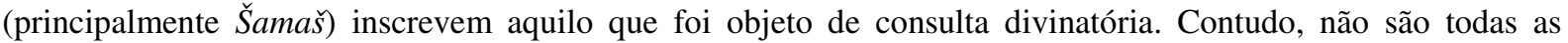
entranhas dos animais que são privilegiadas, haja vista inclusive que tal contato com as entranhas deveria ser feito somente por sujeitos especializados, seja os que manipulavam animais para os cortes de carne e preparação, seja os escribas preparados para realizar os rituais de adivinhação.

166 Inclusive fazendo referência, como aponta Couto Ferreira (2009, p. 354), à mitologia de criação do ser humano, misturando sangue à carne.
} 
escreveu em seu cabeçalho padrão: “A melhor da plenitude e bem-estar/saúde (UZU.MEŠ) possam eles [os deuses Nabû e Marduk] te [ao rei] dar" (SAA X 84 6-8).

Há possibilidade de essas frases formulares serem repetidas ao final das cartas, reiterando os desejos adulatórios ao rei. Isso acontece especialmente nas correspondências com o relato de algum sinal ou presságio. Nas cartas, são mencionadas especialmente as observações e interpretações astronômicas que serviam como diretriz para a tomada de decisões (mais ou menos importantes) por parte do governo imperial. Em casos de um sinal não favorável, a recomendação do escriba erudito é em direção a atitudes de cuidado ou até de tentativa de contornar a situação ruim. Assim, a consulta a presságios contém simultaneamente a expectativa por um bom sinal e a geração de uma atitude favorável, em caso de um indício negativo. No texto dessas cartas, o trecho adulatório que aparece nos cabeçalhos é repetido, visando fortalecer a dinâmica ou o ritual de consolidar as recomendações favoráveis ao rei. A abertura formular, o detalhamento do sinal observado com sua interpretação e a repetição final de bons votos ao rei, incluindo de seu corpo, perfazem a prática divinatória, que acompanha a dinâmica do exercício da realeza assíria. A dimensão corporal do rei precisa ser invocada como componente da ordem do real e ao bom estado das regiões do império.

Esses trechos onde a palavra šĭru em sua forma logogrâmica UZU ilustram um argumento de Luukko (2004) a respeito do uso dos logogramas sumérios para tornar a escrita e a comunicação mais eficientes - principalmente relacionadas à velocidade da comunicação. Por exemplo, a noção de saúde (física) supramencionada relaciona-se à escrita țiābu/țābu šīru ou, mais frequentemente, à forma logogrâmica UZU.MEŠ. Literalmente, seria "bom corpo" ou "boa carne". As ocorrências aparecem em frases com suas transliterações: $t u-u b$ (ou $\left.\mathrm{DUG}_{3}\right) \check{\mathrm{S}}_{3}-b i t \underline{t} u-u b \mathrm{UZU}(. \mathrm{MES})^{167}$.

A palavra țūbu deriva do verbo (e de sua consequente forma de adjetivo verbal) țiābu, que significa tornar-se bom. A forma substantivada țūbu pode significar bondade, felicidade, prosperidade. Então, quando associada idiomaticamente a UZU/šĭ $r i$, tem o sentido de bemestar físico. Na expressão completa, seria bem-estar físico e mental (sendo ŠA 3 o logograma

\footnotetext{
${ }^{167} \mathrm{UZU} / \check{s} \bar{r} r u$ aparece com sentido semelhante nas inscrições reais do período de Senaqueribe, sempre ao final das inscrições, em situações de dedicatórias. Em algumas delas, há variações na escrita, como "i-na țu-ub UZU hu-ud lib 3 -bi" (RINAP 3/2 34 92, inscrição relatando as oito campanhas militares de Senaqueribe, encontrada no monte Nebi Yunus). A mesma escrita também aparece em um par de esfinges (RINAP 3/2 40 47"). Outra variação é i-na tu-ub UZU.MEŠ hu-ud lib-bi (RINAP 3/2 49 3" "-4"', em inscrição encontrada em fragmentos de um colosso (lamassulaladlammu)).
} 
referente à palavra libbu, que pode significar interior, assim como coração) ${ }^{168}$. Então, uma "boa carne" ganha o sentido idiomático de boa condição física. A recorrência da expressão reitera a necessidade do bom estado do rei, como pilar do governo, associada às boas condições do "corpo" territorial do império.

Há outras ocorrências de UZU/šĭru com significados particulares. Duas cartas relatam as condições de saúde da rainha-mãe e do príncipe Šamaš-šumu-ukin (irmão de Assurbanipal II). Na primeira (SAA X 297), uma carta fragmentária, os escribas Nabû-nașir e UradNanaya, ambos exorcistas, mencionam duas vezes (linhas 9-10; r. 6'-7') que a mãe do rei está recuperada e está indo bem. Tal condição física é escrita com ššru (̌̌i-ir-ša $\left.a_{3}\right)$, assim como com šulmu (ou DI-mu).

Na segunda carta (SAA X 328), o "médico" Ikkaru também inicia a carta mencionando o desejo de bem-estar (țu-ub $\breve{S}_{3}-b i t ̦-u b$ UZU.ME ̌̌, linhas 6-7) ao rei Esarhaddon (no fim de seu reinado). Ele relata que enviou determinados produtos medicinais ao soberano, mas que ele não sabe se foram de fato entregues, já que não teve resposta (linhas 8-14). Sendo assim, o escriba não sabe (lit. não "ouviu”) sobre a saúde (DI-mu, linha 14) do rei. Após relembrar uma antiga situação em que Esarhaddon, quando príncipe herdeiro, teve uma febre - provavelmente buscando comparar o momento contemporâneo com o anterior -, Ikkaru menciona que o príncipe herdeiro ao trono da Babilônia, Šamaš-šumu-ukin, está muito melhor (utilizando DI-mu, na linha r. 13). O "médico" detalha o tratamento e, por fim, agradecendo aos deuses, diz que a "carne"/corpo do príncipe (UZU, linha r. 19) está muito melhor.

Semelhante menção aparece numa carta atribuída a Urad-Nanaya, o mesmo exorcista que escreveu sobre a condição da mãe do rei. Ele relata que realizou uma visita ao príncipe herdeiro (provavelmente se referindo a Šamaš-šumu-ukin) e o mesmo lhe disse, em primeira pessoa, “meu corpo (UZU.MEŠ-ia) todo ficou bom” (SAA X 323 10-11) ${ }^{169}$.

\footnotetext{
${ }^{168}$ Essa expressão pode ser vista em algumas cartas como, por exemplo, em SAA X 168 4; 178 6; 196 7; 218 r. $11 ; 233$ r. $6 ; 323$ 5. Em outros casos, há o uso da palavra ḩŭdu em vez de țūbu ou a inversão de colocação entre UZU e ŠA $\mathrm{A}_{3}$. Nas cartas, isso ocorre especialmente em comunicações de Mar-Iș̦ar, agente de Esarhaddon na Babilônia (principalmente nas cartas SAA X 347 a 349, 351 a 355, 357 a 359, 363, 368 e 369). A forma escolhida pelo escriba em seus cabeçalhos padrão é "ț-ub UZU $u_{3} h u-u d$ ŠA $\mathrm{A}_{3}$ ”. A palavra huudu está dentro do campo semântico de felicidade, estar feliz.

${ }^{169}$ As formas UZU e UZU.MEŠ possuem uma diferença para além de simplesmente serem a grafia singularizada e pluralizada do logograma para palavra šir ru. A primeira geralmente forma a expressão idiomática com țubu. Já quando aparece UZU.MEŠ, o segundo logograma é referente à partícula suméria meš. Comumente, meš pluraliza o elemento que a precede. Contudo, pode também funcionar para realçar o termo precedente, o que significa para o caso de UZU.MEŠ que não se está tratando de carne como uma parte do corpo, mas sim da totalidade corporal.
} 
A variação de uso entre šulmu (DI) e šĭru (UZU) parece indicar uma maior generalidade da primeira, com relação a um estado (abstrato) de bem-estar, saúde e plenitude. Já a segunda palavra, apesar de ser também genérica em termos da referência à totalidade corporal, é mais específica e concreta com relação ao corpo físico ${ }^{170}$.

Dois outros casos de šîru estão circunscritos a um sentido mais literal de carne enquanto parte específica da constituição do corpo. A carta de Marduk-šapik-zeri (SAA X 160) é bastante particular: ele começa construindo um discurso de auto-humilhação (descrito acima, usando a palavra pagru), seguido de um trecho relatando um período de distanciamento do rei, mesmo ele tendo atuado na coleta de sinais celestes. Pelo medo desse distanciamento, ele relata o que tem observado. Na sequência, novamente discursa fazendo uma auto-humilhação e um suplício, seguido pelo realce de todos os seus atributos e competências escribais. Nesse sentido, além de destacar o conhecimento de textos tidos como canônicos e seu papel na formação de vários outros escribas (inclusive indicando alguns deles em particular para servir ao rei), ele menciona o conhecimento prático de rituais, inclusive o exame de carne (saudável ou não), provavelmente relativa aos rituais de extispicia (linha 39). O trecho foi escrito com os logogramas UZU DI GIG, podendo ser traduzido para o acadiano como šĭru šulmu и murșu, que significa carne boa e doente.

Em outra carta, os escribas Adad-šumu-ușur e Urad-Ea, respectivamente o exorcista do rei e o encantador, mencionam a realização de rituais, sendo que Adad-šumu-uṣur realizará um deles, chamado "perda da carne" (ha-liq-ti UZU!) (SAA X 212 12) ${ }^{171}$. Segundo Parpola (1970, p. 156), tal ritual pode estar associado a menções da mesma expressão em textos médicos, possivelmente relacionado à perda patológica de massa corporal. Novamente, mesmo sendo um caso bastante circunscrito, tal referimento ao ritual remete à totalidade corporal, por meio da perda de sua massa.

Esses são os casos em que aparece a forma UZU/šǐru em cartas, especialmente de um modo bastante formular, mas visando possivelmente a uma estratégia de reforço da dimensão corporal do rei. Alguns outros exemplos textuais destacam a totalidade corporal a partir do uso da palavra šĭru. Nos textos literários, as alusões são mais sofisticadas de acordo com o estilo do gênero, solicitando eventualmente a dimensão metafórica. Um primeiro caso ocorre

\footnotetext{
${ }^{170}$ A escrita combinada DI-mu para šulmu aparece em quase todos os cabeçalhos das cartas dos escribas, no sentido de bem-estar e plenitude.

${ }^{171}$ Em outra carta, fragmentária, de Adad-šumu-ușur, ele menciona, para tranquilizar o rei, a realização do ritual contra perda da carne e outras "contramágicas" em favor de alguém (difícil saber quem pelo estado do tablete) que ficou doente.
} 
na oração do "justo sofredor" a Nabû (SAA III 12) ${ }^{172}$. Nela, aparece o trecho "la tu-ub UZU ina UGU-[ia]" (linha 20), que literalmente poderia ser traduzido como "não boa carne/saúde em/sobre minha cabeça". A expressão seria a negativa da "boa carne", ou do bem-estar corporal, podendo ser traduzido por doença. Possivelmente por razões de ênfase estilística, optou-se pela referência ao adoecimento mantendo a expressão para corpo bom, mas adicionando a partícula de negação à frente, em vez de escrever alguma expressão para doença (por exemplo, marșūtu, marșu ou murșu). O complemento ina UGU pode ser, em acadiano, ina muhhhu, que significa literalmente "na cabeça", ou elīja, que significa "sobre mim”. Então, uma tradução menos literal poderia ser "mal-estar em mim”.

Nas versões provenientes de Assur e de Nínive de um texto denominado o Sofrimento de Marduk (SAA III 34, 35) ${ }^{173}$, ao final do texto há uma maldição. A última frase seria: "seu nome e sua semente da terra eles (os deuses) possam remover e seu corpo/carne (UZU.MEŠ$\check{s} u_{2}$ ) na boca do cão possam colocar" (linha 76 em ambos os textos). Tal menção a šĭru para a carne dada a um animal não parece sem um sentido atrelado ao uso do vocábulo. Como indica Couto Ferreira (2009, p. 353), primeiramente, essa palavra dentro de seu contexto de significado semítico mais amplo pode significar vingança; em segundo lugar, o uso da mesma palavra, a partir do sumério uzu, servia para designar carne animal e utilizada à alimentação (p. 353-354). Então, a expressão pode realçar o sentido negativo: sua carne/corpo, tratada como a carne de um animal, será dada a um cachorro. Se šǐru pode ser associada ao corpo total da pessoa, seu rebaixamento no tratamento como carne que serve à alimentação de um animal é também uma diminuição da condição da pessoa em sua totalidade. Nesse sentido, como na dinâmica da maldição descrita anteriormente, aqui também o realce amaldiçoador se dá por meio da menção ao corpo da pessoa.

Em um texto literário que compila descrições do corpo de divindades (SAA III 39) ${ }^{174}$, possuindo relações com o texto sobre os rituais de Egašankalamma (SAA III 38), além das

\footnotetext{
172 Segundo Livingstone (1989, SAA III, p. XXVI), o texto é um exemplar único de um tipo textual melhor documentado na região Babilônica. Para além de ser visto como uma evidência da influência da literatura babilônica na Assíria, essa versão incorpora, segundo o autor, elementos exemplares que fazem referência a algum rei assírio, possivelmente Assurbanipal II, através de paralelos com as inscrições reais desse rei e outros textos literários do período.

${ }^{173}$ Este também é um trabalho explicativo e interpretativo que mobiliza elementos da mitologia mesopotâmica, além de particularmente exigir dos escribas da época, conforme Livingstone (1989, SAA III, p. XXIX), um aprendizado desse gênero de interpretação. Também segundo o autor, esse é um texto relevante para se compreender dois aspectos da relação entre literatura (mais de cunho religioso) assíria e babilônica: a referência à Marduk (típico da cosmogonia babilônica) para indicar o patrono assírio Ǎ̌šur e possivelmente o modo assírio explicar parte da ritualística da Babilônia.

${ }^{174}$ Um trecho do texto SAA X 39 aproxima-se daquele sobre rituais do templo de Ištar especialmente na descrição das partes específicas do corpo da divindade. Segundo Livingstone (1989, SAA III, p. XXX), a descrição de um deus, equalizando as partes de seu corpo com animais e objetos, poderia ter funções em rituais
} 
referências a porções corporais, indica-se o corpo de maneira genérica. Cada parte corporal é associada a um elemento da natureza. A palavra corpo/carne aparece no trecho: "As tâmaras secas são seu corpo/carne (UZU.MEŠ-šu $u_{2}$ ” (linha 17). No final da descrição, menciona-se que "a resina do cedro, que na frente deles (dos deuses) eles queimaram, é a carne (UZU) perdida dos deuses maus" (linha r. 24-25). A expressão carne perdida é referente à expressão idiomática šihhatu ššri (CDA, p. 371), sendo a primeira parte derivada de šah̆ăhu, que significa tornar-se perdido, desintegrado (CDA, p. 346).

Numa inscrição real (RINAP 3/1 16 vii 48), aparece UZU com referência a "aquele que realiza/exorciza a carne (UZU) de um demônio Asakku"175. Nesse trecho e no texto anteriormente citado sobre rituais de Egašankalamma (SAA III 38), surge a indicação de um tratamento ou manipulação do corpo de uma outra divindade ou entidade sobrenatural. Dessa forma, há referências textuais sobre a materialidade do corpo divino, assim como há similaridades nas formas de tratamento do corpo humano e do corpo de uma divindade.

Um outro texto literário de interesse é uma resposta do deus $A \check{s} \check{s} u r$ ao relatório de Assurbanipal II a respeito da guerra contra seu irmão, Šamaš-šumu-ukin (SAA III 44) ${ }^{176}$. Na "carta", há o suposto discurso da divindade apoiando a investidura e as ações do rei e relatando o que seu designado conquistou com seu auxílio. Na segunda parte da carta, em um tom um pouco mais incisivo, Aššur relata o que ele mesmo fez por intermédio do rei. Uma das ações descritas, mais destrutiva e violenta, foi: “o povo de Akkad (uma referência à região da Babilônia) eu fiz dominar e eu fiz eles comerem a carne (UZU) uns dos outros" (linha r. $10)$.

No tratado de lealdade do período de Esarhaddon (SAA II 6), destinado à sucessão de seus filhos, aparecem vários trechos com o termo šĭru, especialmente em sua forma logogrâmica UZU. Em especial, eles ocorrem nas partes específicas de maldição:

Possa Ninurta, o primeiro dos deuses, com seu arco furioso fazer-vos cair. Vosso sangue possa preencher a terra; vossa carne (UZU-ku-nu) a águia e o abutre possam comer (linhas 425-427).

específicos: possivelmente, essa descrição expressasse "a unidade entre a cena de culto e a leitura da divindade presente". Nesses textos, também se encontram especulações de ordem cosmológicas, seguidas de elaborações sobre a etiologia de animais.

${ }^{175}$ No período Neoassírio, um demônio ou monstro Asakku (ou Asag, do sumério), causador de males aos seres humanos, tinha uma configuração híbrida e zoomórfica, metade leão, metade pássaro (BLACK; GREEN, 2004, p. 35-36; 107; 121).

${ }^{176}$ Esse tipo de gênero, bastante próximo da literatura dos anais e inscrições reais, é composto por comunicações com deus Ǎšsur na forma de cartas. O deus patrono responde às cartas enviadas pelo rei comentando as campanhas militares. Conforme Livingstone (1989, SAA III, p. XXX), estabelece-se nesse gênero uma proximidade entre rei e deus através da repetição das palavras do soberano por parte de $A \check{s}$ šur, algo típico de uma correspondência epistolar do período. 
[...] em vossa fome a carne (UZU.MEŠ) dos vossos filhos coma! Em fome e necessidade, o homem a carne (UZU) de (outro) homem possa comer. [...] Vossa carne (UZU.MEŠ- $k u-n u$ ) os cães e os porcos possam comer (linhas 449-451).

Possa Palil, senhor primeiro, a vossa carne (UZU-ku-nu) a águia e o abutre fazer comer (linhas 519 e 520) ${ }^{177}$.

Como dito, assim como essa ovelha foi aberta e a carne (UZU) de seu filho em sua boca colocada, o mesmo a carne (UZU) de vossos irmãos, filhos e filhas em vossa fome possais comer (linhas 547-550).

Como dito, assim como os suprimentos os vermes comem, ainda em vida a vossa carne (UZU.MEŠ $-k u$ - $n u$ ), a carne (UZU) das vossas mulheres, de vossos filhos e de vossas filhas, os vermes possam comer (linhas 570-572).

Como dito, vossa carne (UZU.MEŠ-ku-nu), a carne (UZU) de vossas mulheres, de vossos irmãos, de vossos filhos e de vossas filhas como betume, piche e nafta possam enegrecer (linhas 585-587).

Como dito, vossa carne (UZU.MEŠ- $k u-n u$ ), a carne (UZU.MEŠ) de vossas mulheres, de vossos irmãos, de vossos filhos e de vossas filhas como a carne (UZU.MEŠ) do camaleão possam complementar-se/misturar-se (linhas 591593).

Como dito, assim como no interior de uma colmeia o buraco para o mel é furado, no interior de vossa carne (UZU.MEŠ- $k u-n u)$, a(s) carne(s) (UZU.MEŠ) de vossas mulheres, de vossos irmãos, de vossos filhos e de vossas filhas ainda vivos (lit. em vosso viver) buracos possam ser perfurada(s) (palāšu) (linhas 594-598).

Assim como o óleo no interior da vossa carne (UZU.MEŠ- $k u-n u$ ) entra, que esse juramento no interior da vossa carne (UZU.MEŠ- $k u-n u$ ), da carne (UZU.MEŠ) de vossas mulheres, de vossos irmãos, de vossos filhos e de vossas filhas possa entrar (linhas 622-625).

A palavra šĩru nessa compilação de trechos no tratado de sucessão de Esarhaddon reitera a dinâmica já descrita da maldição. Contudo, há algumas ênfases em outros aspectos ainda não elencados. A destinação do corpo/carne à alimentação animal não é genérica: o alvo não seria composto por aqueles animais criados ou domésticos, mas sim àqueles não criados e que são reconhecidos por se alimentarem de carne em apodrecimento (águia, abutre e vermes). Além disso, é evocativa a menção à situação de fome que atinja o limite de que uns e outros, entre si, alimentem-se com os próprios corpos. Também são evocadas imagens relacionadas à cor de objetos pretos para indicar o estado de putrefação do corpo, além da

177 Palil é uma divindade associada a Ninurta, como patronos da caça. Ninurta também era associado às tempestades (como Adad), à guerra (como umas facetas de Ištar) e ao cultivo. 
mistura de coloração da pele do camaleão para indicar uma fragilidade da condição corporal a ponto de elas misturarem-se entre $\mathrm{si}^{178}$; a multiplicidade de buracos numa colmeia é sugestiva como imagem de uma destinação punitiva ao corpo daquele que vier a descumprir o acordo. Por fim, um uso positivo da noção de carne (associada mais provavelmente à pele) é sua capacidade de absorção de um óleo, provavelmente uma imagem evocativa de uma experiência conhecida ${ }^{179}$.

Por fim, dentre os termos utilizados como referência à totalidade corporal, a palavra lānu indica a figura corporal, em termos de forma ou, até certo ponto, estética corporal. Ela serve para uma indicação vinculada à imagem do corpo. O termo lānu aparece com certa variedade de sentido que pode tanto referir-se ao corpo (figura, aparência, estatura), como à configuração de objetos.

Numa carta de Mar-Issar, agente de Esarhaddon na Babilônia, o escriba relata os procedimentos de "decoração" do templo de Nanāia ${ }^{180}$, em Der ${ }^{181}$. O remetente fez uso de lānu para se referir ao corpo de uma estátua (SAA X 349). “[...] a face (pa-ni) [e as mãos de Ușur]_amașa em ouro foram cobertos, a figura (la-a-nu) e [os pés] em ouro não foram cobertos [...]" (linhas 13-15) ${ }^{182}$. Então, essa palavra possui uma acepção mais ampla, mas ainda sendo relativa a uma forma concreta humana ou de um objeto (CAD L, p. 78-80).

No texto literário de um diálogo entre Assurbanipal II e Nabû (SAA III 13) ${ }^{183}$, o deus "responde" a um primeiro apelo do rei. "Atenção, Assurbanipal II! Eu sou Nabû. Até o fim dos dias, teus pés (GIR3.2.MEŠ́-ka) não ficarão desamparados e não tremerão tuas mãos (ŠU.2.MEŠ- $k a$ ). Tua língua/lábios não hesitarão, que eu te dotarei de boa fala. Eu levantarei tua cabeça e endireitarei sua figura/corpo (la-an-ka) na Casa de Emašmaš” (linhas 7-12). Nabû continua em um trecho do tablete separado por linhas divisórias: "aquela tua boca de

\footnotetext{
178 A evocação de um sentido semelhante está no trecho de SAA III 39, em que se sugere o corpo de deuses maus, desintegrado como resina queimada. Em ambos os casos, é indicativa uma imagem de desmaterialização da constituição sólida do corpo.

${ }^{179}$ Como exemplo, a prática de aplicação de unguentos é comum nos tratamentos médicos. No acadiano, o verbo pašāšum serve para expressar o ato de ungir, untar. Outros casos são a passagem de óleo em estátuas ou inscrições reais para sua proteção.

${ }^{180}$ Nanāia (ou Nanaya) era o nome utilizado, em textos cúlticos do período, para se referir à deusa Ištar (Inanna em sumério) em sua faceta de deusa do amor e dos aspectos sexuais (BLACK; GREEN, 2004, p. 134).

${ }^{181}$ A cidade de Der (no moderno Tell Aqar) foi uma cidade-estado suméria, na fronteira iraquiana com o Irã (na região do antigo Elam).

${ }^{182}$ A menção a Ușur-amașa (ou Ușur-amassa) é o nome em acadiano relativo à Kanisura, filha de Inanna. O aspecto sexual de Inanna (associado à deusa Nanaya) era devotado juntamente com sua filha (BLACK; GREEN, 2004, p. 134).

183 Segundo Livingstone (1989, p. XXIX), este é um texto fragmentário de tipo literário, mas que mobiliza elementos cúlticos e mitológicos.
} 
bondade que reza a Urkittu; tua figura/corpo $(l a-a n-k a)$ que eu criei reza para mim em Emašmašs” (linhas 13-15) ${ }^{184}$.

Também nos ritos de Egašankalamma (SAA III 38) aparece a palavra lānu em meio às menções a partes corporais. Num trecho com as vinculações de elementos da natureza a uma dada porção do corpo de uma divindade (linhas r. 9-r. 17), aparece: “A tamargueira é seu coque. Cipreste é [seu] tronco (la-an-[šu])” (linha r. 10). Na compilação de excertos místicos (SAA III 39), relacionados a esse trecho descritivo das partes corporais de uma divindade, aparece: "o choupo/álamo é (seu) corpo (la-an-[šu])" (linha 10).

O correspondente lexical sumério de lānu é alan, significando aspectos relacionados à aparência e figura humana, assim como pode se referir a estátuas (COUTO FERREIRA, 2009, p. 349). Couto Ferreira afirma que lānu é similar às palavras pānū, bunnannû e zîmu; no entanto, estas podem se referir à aparência ou figura geral ou somente do rosto, enquanto lānu indica o corpo ou a figura, podendo ser específica do peito para abaixo, diferenciando-se da cabeça $\left(2009\right.$, p. 350) ${ }^{185}$.

Também na parte de maldições do tratado de sucessão de Esarhaddon, há um trecho com a descrição de uma punição que envolve a palavra lānu. "Assim como uma imagem de cera no fogo é sugada e uma de argila na água se dissolve, vossa figura (la-an-ku-nu) no fogo possa queimar e na água possa ser consumida" (SAA II 6 608-611) ${ }^{186}$.

\section{As partes corporais}

No acadiano, o vocabulário composto por nomes de partes do corpo é utilizado para indicar as porções físicas do organismo e as ações corporais realizadas por elas. Esse vocabulário aparece especialmente em gêneros textuais em que o corpo é objetivado

\footnotetext{
${ }^{184}$ Emašmaš é o nome do templo dedicado à Ištar em Nínive. A menção à Urkittu é uma referência apelativa à Ištar, em sua versão devota em Uruk, antiga cidade ao sul da Mesopotâmia.

185 Assim como a palavra șalmu, lānu também compreende a ideia de correlação entre a imagem e seu correspondente. Couto Ferreira $(2009$, p. 350) exemplifica tal acepção pela prática ritualística de afetar uma pessoa (para o bem ou para mal) a partir de uma figura em forma de estátua. Além disso, a palavra correspondente em língua suméria para lānu, alan, forma o título de uma coleção canônica de textos divinatórios, voltados a leitura de sinais fisionômicos: alamdimmû. A palavra também serve para se referir à fisionomia humana. Por fim, destaca-se a palavra lanūtu, derivada de lānu para indicar a condição genérica e abstrata de estética, figura. Bahrani (2008, p. 85-92) teceu algumas considerações interpretativas sobre os alamdimmû, além de outras formas de presságios corporais. Ver também a edição dos tabletes fisionômicos e a explicação de sua estrutura, feitas por Böck $(2000 ; 2010)$. A título comparativo, sobre presságios que têm como base uma realidade corporal, ver também o Šumma izbu, um texto canônico sobre presságios de má-formação, anomalia ou monstruosidade (BAHRANI, 2008, p. 85-95; ZORZI, 2010; 2011).

${ }^{186}$ Novamente, aqui a imagem de desintegração corporal é evocada a partir de uma imagem de cera que pode ser derretida ao fogo e de um objeto de argila dissolvido em água.
} 
pragmaticamente, como é caso dos textos de cunho médico e divinatório ${ }^{187}$. A observação e o envolvimento com a realidade corporal são os fundamentos que constituem esses gêneros textuais. Adicionalmente, esse vocabulário era organizado e exercitado durante o aprendizado por parte dos escribas, por meio da elaboração e cópia de listas léxicas (CAVIGNEAUX, 1983; COUTO FERREIRA, 2009). Contudo, as menções diretas às partes do corpo aparecem em todos os gêneros textuais. No corpus escolhido, há: cabeça, crânio/caveira, cabelo, orelha(s), olho(s), face, nariz, boca, língua, lábios, garganta, pescoço, ombros, peito, seios, barriga/entranhas, cintura/quadril, pênis, braços, cotovelos, antebraços, mãos, dedos, pernas, joelhos, pés, ossos, sangue, coração. Dessa forma, a expressão textual a respeito de alguma ação corporal pode envolver a nomeação da parte do corpo mobilizada.

Em complemento a esses usos diretos, há a formação de expressões linguísticas em que a palavra extrapola o significado para além da referência corporal. Esses são os casos de expressões idiomáticas: a combinação de alguma partícula da língua com o substantivo indicativo da parte do corpo assume um significado diferente de uma referência direta à parte física do organismo. Essas expressões idiomáticas configuram um campo semântico corporal, cujo espectro comporta desde o aspecto sensorial até a dimensão gestual. Um traço da expressão escrita é o uso, na maioria das ocorrências, de palavras de partes do corpo escritas em logogramas sumérios, com a intenção de aumentar a rapidez da comunicação textual.

Essas expressões idiomáticas são formadas seja por uma preposição, seja por um outro substantivo, combinado à palavra da parte corporal. No caso das expressões preposicionadas, são recorrentes as preposições ina (em) e ištu (de, com sentido de procedência), com a última comumente escrita na forma logogrâmica $\mathrm{TA}^{188}$. Sendo a primeira mais prevalente que a segunda, essas preposições são combinadas com as palavras para cabeça (rēšu ou qaqqadu, SAG ou SAG.DU), crânio (muhh̆u, UGU), olho (īnu, IGI), coração (libbu, ŠS $\mathrm{A}_{3}$ ), mãos (qātu, ŠU.2) e pés (̌̌ep $\left.\bar{u}, \mathrm{GIR}_{3} .2\right)$. Essas palavras aparecem também fora de uma estrutura preposicional, indicando o sentido de uma menção à própria parte corporal, mas elas são amplamente utilizadas idiomaticamente na construção dos textos do período Neoassírio ${ }^{189}$.

\footnotetext{
187 Poder-se-ia incluir as listas léxicas que organizam os vocábulos referentes às partes corporais, como, por exemplo, as listas UGU-mu, estudadas por Couto Ferreira (2009). Contudo, a diferença elementar entre esse tipo de listas e os textos destinados à prática médica e divinatória é a proximidade com uma realidade corporal concreta: enquanto as listas ordenavam o vocabulário das partes corporais, para fins de aprendizado escribal, os textos médicos e divinatórios implicam uma realidade corporal objetificada, seja para a elaboração do material escrito, seja para sua implementação durante um diagnóstico ou uma leitura e interpretação de presságios.

188 A palavra ištu também pode ter uma acepção como conjunção, significando desde, depois, o quanto antes (CAD I, p. 284; CDA, p. 135-136). A sua forma logogrâmica TA pode estar relacionada a išti, uma preposição que significa “com" (assim como a preposição itti), da qual ištu deriva como variação dialetal (CAD I, p. 283). ${ }^{189}$ Outras expressões idiomáticas com partes corporais são apresentadas por Dhorme (1923), Oppenheim (1941), Gruber (1980) e Couto Ferreira (2009).
} 
A cabeça é considerada a porção mais sobressalente da unidade corporal; ela é a extremidade superior da pessoa, em contraposição aos pés (COUTO FERREIRA, 2009, p. 7374). As palavras rēšs q qaqqadu (ou kaqqadu) e muhhu referem-se à parte superior do corpo, assim como servem para indicar uma extremidade (superior) de outras porções do organismo e de objetos. A cabeça também é o local de colocação de adereços, de implementação de cuidados "médicos" ou de ataques físicos dirigidos à pessoa (COUTO FERREIRA, 2009, p. $75)^{190}$. Contudo, esses termos possuem nuances de sentido. As palavras rēšu e muhh̆u podem significar a parte mais alta da cabeça, sendo muhhu também usada para aludir ao crânio (ou caveira). Já qaqqadu expressa a totalidade da cabeça. Um exemplo de uso idiomático básico é a expressão ina SAG.DU, que literalmente significa "na cabeça", mas possui a conotação de algo existente ou colocado numa posição mais alta. Outra expressão é ina UGU, que na literalidade seria também "na cabeça", mas nesse caso estão implicadas duas preposições: ina (em) e UGU como eli em acadiano, que significa "sobre". Nesse sentido, é literalmente "em sobre", mas a expressão é traduzida por "a respeito, com relação a...”. Esse tipo de construção é recorrente após os cabeçalhos formulares das cartas de escribas, para retomar uma comunicação anterior, principalmente feita pelo rei. Outros exemplos, em inscrições reais, são para mencionar uma passagem sobre as terras (ou as tendas) de outras comunidades (RINAP 3/2 149 8); a colocação de um metal precioso sobre um objeto (RINAP 3/2 162 r. iii 23'); ou que uma inscrição de um objeto foi apagada (então, algo estava escrito sobre um suporte) (RINAP 3/2 162 r. iii 36'); ou até para indicar a pedra sobre a qual o rei se posiciona para se curvar e beijar o solo diante (de uma estátua) de Ǎšsur no templo do deus patrono assírio (RINAP 3/2 163 r. 3').

A palavra īnu alude tanto ao órgão (olho), como à percepção e a sentimentos relacionados à experiência visual. Referências diretas podem, por exemplo, indicar o acometimento patológico ou um tratamento médico realizado no local ${ }^{191}$. Já o sentido ampliado da palavra relativa à experiência visual vem desde sua acepção na língua suméria

\footnotetext{
${ }^{190}$ Nas inscrições, a título ilustrativo, há o relato de uma cena quando o rei "se enfurece" e veste sua indumentária guerreira para atacar. Nesse trecho, ele menciona a armadura e o capacete para sua cabeça, este adequado ao combate (RINAP 3/1 18 v 14'; 23 v 58; 3/2 145 i' 5). Outro exemplo de uso do logograma SAG é para indicar um funcionário elevado na corte assíria, como um eunuco (como aparece em inscrições reais, por exemplo: RINAP 3/1 120 e 32; 26; 3 26; 4 24; 4 30; 22 ii 6; 23 ii 5; 4 11; $811 ; 15$ ii 29 ; 22 ii 31; 23 ii 29; 16 ii $33 ; 16$ ii $66 ; 17$ ii $16 ; 17$ ii $48 ; 213$ 20). O logograma SAG.DU também é utilizado recorrentemente em inscrições (e em alguns poucos casos em cartas) para fazer referência aos sumérios ou povos do sul, chamados de "cabeças pretas" (șal-mat SAG.DU). Também pode indicar o início de algo (ina SAG), ou acima de algum lugar, como referência espacial: ša SAG [nome de um lugar] (por exemplo, em RINAP $3 / 2229$ 3).

${ }^{191}$ Por exemplo, numa carta do chefe exorcista Marduk-šakin-šumi (SAA X 243), é mencionada pelo escriba uma inflamação do olho do rei. Em outra comunicação (SAA X 242), o exorcista faz referência a um relato do soberano sobre seu mal-estar e, dentre as sensações e incômodos corporais contados, o rei disse que seus olhos não abriam.
} 
(da palavra igi) (COUTO FERREIRA, 2009, p. 129-130). As expressões que incluem a palavra olho(s), especialmente em sua forma logogrâmica, apresentam dois sentidos básicos: o sentido de uma ação ou estado relacionado à visão (vindo marcada sua forma pluralizada, IGI.2), ou, na forma ina IGI, o significado "estar diante de”. Esse último significado implica uma relação cujo ponto de partida é uma entidade (animada ou inanimada) diante de outra. Nesse caso, a normalização e tradução da expressão não seriam com a palavra para olho, mas com a palavra $p \bar{a} n u$, que significa face.

A palavra coração $(l i b b u)$ é abundante em ocorrências, pois serve para indicar o interior da pessoa, de um objeto, de um lugar ou de um conteúdo, através da expressão ina ŠA $_{3}$ ou ina libbi. O uso com a preposição ina reforça a localização interna à qual a mensagem faz referência. Adicionalmente, Oppenheim define a palavra libbu como "centro da vida espiritual e o lugar dos afetos" (1941, p. 263).

A palavra para mãos (qātu, ŠU.2) é bastante utilizada com a preposição ina para indicar possessão ou a mão de um indivíduo como ponto de partida de algo que está sendo dado a outra pessoa. A expressão preposicionada ina qāti também realça uma determinada atividade que está sendo ou vai ser realizada por alguém, especialmente sugerindo uma tarefa de manipulação. Nas inscrições reais no período de Senaqueribe, as narrativas sobre os momentos de construção, de campanhas militares, de conquista de espólios e da transferência de deportados envolvem grandes ações simbolizadas por gestos manuais do rei. Em todas as frases que ocorrem, a palavra qātu ou sua forma logogrâmica ŠU.2 aparece para realçar uma ação realizada. Como exemplos, Senaqueribe destaca que levou (com as suas mãos) certos objetos ao palácio visando complementar sua construção (RINAP 3/1 1 72); ele destaca que esculpiu relevos (com suas mãos) (RINAP 3/1 1 86) ${ }^{192}$; em vários trechos de relato de campanhas, o rei narra que capturou e dominou lugares, pessoas e objetos, ações verbais enfatizadas pela menção às mãos do rei ${ }^{193}$; com elas, ele também estabeleceu as pessoas (deportadas) das terras que conquistou (RINAP 3/1 2 24, 4 22; RINAP 3/2 46 12, 165 ii 19); o

\footnotetext{
192 A ênfase no trabalho manual, principalmente sofisticado e dirigido à construção do palácio, também é reforçado na escrita pela menção às mãos. A indicação de atividade manipulativa aparece, em inscrições reais, no relato sobre as vitórias militares inscritas em uma estela (RINAP 3/1 2 26), na descrição de outros objetos inscritos manualmente em suas partes (RINAP 3/2 136 r. i'13'; 153 r. 3') e num trecho com um pedido a $A \breve{s}$ šur para que a obra e o trabalho manual implicados na construção do palácio de Senaqueribe possam ser completados (RINAP 3/2 40 3"'). Excertos semelhantes onde se menciona os pedidos dirigidos aos deuses para que o trabalho manual no palácio seja próspero estão em RINAP 3/2 151 i' 9; 155 r. 10'.

193 São vários os trechos (repetidos ou não) especialmente com os verbos kašādu e șabātu acompanhados com qātu ou ŠU.2. Alguns deles estão em: RINAP 3/1 1 28-29; 2 8; 3 7; 4 45; 22 iv 49; 23 vi 15; 26 ii 3'; 3453 e 89; 35 r. 50’; RINAP 3/2 46 5, 25 e 60; 74 4; 145 i’ 10’; 22345 e 48; 230105.
} 
soberano é quem coloca nas mãos de um alto funcionário (um eunuco, por exemplo) a autoridade e responsabilidade para determinada missão, após uma campanha ${ }^{194}$.

Já a palavra para pés ( ̌̌êpu) faz referência óbvia à parte do corpo, mas também serve para indicar uma posição espacial: assim como os termos formados com a palavra cabeça apresentam uma posição elevada no espaço, os pés fazem referência a uma disposição mais rebaixada (por exemplo, os pés de uma montanha). Nas inscrições reais, momentos narrados durante as campanhas mostram uma etapa de aproximação, pausa ou enfrentamento de regiões montanhosas; nesses casos, a chegada ao local é destacada pela aproximação aos pés do monte ou montanha ${ }^{195}$.

Também são mencionados os pés para mostrar um processo de caminhada, envolvendo, por exemplo, o ato de ir a pé (RINAP 3/2 160 r. 15); a referência a soldados que vão a pé (especialmente aqueles que compõem uma infantaria do exército, em RINAP 3/1 4 50, 17 iv 80, 3/2 1015 8'); e até um trecho em que Senaqueribe relata a elaboração de uma figura num portão, representando deuses, parte deles figurados em carros e outra parte grupo que segue a pé (RINAP 3/2 160 10,13). Outro sentido é através de uma referência aos pés para indicar um movimento de aproximação entre astros celestes (SAA X 100) ${ }^{196}$.

Então, as palavras para cabeça, olhos, coração, mãos e pés são mais recorrentes especialmente pelo seu uso preposicional ou idiomático. Quando esses termos são utilizados de maneira não idiomática, eles remetem às próprias partes do corpo, funcionando como substantivos. Essas formas podem vir acompanhadas por sufixos pronominais possessivos, indicando a parte do corpo de alguém (por exemplo, a expressão SAG.DU-ia significa minha cabeça). Uma particularidade desse uso é com relação à palavra coração. Em seu emprego acompanhado com sufixos pronominais, a menção pode não ser literal ao coração, órgão do corpo, mas àquilo que é interior ao sujeito, considerado o lugar central de vontades e sentimentos pessoais. Nesse sentido, uma tradução bastante utilizada para libbu é mente (Oppenheim, 1941, p. 266) ${ }^{197}$.

\footnotetext{
${ }^{194}$ Os excertos onde aparecem essa atribuição colocada enfaticamente nas mãos de eunucos são, por exemplo, RINAP 3/1 4 30; 15 ii 19'; 16 vii 14; 3/2 74 4; já algumas ocorrências onde são mencionados outros altos funcionários são: RINAP 3/1 18 iv 16'; 22 iv 60; $3 / 246$ 12).

${ }^{195}$ Como exemplos, ver nas inscrições RINAP 3/1 16 iv 78, mencionando os pés de montanhas, e em RINAP 3/1 16 v 17; 17 viii $31 ; 3 / 215211$ onde aparece pés de montes.

$196 \mathrm{O}$ uso das palavras para as partes do corpo também se refere à posição e movimentação dos astros. Na prática astronômica, não só formas celestiais são associadas a formas corporais, como também há referências a movimentos e gestos corporais para expressar uma movimentação celeste (OSSENDRIJVER, 2016, p. 143-147). $\mathrm{O}$ excerto citado de aproximação astral é referente à visibilidade de Marte próxima "aos pés" da constelação de Perseu, conjunto estrelar visto no hemisfério norte do planeta.

${ }^{197}$ Esta opção de tradução é bastante recorrente nas edições das cartas dos escribas feitas por Parpola (2014, SAA X).
} 
Duas outras palavras que aparecem, mas com menor frequência, em expressões preposicionadas, são boca ( $p \hat{u}, \mathrm{KA})$ e braço $\left(a h u, \mathrm{~A}_{2}\right)$. O uso com a preposição ina sugere a boca como o lugar onde estão as palavras (ina pî), ou, quando há o uso da partícula ša, mostra-se de onde elas são proferidas $(\check{s} a p \hat{\imath})$. Também pode servir para indicar uma localização espacial-geográfica, como a foz de um rio ${ }^{198}$. Já a palavra $a h u$ para braço, incluindo eventualmente a mão, tende a ser mais literal, mas pode servir para se referir à posição espacial de um ser, como estar ao lado de alguém (semelhante a uma acepção de ina IGI). Com esse sentido de braço como lado, dois exemplos nas próprias inscrições reais indicam um posicionamento espacial relativo à lateralidade: durante as descrições sobre as obras de construção em Nínive, Senaqueribe menciona onde foi feita uma plantação, estando ao lado de uma área livre (RINAP 3/1 17 viii 19). Em outra inscrição, o rei menciona a largura de uma estrada que foi construída - e que não deve ser diminuída -, onde estelas foram postas de ambos os seus lados (RINAP 3/1 38 21).

Por fim, a referência à face (pānu) vem do uso da expressão ina IGI ou de sua forma silábica. A proximidade de sentido pela mesma palavra advinda do sumério pode ser devida à acepção de pānu como "área do olho" (COUTO FERREIRA, 2009, p. 202). Nesse sentido, é uma indicação a uma parte específica da superfície corporal. Segundo Couto Ferreira (2009, p. 201), o uso da palavra suméria igi possui uma acepção, por metonímia, de rosto, face. A autora afirma a noção de pānu não somente para a superfície frontal e anterior (de uma pessoa, objeto ou construção), mas à aparência em geral e a uma alusão mais precisa ao rosto (p. 202). Outras expressões que podem ter um significado direcionado à face são: bunnanû ${ }^{199}$, būnu e zīmu. Nesse sentido, essa palavra apresenta similaridade à noção de figura corporal (lānu), e de outras palavras que compartilham esse sentido, como pānutu, pūtu.

Portanto, como afirmou Oppenheim (1941, p. 251), a língua acadiana possui muitos homônimos, ou seja, palavras com a mesma grafia e/ou fonética que sugerem significados diferentes. Tal característica é uma particularidade do uso de expressões de partes do corpo na língua dos assírios.

Além dos usos já mencionados, esses tipos de palavras ocorrem também quando seu lugar e significado literais fazem uma referência direta ao corpo, porém constituem um contexto de linguagem figurativa por meio, por exemplo, de metáforas. As expressões

\footnotetext{
${ }^{198}$ Tal menção aparece numa das inscrições analisadas: durante a narrativa de uma campanha, é relatado que o rei alcançou a "boca" de um rio (RINAP 3/2 46 77).

${ }^{199}$ Uma acepção mais estendida de bunnanû como figura corporal é mencionada no capítulo 3, com relação à terminologia acadiana para imagens.
} 
metafóricas utilizando as palavras de partes corporais mostram as possibilidades da linguagem figurada: seja com os termos fazendo uma indicação precisa e direta ao corpo, seja com o uso de expressões preposicionadas, a situação comunicativa sugere um sentido para além da referência corporal direta. Contudo, a base corporal é o ponto de partida para atingir o objetivo do conteúdo da mensagem.

Começando pela cabeça e olhos, em uma carta de Adad-šumu-ușur, escriba e harúspice (adivinho) do rei, ele relata o desempenho de um funcionário encarregado de atuar no palácio auxiliar. Numa passagem fragmentária e um pouco obscura, ao dizer que o sujeito está indo bem na função, o escriba detalha: "sua cabeça ( $r e-\check{s} i$-šu $\left.u_{2}\right)$ foi levantada" (SAA X 218 7). Em outra carta, do escriba astrônomo Balasî, é retomado que o rei foi informado sobre a visibilidade do planeta Mercúrio na região da Babilônia. Dentro do contexto da realeza e do governo imperial assírio, era comum o rei receber, por meio de seus especialistas, relatos a respeito de eventos ominosos, com a finalidade de basear a direção de suas condutas cotidianas. Balasî reconhece que quem disse a informação ao rei pôde realmente ter observado o fenômeno. Contudo, ele relativiza a observação, chamando a atenção do rei: “seus olhos (IGI.2-̌̌̌ $u_{2}$ ) sobre isso devem recair" (SAA X 50 r. 5-6). A recomendação ao soberano para que haja uma atenção detida no assunto é enfatizada pela ação corporal focada nos olhos. Fundamentando sua recomendação, Balasî escreve relatando que ele e seu(s) associado(s) não observaram ${ }^{200}$ o fenômeno, por ser um evento um pouco difícil de visualização precisa, já que "um dia pode ser cedo, outro tarde" (linhas r. 9-10) para se perceber tal movimentação astral. Nesse sentido, ele atesta e reitera que "nossos olhos (e-niin-ni) sobre (isso) devem recair" (linhas r. 11-12). Enquanto na carta de Adad-šumu-uṣur o ato de levantar a cabeça assemelha-se às menções aos olhos para dirigir a atenção a uma situação, a passagem sobre o desempenho do funcionário evoca o sentido de que o sujeito está atento e dedicado ao serviço prestado, sentido expresso por um gesto caracterizador de uma postura corporal. Já na carta do astrônomo Balasî, a ênfase na ação da pessoa é feita por meio dos olhos, sugerindo também uma forma de se atentar a um evento. Nesse caso específico, tal ênfase correlaciona-se com o que caracteriza a atividade "profissional" do astrônomo: a observação visual. Então, a recomendação à atenção por meio do direcionamento dos olhos e da visão é evocativa e sugestiva pela própria especialidade da atividade do escriba.

Esse realce da capacidade visual relacionada à atividade astrológica é feito de modo mais direto por outro astrônomo, Akkullanu. Numa carta, ele primeiro interpreta ao rei a

\footnotetext{
${ }^{200}$ Nesse trecho, o escriba escreve em primeira pessoa do plural, talvez se referindo aos outros especialistas com quem trabalhava mais proximamente.
} 
posição de Júpiter atrás da Lua, sinal indicativo de que haverá uma situação hostil ao império. O escriba apela ao rei dizendo que esse assunto é de sua importância e que uma atualização dessa disposição astral será enviada por ele ao soberano. Tal apelo não é arbitrário: na sequência, Akkullanu finaliza a carta mencionando a descrença do rei com relação à leitura da disposição celeste. Nesse sentido, ele sugere o recrutamento de uma outra testemunha que

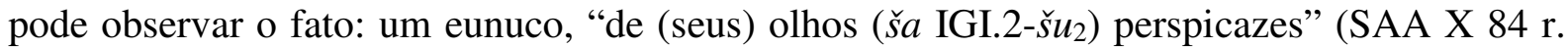
8). O escriba diz que o eunuco poderia ver o fenômeno rapidamente, recomendando que ele fique à sombra para fazer a observação. Assim, o rei poderá acreditar no astrônomo. Então, além do escriba apelar à atenção do rei, ele credita a um funcionário mais próximo ao soberano, um eunuco palaciano, a possibilidade de confirmação de sua leitura astronômica. É necessário somente que o eunuco tenha "bons olhos" e saiba se posicionar.

$\mathrm{Na}$ ocorrência anterior, a referência aos olhos é direta e realça o papel e a função da visão tanto à dedicação da atenção, como à atividade especializada dos astrônomos. A capacidade visual também é realçada como aspecto do corpo do rei. Numa inscrição, Senaqueribe relata: "Com/na sabedoria (ina IGI.2 ra-pa-aš-ti, lit. com/nos olhos amplos) que Ea me presenteou [...]" (RINAP 3/2 166 10) ${ }^{201}$.

A atenção do rei a um assunto também é solicitada por Akkullanu em outra carta, a respeito da condução de rituais para a festividade de Kanūnu ${ }^{202}$. O escriba recomenda ao soberano para questionar um governador sobre alguns rituais sacrificiais. "O rei deveria deixar claro entre/para seus olhos (IGI.MEŠ-š̌ ${ }_{2}$ ) que estes dias de festival Kanūnu não podem se perder!" (SAA X 95 r. 13'-15'). Esse sentido da ação de colocar os olhos em algo de importância aparece numa terceira carta de Akkullanu. Ele informa o rei que o prato de ouro que desapareceu do templo de Ǎ̌šr foi visto nas mãos (ina ŠU.2) de um cortador de pedras/lapidador (de nome Qurdî-Nergal). Na sequência do relato, e referindo-se ao empregado, o escriba menciona: "Agora o ouro para seus olhos (IGI.2.MEŠ- ̌̌̌ $u_{2}$ ) está” (SAA X 107 10-11). Algo "estar para os olhos" indica que a pessoa destina seu interesse ao objeto. Sabendo que é um bem de alto prestígio por ser de ouro e provavelmente por ser um implemento utilizado em funções ritualísticas no templo dedicado ao patrono assírio, o objeto tem um significado importante para o funcionário que tomou posse do prato. Tal significado

\footnotetext{
${ }^{201}$ A divindade $E a$ (ou Enki em sumério) estava associada à sabedoria primoridal do mundo, assim como às águas e à criação do ser humano. O editor nota que seria esperado nesse trecho o logograma GEŠTU, significando "mente" e, por essa razão, a edição trata IGI.2, rapašti, como sabedoria. Na linha seguinte da mesma inscrição, há a palavra igigallūtu, traduzida por "perspicácia". Essa palavra é apresentada em sua forma acadiana, mas é uma absorção por empréstimo sumério: a palavra é composta por igi (olho), gal (grande) e a partícula substantival - ut- do acadiano. Nesse trecho da inscrição, Senaqueribe descreve sua avaliação e alguns procedimentos a serem realizados no templo de $A \check{s}$ šur.

${ }^{202}$ Referência a uma festividade que era realizada no décimo mês do calendário assírio.
} 
desejoso em possuir o bem é expresso por Akkullanu por uma disposição dos olhos e da visão. A sugestão de desejo através do direcionamento dos olhos também aparece numa inscrição real, quando o rei Senaqueribe descreve sua abordagem inicial à região de Nínive, visando o estabelecimento da nova capital. Logo no início da inscrição, é relatado o estado do lugar antes da chegada do soberano e de suas obras urbanas. É mencionada a ausência de água e que as pessoas do local "água de irrigação não conheciam. Para a chuva e gotas do céu, dirigidos seus olhos (IGI.2.MEŠ-šun) estavam” (RINAP 3/2 223 7). A espera e a dependência da chuva como evento natural e importante à subsistência da comunidade local são destacadas pelo cotidiano de expectativa ao olhar para o céu. Tal descrição também implica a dualidade ordem e caos, no sentido do povo não governado pelo rei assírio que ainda depende da fortuna e deposita no acontecimento natural sua própria subsistência, ao invés da postura assíria de “controle" e organização que, por meio de grandes obras construtivas, traz a água à região por meio de canais e aquedutos.

$\mathrm{Na}$ carta de um outro escriba, Nabû-aḩhe-eriba, que estava associado ao astrônomo Balasî, ele celebra uma mensagem do rei na qual é enfatizada sua inclusão no "círculo interno" dos especialistas da corte. Num tom bastante comum ao modo de se dirigir ao soberano em correspondências, ele faz algumas perguntas retóricas e adulatórias: "Como diante (ina pu-ut) do rei, meu senhor, eu não ficarei? A quem além devotaríamos (lit. nossos olhos (e-ni-in-ni) estariam colocados)?” (SAA X 68 14-18, r. 1-2) ${ }^{203}$. Nesse caso, além do sentido de dedicar atenção, a menção a "colocar os olhos" tendo como direção a figura do rei sugere uma outra qualidade: nesse caso, seria uma devoção. Tal devoção expressa por meio dos olhos também aparece numa carta de Adad-šumu-uṣur, um exorcista. Ele celebra que seu filho, Urad-Gula, também exorcista, fará parte do "círculo interno" dos especialistas do governante $^{204}$. Numa parte ao longo da copiosa adulação feita na carta, o escriba afirma “meus olhos (IGI.2-ia) ao rei, meu senhor, estão postos" (SAA X 226 r. 13-14).

A relação entre o levantar a cabeça e os olhos como sinal de atenção e devoção é uma marca que caracteriza o próprio rei. Em um tablete contendo um texto típico de uma inscrição real, logo na apresentação de abertura, onde é comum haver a descrição de Senaqueribe como grande rei e todas as suas características, uma delas é ser "o rei escolhido por vós” (LUGAL $n i-i s ̌$ IGI.2-ku-un, lit. rei levantado por vossos olhos) (RINAP 3/1 230 3). Como este trecho é

\footnotetext{
${ }^{203}$ As linhas 16-18 do texto encontram-se na borda inferior do tablete.

${ }^{204}$ Nas cartas dos escribas do período Neoassírio, especificamente dos anos de reinado de Esarhaddon e Assurbanipal II, há um contexto coligado de referências a momentos de apelação, petição e celebração a respeito da proximidade ou distanciamento dos escribas especialistas em relação aos serviços prestados ao rei. Tal rede contextual aparece nas menções a algumas cartas feitas neste capítulo, mas não é objeto de análise focalizada. Análises dessa interligação foram feitas por Parpola (1983; 2014) e Verderame (2014).
} 
precedido pela menção às divindades que dão suporte ao rei e são reverenciadas por ele, quem escolheu o rei, conforme aparece no trecho, foram, portanto, os deuses. Contudo, o sentido dos olhos como dedicação da atenção e devoção marca a apreciação e aderência ao rei, ao mesmo tempo que sua legitimidade ao ser escolhido. Se os deuses confiam a tarefa de governo ao rei, a adesão é extrapolada: como os assírios são aqueles "devotos" a A $\check{s}$ šr, consequentemente são adoradores da realeza, e vice-versa.

O movimento de levantar não somente os olhos, mas também a cabeça, é realçado no trecho final de uma inscrição, em que o rei está fazendo uma rogação: "Na/entre a totalidade dos entronados (lit. aqueles sentados em plataformas para o trono), minha cabeça ( $r e-s ̌ i-i a$ ) levante" (RINAP 3/2 158 r. 4). O sentido é ambíguo, podendo estar relacionado ao pedido do rei para que seja mantido entre aqueles aptos e escolhidos a reinar, ou para que ele seja destacado entre os soberanos que já existiram.

O uso da cabeça e dos olhos para expressar um sentido de direção de atenção e devoção serve em si mesmo para provocar o próprio leitor, pois o ato da leitura é realizado por meio da visão de alguém. Nesse sentido, na textualidade, manipula-se o sentido visual que se realiza na própria ação de ler. Tal manipulação da visão também aparece num trecho fragmentário de uma outra inscrição, onde é descrita uma cena de aproximação a uma cidade durante uma campanha militar de Senaqueribe. Nela, o vasto ambiente e a presença de muitas pessoas são mencionados. Na narrativa da cena, assume-se um ponto de vista narrativo: "Ao olhar, como do/a partir do céu (a-na [ni-țil] IGI.2.MEŠ)" (RINAP 3/2 1015 7'). Então, a descrição da cena solicita do leitor/observador um ponto de vista para acompanhar a narrativa, que também suscita uma descrição visual de um local. Em outra inscrição, é evocado um sentido visual pelo levantar da cabeça. A descrição "em primeira pessoa" feita pelo soberano menciona que, num dado momento de marcha durante uma campanha, ao ter levantado sua cabeça, percebeu a distância percorrida pelo seu grupo (RINAP 3/1 46 71).

As inscrições reais e a documentação epistolar dos escribas do período sargônido não giram em torno somente da pessoa do rei, mas também têm como eixo o propósito singular do Império Assírio. No caso das cartas, a existência desse tipo de correspondência, formando um império de comunicações (RADNER, 2014) e sendo operada por uma rede de escribas altamente especializados, é movida pelo interesse estratégico de controle por parte do núcleo imperial. Em várias delas aparecem tipos de relato e de informações detalhadas ao rei, desde as informações sobre acontecimentos concretos contemporâneos ou extemporâneos, até as previsões divinatórias. Em muitos casos, consta nas cartas, de modo formular, que "tudo está bem", seja com relação à realização de rituais, seja o estado de saúde de pessoas, seja as 
condições de determinadas regiões do império ${ }^{205}$. Além dos detalhes dos assuntos das cartas, a linguagem figurativa indicada com as partes corporais configura o uso do corpo para transmitir um sentido específico. Dirigir a cabeça e os olhos como sinal de atenção e devoção serve para enfatizar a ação e para mostrar o engajamento dedicado ao rei e ao projeto imperial assírio.

Um uso singular da palavra cabeça, associada à crânio pela palavra muhhhu, ocorre numa inscrição real, onde o rei menciona que, quando fez a inauguração do novo palácio de Nínive, ele tinha a cabeça (muhhu) de sujeitos mergulhadas e ele as encheu de vinho (RINAP 3/1 $\left.88^{\prime}\right)^{206}$. A imagem que o trecho suscita não é completamente estranha, evocando uma cena macabra em meio à inauguração do palácio. A cena de uma cabeça/crânio utilizado por Senaqueribe, provavelmente para beber vinho, como elemento presente num momento de celebração conecta-se tematicamente com a cena de banquete do relevo palaciano de seu neto, Assurbanipal II, na sala S1 do Palácio Norte (Figura 106). Esse tipo de referência, com duas ocorrências em texto e imagem, respectivamente, relaciona-se à importância da conquista vitoriosa para a mentalidade real assíria. A exposição disso, em imagem e em texto, é composta pelo produto de sua ação: as cenas de caça contempladas nos relevos palacianos resultam nos leões mortos carregados ao interior palaciano; os reis assírios comemoram suas vitórias na guerra, sendo que nos dois casos supracitados a cabeça de um corpo derrotado e decapitado é participante do cenário comemorativo.

As palavras para boca e lábios estão presentes para destacar a proveniência da mensagem e do seu pronunciamento. Por exemplo, Zakir, um astrônomo, escreveu uma carta com uma configuração diferente: ele relata a designação de um funcionário numa atividade específica na Babilônia, mas o texto não contém o cabeçalho padrão, e apresenta sua assinatura ao final ( $\breve{s} \mathrm{~m}_{z a-k i r}$ ). Após um primeiro trecho de relato do evento, o remetente menciona: "Essa é a palavra da boca ( $\breve{s} a_{3}$ ina pi-i) do rei (das nações), nosso senhor" (SAA X 169 11). Alusão semelhante aparece em outra carta de Adad-šumu-uṣur: ele dedica agradecimentos ao rei, retomando o que Assurbanipal II disse: "na/da boca (ina pi-i) de meu pai, eu ouvi como tu és uma família leal [...]” (SAA X 228 15-16). O escriba continua: "o pai do rei, meu senhor, é a imagem (sa-lam) de Bel (...) na/da boca (ina pi-i) de meus dois

\footnotetext{
${ }^{205}$ Por exemplo, em SAA X 130 (o palácio e os habitantes de Nínive estão bem), 247 (todas as funções estão sendo bem realizadas), 320 (o bebê, o príncipe herdeiro e todas as crianças do rei estão bem), e em 193, 194 e 196 (sobre a condução de rituais específicos).

${ }^{206}$ Outras ocorrências do mesmo trecho estão, por exemplo, em: RINAP 3/1 15 viii 17'; 16 viii 62; 17 viii 75; $3 / 24254^{\prime} ; 46163$.
} 
senhores isso saiu (lit. caiu)" (linhas 18-20) ${ }^{207}$. A menção à boca para enfatizar a pessoa e/ou a mensagem proferida encontra paralelo na palavra libbu, pois o interior da pessoa é a fonte de onde provêm as palavras. A ocorrência desse tipo aparece numa carta de Akkullanu, onde há uma longa explicação a respeito de um ritual de substituição do rei ${ }^{208}$. Após a explicação (contendo um trecho fragmentário), o escriba conclui: "eu, estas palavras do meu coração (ŠA 3 -bi-ia $)$, escolhi”" (SAA X 90 r. 21', b. 22). Um trecho semelhante é encontrado na carta de um outro exorcista, Marduk-šakin-šumi. Ele relata todos os rituais que foram e estavam sendo realizados por causa de um eclipse solar. Ao final, ele indica sua recomendação, iniciando o trecho com: "do meu interior (TA ŠA 3 - $b i-i a$ ) eu digo, o conselho possa ser" (SAA X 240 r. 15-17). Após o relato de todos os procedimentos ritualísticos realizados, a diretriz do escriba é precedida pela ênfase na proveniência interior de seu conselho.

A palavra pronunciada e marcada pelo canal de transmissão configurado pelo coração e pela boca é reforçada, tornando-se uma palavra poderosa. Tal característica aparece em inscrições reais, em trechos onde divindades são evocadas, seja em fórmulas amaldiçoadoras ou referências a ordens pela palavra divina. Na parte final de algumas inscrições mais longas, há uma espécie de maldição dirigida a quem adulterar o objeto inscrito. Num trecho dessas fórmulas, é mencionado "possam seu nome, sua semente e sua ascendência da/na boca (ina $p i-i$ ) das pessoas desaparecer" (RINAP 3/1 10 29) ${ }^{209}$. Em uma outra inscrição, no mesmo momento final amaldiçoador, roga-se aos grandes deuses para que, pelo "seu decreto sagrado" (ina și-it pi-i-šu $u_{2}-n u$ el-li, lit. "no/pelo sair de suas bocas puras”) (RINAP 3/2 153 r. 8') 210, a maldição atinja a quem cometer a adulteração. A ênfase na proclamação dos deuses através, no sentido literal, da menção ao comando que sai de suas bocas também aparece no início da mesma inscrição, num trecho fragmentário (ina qi2-bit pi-i-ša $a_{2}$, lit. no comando de sua boca, na linha 6$)^{211}$. Um trecho bastante corrompido pode ter relação com esse sentido do elevado poder daquilo que sai da boca de uma divindade (ou do rei, já que o fragmento não permite reconstrução). No excerto aparece somente "minha boca (KA-ia) temida e obedecida" (RINAP 3/2 1015 r. 2'). Então, a ênfase naquilo que é falado ganha propulsão ao se enfatizar

\footnotetext{
207 A expressão idiomática ina pî maqātu é reconhecida nos dialetos neoassírio e neobabilônico com o significado "declarar solenemente" (CDA, p. 196).

${ }^{208}$ Grosso modo, esse ritual era implementado quando havia algum tipo de presságio negativo, cuja interpretação implicasse algum risco grave à vida do rei. Nesse sentido, o ritual envolvia a colocação de uma estátua, ritualmente preparada, que substituiria o rei e que receberia então o dano causado pelo pesságio. Tendo passado o efeito negativo do presságio, o soberano real voltaria a assumir o trono.

209 Também em RINAP 3/1 12 3' e, com a palavra boca escrita na forma logogrâmica KA, em RINAP 3/2 166 39.

210 Também em RINAP 3/2 223 59-60.

${ }^{211}$ Outras menções a comandos divinos, como de Šamaš e Adad, com a referência às suas bocas, aparecem em RINAP 3/2 160 8, 12-16.
} 
as partes corporais boca e coração, e com maior intensidade pela qualidade daquilo que é falado por uma divindade ou pelo rei. Nesse sentido, mesclam-se as partes corporais, o conteúdo do que é proferido e quem é o falante.

Por essas referências à cabeça, aos olhos, à boca e ao coração, é possível perceber que no teor das cartas são mobilizados procedimentos formulares, relatos, petições e adulações. Sendo o rei o eixo centrípeto da comunicação imperial, os escribas valiam-se de recursos estilísticos e linguísticos para realçar determinados conteúdos. Os relatos permeiam toda a documentação; cada registro é feito, a priori, porque é de importância ao rei e ao império. Mesmo assim, movimentos figurativos são mobilizados no texto para enfatizar a intenção da mensagem. Tal ênfase é feita nesses casos por meio do engajamento da mensagem com alguma disposição corporal. Nas inscrições, o caráter formular também se vale dessas menções às partes corporais para enfatizar a propriedade da mensagem.

A palavra coração tende a apresentar o órgão ou o interior da pessoa como lugar de onde parte um sentimento (como um motor) ou como o lugar que afeta psicologicamente a pessoa. Nas inscrições, tais acepções são mobilizadas, de um lado, para realçar as motivações do rei e, de outro, como seus inimigos são afetados pela ação do soberano. No mesmo trecho das inscrições onde são mencionadas a preparação do rei para uma ofensiva, vestindo uma armadura e um capacete, ele menciona "na raiva de meu interior, sobre Cuta um ataque furioso eu empreguei" (RINAP 3/1 123 ) $^{212}$. Por outro lado, num relato de sua campanha contra os caldeus $^{213}$ (quarta campanha, entre 700 e 699 AEC), o soberano narra: "(para) ele, o terror da minha batalha, sobre ele caiu e seu coração ( $\mathrm{S}_{3} \mathrm{~A}_{3} \breve{s}_{2}$ ) disparou” (RINAP 3/1 15 iv $\left.21^{\prime}-22^{\prime}\right)^{214}$. Seguindo nesse segundo sentido, Senaqueribe descreve a reação de um rei elamita “como um filhote de pomba saído da casca escapa, treme seu coração (lib-bi-šu2-un), sua urina caiu quente" (RINAP 3/1 22 vi 29-31).

O coração como centro de motivações da ação da pessoa fica polarizado entre o coração do rei que se inflama e o faz atacar belicamente, enquanto o coração do inimigo é afetado pela ameaça furiosa do rei assírio. O coração do soberano também é indicado como lugar da qualidade inata de sua habilidade: "No mês propício, no dia favorável, naquele terraço, com minha habilidade inata (i-na nik-lat lib-bi-ia, lit. na habilidade de meu coração/interior)...” (RINAP 3/1 22 vi 53).

\footnotetext{
${ }^{212}$ Também em, por exemplo, RINAP 3/1 18 v 16'. A cidade antiga de Cuta (no atual Tell Ibrahim, próximo de Bagdá) ficava na região da Babilônia.

${ }^{213}$ Grupo localizado ao sul da Mesopotâmia, na margem oriental do rio Eufrates.

${ }^{214}$ Também em RINAP 3/1 22 iii 56.
} 
Vale retomar o outro sentido de uso da palavra libbu nas menções às preces de bemestar a pessoa. A palavra UZU na documentação epistolar é mobilizada para evocar a (boa) disposição do rei. Uma estrutura semelhante é utilizada em uma inscrição real, onde é relatado que Senaqueribe, ao entrar na Babilônia, após sua conquista (e destruição) local: “com alegria (i-na hu-ub libs-bi) e face (pa-ni) brilhante, para a Babilônia eu corri”, seguindo sua entrada no palácio para tomar posse de seus objetos (RINAP 3/1 130).

Por fim, numa carta de Adad-šumu-ușur (escriba harúspice), ele menciona a notícia ou acontecimento da definição do destino de Assurbanipal II e Šamaš-šumu-ukin aos tronos da Assíria e da Babilônia, respectivamente ${ }^{215}$. O escriba disse: "quando nós vimos isso, ao rei, nosso senhor, nós abençoamos e nosso coração (lib-bi-in-ni) revigorou-se" (linhas 13-15).

A referência ao corpo é feita também quando se menciona o fato de estar na presença do rei ou de uma divindade. Por exemplo, nas cartas de Adad-šumu-uṣur (SAA X 228) e de Nabû-ahhe-eriba (SAA X 68), eles enaltecem o fato de "estar na equipe/comitiva do rei”. Essa expressão é construída fundamentalmente por ina IGI, que no acadiano normalizado é ina pāni, significando estar diante, ou ao lado, do rei. Assim como as expressões com šalina $\breve{\mathrm{S}} \mathrm{A}_{3}$ (libbi), ina IGI ( $p \bar{a} n i)$ é bastante recorrente para indicar tal relação de oposição entre entidades ou um "estar com". Além disso, tal recurso é usado nas cartas para mencionar, como exemplos, uma oferenda ou agradecimento a um deus (SAA X 82, 358), realizar um ritual diante de divindades específicas (SAA X 370), ou mencionar que alguém está diante do santuário/templo e, portanto, diante dos deuses (SAA X 354).

Pelas ocorrências das palavras em acadiano para cabeça, olhos e face, são estabelecidas relações entre entidades, de alguém dedicar atenção a algo ou outrem, ou estar diante de outra pessoa ou algo que sugere a presença de uma divindade. Já a boca como parte da extremidade superior do corpo é o local de saída de uma mensagem, podendo ser realçada a interioridade geradora da mesma, a partir do coração. Mesmo que sejam menções a partes específicas do corpo, parece haver uma carga elevada de engajamento da pessoa em cada uma das ações narradas.

As palavras para braços e mãos são utilizadas para expressar, por um lado, as ações realizadas com os membros superiores e, por outro, realçar a qualidade física do membro. $\mathrm{O}$ termo mais comum é $a h \bar{u}$, desde as versões mais antigas da língua acadiana, aparecendo especialmente nos textos em sua escrita logogrâmica $A_{2}$. Também pode significar, através das

\footnotetext{
215 Provavelmente, essa carta tem relação com o tratado de Esarhaddon.
} 
menções nas inscrições reais, costa (área margeada pelo mar). O termo id̄̄ também é recorrente, podendo significar braço, lado, lateral, limite, borda, asa (CDA, p. 125; CAD I, p. 10). O complemento do braço no membro superior é o antebraço, em acadiano ammatu $\left(\mathrm{KUS} \check{S}_{3}\right)^{216}$.

As mãos como a extremidade dos membros superiores compartilham o sentido das ações realizadas por todo o membro, ou seja, a descrição de movimentos efetivados com as mãos ou com os braços pode ser intercambiável. No entanto, o destaque das mãos pode implicar nuances em termos de sentido: diversas ações exigem a mão ou as mãos como ponto de referência de onde provém a realização de um gesto ${ }^{217}$. Um exemplo a partir de um trecho já mencionado é a carta de Akkullanu informando ao rei que o prato de ouro do templo de A ̌̌šur foi visto nas mãos de um funcionário específico (SAA X 107). Outro exemplo é na carta, com uma passagem obscura, de Adad-šumu-ușur, mencionando, ao final, que agora sabe que tudo vai ocorrer bem, tendo em vista a dedicação das bênçãos dadas pelo o rei. $\mathrm{O}$ detalhe está na forma que o escriba escreve sobre a atuação de seu servo: “[...] e a atividade (ši-pir ŠU.2) de seu servo será completa/bem-sucedida” (SAA X 218 r. 15 e r.16e).

Também é presente um uso figurativo da mão como um lugar relacionado a uma pessoa. Esse é o caso de declarações que os inimigos cairão nas mãos do rei (como, por exemplo, em SAA X 100). Esse uso figurativo especial para mencionar a mão do rei é repleto de sentido tradicional e mitológico. Numa outra carta, o exorcista Marduk-šakin-šumi menciona que "Bel e Nabû mão boa (ŠU.2 SIG5) ao rei estabeleceram" (SAA X 235 r. 8-9). Semelhantemente, em outra carta do mesmo escriba, as ações dos mesmos deuses são enfatizadas por meio de suas mãos. "Bel e Nabû suas mãos (qa-su-nu) de vida sobre o rei, meu senhor, irão recair" (SAA X 243 r. 4'-6'). Já no início de uma inscrição real, o rei descreve seus atributos mencionando que Ǎšsur e Ištar deram a ele uma arma sem igual e "abriram meus braços (i-da-a-a)" o que é traduzido como "deram força" (RINAP 3/1 38 9). Esse tipo de alusão aos braços fortes do rei é um motivo tradicional na construção da imagem do soberano em fontes oficiais, isto é, que provêm do núcleo palaciano e estão destinadas ao registro histórico e eventualmente à exposição. Logo no início de uma inscrição real, na

\footnotetext{
${ }^{216} \mathrm{O}$ vocábulo ammatu (KUŠ ${ }_{3}$ ) também se refere a uma unidade de mensuração, relativa ao côvado ou cúbito. Uma outra palavra que aparece no período é iziru, um empréstimo aramaico que ocorre na versão neoassíria do acadiano. Tal palavra é evidente em textos oraculares e proféticos. Especula-se se tal empréstimo aramaico tenha sido um indicativo da influência de ocidental (síria) nesse tipo de gênero textual (ver Parpola, 1997, SAA IX, p. LXVII).

${ }^{217} \mathrm{Um}$ sentido que pode estar implicado no uso da palavra para mãos é o de toque. Por exemplo, numa carta bem fragmentada de Nabû-nadin-šumi (exorcista), aparece um trecho: "agora com sua mão ( $a h$-šs̆ $\left.u_{2}\right)$ a casa de seu pai ele foi" (SAA X 283 r. 4"). A expressão "ir com as mãos" implica o sentido tátil para dar um significado de alcançar um lugar.
} 
descrição de Senaqueribe, é indicado que o soberano é protegido e "(sob) vossa mão (ŠU.2ku-un) no consentimento verdadeiro, ele marchou..." (RINAP 3/2 222 8).

O que está implicado nessa referência ao corpo do rei, especificamente aos seus braços e mãos, é a intenção da ação incorporada no gesto com os membros superiores. A motivação expressa por meio dos braços e mãos também é usada para caracterizar o que não se deve fazer em direção ao soberano assírio. No tratado de sucessão de Esarhaddon, no trecho que trata das obrigações para com a proteção aos sucessores, aparece: “[...] vossas mãos (ŠU.2-ku$n u$ ) com intenção ruim ( $a$-na HUUL-tim ina ŠA.3-bi-š̌n, lit. para o mal no seu interior) (não) tragais [...]" (SAA II 6 66-67) ${ }^{218}$. Em outro momento do documento, uma diretriz semelhante é “[...] vossos braços/mãos $\left(\mathrm{A}_{2}\right.$.2-ku-nu) na/contra a casa deles não tragais [...]" (SAA II 6 271-272). Esse último é encontrado na parte de diretrizes do que se deve ou não fazer em direção aos príncipes herdeiros (Assurbanipal II e Šamaš-šumu-ukin), compromisso assumido por meio do tratado. A mensagem da ação de trazer (ou levantar) as mãos contra alguém é uma frase encontrada também em cartas. Contudo, tal gesto pode ser mobilizado de maneira positiva ou negativa, a depender de quem é o realizador da ação. No tratado, o sentido de proibição à violência contra a "casa" dinástica, isto é, aos sucessores reais, é expresso textualmente por meio de um gesto corporal. Além disso, no primeiro excerto, o gesto é "carregado" de uma intenção negativa em seu interior (enfatizado na literalidade da expressão pela presença da palavra $l i b b u$ ).

Ainda no tratado de sucessão, em meio ao trecho de maldições previstas em caso de descumprimento do acordo, é invocada uma ameaça pela intervenção divina. A ação da divindade é focalizada também nos braços: "Possa Ištar, senhora da batalha e da guerra, em meio à batalha vosso arco arrebentar, possa vossos braços (i-di-ku-nu) reprimir, e abaixo de seus inimigos vos colocar" (SAA II 6 453-454). Há uma duplicidade no sentido da ênfase dos braços e mãos: se são eles que são focalizados para dar sentido a uma ação positiva ou negativa da pessoa, foca-se neles também para, no caso de uma ação negativa contra o império (o soberano, seus filhos, sua dinastia), para anular a tal gesto de um indivíduo "malintencionado".

Nesse trecho, também aparece o arco (a ser arrebentado por Ištar), referência que se conjuga intertextualmente e com a presença imagética do arco em alguns relevos

\footnotetext{
${ }^{218}$ Um trecho semelhante aparece no mesmo tratado, na parte denominada de proibições contra condutas desleais (SAA II 6 105-106).
} 
palacianos $^{219}$. Ištar é invocada para arrebentar o arco do inimigo, como uma imagem amaldiçoadora. Nas inscrições reais de Senaqueribe, no mesmo trecho onde o rei descreve sua investida numa batalha, mencionando vestir-se com uma armadura e colocar um capacete adequado em sua cabeça, a continuidade diz que ele pegou em suas mãos (ŠU.2-ia) um arco poderoso (dado a ele por Aššur) e agarrou com a mão ( $r i-t u-u-a)$ uma flecha que "tira vida" (RINAP 3/1 18 v 18'-19') ${ }^{220}$. Ao proporcionarem ao rei "braços fortes", as divindades também permitem que ele porte armas poderosas:

Aššrur, pai dos deuses, a totalidade dos cabeças-pretas (sumérios, povos do sul), fez dobrarem-se em meus pés ( $\left.\check{s} e-p u-u_{2}-a\right)$ e ao pastoreio da terra e do povo me elevou. Ele me deu um cetro justo que alarga o país e uma arma sem perdão para fazer cair os inimigos fez pegar em minhas mãos (rit-tu- $u 2$ a) (RINAP 3/2 43 5).

Nesse trecho, aparece uma outra palavra utilizada para se referir às mãos: rittu. Ela é empregada para precisar o lugar onde são amarrados objetos preciosos de estrangeiros ${ }^{221}$. Assim como a palavra qātu, rittu é também serve para mencionar uma ação bélica de ataque $^{222}$. Por fim, pode se referir às mãos de objetos esculpidos, como é o caso de grandes colossos do interior dos palácios ${ }^{223}$.

Então, tendo as mãos poderosas do rei atuando, a contrapartida é composta pelas mãos dos outros. Nos relatos das campanhas militares, o rei diz que cortou as mãos de seus inimigos numa batalha específica - além de ter recebido em suas mãos uma espada afiada, além de outros objetos de metais preciosos (RINAP 3/1 18 vi 3' -5' $)^{224}$.

Outra menção bastante frequente em inscrições aparece na descrição de batalhas, quando o rei relata que os adversários "levantaram suas mãos (i-da-šu2-un)" por se

\footnotetext{
${ }^{219}$ Reitera-se a presença significativa do arco acompanhando o rei em momentos solenes de acompanhamento de tributos (Figuras 57-58) e em banquetes (Figuras 104 e 106), assim como os arcos inativos durante as batalhas, não vinculados aos inimigos assírios (Figuras 43-45), ou com eles em momento de rendição (Figura 29), ou até seu empilhamento para contabilização dos resultados de uma batalha (Figuras 25, 38 e 120, e as exceções das Figuras 83 e 84, na qual os arcos são empilhados, mas é uma cena de caça).

${ }^{220}$ Trecho idêntico e com a mesma escrita também aparece, por exemplo, em RINAP $3 / 122$ v $74 ; 23$ v 63; 3/2 145 i' 9.

${ }^{221}$ Em RINAP 3/1 22 v 87; 23 v 75; 34 52; 35 r. 50; 3/2 23087.

${ }^{222}$ Por exemplo, quando Senaqueribe relata em uma de suas inscrições um ataque (com as suas mãos) à Babilônia (RINAP 3/1 34 6). Em RINAP 3/1 3710 e 3/2 43 7, o soberano menciona que recebeu em suas mãos, com uso da palavra rittu, um bastão ou arma sem misericórdia, para cair sobre seus inimigos.

${ }^{223}$ Ver, por exemplo, em RINAP 3/1 17 vi 33; 3/2 40 8'; 43 27; 44 46; 46 128; 4926.

${ }^{224}$ Outros exemplos desse trecho estão em RINAP 3/1 22 vi 14; 23 vi 11; 3/2 145 i' 5'-6'; 230 94; 145. Uma metáfora acompanha o relato do corte das mãos. É mencionado que as mãos foram cortadas como se corta pepino na temporada. $\mathrm{O}$ uso de uma metáfora da prática da colheita talvez suscitasse a imagem da facilidade com que as mãos foram cortadas, assim como o poder e o controle por parte daquele que realiza a colheita em relação ao objeto colhido.
} 
amedrontarem ao batalhar contra ele ${ }^{225}$. Essa alusão aos inimigos que levantam as mãos como um gesto de rendição encontra ressonância em algumas partes dos relevos palacianos, onde, em cenas de batalha, alguns sujeitos não assírios levantam as mãos (com ou sem armas) sobre as cabeças (por exemplo, nas Figuras 29 e 43).

Uma ênfase aos atos violentos é feita pelo gesto com os membros superiores. Paralelamente, a ação de dominação do rei é mencionada nas cartas e em inscrições reais por meio também de ações com os membros superiores. No caso da proibição do atentado contra a dinastia real (mencionada no tratado de Esarhaddon), complementa-se contextualmente o sentido desse tipo de ação: assim como é o rei que conquista uma cidade com suas mãos, ou uma divindade que pune com suas mãos poderosas, ninguém pode levantar a mão contra rei. Portanto, a potencialidade do gesto violento parece fazer parte inerente ao sentido de uma ação específica das mãos ou dos membros superiores. Assim, não seriam poderosas somente as mãos do rei ou dos deuses, mas toda e qualquer mão. $\mathrm{O}$ ato violento constitui a ação corporal, e o que é manipulado no nível textual é sua autorização (a afirmação da ação) ou não (a negação da ação). Na ameaça incorporada pela ação de Ištar, reprimir os braços (ou as mãos) vai desde um efetivo aprisionamento até a anulação, literal ou metafórica, do outro. A distinção entre as mãos dos deuses, dos reis e dos outros é a de que, para os últimos, elas não apresentam qualidades positivas e negativas, de modo declarado; quando a negatividade do que suas mãos podem fazer é enfatizada, só é feita pela proibição de fazê-lo, especialmente em direção aos assírios. Nessa linha, reitera-se o sentido da mão e dos braços como os "índices" portadores/vetores de uma intenção da pessoa.

Então, de um lado, há um uso constante de referências às partes do corpo do rei e dos deuses para destacar uma ação grandiosa, talvez a mais potente de todas. Por outro lado, o fato de expressar essas partes na escrita é o que justamente possibilita a construção do corpo poderoso das divindades e do soberano.

Uma carta de Adad-šumu-ușur, exorcista do rei, relata que não houve um eclipse solar (que talvez fosse esperado), descrevendo o movimento e a visibilidade de outros astros, e predizendo que haverá forte chuva e trovoada. O rei deve saber disso. Depois, ele menciona um esquecimento (da parte do rei) a respeito de Urad-Gula, outro escriba a serviço do soberano. A petição é acompanhada enfaticamente pelo "estado de espírito" de Urad-Gula: “em/de coração partido ( $h u$-up lib-ba-te) ele morre/está morrendo e (está) estilhaçado (por cair) das mãos (qa-at) do rei meu senhor (SAA X 224 r. 3-5). Tal trecho constitui uma figura

${ }^{225}$ Por exemplo, em RINAP 3/1 18 vi 10’; 22 vi 18; 23 vi 14; 25 i’ 4’; $3 / 2145$ i’ 9’; 230103. 
do corpo rei e de suas funções: a mão cuidadosa, que cuida tanto do império, como das relações interpessoais na unidade palaciana.

Ainda com Adad-šumu-ușur, o escriba conta sobre a realização de um ritual de proteção e, na sequência, adula:

e possa eu, abençoando o rei, meu senhor, diante (i-na pa-an) do rei, meu senhor, estar presente/ficar e possa de todo meu coração (ina gu-mur-ti $\breve{S}_{3}$ $b i-i a$, lit. na completude de meu coração), nos/com meus braços ( $a$-hii-ia) reverenciar; como/quando meus braços $(a-h i-i a)$ fatigarem, possa, no/com sustentar meus cotovelos/antebraços (am-ma-ti-ia), minha força realizar (SAA X 198 r. 1-8).

O trecho é da parte final da carta, de praxe encontrada como uma declaração de autoentrega para servir ao rei. O escriba, que atua na realização do ritual, também incansavelmente continuará a louvar seu rei, expressando corporalmente seu empenho total, a partir de um gesto muito comum de erguer os braços.

Por fim, a carta de Mar-īssar, agente assírio na Babilônia, relata o aparecimento de $\mathrm{Bel}$ em um sonho. "Bel seus braços $\left(\mathrm{A}_{2} .2-\check{s} u_{2}\right)$ sobre meus braços ( $\left.\mathrm{A}_{2} .2-i a\right)$ (e disse: minha) mão (qa-ti) está/estará em tua mão (qa-ti-ka)" (SAA X 361 b. 19, r. 1). Os gestos são de Bel, como um bom presságio protetivo ao rei, através da missão desempenhada por seu funcionário. Os braços protegem e são protegidos; as mãos recebem e realizam a ação de poder. Então, paralelamente, há a relação da força e do cuidado divino com relação ao rei e este, por sua vez, também assume tais tarefas com relação ao seu império e aqueles que estão à sua volta $^{226}$.

O gestual envolvendo os braços e as mãos é mobilizado recorrentemente para indicar a louvação ${ }^{227}$. Um caso em que há um detalhamento do gesto manual para a realização da

\footnotetext{
226 Um caso particular ocorre num texto de outro gênero textual. Numa profecia dirigida a Esarhaddon (PARPOLA, 1997, SAA IX), há o detalhamento de garantias e promessas ao rei, logo no início de seu governo. Numa parte aparece: "Não tenha medo, Esarhaddon! Eu coloco-te entre meu braço e antebraço" (SAA IX 2.5 r. 29-31). O excerto é a segunda exortação para que Esarhaddon não tema, seguida de uma promessa (a sexta do documento até este ponto), todas elas relacionadas à proteção e defesa do rei e, consequentemente, da Assíria. A expressão por parte da divindade de colocação do rei entre o braço e o antebraço evoca, juntamente com todas as outras disposições protetivas, o sentido de cuidado e proteção através dos corpos: o corpo divino, poderoso, protege o corpo de seu designado. Além disso, o oráculo profético menciona também que é pai e mãe do rei, o que realça esse sentido: colocar o soberano entre os braços e antebraços parece um gesto de acolhimento, um abraço protetor familiar. Além disso, tais funções através do corpo podem estar implicadas com o "poder" do rei para "reviver" aqueles que estão próximos.

${ }^{227}$ Ver Frechette (2012) sobre a associação específica de tipos gestuais de levantar as mãos na interação com divindades e com ações específicas de certos funcionários, rogadores ritualísticos. Segundo o autor, levantar a mão (ou as mãos) funciona como sinal de disposição diante da divindade. O gesto inclusive é uma rúbrica para designar esse tipo de funcionário, dedicado na recitação procedimental em algum tipo de cerimônia ritualística. Frechette também destaca que o ato de levantar as mãos é um gesto formal de saudação. Nesse sentido, com relação às divindades, levantar as mãos pode expressar uma busca por manter uma relação positiva com os
} 
oração está numa carta de Balasî, que escreve ao rei a respeito da interpretação de um presságio. Ele explica ao soberano que cada interpretação de presságio não é idêntica e que, no caso de sua interpretação dada, há um risco de terremoto, exigindo um resguardo da parte do rei e a realização de rituais específicos. De forma bastante assertiva, o escriba finaliza a carta: "na descendência (lit. no interior dos pais e avôs) do rei terremoto não há/houve? Eu quando pequeno terremoto não vi? O deus, ele os ouvidos (uz-ni) do rei abre e suas mãos em forma de concha ${ }^{228}$ (up-ni-šsu $)$ para o deus possa abrir e o ritual apotropaico possa fazer e possa estar em alerta/guarda" (SAA X 56 r. 13-20, b. 1-2) 229. Essa referência também aparece na carta do chefe exorcista Marduk-šakin-šumi. Ele relata a organização e realização de alguns rituais e menciona ao final: "minhas mãos em forma de concha (up-ni-ia) eu abri e aos deuses rezei" (SAA X 240 r. 6-7)

Por fim, um tipo de referência às mãos e braços é evocado para indicar o corpo como um todo. Em outra carta de Marduk-šakin-šumi, o escriba menciona uma comunicação anterior do rei, sobre seu bem-estar. "Aquilo o que o rei, meu senhor, disse: 'Meus braços ( $a$ hi-ia) e meus pés (̌̌e-pi-ia) não têm força' e disse 'meus olhos (IGI.2-ia) não abrem; (eu estou) quebrado e debilitado" (linhas 6-9). O escriba explica ao rei as razões do acometimento: "no interior ( $\left.\check{\mathrm{S}}_{3}\right)$, que a febre dentro $\left(\check{\mathrm{S}}_{3}\right)$ dos ossos (eș-ma-a-ti) ela está, ela resiste/se obstinou. Ela está no interior ( $\check{S}_{3}$ ), não há seriedade” (SAA X 242 10-14). O acometimento temporário de uma doença é expresso por meio de sentimentos envolvendo partes e gestos corporais.

As referências aos pés relacionam-se ao deslocamento corporal e à disposição vertical numa hierarquização espacial, criando condições textuais para indicar submissão ${ }^{230}$. Numa carta de Akkullanu, ele primeiramente relata que o procedimento de visita dos deuses Aššur e Mullissu $^{231}$ (e outros, não mencionados) ocorreu bem e que as divindades partiram e reentraram em suas residências. Então, o rei pode se alegrar porque tudo deu certo. Depois, em tom de denúncia, o escriba aponta que os funcionários que preenchem os baús (de libação) em frente à mesa do rei no templo estão em "greve", como Akkullanu já o tinha notificado.

\footnotetext{
deuses. Levantar as mãos "refere-se a um gesto formal de saudação a uma divindade, que expressa a submissão leal e antecipa um reconhecimento favorável" (p. 9).

228 Nas traduções da palavra upnu ao inglês, usa-se cupped hand. Esse termo busca precisar um gestual envolvendo a mão e certa abertura de dedos, dirigido especificamente a uma rogação aos deuses.

${ }^{229}$ As linhas r. 17-20 aparecem na borda final do reverso do tablete original, enquanto as linhas b. 1-2 aparecem na lateral do tablete.

${ }^{230}$ Uma menção mais direta ao pé como parte de corpo pode ser encontrada em SAA X 207, uma carta de Adadšumu-ușur, em que ele faz referência aos pés de deuses.

${ }^{231}$ Mullissu é a consorte ou esposa do deus patrono Ǎ̌šur, na versão assírio-acadiana do panteão mesopotâmico.
} 
Agora, no sétimo mês, eles (nem o mestre dos vinhos, nem seu encarregado) não preencheram o vinho de libação nem os tanques de frente a Aššur. Sobre a conduta dos funcionários, o escriba enfatiza: "Pés a/em pés (GIR3.2 ana GIR3.2, traduzido por mão em mão) cessados eles colocaram" (SAA X 98 r. 13-14). O escriba enfatiza a paralização dos funcionários, mesmo já tendo dito que eles não estavam fazendo determinadas ações específicas de seus ofícios no templo. Tal ênfase à inatividade dos sujeitos dá-se através da menção a uma parte corporal tida como aquela que põe a pessoa em movimento. $\mathrm{O}$ editor adotou a tradução como mão em mão, enquanto no texto literalmente aparece escrita a expressão para pés. Por um lado, a tradução oferecida em inglês favorece a compatibilidade entre as ações descritas anteriormente e não realizadas pelos funcionários (ações realizadas com as mãos), enquanto, por outro lado, é possível considerar a opção do escriba por pés: mencioná-los enfatiza que os funcionários estão parados, sem movimento, e não somente não fazendo determinada função. Eles não estão fazendo nada.

Os pés também são uma parte realçada do corpo do rei quando da marcha a uma batalha. No relato de sua segunda campanha, num momento do trajeto em um terreno montanhoso e difícil, "o carro e meus pés (GIR3.2-ia) na nuca (dos funcionários) foram elevados. Em um terreno difícil, nos/com os meus pés (GIR3.2-ia) como um touro selvagem eu passeei” (RINAP 3/1 2 21). Em trecho semelhante em outra inscrição, relata-se o avanço com dificuldade por um terreno, pois com o carro era muito complicado fazer o percurso. Então, Senaqueribe "se lançou em seus próprios pés (GIR3.2-ia) como uma cabra montanhosa" (RINAP 3/1 16 v 3) ${ }^{232}$.

Um contraste é feito para destacar a poeira levantada pelos grupos de combatentes assírios e não assírios. De um lado, Senaqueribe destaca numa inscrição que "ele, Maniye (rei de $U k k u$ ), a poeira dos pés (GIR3.2) de meus soldados viu" (RINAP 3/1 $16 \mathrm{v} 23$ ) 233 . Por outro

\footnotetext{
${ }^{232}$ No relato de outra inscrição real, também sobre um percurso realizado durante uma campanha, Senaqueribe narra que, quando seus joelhos ( $b i r-k a-a-a$, em acadiano normalizado birku), tornaram-se cansados, ele sentou-se (RINAP 3/2 222 40). Há um paralelo desse trecho com o excerto da carta de Adad-šumu-ușur (SAA X 198), mencionando a persistência da louvação ao rei, enfatizando o uso das mãos e, quando houver fatiga, haverá sustentação com os antebraços/cotovelos. Uma hipótese para entender tal tipo de ênfase é pela passagem da extremidade cansada à próxima parte corporal. Na inscrição, por comparação, mesmo quando Senaqueribe enfrenta as dificuldades de terreno, enfatizando a ação de seus pés, menciona-se em seguida os joelhos cansados, ou seja, ele sustentou sua força com os pés e joelhos, até esses últimos tornarem-se fatigados. Portanto, possivelmente esse tipo de realce sirva para mostrar um empenho corporal maior durante uma atividade extenuante. Outro elemento que pode estar contido nesse tipo de referência é a imagem de atravessamento de longas distâncias, seja numa campanha militar, seja num percurso de transporte de correspondências, este último bastante comum no âmbito da corte imperial.

${ }^{233} U k k u$ (moderna Hakkari, na Turquia, próxima às fronteiras com Iraque e Irã) é o nome de uma cidade pertencente ao antigo reino de Urartu, que atingiu sua maior extensão no século VIII AEC, entre o leste/sudeste da Turquia, a Armênia e noroeste do Irã.
} 
lado, o rei assírio menciona que os pés da tropa grande de um rei caldeu da Babilônia ${ }^{234}$, levantaram muita poeira (RINAP 3/1 22 v 58). Em ambos os casos, é destacado o tamanho da tropa militar e, consequentemente, seu poderio, evocando a imagem da poeira levantada pelos seus pés em marcha. Contudo, na continuidade do trecho sobre o exército caldeu, Senaqueribe destaca a grandiosidade do inimigo, dizendo que fez uma prece aos deuses; na sequência, relata que avançou, como de costume, "como um leão" sobre a tropa adversária (RINAP 3/2 230 59). Nesse sentido, a possibilidade de enfatizar o poder do outro não assírio serve como uma preparação narrativa ao grande ataque de Senaqueribe.

As menções aos pés são realçadas na condição de um sujeito ou grupo ser subordinado ao poder imperial assírio. As ocorrências aludem à submissão diante aos pés. $\mathrm{O}$ ato de submeter-se aos pés de Senaqueribe (como em RINAP 3/2 222 11) é semelhante ao gesto de sujeição que também vale para o rei, numa alusão literal que ele está "nos pés de Ǎ̌šur (ina GIR3.2 AN.ŠAR 2 ) (RINAP 3/2 181 5). Submeter-se aos pés de Senaqueribe por parte dos outros e a subordinação do soberano aos pés do patrono assírio demonstram a disposição ao serviço ao projeto imperial da Assíria.

Em seguida, o gesto de submissão é acompanhado em alguns casos pelo ato de dobrarse diante dos pés do rei. Por exemplo, durante o trecho de relato da terceira campanha, Senaqueribe destaca que, "em Hatti, eles dobraram-se aos (diante) meus pés (̌̌e-pu-u-a)" (RINAP 3/1 4 34; 22 ii 46) ${ }^{235}$. Em outros casos, destaca-se que os sujeitos também trouxeram presentes e "beijaram meus pés (GIR3.2-ia)" (RINAP 3/1 4 38), ou que aos pés do rei, essas pessoas pediram pela própria vida (RINAP 3/2 230 99). Num trecho específico, Senaqueribe declara que algumas dessas pessoas "de/para meus pés (GIR3.2-ia) rapidamente eles não se dobraram" (RINAP 3/1 4 41). Assim como há a ênfase em outros trechos sobre as dificuldades encontradas pelo rei em suas campanhas, tais adversidades durante a narrativa parecem, por um lado, dar realismo ao acontecimento histórico narrado (por parte do rei), e, por outro, criar "pretexto" para a ação violenta que virá como reação à adversidade encontrada.

As menções aos membros inferiores são especialmente dirigidas aos pés, por ser uma posição rebaixada do corpo, estabelecendo então uma relação vertical de orientação espacial. A relação de verticalidade implica o sentido figurado do rebaixamento de alguns diante dos

\footnotetext{
${ }^{234} \mathrm{Na}$ inscrição, o nome do rei é Šuzubu, que corresponde ao nome do rei babilônico Mušezib-Marduk (692-689 AEC).

${ }^{235}$ Logo no trecho de apresentação da inscrição RINAP 3/1 16 i 23, destaca-se como atributo de Senaqueribe que povos se dobram diante de seus pés (também RINAP 3/2 223 4). A menção a Hatti faz referência uma forma de denominar a região nordeste da Síria e da antiga Anatolia.
} 
pés do rei, gerando uma situação semântica bastante particular. Além disso, assim como a disposição dos membros inferiores nas imagens dos relevos palacianos sugere em muitos casos uma locomoção corporal, nos textos os pés podem indicar deslocamentos das pessoas.

Uma ocorrência da palavra perna (purīdu) sugere esse contexto de rebaixamento. $\mathrm{Na}$ carta de Ișșar-šumu-ereš, astrólogo (SAA X 33), o rei consulta o escriba sobre a leitura e interpretação de um presságio, que versa "se um mangusto/suricato" passar "entre as pernas" (bi-rit pu-ri-di, linhas 7-13) de um homem; o soberano quer saber se o acontecimento seria aplicável para debaixo do carro real: se um mangusto viesse a passar por debaixo do carro do rei. O escriba busca explicar a interpretação, concluindo que se o animal passar "entre as pernas" (bi-rit PAB.HAL), a mão (ŠU) do deus ou do rei irá pegá-lo" (linhas r. 8-10). Ou seja, o resultado é favorável ao rei. A carta é finalizada com uma parte específica em separado (dividida por uma linha), mencionando os nabateus ${ }^{236}$. Essa menção talvez implique, por figurar em separado no tablete, que seja uma resposta a uma comunicação anterior entre o escriba e seu senhor. O astrólogo pergunta, possivelmente de forma retórica, se deve haver perdão para com os nabateus, já que eles são hostis. O escriba finaliza a carta fazendo um paralelo com a interpretação da primeira parte da carta: os Nabateus não irão pôr abaixo o carro do rei (linhas r. 11-16), uma metáfora para o reinado do soberano.

Por fim, um caso onde os pés são enfatizados indica uma noção de deslocamento não no espaço, mas na temporalidade da vida. O escriba roga ao rei para que prepare seu “caminho" (que será percorrido pelos seus pés):

assim como para estes teus filhos bom caminho nos seus pés (GIR 3.2.MEŠ$\left.\check{s} u_{2}-n u\right)$ tu colocaste, para teus muitos filhos bom caminho nos seus pés $\left(\mathrm{GIR}_{3} .2 . \mathrm{MES}-\check{s}_{2}-n u\right)$ coloque! Traga(-os) para (tua) sombra/proteção (șillu) e proteção/cobertura/teto (sulülu)! Como semente de grama todas as nações possam governar (SAA X 185 22-26, e. 27-29, r. 1-2).

A produção textual no período Neoassírio implicava, de um lado, o contexto escribal altamente erudito e sofisticado, com a participação de sujeitos engajados em suas funções a serviço do rei, ao mesmo tempo que estavam afinados com a tradição e com os propósitos da realeza. Por outro lado, partindo dessa sólida formação cultural, o uso das mensagens era altamente eficiente para cumprir seja o objetivo comunicativo (em cartas e nos tratados), seja

\footnotetext{
${ }^{236}$ Referência a um grupo da região Levantina oriental, entre os atuais Jordânia, Síria, Iraque e Arábia Saudita.
} 
o objeto de registro histórico (inscrições reais), seja o reprocessamento de elementos do "espírito" religioso do período (textos literários). Nesse contexto, as menções às partes corporais são sugestivas e visam suscitar no destinatário uma referência concreta à mensagem, de modo figurativo ou literal. Para a expressão de si, de uma alegria ou tristeza pessoal, ou para falar de outro, ou até para ameaçar por meio de uma maldição, o corpo e suas partes são utilizados como meio e ponto final de uma intenção que chamava à atenção do leitor para um sentimento.

Nos trechos dos textos analisados, há as menções ao corpo como uma totalidade material que se refere à pessoa, estando viva ou morta. As partes do indivíduo também servem, de um lado, para aludir à pessoalidade e, por outro, para enfatizar uma ação específica. Todas as partes do corpo se referem à pessoa, e não são mencionadas como algo descolado ou abstraído da mesma.

O apelo ao corpo nos trechos de maldições tem suas matrizes no contexto do período: a maldição escrita faz parte de um conjunto textual que visa o estabelecimento de um acordo e juramento (principalmente desbalanceado) entre as partes. Nesse sentido, os trechos amaldiçoadores constituem uma tradição de transmissão de mensagens ao futuro: registra-se e acorda-se, num dado momento, determinadas posturas e comportamentos, tendo em vista um acontecimento (ameaçador) no tempo futuro. Contudo, o sentido futuro é amplificado e se realiza no presente: mesmo o acordo sendo de uso pelos destinatários contemporâneos e ao mesmo tempo em direção à posteridade, a imagem daquilo que acontece a quem vier a descumprir o tratado é bastante ancorada numa experiência (real ou imaginada) no presente. Nesse sentido, as apelações amaldiçoadoras não são somente evocativas de danos dirigidos ao nome, à casa ou à "semente" da pessoa (temas bastante tradicionais no estilo de construção das maldições), nem dependem somente do apelo aos poderes sobrenaturais de divindades, mas as maldições são fundamentadas em visões da experiência corporal concreta - que, apesar de extrema violência, não perdem sua possibilidade de realização. Assim, as referências ao tratamento dado ao corpo são usadas de maneira geral nos textos, mas aparecem especialmente nos trechos de maldições, para ancorar no corpo do leitor o sentido da mensagem escrita. Tal elemento pode constituir parte da diminuição da "carga simbólica" das manifestações escritas e imagéticas assírias mobilizando estritamente temas evocativos de divindades. Assim como nos relevos palacianos, o realismo da mensagem expressada é bastante presente e se faz por meio de outros indícios, como o corpo.

Nas cartas dos escribas, é recorrente o uso de adulações ao rei, sendo que muitas delas envolvem uma menção ao corpo. Tal estratégia estilística está conectada com a importância 
cada vez maior de participar do império: primeiramente, buscando estar nas cidades capitais ou no núcleo imperial, o que favoreceria uma experiência de habitação urbana mais desenvolvida; depois, para aqueles que podiam gozar de tal privilégio, buscando estar dentro dos palácios; e, por fim, a possibilidade de estar próximo ao rei para servi-lo. Nesse sentido, o tom do discurso dos escribas é amplificado e exagerado, e o uso de aspectos corporais favorece os apelos, as petições e as adulações. Ao mesmo tempo, dado que os escribas vêm de uma tradição de formação, especialmente pelas suas famílias, este estilo é próprio da cultura letrada dentro da qual são preparados e que buscam fazer uso para atuar junto ao rei. É por meio das referências ao corpo que se penetra em camadas de sentido que podem ser mais eficazes para suscitar no leitor uma dada mensagem. Portanto, a base comum da experiência corporal é compartilhada culturalmente e é mobilizada na língua para cumprir seus objetivos comunicativos (na escrita ou na fala) (DINGEMANSE, 2009). 


\section{CONCLUSÃO \\ CONCEPÇÕES DE CORPO: ENTRE MATERIALIDADE, TEXTUALIDADE E CORPOREIDADE}

Nesta tese, os aspectos corporais relativos a uma concepção de corpo do período Neoassírio foram examinados a partir de imagens e textos provenientes de Nínive, especificamente dos palácios de Senaqueribe e Assurbanipal II. Os relevos parietais são integrantes do ambiente palaciano, assim como os textos têm como eixo de produção e circulação o palácio e a figura do soberano. Fundamentais para uma caracterização do Império Assírio, os palácios eram arquiteturas monumentais e tinham seu papel como casa real, lugar do poder e pivô de uma ideia de governo imperial. A marca dessa política envolvia, para além do palácio, um sistema militar e administrativo difuso e sofisticado para ocupar a dispersão da proposta imperial. Além disso, o império foi se centralizando em diversas cidades assírias ao longo do primeiro milênio AEC, processo marcado por uma transferência de capitais para valorizar os novos projetos dos reis e o desenvolvimento urbano, além do favorecimento ao acesso de rotas e matérias primas.

Em meio ao projeto imperial assírio, a "missão ideológica" teria seus indícios nas fontes imagéticas e textuais. As imagens dos relevos possuem como característica a narratividade, que envolve a espacialidade das cenas esculpidas e do recinto palaciano, assim como a visualidade. Esse caráter narrativo possibilitou um registro histórico cujo realismo contribuiria para uma nova construção ideológica, a partir das intenções da corte imperial. Contudo, os relevos palacianos dependiam de condições de visibilidade para propagarem sua ideologia. Apesar de um dos temas principais da escultura ter sido as ações violentas em meio a batalhas, os relevos tinham uma audiência muito restrita, formada por aqueles que habitavam e circulavam pelos palácios. Tal grupo era o mesmo que participava tanto da produção como do compartilhamento daquelas experiências visualmente registradas. Adicionalmente, a dimensão de exposição dos relevos nas salas dos palácios dependia da circulação em seus ambientes, sendo tal fator importante para se problematizar a relação entre as pessoas e os relevos. Portanto, em meio a um desenvolvimento grandioso do império assírio, os relevos tinham um papel social para além da difusão ideológica e da propaganda imperial. Os relevos eram integrantes da experiência da realeza e eram incorporados ao ambiente palaciano. 
O registro histórico das cenas esculpidas tende ao realismo devido ao emprego de estratégias figurativas. As manipulações e configurações dos elementos nas placas fundamentavam iconograficamente esse realismo cenográfico, porém não transformando os relevos em uma imagem exata para ser vista de uma única forma. Há uma abertura durante o engajamento do observador com a cena esculpida: o caráter narrativo e a exigência da movimentação ocular e corporal pelos recintos, além das ocorrências de múltiplas linhas de direção da visualização, fazem com que o ponto de vista do observador seja requisitado no processo de observação das imagens. Assim, além do posicionamento do observador, o realismo histórico proposto nos relevos é dependente dos elementos figurativos que compõem as narrativas visuais.

Os relevos como registro da memória compartilhada por um grupo pequeno no ambiente palaciano mantêm uma tradição atualizada no presente e dirigida a uma disposição que continuará no futuro próximo. Nesse sentido, não há somente uma narrativa da cenografia, mas também existe uma narrativa da temporalidade vivida por aqueles que habitavam os palácios. Os registros dos eventos passados serviam aos moradores para manter e continuar com tal disposição imperial. Assim, os relevos constituem uma prática, pois envolvem um registro imagético intencional e incorporam elementos compartilhados da perspectiva assíria. Eles tinham uma operatividade interna ao grupo e ao âmbito dos palácios. Por fim, seus registros em imagens renovam aquilo que era expresso nesses mesmos suportes.

Os relevos e textos são produtos palacianos coligados à figura do rei. Os dois palácios em Nínive foram frutos do período de maior expansão e sistematicidade do governo e dominação territorial assíria. A época Neoassíria é bastante documentada, o que não é somente uma fortuna em termos dos achados arqueológicos, mas pode indicar uma produção documental volumosa no período. A presença de muitas fontes favorece o conhecimento do panorama contextual assírio. No caso dos relevos palacianos, a opção por acessar as placas remanescentes (inclusive com a oportunidade de visualizá-las e fotografá-las) permitiu uma observação mais detida dos aspectos corporais. Além disso, o contato com os relevos contribuiu para a percepção de seus elementos narrativos, os quais exigem o deslocamento corporal (como o caso dos relevos em ambientes de corredores).

Algo característico da região mesopotâmica é o perfil de complementaridade entre as fontes, algo destacado na literatura especializada, especialmente a partir da confluência entre texto e imagem num mesmo suporte. O caso das imagens implica a noção acadiana de șalmu, que coliga a realidade concreta e a figurada. No entanto, há um outro nível de confluência através dos aspectos corporais: as formas de tratar o corpo têm seus paralelos em imagens e 
textos do período. Por meio dos modos de esculpir o corpo, é possível entender que a imagem antiga implica um modo de ver e uma experiência vivida daqueles sujeitos. Indo além, as referências corporais encontradas nos relevos remetem a uma experiência corporal do observador antigo, inclusive a experiência fruto do contato entre as placas esculpidas e as pessoas que tinham acesso a elas.

Uma característica escultórica nos relevos é a decomposição das figuras corporais: as partes do corpo dos personagens são apresentadas conjugadas em suas faces diferentes. A cabeça e os membros inferiores aparecem em sua visão lateral, enquanto o tronco é visto em sua face frontal. Essa é uma estratégia visual utilizada pelos artíficies assírios, criando uma simultaneidade de porções diferentes do corpo. A construção das ações dos personagens nas cenas é feita tendo como base imagética essa disposição corporal, que favorece a elaboração da narrativa (o direcionamento da imagem) e dos sentidos pretendidos por meio do corpo. Tal característica contribui para a noção dos objetos como práticas, pois a realidade esculpida faz referência a uma realidade corporal específica.

Em termos de concepções de corpo, a análise dos relevos palacianos e de textos dos períodos de Senaqueribe e Assurbanipal II permite visualizar, em primeiro lugar, o corpo sempre em sua totalidade material. Nos relevos palacianos, a presença dos corpos se dá em sua inteireza na maioria das situações, havendo os casos de corpos sem cabeça ou cabeças decepadas. No entanto, a falta de correspondência na maioria das cenas entre cabeças sem corpos e corpos sem cabeças faz com que tais figuras se tornem uma unidade em si, um novo indicador corporal, mesmo que em referência a um corpo total.

Nos relevos do período de Senaqueribe, aparecem somente as cabeças decepadas e os momentos prévios de punição corporal, enquanto nos relevos do período de Assurbanipal II, acrescentam-se os corpos decapitados e espalhados pelo espaço cenográfico. O primeiro caso tem sido interpretado como parte de uma sofisticação estilística na escultura, visando aumentar o realismo e a dinâmica das cenas. Nesse sentido, a apresentação dos momentos prévios à punição e a contagem de cabeças serviriam para mostrar um processo, um modo de proceder relacionado à atuação bélica. Isso pode estar relacionado ao reinado de Senaqueribe, que implementou a constituição de uma nova capital, buscando legitimar seus investimentos urbanos e monumentais. Assim como em parte de suas inscrições reais há o relato das obras realizadas em Nínive, descrevendo os recursos humanos e materiais empregados e os méritos dessa implementação, os relevos também apresentam um caráter processual das cenas. Essa característica não se faz presente somente por ser uma narrativa visual, mas a presença de uma noção de processo se constitui pelo modo de apresentar os temas: o movimento de 
marcha às batalhas, as investidas do exército e o encaminhamento dos resultados; o registro das cenas de construção; e, por fim, os modos de atuar e punir os outros nas cenas bélicas.

Nos relevos do período de Assurbanipal II, o caráter processual também é presente, tendo sido ampliado na configuração das cenas de caçada. No entanto, aparecem também os resultados das ações em termos dos animais caçados e dos corpos humanos estirados ao chão em meio a batalhas, com ou sem cabeça. Dessa forma, à característica processual são acrescentadas as imagens dos resultados, que visam reforçar o processo apresentado. Uma relação possível com o contexto histórico é a necessidade do soberano em legimitar não só pelos modos de atuação, mas também pela ênfase nos resultados de sua ação. Tal relação contextual depende da visualização do que sucedeu esse período: por volta da metade de seu reinado, em 652 AEC, Assurbanipal II estava engajado num conflito bélico com seu irmão, Šamaš-šumu-ukin, que assumiu o trono babilônico. A dificuldade em lidar com os conflitos bélicos recorrentes foi um dos fatores que levou à perda da hegemonia assíria após 630 AEC e à consequente destruição de Nínive. Então, nesse contexto, é possível que o acréscimo de detalhes nos resultados da ação figurada nos relevos esteja relacionado às intenções de Assurbanipal II e sua corte em aumentar a ênfase de suas ações, em mostrar objetivamente por meio das imagens os produtos daquilo que realizam.

Nos textos, as diversas palavras para se referir ao corpo sempre comportam a sua totalidade em seu sentido, aludindo a uma pessoa, viva ou morta. Já as menções às partes corporais sempre se referem a um ser, especialmente a uma pessoa, e nunca são descoladas e abstraídas. Esse modo textual contribui para pensar os corpos nos relevos: mesmo nos casos de cabeças sem corpos e corpos sem cabeça, e por mais padronizados e não identificáveis que sejam, todos eles também são referentes a pessoas. Portanto, um primeiro aspecto das concepções de corpo no período Neoassírio, pelas fontes imagéticas e textuais, é a inteireza e a pessoalidade do corpo. O referimento à totalidade corporal e à correspondência da menção ao corpo (ou à parte corporal) a um ser vivo favorece o realce das expressões relativas ao corpo nos textos e nas imagens. Elas se vinculam a uma realidade concreta.

Nessa linha, implicado no aspecto anterior, um segundo componente da concepção de corpo é o corpo como algo comum: o corpo é igual para todos, não é em si diferenciador entre pessoas. A necessidade de diferenciação entre pessoas nos conteúdos dos textos e relevos se dá a partir de gestos, posições, lugares e o que elas portam, e não a partir de corpos diferentes, com características que os distinguem em sua forma (estatura, poderes sobrenaturais etc.). $\mathrm{O}$ estatuto corporal é o mesmo para todos, inclusive para os deuses. Além disso, uma diferenciação entre corpos acontece além do ambiente imagético e textual: existe uma 
distinção entre aqueles que interagem com os textos e imagens. Há os corpos daqueles sujeitos que podem produzir as mensagens, fazendo uso de diversas expressões corporais, e que sabem provocar no corpo dos outros um determinado sentido. De um lado, os produtores, pela sua base corporal (corporeidade), sabem como conduzir um efeito que não é para eles, mas para outros que devem receber a mensagem. Isso gera mais uma característica de distinção entre os corpos assírios e não assírios: pode-se agir sobre o corpo do outro de uma maneira específica que não é recíproca. Os assírios assumem um papel corporal ativo no plano da intenção sobre o corpo (passivo) de outros. O emblema disso são as maldições presentes nos tratados e juramentos. Simultaneamente, esses sujeitos sabem dirigir as vantagens de um tratamento positivo aos corpos de seus pares e próximos. Os bons votos e precações dirigidas ao rei solicitam uma menção aos cuidados em direção ao corpo do soberano. Então, as referências aos aspectos corporais são usadas para afetar as pessoas através de uma base na experiência corporal, num corpo considerado em sua inteireza.

Um terceiro aspecto é a verticalidade, que parece ser mais do que algo inerente à postura ereta humana. Na contraposição entre figuras identificadas como assírias e nãoassírias, há uma ênfase na verticalização dos assírios, enquanto os outros aparecem nas mais diversas posições. A verticalidade se combina à ordem da atuação assíria. Estar na vertical não é somente uma postura corporal vetorial ou um eixo com relação ao solo; a verticalidade também parece implicar um plano de ação, uma disposição num espaço abstrato. Isso aparece especialmente nos textos. Uma relação vertical é estabelecida entre deuses, reis e outras pessoas. As ações dos deuses parecem vir sempre de cima para baixo, sejam aquelas positivas ou protetivas com relação ao rei, sejam as maldições destinadas aos outros. Os reis levantam as mãos e as cabeças em sinal de devoção. Os outros devem beijar ou se prostar aos pés dos reis, enquanto estes podem fazer recair sobre outros as suas punições. Os outros ainda podem ser mais rebaixados, a ponto de serem nivelados a animais, ou jogados e dispersos pelo solo, ou, no limite, não serem aceitos pela própria terra. No realismo proposto pelos relevos, a diferenciação entre os corpos não se dá através da disposição de corpos maiores e menores. São corpos reais que são colocados em cena. No entanto, a distinção entre sujeitos é feita pelas posturas e gestos corporais que cada um pode realizar. A equalização e distinção entre seres é feita por patamares de submissão, marcados por gestos corporais.

Por fim, a forma de representar o corpo é que faz com que ele deixe de ser um sinal que tenha pouco de seu referente corpóreo e torne-se meio para expressar um sentido. As cabeças que são contabilizadas, a dispersão de corpos mortos, as procissões de deportados são unidades corporais expressadas para atingir um outro fim para além de sua presença. A marca 
dessa passagem da presença do corpo enquanto tal a um meio que contribui para outro sentido é baseada no lugar dos corpos decompostos nos relevos. A simultaneidade das faces de suas partes faz com que o corpo seja abstraído para servir em uma outra função na imagem. Esta característica imagética pode remeter ao modo de elaboração, visualização e concepção das imagens dos relevos.

Os corpos mencionados em textos encontram-se muitas vezes em situação de punição. Há um apelo ou uma evocação a uma base corporal, em diversos casos extremado e para além das experiências corporais comuns, como os danos corporais (e, consequentemente, as dores) infligidos violentamente. Essas menções remetem a uma integralidade normal do corpo, mas são utilizadas para transmitir a mensagem com a expectativa de afetar a pessoa. Comparativamente, assim como nos casos de adulação ao rei apela-se a sentimentos relacionados a aflições corporais, visando um realce do conteúdo da mensagem, há nesse tipo de estratégia retórica uma busca de afetar efetivamente o receptor. As ocorrências desses tipos de menções aparecem em meio a documentos importantes para o contexto histórico assírio: comunicações com o rei, tratados e textos que possuem uma sofisticação cultural e linguística. No caso dos tratados, a necessidade de afirmar longamente, por meio de maldições, a afetação corporal é constituinte de um documento relevante no sistema de administração assírio. Assim como os relevos ganham amplitude com o desenvolvimento grandioso do império, os tratados também passam a ser mais utilizados no período, como uma forma "econômica" de estabelecer uma primeira abordagem ao controle territorial, em detrimento a uma dominação somente por conquistas bélicas. Assim, os tratados e juramentos contêm substanciais menções ao corpo, na tentativa de engajar o outro pela ameaça imaginada à integridade corporal. Novamente, os assírios são aqueles que têm o poder de evocar tal sentido sobre o corpo dos outros.

As concepções de corpo na Assíria do primeiro milênio, vistas a partir das imagens e textos relativos aos reinados de Senaqueribe e Assurbanipal II, são definidas em relação aos suportes e meios de sua expressão através dos aspectos corporais. Mesmo o corpo sendo uma unidade total e personalizada, as ações por meio dele e de suas posições num espaço cenográfico ou abstrato distinguem as pessoas, o que as coloca e identifica como participantes do projeto imperial assírio ou não. Por meio do corpo expresso em textos e imagens, busca-se afetar as pessoas, positiva ou negativamente. Sendo assim, o corpo expressado, pelas suas características imagéticas ou textuais, torna-se meio de afetação dos corpos que interagiam com os relevos e textos palacianos. Nesse sentido, a partir desses elementos do caso assírio, as 
concepções de corpo registradas na materialidade e na textualidade engajam corporalmente os sujeitos a seus objetos no ambiente circundante. 


\section{REFERÊNCIAS}

Edições dos textos, catálogos de imagens e obras de referência

The Assyrian dictionary of the Oriental Institute of the University of Chicago. (CAD). Illinois: The Oriental Institute, 1956-2010. 21 volumes.

BARNETT, R. D. Sculptures from the North Palace of Ashurbanipal at Nineveh (668627 B.C.). London: British Museum, 1976.

BARNETT, R. D.; BLEIBTREU, E.; TURNER, G. Sculptures from the Southwest Palace of Sennacherib at Nineveh. London: British Museum, 1998.

BLACK, J. et al. A Concise Dictionary of Akkadian. (CDA) 2 ed. Wiesbaden: Harrassowitz Verlag, 2000.

GRAYSON, A. K.; NOVOTNY, J. The royal inscriptions of Sennacherib, King of Assyria (704-681 BC). Indiana: Eisenbrauns, 2012a. RINAP 3/1.

GRAYSON, A. K.; NOVOTNY, J. The royal inscriptions of Sennacherib, King of Assyria (704-681 BC). Indiana: Eisenbrauns, 2012b. RINAP 3/2.

LIVINGSTONE, A. Court Poetry and Literary Miscellanea. (SAA III). Helsinki: Helsinki University Press, 1989.

PARPOLA, S. Letters from Assyrian and Babylonian Scholars. (SAA X). Indiana: Eisenbrauns, 2014. (Original publicado em 1993).

PARPOLA, S.; WATANABE, K. Neo-assyrian Treaties and Loyalty Oaths. (SAA II). Helsinki: Helsinki University Press, 1988.

\section{Referências Gerais}

ALBENDA, P. Assyrian carpets in stone. Journal of the Ancient Near Eastern Society, v. 10, p. 1-34, 1978.

Observations on Egyptians in Assyrian art. Bulletin of the Egyptological Seminar, v. 4, p. 5-23, 1982.

The Palace of Sargon, King of Assyria: Monumental wall reliefs at Dur-Sharrukin, from original drawings made at the time of their discovery in 1843-1844 by Botta and Flandin. Paris: Editions Recherche sur les Civilisations, 1986.

Decorated assyrian knob-plates in the British Museum. Iraq, v. 53, p. 43-53, 1991.

Assyrian wall reliefs: a study of compositional styles. In: WAETZOLDT, H.; HAUPTMANN, H. Assyrien im wandel der zeiten. XXXIX Rencontre Assyriologique Internationale. Heidelberg 6.-10. July 1992. Heidelberg: Heidelberger Orientverlag, 1997. p. 223-226. 
Dur-Sharrukin, the Royal City of Sargon II, King of Assyria. The Canadian Society for Mesopotamian Studies, v. 38, p. 5-13, 2003.

ALES BELlO, A. Fenomenologia e Ciências Humanas: psicologia, história e religião. Tradução de M. Mahfoud e M. Massimi. Bauru: EDUSC, 2004.

ASHER-GREVE, J. M. The essential body: Mesopotamian conceptions of the gendered body. Gender \& History, v. 9, n. 3, p. 432-461, 1997.

ASSANTE, J. Inside and Out: Extra-dimensional aspects of the Mesopotamian body, with Egyptian parallels. In: DIETRICH, M. et al. Mitteilungen für Anthropologie und Religionsgeschichte: Religion und Menschenbild (MARG 20), 2009. p. 1-17.

ATAÇ, M.-A. Visual Formula and Meaning in Neo-Assyrian Relief Sculpture. The Art Bulletin, v. 88, n. 1, p. 69-101, 2006. Press, 2010.

The mythology of kingship in Neo-Assyrian art. New York: Cambridge University

BACHELOT, L. La fonction politique des reliefs néo-assyriens. In: CHARPIN, D.; JOANNÈS, F. Marchands, diplomats et empereurs. Études sur la civilization mésopotamienne offerts à Paul Garelli. Paris: Éditions Recherche sur le Civilisations, 1991. p. 109-127.

Corps, image et perception de l'espace : l'apport de la phénoménologie. In: GILLMANN, N.; SHAFER, A. (Org.). Corps, image et perception de l'espace. De la mesopotamie au monde classique. Paris: L'Harmattan, 2014. p. 13-32.

BAHRANI, Z. Assault and Abduction: the fate of the Royal Image in the Ancient Near East. Art History, v. 18, n. 3, p. 363-382, 1995.

Women of Babylon: Gender and representation in Mesopotamia. London, New York: Routledge, 2001. 48-59, 2006.

Race and ethnicity in Mesopotamian antiquity. World Archaeology, v. 38, n. 1, p. 2008 .

Rituals of War: The Body and Violence in Mesopotamia. New York: Zone Books,

The infinite image. Art, time and the aesthetic dimension in antiquity. London: Reaktion Books, 2014.

BAINES, J. Visual and written culture in ancient Egypt. New York: Oxford University Press, 2007.

BAGG, A. Where is the public? A new look at the brutality scenes in Neo-Assyrian royal inscriptions and art. In: BATTINI, L. (Org.). Making Pictures of War. Realia et Imaginaria in the Iconology of the Ancient Near East. Oxford: Archeopress, 2016. p. 57-82. 
BANG, P. F.; BAYLY, C. A. Tributary Empires - Towards a global and comparative history. In: _ (Org.). Tributary empires in global history. Basingstoke: Palgrave Macmillan, 2011. p. 1-17.

BATTINI, Laura. Middle Assyrian Drama in depicting war: a step towards Neo-Assyrian Art. In:___ (Org.). Making Pictures of War. Realia et Imaginaria in the Iconology of the Ancient Near East. Oxford: Archeopress, 2016. p. 37-44.

BEDFORD, P. R. The Neo-Assyrian Empire. In: MORRIS, I.; SCHEIDEL, W. (Org.). The dynamics of ancient empires. State power from Assyria to Byzantum. New York: Oxford University Press, 2009. p. 30-65.

BELTING, H. Introduction. In: Likeness and Presence: A History of the Image before the Era of Art. Tradução de E. Jephcott. Chicago: The University of Chicago Press, 1997.

BEZOLD, C. Catalogue of the cuneiform tablets in the Kouyunjik Collection of the British Museum. London: Trustees of British Museum, 1889.

BLACK, J.; GREEN, A. Gods, demons and symbols of Ancient Mesopotamia. An illustrated dictionary. London: The British Museum Press, 2004.

BODIOU, L; FRÈRE, D.; MEHL, V. (Org.). L'expression des corps: Gestes, attitudes, regards dans l'iconographie antique. Rennes: Presses Universitaires, 2006.

BOIVIN, N. et al. Sensual, material, and technological understanding: exploring prehistoric soundscapes in south India. Journal of the Royal Anthropological Institute, v. 13, p. 267294, 2007.

BOIVIN, N. Material Cultures, Material Minds: The Impact of Things on Human Thought, Society, and Evolution. New York: Cambridge University Press, 2008.

BÖCK, B. Die babylonisch-assyrische Morphoskopie. Horn: Berger \& Söhne, 2000.

Physiognomy in Ancient Mesopotamia and beyond: from practice to handbook. In: ANNUS, A. (Org.). Divination and interpretation of signs in the ancient world. Ann Arbor: The Oriental Institute of the University of Chicago, 2010. p. 199-224.

The healing goddess Gula. Towards an understanding of Ancient Babylonian Medicine. Leiden: Brill, 2014.

BREASTED, J. H. Assyrian relief sculpture and the influence of Egyptian art. In: GAUTHIER, H. et al. Studies presented to F. Ll. Griffith. London: Egypt Exploration Society, 1932. p. 267-271.

BUNNENS, G. Assyrian empire building and aramization of culture as seen from Tell Ahmar/Til Barsib. Syria, v. 86, p. 67-82, 2009. 
CARR, D. M. Writing on the tablet of the heart: Origins of scripture and literature. New York: Oxford University Press, 2005.

CAVIGNEAUX, A. Lexikalische Listen. In: Reallexikon der Assyriologie und Vorderasiatischen Archäologie. Berlin: de Gruyter, 1983. v. VI. p. 609-641.

CHARPIN, D. The History of Ancient Mesopotamia: An Overview. In: SASSON, J. M. Civilizations of the Ancient Near East. Massachusetts: Hendrickson Publishers, 2000. p. 807-829.

CIFARELLI, M. Gesture and Alterity in the Art of Ashurnasirpal II of Assyria. The Art Bulletin, v. 80, n. 2, p. 210-228, 1998.

CLELAND, L.; HARLOW, M.; LLEWELLYN-JONES, L. (Org.). The clothed body in the ancient world. Oxford: Oxbow Books, 2005.

COAKLEY, S. Religion and the body. Cambridge: Cambridge University Press, 1997.

CORBEILL, A. Nature embodied: gesture in ancient Rome. Princeton: Princeton University Press, 2004.

CORBIN, A.; COURTINE, J.-J.; VIGARELlO, G. História do Corpo. São Paulo: Vozes, 2012. 3 vol.

COURTINE, J.-J. Decifrar o corpo: pensar com Foucault. Tradução de F. Morás. Petrópolis: Vozes, 2013.

COUTO FERREIRA, M. E. Etnoanatomía e partonomía del cuerpo humano en sumerio y acadio: El léxico Ugu-mu. 2009. 446 f. Tese de doutorado - Universitat Pompeu Fabra, Barcelona, 2009.

CZICHON, R. M. Die Gestaltungsprinzipien der Neuassyrischen Flachbildkunst und ihre Entwicklung vom 9. zum 7. Jahrhundert v. Chr. München; Wien: Profil-Verlag, 1992.

DASEN, V.; WILGAUX, J. (Org.). Langages et métaphores du corps dans le monde antique. Rennes: Presses Universitaires, 2008.

DHORME, E. L'emploi métaphorique des nomes de parties du corps en hébreu et akkadien. Paris: J. Gabalda, 1923.

DI PAOLO, S. Visualizing war in the Old Babylonian Period: drama and canon. In: BATTINI, L. (Org.). Making Pictures of War. Realia et Imaginaria in the Iconology of the Ancient Near East. Oxford: Archeopress, 2016. p. 29-36.

DINGEMANSE, M. The selective advantage of body-part terms. Journal of Pragmatics, v. 41, n. 10, p. 2130-2136, 2009.

DOLCE, R. The "head of the enemy" in the sculptures from the palaces of Nineveh: an example of "cultural migration"?. Iraq, v. 66, p. 121-132, 2004. 
EMBERLING, G. Ethnicity in Empire. Assyrians and Others. In: MCINERNEY, J. A Companion to Ethnicity in the Ancient Mediterranean. Oxford: Wiley-Blackwell, 2014. p. 158-174.

FALES, F. M. (Org.). Assyrian Royal Inscriptions: new horizons in literary, ideological, and historical analysis. Roma: Istituto per l'Oriente, 1981.

2001.

L’impero assiro. Storia e amministrazione (IX-VII secolo A.C.). Bari: Laterza,

Narrazione visuale e testuale: il caso delle campagne militari assire. In: (VÁRIOS AUTORES). L'arte nel vicino oriente antico: bellezza, rappresentazione, espressione. Milano: Ares, 2006. p. 79-116.

Art, Performativity, Mimesis, Narrative, Ideology, and Audience: Reflections on Assyrian Palace Reliefs in the light of recent studies. KASKAL - Rivista di storia, ambienti e culture del Vicino Oriente Antico, v. 6, p. 237-295, 2009.

2010.

Guerre et paix en Assyrie. Religion et impérialisme. Paris: Les Éditions du Cerf,

FELDMAN, M. H. Object Agency? Spatial perspective, social relations, and the Stele of Hammurabi. In: STEADMAN, S. R.; ROSS, J. C. (eds.). Agency and Identity in the Ancient Near East: news paths forward. London: Equinox, 2010. p. 148-165.

Creating Assyria in its own image. In:

Communities of style: portable luxury arts, identity, and collective memory in the Iron Age Levant. Chicago: The University of Chicago Press, 2014. p. 79-110.

FRAHM, E. The Great City: Nineveh in the Age of Sennacherib. The Canadian Society for Mesopotamian Studies, v. 3, p. 13-20, 2008.

The Neo-Assyrian Period (ca. 1000-609 BCE). In: (Org.). A Companion to Assyria. Hoboken: John Wiley \& Sons, 2017. p. 161-208.

FRECHETTE, C. G. Mesopotamian Ritual-prayers of "Hand-lifting” (Akkadian Šuillas). An Investigation of Function in Light of the Idiomatic Meaning of the Rubric. Münster: Ugarit-Verlag, 2012.

GARELLI, P.; NIKIPROWETSKY, V. Oriente Próximo Asiático: impérios mesopotâmicos, Israel. Tradução de E. O. Araújo. São Paulo: Pioneira, EDUSP, 1982. (Original publicado em 1974).

GARISSON, D. H. (Org.). A cultural history of the body in antiquity. Oxford, New York: Berg, 2010.

GERARDI, P. Epigraphs and Assyrian Palace Reliefs: The development of the epigraphic Text. Journal of Cuneiform Studies, v. 40, n. 1, p. 1-35, 1988. 
GILLMANN, N. A propos du mouvement dans les bas-reliefs Neo-Assyrians. KTÈMA: Civilisations de l'Orient, de la Grèce et de Rome antiques, v. 32, p. 41-56, 2007.

. Art assyrien et Cubisme. In: MART, L. La famille dans le Proche-Orient ancien: réalités, symbolismes, et images: proceedings of the 55th Rencontre assyriologique internationale at Paris, 6-9 July 2009. Winona Lake: Eisenbrauns, 2014a. p. 729-742.

Quelques réflexions sur le statut ontologique des images à la lumière du cas assyrien.

Journal Asiatique, v. 302, n. 2, p. 391-409, 2014 b.

Tradition and innovation in the Neo-Assyrian reliefs. In: ARCHI, A. Tradition and innovation in the Ancient Near East. Winona Lake: Eisenbrauns, 2015. p. 267-276.

Les representations architecturales dans l'iconographie Neo-Assyrienne. Leiden; Boston: Brill, 2016.

GINZBURG, C. Medo, reverência, terror: Quatro ensaios de iconografia política. Tradução de F. Carotti, J. A. d'Ávila Melo, J. C. Guimarães. São Paulo: Companhia das letras, 2014.

GRABAR, A. Gypsum, alabaster and "egyptian" alabaster. In: BOSTRÖM, A. The encyclopedia of sculpture. New York: Taylor \& Francis, 2004. v. 2. p. 728-729.

GRUBER, M. I. Aspects of nonverbal communication in the Ancient Near East. Roma: Biblical Institute Press, 1980. 2 volumes.

HESSE, H. Debaixo das rodas. Tradução de A. Cabral. Rio de Janeiro: Civilização Brasileira, 1971.

JOANNÈS, F. La Mésopotamie au $1^{\text {er }}$ millénaire avant J.-C. Paris: Armand Colin, 2002.

KALIMI, I.; RICHARDSON, S. (Org.). Sennacherib at the Gates of Jerusalem. Story, History and Historiography. Leiden: Brill, 2014.

KATAJA, L.; WHITING, R. Grants, decrees and gifts of the Neo-Assyrian Period. (SAA XII). Helsinki: Helsinki University Press, 1995.

KAUFMAN, S. A. The Akkadian influences on Aramaic. Chicago: The University of Chicago Press, 1974.

KEPINSKI, C.; TENU, A. AVANT-PROPOS: Interaction entre Assyriens et Araméens. Syria, v. 86, p. 7-15, 2009.

KERTAI, D. The art of building a late Assyrian royal palace. In: BROWN, B. A.; FELDMAN, M. H. (Org.). Critical approaches to Ancient Near Eastern art. Berlin: De Gruyter, 2014a. p. 689-712.

From bābānu to bètānu, looking for spaces in Late Assyrian palaces. In: MAY, N. N.; STEINERT, U. (Org.). The Fabric of Cities. Aspects of Urbanism, Urban Topography and Society in Mesopotamia, Greece and Rome. Leiden: Brill, 2014b. p. 189-201. 
$2015 \mathrm{a}$.

The architecture of late Assyrian royal palaces. Oxford: Oxford University Press,

Imagining second storeys in Late Assyrian Palaces: the architectural reconstructions of James Fergusson and Jean-Claude Margueron. In: MICALE, M. G..; NADALI, D. (Org.). How do we want the past to be?: on methods and instruments of visualizing ancient reality. Piscataway: Gorgias Press, 2015b. p. 49-76.

KRISTIANSEN, K. Ideology and material culture: an archaeological perspective. In: SPRIGGS, M. (Org.). Marxist perspectives in Archaeology. Cambridge: Cambridge University Press, 2009. p. 72-100.

KUHRT, A. The Neo-Assyrian Empire (934-610). In:

3000-330 BC. v. 2. New York: Routledge, 2003. p. 473-546.

. The ancient near east c.

LANFRANCHI, G. B. The Ideological and Political Impact of the Assyrian Imperial Expansion on the Greek World in the $8^{\text {th }}$ and $7^{\text {th }}$ Centuries BC. In: ARO, S.; WHITING, R. M. (Org.). The Heirs of Assyria. Helsinki: The Neo-Assyrian Text Corpus Project, 2000. p. 7-34.

LATOUR, B. The Berlin key or how to do words with things. In: GRAVES-BROWN, P. M. (Org.). Matter, Materiality and Modern Culture. London: Routledge, 1991. p. 10-21.

LAYARD, A. H. Nineveh and its remains. London: John Murray, 1849. v. II.

LE GOFF, J.; TRUONG, N. Une histoire du corps au Moyen Âge. Paris: Liana Levi, 2003.

LEICHTY, E. Esarhaddon, King of Assyria. In: SASSON, J. M. Civilizations of the Ancient Near East. Massachusetts: Hendrickson Publishers, 2000. p. 949-958.

LEICK, G. Mesopotâmia: a invenção da cidade. Tradução de A. Cabral. Rio de Janeiro: Imago, 2003.

OPPENHEIM, A. L. Idiomatic Accadian (Lexicographical Researches). JAOS, v. 61, n. 4, p. 251-271, 1941.

LIVERANI, M. Antigo Oriente: História, Sociedade e Economia. Tradução de I. E. Rocha. São Paulo: Edusp, 2016.

Assiria. La preistoria dell'imperialismo. Bari: Laterza, 2017.

LUUKKO, M. Grammatical variation in Neo-Assyrian. (SAAS SVI). Indiana: Eisenbrauns, 2004.

MALAFOURIS, L. How things shape the mind: a theory of material engagement. Cambridge: The MIT Press, 2013.

MARCUS, M. I. Art and ideology in ancient western Asia. In: SASSON, J. M. Civilizations of the Ancient Near East. Massachusetts: Hendrickson Publishers, 2000. p. 2487-2505. 
MARINHO, D. C.; SIQUEIRA, G. M.; POZZER, K. M. P. A interpretação de imagens e o ensino da História: iconografia da guerra assíria. Aedos, v. 4, n. 11, p. 232-244, set. 2012.

MASETTI-ROUAULT, M. G. Cultures in contact in the Syrian lower middle Euphrates Valley: aspects of the local cults in the Iron Age II. Syria, v. 86, p. 141-147, 2009.

MAUSS, M. As técnicas do corpo. In:

Neves. São Paulo: Cosac \& Naif, 2003. p. 399-422.

MEISTER, J. História cultural e história do corpo na História Antiga alemã. História da Historiografia, Ouro Preto, n. 14, p. 131-146, 2014.

MENESES, U. T. B. A cultura material no estudo das sociedades antigas. Revista de História, n. 115, p. 103-117, 1983.

História e imagem: iconografia/iconologia e além. In: CARDOSO, C. F.; VAINFAS, R. (Org.). Novos Domínios da História. Rio de Janeiro: Elsevier, 2012. p. 243-262.

MESKELL, L. Writing the body in Archaeology. In: RAUTMAN, A. E. (Org.). Reading the body: representations and remains in the archaeological record. Philadelphia: University of Pennsylvania Press, 2000. p. 13-21.

Corpo e alma na arqueologia do Egito. In: MARQUETTI, F. R.; FUNARI, P. P. A. (Org.). Corpo a Corpo: representações antigas e modernas da figura humana. São Paulo: Fap-Unifesp, 2014. p. 69-108.

MICALE, M. G. L'immagine dell'architettura nel rilievo storico neoassiro: la forma, i componenti e la funzione della rappresentazione architettonica tra percezione e riproduzione dello spazio. (Contributi e materiali di archeologia orientale - CMAO 12). Roma: Università La Sapienza, Dipartimento di scienze storiche, archeologiche ed antropologiche dell'antichità, 2011.

MIDDLETON, A. P. Stone analysis. In: BARNETT, R. D.; BLEIBTREU, E.; TURNER, G. Sculptures from the Southwest Palace of Sennacherib at Nineveh. London: British Museum, 1998. p. 41-43.

MILLER, D. R. Objectives and Consequences of the Neo-Assyrian Imperial Exercise. Religion \& Theology, v. 16, p. 124-149, 2009.

MIRABELLA, S. Relief Sculpture. In: BOSTRÖM, A. The encyclopedia of sculpture. New York: Taylor \& Francis, 2004. v. 3. p. 1399-1404.

MITCHELL, T. C.; MIDDLETON, A. P. The stones used in the Assyrian sculptures. Journal of Cuneiform Studies, v. 54, p. 93-98, 2002.

MONTSERRAT, D. (Org.). Changing bodies, changing meanings: studies on the human body in Antiquity. London: Routledge, 2011.

MOONEY, P. R. S. Ancient Mesopotamian materials and industries. The archaeological evidence. Winona Lake: Eisenbrauns, 1999. 
MOREAU, P. (Org.). Corps romains. Grenoble: Éditions Jérome Millon, 2002.

MORIARTY, C. Memorial: war. In: BOSTRÖM, A. The encyclopedia of sculpture. New York: Taylor \& Francis, 2004. v. 3. p. 1046-1047.

MUTH, S. et al. Texte et image dans l'Antiquité : lire, voir et percevoir. Perspective, v. 2, p. 219-236, 2012.

NADALI, D. Percezione dello spazio e scansione del tempo. Studio della composizione narrativa del rilievo assiro di VII secolo a.C. (Contributi e materiali di archeologia orientale CMAO 12). Roma: Università La Sapienza, Dipartimento di scienze storiche, archeologiche ed antropologiche dell'antichità, 2006.

The role of the image of the king in the organizational and compositional principles of Sennacherib's throne room: a guide to the historical narrative and meaning of a specified message. In: KÜHNE, H; CZICHON, R. M.; KREPPNER, F. J. (Org.). Proceedings of the $4^{\text {th }}$ International Congress of the Archeology of the Ancient Near East, Berlin, mar./abr. 2004. v. 1. Wiesbaden: Harrassowitz Verlag: 2008. p. 473-493. 2009/2010.

Neo-Assyrian State Seals: An Allegory of Power. SAAB, v. 18, p. 215-244, Interpretations and Translations, Performativity and Embodied Simulation. Reflections on Assyrian Images. In: LANFRANCHI, G. B. et al. Leggo! Studies presented to Frederick Mario Fales on the occasion of his 65th birthday. Wiesbaden: Harrassowitz Verlag: 2012. p. 583-595.

Moveo, ergo sum. Living in the space around us: distance, perspective and reciprocity. In: GILLMANN, N.; SHAFER, A. (Org.). Corps, image et perception de l'espace. De la mesopotamie au monde classique. Paris: L'Harmattan, 2014. p. 33-55.

An urban perspective of Nineveh. Mesopotamia, v. L, p. 157-176, 2015.

Images of War in the Assyrian Period: What They Show and What They Hide. I In: BATTINI, L. (Org.). Making Pictures of War. Realia et Imaginaria in the Iconology of the Ancient Near East. Oxford: Archeopress, 2016. p. 83-88.

. Timing Space / Spacing Time. Narrative Principles in Assurbanipal Hunt Reliefs of Room $\mathrm{C}$ in the North Palace of Nineveh. In: PEDDE, F.; SHELLEY, N. (Org.). Assyriomania and More. In memory of Samuel M. Paley. Münster: Zaphon, 2018. p. 211225.

NADALI, D.; POLCARO, A. (Org.). Archeologia della Mesopotamia antica. Roma: Carocci, 2015.

NADALI, D. RIVAROLI, M. Definire lo spazio: l'interpretazione del paesaggio nei rilievi e nell iscrizioni di età Neo-Assira. Studi e materiali di storia delle religioni, v. 73, n. XXXI, p. 5-50, 2007. 
NYORD, R. On (Mis)conceptions of the Body in Ancient Egypt. Ling Aeg, v. 20, p. 165-184, 2012.

OPPENHEIM, A. L. Idiomatic Akkadian. JAOS, v. 61, n. 4, p. 251-271, 1941.

OSBORNE, R. Changing Ancient Greek History. In: HARLAFTIS, G. et al. (Org.). The new ways of History. Developments in Historiography. New York: I. B. Tauris, 2010. p. 35-47.

The History Written on the Classical Greek Body. Cambridge: Cambridge University Press, 2011.

OSSENDRIJVER, M. Conceptions of the body in Mesopotamian cosmology and astral science. In: BUCHHEIM, T.; MEISSNER, D.; WACHSMANN, N. (Org.). $\boldsymbol{\Sigma} \boldsymbol{\Omega M A .}$ Körperkonzepte und körperliche Existenz in der antiken Philosophie und Literatur. Hamburg: Felix Meiner Verlag, 2016. p. 143-158.

PARKER, B. J. The construction and performance of kingship in the Neo-Assyrian Empire. Journal of Anthropological Research, v. 67, p. 357-385, 2011.

PARPOLA, S. Letters from Assyrian Scholars to the Kings Esarhaddon and Assurbanipal. 1970. v. I.

1983. v. II.

Letters from Assyrian Scholars to the Kings Esarhaddon and Assurbanipal.

The construction of Dur-Sharrukin in the Assyrian Royal Correspondence. In: CAUBET, A. Khorsabad, le palais de Sargon II, roi dassyrie. Paris: La documentation Française, 1995. p. 49-77.

Assyrian prophecies. (SAA IX). Helsinki: Helsinki University Press, 1997.

Assyria's expansion in the 8th and 7th Centuries and its long-term repercussions in the west. In: DEVER, W. G.; GITIN, S. Symbiosis, symbolism and the Power of the Past. Indiana: Eisenbrauns, 2003. p. 99-111.

PARPOLA, S.; WHITING, R. M. (Org.). Assyria 1995. Proccedings of the 10 th Anniversary Symposium of the Neo-Assryian Txext Corpus Project. Helsinki: The Neo-Assyrian Text Corpus Project, 1997.

PESEZ, J.-M. História da cultura material. In: LE GOFF, J. (Org.). A história nova. Tradução de E. Brandão. São Paulo: Martins Fontes, 1993. p. 177-213.

PONGRATZ-LEISTEN, B. Religion and ideology in Assyria. Berlin: De Gruyter, 2015.

PORTER, J. I. (Org.). Constructions of the Classical Body. Ann Arbor: University of Michigan Press, 1999.

PORTER, R. História do corpo. In: BURKE, P. (Org.). A escrita da história: novas perspectivas. Tradução de M. Lopes. São Paulo: Editora Unesp, 2011. p. 297-333. (Original publicado em 1991). 
POStGAte, J. N. The Land of Assur and the Yoke of Assur. World Archaeology, v. 23, n. 3, p. 247-263, 1992.

POST, F.; WILGAUX, J. (Org.). Penser et représenter le corps dans l'Antiquité. Rennes: Presses Universitaires, 2006.

POZZER, K. M. P. Poder, guerra e violência na iconografia assíria. Phoînix, Rio de Janeiro, v. 17, n. 2, p. 12-25, 2011.

Relação de Poder no Império - Arqueologia e Iconografia da Conquista de Lakiš. Maracanan, v. 9, n. 9, p. 10-30, 2013.

POZZER, K. M. P.; SANTOS, L. B. Tortura, sujeição e flagelo nos relevos assírios. Revista Mundo Antigo, v. 1, p. 206-219, jun. 2012.

RADNER, K. The relation between format and content of Neo-Assyrian texts. In: MATTILA, T. R. Nineveh, 612 BC: The glory and fall of the Assyrian Empire. Helsinki: Helsinki University Press, 1995. p. 63-77.

1.

(Org.). The prosopography of the Neo-Assyrian Empire. Helsinki, 1998. v. 1, part.

The Neo-Assyrian Empire. In: GEHLER, M.; ROLLINGER, R. Imperien und Reiche in der Weltgechichte: Epochenübergreifende und globalhistorische Vergleiche. Wiesbaden: Harrassowitz Verlag, 2014. p. 101-119.

. High visibility punishment and deterrent: Impalement in Assyrian warfare and legal practice. Journal for Ancient Near Eastern and Biblical Law, v. 21, p. 103-128, 2015a.

Ancient Assyria. A very short introduction. Oxford: Oxford University Press, $2015 b$.

READE, J. Ideology and propaganda in assyrian art. In: LARSEN, M. T. Power and Propaganda: A Symposium on Ancient Empires. Copenhagen: Akademisk Forlag, 1979. p. 329-343.

Neo-Assyrian monuments in their historical context. In: FALES, F. M. (Org.). Assyrian Royal Inscriptions: new horizons in literary, ideological, and historical analysis. Roma: Istituto per l'Oriente, 1981. p. 143-168.

Assyrian illustrations of Arabs. In: PHILLIPS, C. S.; POTTS, D. T.; SEARIGHT, S. (Org.). Arabia and its neighbours. Essays on prehistorical and historical developments presented in honour of Beatrice de Cardi. Turnhout: Brepols, 1998a. p. 221-232.

Assyrian illustrations of Nineveh. Iranica Antiqua, v. XXXIII, p. 81-94, 1998 b.

Nineveh. In: Reallexikon der Assyriologie und Vorderasiatischen Archäologie. Berlin: de Gruyter, 1998c. v. IX. p. 388-433. 
em 1983).

Assyrian sculpture. London: The British Museum Press, 2016. (Original publicado

REALE, G. Corpo, alma e saúde: o conceito de homem de Homero a Platão. Tradução de M. Perine. São Paulo: Paulus, 2002.

REDE, M. Estudos de cultura material: uma vertente francesa. Anais do Museu Paulista, v. 8/9, p. 281-291, 2000/2001.

História e cultura material. In: CARDOSO, C. F.; VAINFAS, R. (Org.). Novos Domínios da História. Rio de Janeiro: Elsevier, 2012. p. 133-150.

Imagem da violência e violência da imagem. Guerra e ritual na Assíria (séculos IX-

VII a.C.). Varia Historia, v. 34, n. 64, p. 591-623, 2018.

RELIEF SCULPTURE. In: WARD, G. W. R. (Org.). The Grove Encyclopedia of materials and techniques in Art. New York: Oxford University Press, 2008. p. 569-571.

ROAF, M. Palaces and Temples in Ancient Mesopotamia. In: SASSON, J. M. Civilizations of the Ancient Near East. Massachusetts: Hendrickson Publishers, 2000. p. 423-441.

ROSS, J. C.; STEADMAN, S. R. Agency and Identity in the Ancient Near East: news paths forward. In: STEADMAN, S. R.; ROSS, J. C. (Org.). Agency and Identity in the Ancient Near East: news paths forward. London: Equinox, 2010. p. 1-10.

ROSS, J. C. The Scribal Artifact: Technological innovation in the Uruk Period. In: STEADMAN, S. R.; ROSS, J. C. (Org.). Agency and Identity in the Ancient Near East: news paths forward. London: Equinox, 2010. p. 80-98.

ROUAULT, O. Assyrians, Aramaeans and Babylonians: the Syrian Lower Middle Euphrates valley at the end of the Bronze Age. Syria, v. 86, p. 133-139, 2009.

RUSSELL, J. M. Bulls for the Palace and Order in the Empire: The Sculptural Program of Sennacherib's Court VI at Nineveh. The Art Bulletin, v. 69, n. 4, p. 520-539, dez. 1987.

Sennacherib's Palace without Rival at Nineveh. Chicago: The University of Chicago Press, 1991.

Writing on the Wall: Studies in the Architectural Context of Late Assyrian Palace Inscriptions. Indiana: Eisenbrauns, 1999.

SALLABERGER, W. The palace and the temple in Babylonia. In: LEICK, G. (Org.). The Babylonian World. New York, Routledge, 2007. p. 265-275.

SANTOS, L. B. Representações da guerra nos relevos assírios. Phília, Informativo de História Antiga, v. 15, n. 46, p. 6-7, 2013 a.

. O poder legitimador das representações nos relevos assírios. Aedos, v. 15, n. 13, p. 256-271, ago./dez. 2013 b. 
SCHMITT, J.-C. La pluralité interprétative : entre textes et images. Les conférences du Collège de France. 2010.

SILVA, R. K. P. Arte no império: a função real e a ideologia da guerra em relevos parietais de palácios reais neoassírios (934-605 a.C.). In: SIMPÓSIO NACIONAL DE HISTÓRIA, 27. 2013, Natal. Anais... Natal: ANPUH, 2013.

SQUIRE, M. The art of the body: Antiquity \& its legacy. London, New York: I. B. Taurus, 2011.

STEADMAN, S. R.; ROSS, J. C. (Org.). Agency and Identity in the Ancient Near East: news paths forward. London: Equinox, 2010.

STEINKELLER, P. The Babylonian healing goddess gula, and her Dog, and some Classical analogues. manuscrito.

STONE, E. C. The Development of Cities in Ancient Mesopotamia. In: SASSON, J. M. Civilizations of the Ancient Near East. Massachusetts: Hendrickson Publishers, 2000. p. 235-248.

TADMOR, H. History and ideology in the Assyrian Royal Inscriptions. In: FALES, F. M. (Org.). Assyrian Royal Inscriptions: new horizons in literary, ideological, and historical analysis. Roma: Istituto per l'Oriente, 1981. p. 13-33.

The aramaization of Assyria: aspects of western impact. In: NISSEN, H. J.; RENGER, J. (Org.). Mesopotamien und seine Nachbarn. Politische und kulturelle Wechselbeziehungen im alten Vorderasien vom 4. bis 1. Jahrtausend v. ChrBerlin: Dietrich Reimer, 1982. p. 449-470.

TAKLA, P. R. Desenvolvimento do esquema decorativo das salas do trono do período Neo-Assírio (934-609 a.C.): Imagem, texto e espaço como veículos da retórica real. 2008. Dissertação (Mestrado em Arqueologia). Museu de Arqueologia e Etnologia, Universidade de São Paulo, São Paulo, 2008.

TENU, A. Ninive et Assur àl'époque médio-assyrienne. Iraq, v. 66, p. 27-33, 2004. Looting and destruction in Iraq and Syria. The International Association for Assyriology, mar. 2015. Disponível em: <http://iaassyriology.org/news-and-currentevents/ looting-and-destruction-in-iraq-and-syria>. Acesso em: 8 out. 2015.

THOMASON, A. K. From Sennacherib's Bronzes to Taharqa's Feet: Conceptions of the Material World at Nineveh. Iraq, v. 66, p. 151-162, 2004.

The Sense-scapes of Neo-Assyrian Capital Cities: Royal Authority and Bodily Experience. Cambridge Archaeological Journal, v. 26, n. 2, p. 243-264, 2016.

TILLEY, C. Y. Body and Image: explorations in landscape phenomenology 2. Walnut Creek: Left Coast Pres, 2008.

TURNER, G. Tell Nebi Yunus: the ekal māšarti of Nineveh. Iraq, v. 32, n. 1, p. 68-85, 1970. 
The architecture of the Palace. In: BARNETT, R. D.; BLEIBTREU, E.; TURNER, G. Sculptures from the Southwest Palace of Sennacherib at Nineveh. London: British Museum, 1998. p. 20-39.

VAN DER LEEUW, G. Epilogo - Fenomeno e Fenomenologia. In: Fenomenologia della Religione. Torino: Universale Bollati Boringhieri, 1992. p. 529-535 (Original publicado em 1933).

VERDERAME, L. A glimpse into the activities of experts (ummânu) at the assyrian royal court. In: GASPA, S. et al. From Source to History. Studies on Ancient Near Eastern Worlds and Beyond. Dedicated to Giovanni Battista Lanfranchi on the Occasion of His 65th Birthday on June 23, 2014. Münster: Ugarit-Verlag, 2014. p. 713-728.

VEYNE, P. Fini dell'arte, propaganda e fasto monarchico. In: L'impero grecoromano. Le radici del mondo globale. Tradução de S. Arena, L. C. Dapelli, S. Stucchi. Milano: Bur Rizzoli, 2010.

VLASSOPOULOS, K. Unthinking the Greek Polis. Ancient Greek History beyond Eurocentrism. Cambridge: Cambridge University Press, 2007.

WATANABE, C. E. The "continuous style" in the narrative scheme of Assurbanipal's reliefs. Iraq, v. 66, p. 103-114, 2004.

Styles of Pictorial Narratives in Assurbanipal's Reliefs. In: In: BROWN, B. A.; FELDMAN, M. H. (Org.). Critical approaches to Ancient Near Eastern art. Berlin: De Gruyter, 2014. p. 345-367.

WINTER, I. J. The body of the able ruler: toward an understanding of the statues of Gudea. In: BEHRENS, H. et al. (Org.). Dumu-É-dub-ba-a: Studies in honor of A. W. Sjöberg. Philadelphia: The University Museum, 1989. p. 573-583.

. "Seat of Kingship"/“A Wonder to Behold": The Palace as Construct in the Ancient Near East. Ars Orientalis, v. 23, p. 27-55, 1993.

Aesthetics in Ancient Mesopotamian Art. In: SASSON, J. M. Civilizations of the Ancient Near East. Massachusetts: Hendrickson Publishers, 2000. p. 2569-2582.

Royal Rhetoric and the Development of Historical Narrative in Neo-Assyrian Reliefs. In: (Org.). On Art in the Ancient Near East. v. 1. Leiden: Brill, 2010a. p. 3-70. (Original publicado em 1981).

Art in Empire: the royal image and the visual dimensions of assyrian ideology. In:

. (Org.). On Art in the Ancient Near East. v. 1. Leiden: Brill, 2010b. p. 71-108. (Original publicado em 1997).

Sex, Rhetoric, and the Public Monument: The alluring body Of Naram-Sin of Agade. In: _ (Org.). On Art in the Ancient Near East. V. 2. Leiden: Brill, 2010c. p. 85-107. (Original publicado em 1996). 
ZORZI, N. Divinazione e intertestualità: La serie divinatoria Shumma izbu e il suo orizzonte culturale. 2010. 742 f. Tese (Doutorado em História Antiga e Arqueologia). Università Ca'Foscari, Venezia, 2010.

The omen series Šumma izbu: internal structure and hermeneutic strategies. KASKAL, v. 8, p. 43-75, 2011. 
APÊNDICE 
Figura 1 - Mapa do núcleo da Região Mesopotâmica.

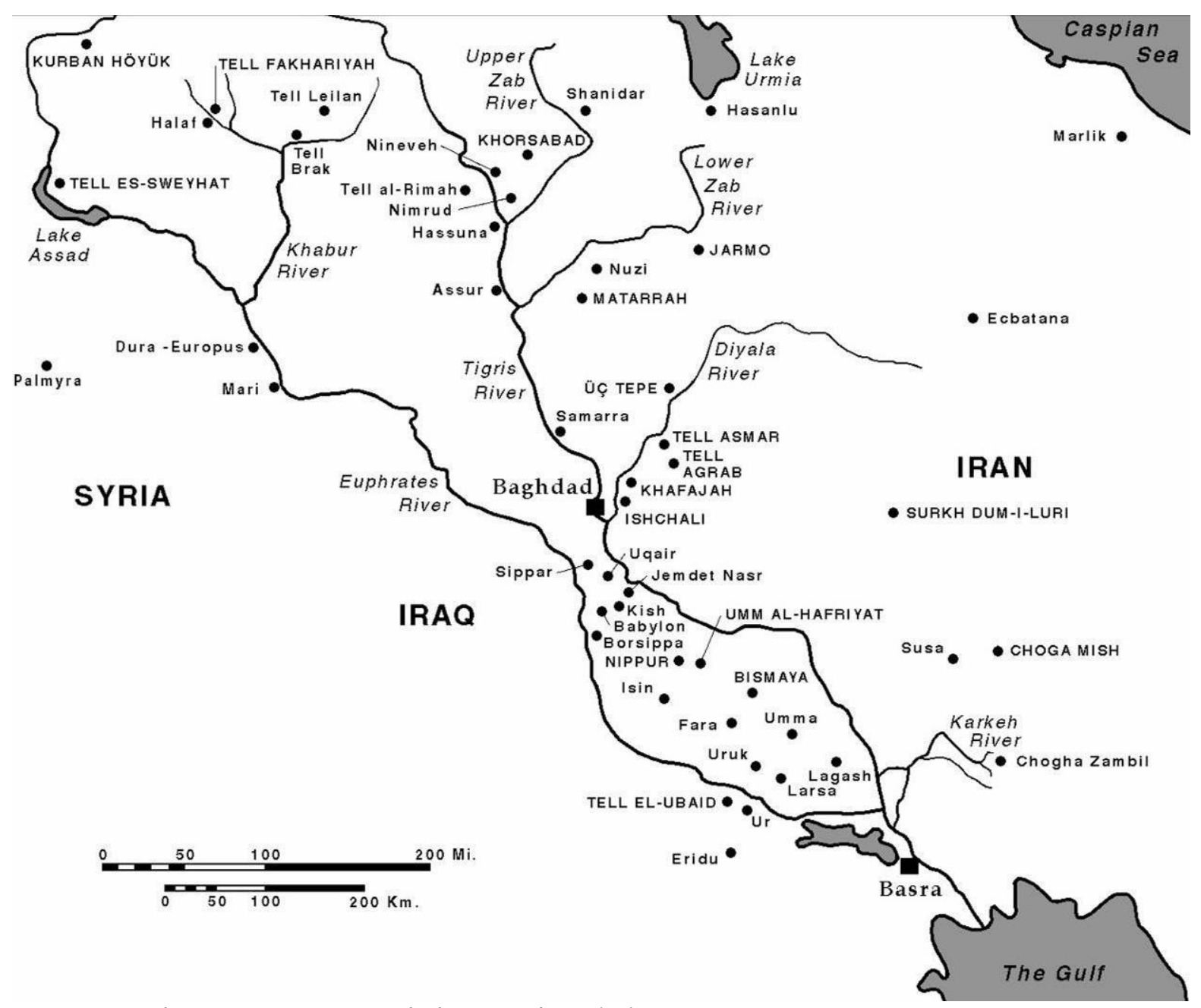

Fonte: Oriental Institute, University of Chicago. Disponível em:

$<$ https://oi.uchicago.edu/sites/oi.uchicago.edu/files/uploads/shared/images/archive/Iraq_Site_300dpi.gif >. Acesso: 3 mar. 2016. Adaptado por Ranieri. 
Figura 2 - Mapa do núcleo assírio na Alta Mesopotâmia.

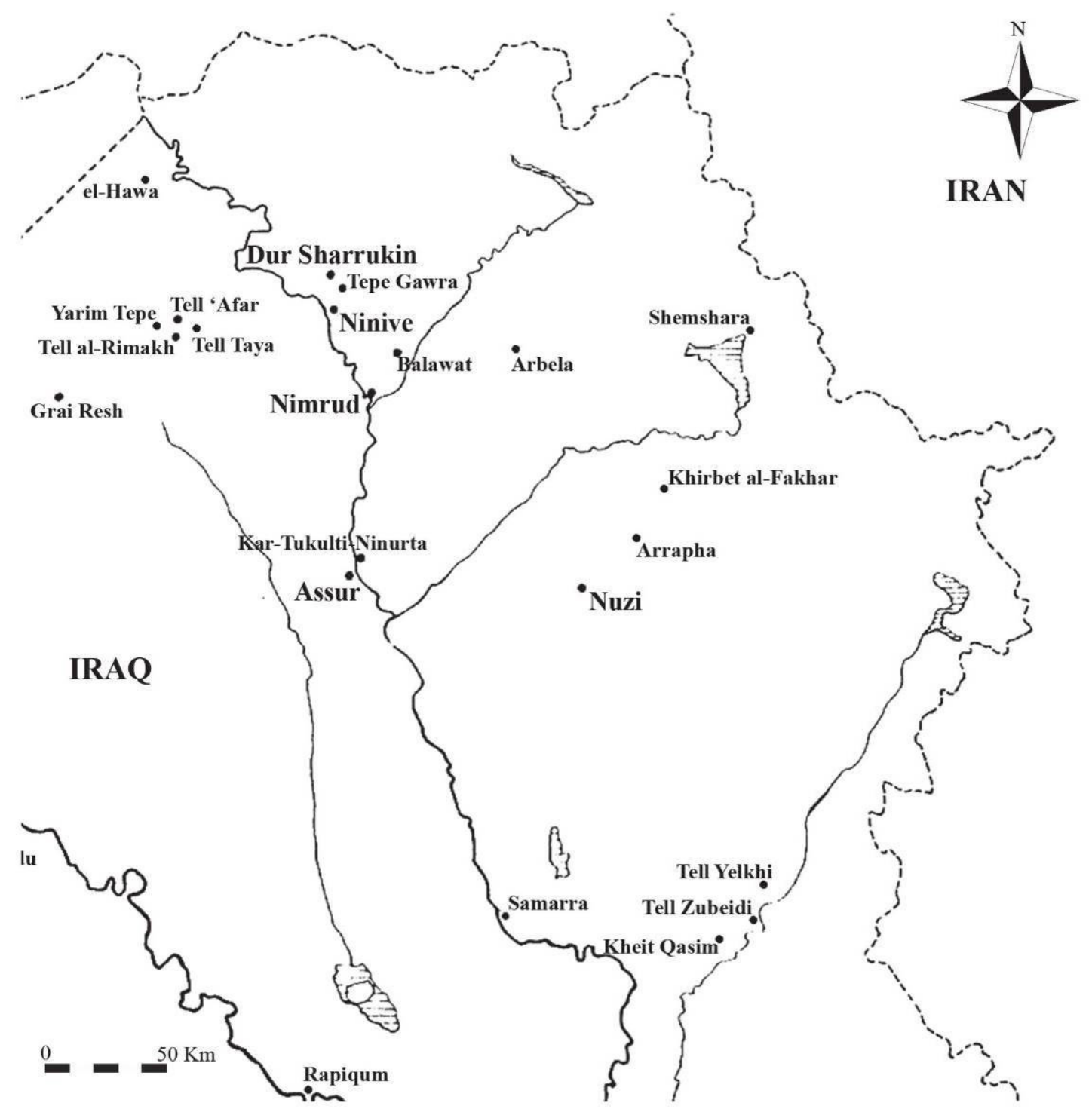

Fonte: Nadali e Polcaro (2015). Adaptado por Ranieri. 
Figura 3 - Reconstrução da cidade de Nínive.

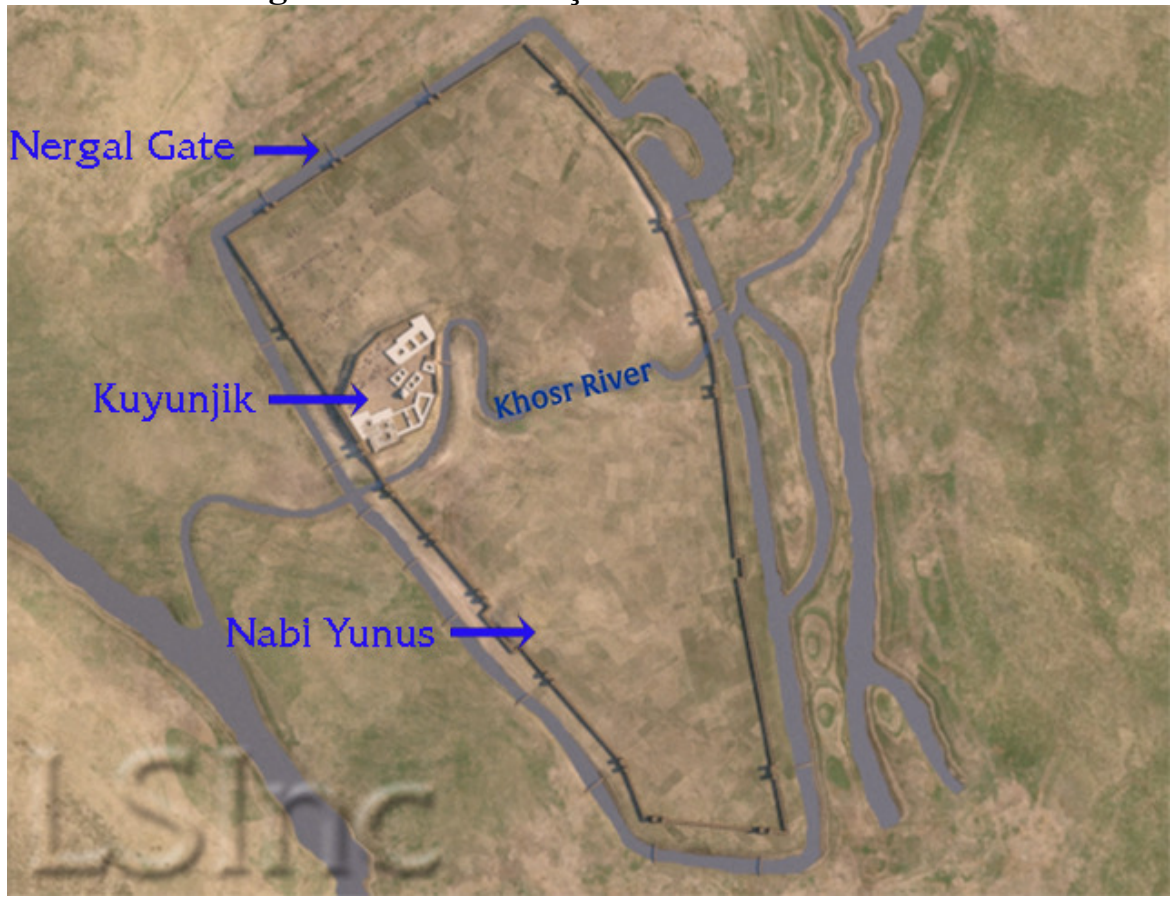

Fonte: OLearning Sites. Disponível em:

$<$ http://www.learningsites.com/Nineveh/Nineveh_pix/LSInc_Nineveh_aerial01.jpg > Acesso em: Acesso: 26 out. 2017. Adaptada por Ranieri.

Figura 4 - Reconstrução do monte Kuyunjik, cidadela de Nínive.

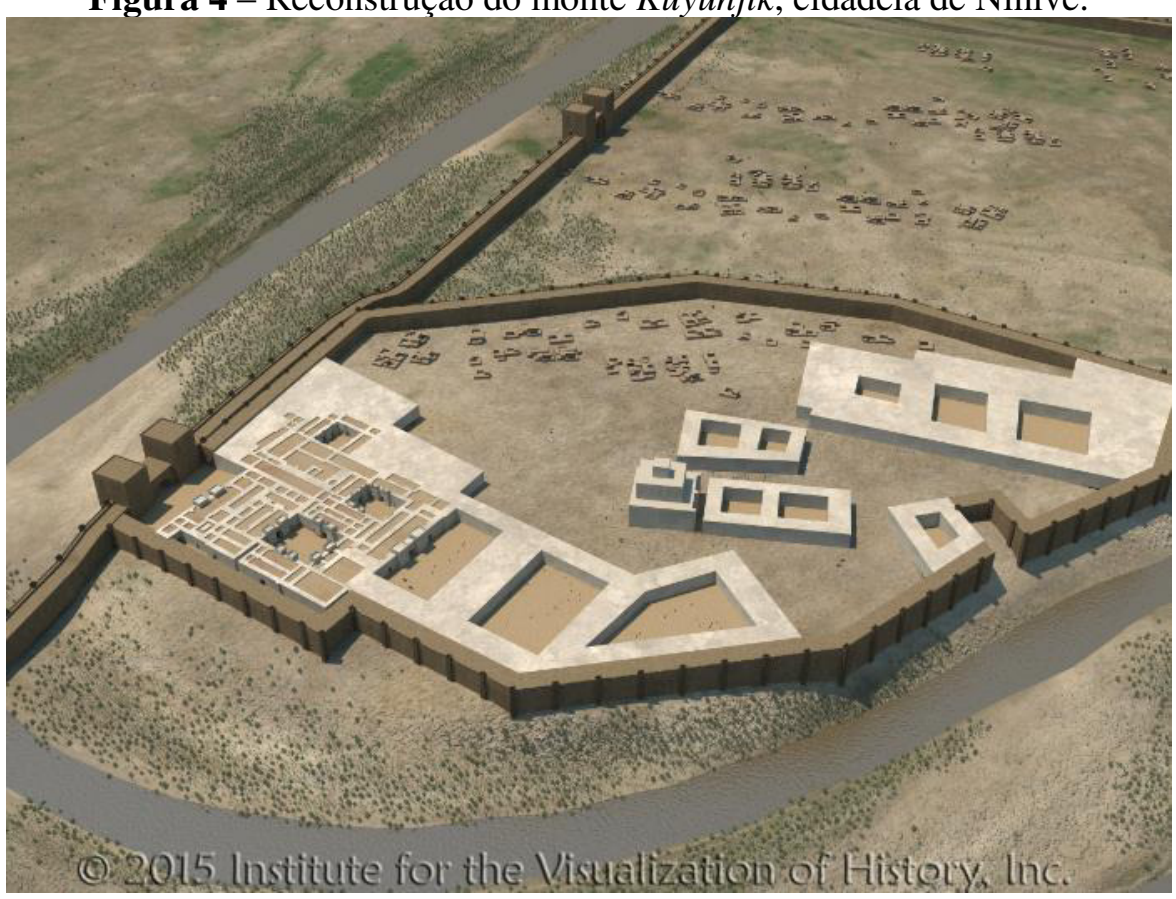

Fonte: (C) Institute for the Visualization of History. Disponível em:

$<$ http://www.learningsites.com/Nineveh/Nineveh_home.php>. Acesso: 26 out. 2017. Adaptada por Ranieri. 
Figura 5 - Plano reconstrutivo do monte Kuyunjik, a partir do plano de Thompson (1934).

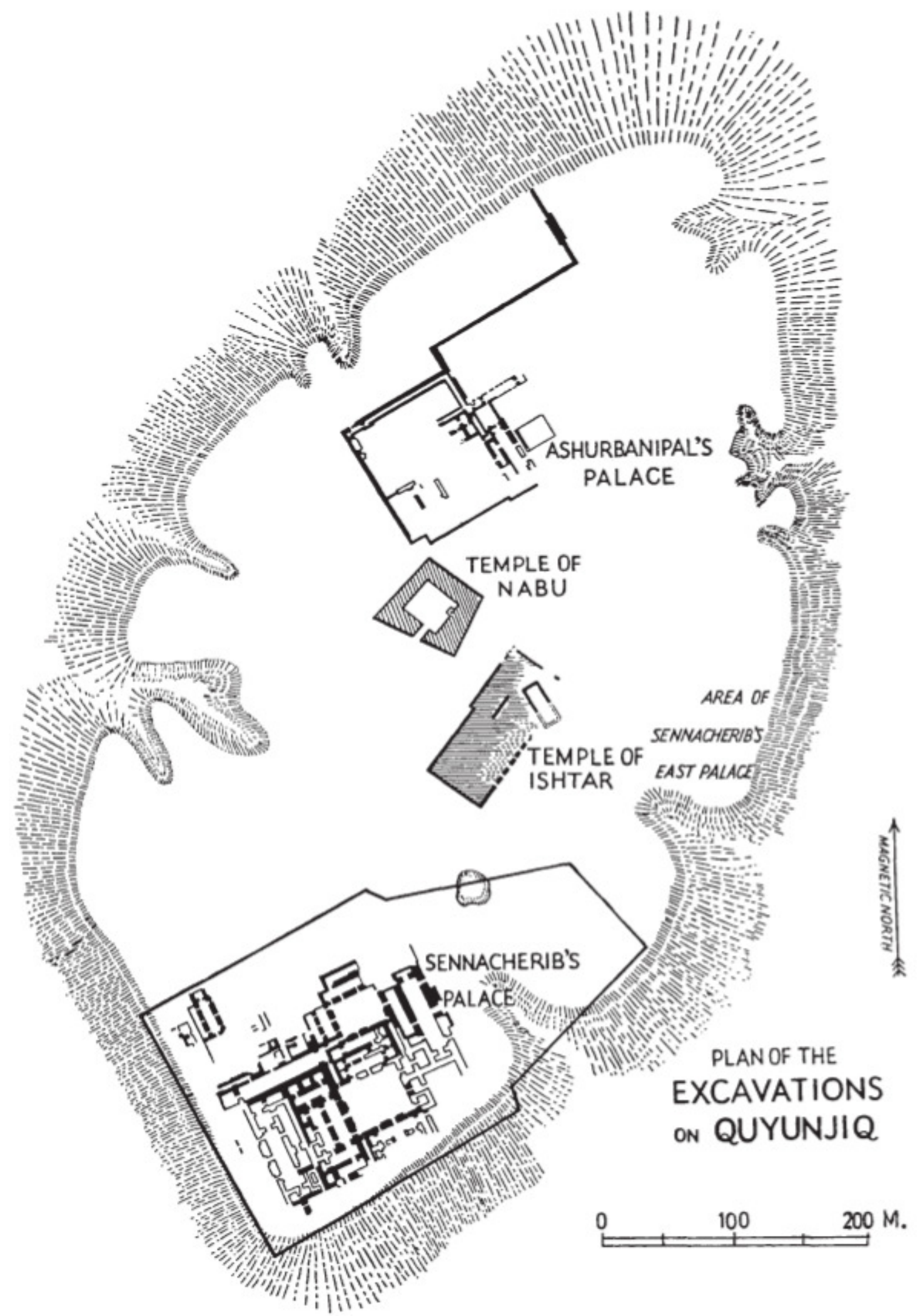

Fonte: Barnett, Bleibtreu e Turner (1998, p. 21). Adaptada por Ranieri. 
Figura 6 - Plano baixo do Palácio Sudoeste de Nínive, de Senaqueribe (PATERSON, 1915).

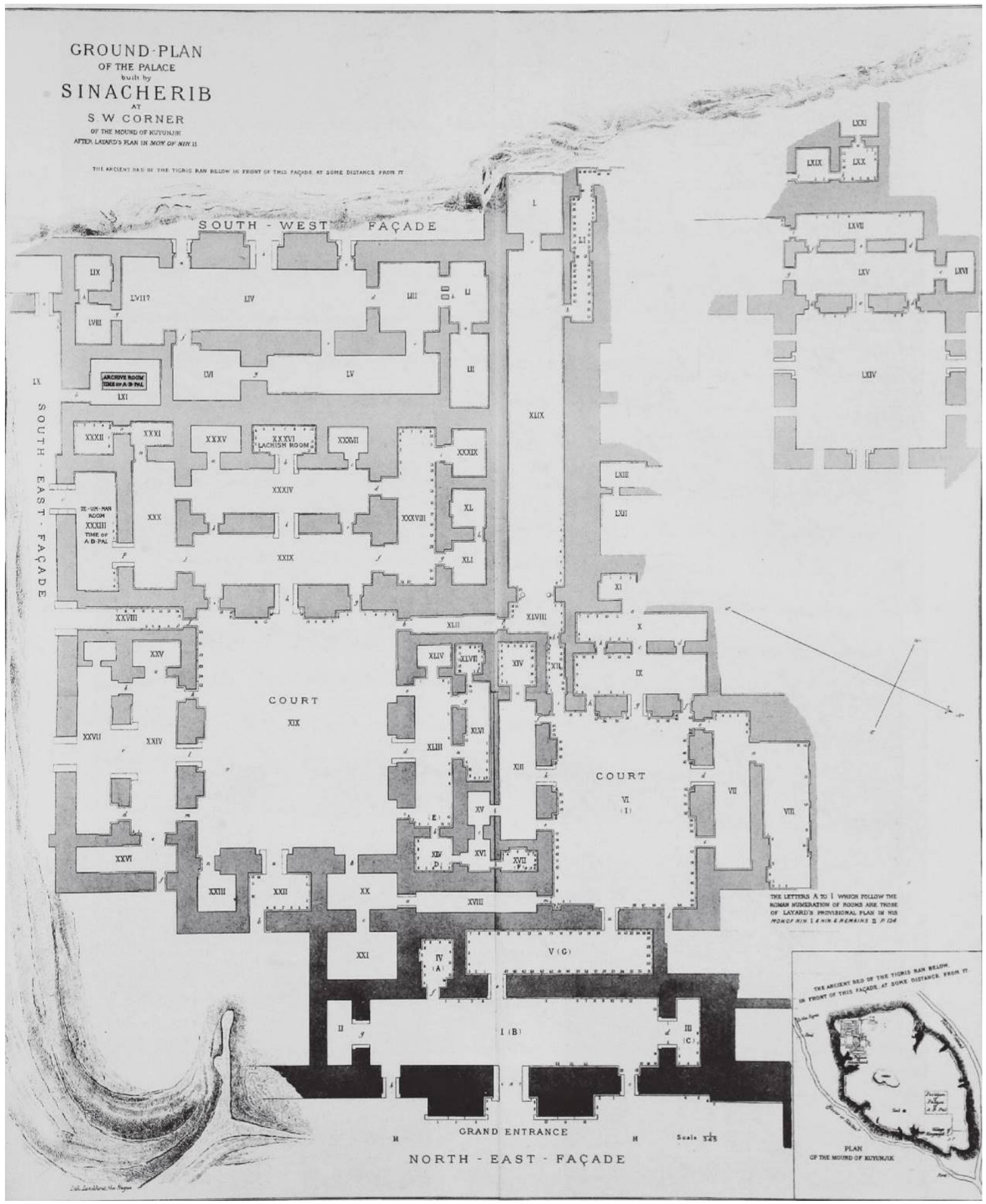

Fonte: Barnett, Bleibtreu e Turner (1998, prancha 15). Adaptado por Ranieri. 
Figura 7 - Plano baixo do Palácio Sudoeste de Nínive, de Senaqueribe (KERTAI, 2015a).

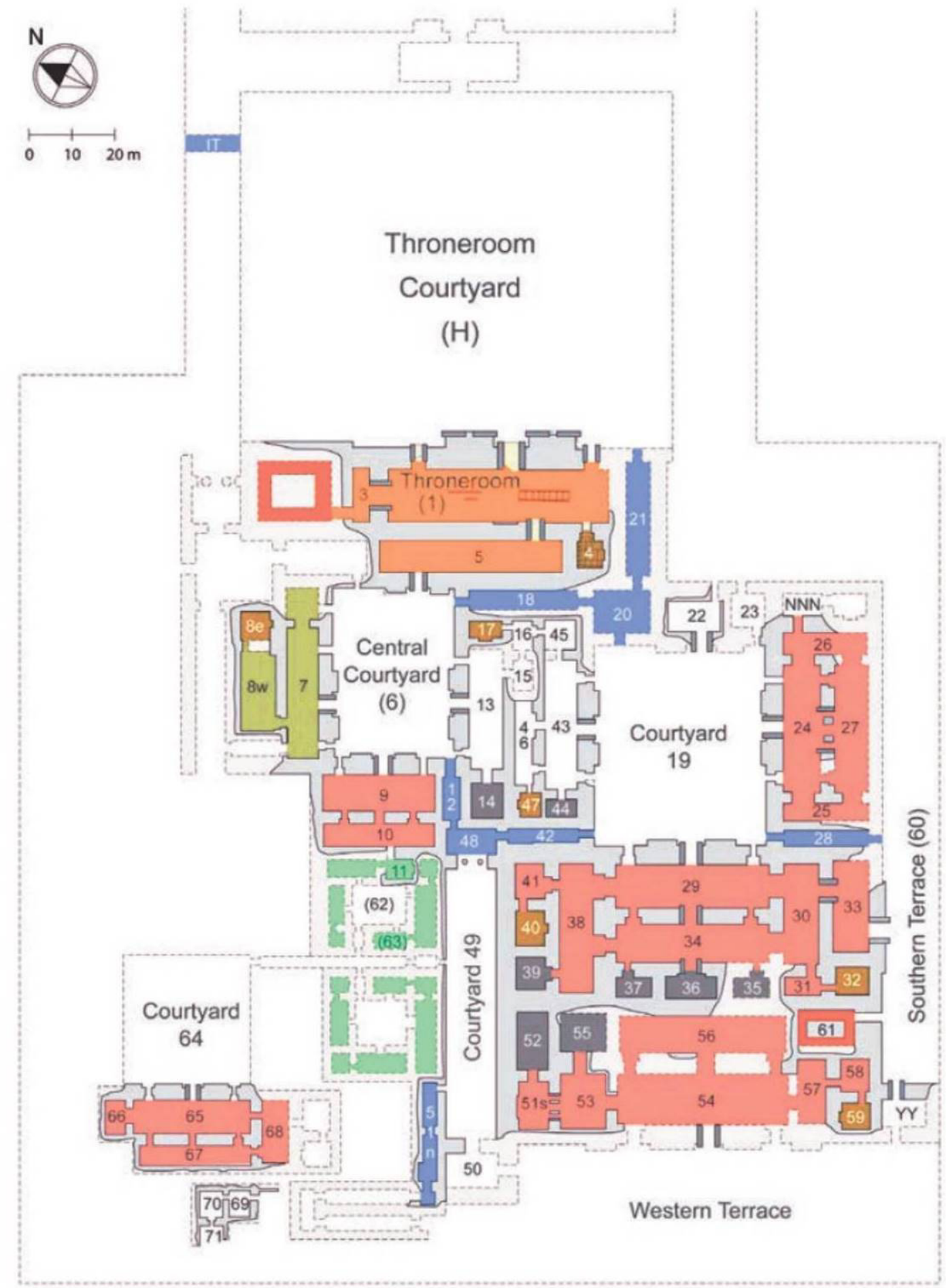

Fonte: Kertai (2015a, fig. 17). Adaptado por Ranieri. 
Figura 8 - Plano baixo do Palácio Norte de Nínive, de Assurbanipal II (BARNETT, 1976).

\section{NINEVEH}

NORTH PALACE
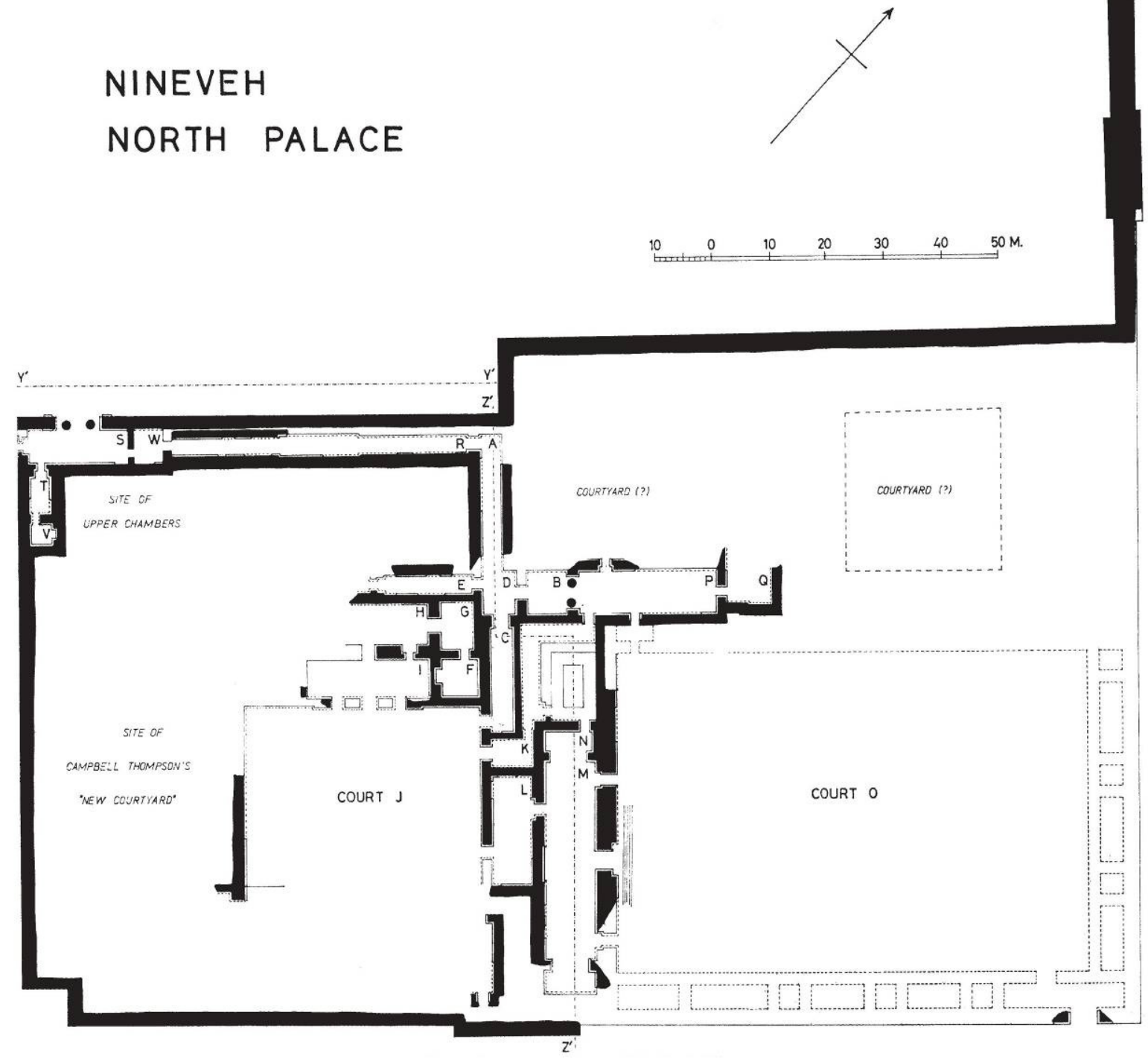

Fonte: Barnett (1976, p. 28). Adaptado por Ranieri. 
Figura 9 - Plano baixo do Palácio Norte de Nínive, de Assurbanipal II (KERTAI, 2015a).

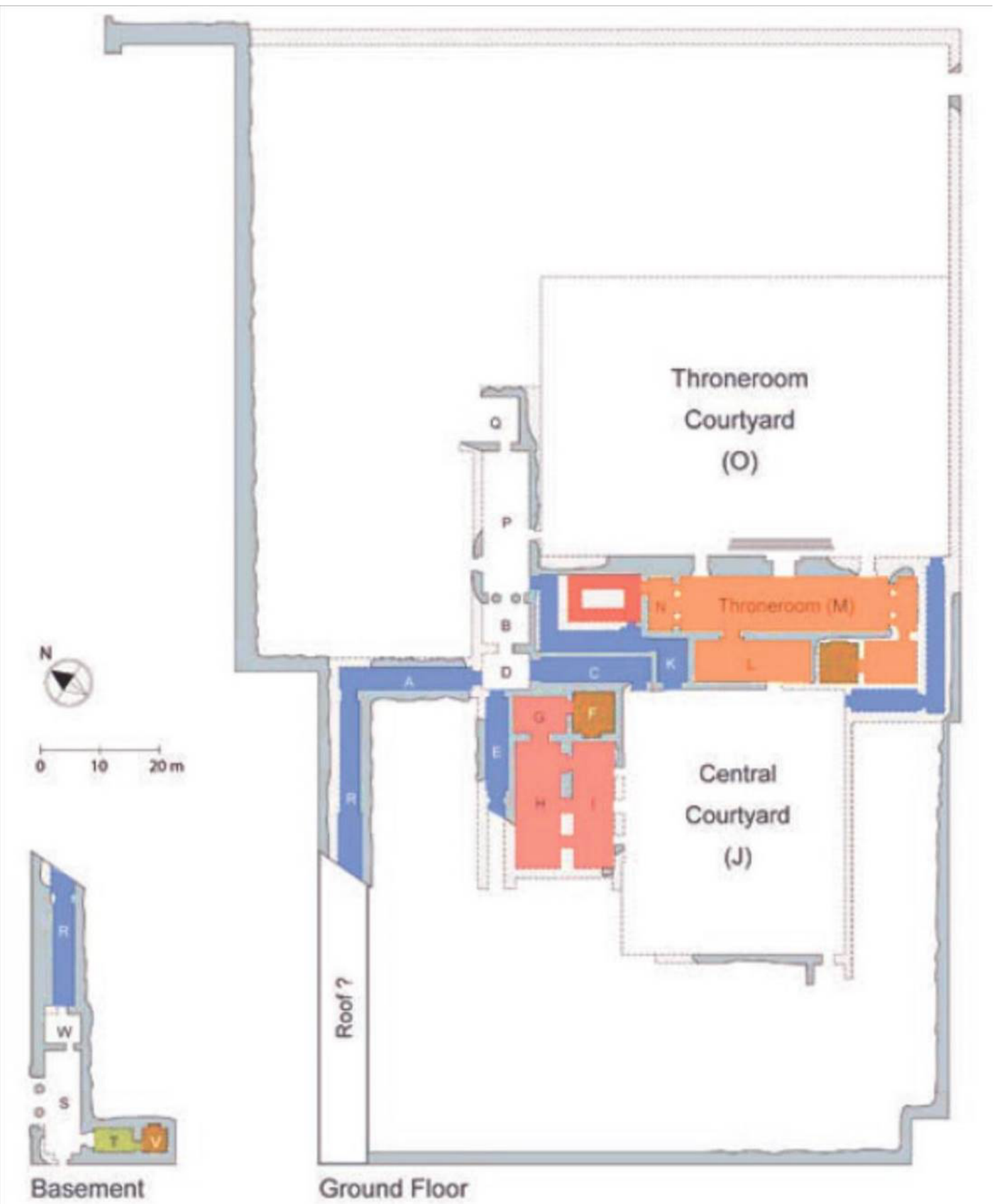

Fonte: KERTAI (2015a, fig. 19). Adaptado por Ranieri. 
Figura 10 - Relevos da sala VI do Palácio Sudoeste de Nínive (placa 13).

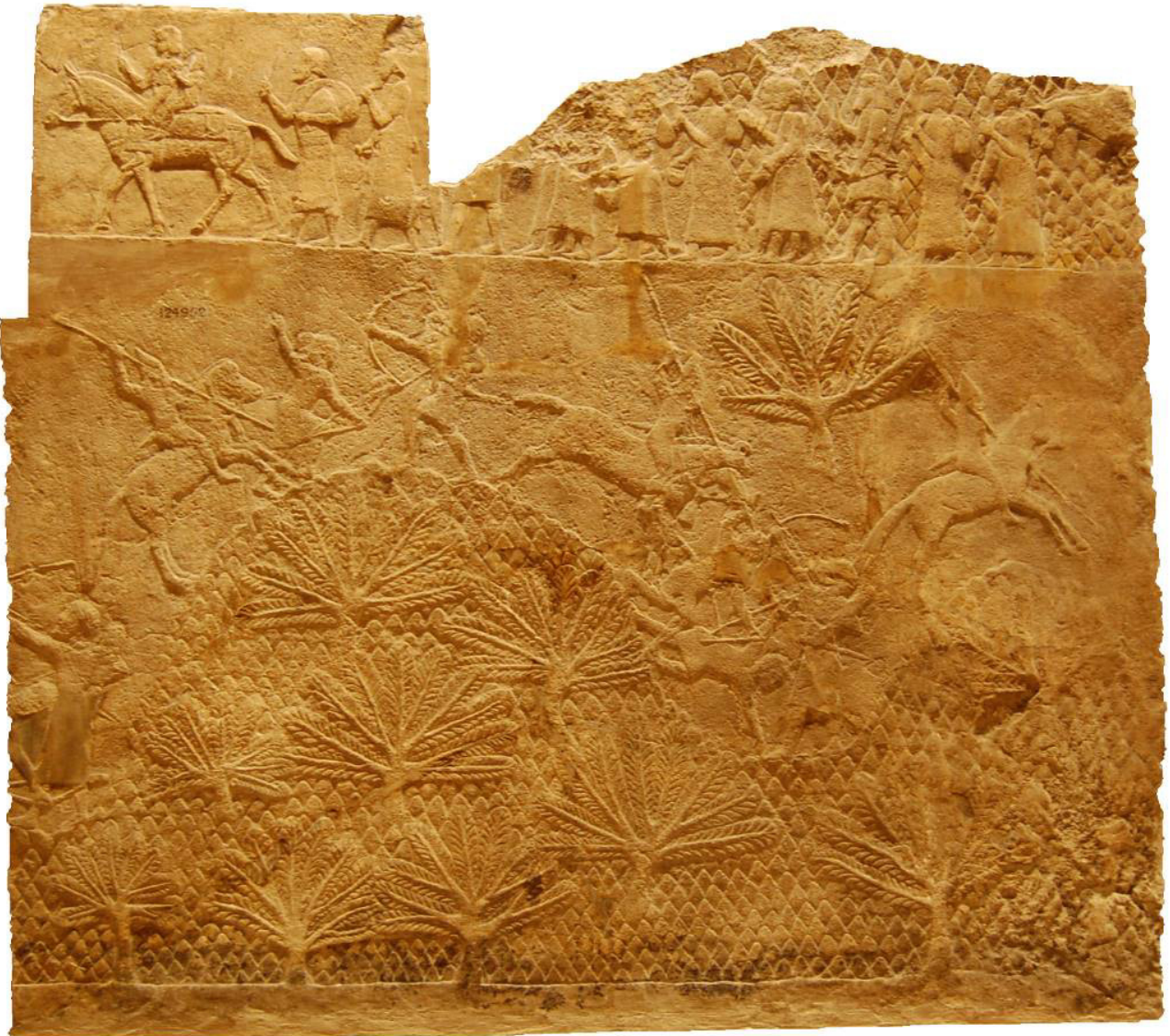

Fonte: (OThe Trustees of the British Museum (BM 124952). Adaptada por Ranieri.

Figura 11 - Relevos da sala VI do Palácio Sudoeste de Nínive (placa 53).

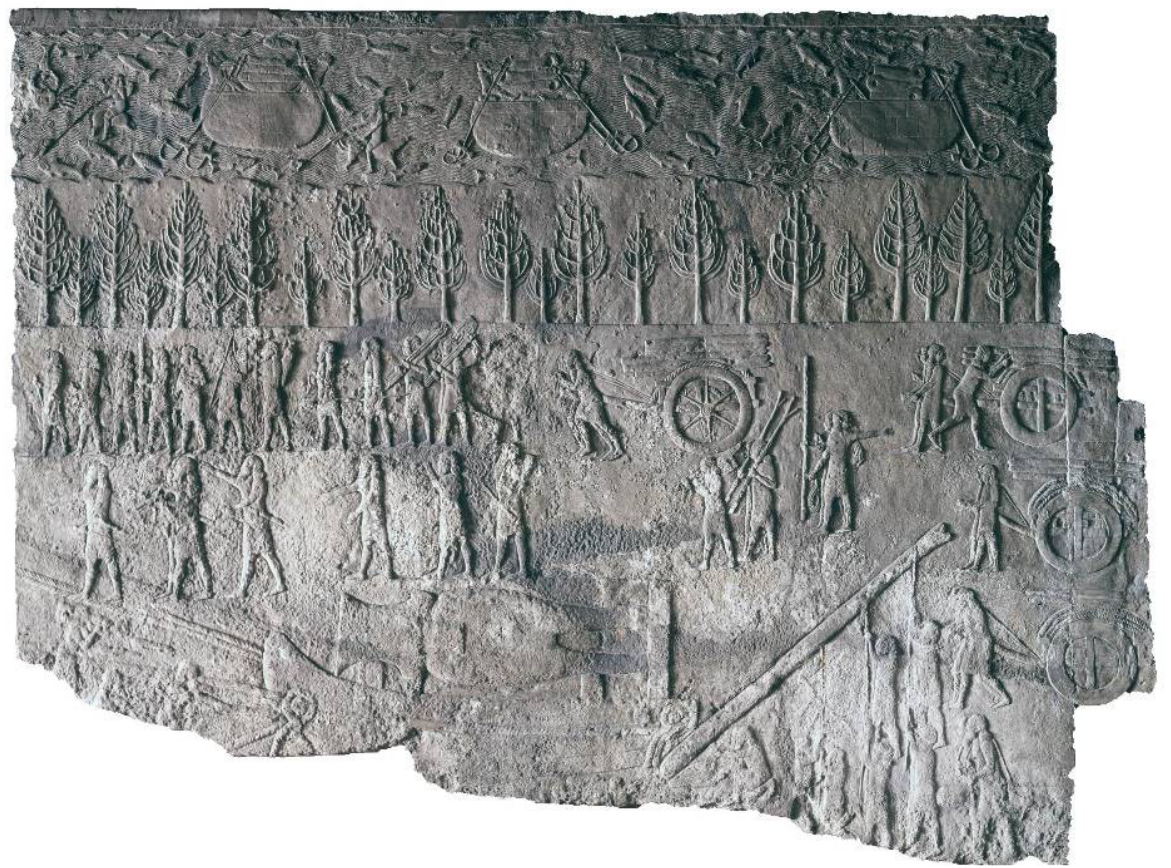

Fonte: @The Trustees of the British Museum (BM 124823). Adaptada por Ranieri. 
Figura 12 - Relevos da sala VI do Palácio Sudoeste de Nínive (placa 59 ou 60).

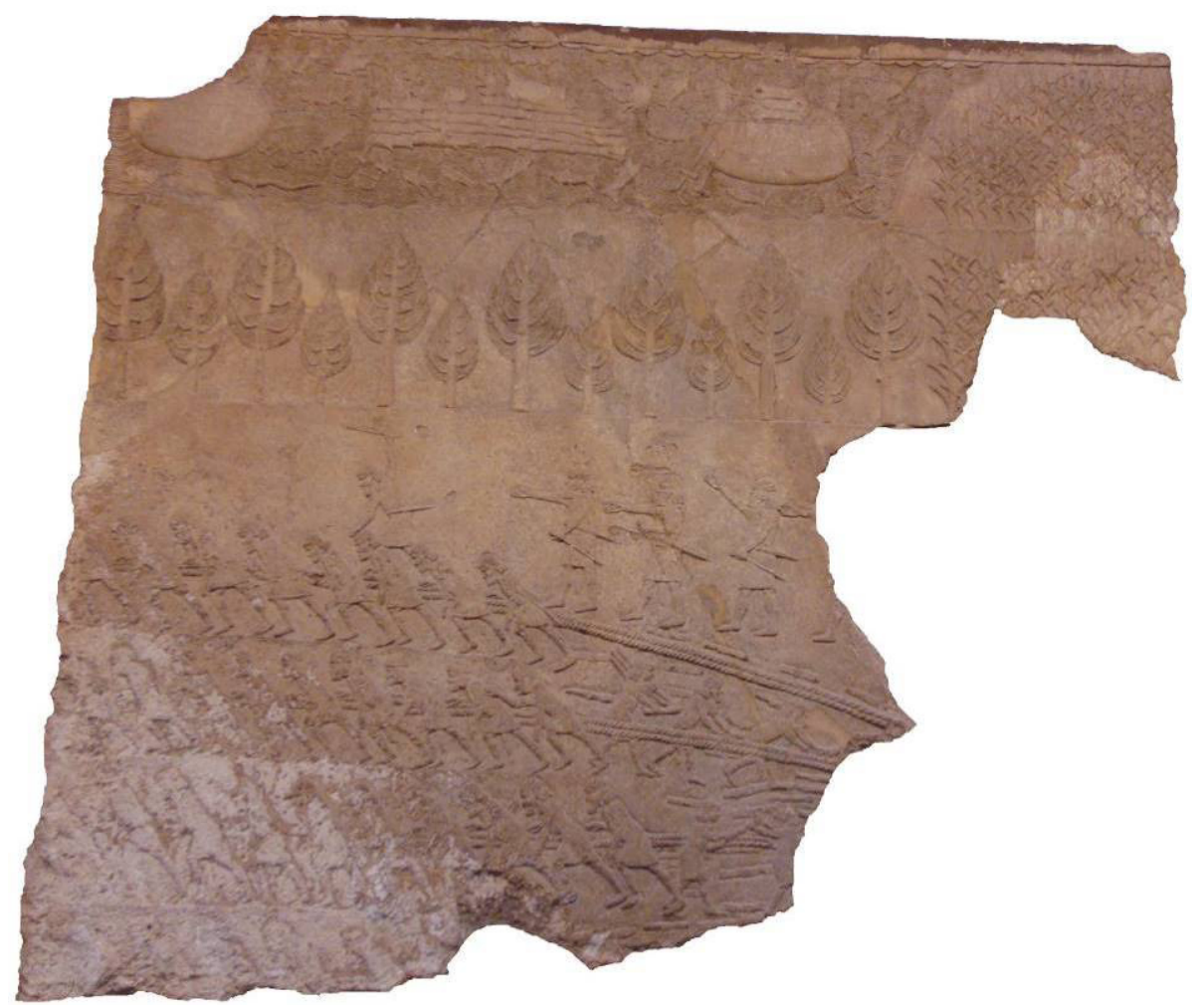

Fonte: (OThe Trustees of the British Museum (BM 124822). Adaptada por Ranieri.

Figura 13 - Relevos da sala VI do Palácio Sudoeste de Nínive (placa 61).

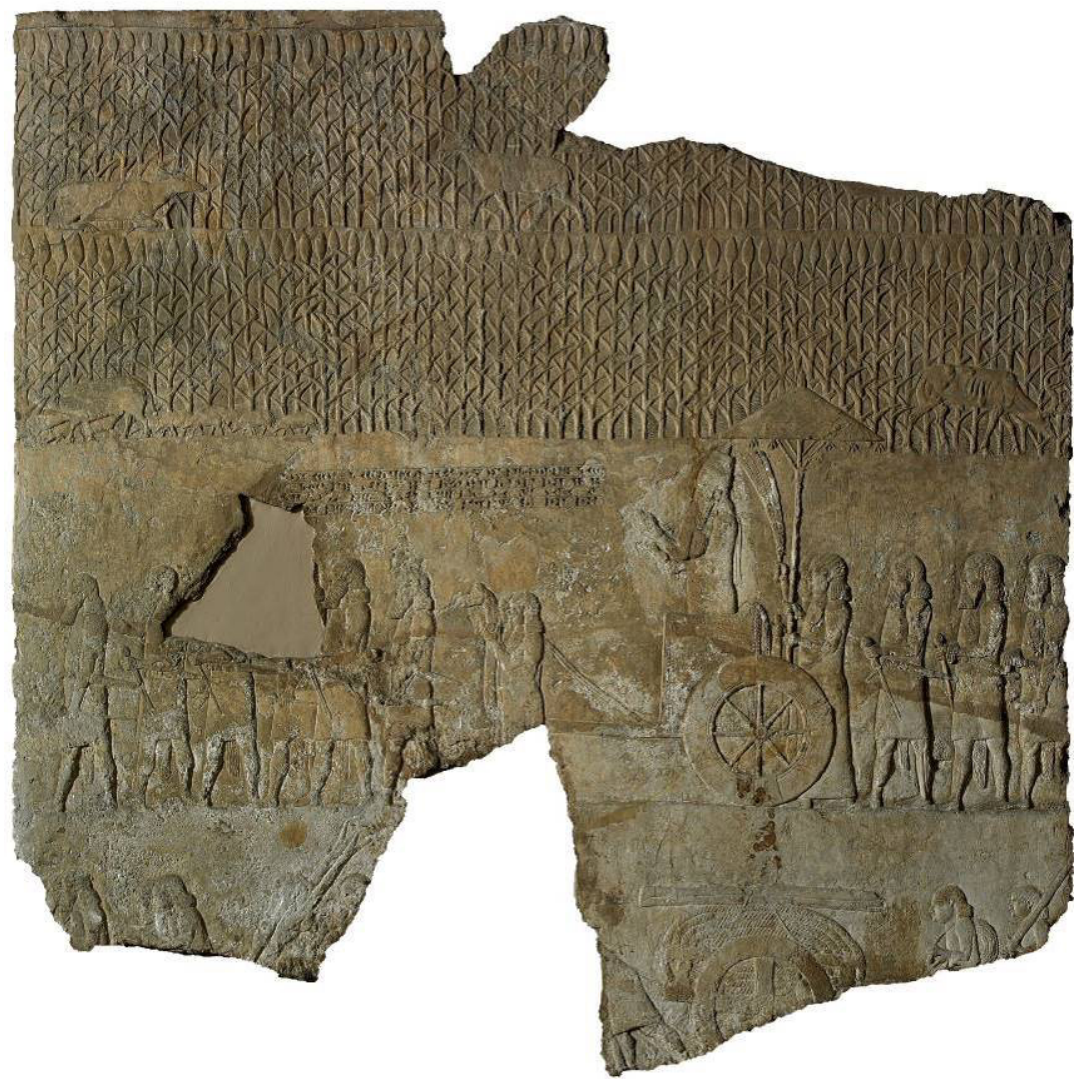

Fonte: @The Trustees of the British Museum (BM 124824). Adaptada por Ranieri. 
Figura 14 - Relevos da sala VI do Palácio Sudoeste de Nínive (placa 63).

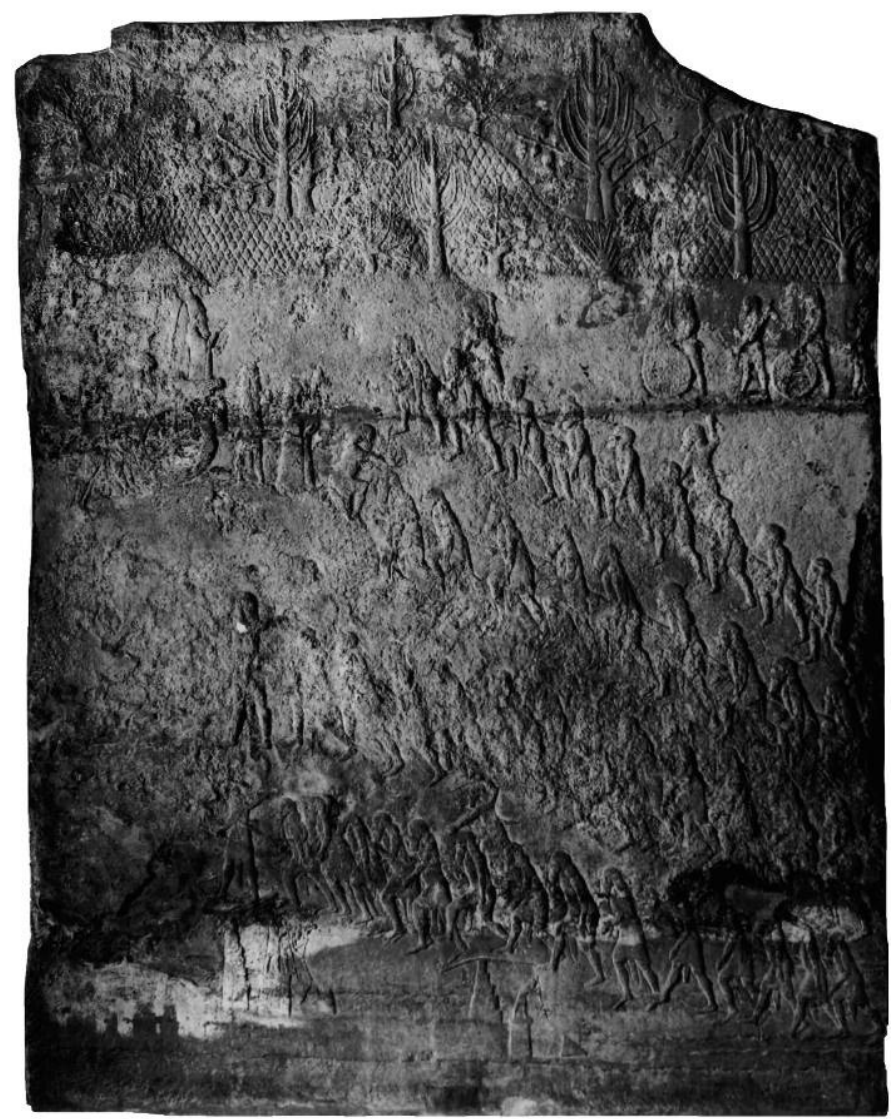

Fonte: Barnett (1976, prancha 114) (BM 124820a). Adaptada por Ranieri.

Figura 15 - Relevos da sala VI do Palácio Sudoeste de Nínive (placa 64).

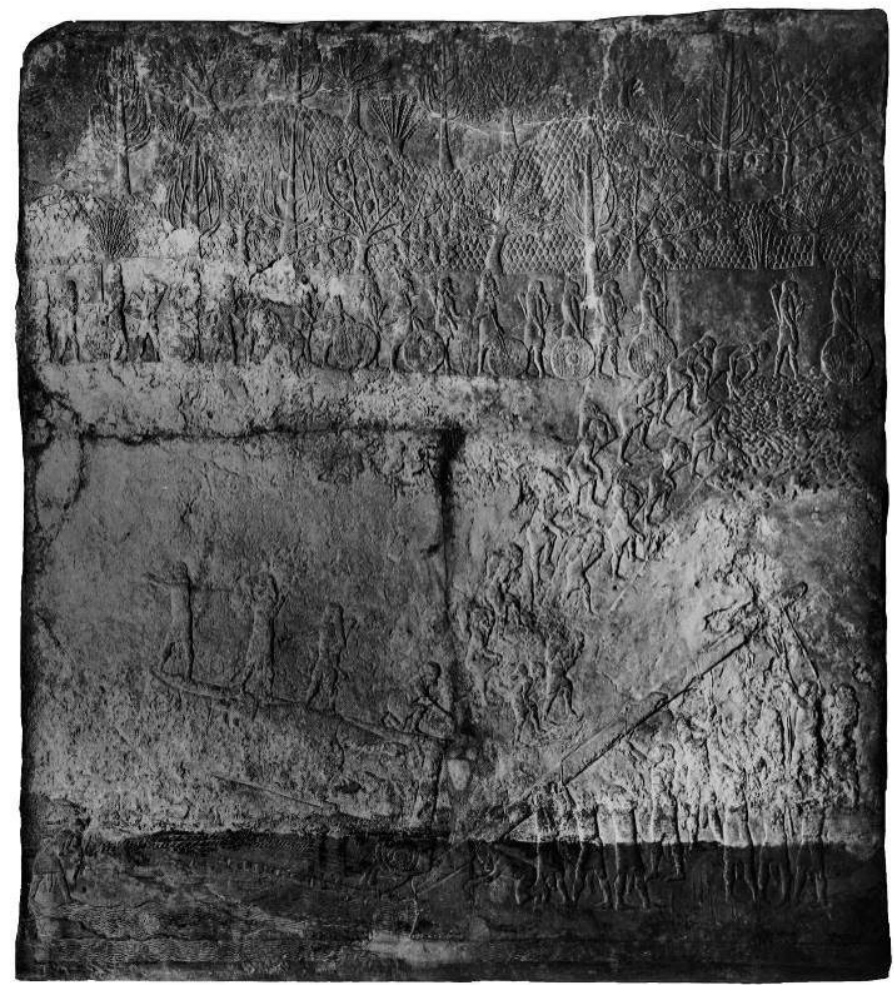

Fonte: Barnett (1976, prancha 115) (BM 124820b). Adaptada por Ranieri. 
Figura 16 - Relevos da sala VI do Palácio Sudoeste de Nínive (placa 66).

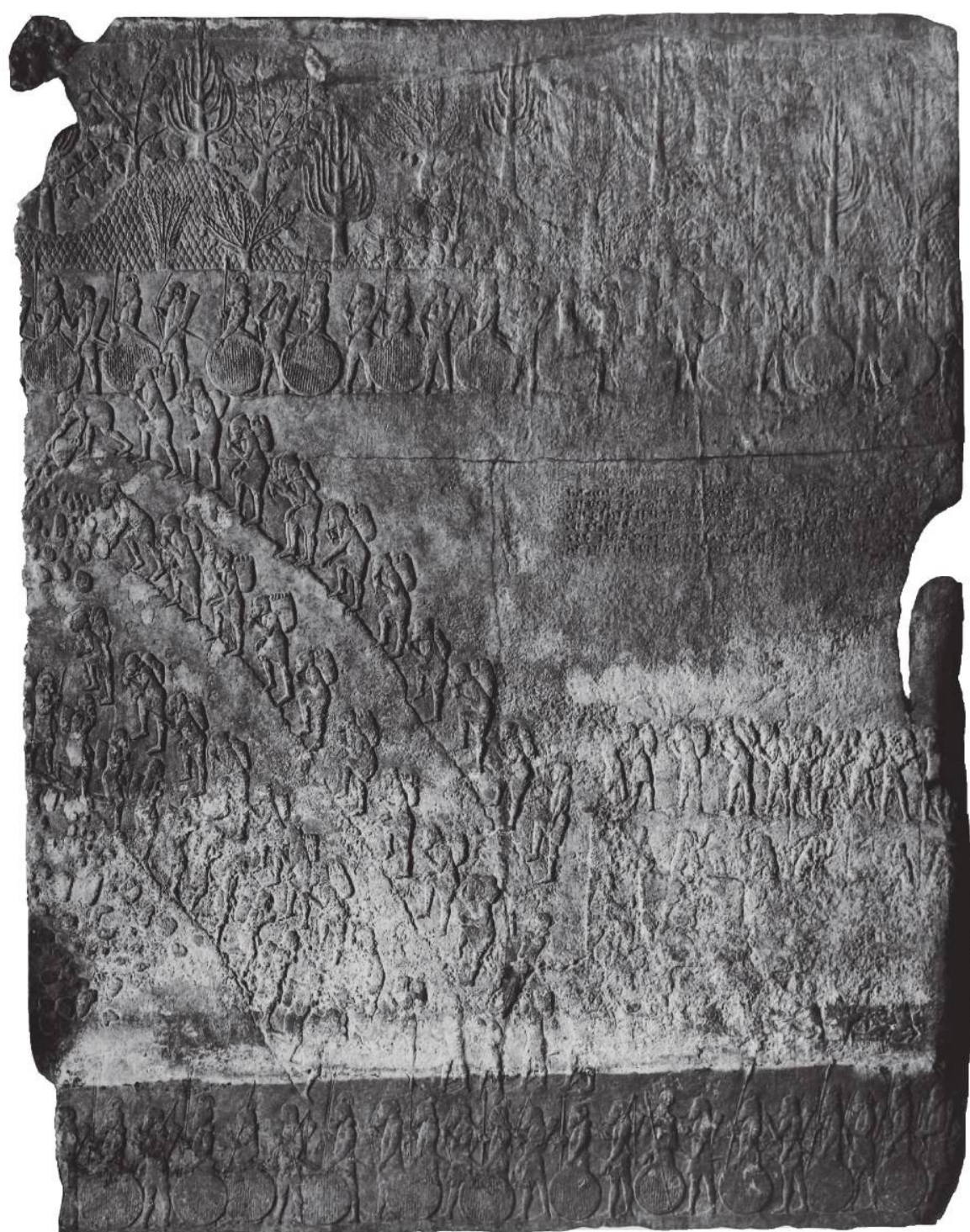

Fonte: Barnett (1976, prancha 119) (BM 124821a-b). Adaptada por Ranieri. 
Figura 17 - Relevos da sala XIV do Palácio Sudoeste de Nínive (placa 4).

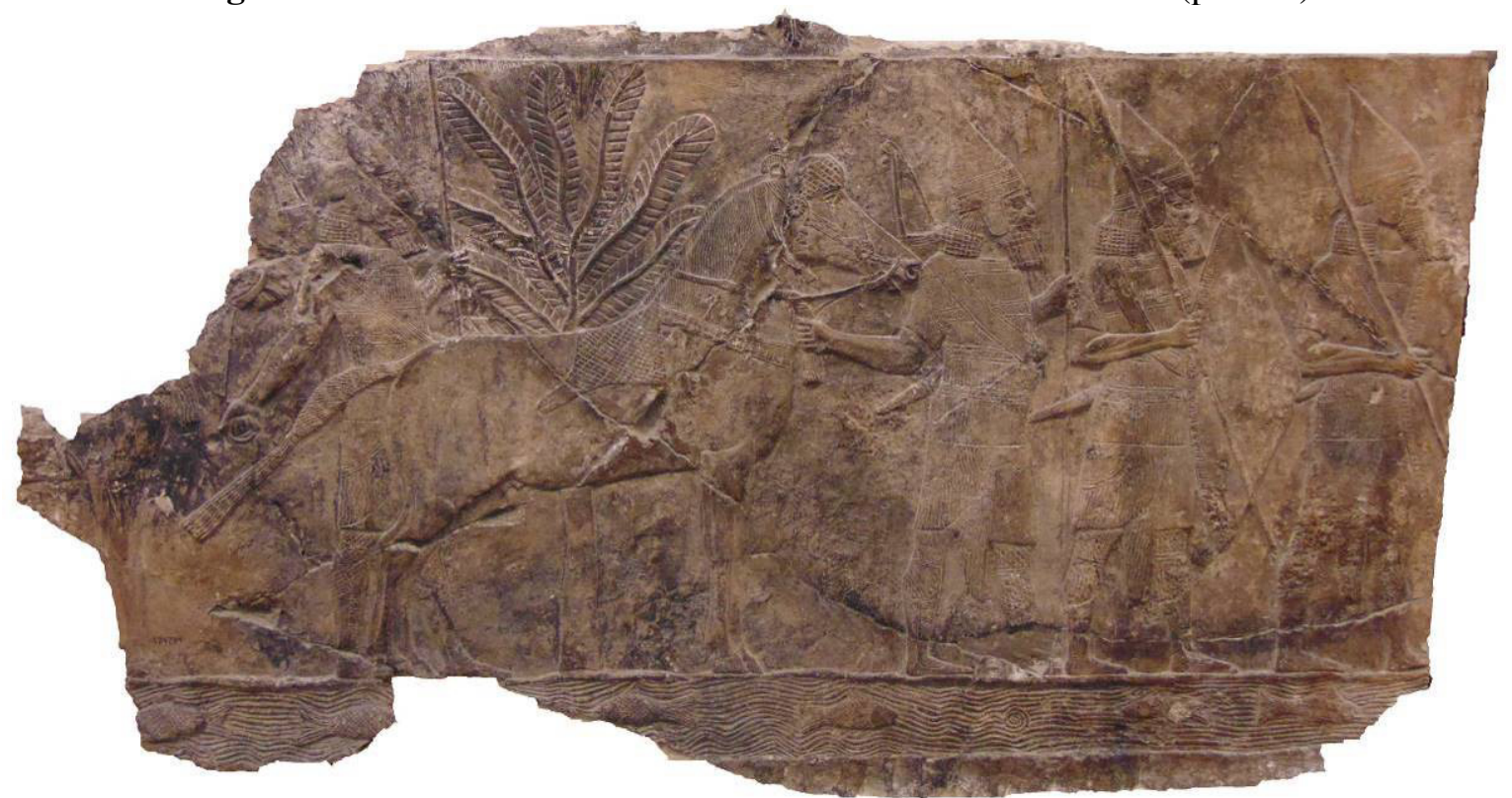

Fonte: (T) The Trustees of the British Museum (BM 124784a). Fotografia realizada e adaptada por Ranieri.

Figura 18 - Relevos da sala XIV do Palácio Sudoeste de Nínive (placa 5).

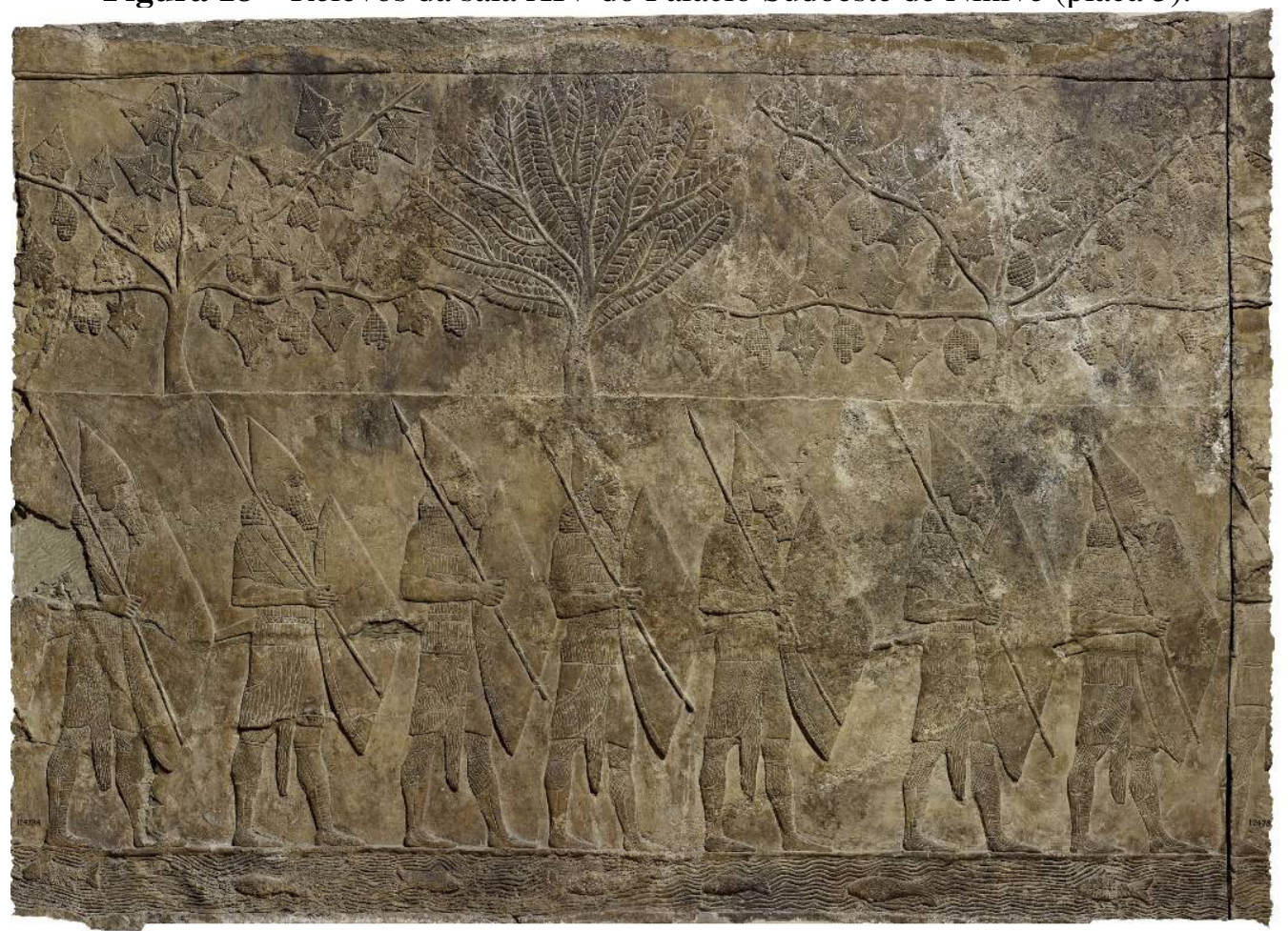

Fonte: (T) The Trustees of the British Museum (BM 124784b). Adaptada por Ranieri. 
Figura 19 - Relevos da sala XIV do Palácio Sudoeste de Nínive (placa 6).

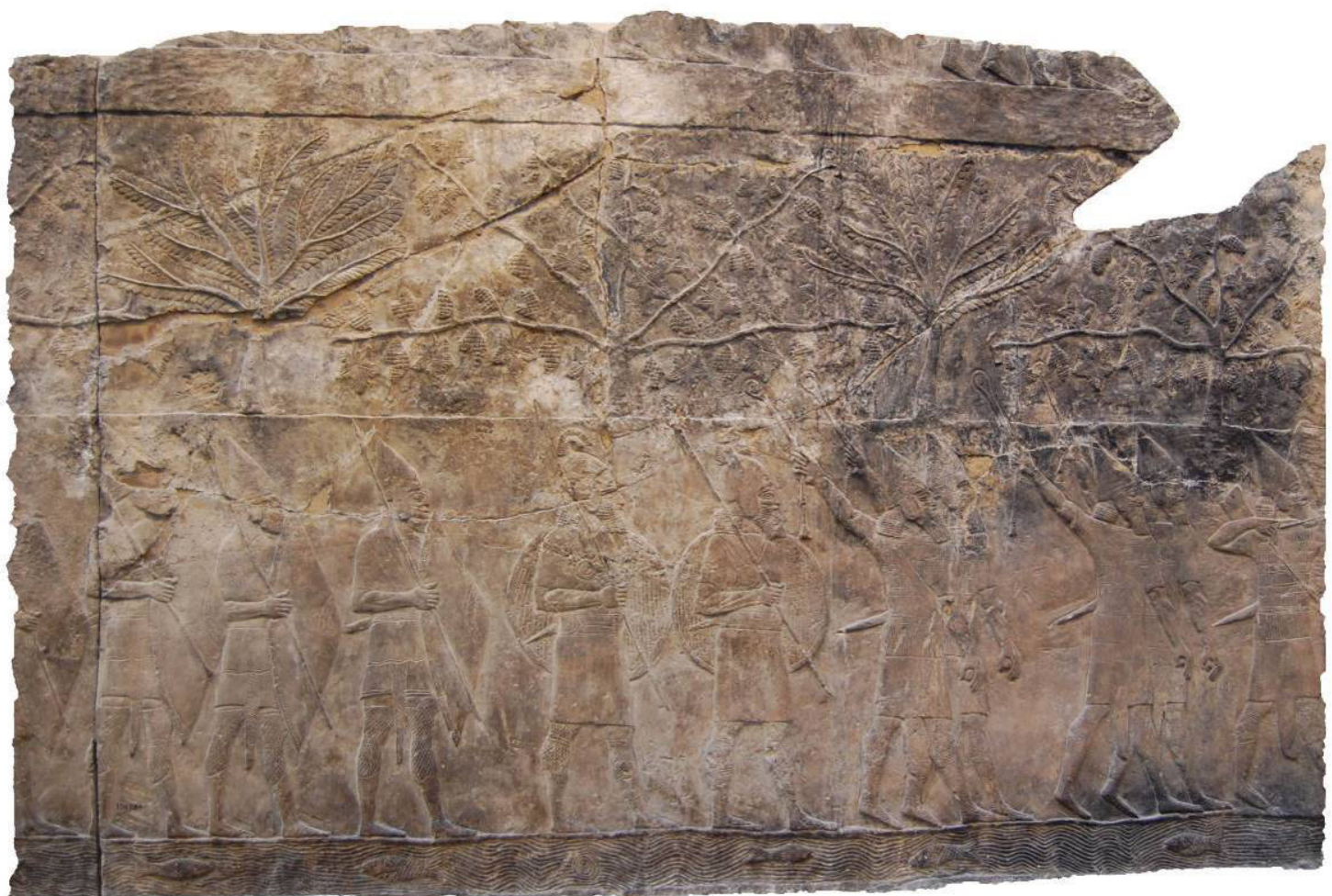

Fonte: (OThe Trustees of the British Museum (BM 124784c). Adaptada por Ranieri.

Figura 20 - Relevos da sala XIV do Palácio Sudoeste de Nínive (placas 8-9).

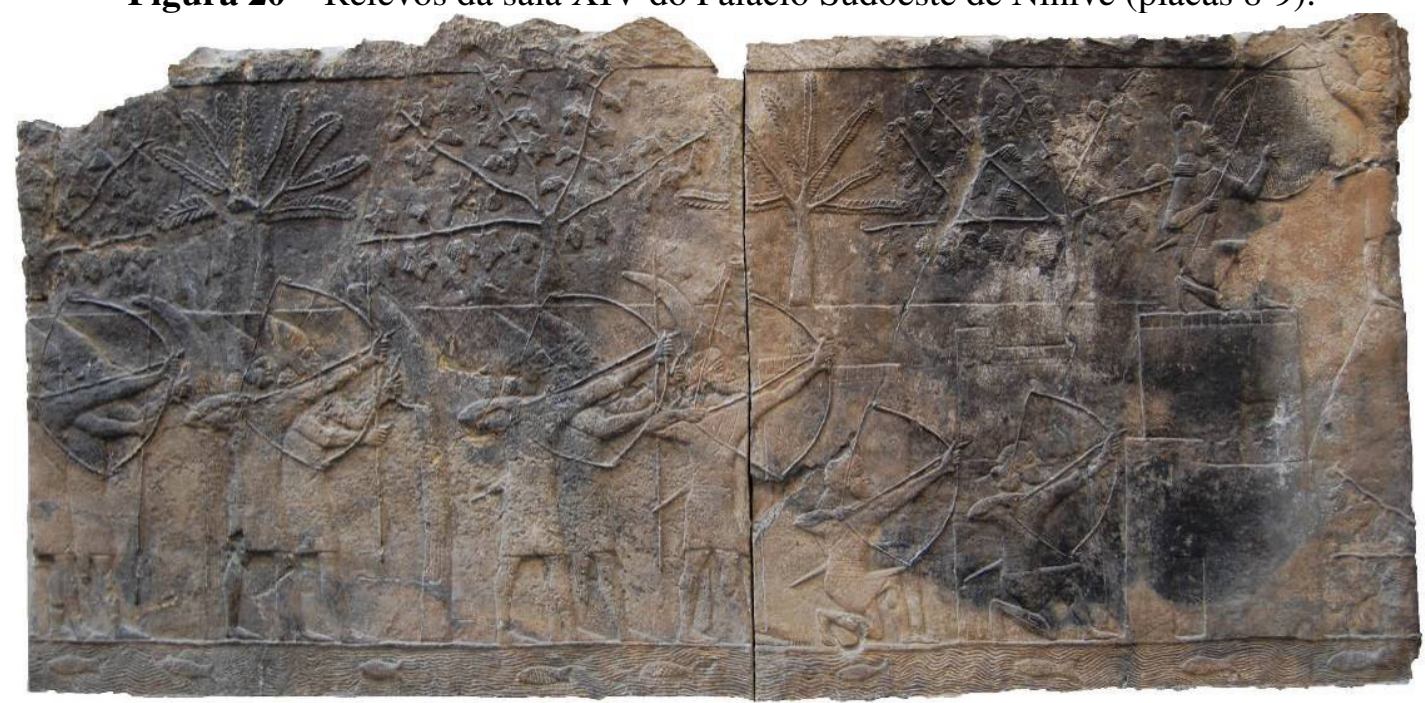

Fonte: @The Trustees of the British Museum (BM 124785a-b). Adaptada por Ranieri. 
Figura 21 - Relevos da sala XIV do Palácio Sudoeste de Nínive (placa 10).

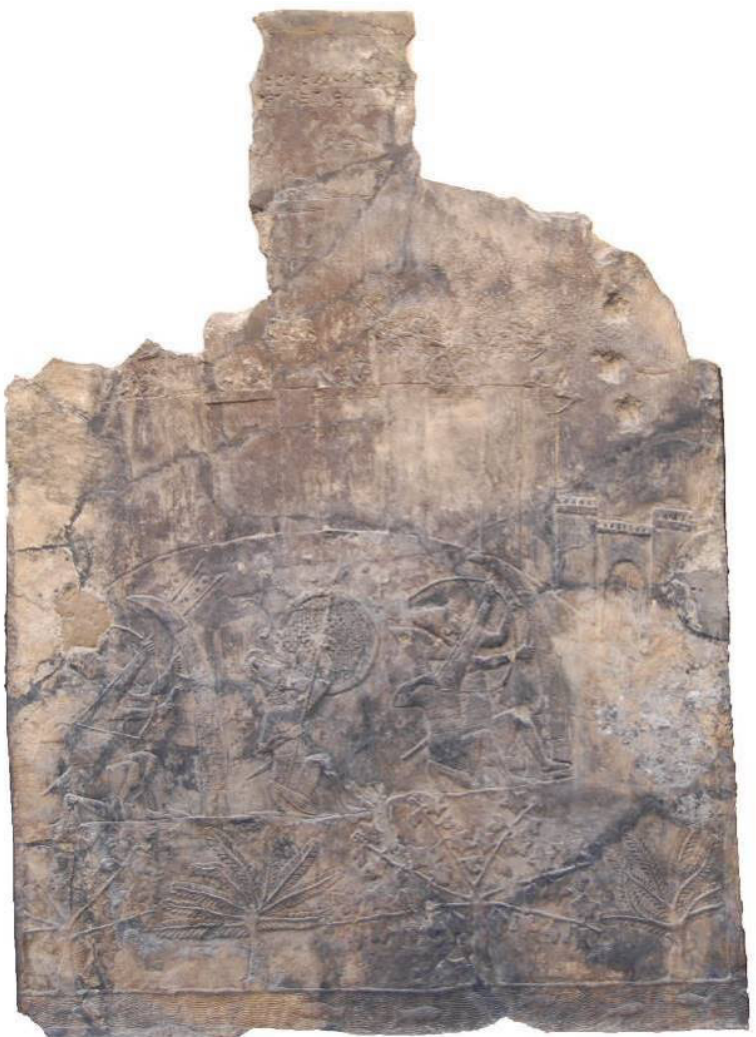

Fonte: (OThe Trustees of the British Museum (BM 124785c). Adaptada por Ranieri.

Figura 22 - Relevos da sala XIV do Palácio Sudoeste de Nínive (placa 11).

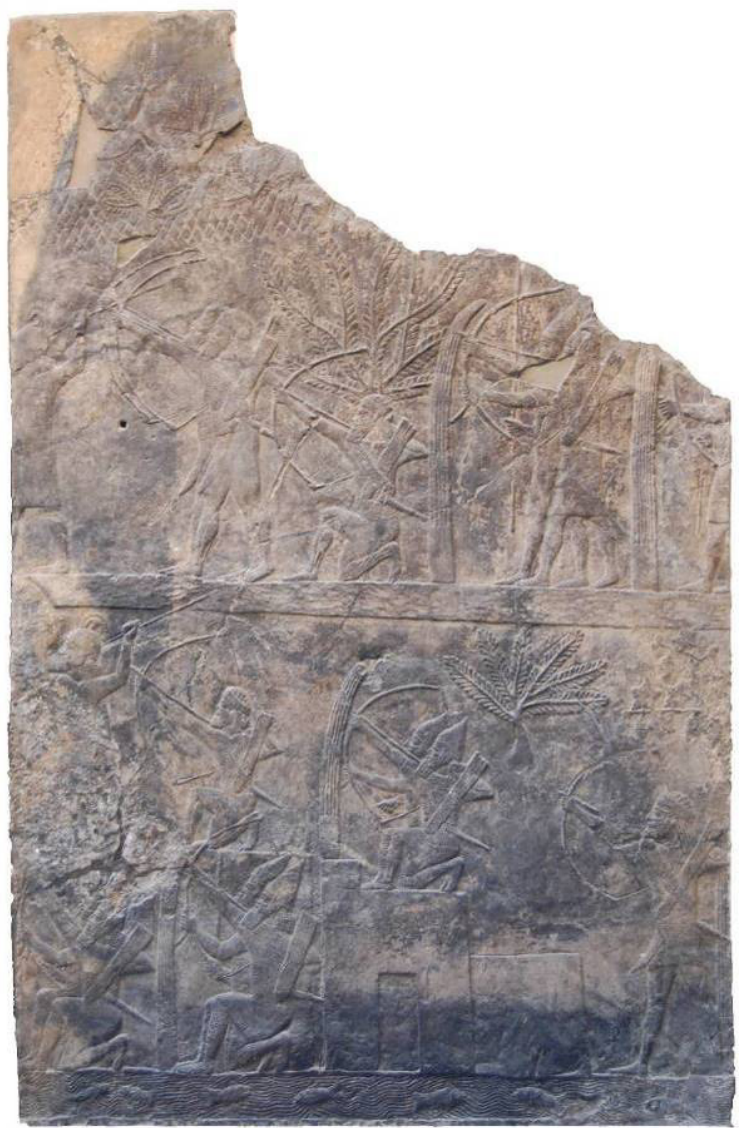

Fonte: @The Trustees of the British Museum (BM 124785d). Adaptada por Ranieri. 
Figura 23 - Relevos da sala XIV do Palácio Sudoeste de Nínive (placas 13-14).

Fonte: @The Trustees of the British Museum (BM 124786a-b). Adaptada por Ranieri.

Figura 24 - Relevos da sala XIV do Palácio Sudoeste de Nínive (placa 15).

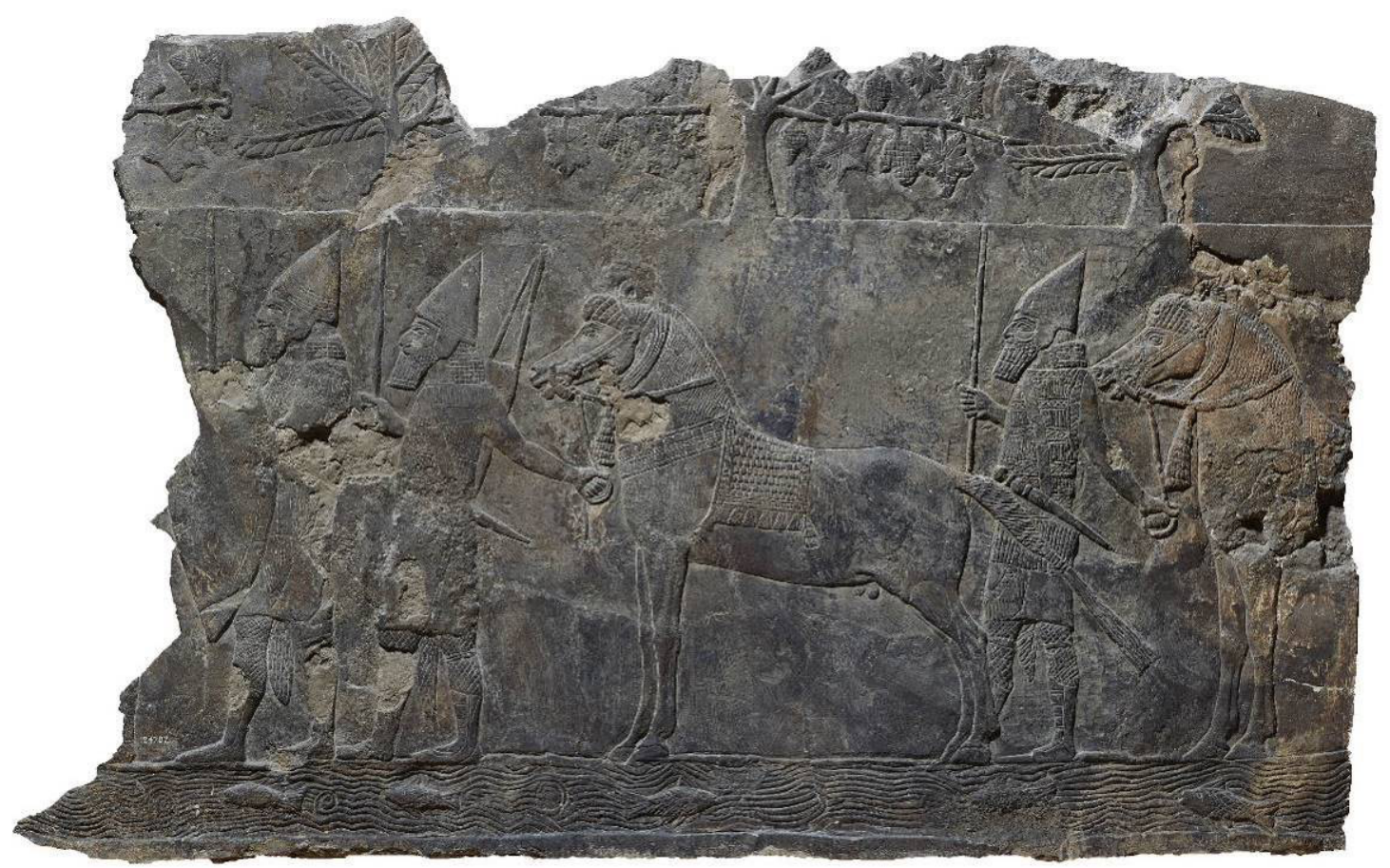

Fonte: @The Trustees of the British Museum (BM 124787). Adaptada por Ranieri. 
Figura 25 - Relevos da sala XIX do Palácio Sudoeste de Nínive (placa 19).

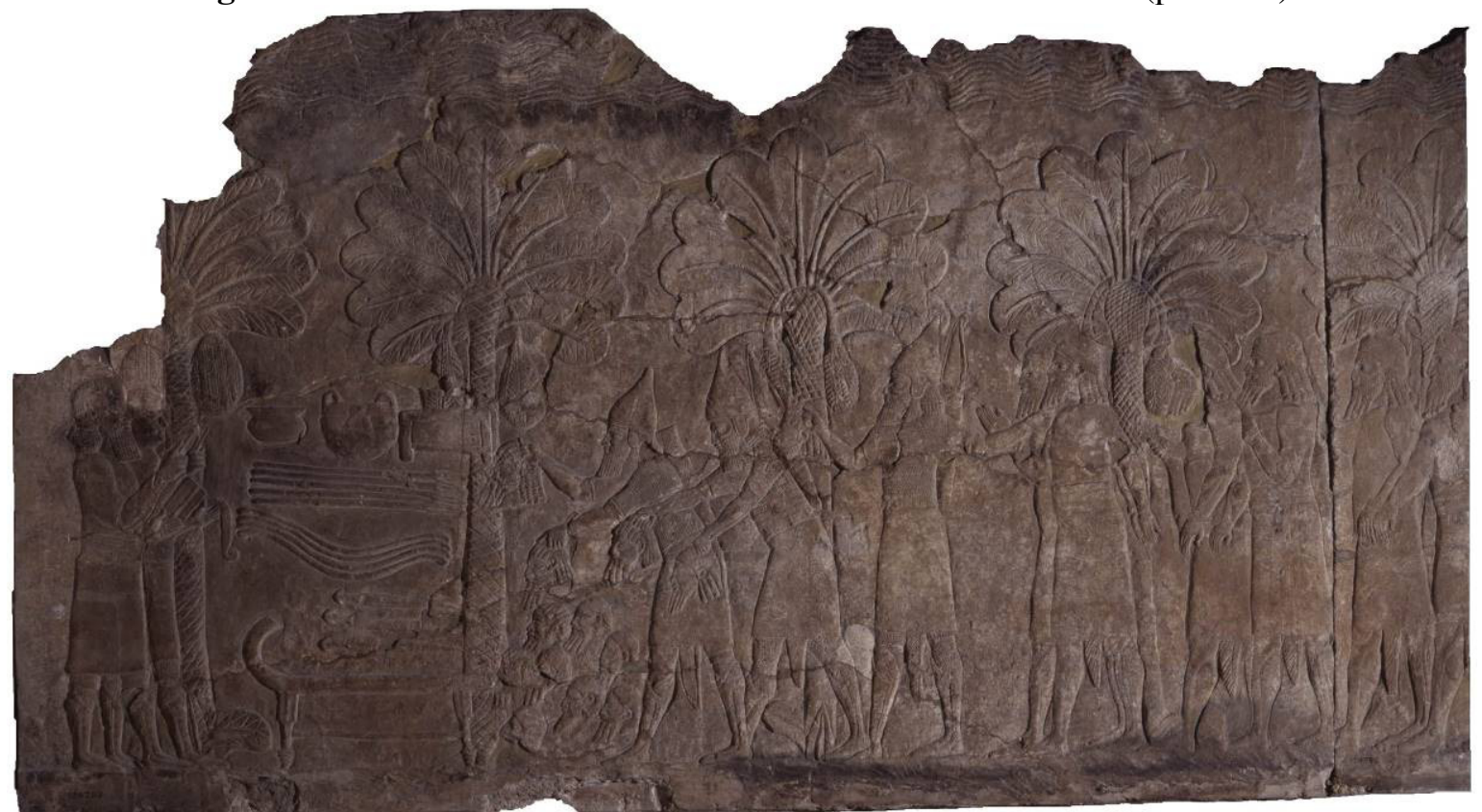

Fonte: (CThe Trustees of the British Museum (BM 124782a). Adaptada por Ranieri.

Figura 26 - Relevos da sala XIX do Palácio Sudoeste de Nínive (placa 18).

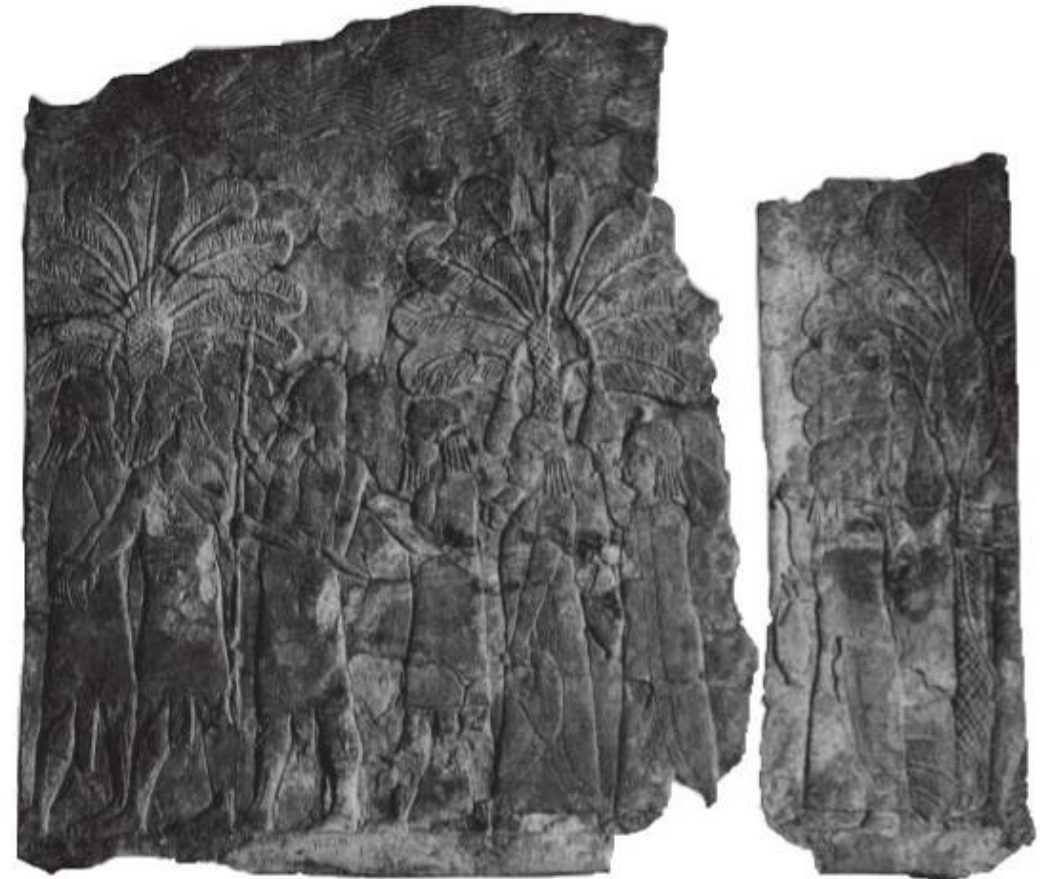

Fonte: Barnett, Bleibtreu e Turner (1998, prancha 195) (BM 124782b). Adaptada por Ranieri. 
Figura 27 - Relevos da sala XIX do Palácio Sudoeste de Nínive (placa 17).

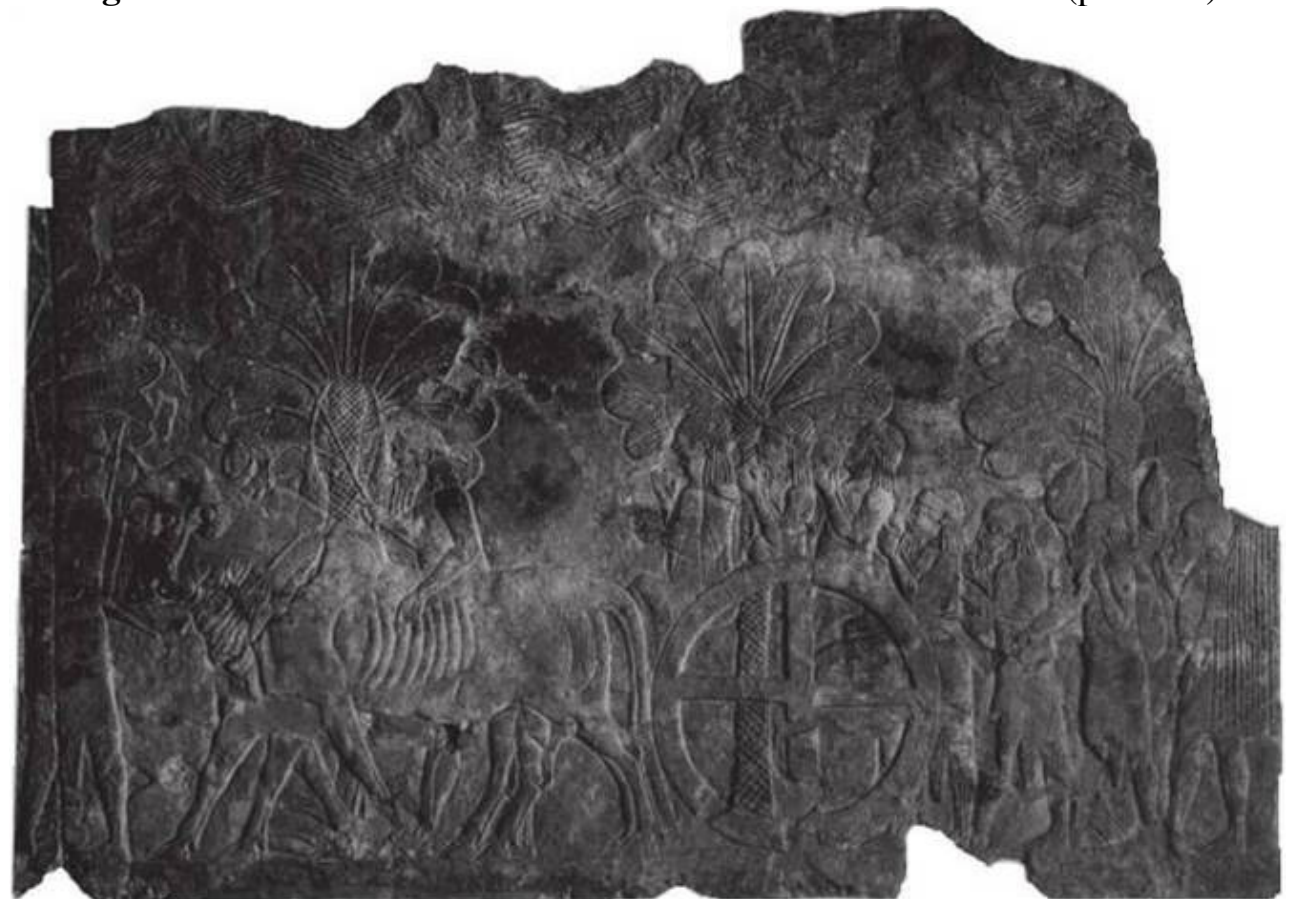

Fonte: Barnett, Bleibtreu e Turner (1998, prancha 197) (BM 124782c). Adaptada por Ranieri. 
Figura 28 - Relevos da sala XIX do Palácio Sudoeste de Nínive (placas 12-11).

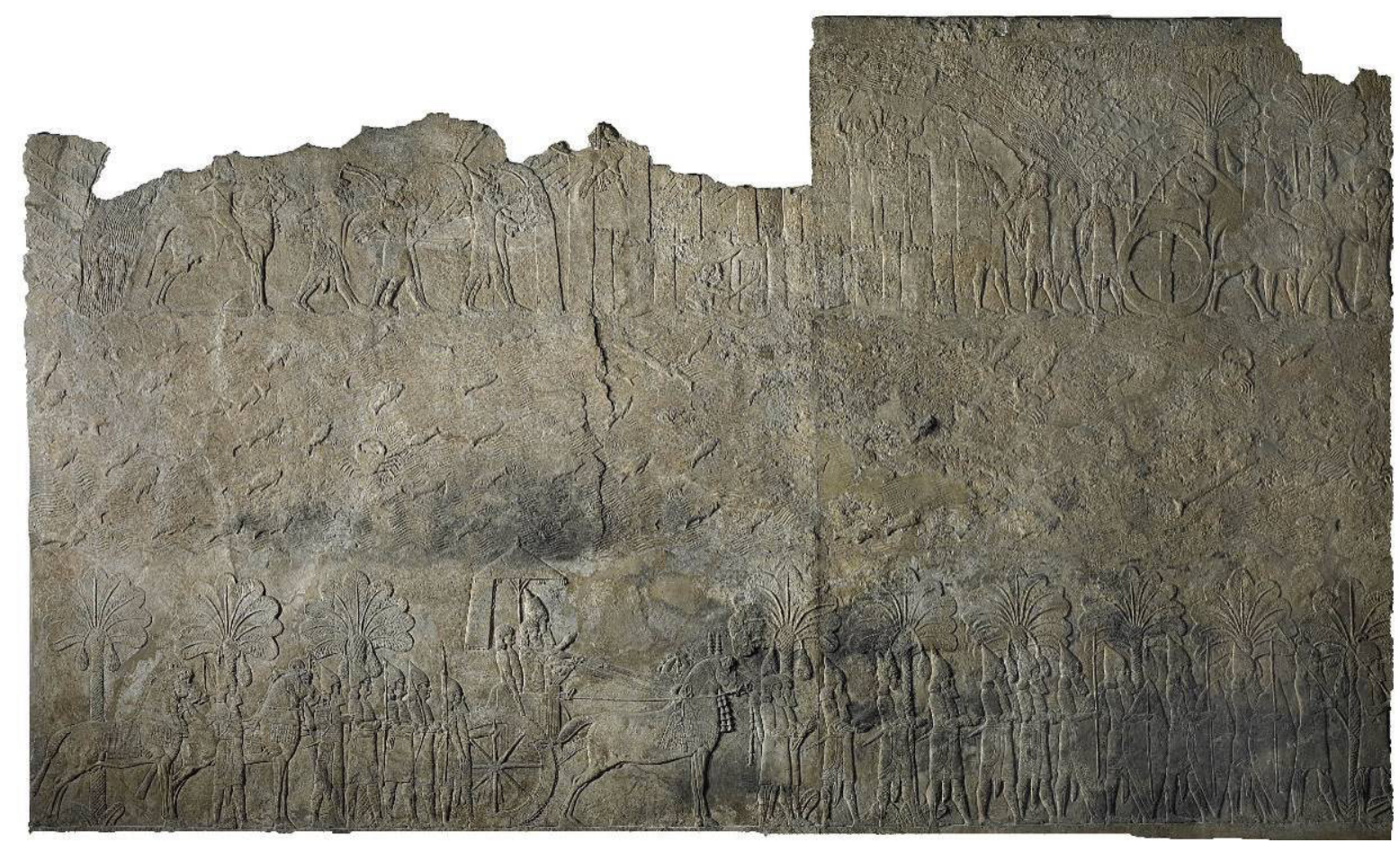

Fonte: (CThe Trustees of the British Museum (BM 124825a-b). Adaptada por Ranieri.

Figura 29 - Relevos da sala XIX do Palácio Sudoeste de Nínive (placas 11-10).

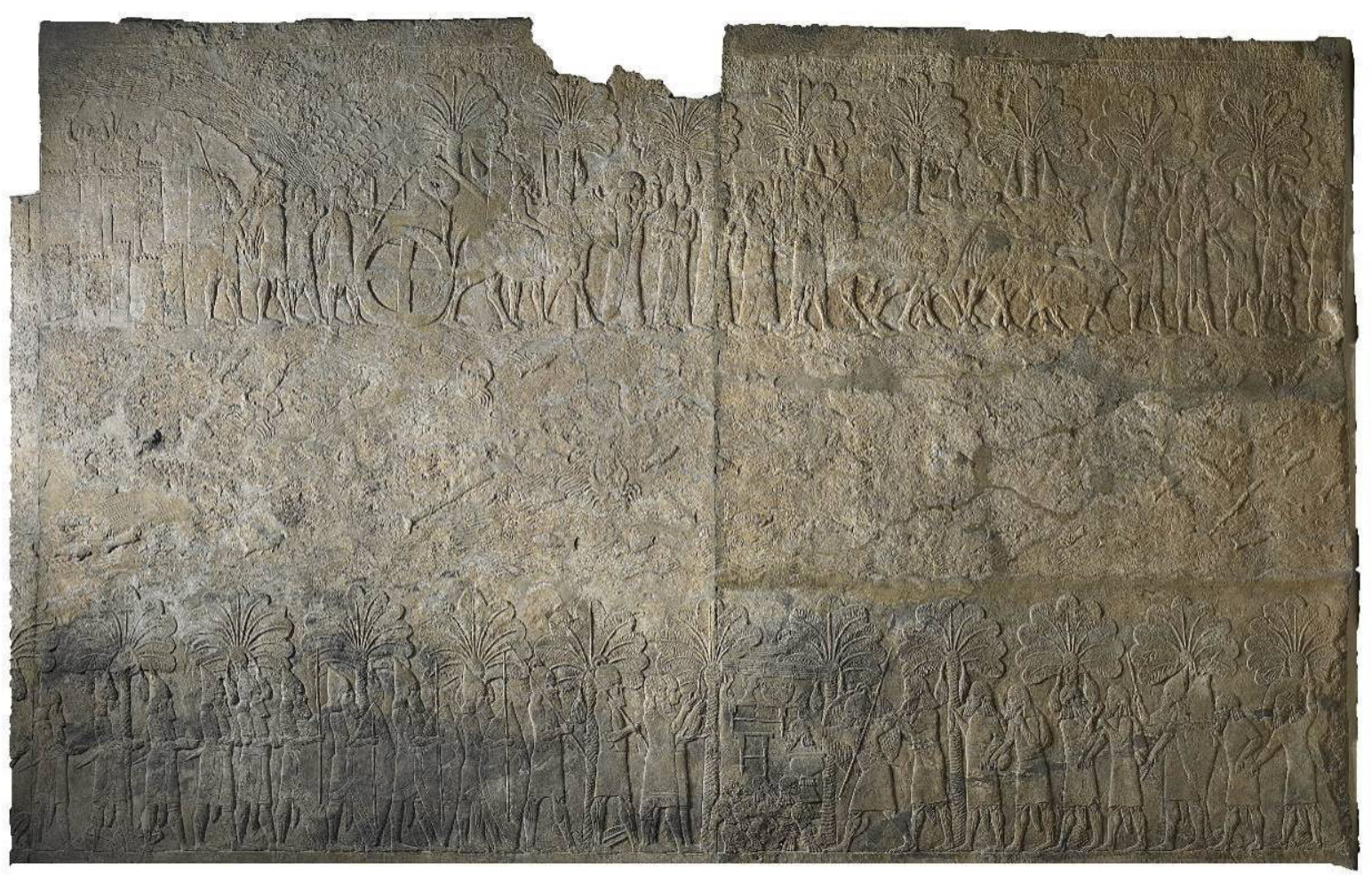

Fonte: @The Trustees of the British Museum (BM 124825b-c). Adaptada por Ranieri. 
Figura 30 - Relevos da sala XXVIII do Palácio Sudoeste de Nínive (placas 2-3).

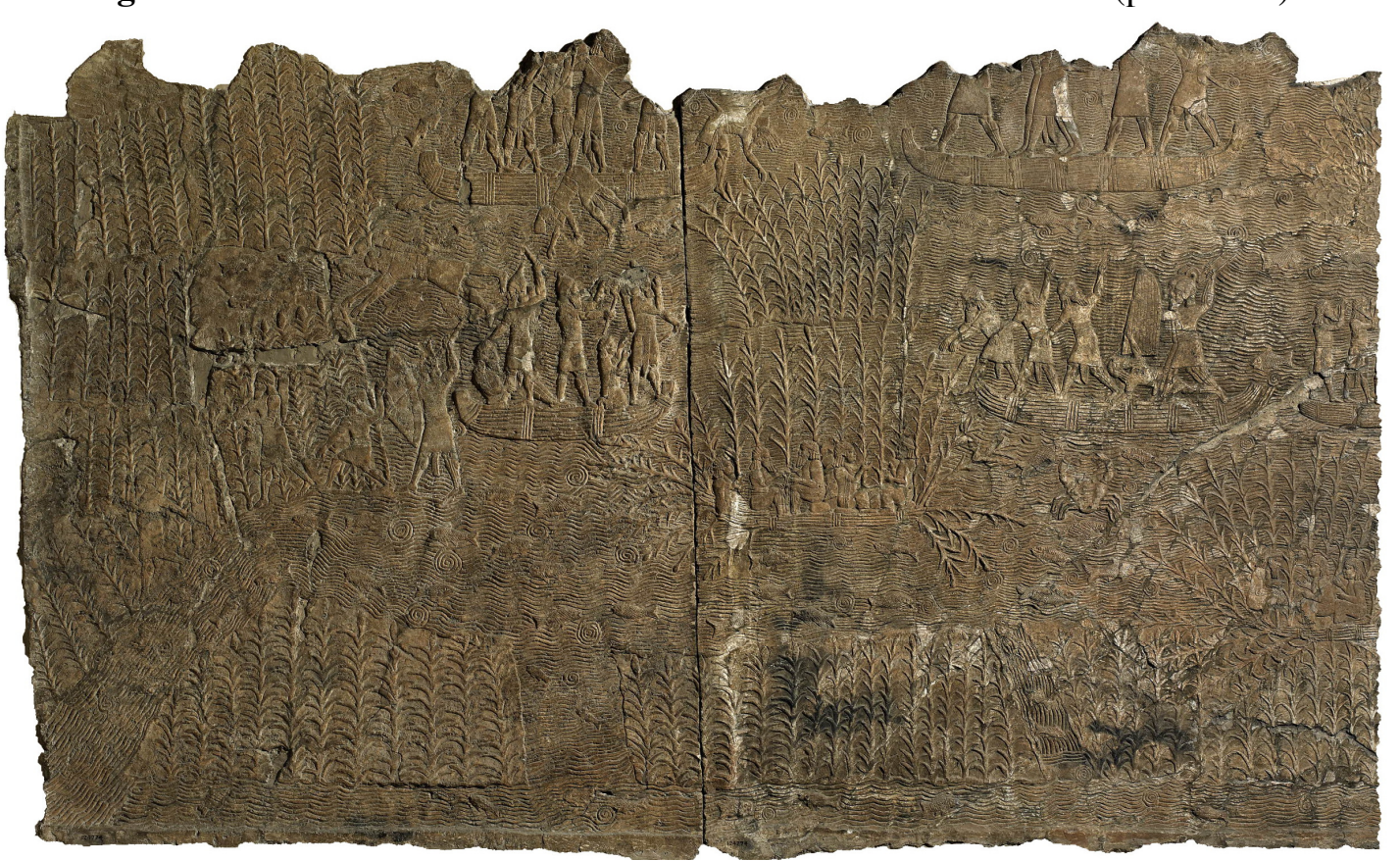

Fonte: @The Trustees of the British Museum (BM 124774a-b). Adaptada por Ranieri.

Figura 31 - Relevos da sala XXVIII do Palácio Sudoeste de Nínive (placa 3).

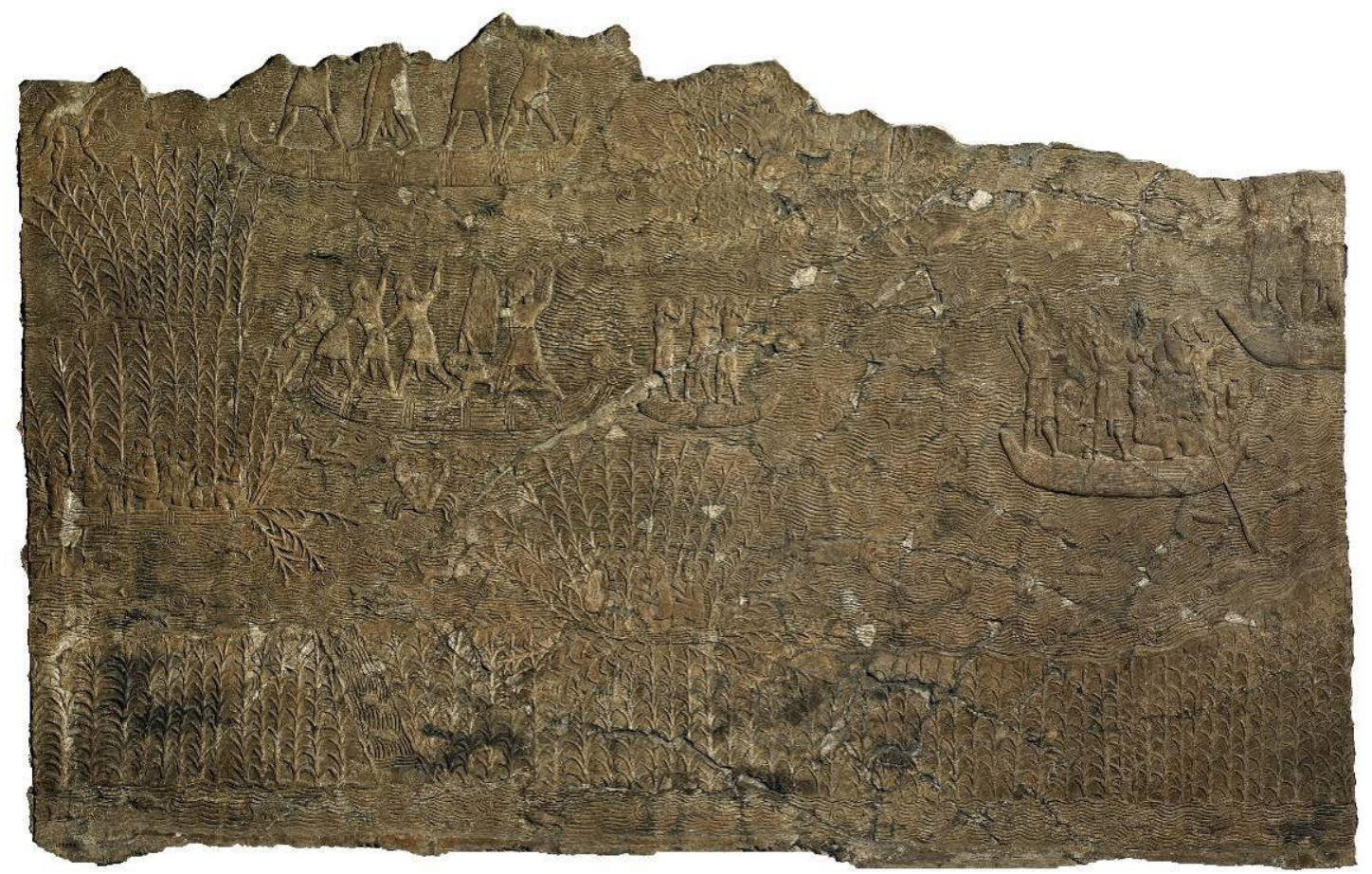

Fonte: (The Trustees of the British Museum (BM 124774b). Adaptada por Ranieri. 
Figura 32 - Relevos da sala XXVIII do Palácio Sudoeste de Nínive (placa 4).

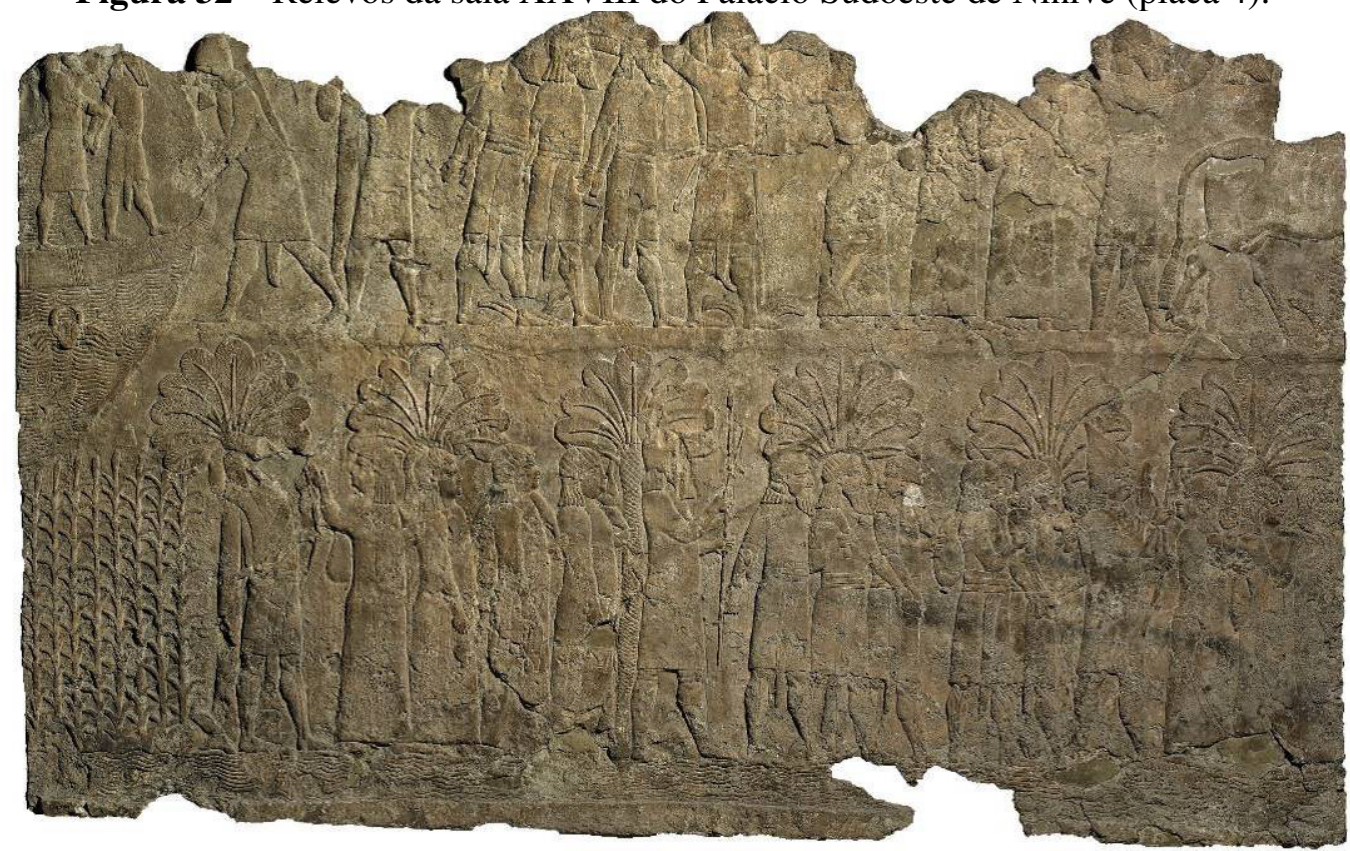

Fonte: @The Trustees of the British Museum (BM 124774c). Adaptada por Ranieri.

Figura 33 - Relevos da sala XXVIII do Palácio Sudoeste de Nínive (placa 5).

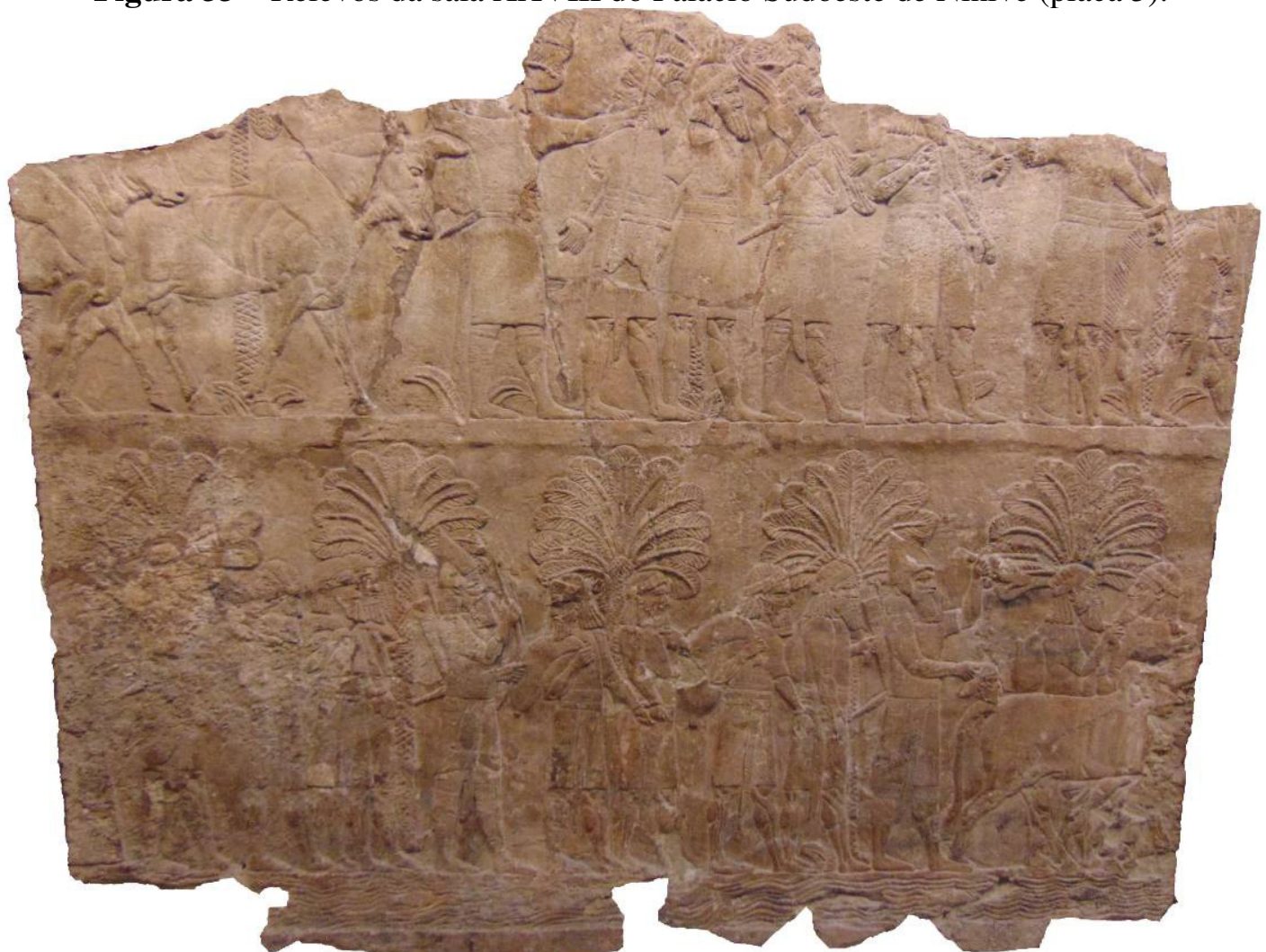

Fonte: (The Trustees of the British Museum (BM 124774d). Fotografia realizada e adaptada por Ranieri. 
Figura 34 - Relevos da sala XXVIII do Palácio Sudoeste de Nínive (placa 6).

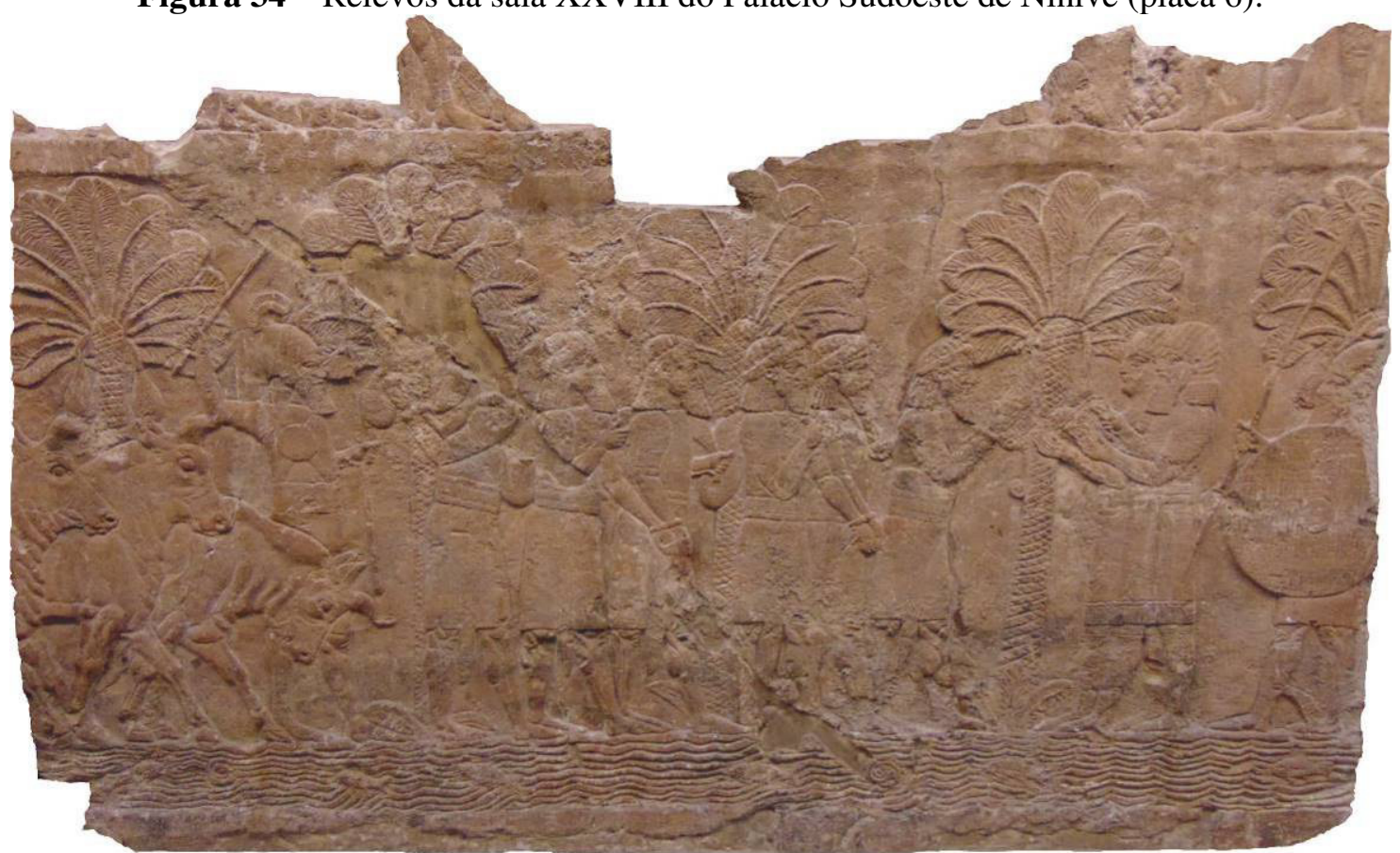

Fonte: (The Trustees of the British Museum (BM 124774e). Adaptada por Ranieri.

Figura 35 - Relevos da sala XXVIII do Palácio Sudoeste de Nínive (placa 7).

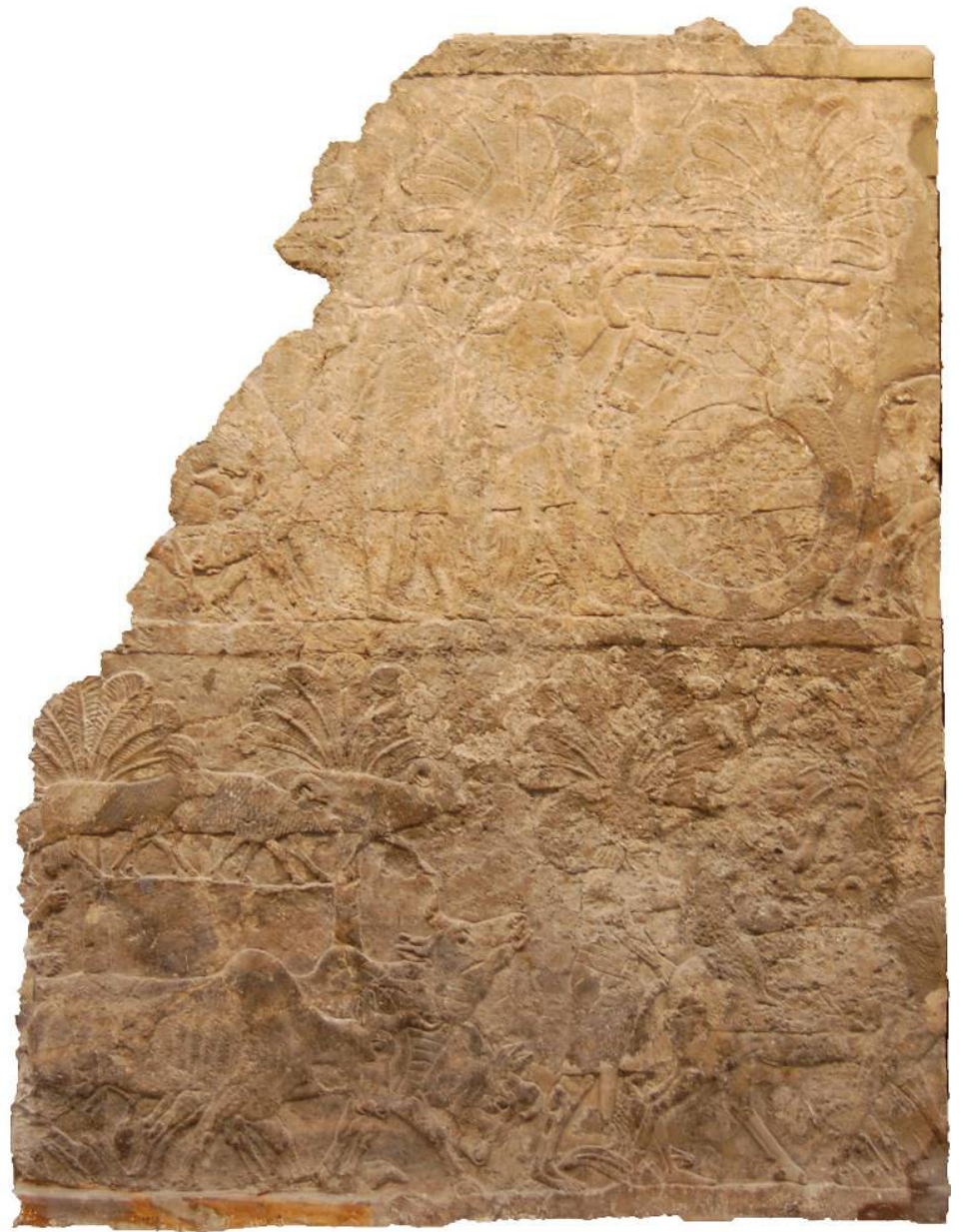

Fonte: @The Trustees of the British Museum (BM 124953). Adaptada por Ranieri. 
Figura 36 - Relevos da sala XXVIII do Palácio Sudoeste de Nínive (placa 8).

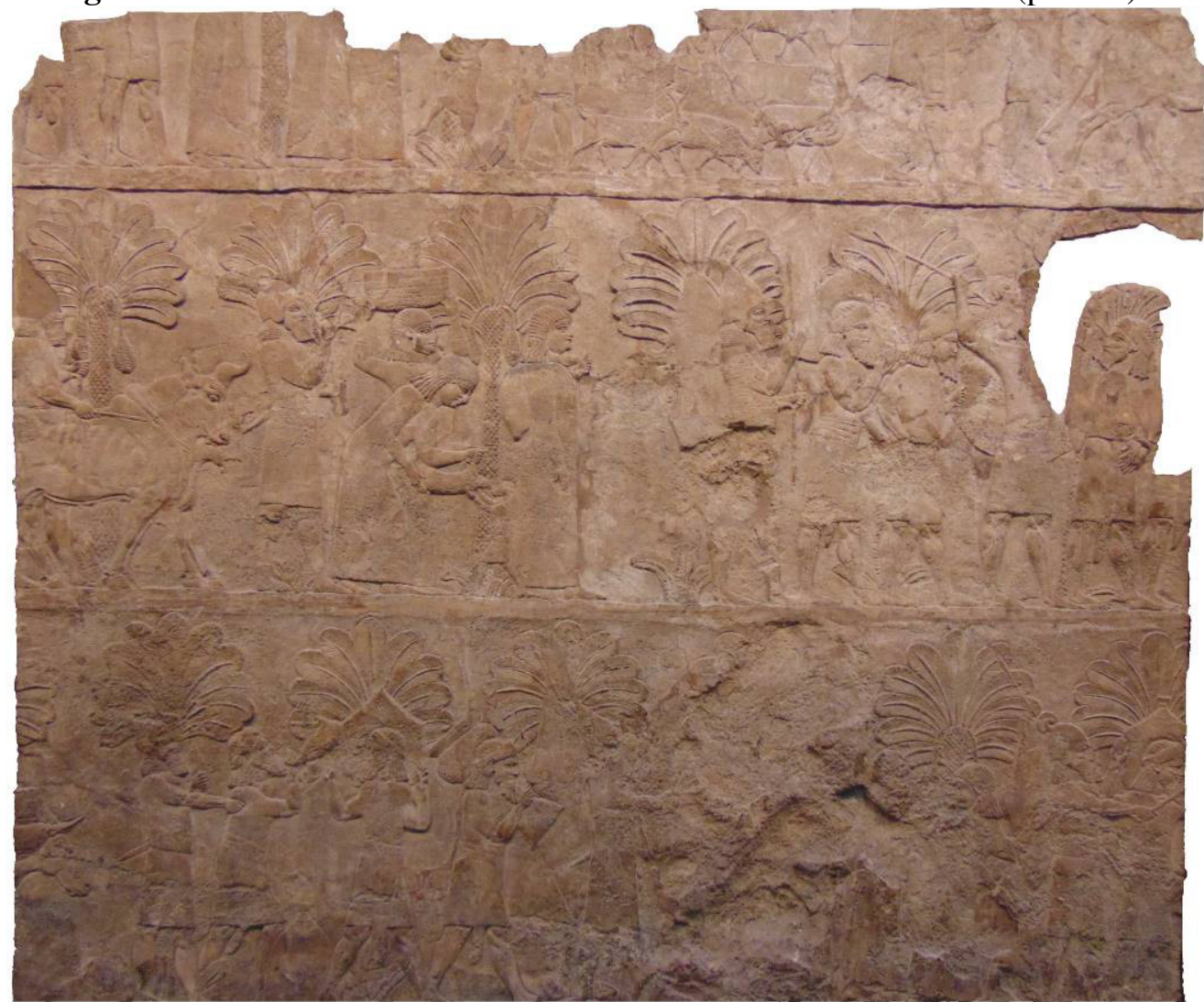

Fonte: (The Trustees of the British Museum (BM 124954). Fotografia realizada e adaptada por Ranieri.

Figura 37 - Relevos da sala XXVIII do Palácio Sudoeste de Nínive (placa 9).

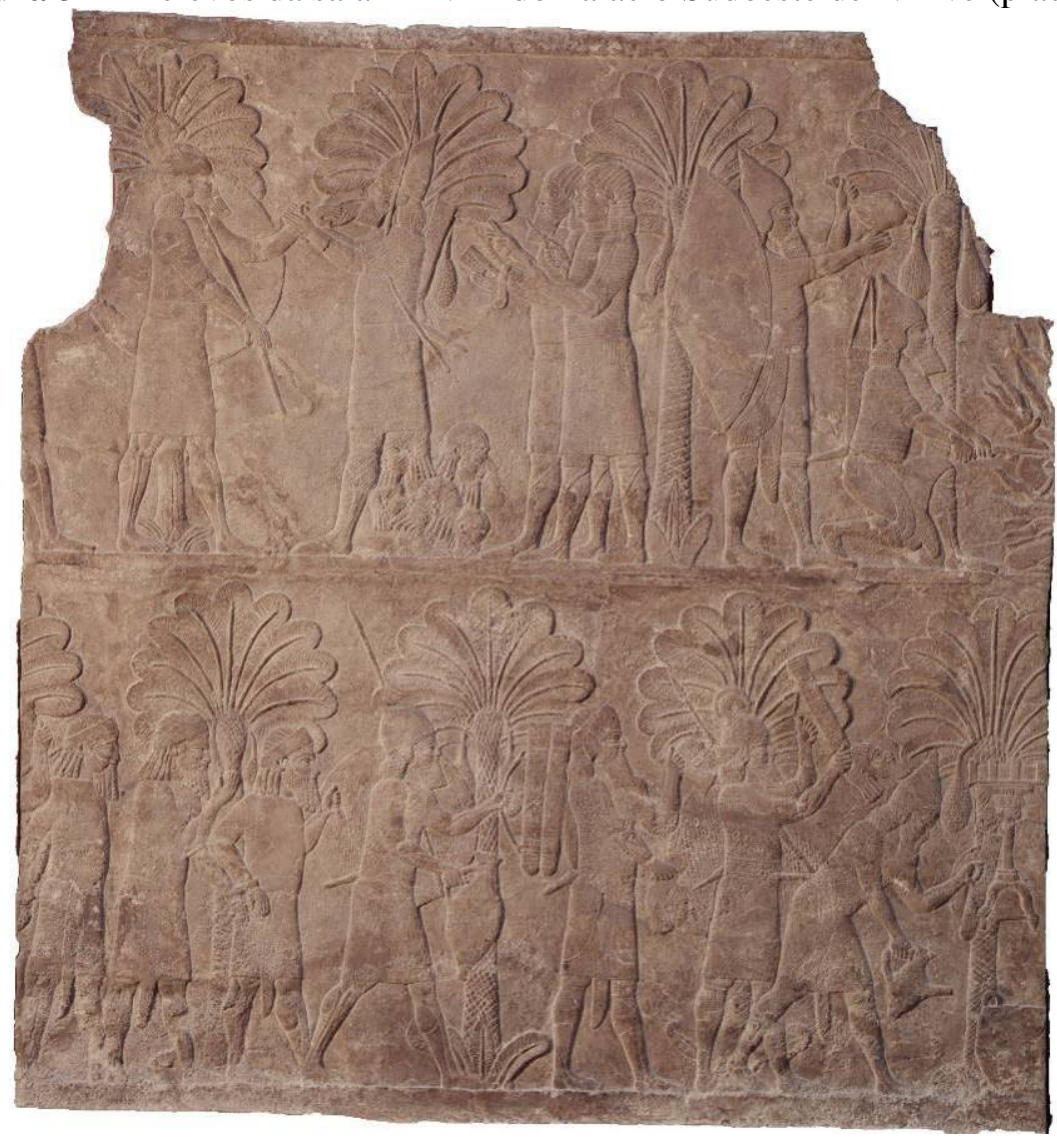

Fonte: @The Trustees of the British Museum (BM 124955). Adaptada por Ranieri. 
Figura 38 - Relevos da sala XXVIII do Palácio Sudoeste de Nínive (placa 10).

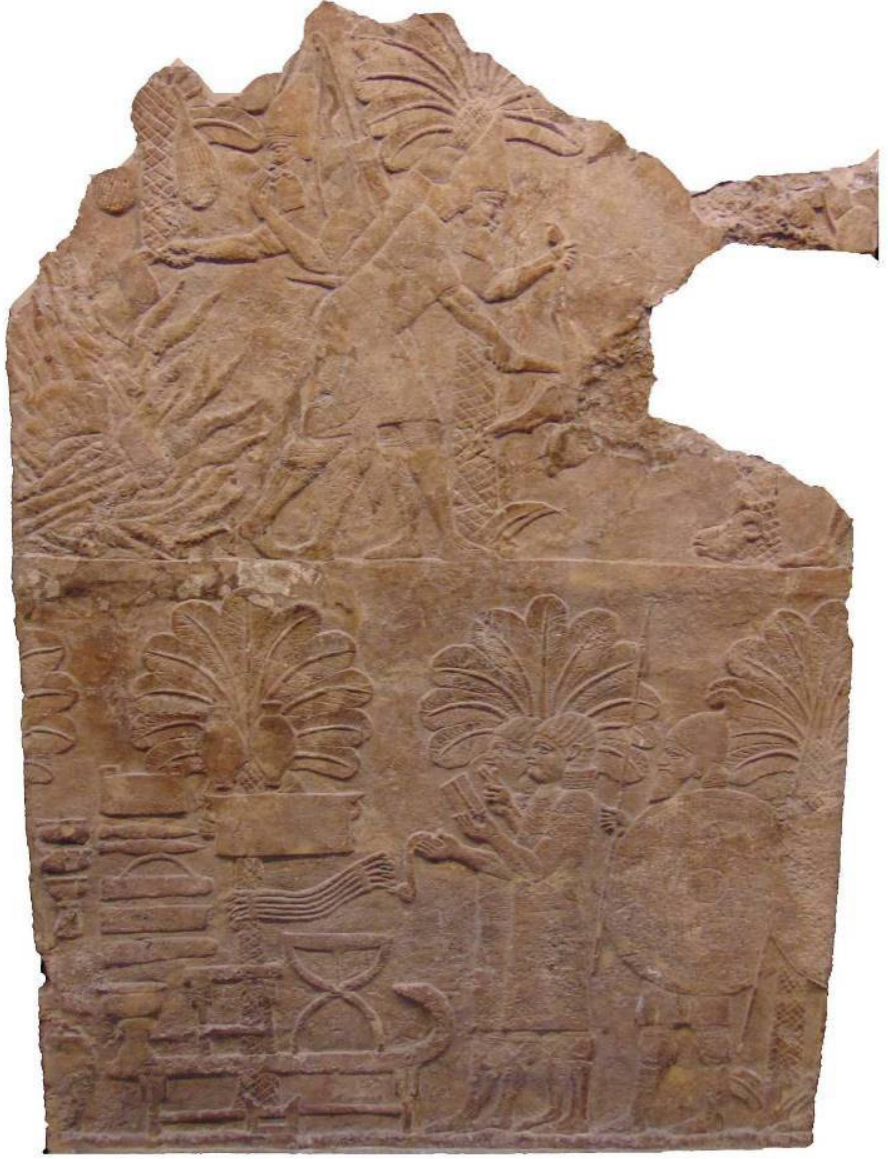

Fonte: @The Trustees of the British Museum (BM 124956). Fotografia realizada e adaptada por Ranieri.

Figura 39 - Relevos da sala XXVIII do Palácio Sudoeste de Nínive (placa 11).

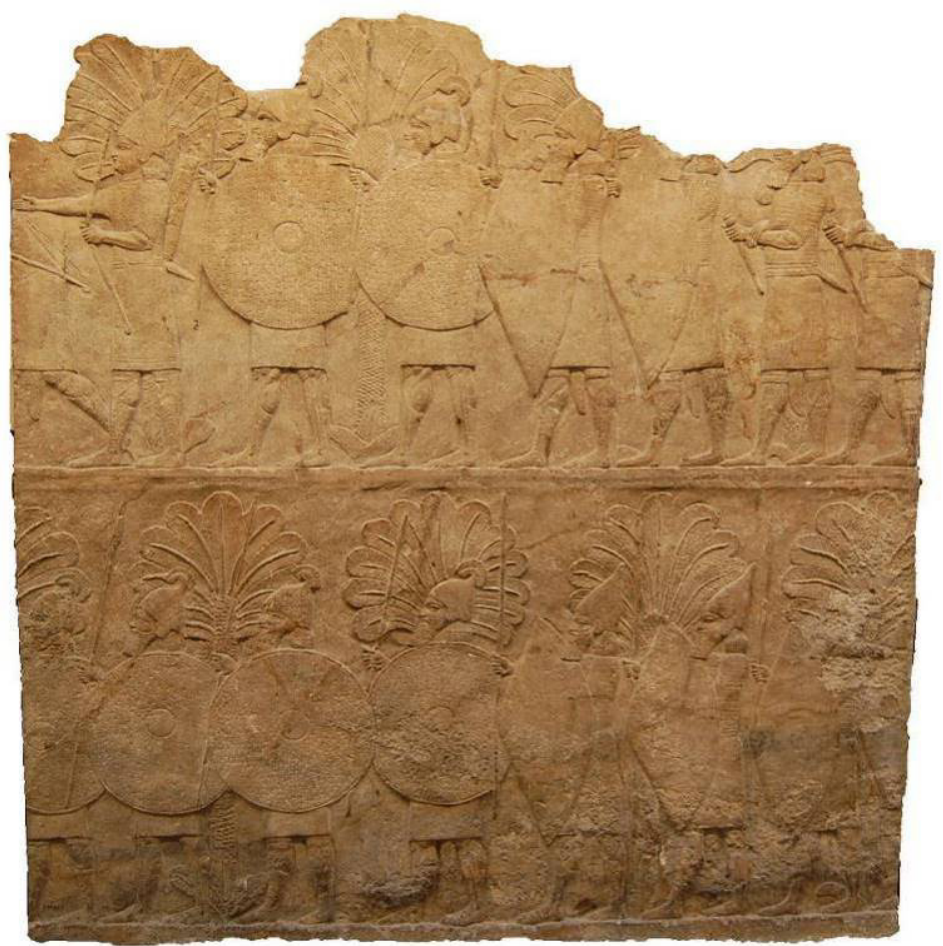

Fonte: @The Trustees of the British Museum (BM 124957). Adaptada por Ranieri. 
Figura 40 - Relevos da sala XXVIII do Palácio Sudoeste de Nínive (placa 12).

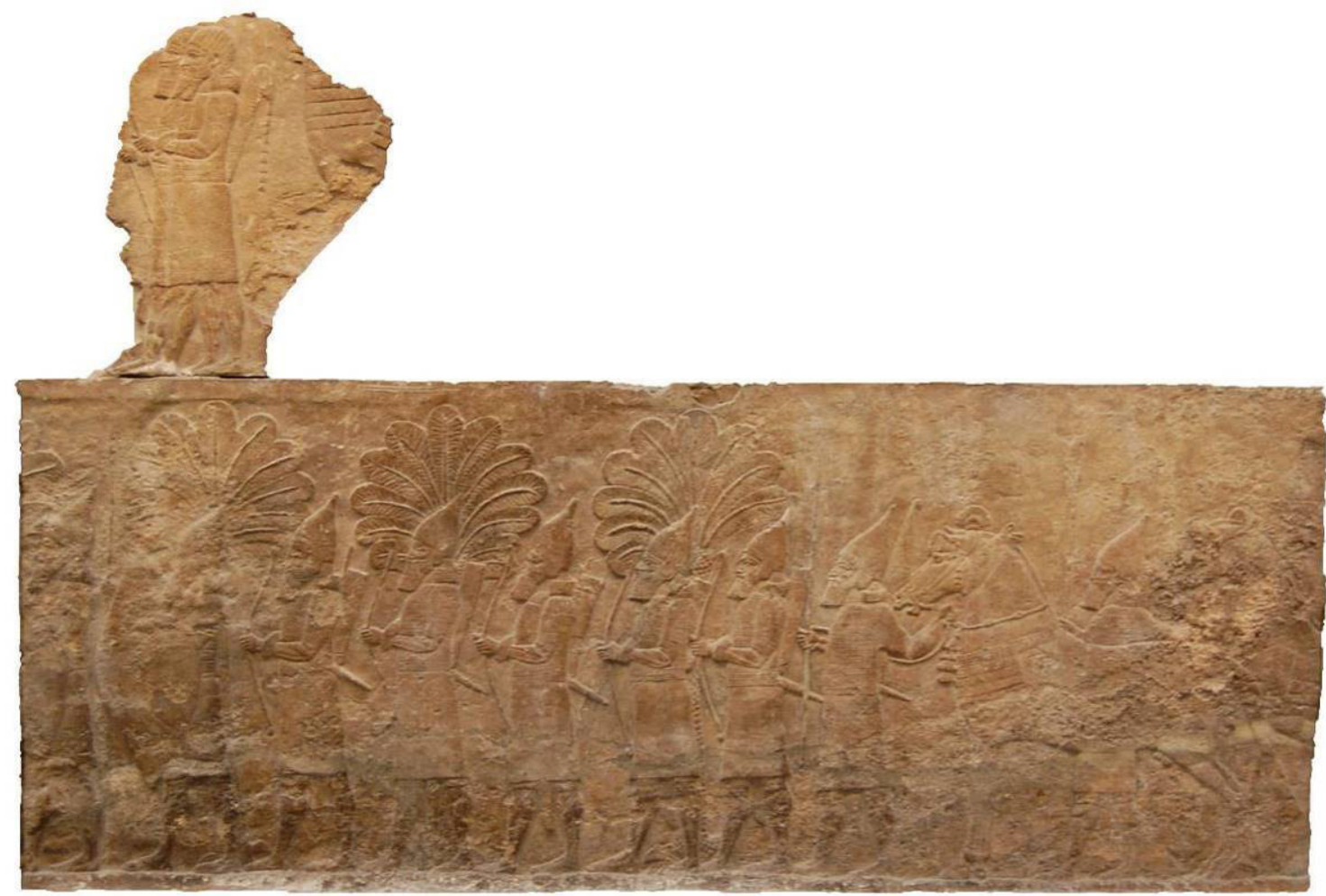

Fonte: (The Trustees of the British Museum (BM 124958). Adaptada por Ranieri.

Figura 41 - Relevos da sala XXVIII do Palácio Sudoeste de Nínive (placa 13).

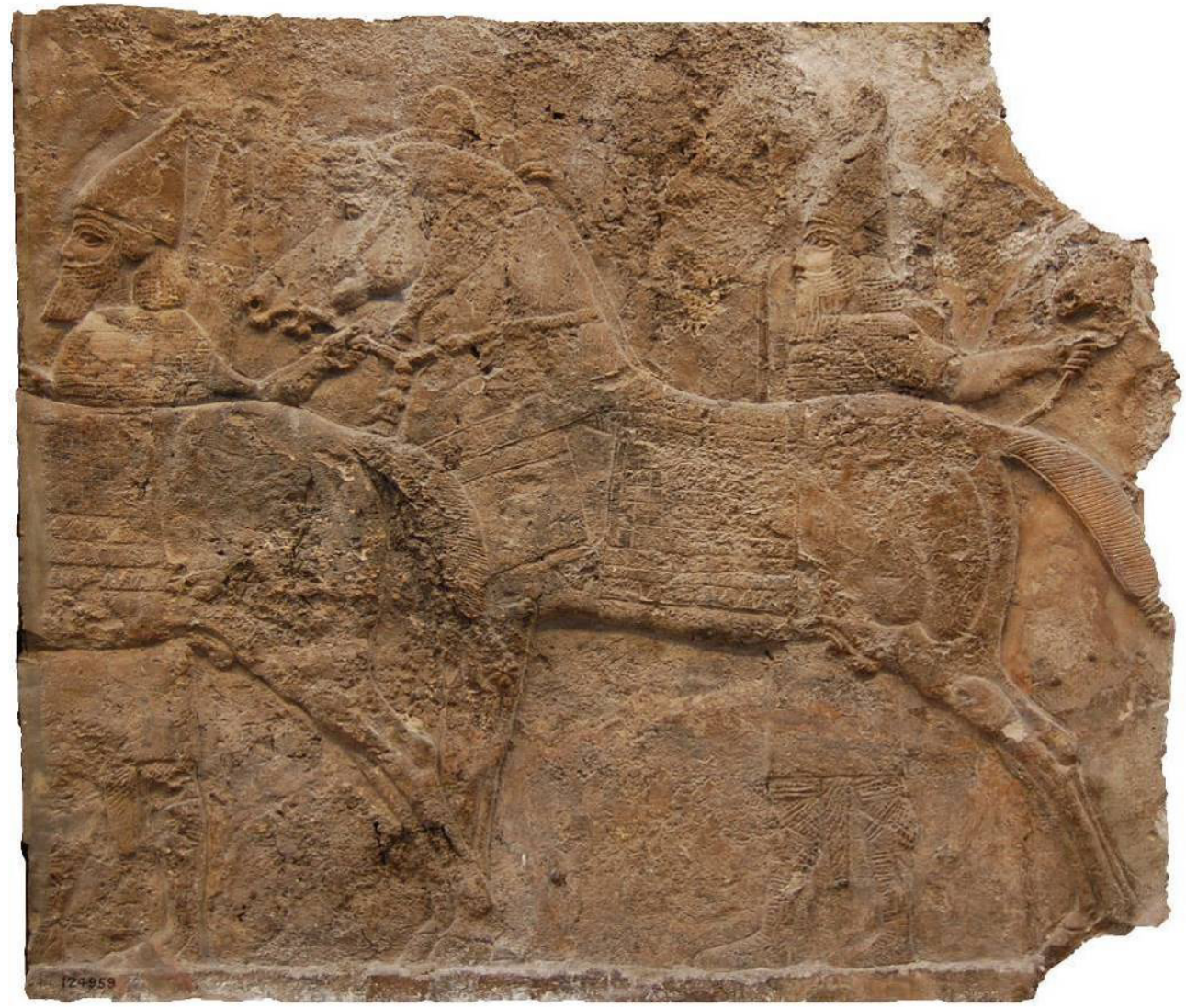

Fonte: @The Trustees of the British Museum (BM 124959). Adaptada por Ranieri. 
Figura 42 - Relevos da sala XXVIII do Palácio Sudoeste de Nínive (placa 14).

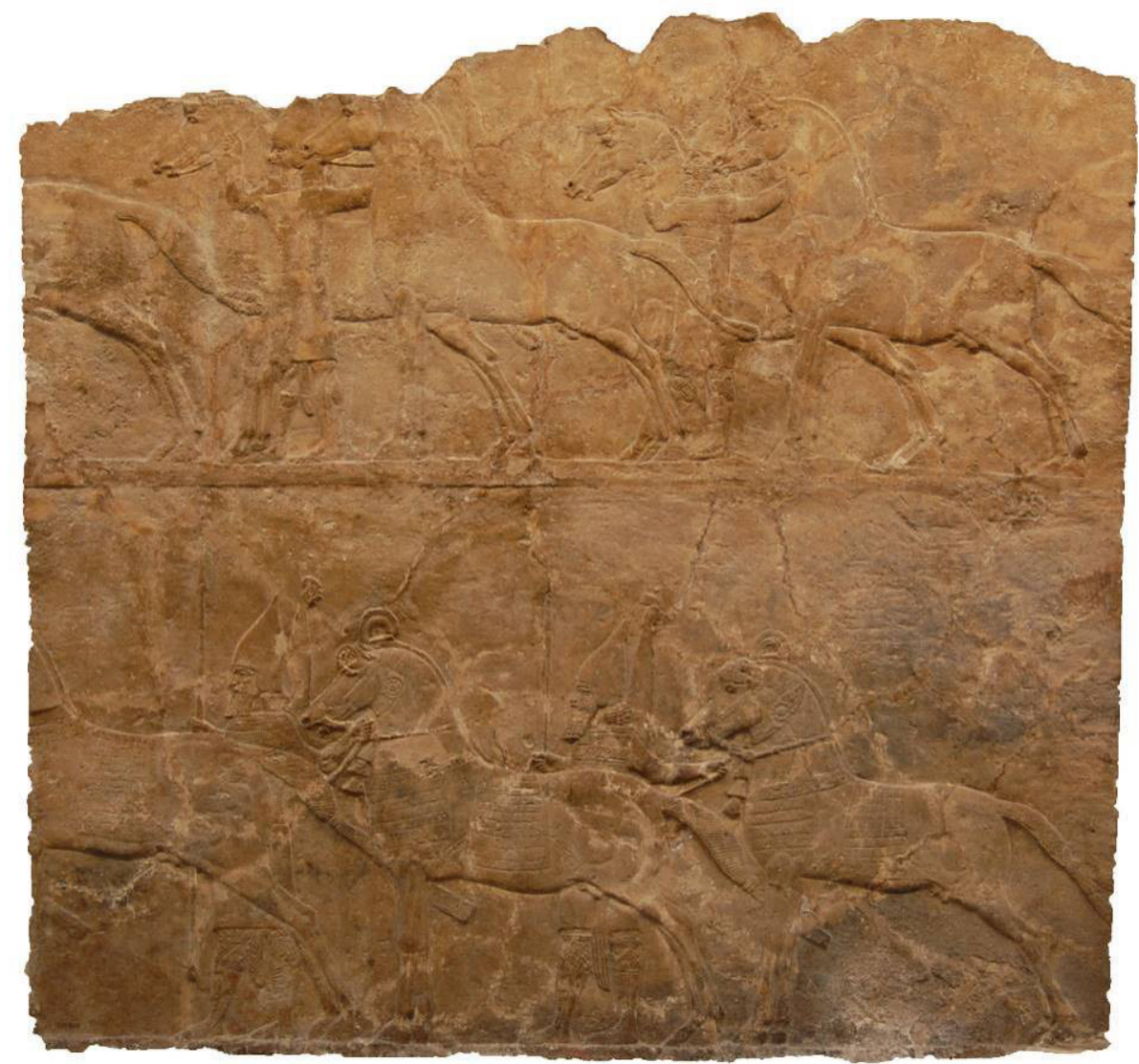

Fonte: @The Trustees of the British Museum (BM 124960). Adaptada por Ranieri. 
Figura 43 - Relevos da sala XXXIII do Palácio Sudoeste de Nínive (placa 1).

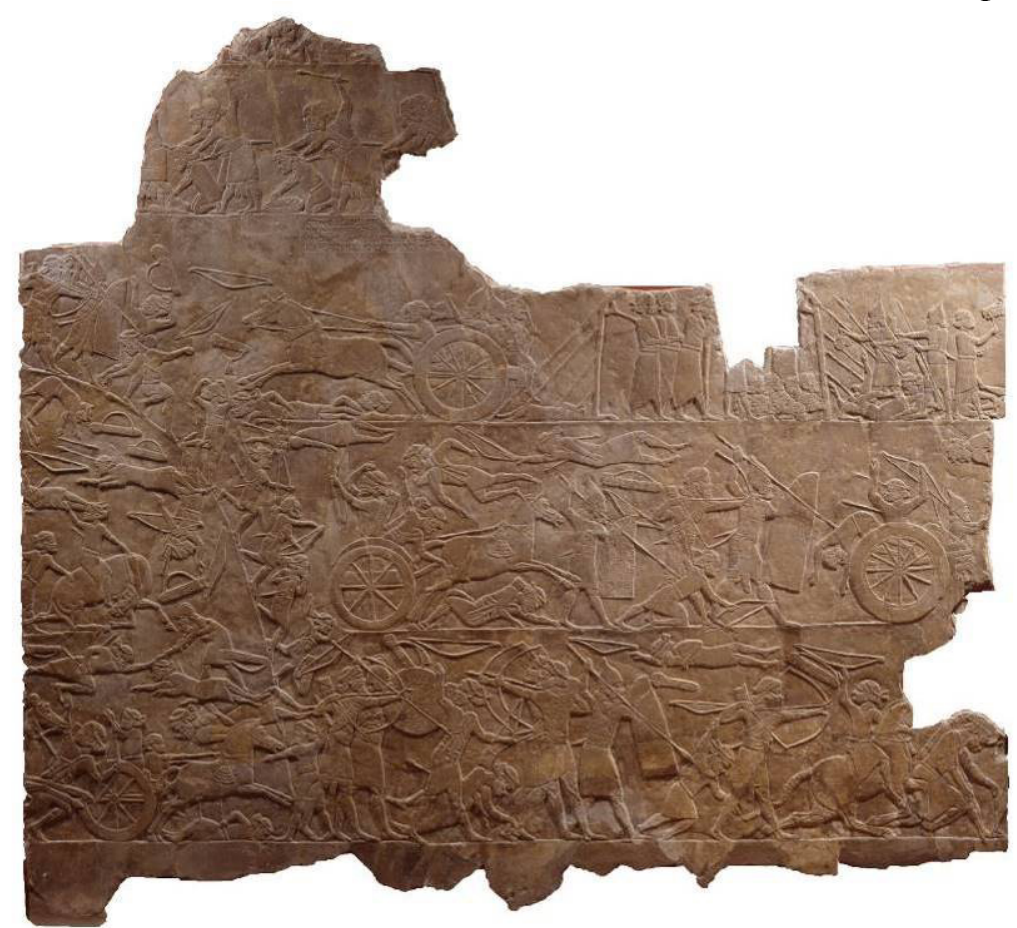

Fonte: (The Trustees of the British Museum (BM 124801a). Adaptada por Ranieri.

Figura 44 - Relevos da sala XXXIII do Palácio Sudoeste de Nínive (placa 2).

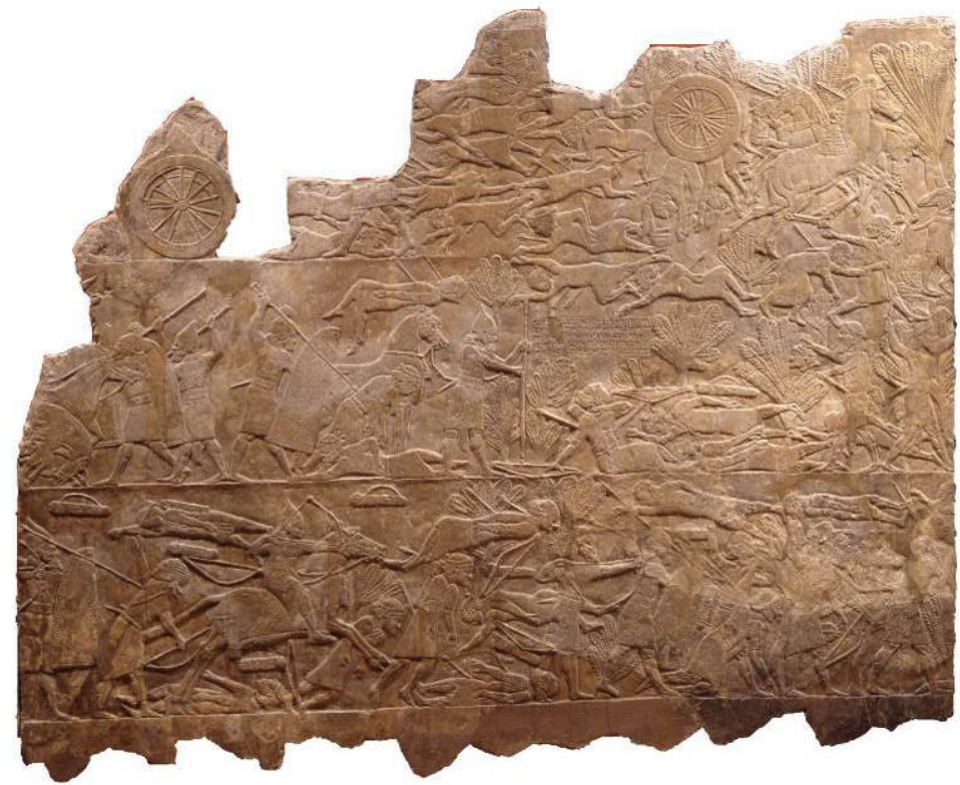

Fonte: @The Trustees of the British Museum (BM 124801b). Adaptada por Ranieri. 
Figura 45 - Relevos da sala XXXIII do Palácio Sudoeste de Nínive (placa 3).

Fonte: CThe Trustees of the British Museum (BM 124801c). Adaptada por Ranieri.

Figura 46 - Relevos da sala XXXIII do Palácio Sudoeste de Nínive (placa 4).

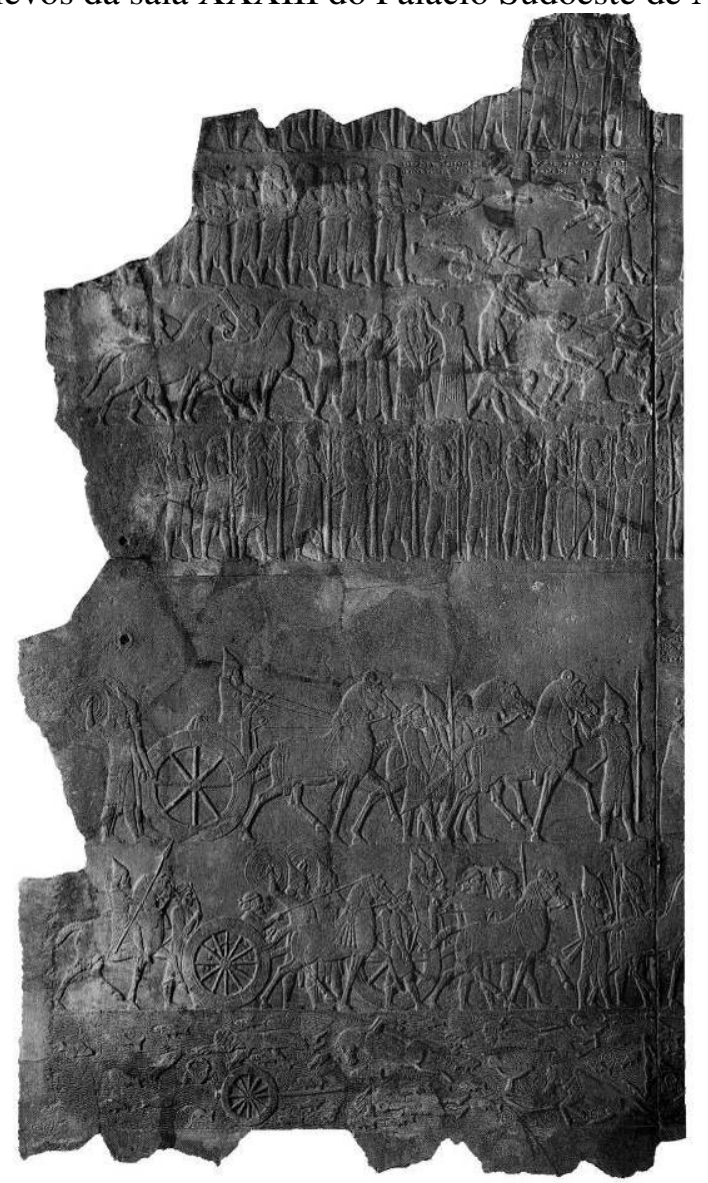

Fonte: (CThe Trustees of the British Museum (BM 124802a). Adaptada por Ranieri. 
Figura 47 - Relevos da sala XXXIII do Palácio Sudoeste de Nínive (placa 5).

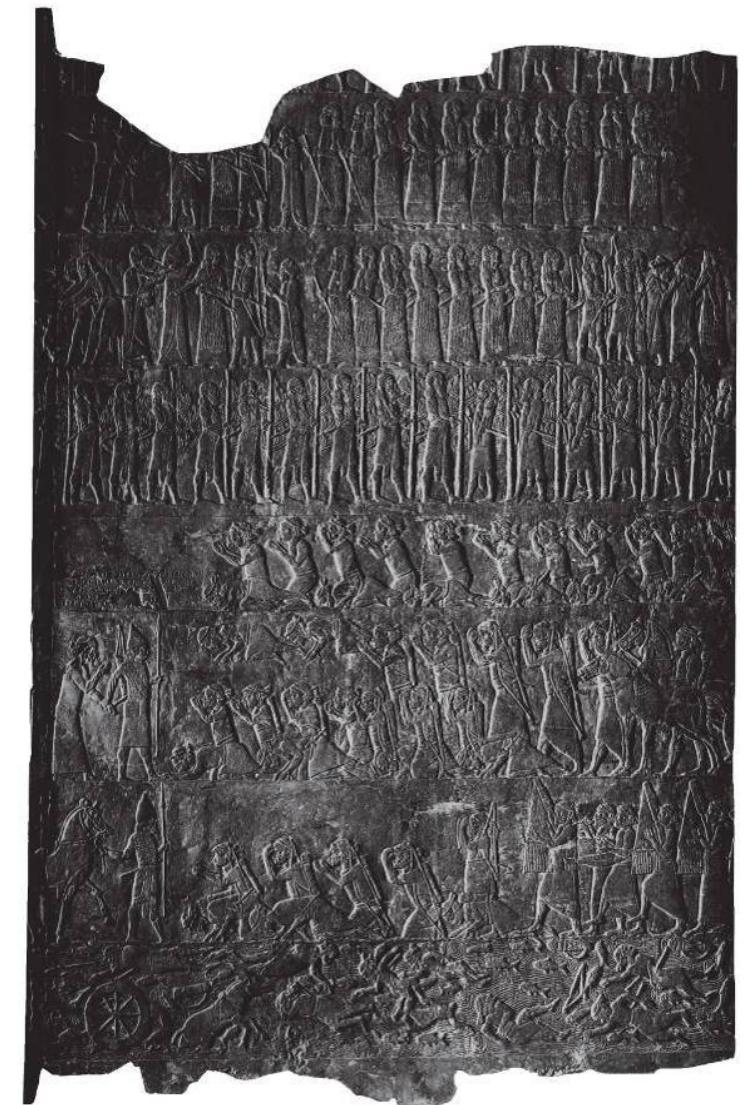

Fonte: Barnett, Bleibtreu e Turner (1998, prancha 305) (BM124802b). Adaptada por Ranieri.

Figura 48 - Relevos da sala XXXIII do Palácio Sudoeste de Nínive (placa 6).

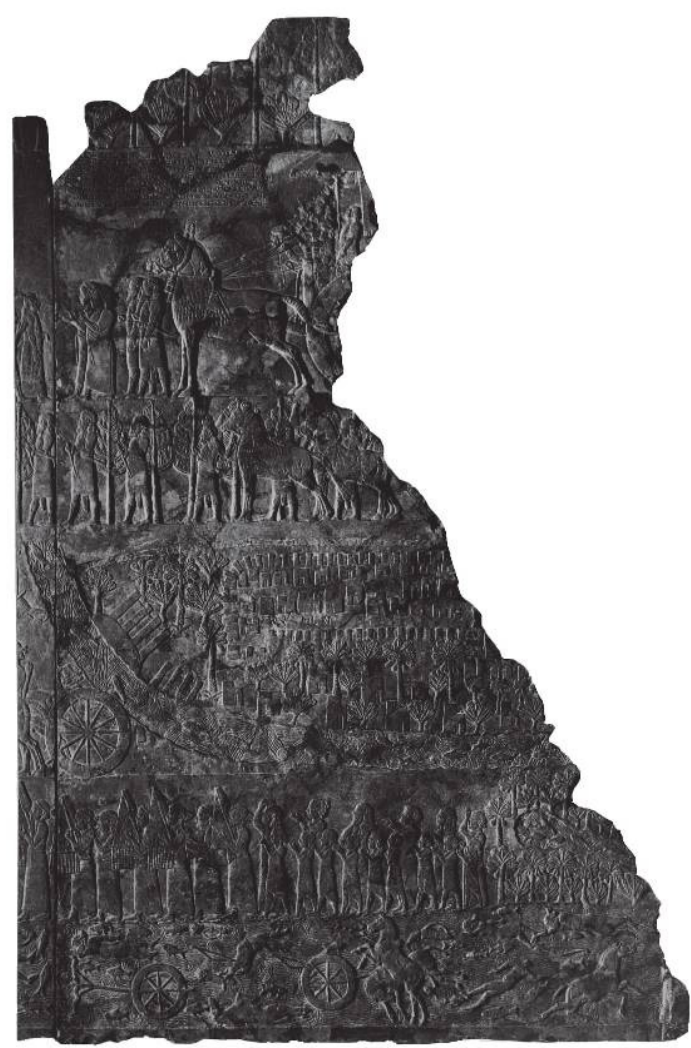

Fonte: Barnett, Bleibtreu e Turner (1998, prancha 309) (BM124802c). Adaptada por Ranieri. 
Figura 49 - Relevos da sala XXXVI do Palácio Sudoeste de Nínive (placa 5).

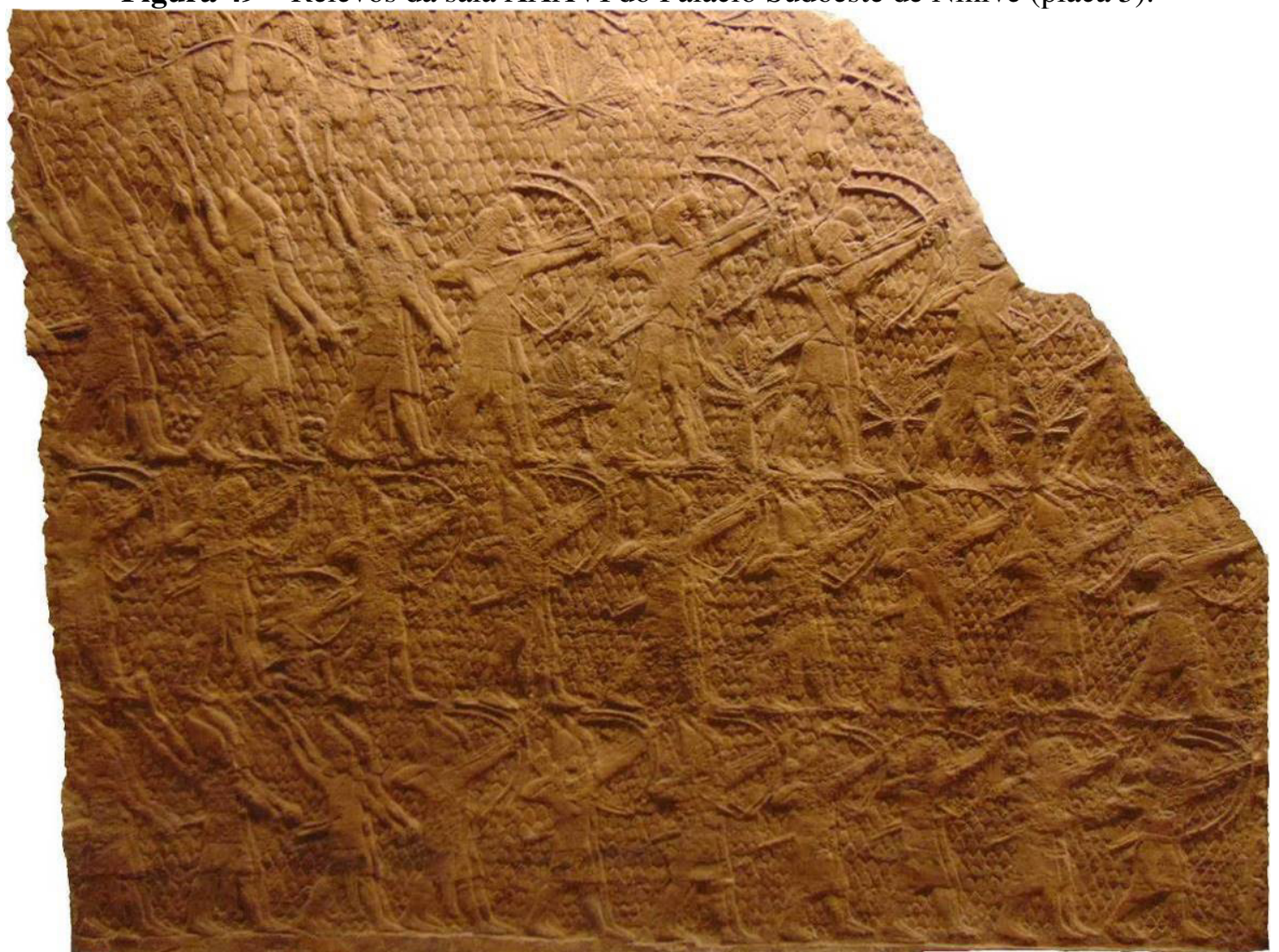

Fonte: (OThe Trustees of the British Museum (BM 124904). Fotografia realizada e adaptada por Ranieri.

Figura 50 - Relevos da sala XXXVI do Palácio Sudoeste de Nínive (placa 6).

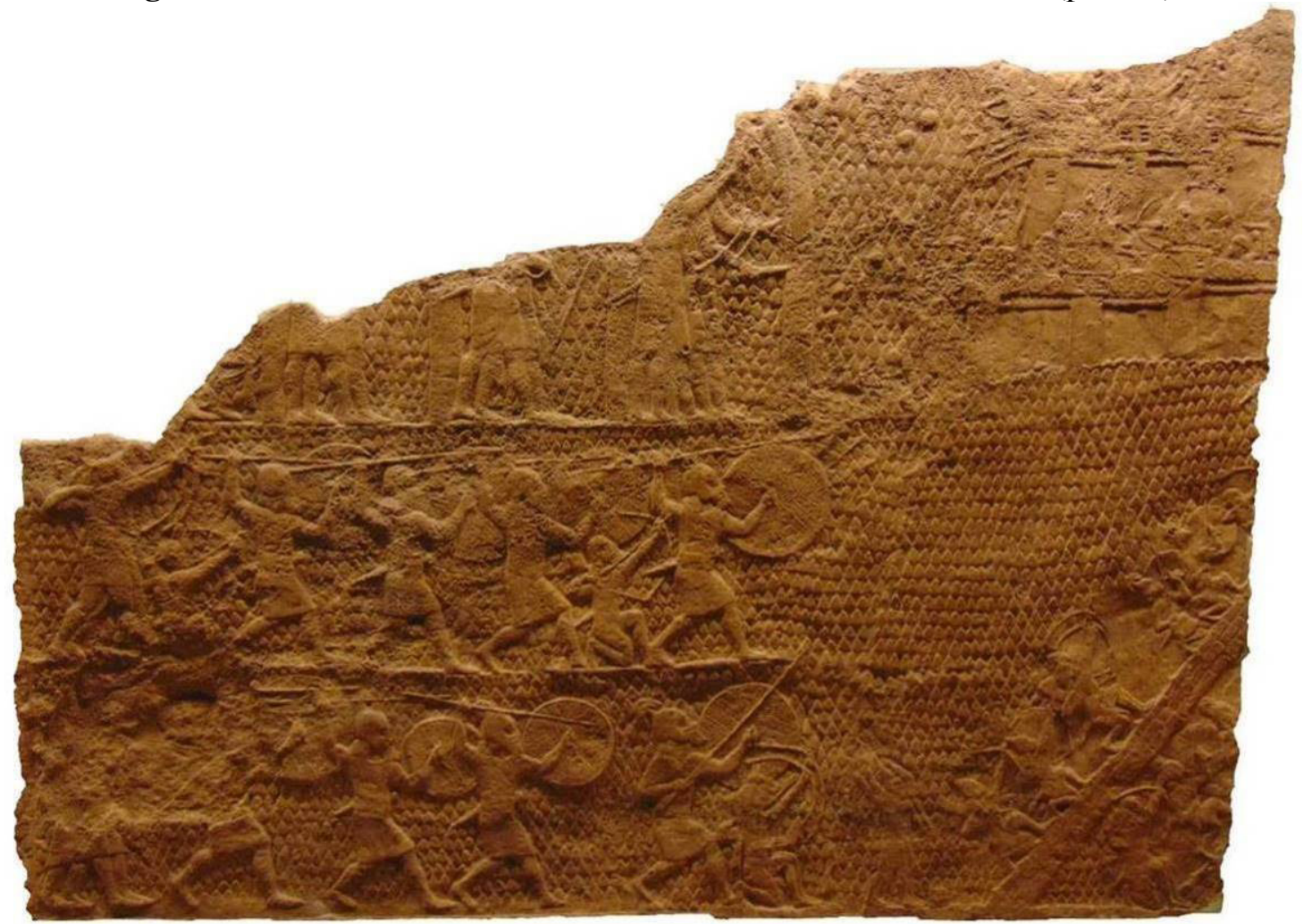

Fonte: (The Trustees of the British Museum (BM 124905). Fotografia realizada e adaptada por Ranieri. 
Figura 51 - Relevos da sala XXXVI do Palácio Sudoeste de Nínive (placa 7).

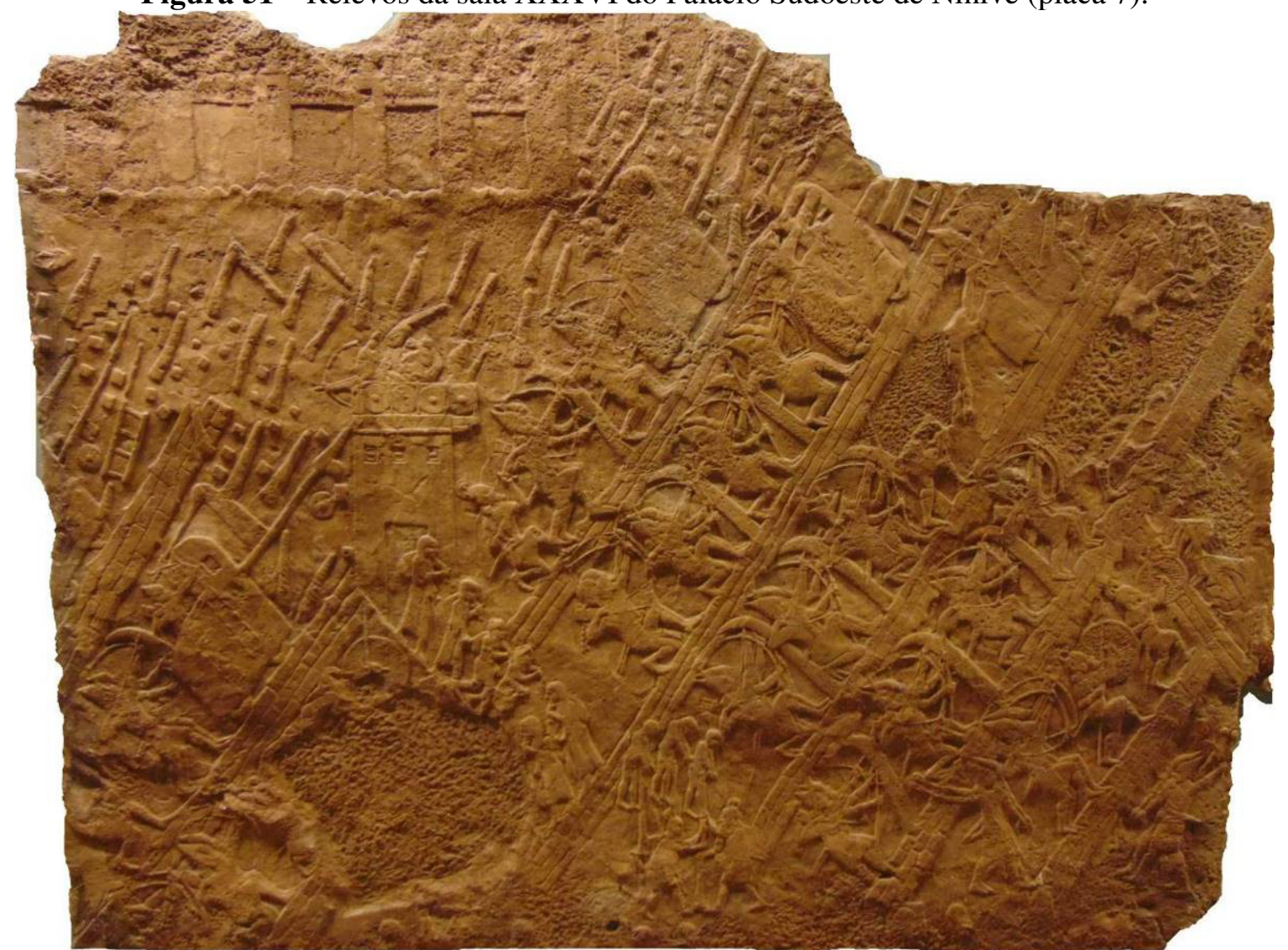

Fonte: (OThe Trustees of the British Museum (BM 124906). Fotografia realizada e adaptada por Ranieri.

Figura 52 - Relevos da sala XXXVI do Palácio Sudoeste de Nínive (placa 8).

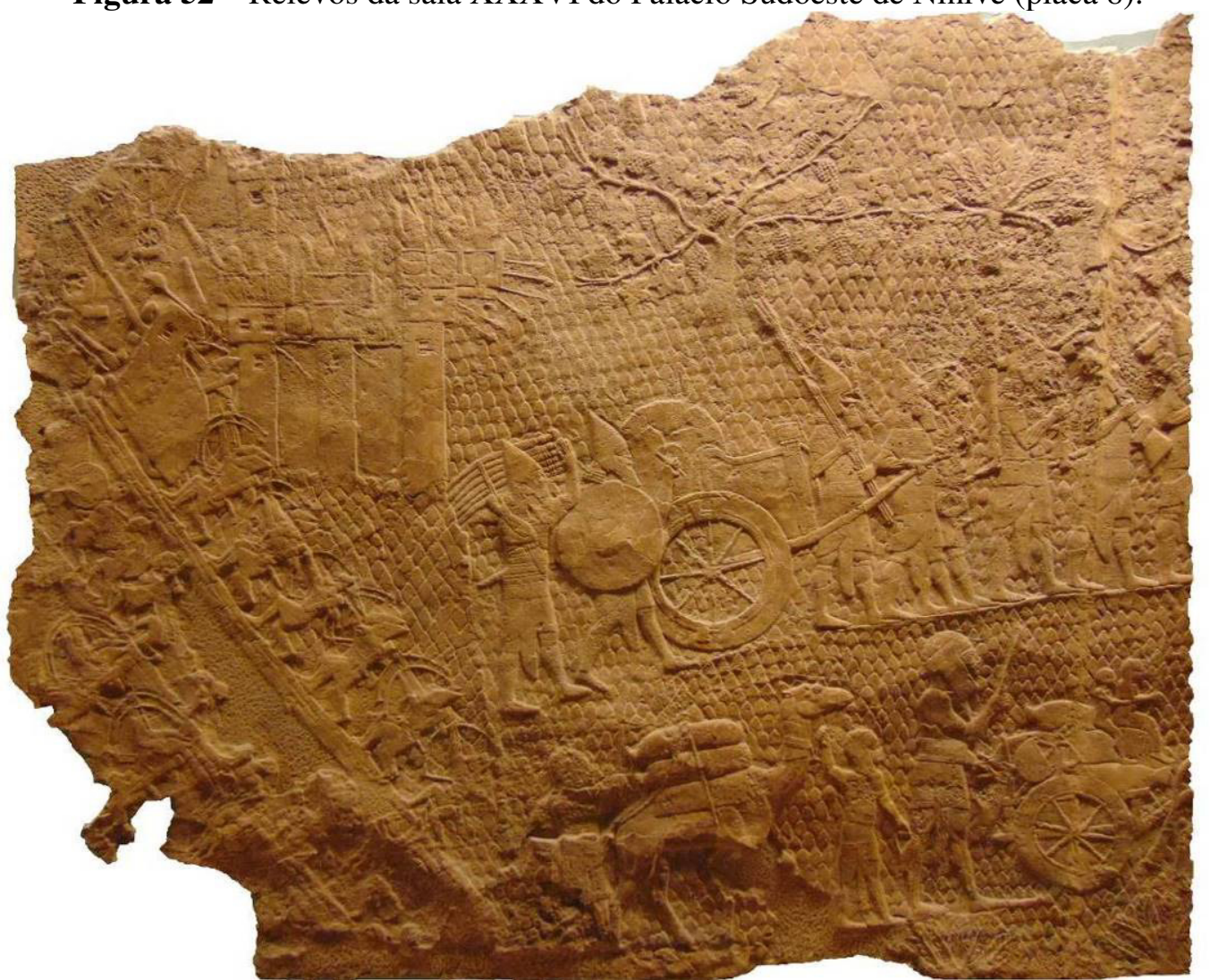

Fonte: OThe Trustees of the British Museum (BM 124907). Fotografia realizada e adaptada por Ranieri. 
Figura 53 - Relevos da sala XXXVI do Palácio Sudoeste de Nínive (placas 8-9).

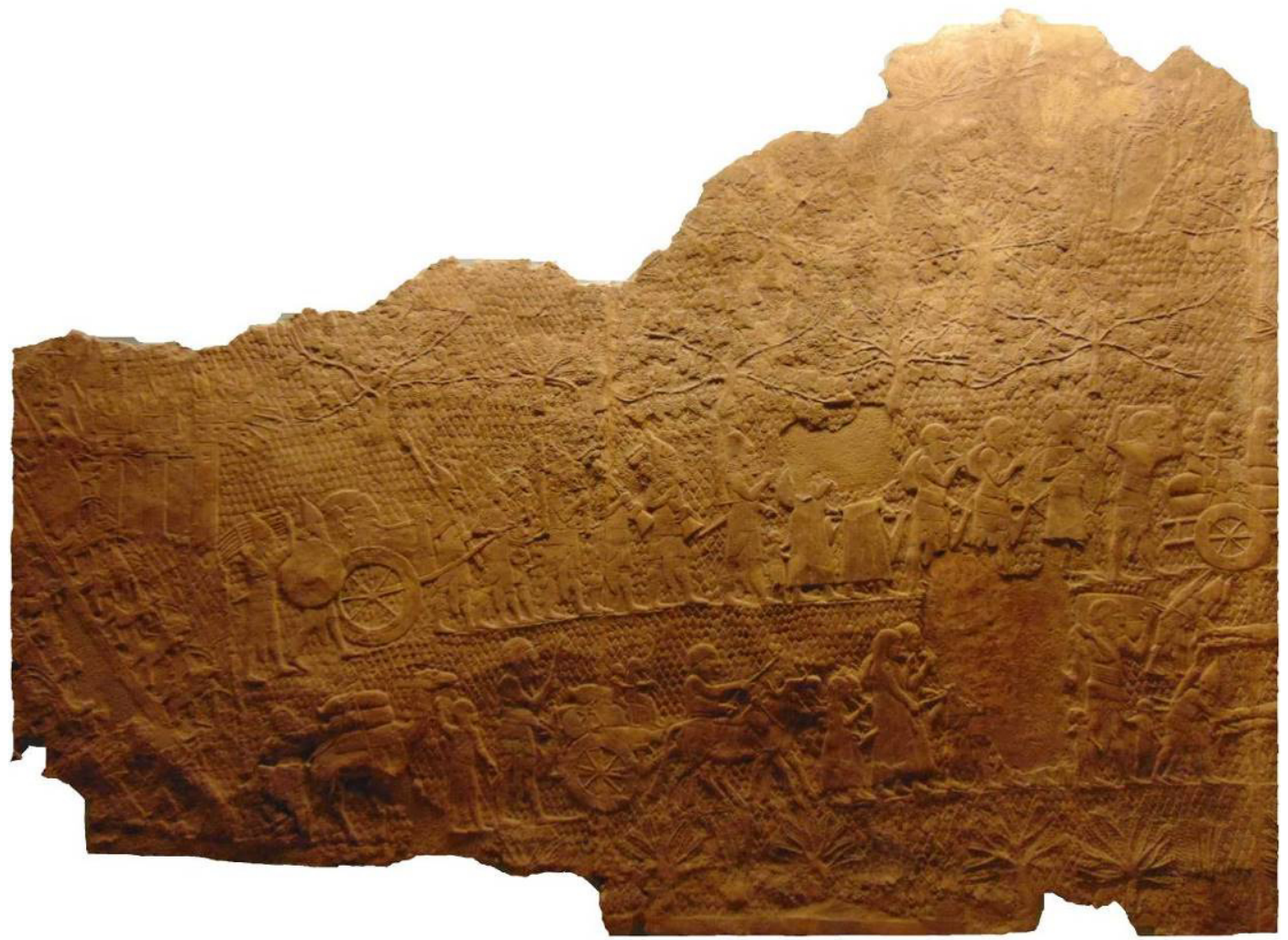

Fonte: @The Trustees of the British Museum (BM 124907-8). Fotografia realizada e adaptada por Ranieri.

Figura 54 - Relevos da sala XXXVI do Palácio Sudoeste de Nínive (placa 9).

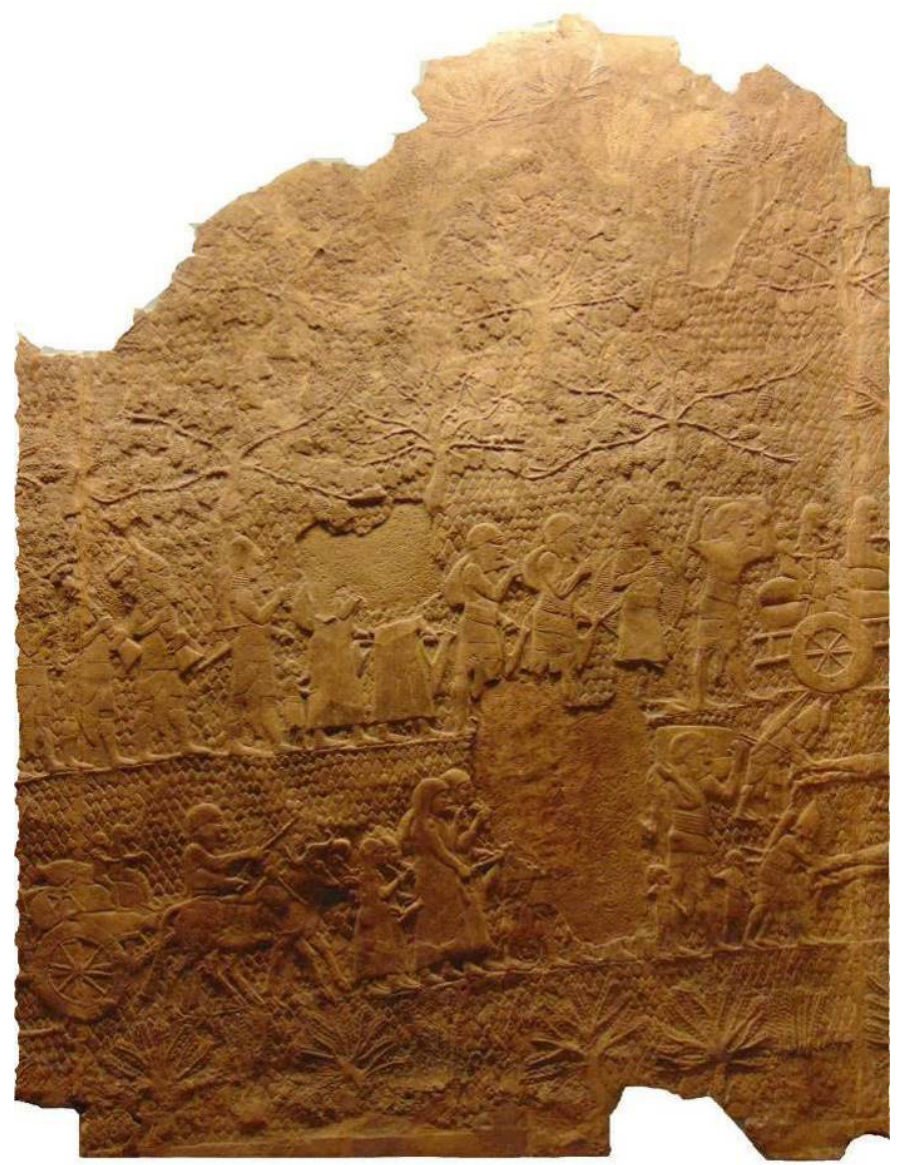

Fonte: (The Trustees of the British Museum (BM 124908). Fotografia realizada e adaptada por Ranieri. 
Figura 55 - Relevos da sala XXXVI do Palácio Sudoeste de Nínive (placas 9-11).

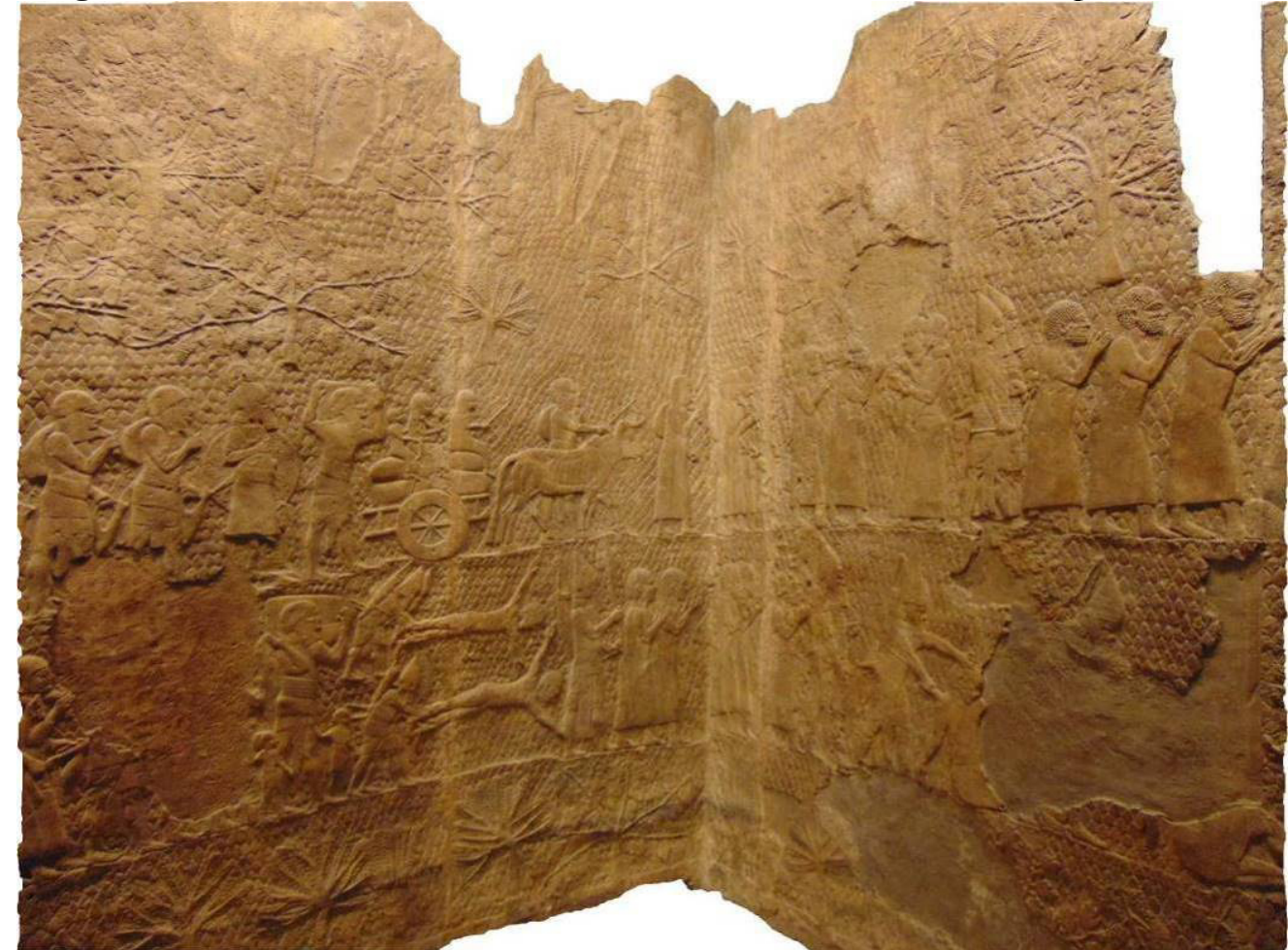

Fonte: (The Trustees of the British Museum (BM 124908-10). Fotografia realizada e adaptada por Ranieri.

Figura 56 - Relevos da sala XXXVI do Palácio Sudoeste de Nínive (placa 11).

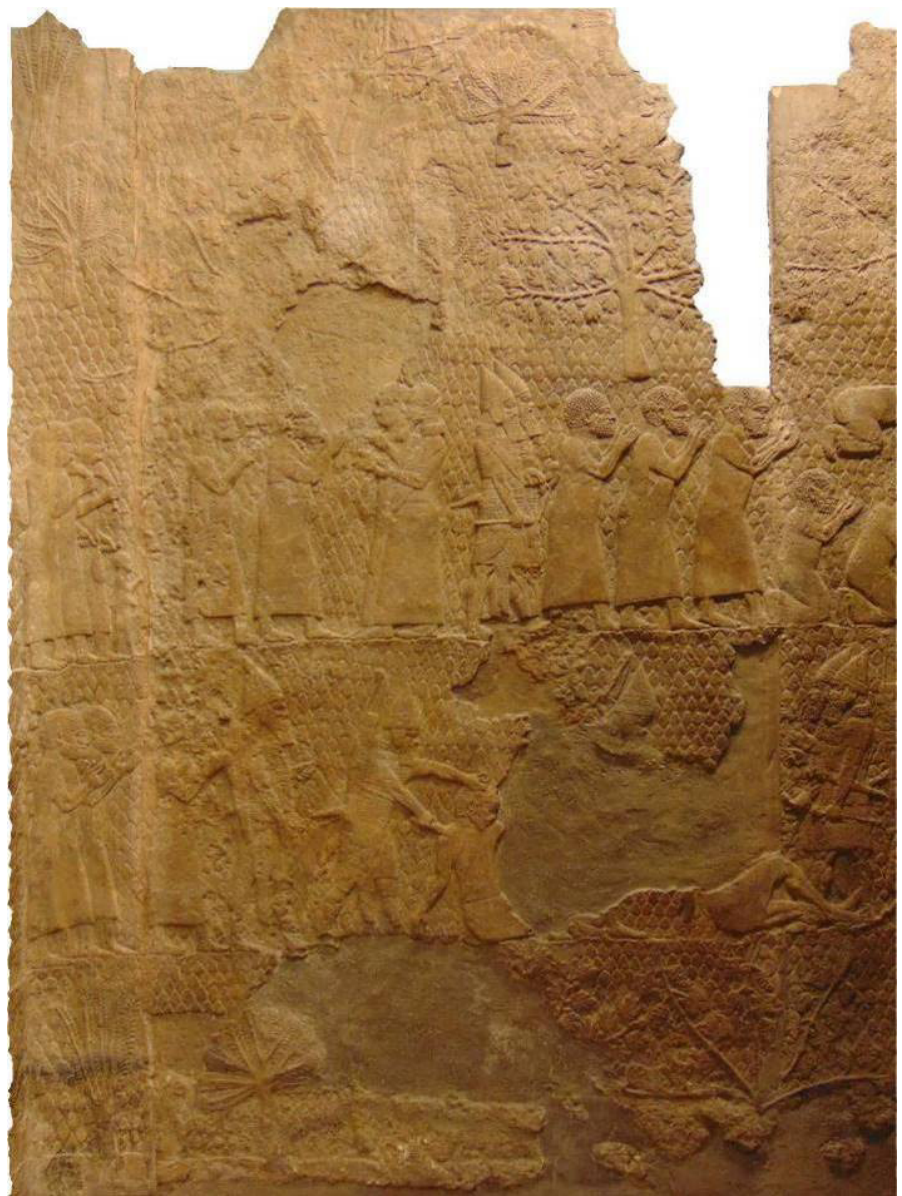

Fonte: @The Trustees of the British Museum (BM 124910). Fotografia realizada e adaptada por Ranieri. 
Figura 57 - Relevos da sala XXXVI do Palácio Sudoeste de Nínive (placa 11-12).

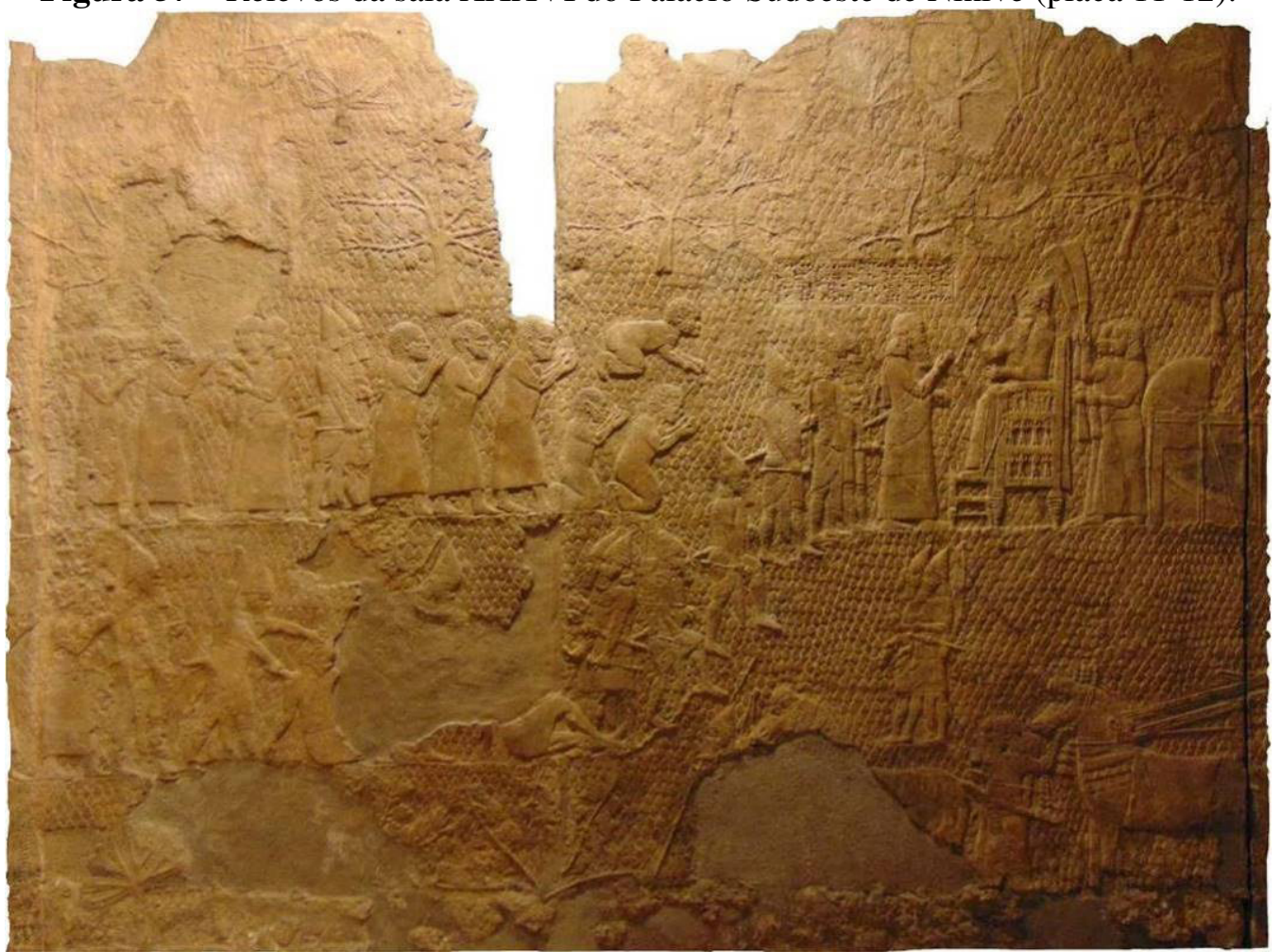

Fonte: @The Trustees of the British Museum (BM 124910-11). Fotografia realizada e adaptada por Ranieri.

Figura 58 - Relevos da sala XXXVI do Palácio Sudoeste de Nínive (placa 12).

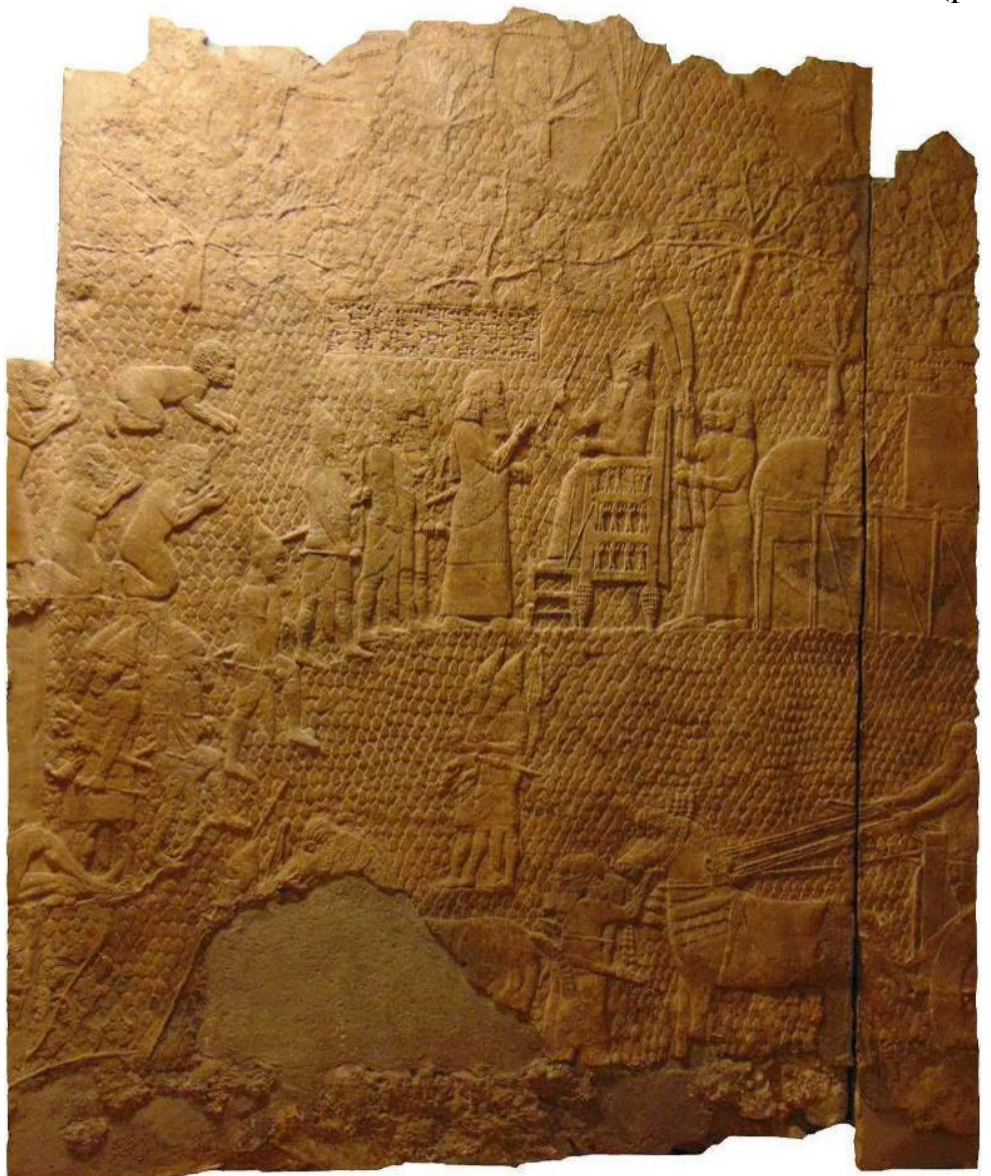

Fonte: @The Trustees of the British Museum (BM 124911). Fotografia realizada e adaptada por Ranieri. 
Figura 59 - Relevos da sala XXXVI do Palácio Sudoeste de Nínive (placa 13).

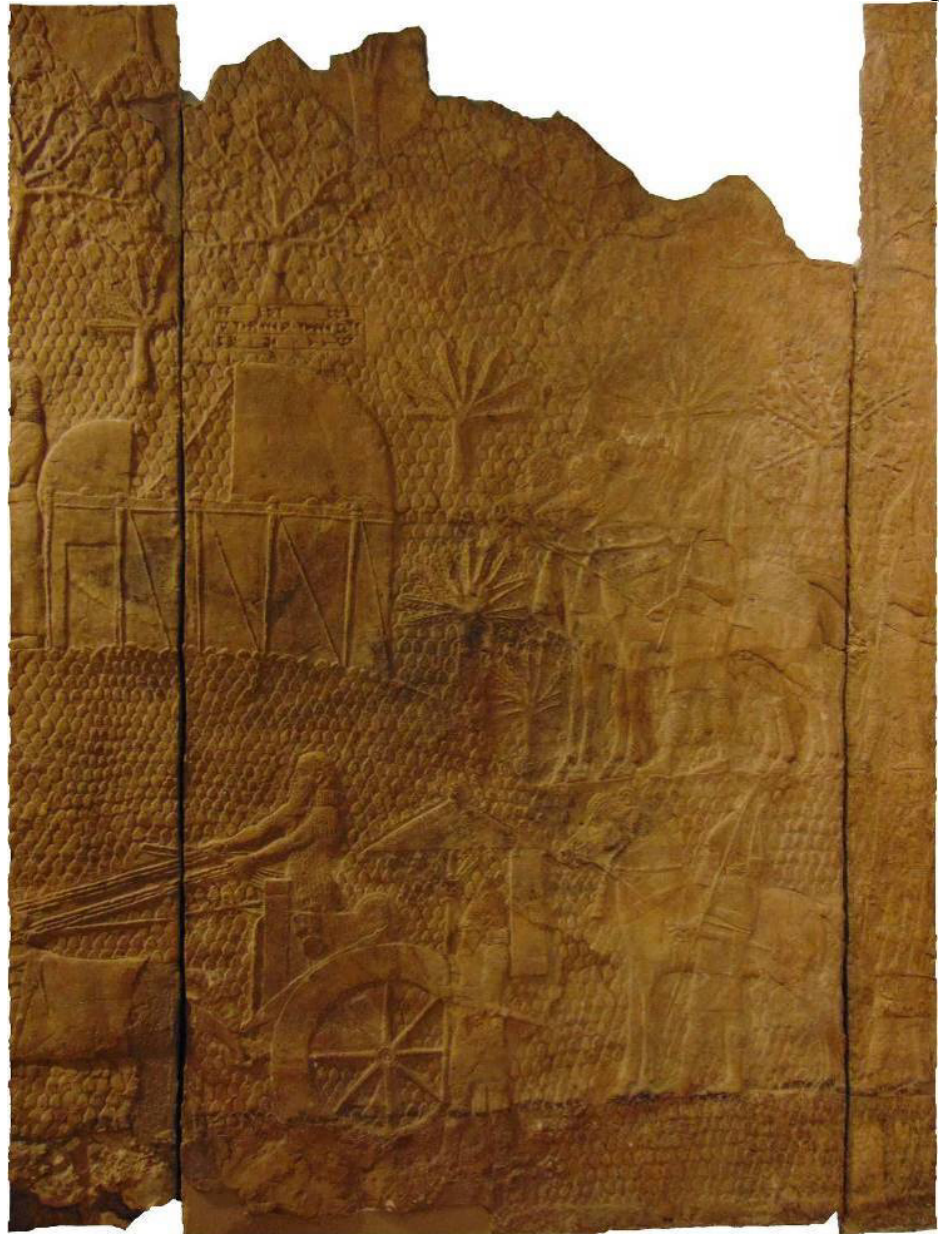

Fonte: @The Trustees of the British Museum (BM 124912). Fotografia realizada e adaptada por Ranieri.

Figura 60 - Relevos da sala XXXVI do Palácio Sudoeste de Nínive (placas 13-15).

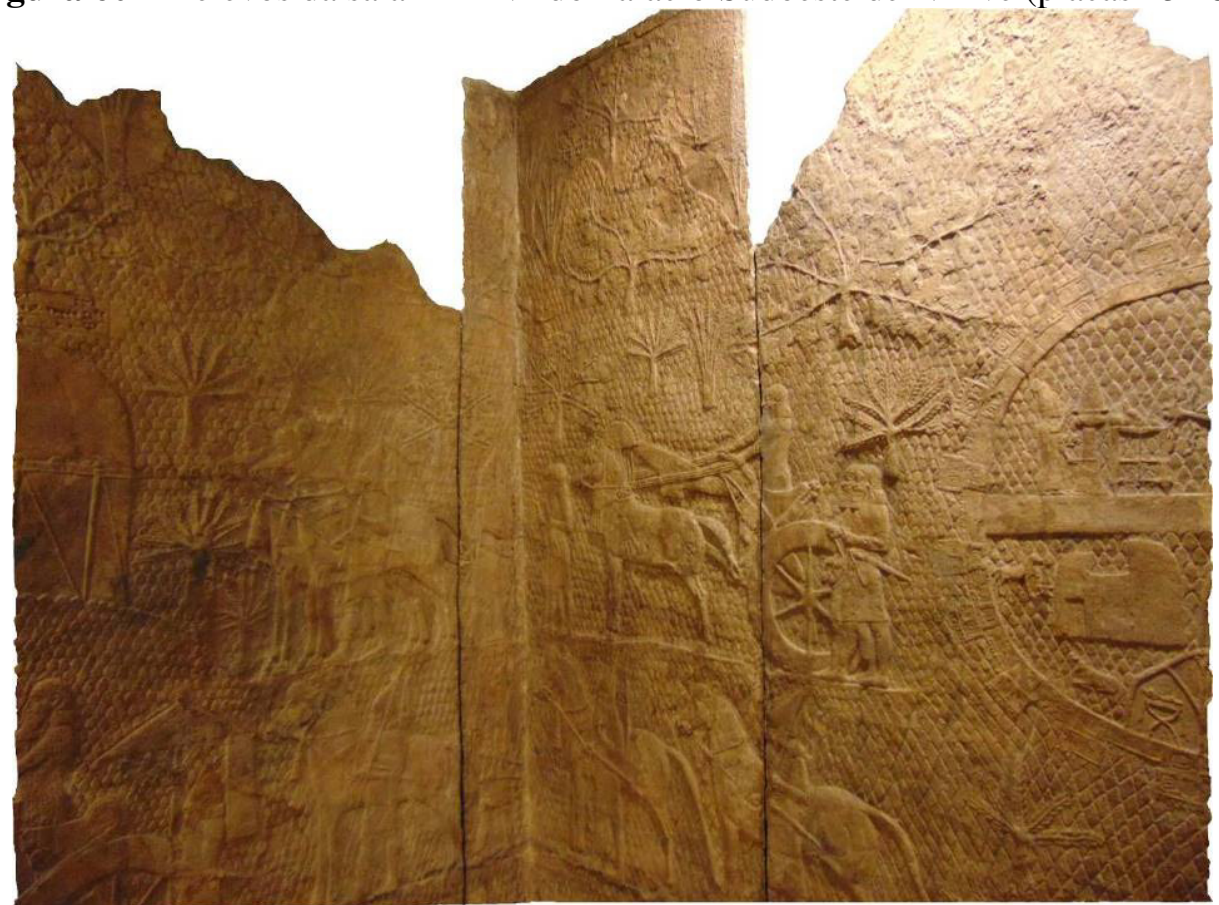

Fonte: @The Trustees of the British Museum (BM 124912-14). Fotografia realizada e adaptada por Ranieri. 
Figura 61 - Relevos da sala LI do Palácio Sudoeste de Nínive (placas 30-32).

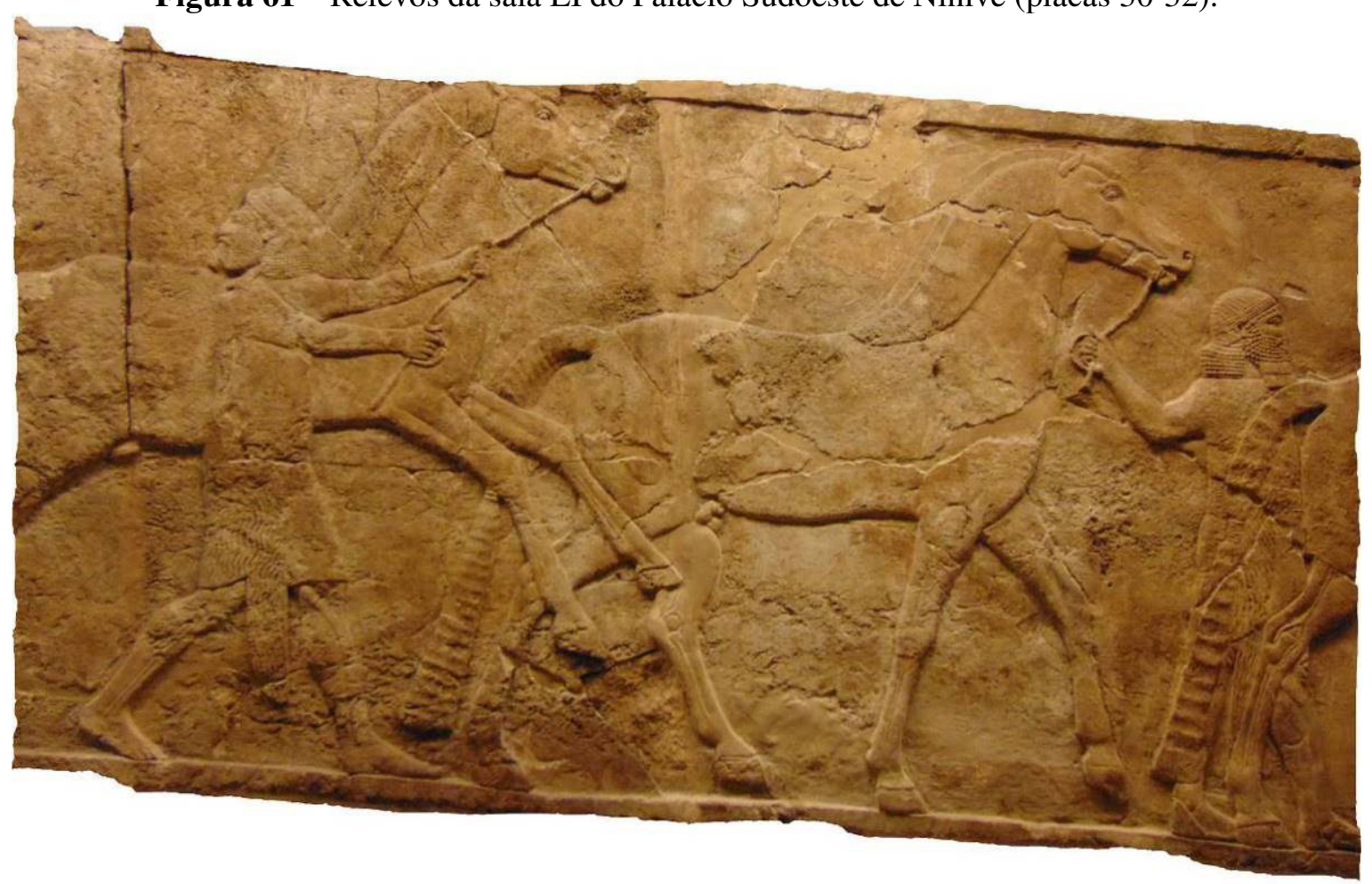

Fonte: @The Trustees of the British Museum (BM 124796a-c). Fotografia realizada e adaptada por Ranieri.

Figura 62 - Relevos da sala LI do Palácio Sudoeste de Nínive (placas de posição imprecisa).

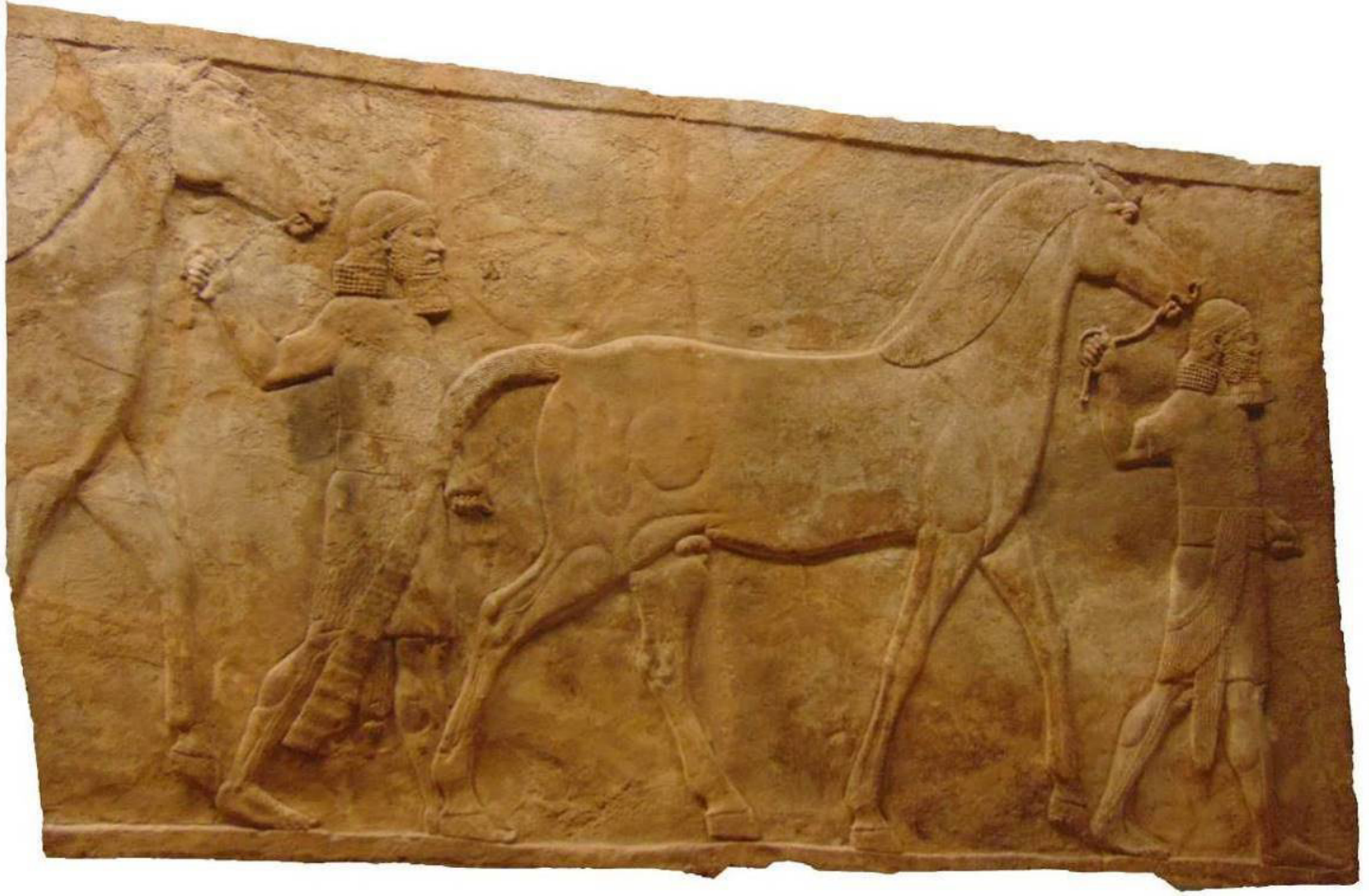

Fonte: @The Trustees of the British Museum (BM 124795a-b). Fotografia realizada e adaptada por Ranieri. 
Figura 63 - Relevos da sala LI do Palácio Sudoeste de Nínive (placas 10-11).

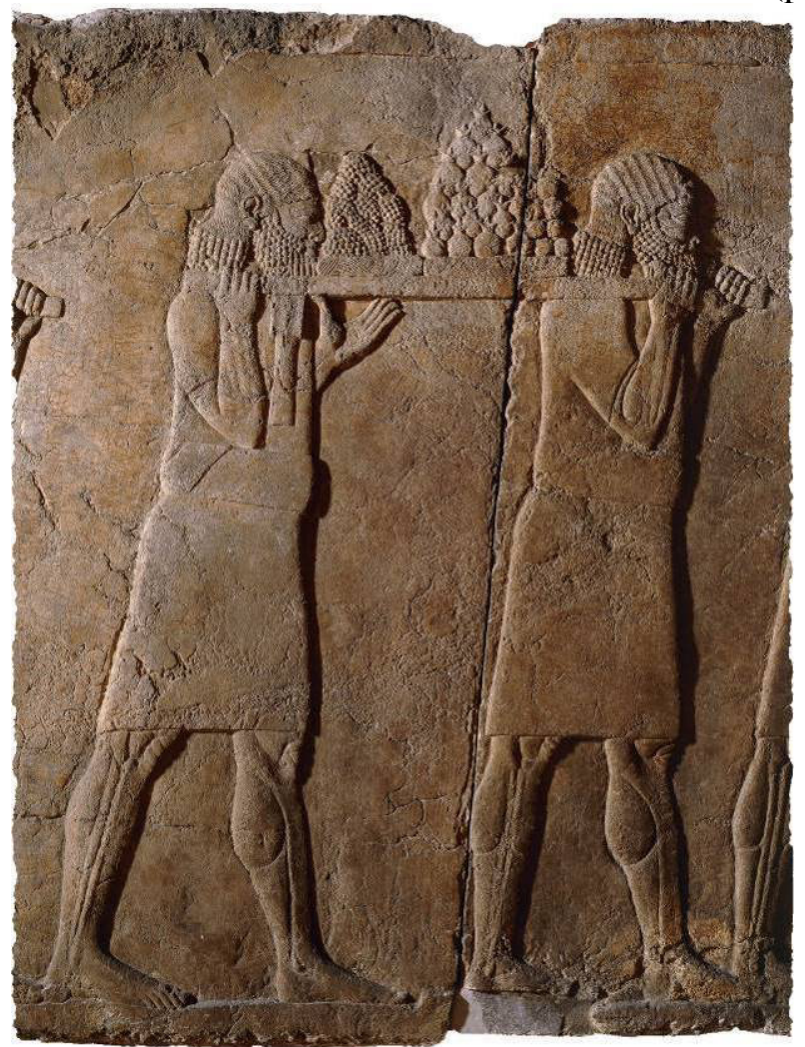

Fonte: @The Trustees of the British Museum (BM 124799a-b). Adaptada por Ranieri.

Figura 64 - Relevos da sala LI do Palácio Sudoeste de Nínive (placa 13).

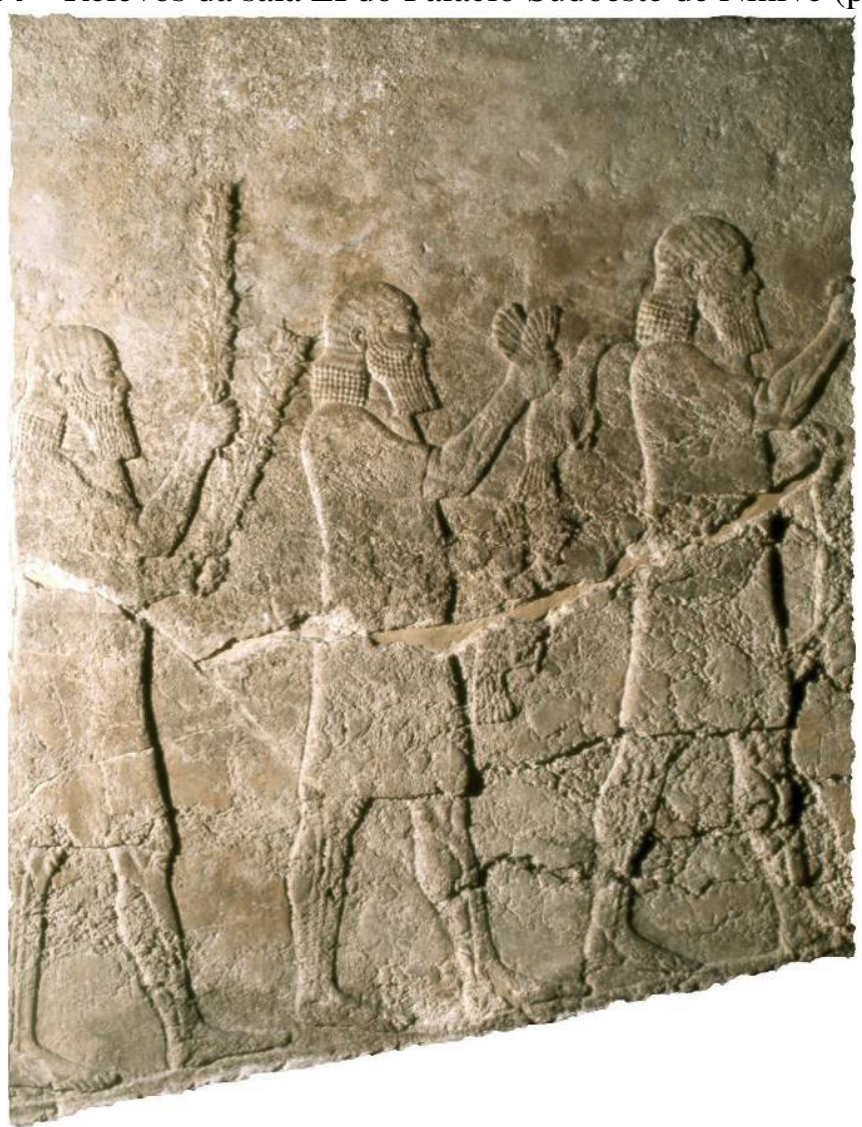

Fonte: @The Trustees of the British Museum (BM 124798). Adaptada por Ranieri. 
Figura 65 - Relevos da passagem ao Templo de Ištar do Palácio Sudoeste de Nínive (placa 2).

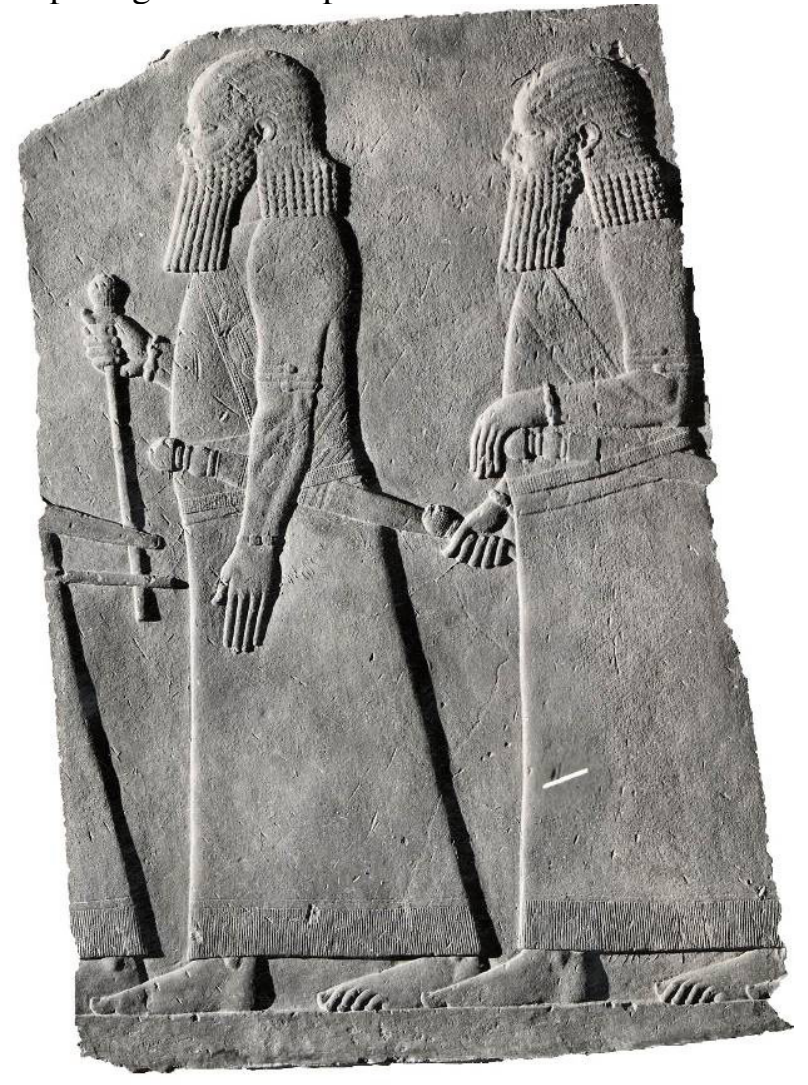

Fonte: @The Trustees of the British Museum (BM 124900). Adaptada por Ranieri.

Figura 66 - Relevos da passagem ao Templo de Ištar do Palácio Sudoeste de Nínive (placa 3).

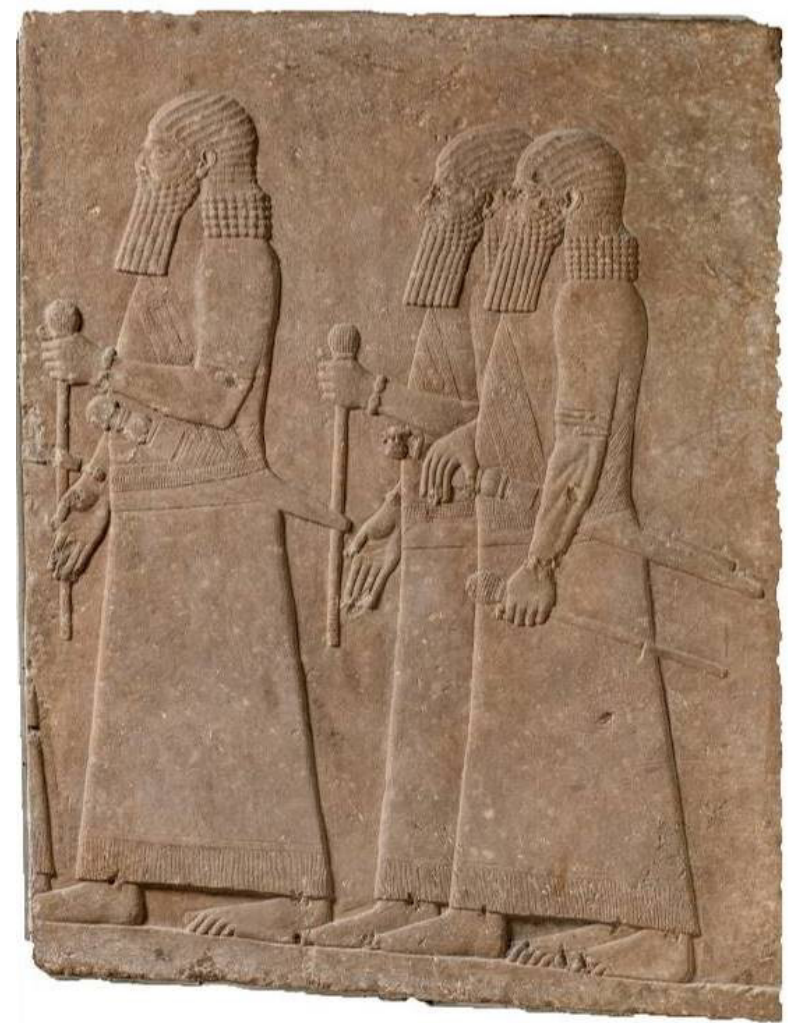

Fonte: () Vorderasiatisches Museum, Staatliche Museen zu Berlin (VA 956). Adaptada por Ranieri. 
Figura 67 - Relevos da passagem ao Templo de Ištar do Palácio Sudoeste de Nínive (placa 4).

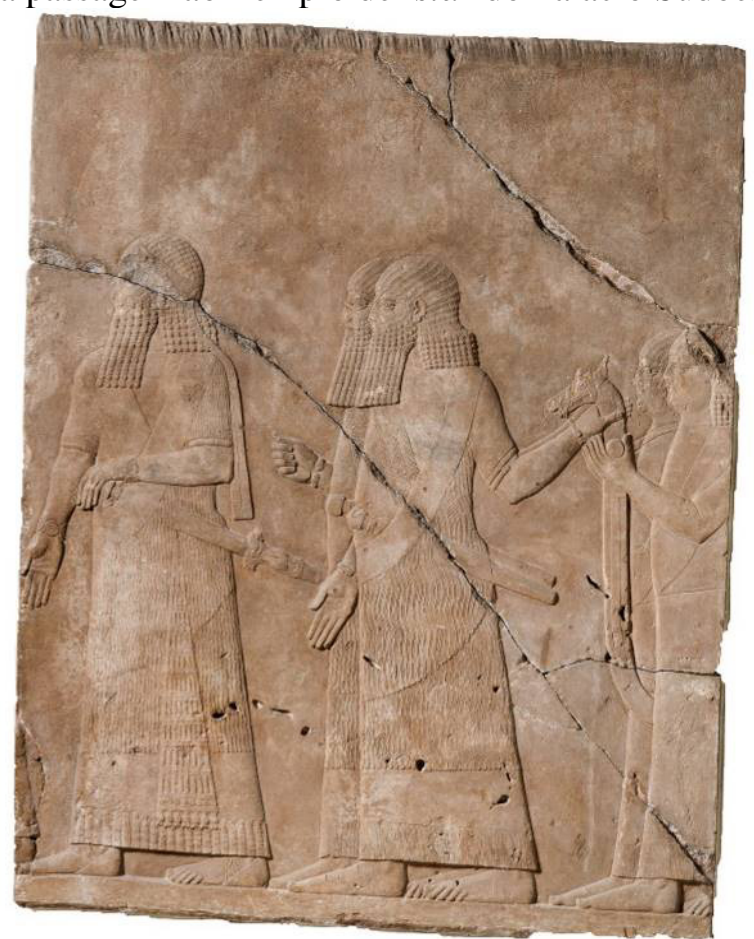

Fonte: @ Vorderasiatisches Museum, Staatliche Museen zu Berlin (VA 955). Adaptada por Ranieri.

Figura 68 - Relevos da passagem ao Templo de Ištar do Palácio Sudoeste de Nínive (placa 8).

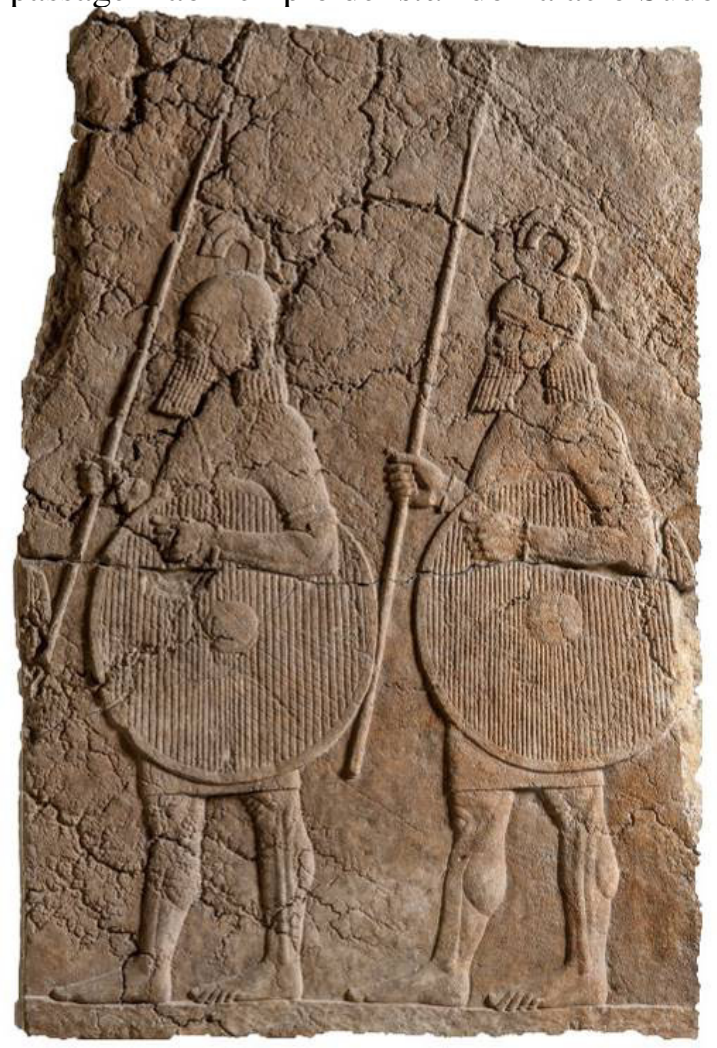

Fonte: @ Vorderasiatisches Museum, Staatliche Museen zu Berlin (VA 958). Adaptada por Ranieri. 
Figura 69 - Relevos da passagem ao Templo de Ištar do Palácio Sudoeste de Nínive (placa A).

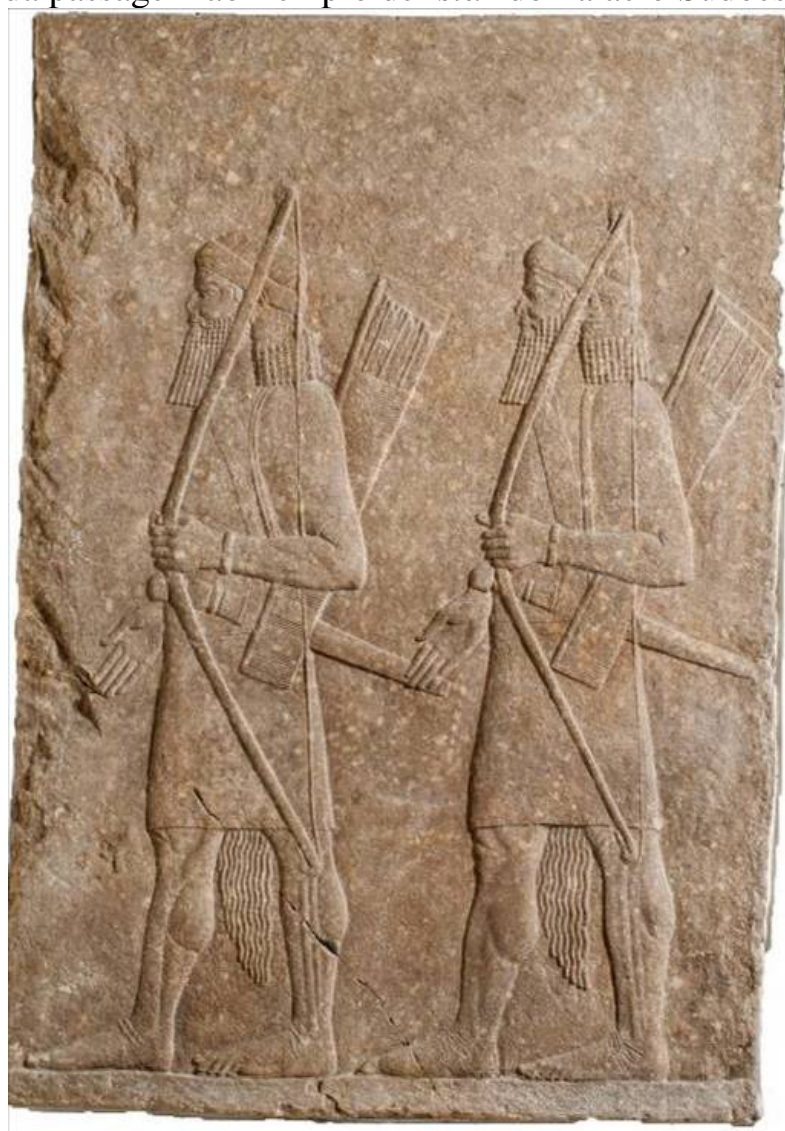

Fonte: @ Vorderasiatisches Museum, Staatliche Museen zu Berlin (VA 957). Adaptada por Ranieri.

Figura 70 - Relevos da passagem ao Templo de Ištar do Palácio Sudoeste de Nínive (placa B).

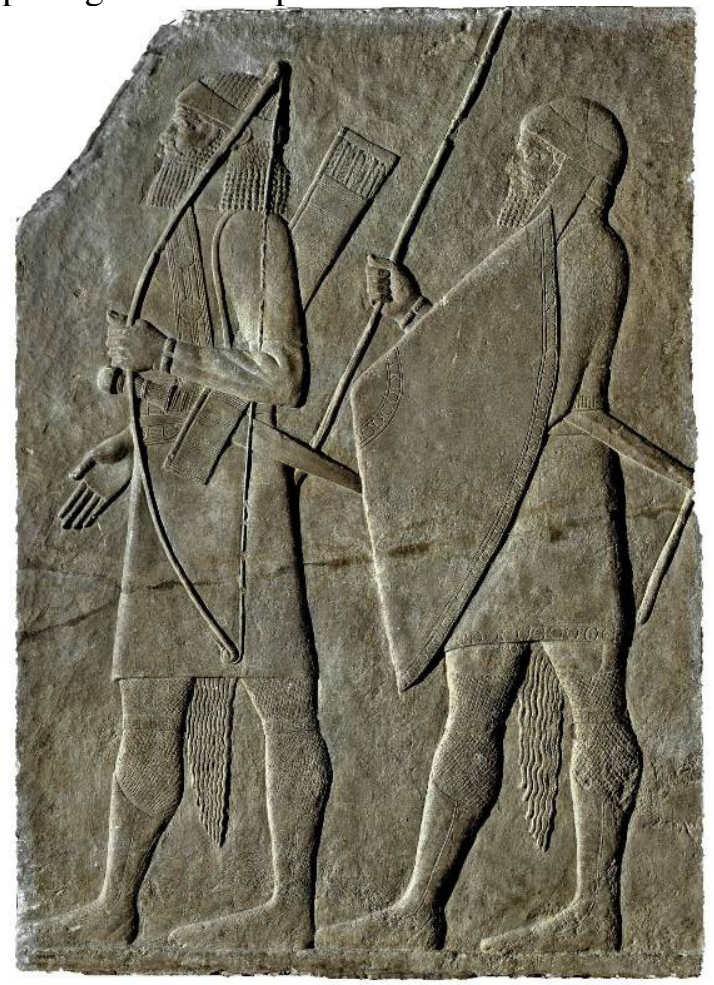

Fonte: (The Trustees of the British Museum (BM 124901). Adaptada por Ranieri. 
Figura 71 - Relevos da passagem ao Templo de Ištar do Palácio Sudoeste de Nínive (placa D).

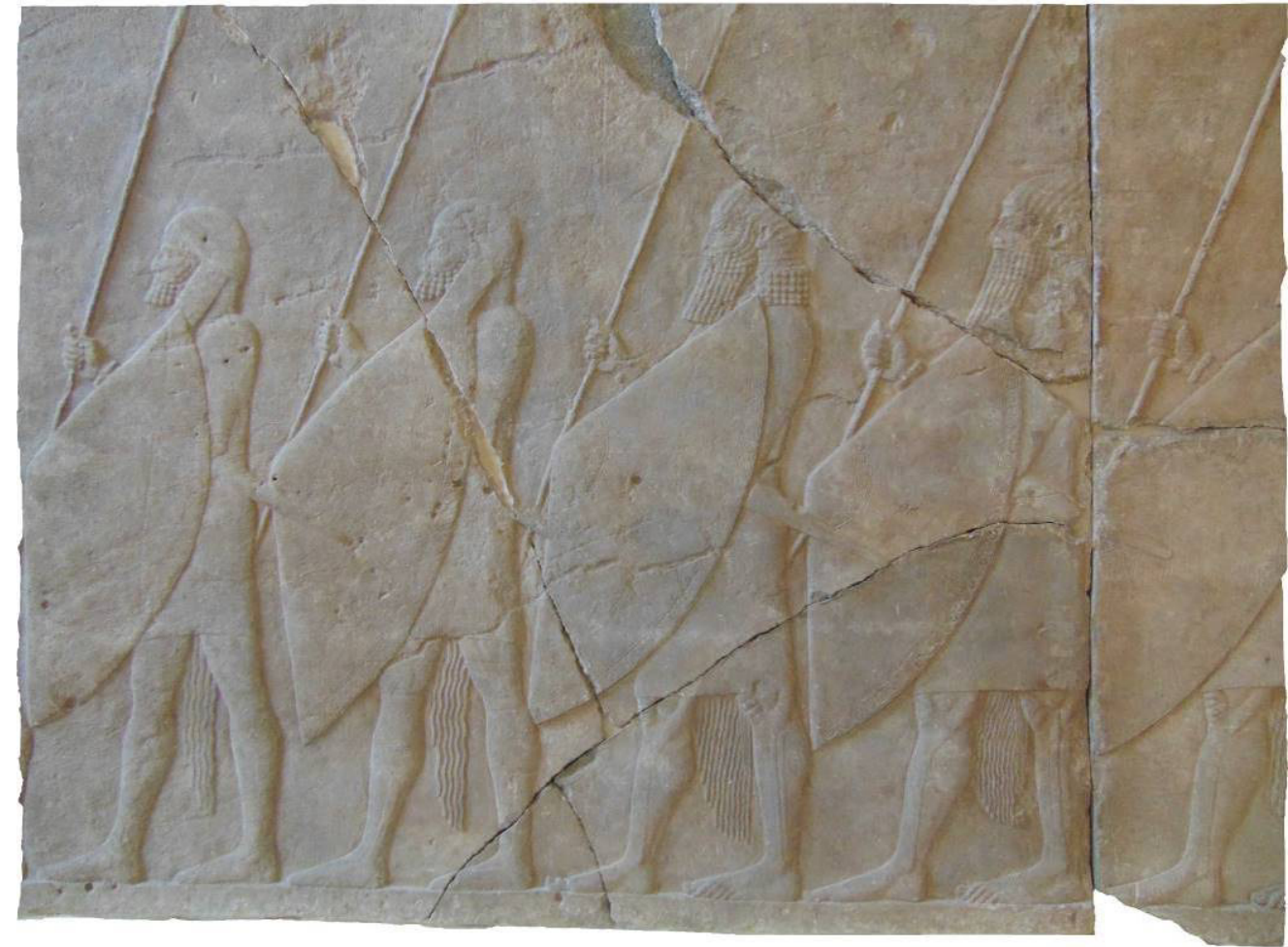

Fonte: () Vorderasiatisches Museum, Staatliche Museen zu Berlin (VA 953a). Fotografia realizada e adaptada por Ranieri.

Figura 72 - Relevos da passagem ao Templo de Ištar do Palácio Sudoeste de Nínive (placa E).

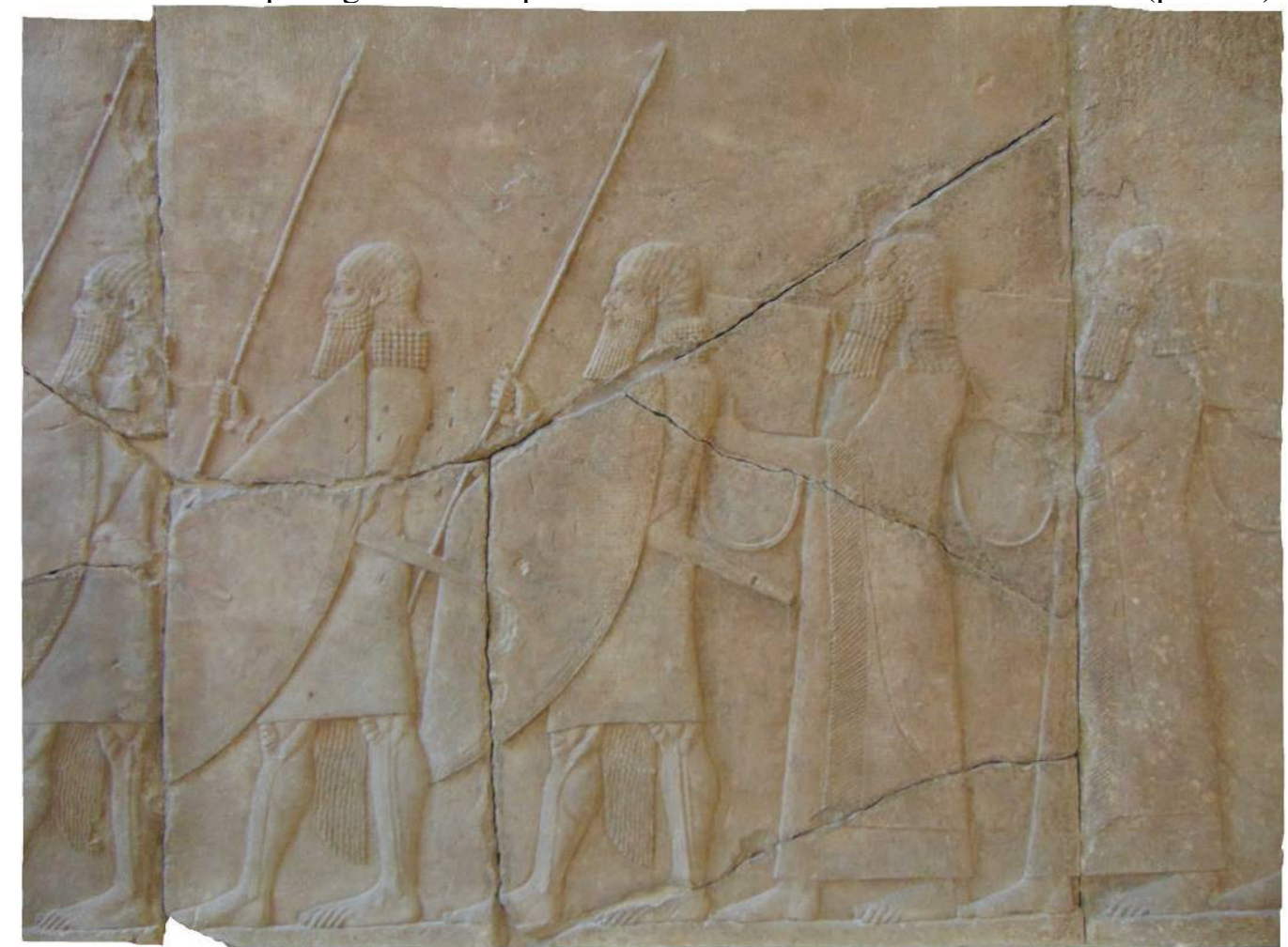

Fonte: ( ) Vorderasiatisches Museum, Staatliche Museen zu Berlin (VA 953b). Fotografia realizada e adaptada por Ranieri. 
Figura 73 - Relevos da passagem ao Templo de Ištar do Palácio Sudoeste de Nínive (placa F).

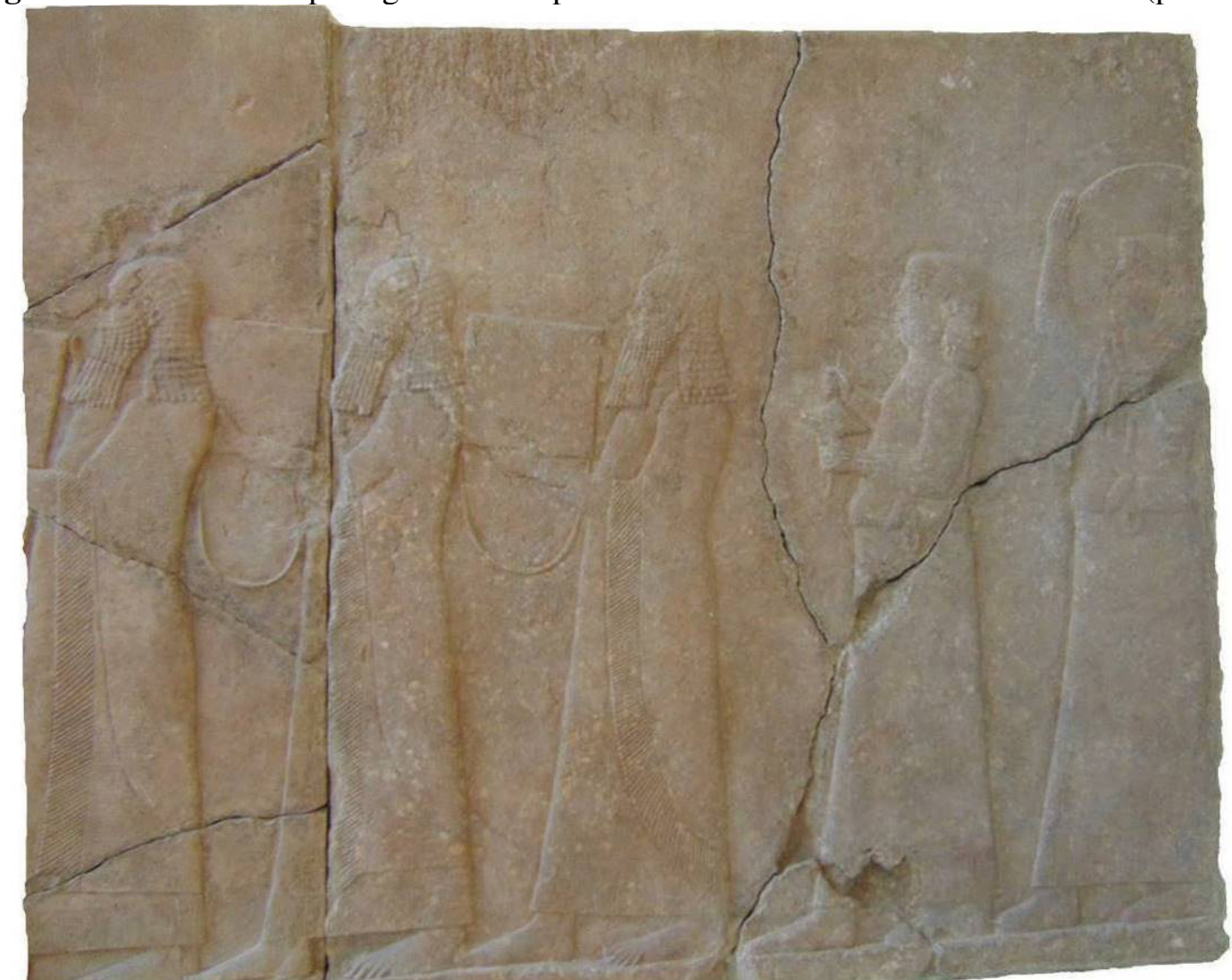

Fonte: @Vorderasiatisches Museum, Staatliche Museen zu Berlin (VA 953c). Fotografia realizada e adaptada por Ranieri. 
Figura 74 - Relevos do corredor R do Palácio Norte de Nínive (placas 6-5).

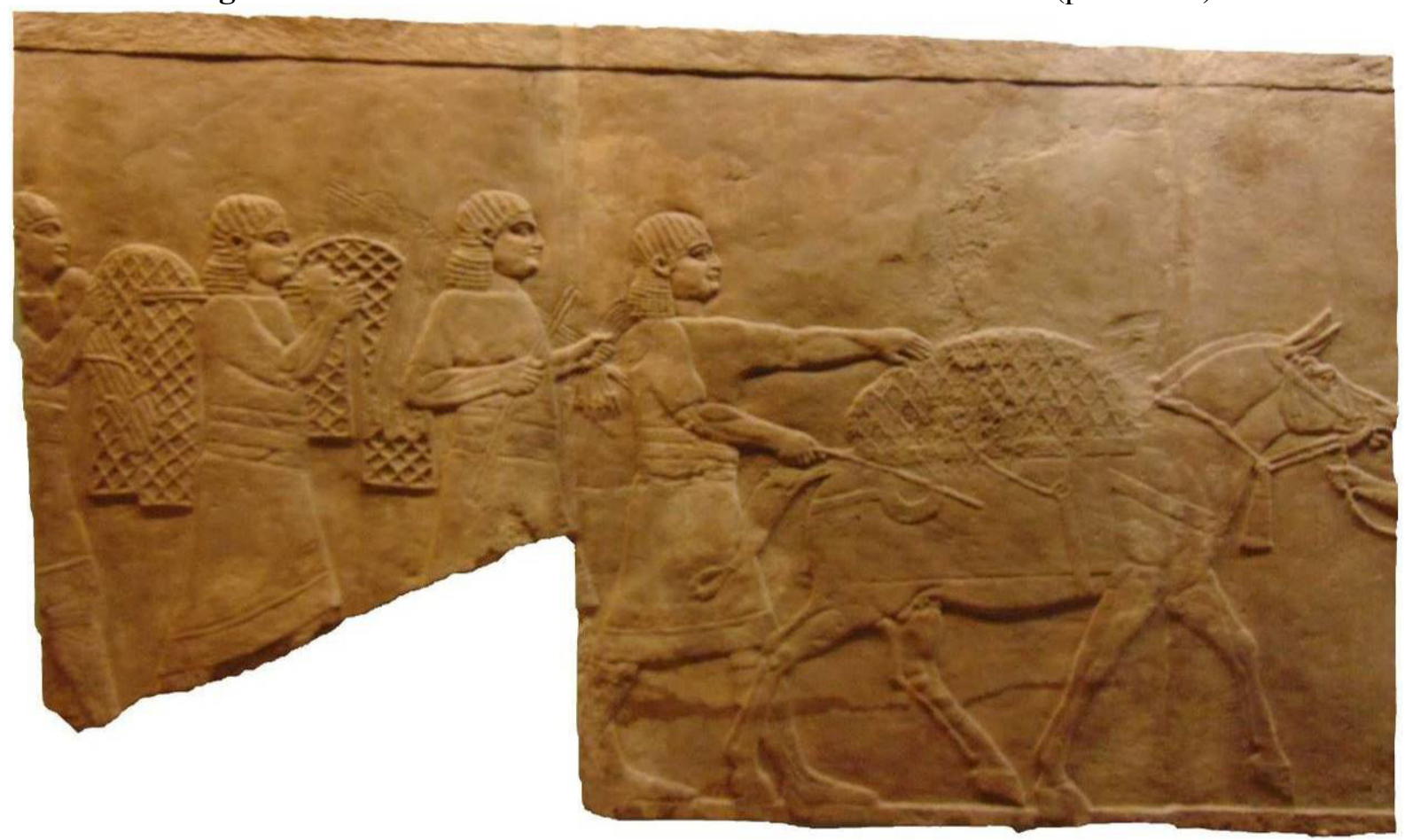

Fonte: @The Trustees of the British Museum (BM 124894-95). Fotografia realizada e adaptada por Ranieri.

Figura 75 - Relevos do corredor R do Palácio Norte de Nínive (placas 4-3).

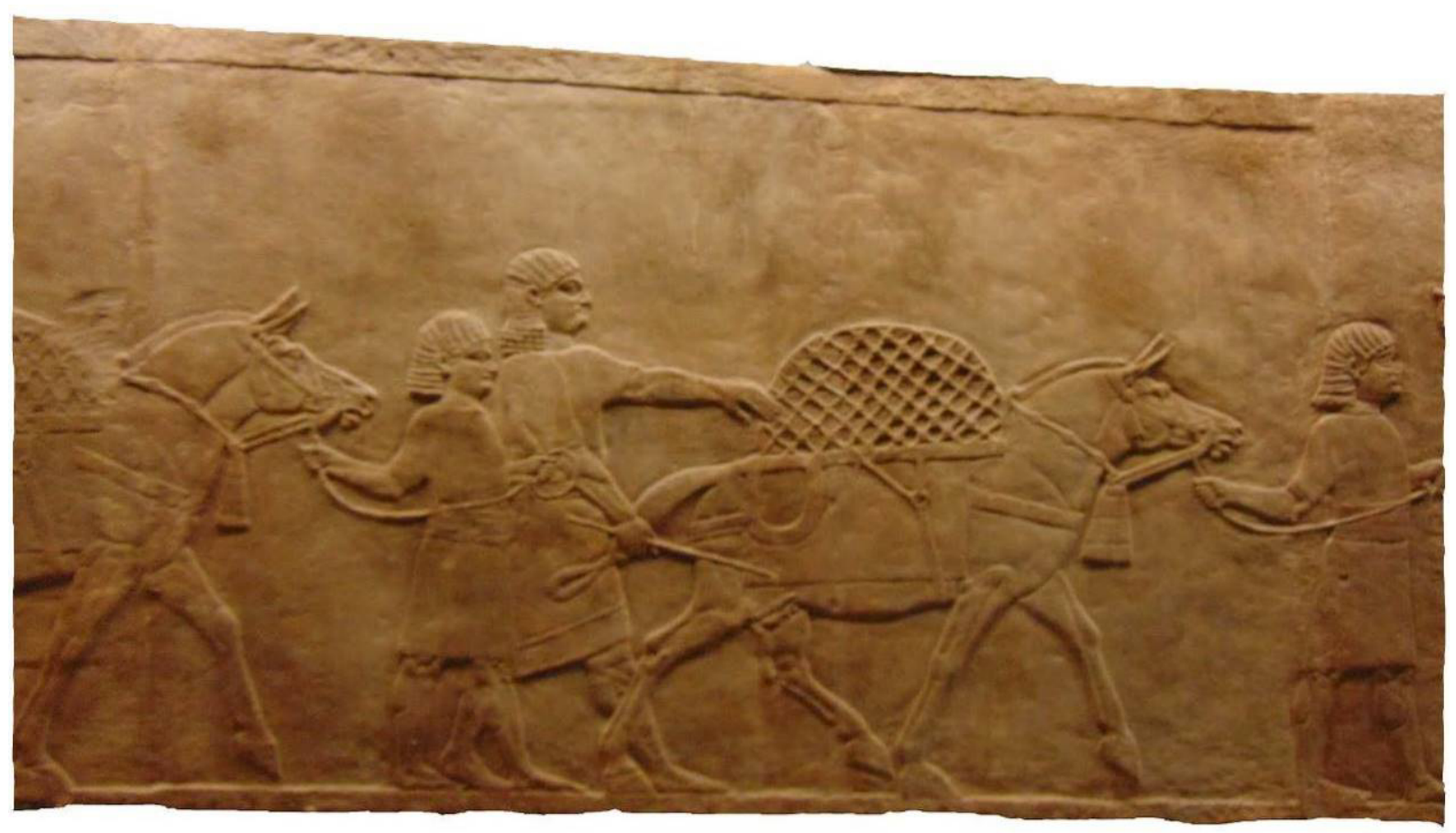

Fonte: @The Trustees of the British Museum (BM 124896-97). Fotografia realizada e adaptada por Ranieri. 
Figura 76 - Relevos do corredor R do Palácio Norte de Nínive (placas 2-1).

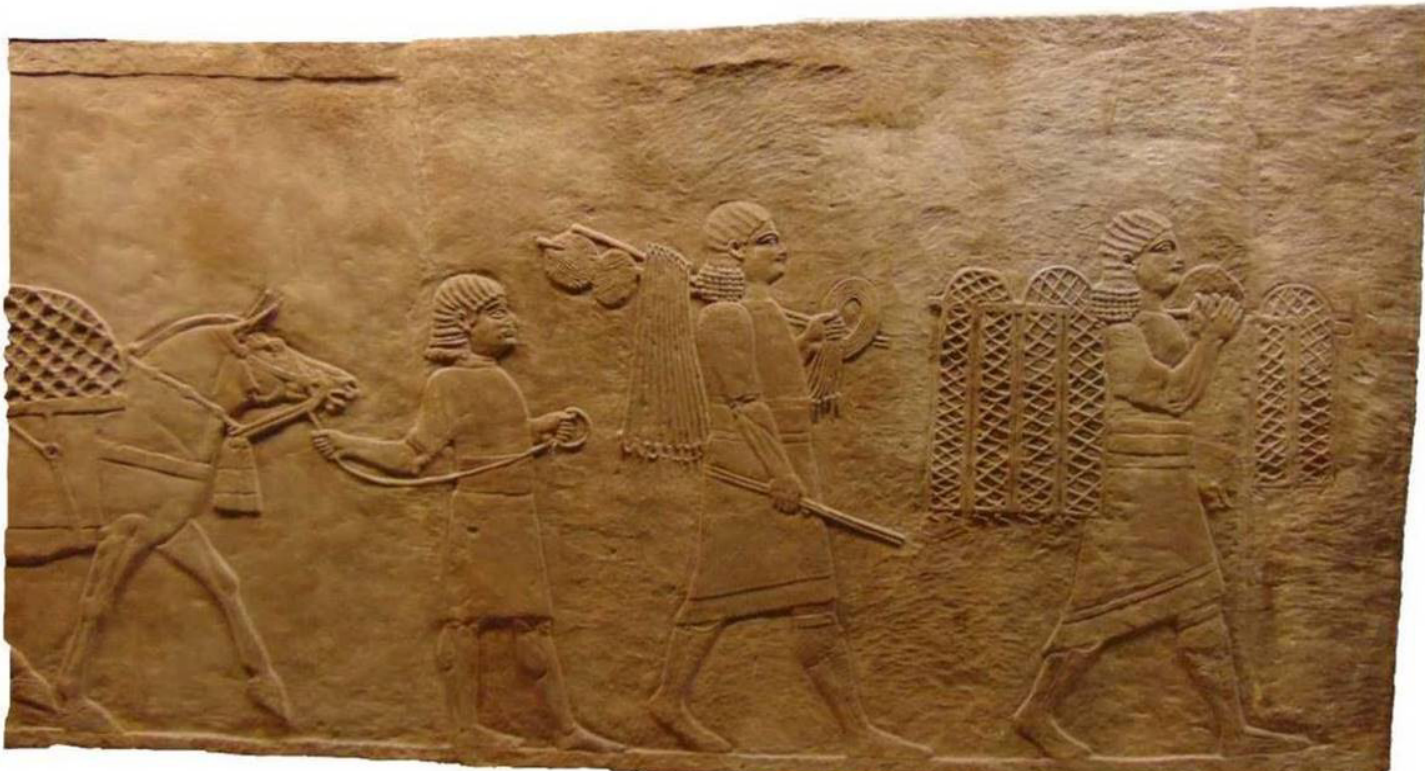

Fonte: @The Trustees of the British Museum (BM 124897-99). Fotografia realizada e adaptada por Ranieri. 
Figura 77 - Relevos do corredor R do Palácio Norte de Nínive (placas 28-27).

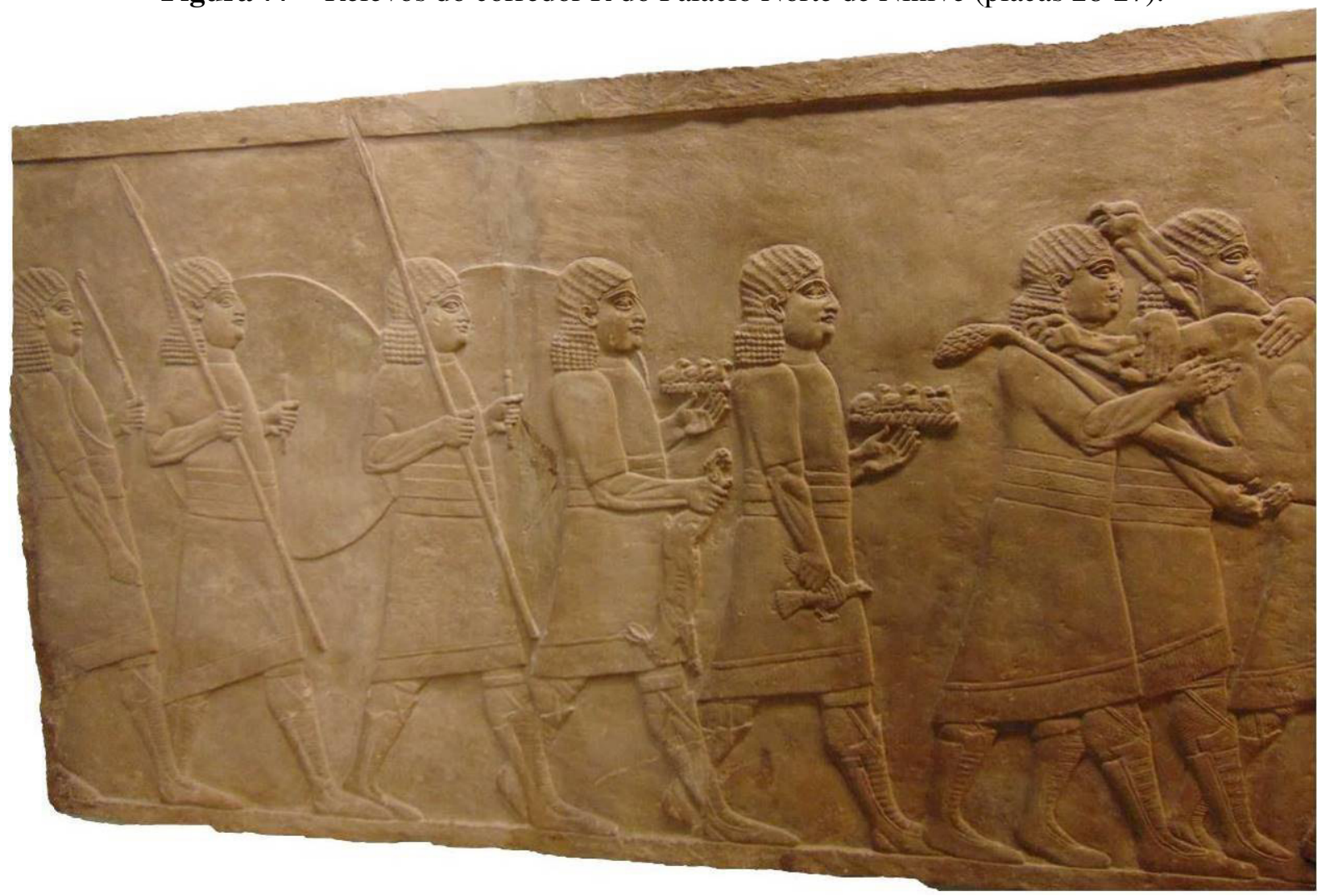

Fonte: @The Trustees of the British Museum (BM 124888-89). Fotografia realizada e adaptada por Ranieri.

Figura 78 - Relevos do corredor R do Palácio Norte de Nínive (placas 26-25).

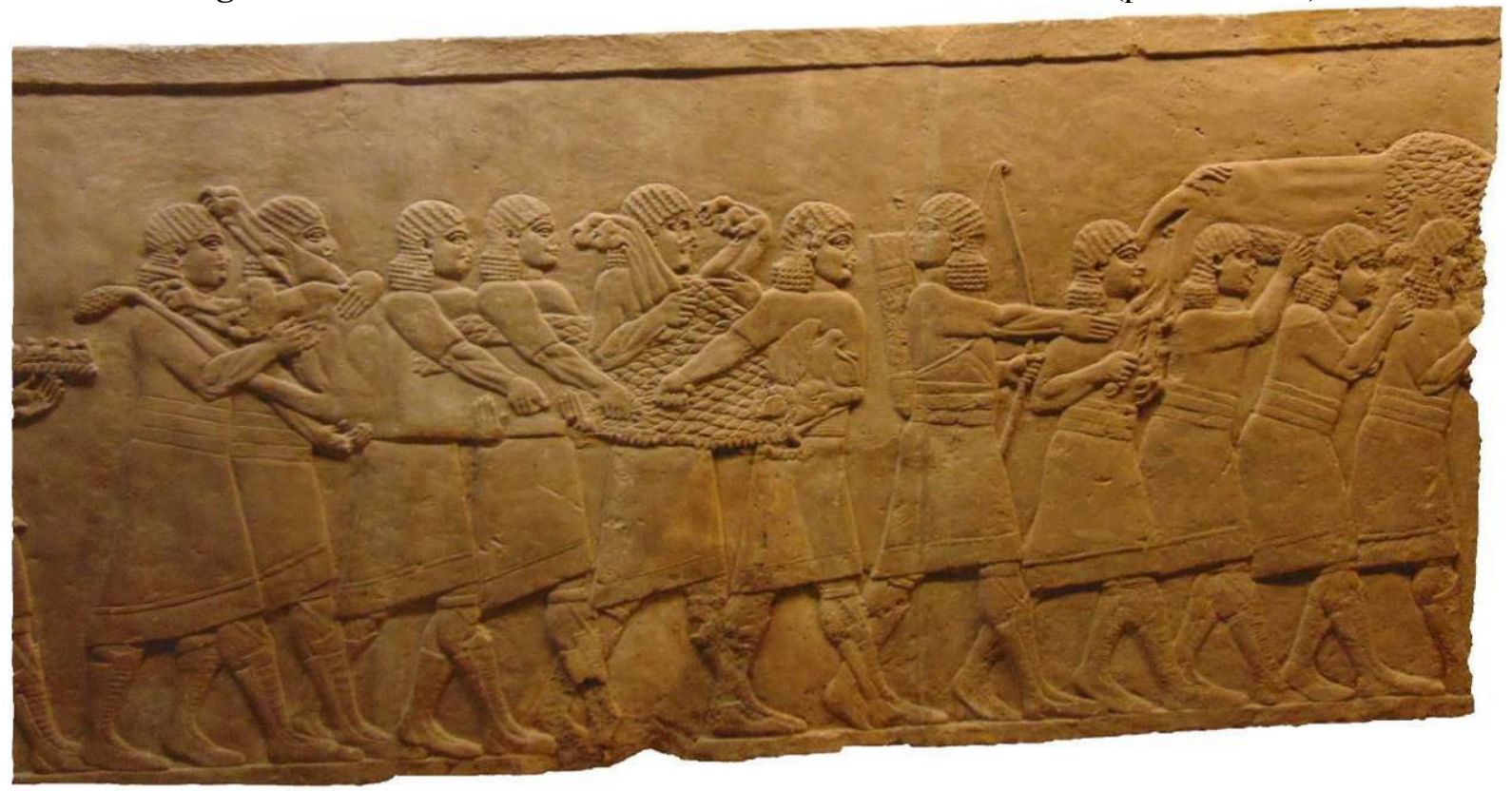

Fonte: (The Trustees of the British Museum (BM 124890-91). Fotografia realizada e adaptada por Ranieri. 
Figura 79 - Relevos do corredor R do Palácio Norte de Nínive (placa 23).

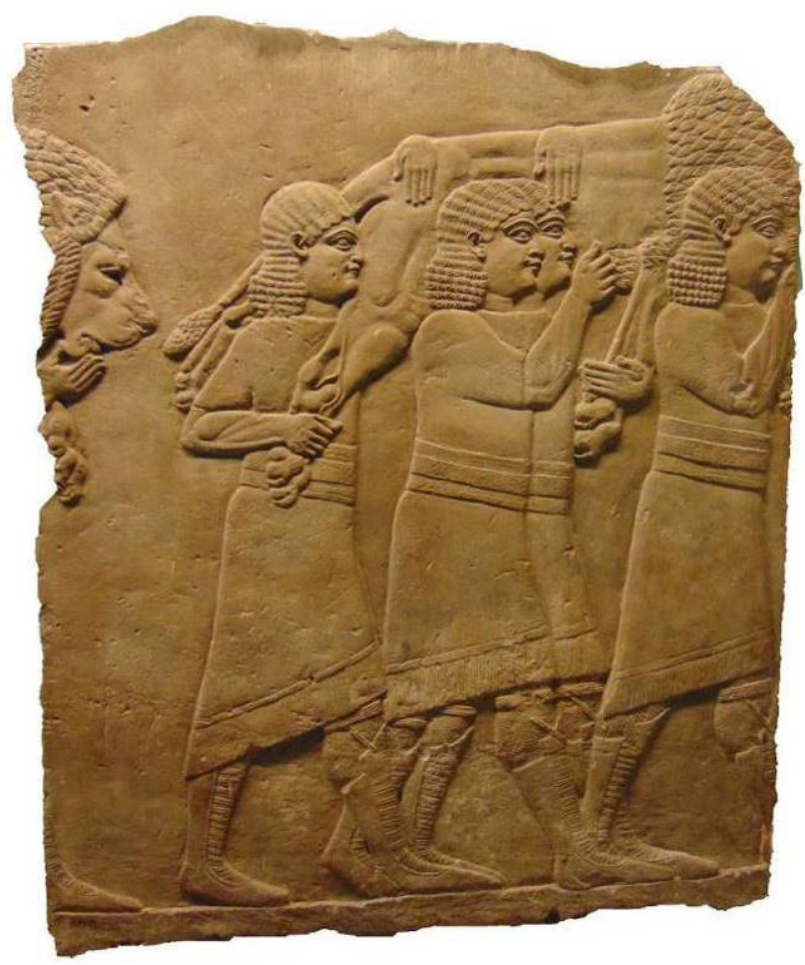

Fonte: (T) The Trustees of the British Museum (BM 124892). Fotografia realizada e adaptada por Ranieri. 
Figura 80 - Relevos da sala A do Palácio Norte de Nínive (placas 14-16).

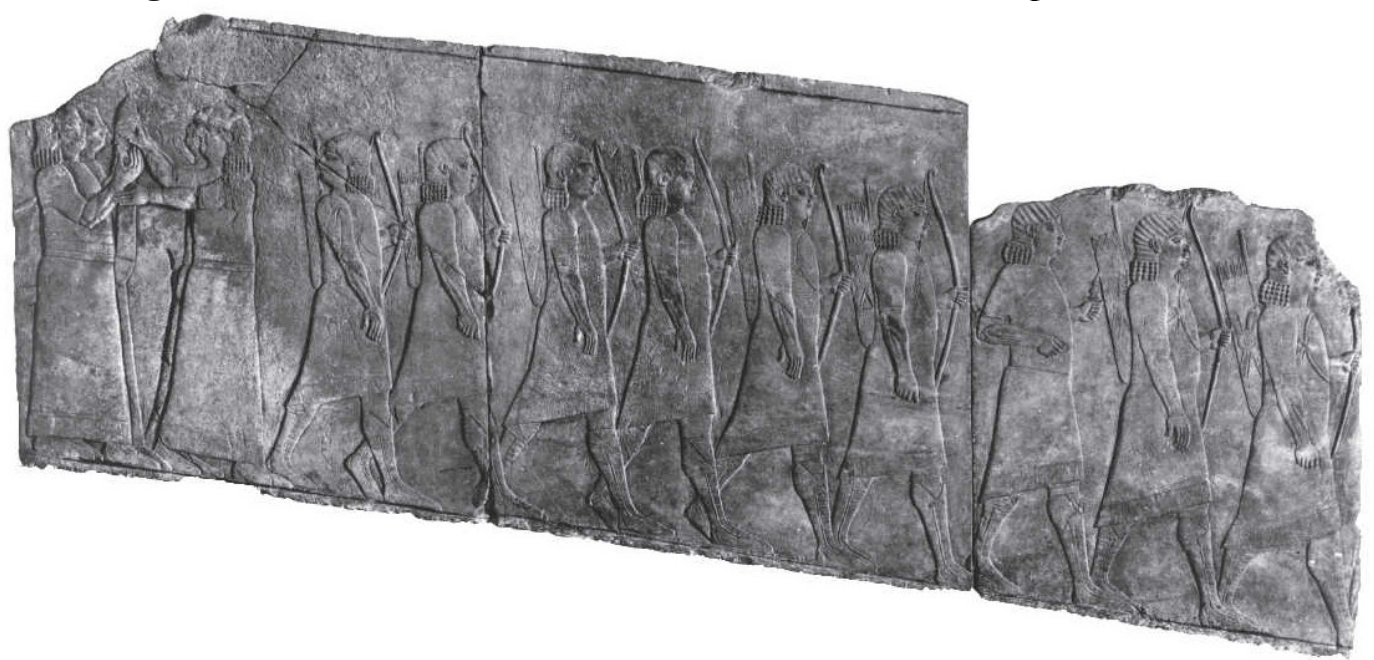

Fonte: Barnett (1976, prancha III) (Louvre AO19901). Adaptada por Ranieri. 
Figura 81 - Relevos da sala S do Palácio Norte de Nínive (placas 14-13).

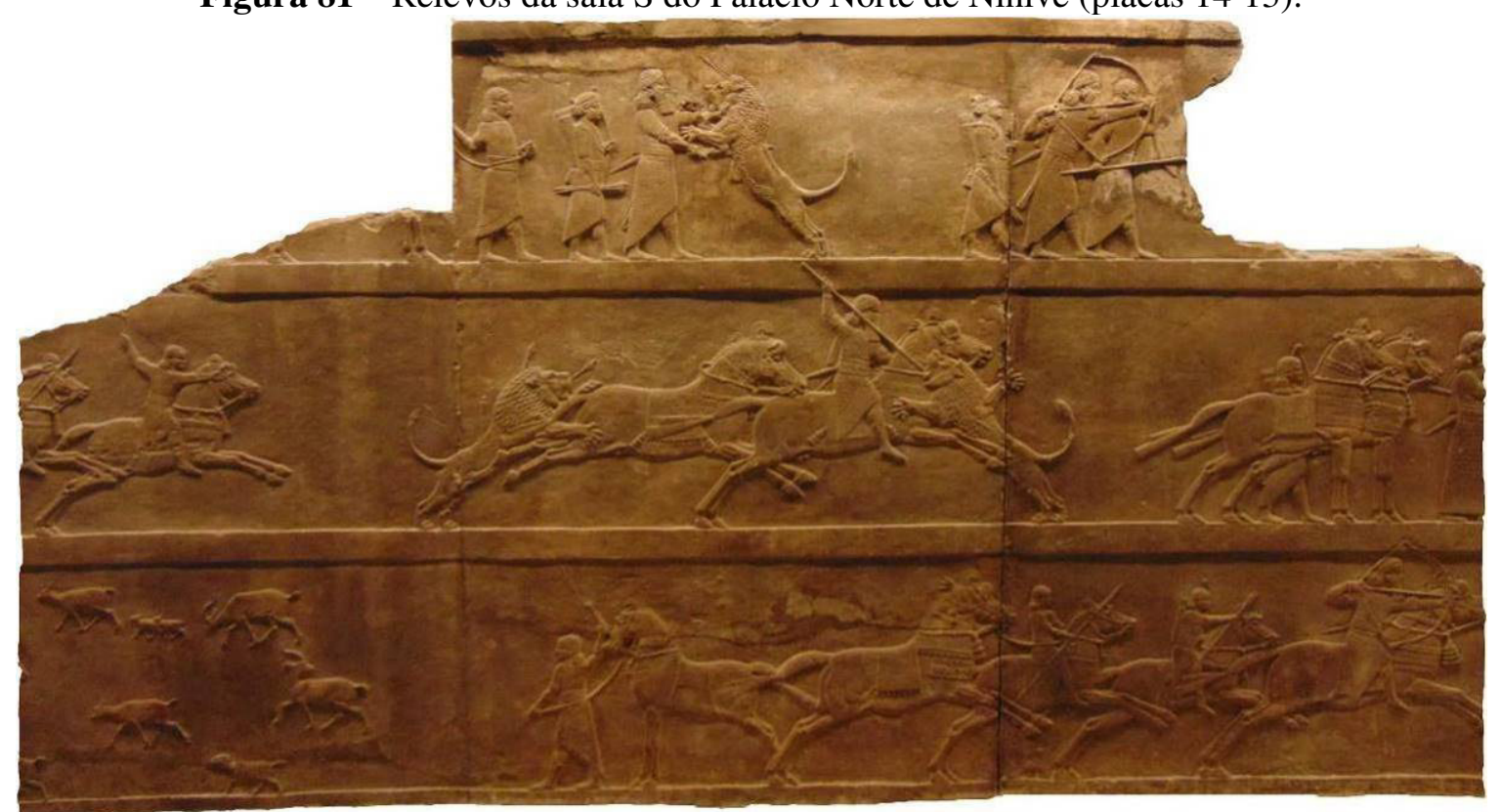

Fonte: (The Trustees of the British Museum (BM 124874-76). Fotografia realizada e adaptada por Ranieri.

Figura 82 - Relevos da sala S do Palácio Norte de Nínive (placas 12-11).

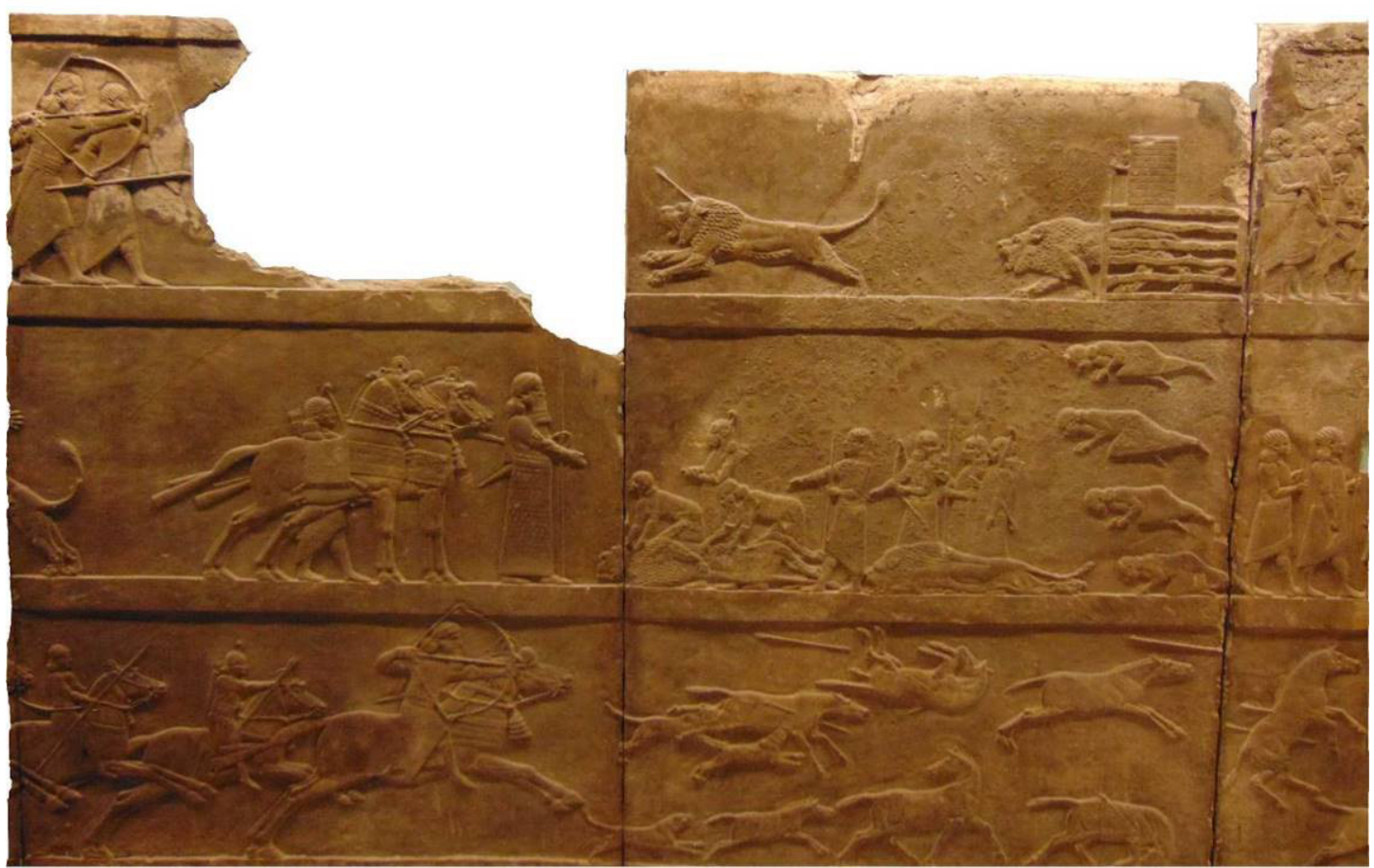

Fonte: @The Trustees of the British Museum (BM 124876-77). Fotografia realizada e adaptada por Ranieri. 
Figura 83 - Relevos da sala S do Palácio Norte de Nínive (placas 11-10).

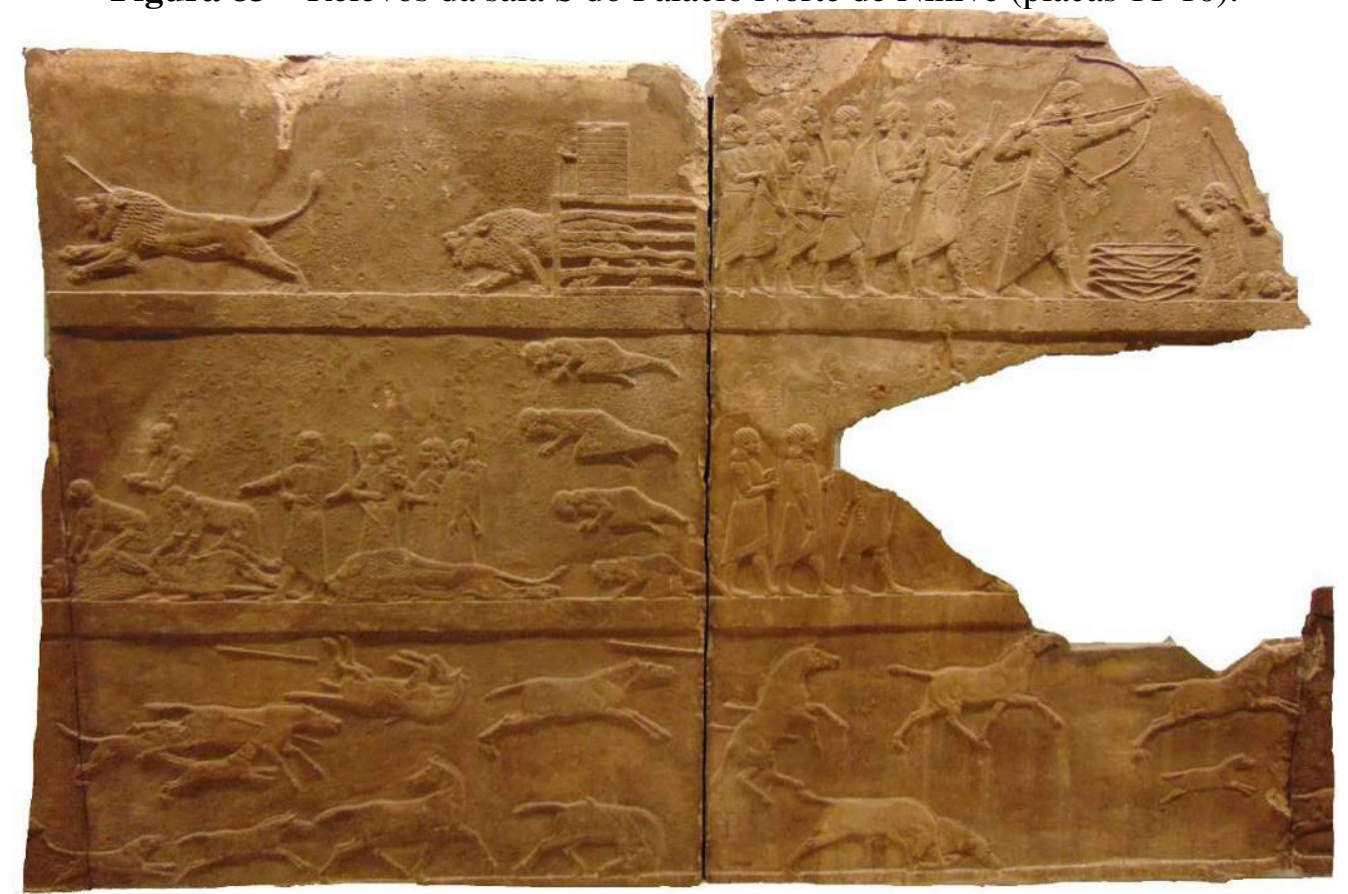

Fonte: (CThe Trustees of the British Museum (BM 124877-78). Fotografia realizada e adaptada por Ranieri.

Figura 84 - Relevos da sala S do Palácio Norte de Nínive (placas 10-9).

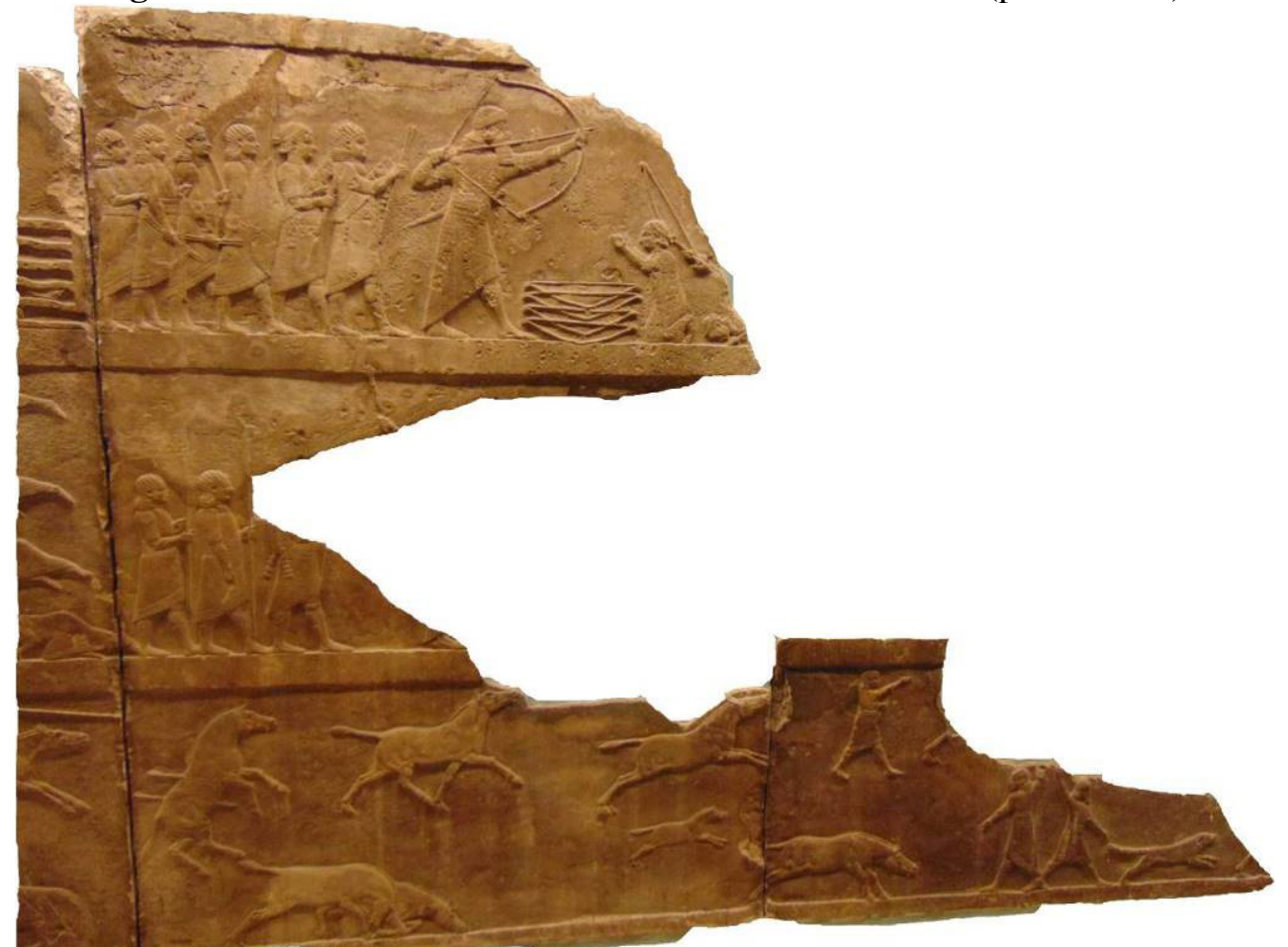

Fonte: (CThe Trustees of the British Museum (BM 124878-79). Fotografia realizada e adaptada por Ranieri. 
Figura 85 - Relevos da sala S do Palácio Norte de Nínive (placa 6).

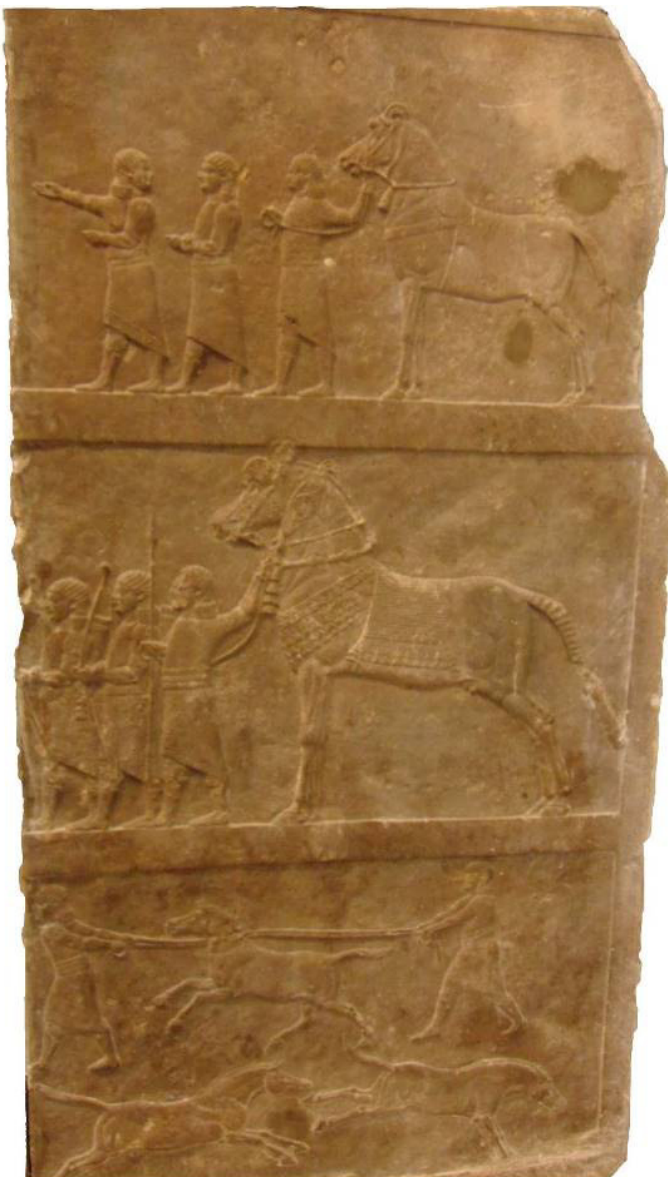

Fonte: (The Trustees of the British Museum (BM 124882). Fotografia realizada e adaptada por Ranieri. 
Figura 86 - Relevos da sala C do Palácio Norte de Nínive (placas 5-6).

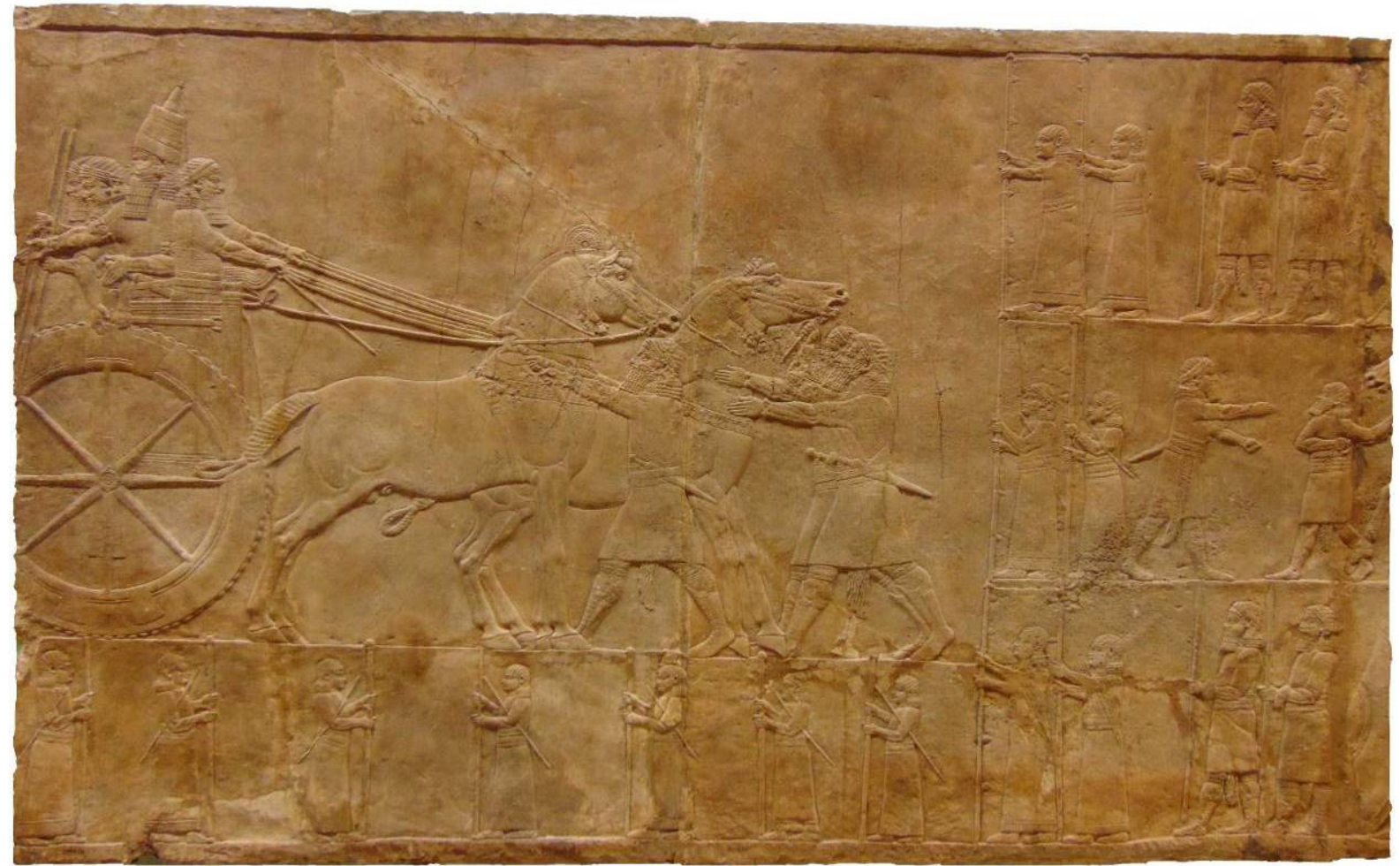

Fonte: @The Trustees of the British Museum (BM 124858-59). Fotografia realizada e adaptada por Ranieri.

Figura 87 - Relevos da sala C do Palácio Norte de Nínive (placas 7-8).

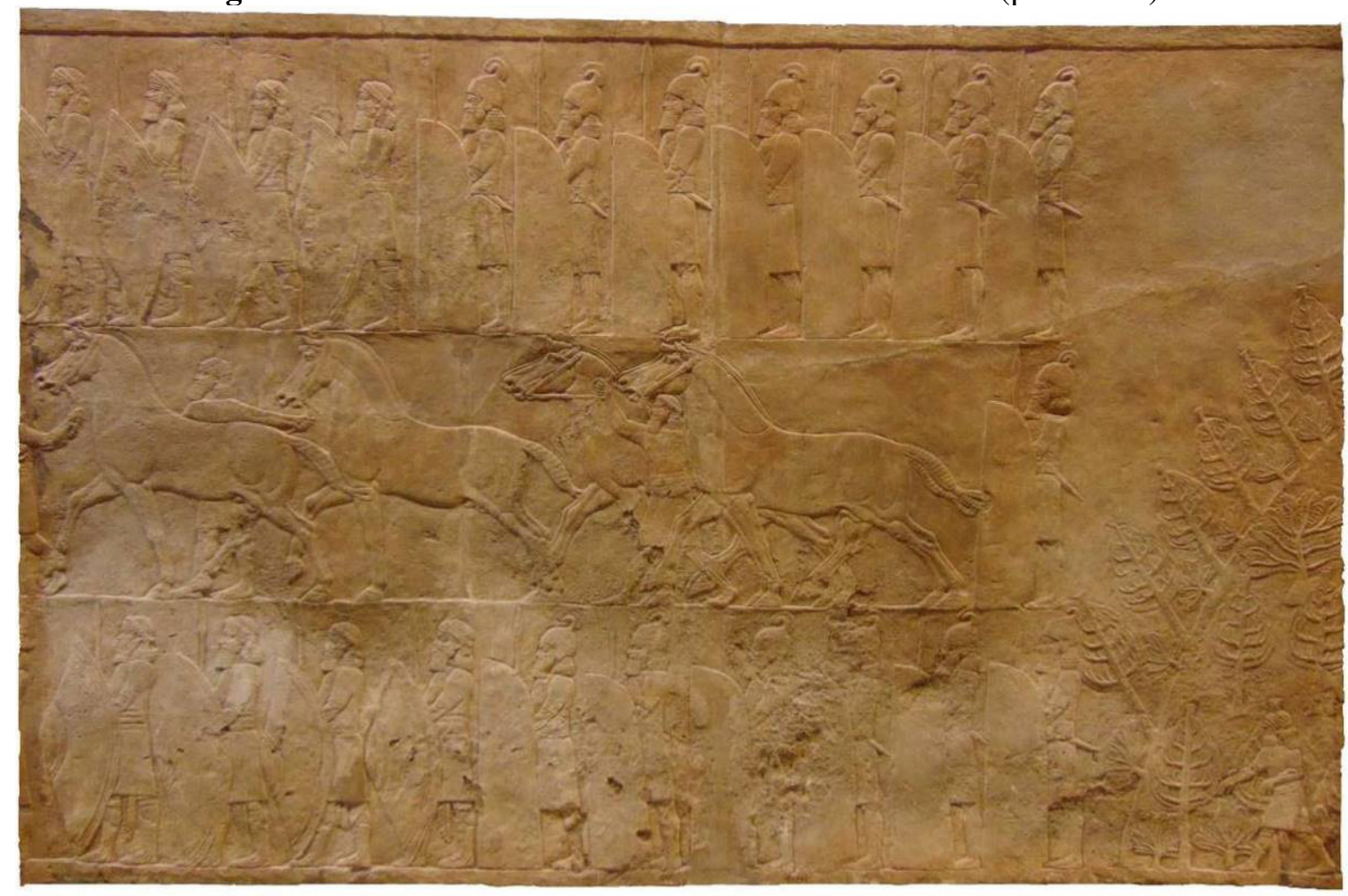

Fonte: @The Trustees of the British Museum (BM 124860-61). Fotografia realizada e adaptada por Ranieri. 
Figura 88 - Relevos da sala C do Palácio Norte de Nínive (placas 10-11).

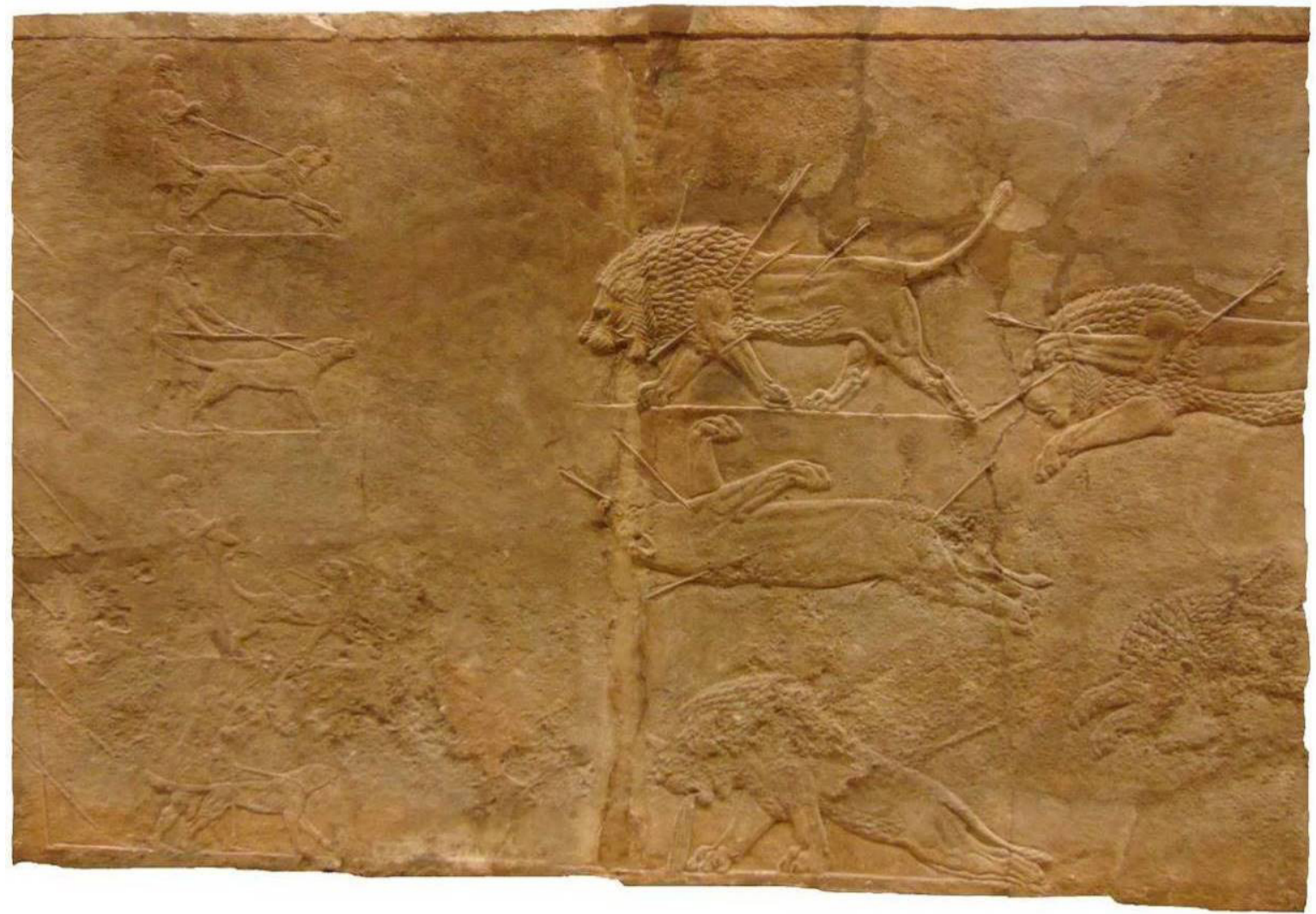

Fonte: @The Trustees of the British Museum (BM 124863-64). Fotografia realizada e adaptada por Ranieri.

Figura 89 - Relevos da sala C do Palácio Norte de Nínive (placas 11-12).

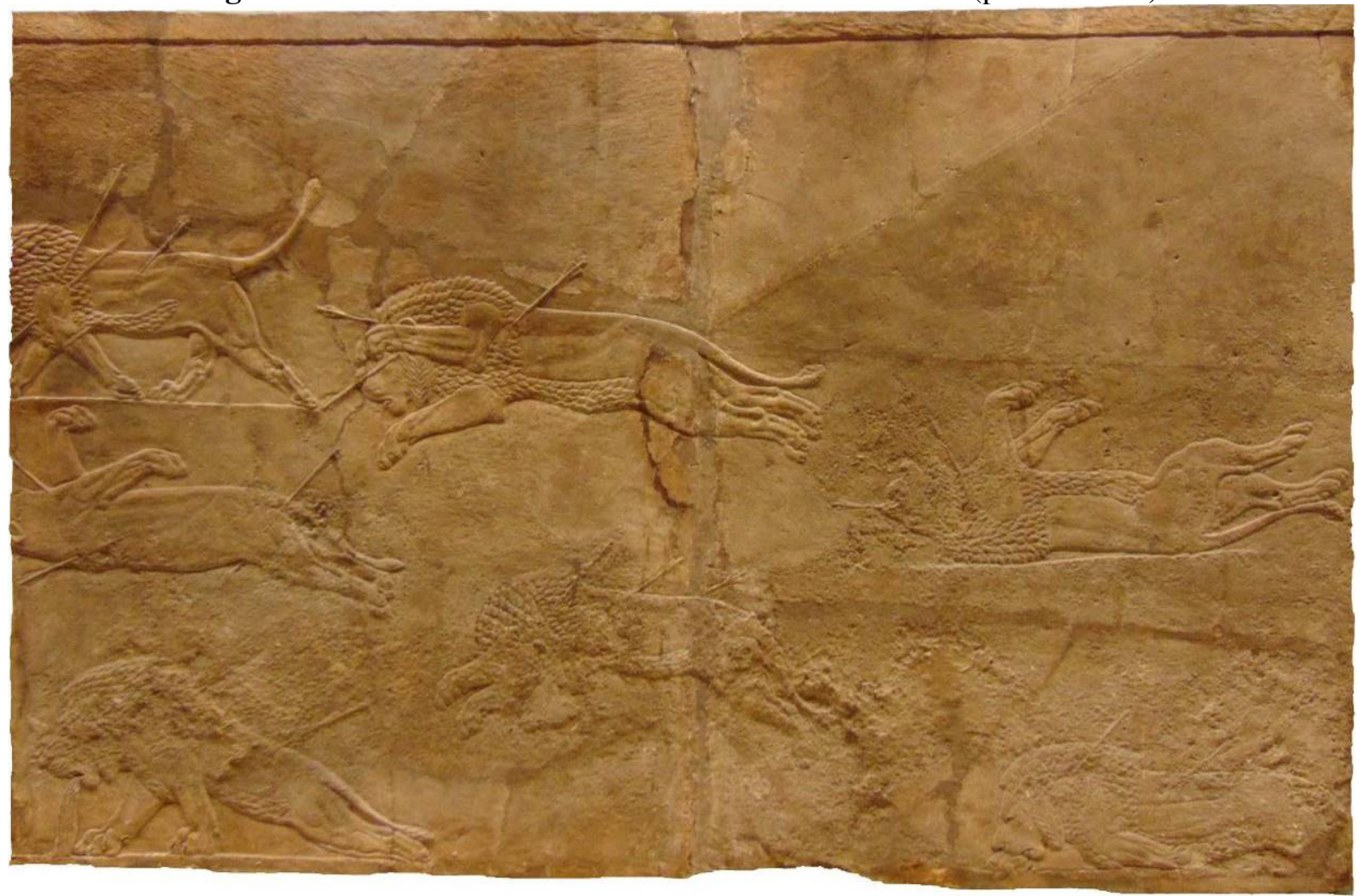

Fonte: @The Trustees of the British Museum (BM 124864-65). Fotografia realizada e adaptada por Ranieri. 
Figura 90 - Relevos da sala C do Palácio Norte de Nínive (placas 13).

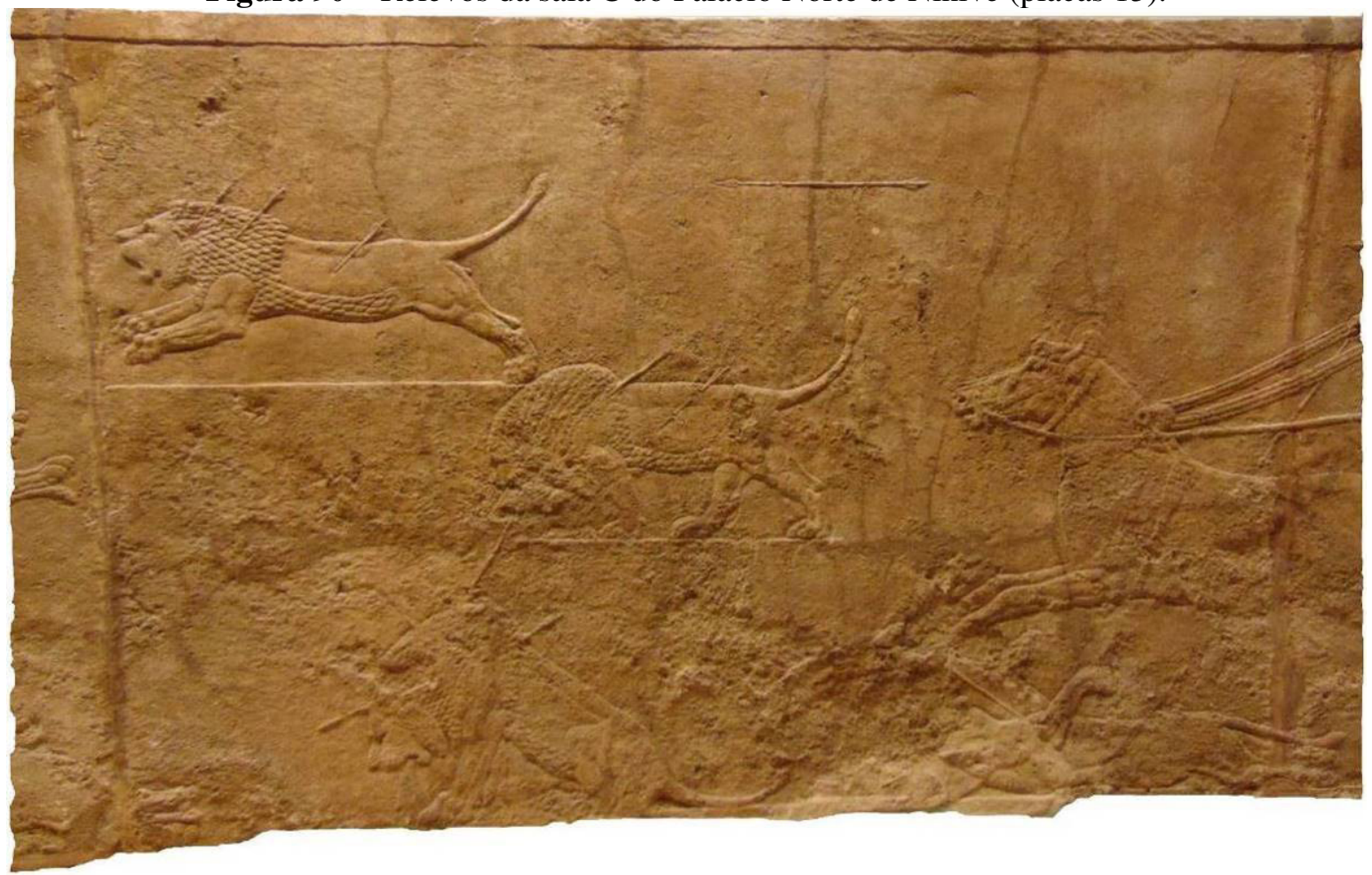

Fonte: (CThe Trustees of the British Museum (BM 124866-67). Fotografia realizada e adaptada por Ranieri.

Figura 91 - Relevos da sala C do Palácio Norte de Nínive (placas 13-14).

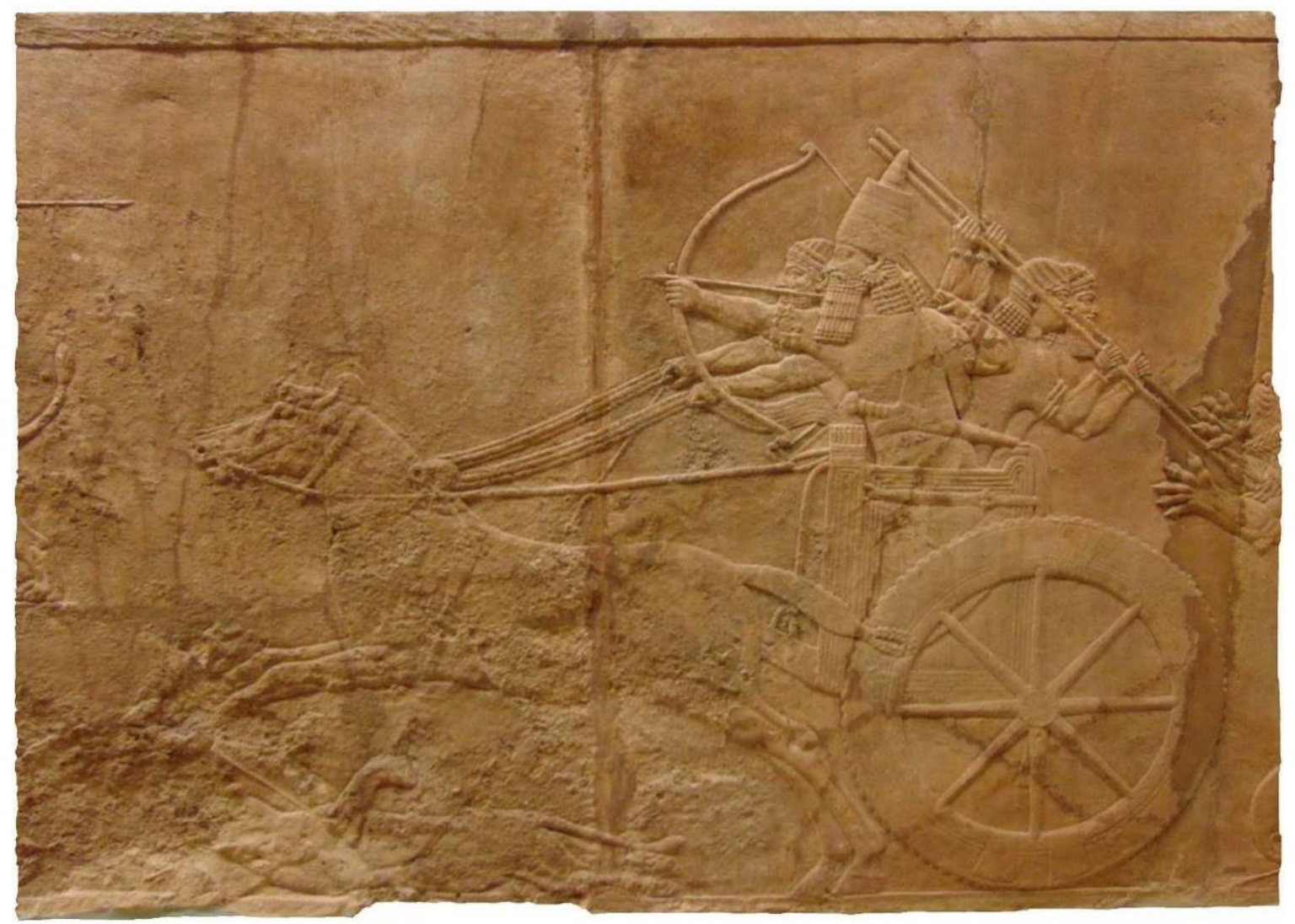

Fonte: (The Trustees of the British Museum (BM 124867-68). Fotografia realizada e adaptada por Ranieri. 
Figura 92 - Relevos da sala C do Palácio Norte de Nínive (placas 14-15).

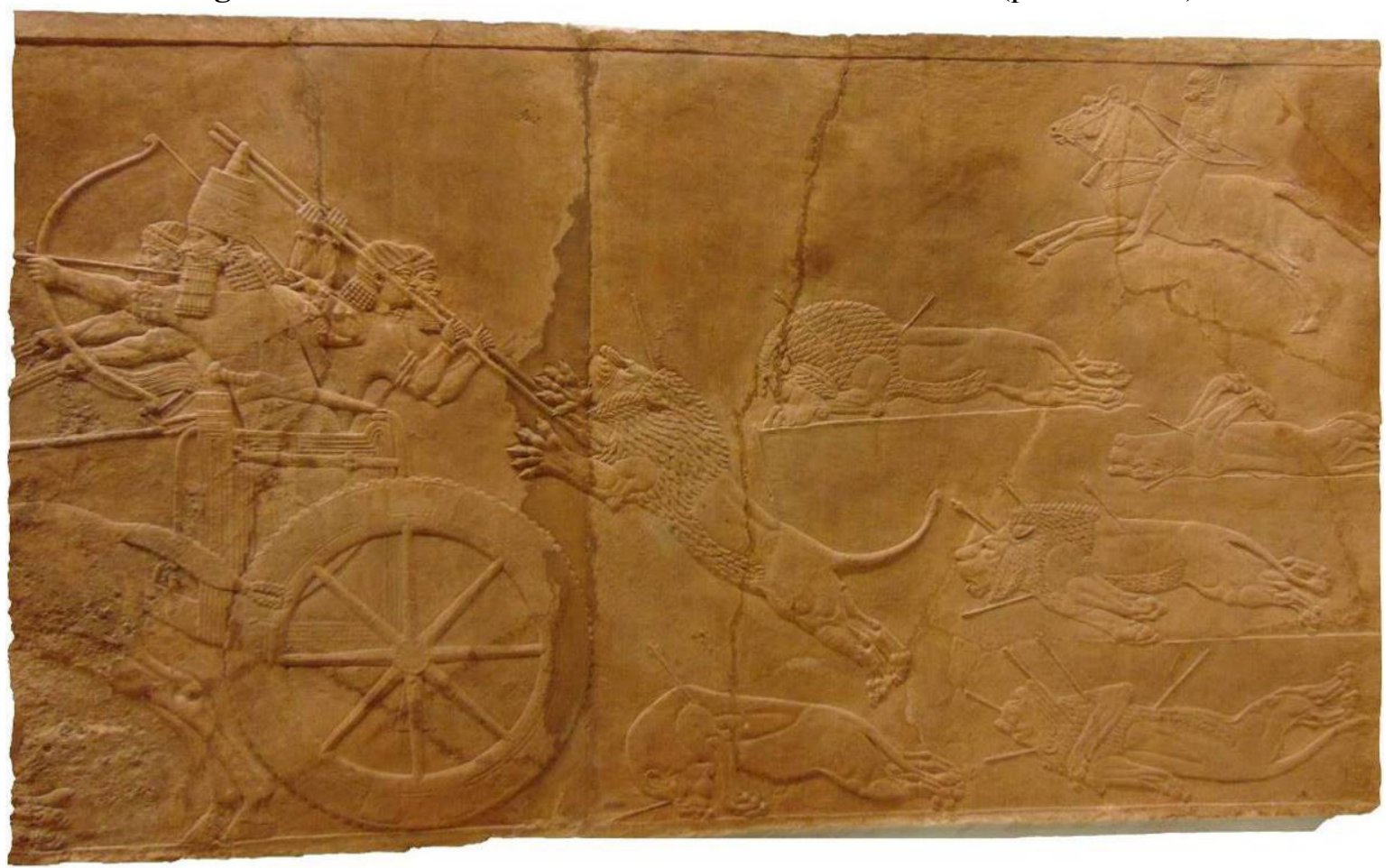

Fonte: @The Trustees of the British Museum (BM 124868). Fotografia realizada e adaptada por Ranieri.

Figura 93 - Relevos da sala C do Palácio Norte de Nínive (placas 15-17).

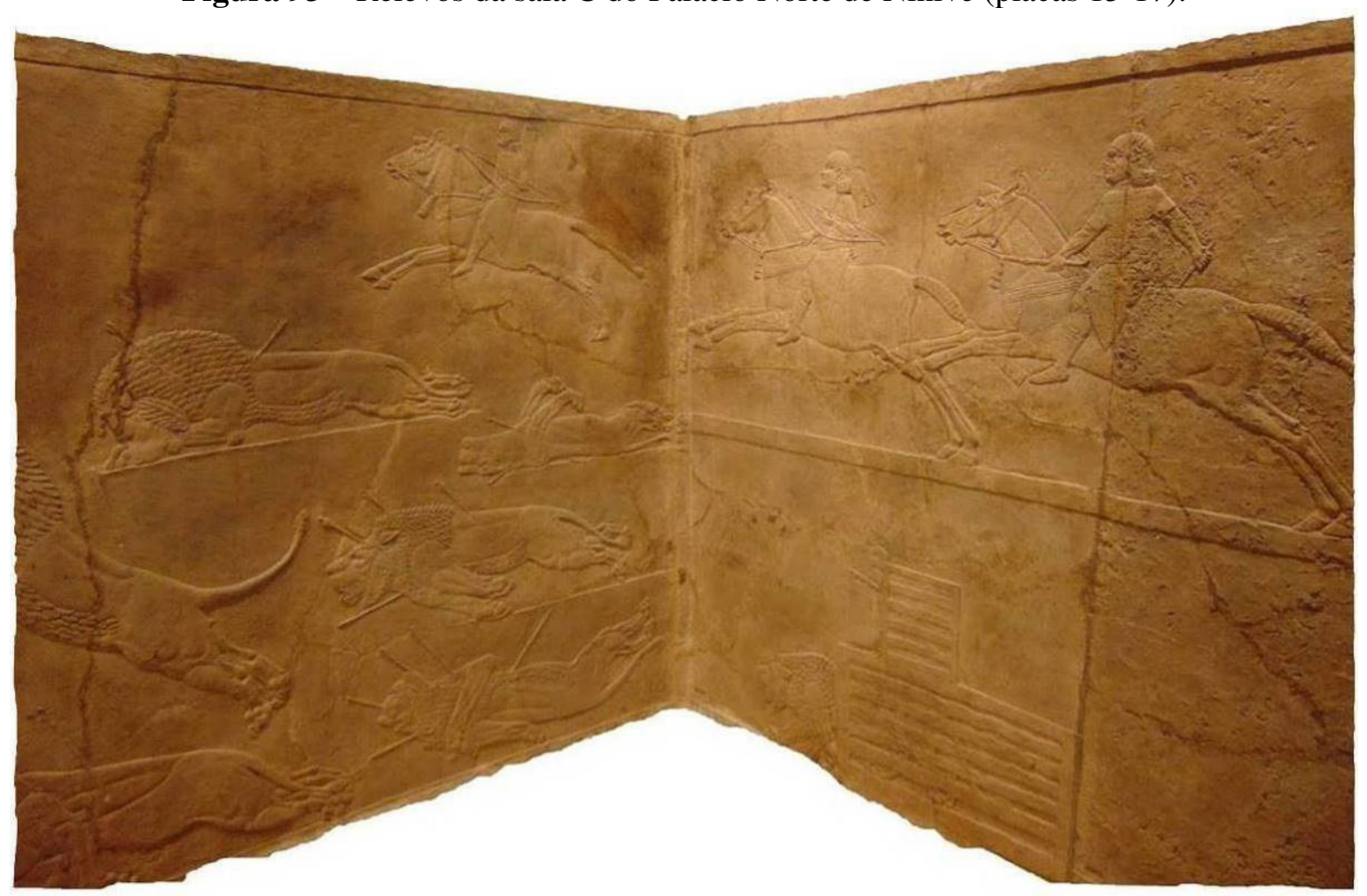

Fonte: @The Trustees of the British Museum (BM 124868-70). Fotografia realizada e adaptada por Ranieri. 
Figura 94 - Relevos da sala C do Palácio Norte de Nínive (placas 16-17).

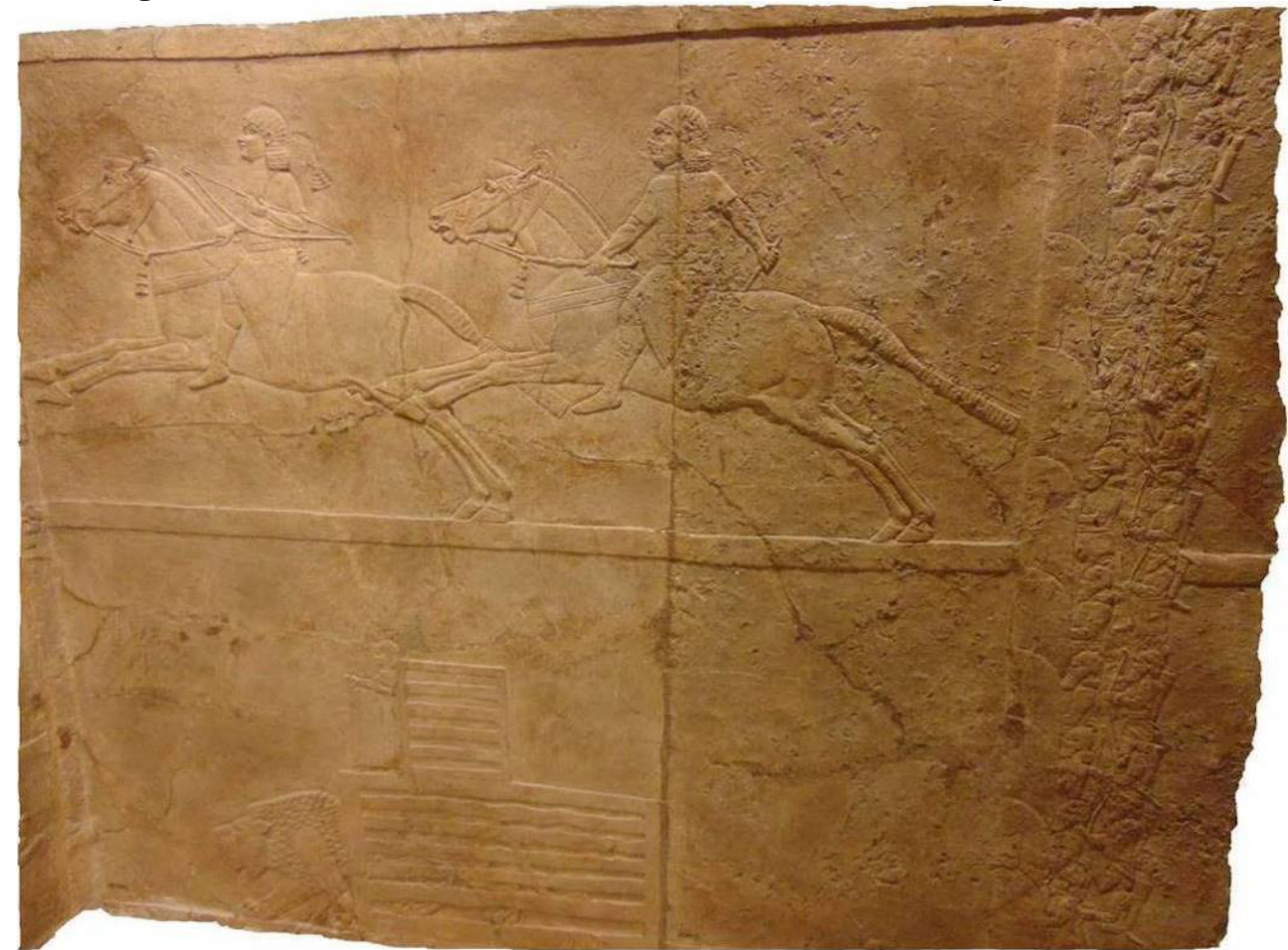

Fonte: OThe Trustees of the British Museum (BM 124869-70). Fotografia realizada e adaptada por Ranieri.

Figura 95 - Relevos da sala C do Palácio Norte de Nínive (placas 20-21).

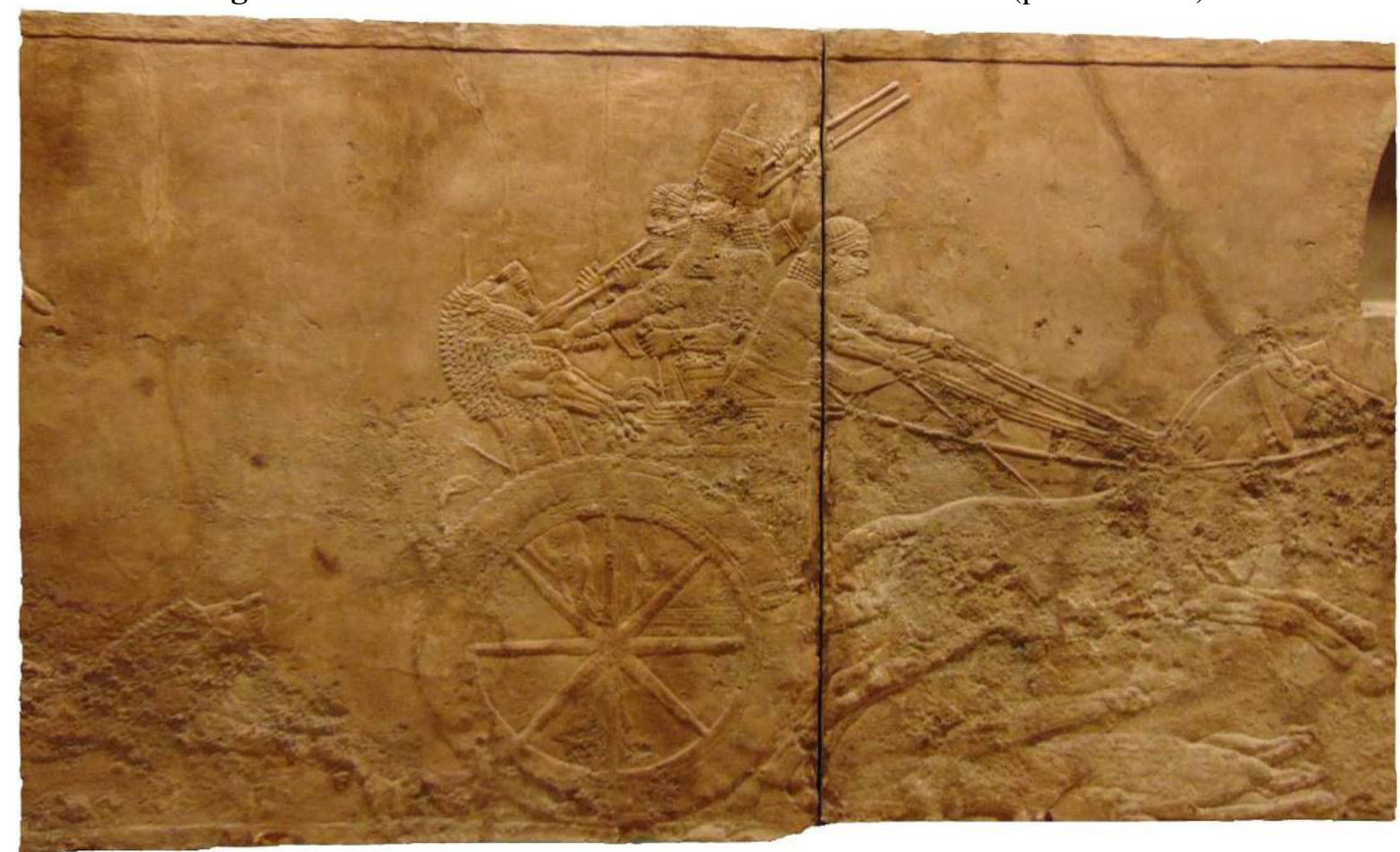

Fonte: @The Trustees of the British Museum (BM 124850-51). Fotografia realizada e adaptada por Ranieri. 
Figura 96 - Relevos da sala C do Palácio Norte de Nínive (placas 20-21).

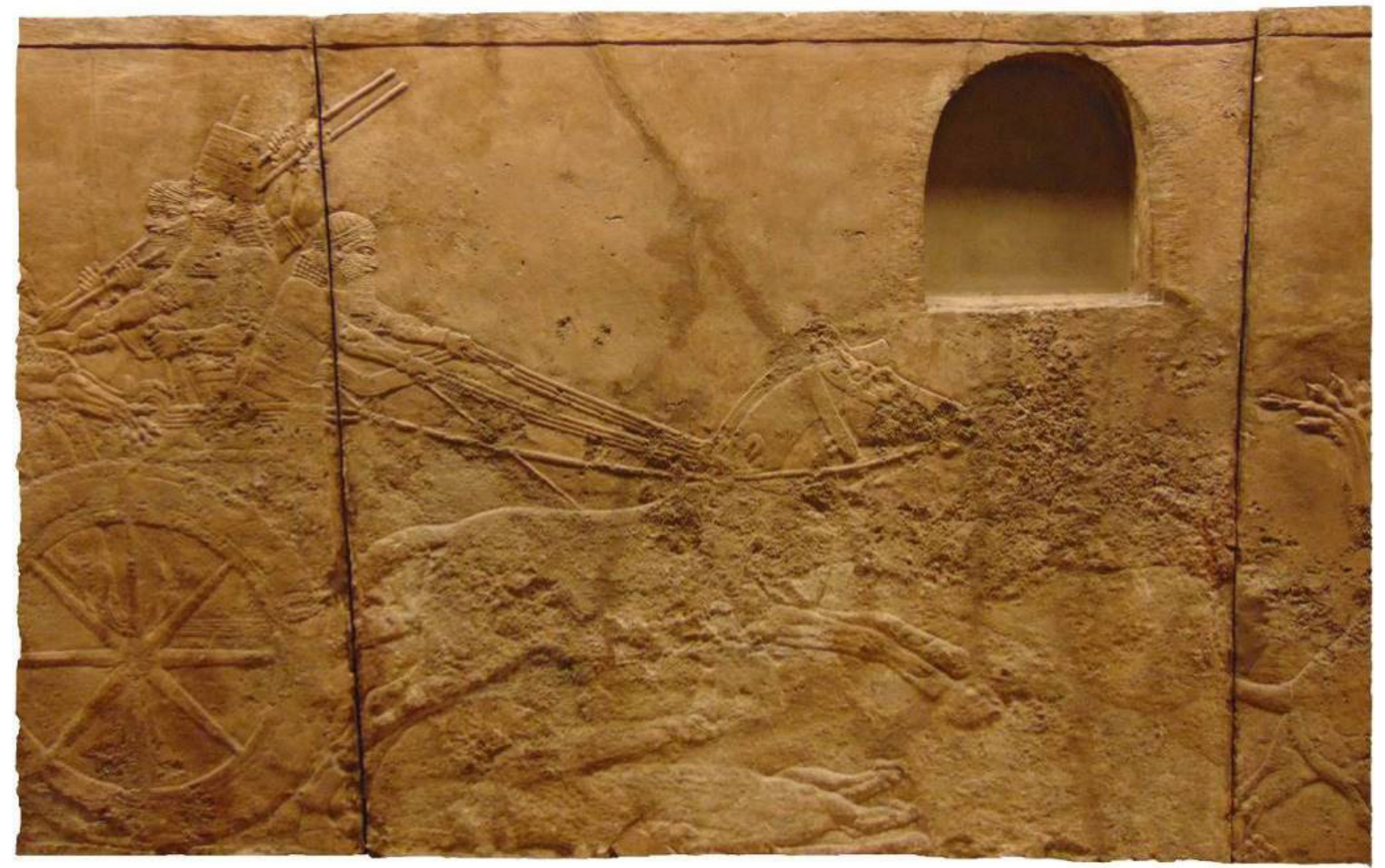

Fonte: (The Trustees of the British Museum (BM 124850-51). Fotografia realizada e adaptada por Ranieri.

Figura 97 - Relevos da sala C do Palácio Norte de Nínive (placa 22).

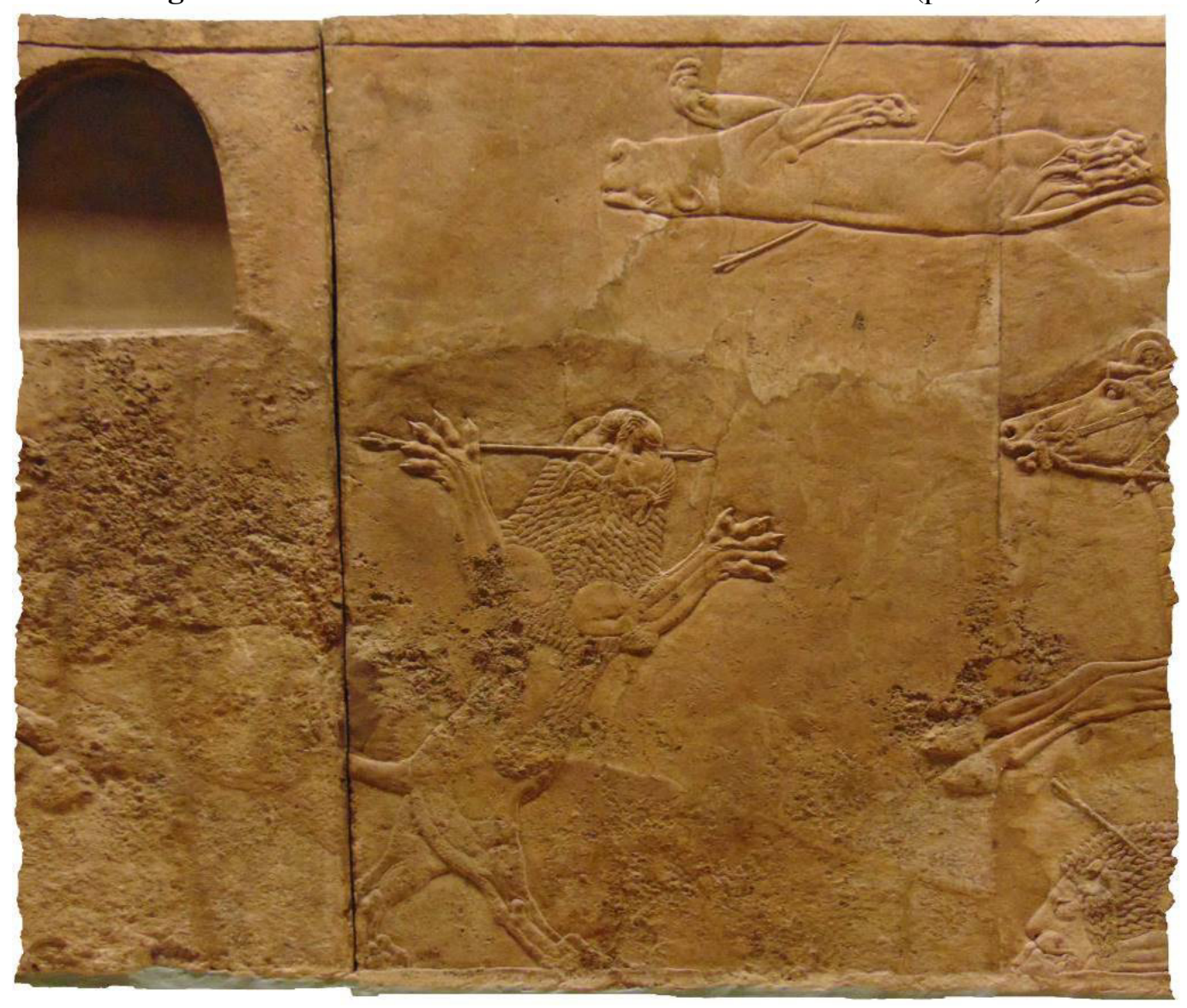

Fonte: OThe Trustees of the British Museum (BM 124851-52). Fotografia realizada e adaptada por Ranieri. 
Figura 98 - Relevos da sala C do Palácio Norte de Nínive (placas 21-23).

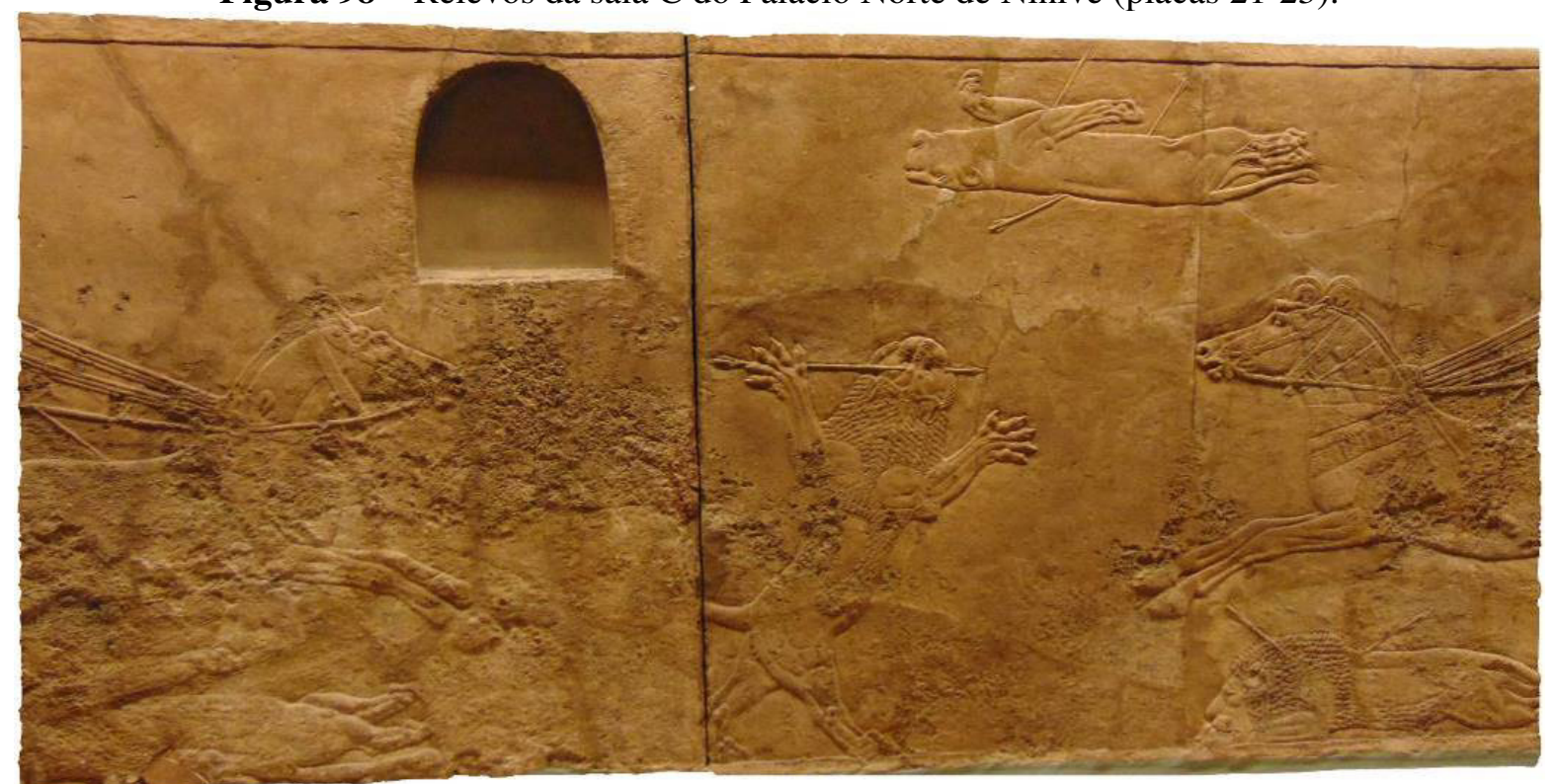

Fonte: @The Trustees of the British Museum (BM 124851-53). Fotografia realizada e adaptada por Ranieri.

Figura 99 - Relevos da sala C do Palácio Norte de Nínive (placas 22-23).

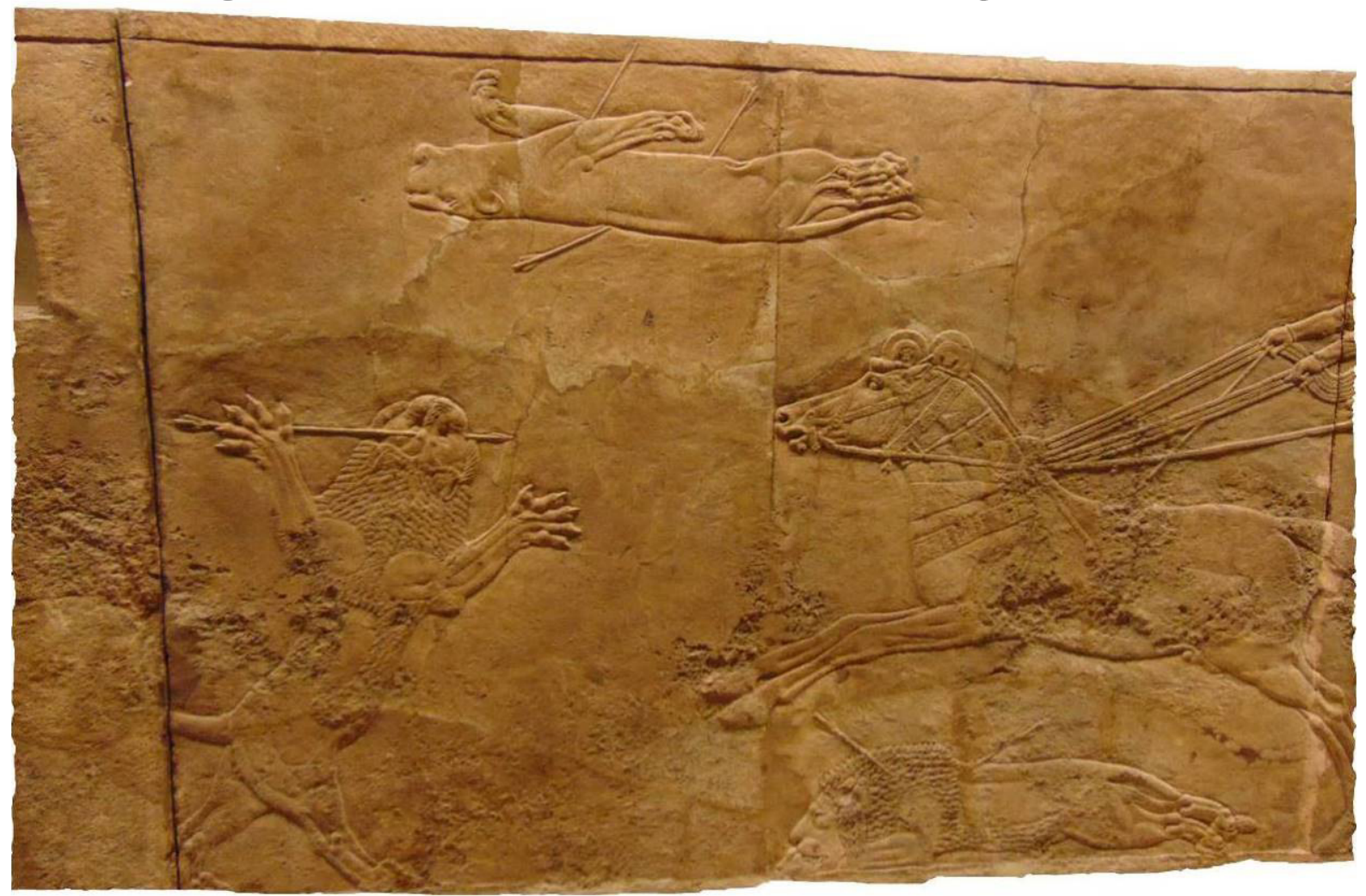

Fonte: @The Trustees of the British Museum (BM 124852-53). Fotografia realizada e adaptada por Ranieri. 
Figura 100 - Relevos da sala C do Palácio Norte de Nínive (placas 23-24).

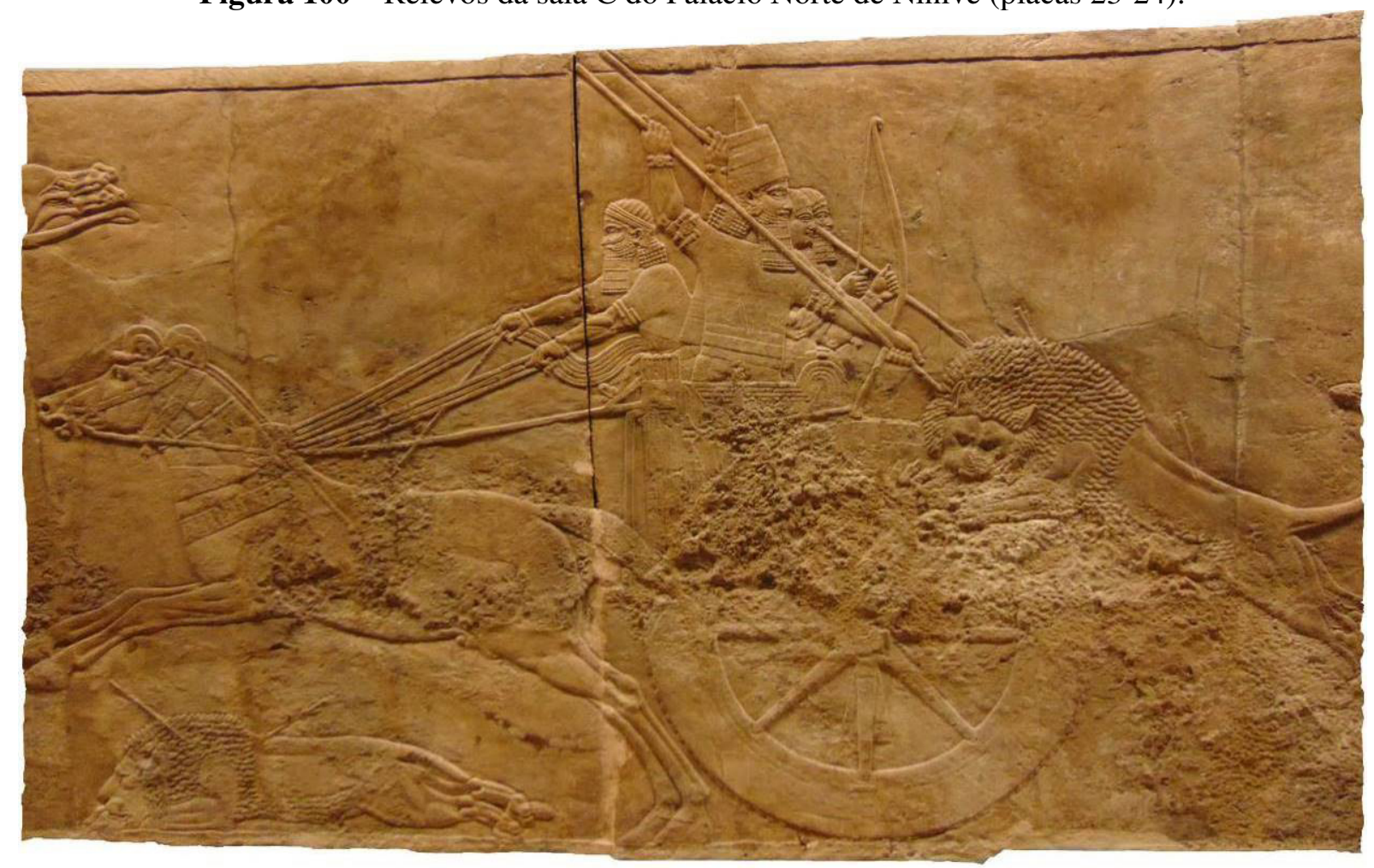

Fonte: (The Trustees of the British Museum (BM 124853-55). Fotografia realizada e adaptada por Ranieri.

Figura 101 - Relevos da sala C do Palácio Norte de Nínive (placas 25-26).

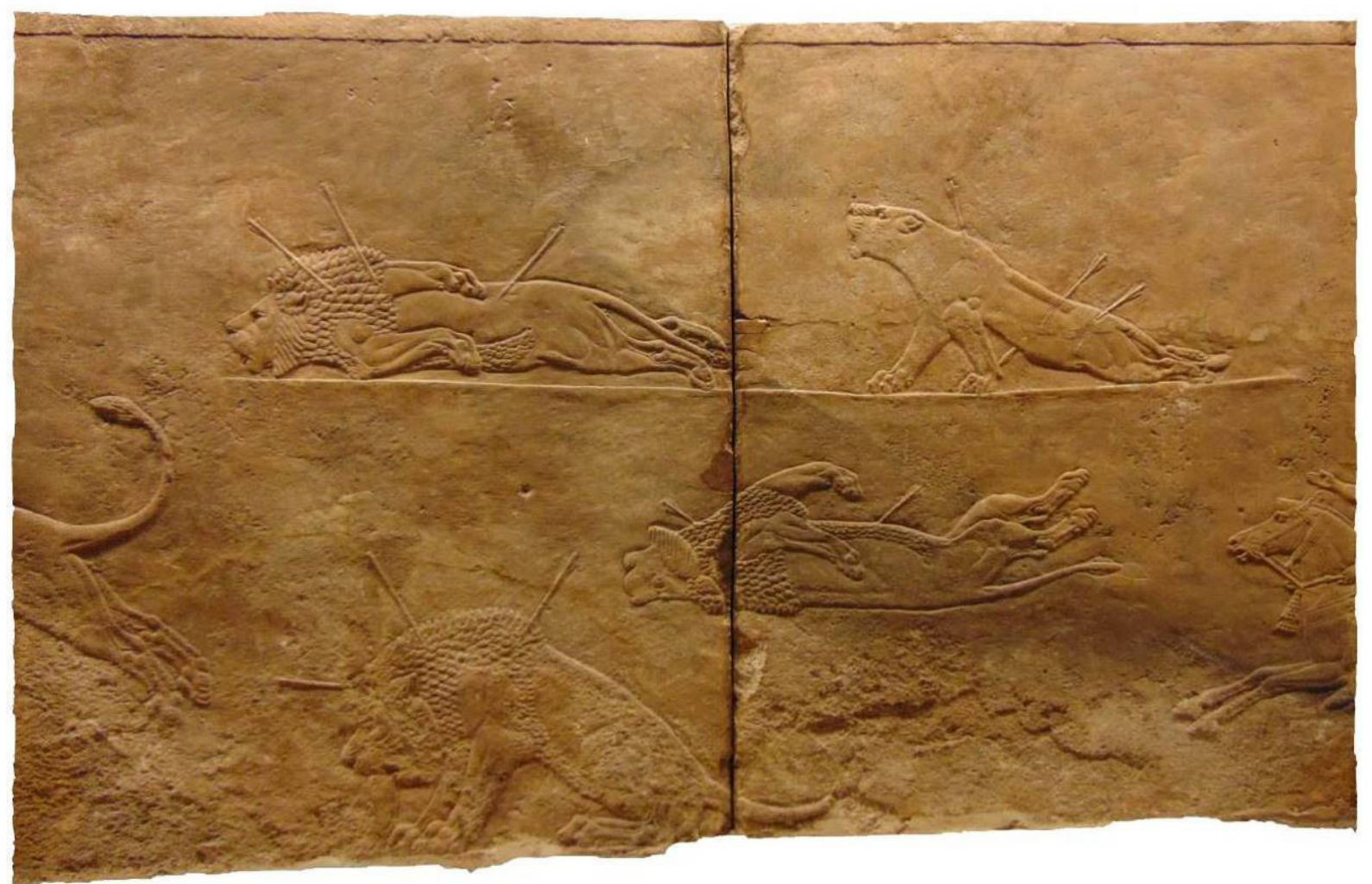

Fonte: @The Trustees of the British Museum (BM 124855-56). Fotografia realizada e adaptada por Ranieri. 
Figura 102 - Relevos da sala C do Palácio Norte de Nínive (placas 26-27).

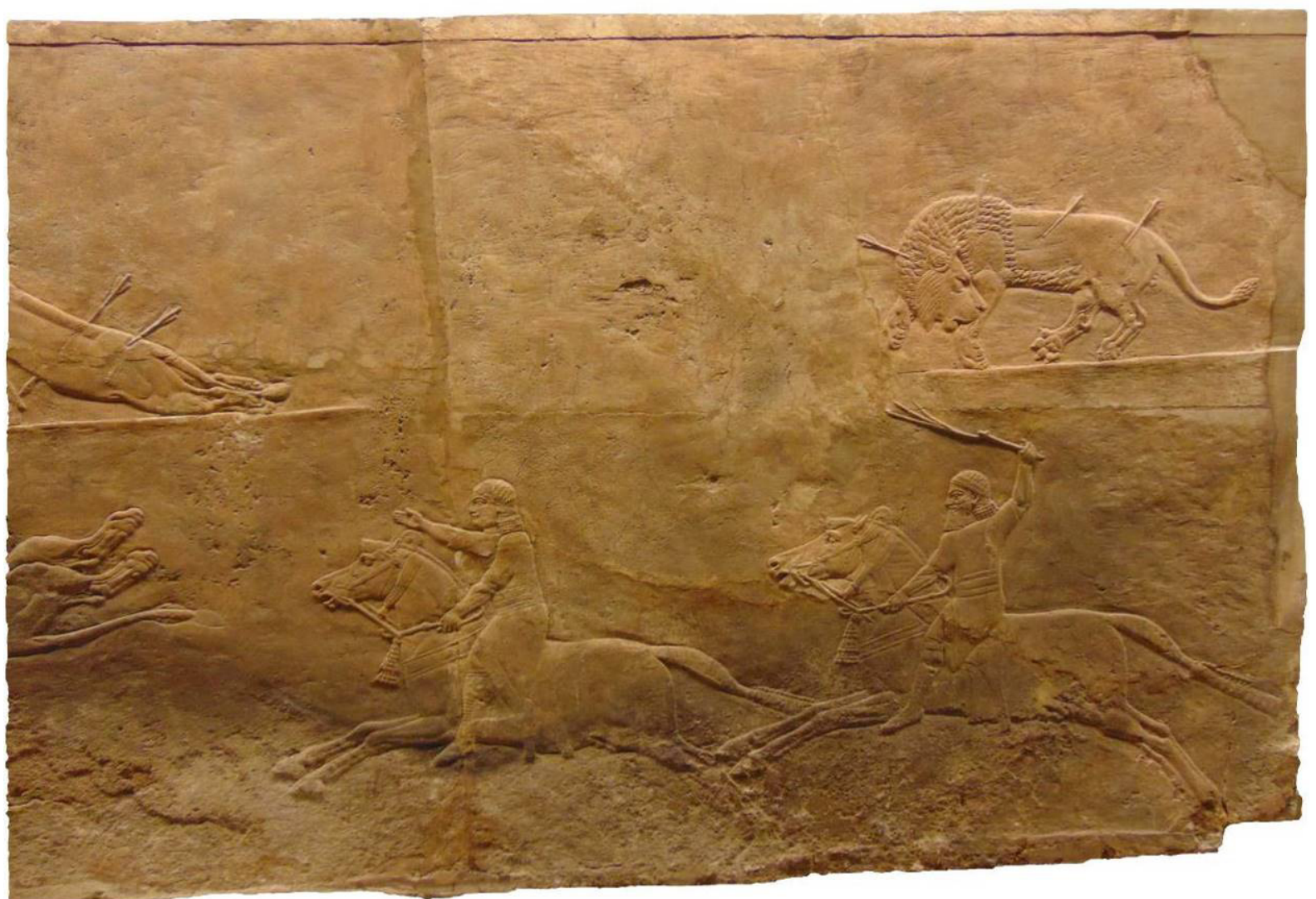

Fonte: (CThe Trustees of the British Museum (BM 124856-57). Fotografia realizada e adaptada por Ranieri. 
Figura 103 - Relevos da sala S1 do Palácio Norte de Nínive (placa B, parte inferior).

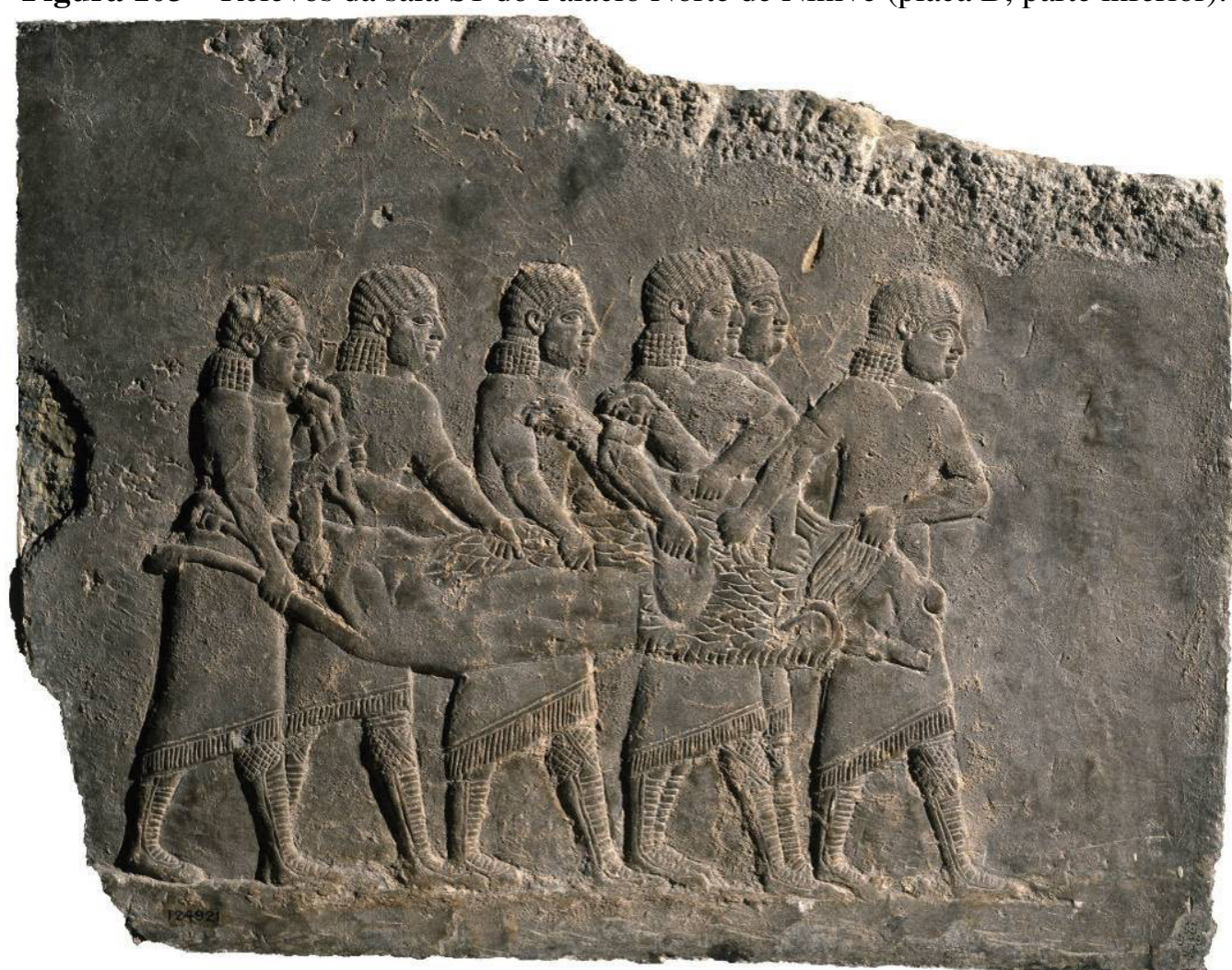

Fonte: @The Trustees of the British Museum (BM 124921). Adaptada por Ranieri.

Figura 104 - Relevos da sala S1 do Palácio Norte de Nínive (placa D-E).

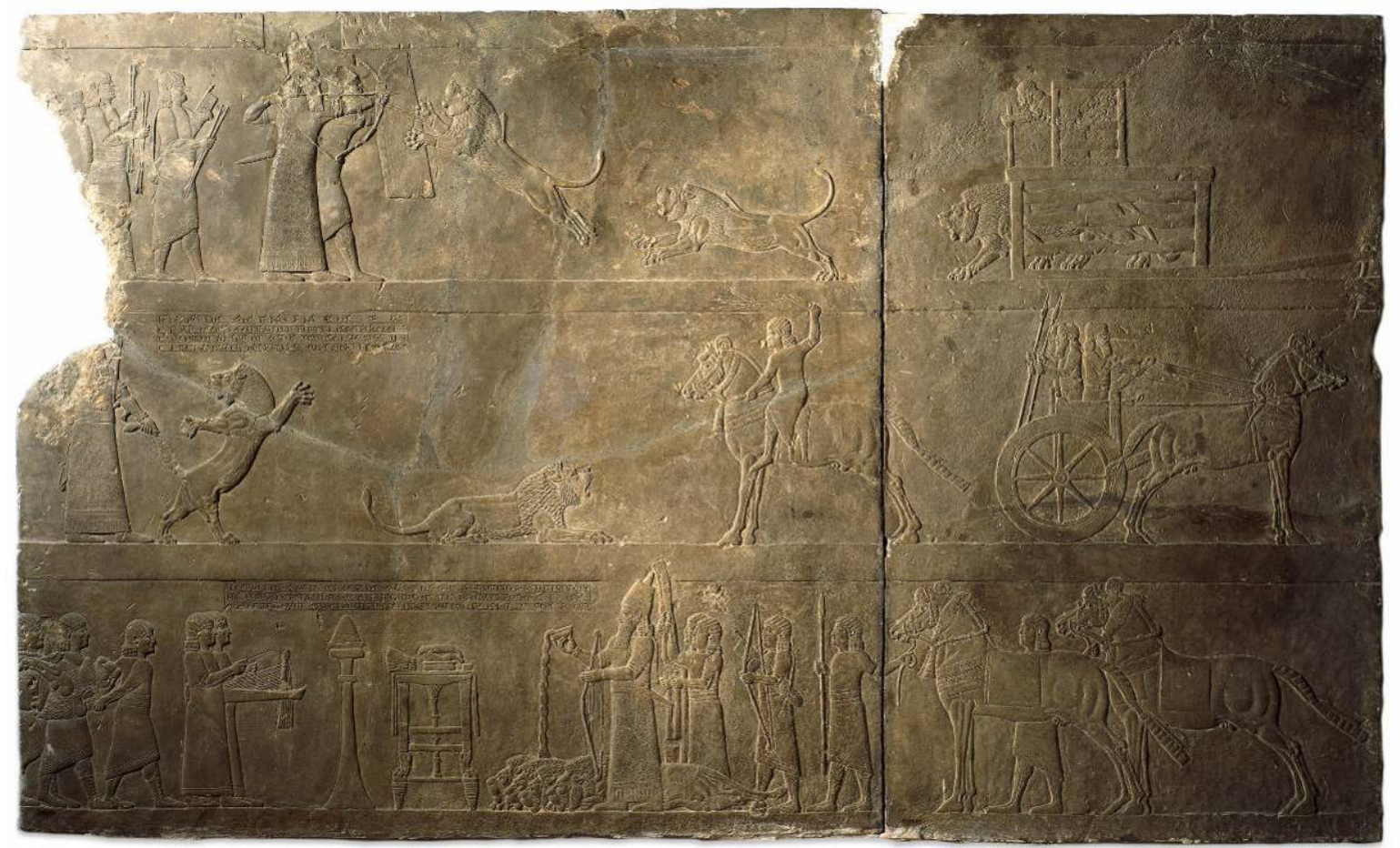

Fonte: @The Trustees of the British Museum (BM 124886-87). Adaptada por Ranieri. 
Figura 105 - Relevos da sala S1 do Palácio Norte de Nínive (placa A, parte superior).

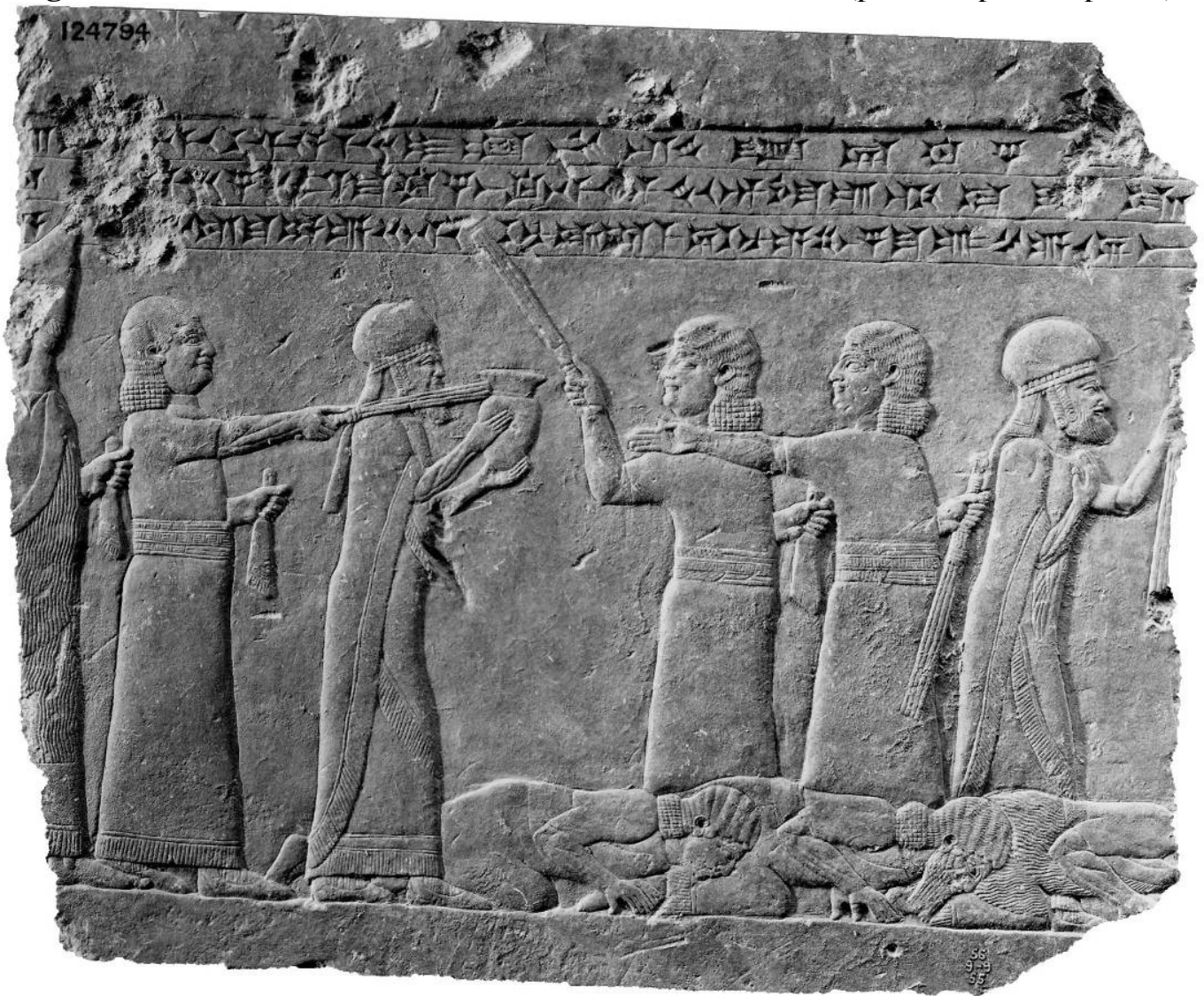

Fonte: @The Trustees of the British Museum (BM 124794). Adaptada por Ranieri.

Figura 106 - Relevos da sala S1 do Palácio Norte de Nínive (placas B-C, parte superior).

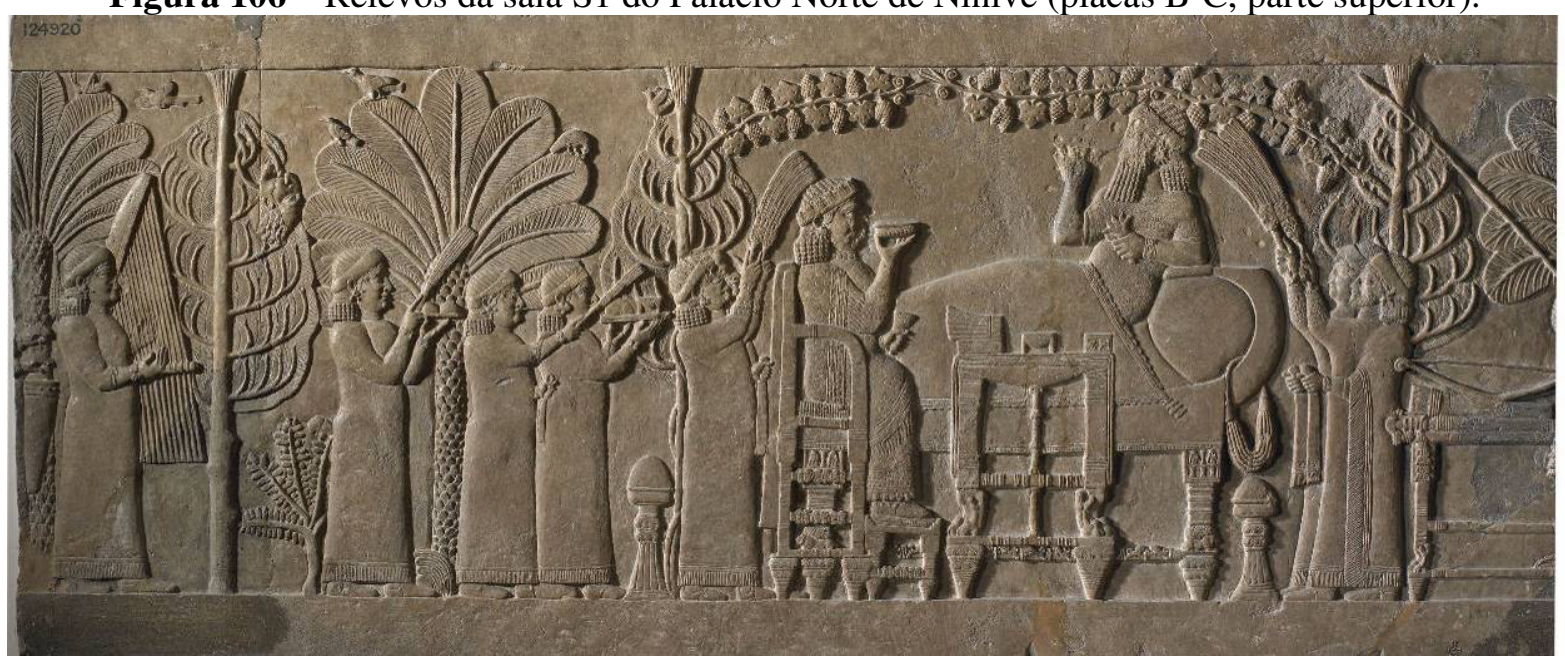

Fonte: (The Trustees of the British Museum (BM 124920). Adaptada por Ranieri. 
Figura 107 - Relevos da sala S1 do Palácio Norte de Nínive (placa E).

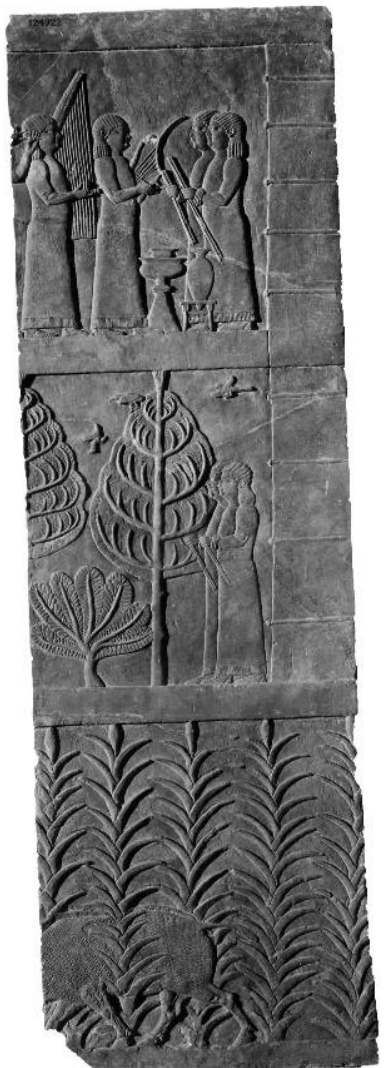

Fonte: @The Trustees of the British Museum (BM 124922). Adaptada por Ranieri. 
Figura 108 - Relevos da sala S1 do Palácio Norte de Nínive (placa A).

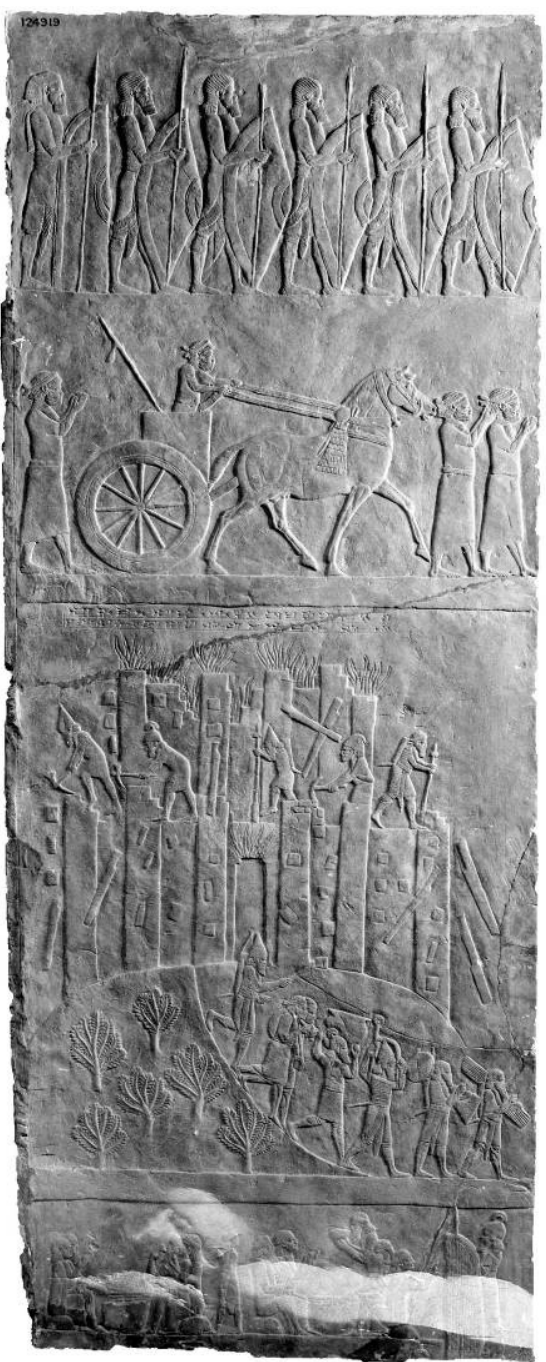

Fonte: @The Trustees of the British Museum (BM 124919). Adaptada por Ranieri.

Figura 109 - Relevos da sala S1 do Palácio Norte de Nínive (placa A, parte inferior).
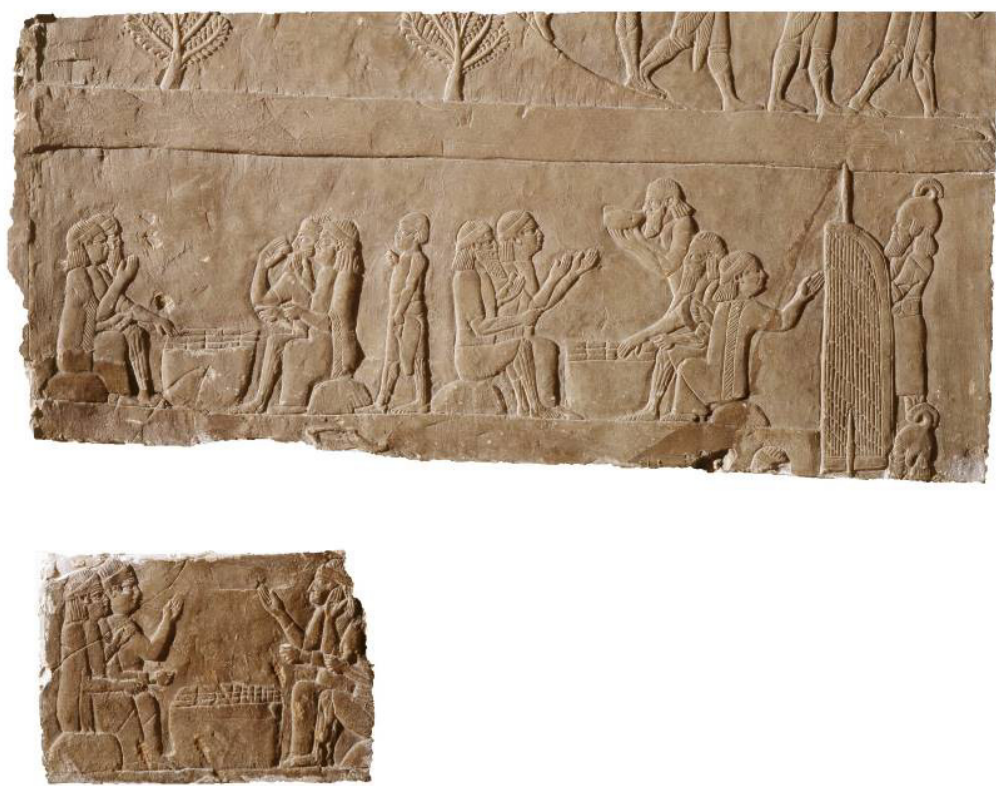

Fonte: (The Trustees of the British Museum (BM 124919; 134386). Adaptada por Ranieri. 
Figura 110 - Relevos da sala F do Palácio Norte de Nínive (placa 1).

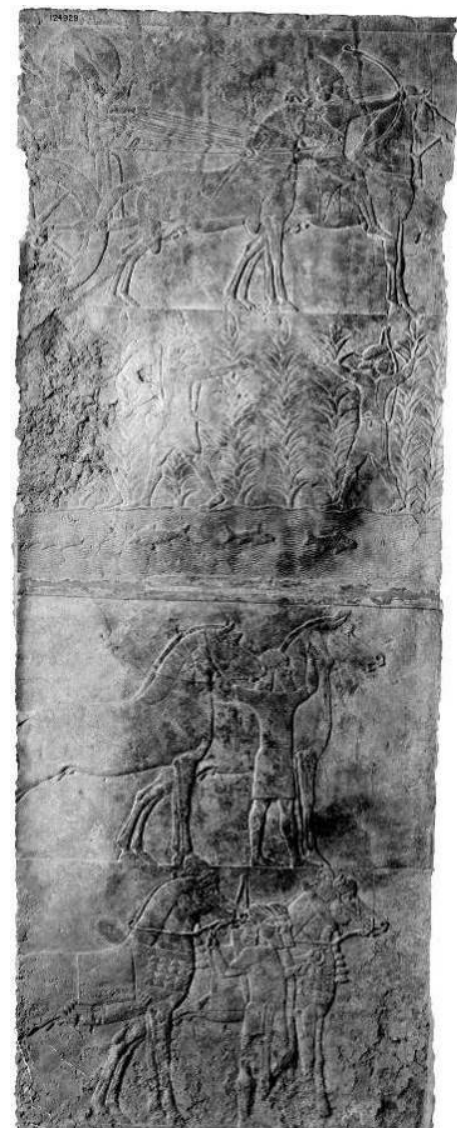

Fonte: @The Trustees of the British Museum (BM 124929). Adaptada por Ranieri.

Figura 111 - Relevos da sala F do Palácio Norte de Nínive (placas 2-4).

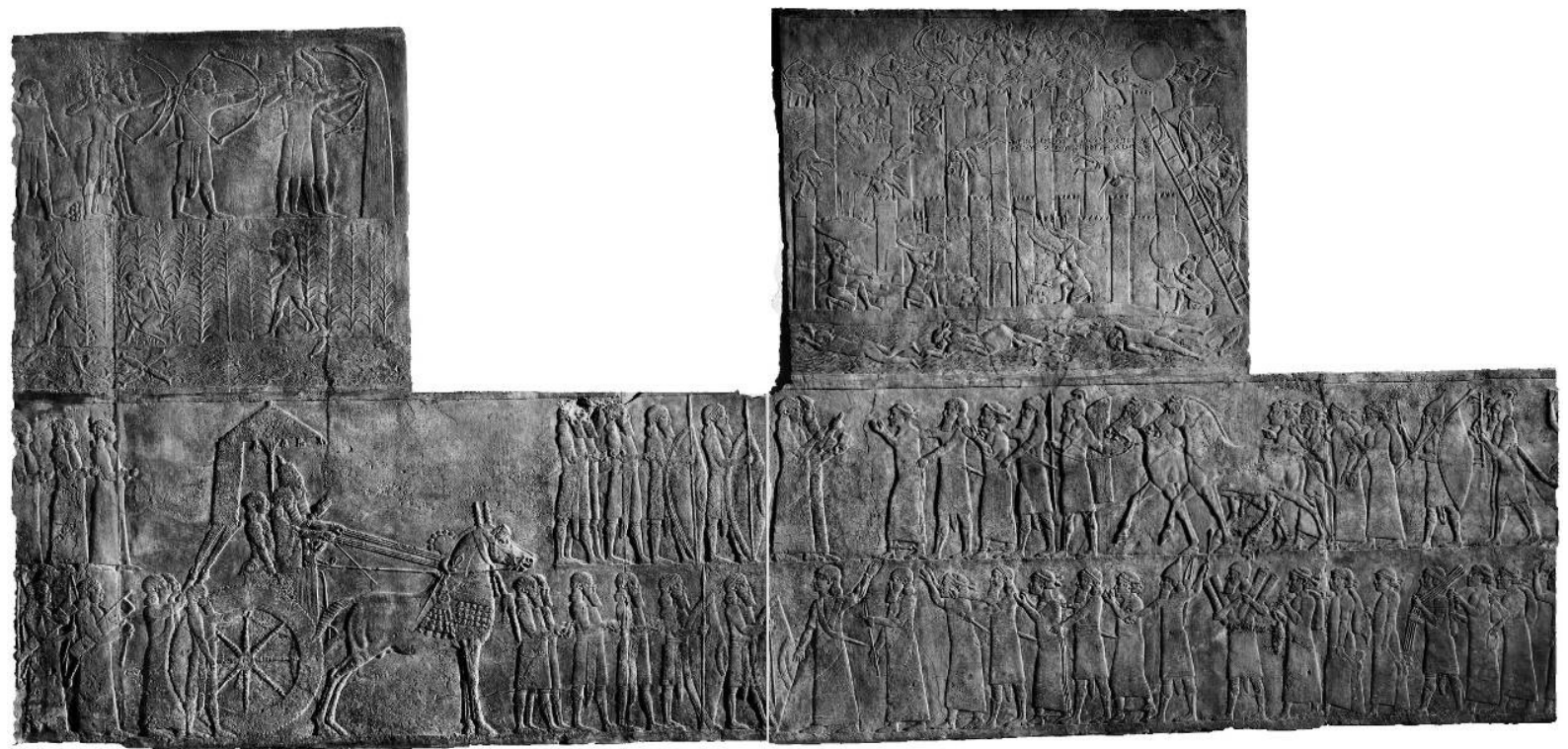

Fonte: @The Trustees of the British Museum (BM 124930-32). Adaptada por Ranieri. 
Figura 112 - Relevos da sala F do Palácio Norte de Nínive (placas 5-6).

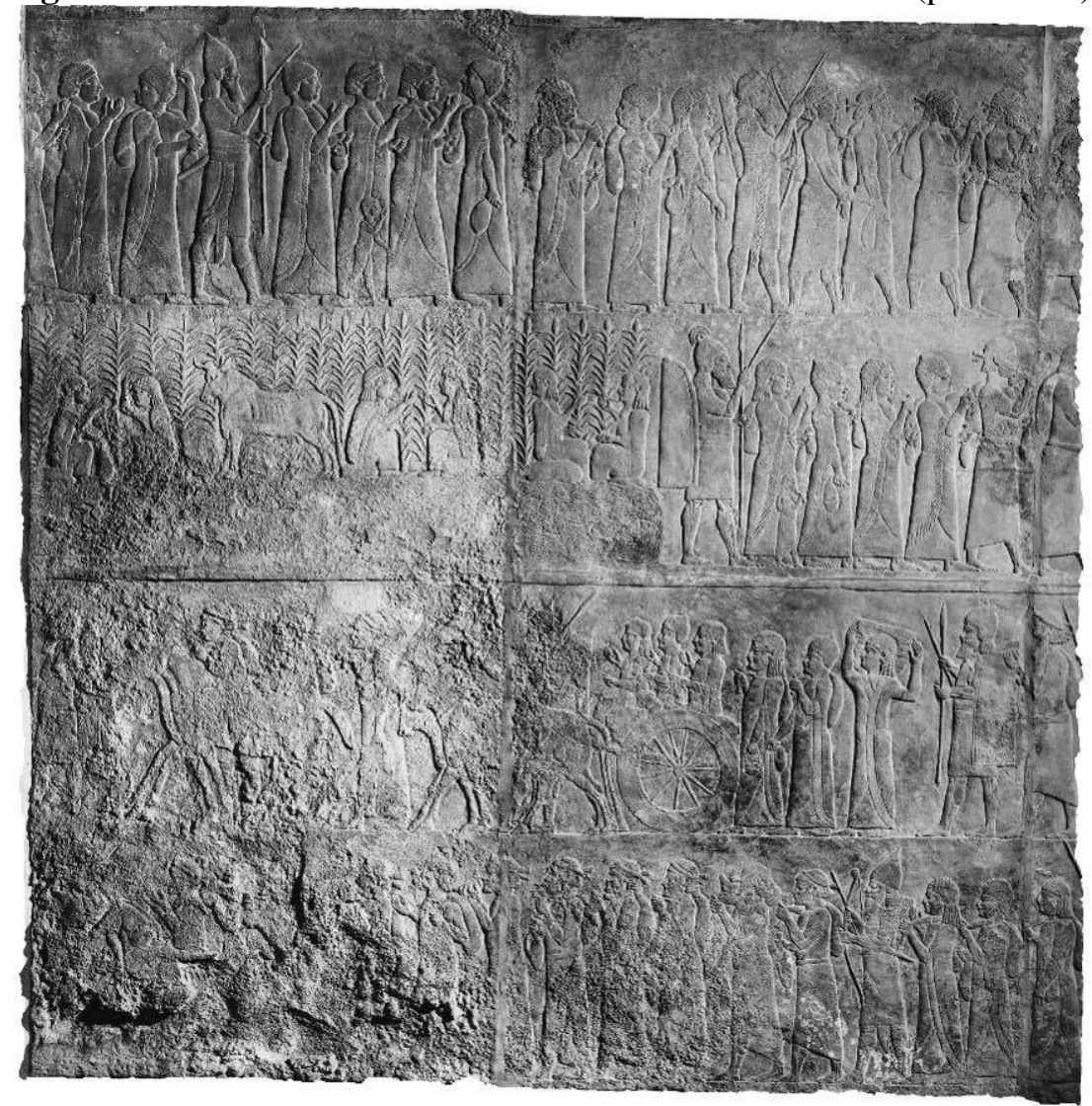

Fonte: @The Trustees of the British Museum (BM 124933-34). Adaptada por Ranieri.

Figura 113 - Relevos da sala F do Palácio Norte de Nínive (placas 7-9).

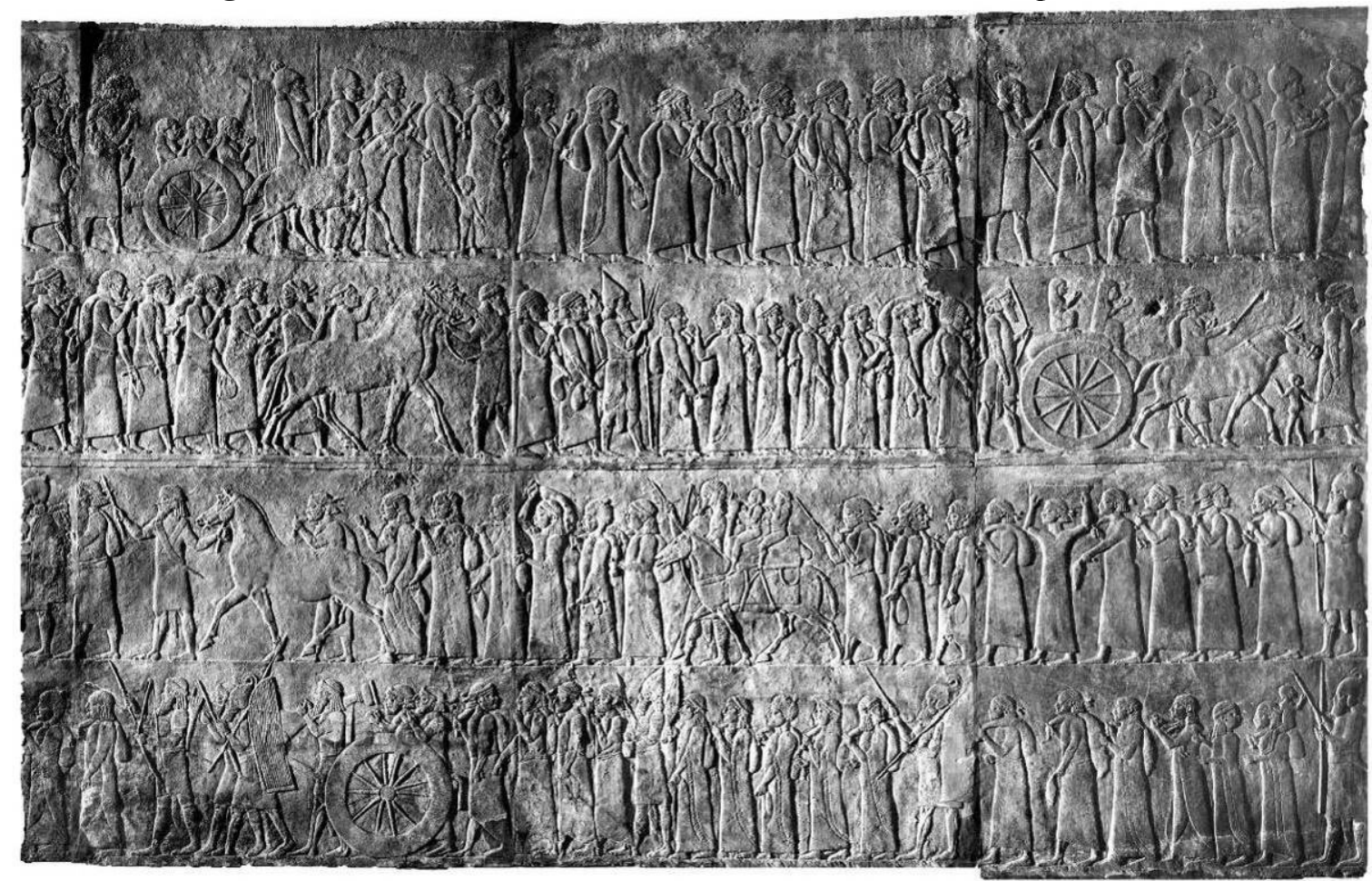

Fonte: @The Trustees of the British Museum (BM 124935-37). Adaptada por Ranieri. 
Figura 114 - Relevos da sala H do Palácio Norte de Nínive (placa 7, metade inferior).

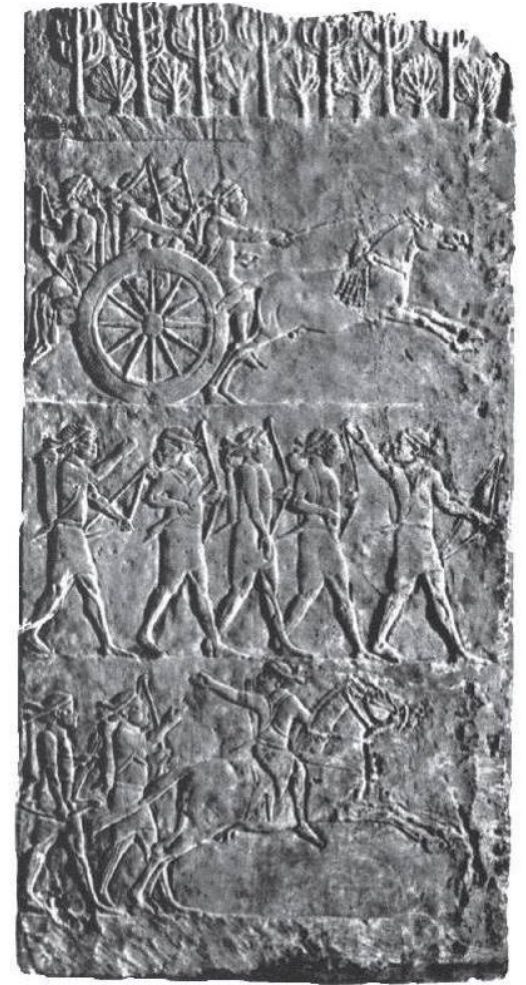

Fonte: Barnett (1976, prancha XXIII) (BM 124937). Adaptada por Ranieri.

Figura 115 - Relevos da sala H do Palácio Norte de Nínive (placas 8-9).

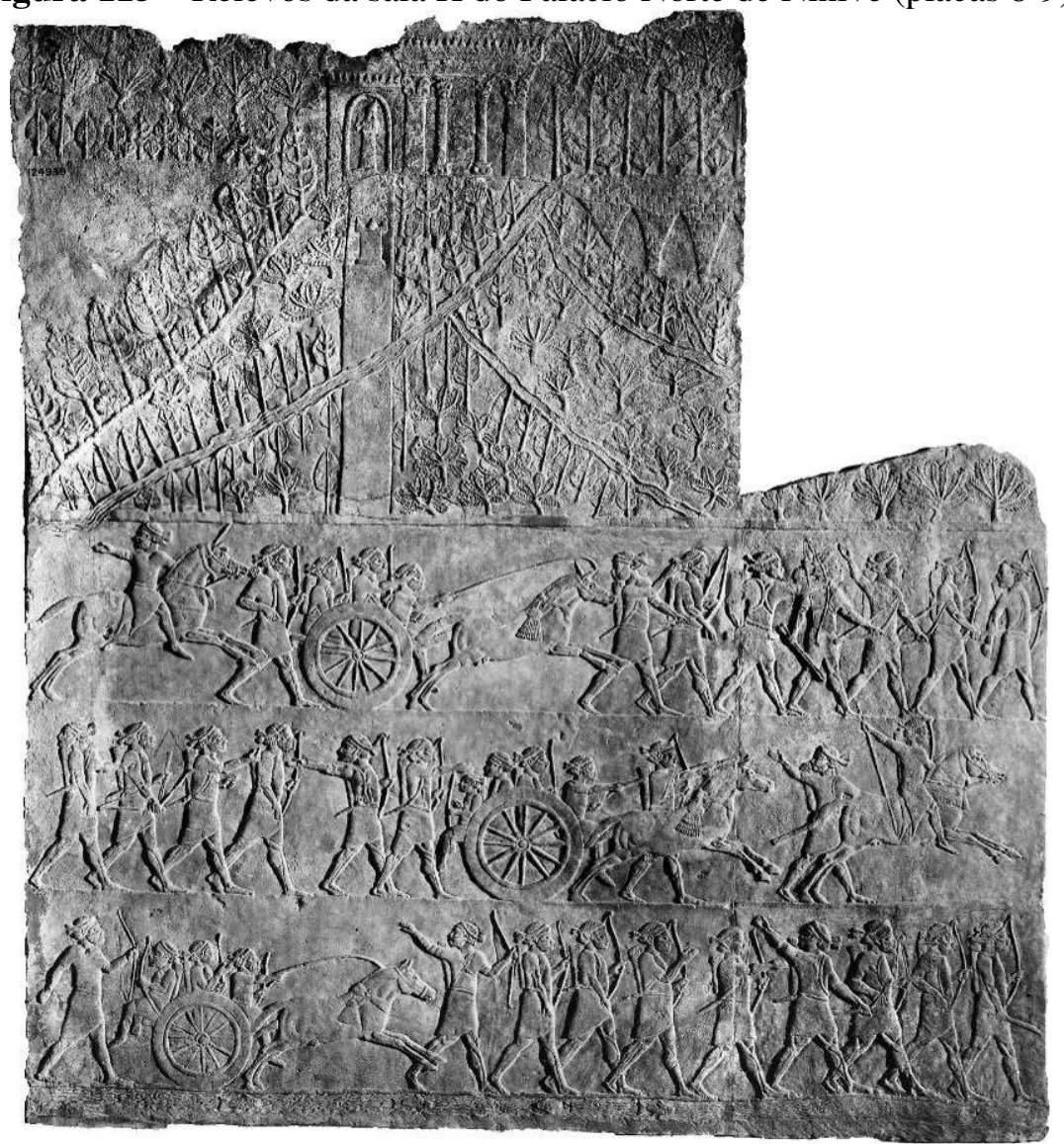

Fonte: @The Trustees of the British Museum (BM 124939). Adaptada por Ranieri. 
Figura 116 - Relevos da sala H do Palácio Norte de Nínive (placa 10).

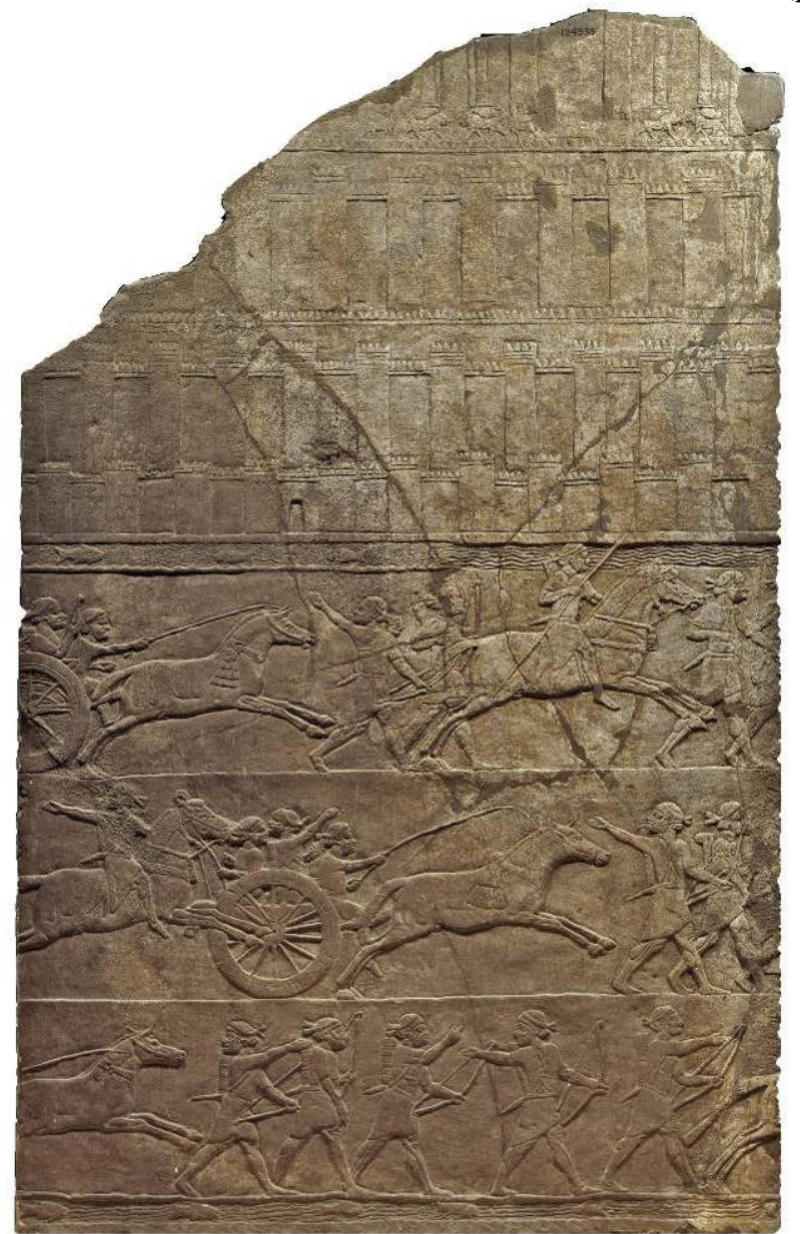

Fonte: @The Trustees of the British Museum (BM 124938). Adaptada por Ranieri. 
Figura 117 - Relevos da sala L do Palácio Norte de Nínive (placa 9).

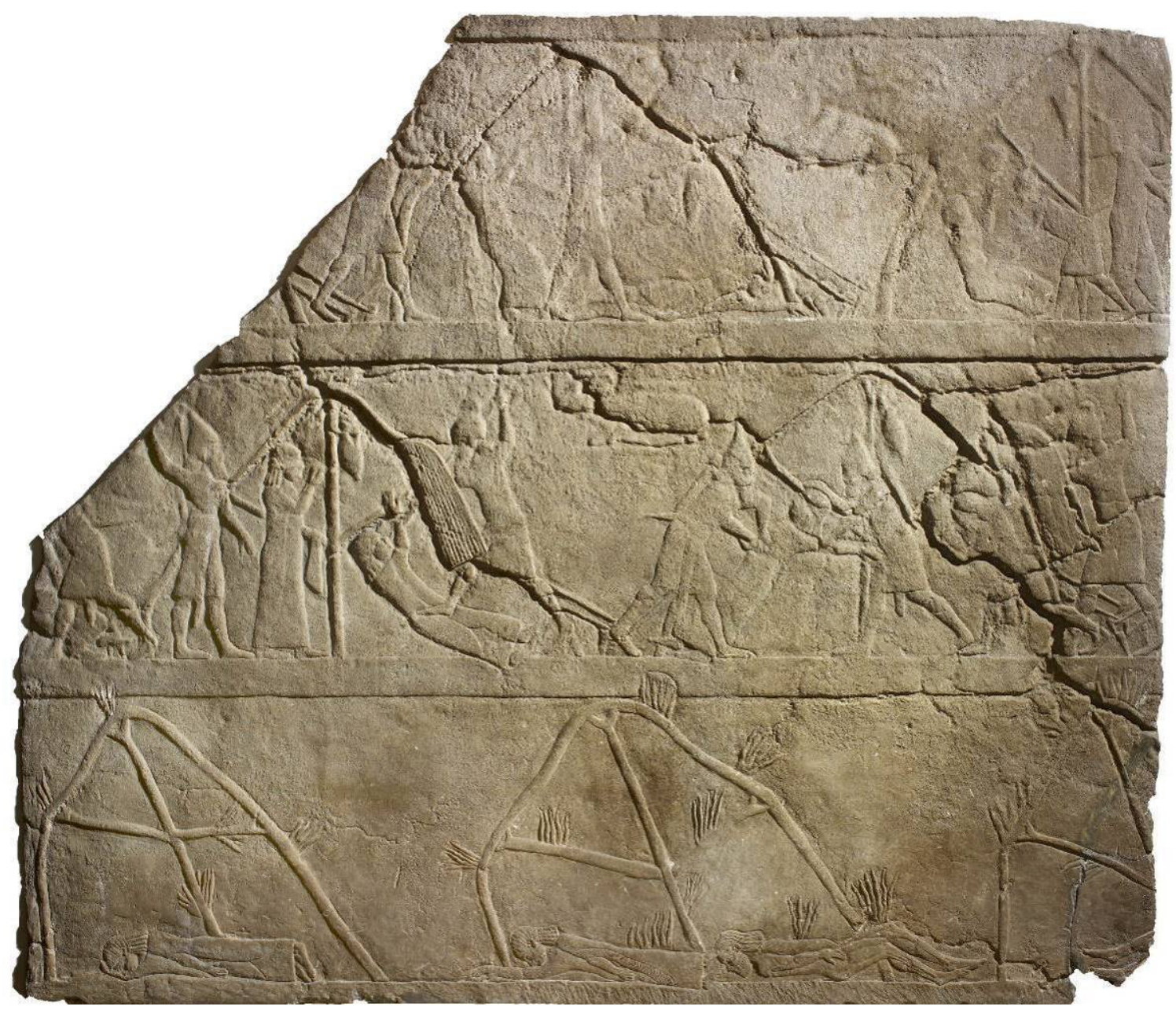

Fonte: @The Trustees of the British Museum (BM 124927). Adaptada por Ranieri.

Figura 118 - Relevos da sala L do Palácio Norte de Nínive (placa 10).

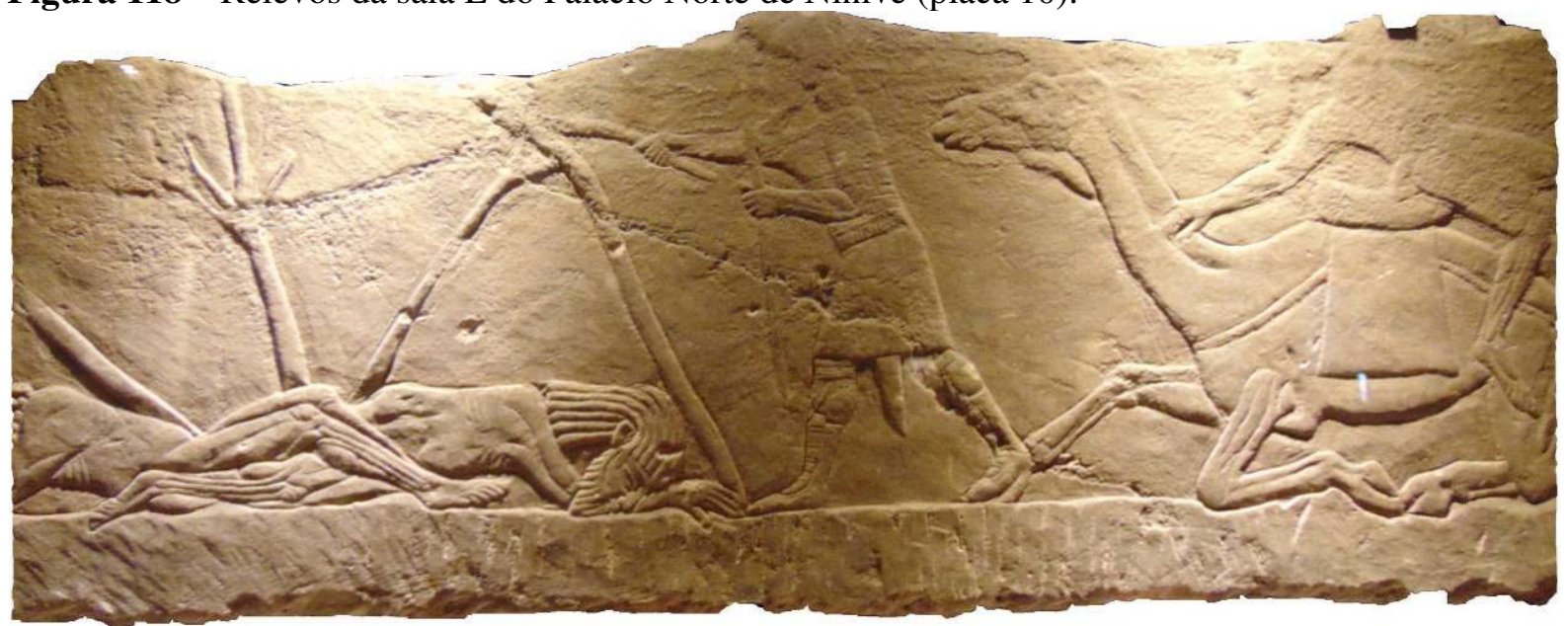

Fonte: @Musei Vaticani (VAT 14997). Fotografia realizada e adaptada por Ranieri. 
Figura 119 - Relevos da sala L do Palácio Norte de Nínive (placas 11-12).

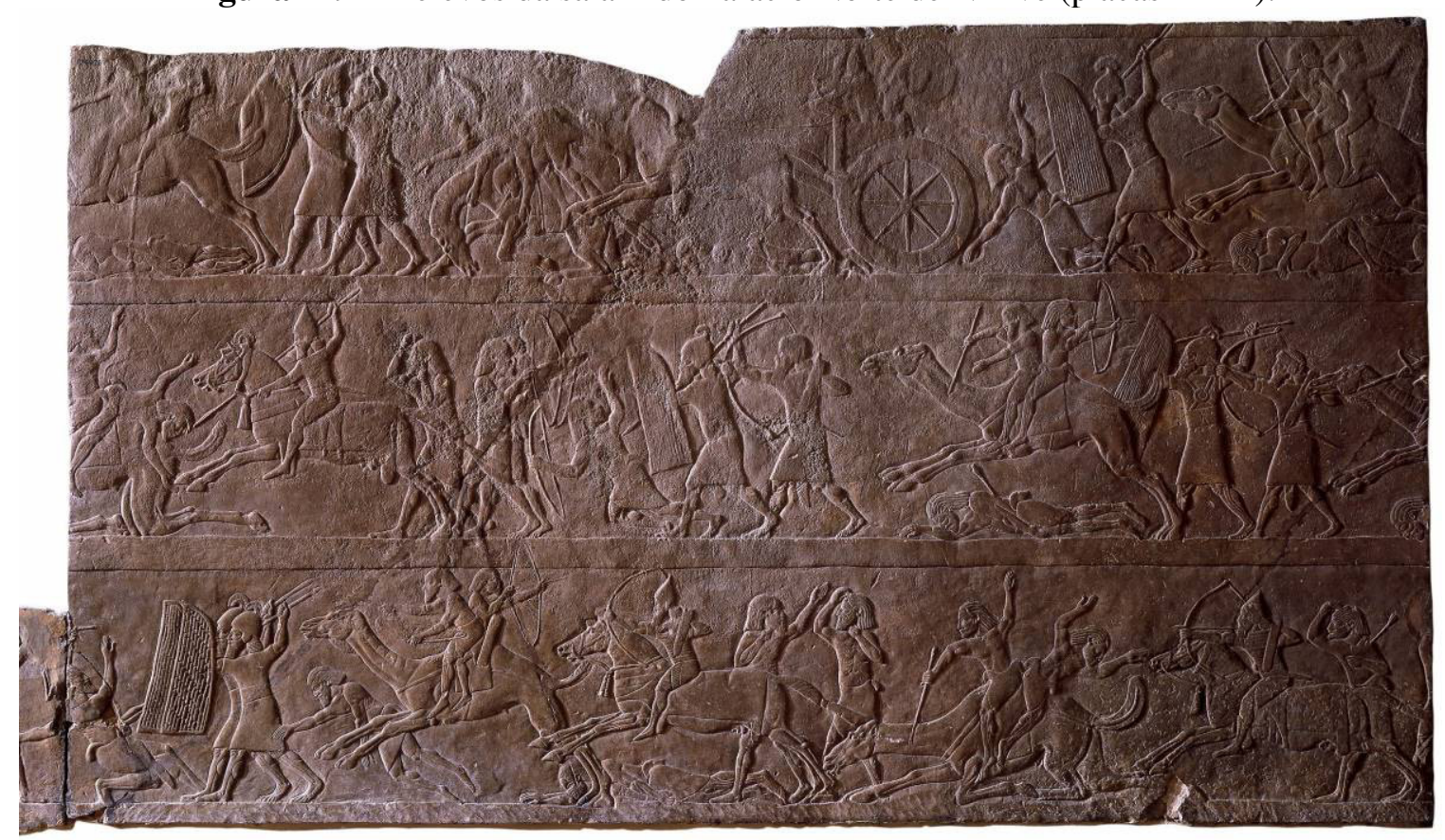

Fonte: @The Trustees of the British Museum (BM 124925-26). Adaptada por Ranieri. 
Figura 120 - Relevos da sala M do Palácio Norte de Nínive (placas 12-13).

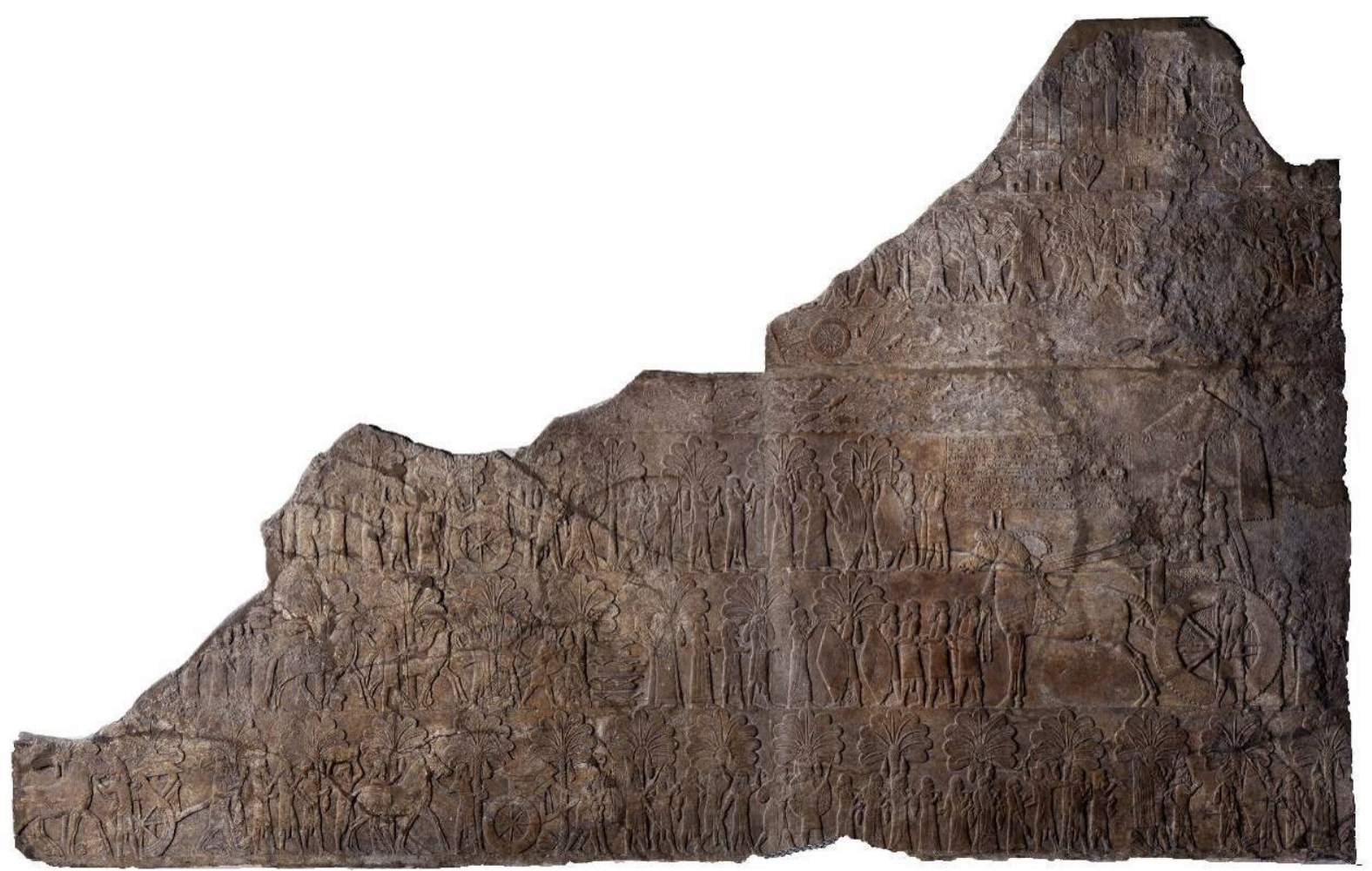

Fonte: @The Trustees of the British Museum (BM 124945-46). Adaptada por Ranieri.

Figura 121 - Relevos da sala M do Palácio Norte de Nínive (placa 17).

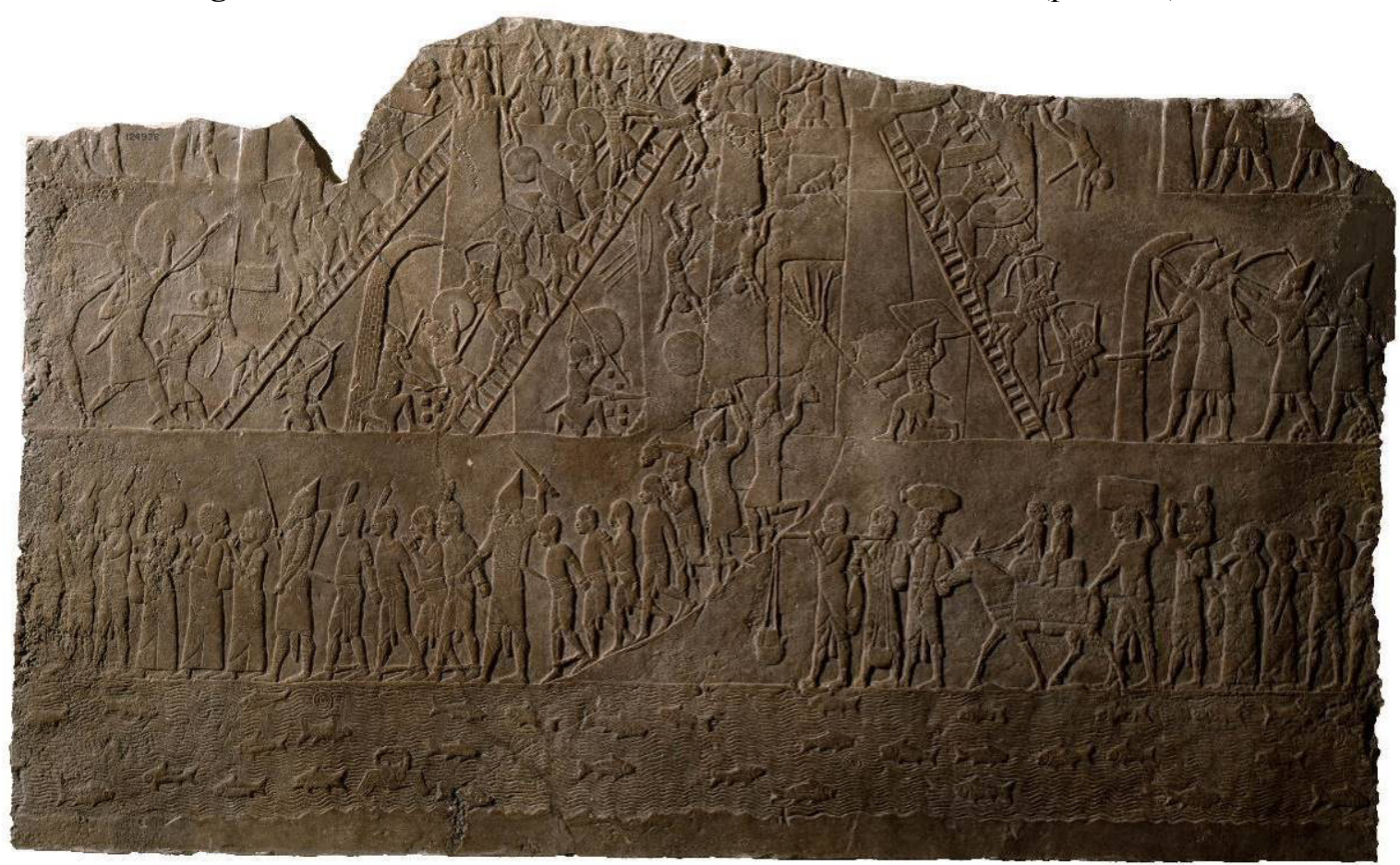

Fonte: @The Trustees of the British Museum (BM 124928). Adaptada por Ranieri. 